UNIVERSIDADE DE SÃO PAULO

FACULDADE DE FILOSOFIA, LETRAS E CIÊNCIAS HUMANAS DEPARTAMENTO DE GEOGRAFIA

PROGRAMA DE PÓS-GRADUAÇÃO EM GEOGRAFIA HUMANA

ANGÉLICA CAMPOS NAKAMURA

COOPERAPAS: AGRICULTURA E COOPERATIVISMO NO EXTREMO SUL DO MUNICÍPIO DE SÃO PAULO

SÃO PAULO

2017

VERSÃO CORRIGIDA 
UNIVERSIDADE DE SÃO PAULO

FACULDADE DE FILOSOFIA, LETRAS E CIÊNCIAS HUMANAS DEPARTAMENTO DE GEOGRAFIA

PROGRAMA DE PÓS-GRADUAÇÃO EM GEOGRAFIA HUMANA

\title{
COOPERAPAS: AGRICULTURA E COOPERATIVISMO NO EXTREMO SUL DO MUNICÍPIO DE SÃO PAULO
}

\begin{abstract}
Angélica Campos Nakamura
Dissertação apresentada ao Programa de PósGraduação em Geografia Humana do Departamento de Geografia da Faculdade de Filosofia, Letras e Ciências Humanas da Universidade de São Paulo, para a obtenção do título de Mestra em Geografia Humana.
\end{abstract}

Orientadora: $\operatorname{Prof}^{\mathrm{a}}$. Dr ${ }^{\mathrm{a}}$. Valéria de Marcos

SÃO PAULO

2017

VERSÃO CORRIGIDA 
Autorizo a reprodução e divulgação total ou parcial deste trabalho, por qualquer meio convencional ou eletrônico, para fins de estudo e pesquisa, desde que citada a fonte.

Catalogação na Publicação Serviço de Biblioteca e Documentação

Faculdade de Filosofia, Letras e Ciências Humanas da Universidade de São Paulo

N163C

Nakamura, Angelica Campos

Cooperapas: agricultura e cooperativismo no extremo sul do município de são Paulo / Angelica Campos Nakamura ; orientador Valeria de Marcos. São Paulo, 2016. $303 \mathrm{f}$.

Dissertação (Mestrado)- Faculdade de Filosofia, Letras e Ciếncias Humanas da Universidade de são Paulo. Departamento de Geografia. Área de concentração: Geografia Humana.

1. Cooperativismo. 2. Cooperapas. 3. Agricultura urbana. 4. Produção familiar. 5. São Paulo. I. Marcos, Valeria de, orient. II. Título. 
Nome: NAKAMURA, Angélica Campos

Título: Cooperapas: agricultura e cooperativismo no extremo sul do município de São Paulo

Dissertação apresentada à Faculdade de Filosofia, Letras e Ciências Humanas da Universidade de São Paulo para obtenção do título de Mestra em Geografia Humana.

Aprovada em:

Banca Examinadora

Prof. Dr.

Instituição: .

Julgamento:

Assinatura:

Prof. Dr. Instituição: .

Julgamento: Assinatura:

Prof. Dr. Instituição: .

Julgamento: Assinatura: 
A todos os mestres que tive ao longo da minha caminhada, meu obrigada e toda a minha gratidão. 


\section{AGRADECIMENTOS}

À minha orientadora Valéria de Marcos, por ter me aceito e acreditado em mim desde o início da minha jornada acadêmica na Geografia. Primeiro, no Trabalho de Graduação Individual (TGI) e, agora, no Mestrado.

À Coordenação de Aperfeiçoamento de Pessoal de Nível Superior (Capes), por permitir o acesso a uma bolsa de estudos, elemento fundamental para o desenvolvimento dessa pesquisa.

Aos meus pais, pelo amor, compreensão e apoio incondicional com todas as decisões e caminhos que decidi tomar ao longo da minha vida.

A todos os membros da Cooperapas, que permitiram eu frequentar seus encontros e reuniões, a conhecer suas casas e sítios, a entrar um pouco nas suas vidas e perguntar sobre elas, a fim de poder desenvolver minha pesquisa acadêmica. Agradeço especialmente a: Ana do Mel, Arpad Spalding, Dona Irma, Dona Massue e Cícero Shirazawa, Edinho, Ernesto Oyama, Mauri da Silva, Manoel da Silva, Mariane Kunze, Mauro Monteiro, Mônica Caetano, Nelson Pati, Seu Osvaldo e Cida, Sérgio Milani, Tomi, Valéria Macoratti, Vânia dos Santos, Zé da Floresta e Zundi Murakami.

A todos os técnicos da Casa de Agricultura (CAE) de Parelheiros, por tirarem minhas dúvidas, permitirem o acesso a dados a respeito dos agricultores e sempre me receberem tão bem na CAE. Agradeço especialmente a: Aline Ferreira de Jesus, Cristiano Gomes, Jair Medeiro, Idee de Moraes e Maria Clara Zuppardo. A Cristiano Mendes, por me atender na Supervisão Geral de Abastecimento e contar sobre o surgimento da Cooperapas.

Aos professores com os quais cursei as disciplinas da pós-graduação e me foram de valiosa ajuda para a dissertação: Ariovaldo Umbelino de Oliveira, Júlio Cesar Suzuki, Rita de Cássia Ariza da Cruz e Valéria de Marcos.

Aos professores Ariovaldo Umbelino de Oliveira e Marta Inez Medeiros Marques, por aceitarem fazer parte da minha banca de qualificação e terem ajudado com opiniões e sugestões importantes para o desenvolvimento da dissertação.

Ao Grupo de Estudos em Agricultura Urbana (Geau), que me ajudou e incentivou em muito com meus estudos ao longo do Mestrado, por todos os êxitos que obtivemos juntos até agora e pela caminhada que teremos pela frente como grupo. 
Aos meus amigos presentes nos mais variados momentos: nas discussões acadêmicas, nos artigos escritos em conjunto, nas viagens, nos cafés etc. Especiais agradecimentos a: Ana Muniz, Camila Soufer, Giulia Giacchè, Guilherme Ranieri, Gustavo Nagib, Lucinei Paes, Luís Amato-Lourenço, Lya Porto, Priscila Helena Lee, Rafael Calabria, Simone Affonso da Silva, professora Thaís Mauad e Victor Iamonti. 
A gente é caipira da capital.

Zundi Murakami, em uma reunião da Cooperapas, em 26 maio de 2015. 


\section{RESUMO}

NAKAMURA, A.C. Cooperapas: agricultura e cooperativismo no extremo sul do município de São Paulo. 2016. 303 p. Dissertação (Mestrado) - Faculdade de Filosofia, Letras e Ciências Humanas, Departamento de Geografia, Universidade de São Paulo, São Paulo, 2016.

A Cooperativa Agroecológica dos Produtores Rurais e de Água Limpa da Região Sul de São Paulo (Cooperapas) foi fundada em 2011 e é a única cooperativa de agricultores do município de São Paulo. Nesse trabalho, pretende-se mostrar um pouco dos problemas, desafios e demandas pelos quais essa cooperativa vem passando desde a sua fundação. Para isso, a sua história foi resgatada e as questões que surgiram, ao longo do ano de 2015 nas reuniões e assembleias, foram trazidas, a fim de se retratar o cotidiano da cooperativa e como ela tenta resolver suas demandas. Para compreender melhor quem faz parte da Cooperapas, traçou-se um perfil geral de seus agricultores. Uma parcela do grupo foi entrevistada, trazendo, assim, as características gerais dos membros sob variados aspectos. Também se procurou contextualizar a região em que vivem esses agricultores, no caso, o extremo sul do município de São Paulo. A agricultura nessa região ganhou mais força no início do século XX, quando imigrantes chegaram e iniciaram a atividade, destacando-se, entre eles, os japoneses. Ao longo do século XX, a cidade de São Paulo cresceu vertiginosamente, tornando-se a principal metrópole do Brasil. A mancha urbana se expandiu, alcançando essa região que continua com a atividade agrícola. Com o crescimento desordenado da cidade, leis e normas começaram a ser estabelecidas a fim de se criar instrumentos urbanísticos que melhorem o espaço urbano e o tornem menos desigual. Assim, surgiram Planos Diretores, os quais também se preocuparam em pensar sobre a agricultura dentro do município. O Plano Diretor de 2002 e de 2014 ganharam destaque nesse trabalho, o primeiro por incluir a agricultura urbana na legislação e, o segundo, por continuar a tratar da atividade agrícola e restabelecer uma zona rural. Uma das áreas da zona rural é esse extremo sul, onde vivem os membros da Cooperapas. Dessa forma, o trabalho procurou contextualizar a região na qual vivem e produzem esses agricultores e as políticas públicas voltadas para a agricultura, quem são os membros da cooperativa e, finalmente, como a Cooperapas realiza sua gestão e enfrenta seus problemas e desafios.

Palavras-chave: Cooperativismo. Cooperapas. Agricultura urbana. Produção familiar. São Paulo. 


\begin{abstract}
NAKAMURA, A.C. Cooperapas: agriculture and cooperativism in the far southern region of the municipality of São Paulo. 2016. 303 p. Dissertação (Mestrado) - Faculdade de Filosofia, Letras e Ciências Humanas, Departamento de Geografia, Universidade de São Paulo, São Paulo, 2016.
\end{abstract}

The Agroecology Cooperative of Rural Producers and Clean Water of São Paulo (Cooperapas) was founded in 2011 and is the only cooperative of family farmers in São Paulo. In this work, it is intended to show some of the problems, challenges and demands that the cooperative has experienced since its foundation. Its story was rescued and the issues that arose, during the year 2015 in the meetings and assemblies, were brought in order to portray the daily life of the cooperative and how it tries to resolve its demands. To better understand who is part of Cooperapas, a general profile of its family farmers was drawn up. A portion of the group was interviewed, to bring the general characteristics of the members in various aspects. It also sought to contextualize the region in which these family farmers live, in the case, the far southern of the municipality of São Paulo. Agriculture in the region gained strength in the early twentieth century, when immigrants arrived and began the activity, standing out among them the Japanese. Throughout the twentieth century, the city of São Paulo has skyrocketed, becoming the main city in Brazil. The urban area has expanded, reaching the region that continues to agricultural activity. With the disorderly growth of the city, laws and regulations began to be established in order to create urban instruments to improve the urban space and become less unequal. Thus arose Master Plans, which also bothered to think about agriculture in the municipality. The Master Plan of 2002 and 2014 were highlighted in this work, the first to include urban agriculture legislation and, second, to continue to think about the agricultural activity and restore a rural area. One of the rural areas is this far southern, home to members of Cooperapas. Thus, the study sought to contextualize the region in which the family farmers of Cooperapas live and produce and public policies for agriculture, who are the members of the cooperative and, finally, how Cooperapas performs its management and face its problems and challenges.

Keywords: Cooperativism. Cooperapas. Urban agriculture. Family production. São Paulo. 


\section{LISTAS}

\section{LISTA DE FIGURAS}

Figura 1.1. Mancha urbana de 1881 a 1995 de São Paulo .................................................... 34

Figura 1.2. Página da internet do Polo de Ecoturismo de São Paulo ...................................... 60

Figura 1.3. Jardineira no site do Polo de Ecoturismo de São Paulo ...................................... 62

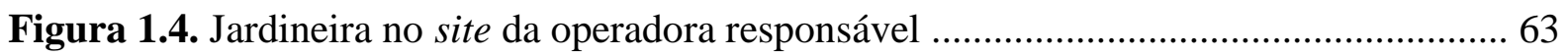

Figura 1.5. Agricultores no site do Polo de Ecoturismo de São Paulo .................................. 64

Figura 1.6. Selo de Indicação de Procedência Guarapiranga e Boas Práticas Agrícolas ....... 76

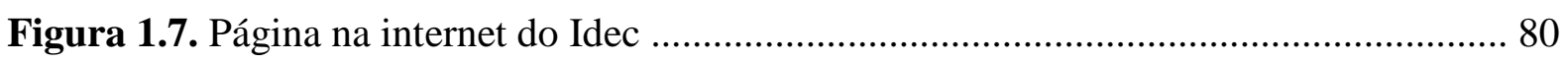

Figura 1.8. $1^{\text {a }}$ Conferência Municipal de Desenvolvimento Rural Sustentável ..................... 87

Figura 3.1. Capa de folder do Grupo Cultivar ................................................................. 181

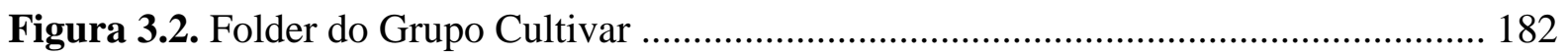

Figura 3.3. Convocação para assembleia publicada no jornal ............................................ 214

Figura 3.4. Convite da festa da Cooperapas ................................................................. 217

\section{LISTA DE FOTOS}

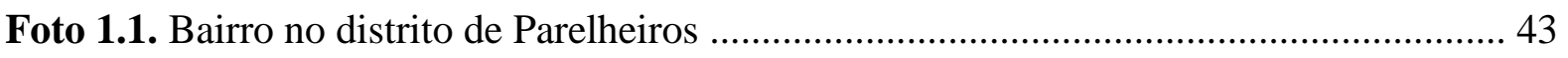

Foto 1.2. Panfleto sobre a venda de chácaras em Parelheiros ............................................... 47

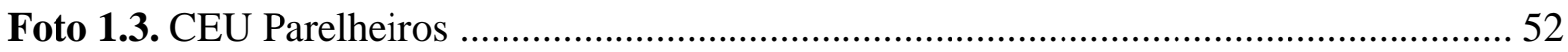

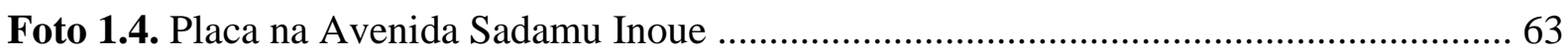

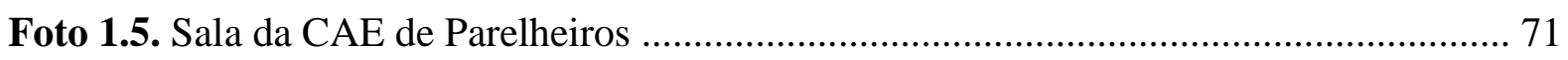

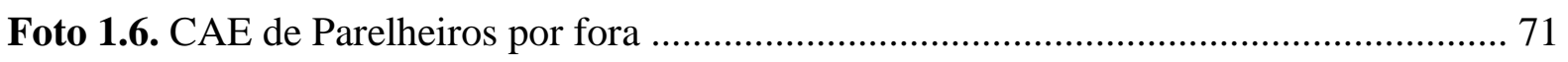

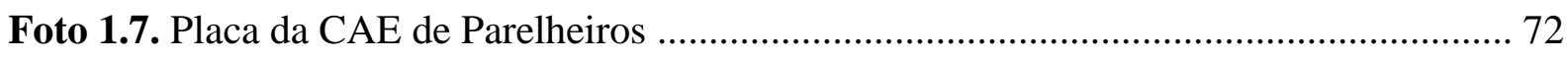

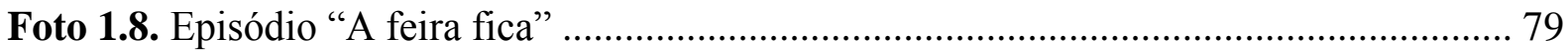

Foto 1.9. Cerimônia de lançamento do programa Agriculturas Paulistanas .......................... 84

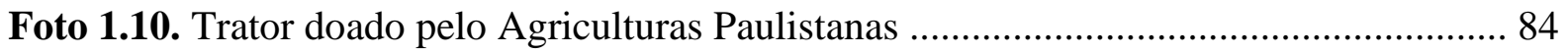

Foto 1.11. Sala da Cidadania, na Subprefeitura de Parelheiros .......................................... 85

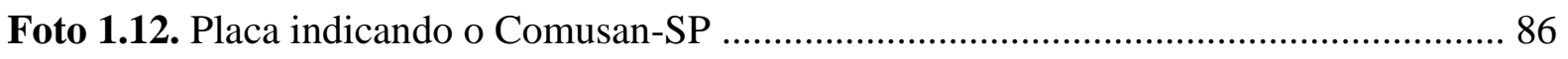

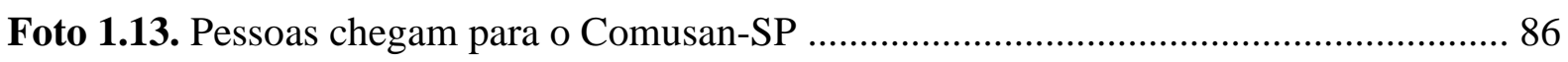

Foto 1.14. Pré-conferência realizada no CEU de Parelheiros .............................................. 88

Foto 1.15. Agricultores fazendo preparados biodinâmicos ............................................ 100 
Foto 1.16. Agricultoras preenchendo a documentação do SPG 103

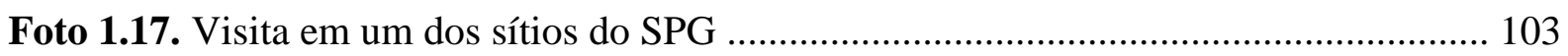

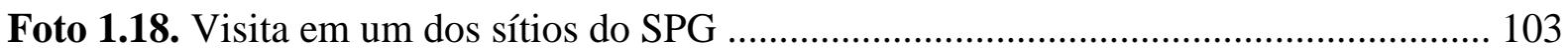

Foto 1.19. Participantes da OCS conhecem o sítio ........................................................... 106

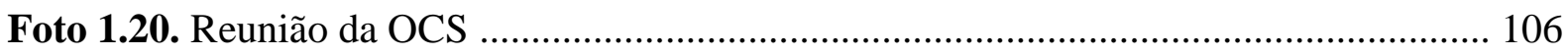

Foto 2.1. Sítio Paiquerê, no município de São Paulo ........................................................... 121

Foto 2.2. Sítio Paiquerê, no município de São Paulo ........................................................... 121

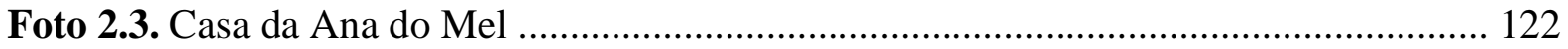

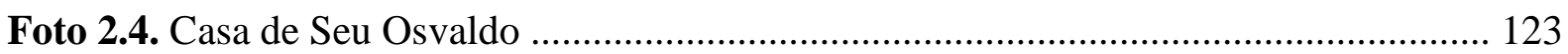

Foto 2.5. Funcionários trabalham em um dos sítios visitados ......................................... 124

Foto 2.6. Canteiros com produção de hortaliças variadas ................................................. 127

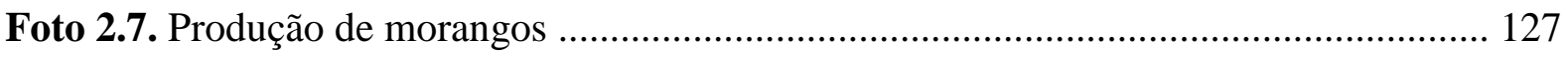

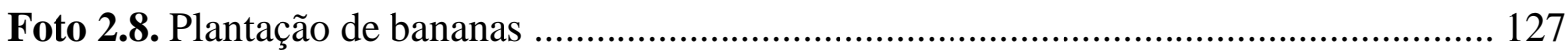

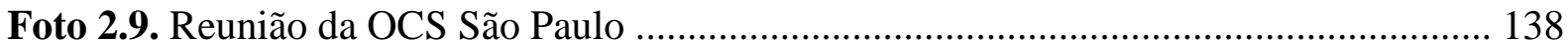

Foto 2.10. Ernesto mostra canteiros de hortaliças em seu sítio ........................................... 140

Foto 2.11. Caixas de abelhas no sítio de Ana do Mel .......................................................... 141

Foto 2.12. Zundi na plantação de bananas em seu sítio ....................................................... 142

Foto 2.13. Zé da Floresta explicando como planta em meio à vegetação ............................ 143

Foto 2.14. Mauri com a plantação de hortaliças ................................................................ 145

Foto 2.15. Seu Osvaldo mostra sua plantação de caqui ........................................................ 146

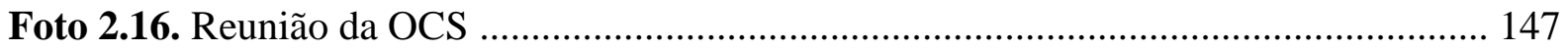

Foto 2.17. Dona Irma preparando a comida no fogão a lenha ........................................... 148

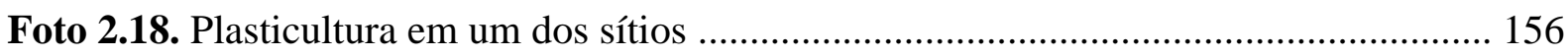

Foto 2.19. Equipamentos e utensílios utilizados na agricultura ........................................ 156

Foto 2.20. Equipamentos e utensílios utilizados na agricultura ....................................... 156

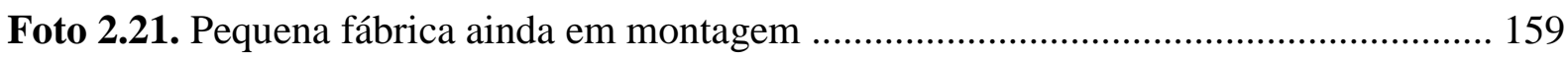

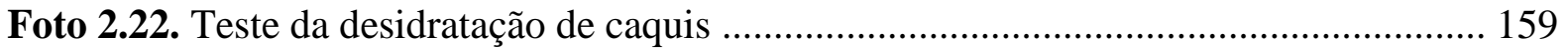

Foto 2.23. Zé da Floresta mostra o café que colheu ............................................................ 161

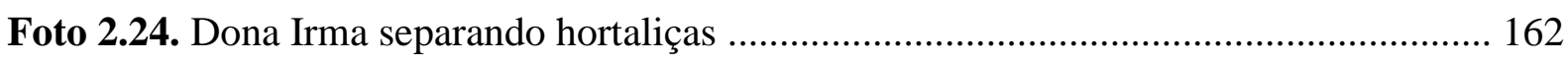

Foto 2.25. Entrada do sítio que Valéria e Daniel arrendavam ............................................ 164

Foto 2.26. A horta com a produção agrícola de Mariane ................................................... 166

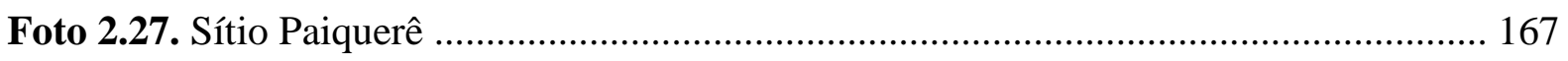

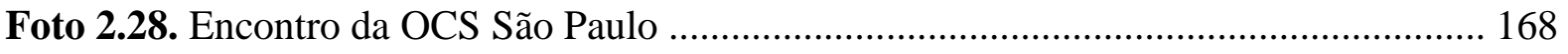

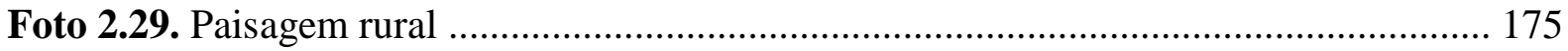


Foto 3.1. Cartaz da Cooperapas 188

Foto 3.2. Reunião da Cooperapas

Foto 3.3. Assembleia da Cooperapas 213

Foto 3.4. Cartaz anunciando o evento e a nova fase da Cooperapas 215

Foto 3.5. Convidados reunidos na festa da Cooperapas ... 216

Foto 3.6. Secretário municipal do Trabalho Artur Henrique 216

Foto 3.7. Bolo com o nome da Cooperapas 216

Foto 3.8. Primeira entrega para o Instituto Chão 225

Foto 3.9. Clientes fazendo compras no Instituto Chão 225

Foto 3.10. Reunião da Cooperapas de padronização 231

Foto 3.11. Reunião da Cooperapas de padronização 232

Foto 3.12. Reunião da Cooperapas de padronização 232

Foto 3.13. Reunião da Cooperapas de padronização 232

Foto 3.14. Reunião da Cooperapas de padronização 232

Foto 3.15. Barraca de Ernesto Oyama 234

Foto 3.16. Barraca de Ana do Mel 235

Foto 3.17. Barraca de Zundi Murakami 235

Foto 3.18. Barraca de Dona Massue 235

Foto 3.19. Alguns dos produtos doados para a Cooperapas 237

Foto 3.20. Cooperados que foram receber os produtos doados 238

Foto 3.21. Assembleia extraordinária da Cooperapas 243

Foto 3.22. Assembleia extraordinária da Cooperapas 243

Foto 3.23. Reunião da Cooperapas 251

Foto 3.24. Reunião da Cooperapas 251

\section{LISTA DE MAPAS}

Mapa 1.1. Município de São Paulo 24

Mapa 1.2. Loteamentos ao longo do reservatório Rio Grande ............................................. 28

Mapa 1.3. Mancha urbana da metrópole de São Paulo ........................................................ 35

Mapa 1.4. Taxas de analfabetismo no município de São Paulo ............................................. 40

Mapa 1.5. Rede hospitalar do município de São Paulo ....................................................... 40

Mapa 1.6. Domicílios sem rede esgoto no município de São Paulo .................................... 41

Mapa 1.7. Macroáreas do Plano Diretor do município de São Paulo ...................................... 55 
Mapa 1.8. Zona urbana e zona rural do Plano Diretor do município de São Paulo 56

Mapa 1.9. Parques e unidades de conservação no município de São Paulo 74

Mapa 1.10. Agricultores participantes do SPG 104

Mapa 1.11. Agricultores participantes da OCS 107

Mapa 2.1. Agricultores da Cooperapas: sítios visitados 118

Mapa 3.1. Agricultores da Cooperapas: onde estão 180

\section{LISTA DE GRÁFICOS}

Gráfico 2.1. Agricultores que possuem DAP 119

Gráfico 2.2. Agricultores que conhecem o Pronaf 120

Gráfico 2.3. Proprietários da Cooperapas 122

Gráfico 2.4. Área dos sítios 125

Gráfico 2.5. Agricultores que são sindicalizados 129

Gráfico 2.6. Nível de instrução dos agricultores 129

Gráfico 2.7. Agricultores com telefone, celular, computador e internet 130

\section{LISTA DE TABELAS}

Tabela 1.1. IDHM do município de São Paulo 39

Tabela 1.2. Macrozonas e macroáreas no Plano Diretor 57

Tabela 1.3. Produção agrícola municipal ............................................................................... 95

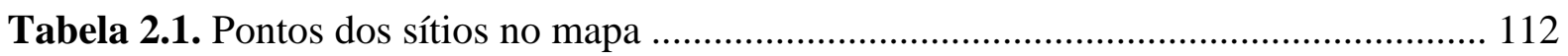

Tabela 2.2. Destino dos produtos vendidos .................................................................... 125

Tabela 3.1. Associação, cooperativa e microempresa/empresa de pequeno porte ............... 204

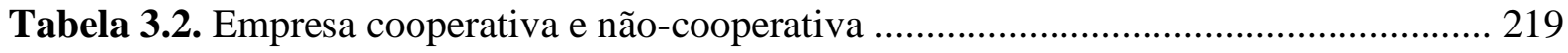

Tabela 3.3. Pontos de Silva e Holz e reorganização da Cooperapas .................................... 222

Tabela 3.4. Preços pagos pelo Instituto Chão em julho de 2015 ......................................... 226

Tabela 3.5. Preços dos equipamentos estipulados pela Cooperapas .................................... 239

\section{LISTA DE ORGANOGRAMAS}

Organograma 3.1. Organização interna da Cooperapas 


\section{SUMÁRIO}

INTRODUÇÃO

\section{O EXTREMO SUL, A AGRICULTURA E A RECRIAÇÃO}

DA ZONA RURAL NO MUNICÍPIO DE SÃO PAULO

1.1. Do início da atividade agrícola no extremo sul do município de São Paulo à expansão da metrópole paulistana

1.2. Da ausência do Estado ao Estatuto da Cidade e a obrigatoriedade de um Plano Diretor

1.3. Do Plano Diretor de 2002 às políticas públicas para a agricultura periurbana no município de São Paulo 65

1.4. Novas políticas públicas para a agricultura periurbana e a questão da conservação ambiental e do desenvolvimento sustentável

1.5. A agricultura praticada pelos membros da Cooperapas e as certificações orgânicas

2. OS AGRICULTORES DA COOPERAPAS

2.1. Um perfil dos membros da Cooperapas 110

2.2. Da legislação às correntes da Geografia Agrária e a agricultura familiar 131

2.3. Uma agricultura camponesa 139

2.4. A campesinidade e o urbano 163

3. O COOPERATIVISMO: DAS ORIGENS À PRÁTICA DA COOPERAPAS 178

3.1. Cooperapas: como surge uma cooperativa de agricultores no município de São Paulo 179

3.2. O cooperativismo: das origens ao surgimento e desenvolvimento no Brasil ............ 189

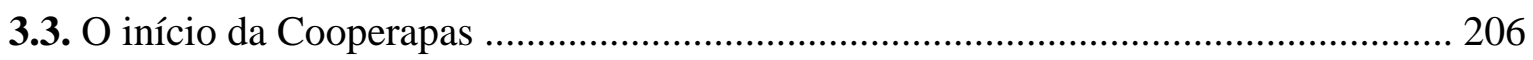

3.4. Princípios e prática do cooperativismo na agricultura: o caso da Cooperapas ......... 217

3.5. Uma cooperativa de economia solidária? .............................................................. 246

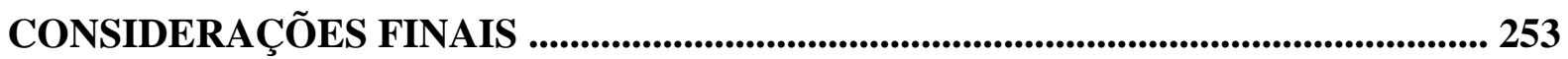

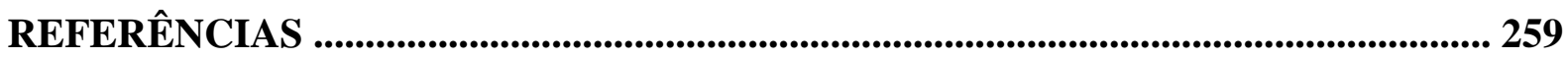

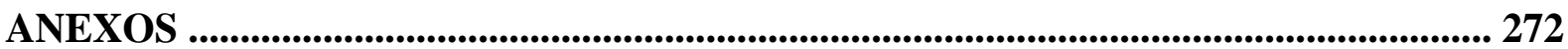


INTRODUÇÃO 
Desde 2011, existe no município de São Paulo uma cooperativa formada apenas por agricultores. Todos os seus membros vivem e produzem no extremo sul do município e nos municípios vizinhos, região essa que compõe parte do cinturão verde da cidade de São Paulo. A cooperativa, chamada Cooperativa Agroecológica dos Produtores Rurais e de Água Limpa da Região Sul de São Paulo, conhecida apenas como Cooperapas, desde a sua criação vem buscando acertar sua documentação e se colocar no mercado para comercializar seus produtos agrícolas orgânicos.

A Cooperapas foi criada com o intuito de fortalecer a comercialização dos agricultores da região. Juntos, poderiam vender seus produtos para programas do governo federal, como o Programa Nacional de Alimentação Escolar (Pnae) e o Programa de Aquisição de Alimentos (PAA), além de se inserir no maior mercado consumidor do país, o da cidade de São Paulo.

Apesar de a Cooperapas estar situada no município de São Paulo, chegar a ela, na minha pesquisa, não se deu logo de início. A primeira intenção desse trabalho era a de buscar uma cooperativa agrícola, composta por pequenos camponeses, no interior de São Paulo ou, mesmo, de outro estado, onde o urbano não fosse tão forte e significativo como no município paulistano.

O interesse em se estudar uma cooperativa partiu da afirmação de Oliveira, ao explicar que a organização cooperativista é um dos três componentes fundamentais identificados pelo autor no processo de reprodução da produção camponesa. Ele lista três componentes:

O primeiro são os proprietários de terras que especulam com a terramercadoria; ao venderem a terra, fazendo principalmente, loteamentos e colonização agrícolas, acabam por criar, contraditoriamente, condições para a recriação do camponês-proprietário.

O segundo componente que atravessa esse processo de reprodução é o Estado, que atua como agente distribuidor de terras em projetos de colonização, e, ao fixar preços mínimos agrícolas, ou cotas de produção, garante condições mínimas contraditórias para que o camponês se reproduza.

E o terceiro, que nasce no seio do próprio campesinato e é incorporado pelo Estado, diz respeito à formação das cooperativas no campo. Estas nasceram no século passado, como instrumento de defesa dos agricultores contra o comerciante, que, de certo modo atuando como comprador e usuário, explorava os camponeses, levando-os à proletarização. Foi por isso que as cooperativas nasceram no campo operando no setor do crédito e da comercialização. Assim, elas se tornaram um instrumento de defesa tanto do pequeno como do grande agricultor (OLIVEIRA, 1990, p. 72 , grifo do autor).

Além de Oliveira levantar a importância do cooperativismo para a reprodução camponesa, ao longo da pesquisa se constatou que há autores que veem as cooperativas como 
uma forma mais justa, democrática e igualitária de organização, além de permitir uma melhor integração ao sistema capitalista, pautado na competição e na desigualdade. Assim, uma cooperativa, poderia permitir a um grupo camponês não só sua reprodução, mas uma inserção melhor em um mercado competitivo com grandes empresas e produtores.

Partindo desses dois pontos, interessei-me pelo estudo de cooperativas e passei a buscar uma para acompanhar com vistas a compreender os avanços, dilemas e desafios por ela vivenciado. Entrei em contato com cooperativas do interior de São Paulo, chegando a realizar algumas visitas a elas. Porém, não consegui ir muito além. Apesar de me receberem, quando explicava que gostaria de acompanhar mais de perto o cotidiano da cooperativa, conversar com seus membros, as respostas se tornavam evasivas, pediam para entrar em contato por e-mail para combinar e, aos poucos, fui deixando de receber respostas.

Mesmo em contato com algumas nesse início, não parei de buscar outras cooperativas. Até que, pesquisando pela internet, encontrei menções à Cooperapas. Achei interessante uma cooperativa de agricultores dentro do município de São Paulo e fui buscar mais informações a respeito dela. Já estava no segundo semestre de 2014 nessa época, ou seja, há quase um ano e meio do início do Mestrado.

Em novembro de 2014, fui conhecer a Casa de Agricultura Ecológica (CAE) José Umberto Macedo Siqueira, na Subprefeitura de Parelheiros. No dia, uma terça-feira, havia uma reunião da Cooperapas, e assim conheci os técnicos da CAE e alguns agricultores que chegaram para a reunião. Nessa ocasião, um deles, Ernesto Oyama, convidou-me para participar de uma reunião da Organização de Controle Social (OCS) São Paulo, que seria realizada no sítio dele na quinta-feira daquela semana. Na época, não sabia que a OCS era uma forma de obter certificação orgânica participativa e não conhecia nada sobre a realidade rural do município de São Paulo.

Comecei a frequentar os encontros da Cooperapas em 2015. Logo no início, senti o interesse deles em chegar uma pesquisadora querendo acompanhar o grupo. Nunca houve reclamações ou oposição de alguém em eu acompanhar os encontros. Ia em todas as reuniões da cooperativa, como os encontros mensais e as assembleias, além das OCS realizadas todo mês. Aos poucos, fui conhecendo melhor os cooperados e, por minha presença nas reuniões serem constantes, alguns agricultores, no início, achavam até que era alguma nova funcionária da CAE. Apesar disso, já havia me apresentado como pesquisadora diversas vezes.

Conforme aprofundei meu contato, comecei a conversar mais com os cooperados até, finalmente, pedir a eles se podia entrevistá-los e conhecer seus sítios. Agendar e conciliar variadas datas foi difícil, pois as vésperas de entrega de produtos ou de feiras, por exemplo, 
sempre impossibilitavam a disponibilidade dos agricultores que precisam colher os produtos um dia antes e prepará-los para enviar ou vender no dia seguinte, tarefa que consome um dia todo de trabalho. Junte-se a isso, encontros e reuniões da cooperativa, ou problemas a resolver relacionados à cooperativa, além, é claro, de suas vidas pessoais. Todos esses aspectos, juntos, dificultavam esse agendamento das entrevistas e visitas aos sítios.

As conversas que tive com os membros da cooperativa e técnicos da CAE também me ajudaram muito a saber como ia a Cooperapas, tanto do ponto de vista da documentação, quanto financeiramente, como era a relação entre os cooperados e quais eram as novidades, como, por exemplo, o aparecimento de novos clientes, feiras e eventos para os quais eram convidados a participar etc.

Ao acompanhar as reuniões da Cooperapas, fui percebendo como era importante contar mais sobre essa realidade de gerir uma cooperativa. Li sobre como uma cooperativa é a empresa dos próprios membros, como a autogestão pode ser boa apesar dos desafios, como muitos autores gostam de culpar os insucessos e fracassos de uma cooperativa pelo fato de seus membros não possuírem uma educação cooperativista. Porém, o dia-a-dia de uma cooperativa vai muito além disso. A dificuldade em se manter em dia a documentação e o excesso de burocracia emperram em muito seu andamento. As reuniões eram os momentos de um encontro geral e de se colocar em dia como iam a documentação, o caixa da cooperativa, a venda dos produtos, os clientes etc. Mas até para se realizar certas reuniões, como as assembleias, é preciso seguir algumas exigências, como anunciar em um jornal. Detalhes esses que só aprendi acompanhando mais de perto o cotidiano da Cooperapas.

Portanto, ao contar a história da Cooperapas nesse trabalho e um pouco dos assuntos tratados pela cooperativa ao longo do ano de 2015, minha intenção foi trazer os problemas, desafios e demandas que surgiram ao longo desse tempo, para buscar compreender, ao máximo, como surgem várias questões no caminho e como esse grupo tenta, junto, resolvêlas. Muitas, até outubro de 2016, não se solucionaram e ainda estão em discussão, e sempre o grupo todo é convocado a participar para que as decisões sejam tomadas conjuntamente.

Muito do que trouxe no capítulo sobre a cooperativa aconteceu ao longo de 2015 e início de 2016. Para o trabalho, é difícil conseguir acompanhar tudo o que acontece em tempo real. O tempo para a escrita e reflexão é outro. Portanto, coisas que ocorreram 2016 não entraram no relato sobre a Cooperapas.

Um dos temas que já previa levantar para esse trabalho era a questão: quem são os membros que constituem a cooperativa? São camponeses mesmo? Como vivem, o que 
produzem, têm um passado na terra? A ideia era acompanhar sua produção e entrevistá-los, a fim de tentar identificar os elementos da produção camponesa.

Quando cheguei na Cooperapas, eu me questionava o que encontraria. Por não conhecer a realidade rural do município, a princípio, parecia que encontrar pessoas com um passado na terra e que continuavam a viver dela, seria difícil, afinal, tudo isso se dava na principal metrópole brasileira. Logo no início, também percebi que estava diante de um grupo muito heterogêneo. Alguns ali já haviam relatado para mim que vieram "da cidade" e buscavam uma outra maneira de ganhar a vida.

O perfil desse grupo da Cooperapas se tornou um capítulo. Procurei trazer dados levantados a partir de um questionário que serve de base para os técnicos da Casa de Agricultura, o qual trata sobre questões socioeconômicas, como idade, situação civil, qual o nível de escolaridade, tamanho da propriedade, se possui água encanada e energia elétrica, o que produz e para quem vende etc. Selecionei parte desses dados e montei um perfil geral, com os 19 membros que consegui entrevistar.

O segundo momento da entrevista buscava compreender o passado da pessoa. Ali sim constatei que existem agricultores com seu passado na terra, que aprenderam a plantar com seus pais e mantiveram esse modo de vida, ou que se distanciaram por um tempo e voltaram para ele depois. Mas havia também os que vieram em busca de uma nova atividade e vida, os "da cidade", e enxergaram na agricultura, essa possibilidade de mudança ${ }^{1}$.

Também procurei tratar um pouco como o fato de viverem no município com a maior metrópole brasileira influencia suas vidas. O urbano está forte, e ele se dá em vários aspectos.

Finalmente, quando entrei em contato com a Cooperapas e comecei a acompanhar a cooperativa e seus agricultores, a questão da agricultura urbana e dessa produção agrícola no extremo sul do município surgiu na pesquisa. Inicialmente, ela poderia ser um conteúdo complementar ao capítulo sobre os agricultores. Entretanto, os membros da Cooperapas sempre comentavam nas reuniões o fato de que ali onde viviam havia se tornado zona rural, e como isso poderia beneficiá-los como agricultores, pois mais políticas públicas voltadas para a agricultura, por exemplo, poderiam surgir. Essa mudança veio no Plano Diretor de 2014, que restabeleceu uma zona rural no município de São Paulo. Uma das áreas identificadas como rurais é justamente esse extremo sul, a qual abrange, praticamente, as Áreas de Proteção Ambiental (APA) Capivari-Monos e a Bororé-Colônia. Portanto, pareceu-me mais importante

\footnotetext{
${ }^{1}$ Não trouxe o relato de todos os 19 entrevistados, pois acredito que com o conteúdo o qual selecionei das entrevistas para o capítulo, será possível perceber esses dois principais tipos de personagem, apesar de cada história ter a sua singularidade.
} 
tentar compreender não só a atividade agrícola desses membros, mas sim esse território no qual eles viviam e que, agora, é rural na legislação.

Busquei uma bibliografia que tratasse sobre o surgimento e fortalecimento da agricultura no sul do município de São Paulo, que é parte, na verdade, de um cinturão verde. Essa agricultura começou a ganhar destaque no início do século $\mathrm{XX}$, com os imigrantes estrangeiros, especialmente os japoneses. Ainda hoje, é notável a quantidade desses descendentes que vivem na região.

Mas ao longo do século XX, principalmente a partir da sua metade, a expansão da mancha urbana cresceu vertiginosamente, e a cidade de São Paulo se tornou a principal capital e centro econômico do Brasil. Apesar de mancha urbana ter alcançado essa região com agricultura, mas ela ainda existe.

Com o crescimento da cidade e a exigência de um Plano Diretor regulamentada por lei, busquei compreender como a atividade agrícola foi tratada no plano de 2002, anterior ao de 2014. Já tinha ouvido falar do Programa de Agricultura Urbana e Periurbana (Proaurp) de 2004, porém, nesse Plano Diretor de 2002 algumas diretrizes para a atividade agrícola no município estavam traçadas. Ali, a agricultura era referida, em muitos momentos, como agricultura urbana. Assim, a atividade agrícola do município acabava enquadrada como tal, incluindo as áreas com agricultura há pelo menos mais de um século, como a do extremo sul.

Dessa forma, enxergar a atividade agrícola dessa área de minha pesquisa como agricultura urbana, aqui mais especificamente como periurbana, é uma nova maneira de estudá-la e enquadrá-la em políticas públicas voltadas para essa atividade. Visto isso, acabei apenas explicando um pouco sobre esse conceito, trazendo alguns autores e instituições as quais a definem. Busquei ainda entender como esse território do extremo sul do município é visto e vem sendo inserido na legislação e nas políticas públicas. Obviamente, todos esses aspectos influenciam na vida desses membros da Cooperapas e, ainda, busquei vivenciar um pouco sobre as práticas agrícolas realizadas por esses membros e como eles obtêm a certificação orgânica.

Para a apresentação do presente trabalho, porém, os capítulos terminaram sendo organizados na ordem inversa em relação a que foram construídos: o primeiro capítulo é o que trata sobre o território do extremo sul e a recriação do rural no município de São Paulo. Como primeiro capítulo, ele pretende contextualizar a região na qual vivem esses agricultores da Cooperapas e como a própria Cooperapas foi fruto de um contexto de criação de políticas públicas para a agricultura. 
O segundo capítulo traz alguns dos personagens que constituem a Cooperapas, ou seja, seu heterogêneo grupo de agricultores. Quem são, suas histórias, a legislação que os enquadra como agricultores familiares, os elementos da produção camponesa, a campesinidade e a influência do urbano em suas vidas.

Finalmente, no último capítulo, foi feito um resgate sobre o desenvolvimento do cooperativismo no Brasil, a fim de compreender qual a origem do cooperativismo e a influência da economia solidária nesse movimento. Além disso, trago a origem da Cooperapas, as dificuldades desde a sua criação e ela como prática. 
1. O EXTREMO SUL, A AGRICULTURA E A RECRIAÇÃO DA ZONA RURAL NO MUNICÍPIO DE SÃO PAULO 


\subsection{Do início da atividade agrícola no extremo sul do município de São Paulo à expansão da metrópole paulistana}

Os distritos de Parelheiros e Marsilac compõem o extremo sul do município de São Paulo. Eles são lembrados pela maioria de seus habitantes por ainda possuírem mata nativa, mananciais que abastecem a cidade de São Paulo, pelos agricultores ${ }^{1}$ que lá vivem e produzem e, ainda, por serem um território do município com índices socioeconômicos mais baixos e distantes do centro da cidade.

De acordo com o IBGE, em divisões territoriais datadas de 1937, Parelheiros já aparecia como distrito. Porém, foi apenas com o Decreto-lei Estadual n ${ }^{\circ} 14.334$ de 1944 que foram criados os distritos de Baquirivu (o qual viria a se tornar São Miguel Paulista) e Parelheiros. A partir desse decreto-lei estadual, tais distritos foram anexados ao município de São Paulo oficialmente. O distrito de Marsilac só veio a ser criado com a Lei Municipal $\mathrm{n}^{\mathrm{o}}$ 10.932 de 1991. Atualmente, a divisão dos distritos do município de São Paulo em vigor (mapa 1.1, na página a seguir) é a de 2007 (IBGE, 2014).

Aroldo de Azevedo já indicava essa região como a área suburbana de São Paulo, em sua tese de concurso à cátedra de Geografia do Brasil da Faculdade de Filosofia da Universidade de São Paulo, de 1945:

[...] a área suburbana estende-se em um raio muito variável através da bacia terciária de São Paulo e, mesmo chega a ultrapassar os seus limites. Para o Norte, por exemplo, a influência da metrópole é bem menor e cessa a uns $10 \mathrm{~km}$ do seu centro; é a zona da Cantareira, que tem na serra do mesmo nome uma barreira natural a dificultar a expansão. Para outras direções, a influência da cidade já vai bem mais longe, porque pode dispor de vias naturais de acesso, constituídas pelos vales fluviais; é o que vemos no Vale do Tietê e no de seus afluentes, sobretudo o Pinheiros e o Tamanduateí. [...] Isto explica que para Leste como para Oeste a zona suburbana se estenda num raio de 25 e $30 \mathrm{~km}$, penetrando nos municípios vizinhos (Santo André, Moji das Cruzes, Guarulhos, Santana de Parnaíba, Cotia, Itapecerica da Serra), que se vêem assim atraídos para a órbita da Pauliceia. [...] Já o mesmo não acontece para o Sul, onde as grandes represas construídas pela "Light and Power" e a escarpa da Serra do Mar constituem barreiras a dificultar a marcha da metrópole (AZEVEDO, 1945 apud PENTEADO, 1958 , p. 6, grifo do autor $)^{2}$.

\footnotetext{
${ }^{1}$ Ao longo do desenvolvimento do trabalho, percebi a necessidade de trazer uma discussão teórica sobre o campesinato e a agricultura familiar. Ela será tratada no capítulo 2 a seguir. A fim de evitar um uso indevido de conceitos, preferi utilizar apenas a palavra agricultor, porém, evitando sempre o termo agricultor familiar, pois seu uso implica em uma determinada corrente da Geografia Agrária.

${ }^{2}$ AZEVEDO, Aroldo de. Subúrbios orientais de São Paulo. São Paulo: Imprimia, 1945. p. 30-31.
} 


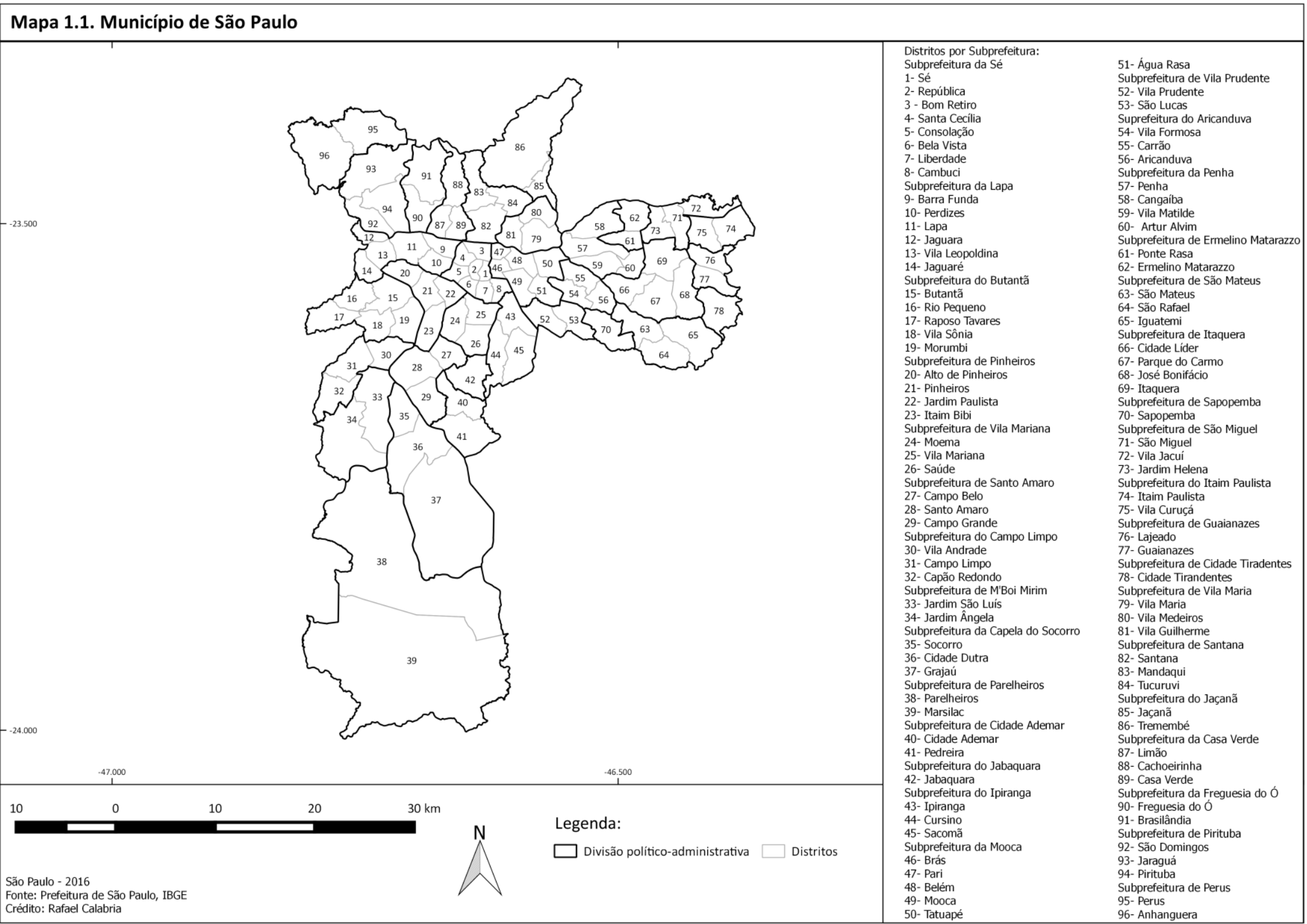


Nesse trecho, Azevedo dá indícios que explicam porque a expansão da mancha urbana para o extremo sul do município não se deu tão intensivamente por toda a região como nas outras de São Paulo: o sul do município tem barreiras que dificultaram a ocupação mais intensa da região, no caso as represas de Guarapiranga e Billings, e a escarpa da Serra do Mar. Penteado destaca que, "em virtude das características topográficas do Planalto Paulistano e sua rede de drenagem, a expansão dos subúrbios se processou muito mais no sentido LesteOeste, do que no sentido Norte-Sul” (1958, p. 57).

Costa indica também algumas características da região, o qual possui uma topografia "bastante movimentada, com desníveis acentuados. Estamos em pleno Planalto Atlântico, com suas rochas cristalinas fortemente trabalhadas pela erosão" (COSTA, 1958, p. 110, grifo da autora). A autora ainda fala sobre os solos, que são de origem granítico-gnáissica e, portanto, não se destacam pela fertilidade e profundidade. De acordo com o Instituto Agronômico (IAC) do estado de São Paulo, o tipo de solo encontrado no Planalto Atlântico é o cambissolo. Esse tipo de solo é encontrado no estado, especialmente nessa província geomorfológica. Sendo assim, "Nestas condições, estes solos têm perfis menos profundos e pedregosidade ou cascalhos na superfície ou na massa do solo" (IAC, 2014).

Ainda, Costa explica sobre o clima da região:

O clima regional caracteriza-se por uma estação chuvosa, nos meses da Primavera e do Verão, e por uma estação seca, nos demais, a exemplo do que se verifica em todo o Planalto paulista. De novembro a março, caem 65 a $80 \%$ das chuvas anuais, ao passo que, de junho a agosto, o total é inferior a $15 \%$, chegando a $5 \%$. [...]

A irregularidade do tempo constitui o traço marcante da climatologia regional (1958, p. 110, grifo da autora).

Costa conta que "A topografia acidentada, aliada à alta pluviosidade, são fatores do empobrecimento do solo, pois a matéria orgânica se vê removida com muita facilidade" (1958, p. 110).

Sobre a vegetação, a região está nos domínios da Mata Atlântica. Na época dos escritos de Costa, ela indicava que essa vegetação aparecia

[...] em sua virgindade original, sobretudo na área próxima da Serra do Mar, em seu "sertão". Mas a devastação das matas também ali foi intensa, notadamente na década de 1940-50, embora continue ainda hoje. Em Juquitiba, localiza-se a frente pioneira dessa marcha devastadora, na ânsia de obter lenha e de fabricar carvão vegetal. No conjunto, porém, a 
predominância cabe às matas secundárias e aos capoeirões ${ }^{3}$, que ainda restam sobretudo nas encostas mais abruptas das vizinhanças do núcleo de Itapecerica da Serra (1958, p. 113, grifo da autora).

Costa afirma que foi nesse quadro natural que os homens viviam desde os tempos coloniais e que, nessa região, foi criada uma paisagem tipicamente agrária (1958, p. 113), ainda que nos limites da cidade de São Paulo que vinha crescendo rapidamente.

Apesar dos escritos de Azevedo datarem da primeira metade do século XX, Penteado já apontava, a partir deles, certos fatores que levaram ao crescimento e desenvolvimento dessas áreas suburbanas do município: "1) o aumento dos impostos territoriais; 2) o crescimento da população da Capital; 3) a expansão do parque industrial paulistano" (PENTEADO, 1958, p. 8). Devido ao aumento dos impostos, ele afirma que "um número elevado de pequenas chácaras dedicadas à horticultura ou à avicultura passou a existir na área suburbana" (PENTEADO, 1958, p. 9), e que o crescimento populacional ocasionou "o deslocamento de numerosas chácaras, de flores ou de legumes, até então localizadas em plena cidade" (PENTEADO, 1958, p. 9). A população dessas áreas suburbanas era

[...] constituída por um número elevado de trabalhadores agrícolas, de operários, de funcionários públicos de modesta categoria ou de comerciários, em sua maioria brasileiros, mas apresentando número apreciável de estrangeiros ou seus descendentes de primeira geração, originários da Itália, especialmente na massa operária, e de Portugal, Espanha e Japão, sobretudo nas áreas agrícolas $^{4}$ (PENTEADO, 1958, p. 11, grifo nosso).

Azevedo ainda indica que essas zonas suburbanas tinham diferentes funções e, uma delas, era a agrícola, além da residencial e da industrial. De acordo com ele:

A função agrícola é também muito importante e constitui, sob certos aspectos, uma tradição dos subúrbios de São Paulo. Nos últimos 25 anos, criou-se em torno da cidade uma verdadeira zona hortense, com a

\footnotetext{
${ }^{3}$ Capoeirão é um termo para se referir a um estágio mais avançado de desenvolvimento da vegetação com estratificação florestal mais nítida, precedido pela capoeirinha ou capoeira-baixa e pela capoeira. A capoeirinha é composta por uma vegetação mais baixa, caracterizada por herbáceas e arbustivas. A capoeira é um estágio secundário, com um estrato arbóreo mais denso e uniforme, podendo ter árvores que chegam de 8 a 10 metros de altura (ROSARIO, 2010, p. 32-33).

${ }^{4}$ Até os dias atuais, é notável a presença dos japoneses e seus descendentes que vivem em Parelheiros, Marsilac e nos municípios do entorno que formam o cinturão verde do município, como Embu-Guaçu. Ao longo do trabalho, a presença dos nipônicos é constante, seja entre os membros da Cooperativa Agroecológica dos Produtores Rurais e de Água Limpa da Região Sul de São Paulo (Cooperapas), tema de estudo dessa dissertação, seja nos relatos de agricultores cujas famílias estão na região há gerações.
} 
multiplicação das culturas de legumes e também de flores [...] (AZEVEDO, 1943 apud PENTEADO, 1958, p. 7, grifo do autor) $)^{5}$.

Esses subúrbios agrícolas, de acordo com Penteado, surgem

[...] em quase todos os quadrantes, ao redor da Capital de São Paulo: para o Norte, na região da Cantareira; para o Sul, no "sertão" que se estende até às bordas do Planalto Paulistano, olhando o mar; para Leste, através da planície do alto Tietê até às vizinhanças de Moji das Cruzes; e para Oeste, assentados na região acidentada que se ergue ao nível médio dos 750-850 metros, em direção a São Roque. Uma vasta área, de limites certamente imprecisos, que apresenta duas funções marcantes - a agrícola e a residencial, ora de maneira homogênea, como é o caso da região de Cotia, onde a agricultura impera; ora um tanto complexa, graças à coexistência de ambas as funções, ao mesmo tempo destacando-se como zona residencial modesta e área agrícola sem grande expressão [...] (1958, p. 37, grifo do autor).

Penteado ainda apresenta um quadro com a população total desses distritos em 1950. Parelheiros já aparecia com 7.141 habitantes, sendo destes, 207 considerados como população urbana. Outro município de interesse para essa dissertação, por ser local onde vivem e produzem os agricultores que fazem parte da Cooperapas, é Embu-Guaçu, que na época tinha 3.815 habitantes e, desses, apenas 633 eram considerados parte da população urbana.

Na primeira metade do século XX, Penteado denominou essa região do extremo sul do município como a região das represas e a do "sertão" de Santo Amaro. A região das represas (mapa 1.2 na página a seguir) se tornou um local "para os que aspiram a passar algumas horas de recreação, longe da vida dinâmica e trabalhosa da metrópole” (PENTEADO, 1958, p. 5152). Ali também o valor dos terrenos passou a ser extremamente valorizado e apenas os mais abastados podiam comprar um terreno ou uma chácara. Ainda de acordo com Penteado

A construção dos reservatórios da "Light" foi a causa direta de uma verdadeira transformação em toda a região e, de maneira particular, nas vizinhanças do Reservatório do Guarapiranga, graças à multiplicação das chácaras de recreio, das habitações destinadas aos fins de semana, dos clubes náuticos e de outros locais destinados à recreação.

As chácaras ocupam, em geral, pitorescos locais, ora às margens da represa, ora junto às boas estradas que servem a região; são de tamanho médio e dispõem, quase sempre, de um conforto que bem atesta o bom gosto e a fortuna de seus proprietários. [...]

A construção daquele reservatório foi [...] aproveitada no sentido de oferecer à cidade de São Paulo [...] aprazíveis e recortados lagos artificiais, com modestas mas apreciadas "praias" (1958, p. 51).

\footnotetext{
${ }^{5}$ AZEVEDO, Aroldo de. Subúrbios de São Paulo. Anuário da Faculdade de Filosofia do instituto "Sedes Sapientiae", São Paulo, 1943.
} 
Mapa 1.2. Mapa com os loteamentos na zona sul de São Paulo e municípios vizinhos ao longo do reservatório Rio Grande na primeira metade do século XX

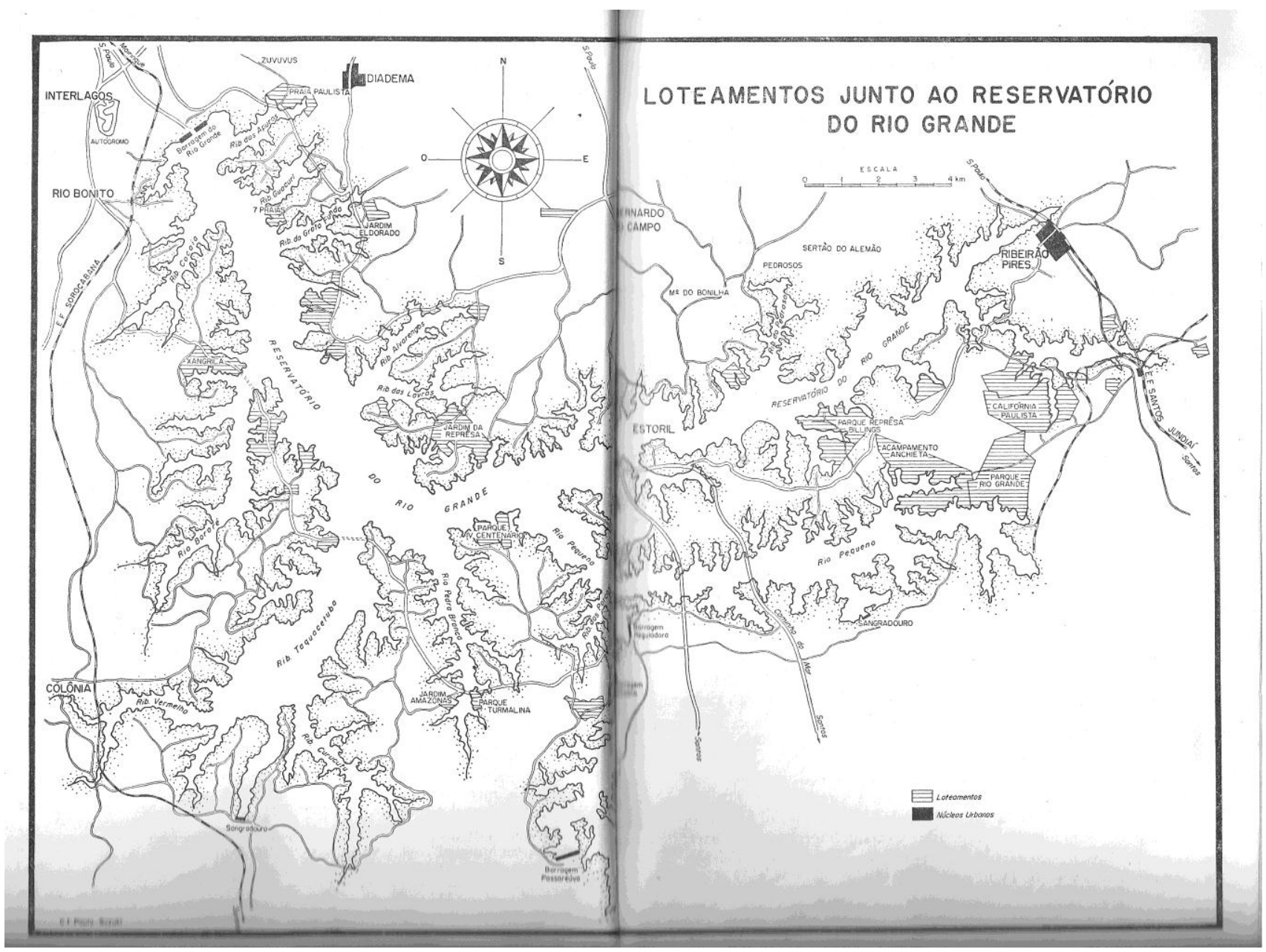

Fonte: PENTEADO, Antonio Rocha. Os subúrbios de São Paulo e suas funções. In: AZEVEDO, Aroldo de (Org.). A cidade de São Paulo: estudos de Geografia Urbana. São Paulo: Companhia Editora Nacional, 1958. v. IV: Os subúrbios paulistanos. p. 54-55. 
Já o "sertão" de Santo Amaro era, na época, um local esquecido e à margem da intensa urbanização que vinha ocorrendo em outras regiões do município. Conforme Penteado relata

[...] basta penetrar uns poucos quilômetros para além dessa área, em direção às escarpas da Serra do Mar, para que outra paisagem se abra aos olhos do observador. É o chamado "sertão" de Santo Amaro - um "sertão" que se encontra mais próximo do litoral do que a cidade de São Paulo... mas que, na verdade, faz lembrar bastante esses recantos esquecidos, perdidos no anonimato, em tão grande número ainda existentes no imenso interior do país.

Trata-se de uma área que ficou inteiramente à margem das vias de comunicação entre São Paulo e o litoral atlântico; suas ligações se fizeram, durante muito tempo, através de péssimos caminhos, apenas com São Bernardo do Campo, com Itapecerica da Serra e, menos frequentemente, com Itanhaém, no litoral.

De início, sua escassa população dedicou-se à extração de madeiras da Mata Atlântica e à produção do carvão vegetal. Proibida a primeira na região de Santo Amaro, continua a existir apenas a segunda dessas atividades econômicas, em franco desenvolvimento sobretudo no "sertão" de Itapecerica da Serra [...]

No reinado de D. Pedro I, registrou-se uma tentativa de colonização alemã, na área que vimos focalizando; a instalação do núcleo colonial teve lugar em junho de 1829, contando, inicialmente, com 62 famílias e um total de 299 pessoas. Entretanto, [...] certamente pelo isolamento em que se encontrava, entrou logo em lamentável decadência. [...] Em 1847, não existiriam mais do que 9 famílias.

Hoje, quem quer que, dirigindo-se para Parelheiros, alcance a localizada denominada Colônia, terá oportunidade de encontrar umas poucas famílias de caipiras típicos, vivendo pobremente. Seus componentes têm cabelos alourados, seus olhos são azuis, sua pele requeimada pelo Sol denuncia sua ascendência europeia, seus sobrenomes são legitimamente germânicos. É o que resta do antigo núcleo colonial instalado em 1829 (1958, p. 55-56, grifo do autor).

Costa também comenta sobre a atividade agrícola praticada na época nessa grande região suburbana que englobava o extremo sul do município de São Paulo, porém, o foco de seu trabalho são os municípios vizinhos de Cotia e Itapecerica da Serra.

De acordo com Costa, é

[...] a paisagem agrária, sem dúvida alguma, a predominante, não apenas pelas marcas ali presentes, como por constituir a verdadeira força econômica dessa extensa área suburbana. Já se chegou a considerá-la, até, um dos celeiros agrícolas da Capital paulista - expressão um tanto forte, se bem que até certo ponto exata, sobretudo em relação à área de Cotia. [...]

Muitos fatores concorreram para que a região em estudo fosse dominada pela vida agrícola. Além das condições naturais, até certo ponto favoráveis, cumpre salientar, desde logo, a presença de um insaciável mercado consumidor - o da Capital paulista, à qual essa área suburbana se vê ligada [...] (1958, p. 113-114, grifo da autora). 
Porém, é importante ressaltar o contraponto que Penteado faz já nessa época, de que “as zonas hortícolas e avícolas, localizadas nos subúrbios, já são insuficientes para atender às necessidades dos 3 milhões de habitantes da Capital" (1958, p. 57).

Para Costa, o fator que impulsionou a agricultura nessa área suburbana foi o imigrante:

Nem as condições físicas, nem a proximidade da cidade trimilionária explicariam, de maneira satisfatória, o incremento da agricultura regional; e tanto isto é uma verdade que a região viveu sonolenta e obscuramente durante dois ou três séculos. Fator decisivo foi a presença de imigrantes agricultores - italianos, portugueses, poloneses e, acima de tudo, japoneses (1958, p. 115, grifo da autora).

Seabra, em seu estudo sobre as cooperativas mistas do estado de São Paulo, cuja atenção maior se voltou para o estudo de caso da Cooperativa Agrícola de Cotia (CAC), também ressalta o desenvolvimento da atividade agrícola no entorno dos grandes centros urbanos, como o caso paulistano, que cresceu ao longo do século $\mathrm{XX}$, e do papel dos imigrantes estrangeiros, especialmente os japoneses, nessa atividade:

Parcela substancial da produção agrícola reclamada pelos grandes centros urbanos, representada pelos cereais, feijão, mandioca, carnes, açúcar, matérias primas como o amendoim, o algodão etc., foi sendo obtida em geral em áreas cada vez mais distantes e, até mesmo no exterior. Mas, a presença destes grandes centros estimulou também o aparecimento, em seus arredores mais ou menos imediatos de atividades agrícolas voltadas para a produção de gêneros alimentícios geralmente muito perecíveis in natura e com funções alimentícias habitualmente diferentes dos produtos anteriormente citados. Trata-se dos produtos hortifrutigranjeiros, a cujo consumo estava habituada parte da população constituída de imigrantes e seus descendentes e que vinha entrando no país em números consideráveis desde a segunda metade do século XIX. [...]

As razões mais fortes que justificam a maior expansão do referido cinturão em torno de São Paulo ligam-se às características da população que participou ativamente da marcha do café e, predominantemente, no crescimento demográfico da cidade de São Paulo, até por volta da Segunda Guerra Mundial: os imigrantes estrangeiros.

Estes tiveram sem dúvida papel importante, tanto na implantação destas áreas de produção como no incremento dos hábitos de consumo destes gêneros pelo centro urbano paulistano, cuja população apresentava-se com uma parcela considerável de italianos, portugueses, espanhóis, japoneses, alemães etc. e seus descendentes, sobretudo no decorrer dos 30 ou 40 primeiros anos deste século [do século XX].

$\mathrm{Na}$ implantação destas atividades produtivas, os agricultores vinculados a uma destas coletividades de origem estrangeira tiveram um papel fundamental. Trata-se dos japoneses e seus descendentes [...]. 
Estes imigrantes japoneses, primeiramente, vindos para o Brasil para trabalhar temporariamente como colonos nas lavouras de café e retornarem a seu país de origem, acabaram desde logo encontrando em outras atividades agrícolas maiores possibilidades de êxito econômico. Começavam a entrar em São Paulo a partir de um momento em que a criação de mercados internos, a industrialização, as crises do café, passavam a possibilitar à população rural outras alternativas que aquelas ligadas ao trabalho assalariado nas fazendas de café (1973, p. 6).

Seabra conta que o governo japonês, para coordenar as atividades econômicas desses imigrantes e seus descendentes, ajudou a criar cooperativas agrícolas mistas, que foi o caso da CAC e da Cooperativa Agrícola Sul-Brasil (1973, p. 7). Conforme mostra seu estudo, a atuação da CAC foi essencial para muitos desses agricultores, pois o cooperado podia contar com assistência técnica, compra de insumos como fertilizantes e agrotóxicos, além de vender seus produtos via cooperativa. Sobre a CAC, Costa destaca seu papel, indicando que além

[...] do amparo técnico-científico dado aos seus associados (através de orientação e ensinamentos, do fornecimento de sementes selecionadas, de adubos e de maquinaria agrícola), essa notável organização facilita o transporte dos produtos e proporciona assistência médico-social (1958, p. 129).

Costa fala mais sobre a origem desses imigrantes japoneses: alguns vieram do Japão, outros do interior do estado de São Paulo, tanto de áreas próximas como Ibiúna, Piedade e Registro, como de áreas mais distantes, como Marília e Lins (1958, p. 115). Ela ainda conta que "Os primeiros japoneses fixaram-se na região em 1913. Em 1920, cerca de 50 famílias dedicavam-se à cultura da batata no bairro do Moinho Velho ${ }^{6}$, em terras do município de Cotia" (1958, p. 115).

O relato de Costa sobre a forma como a agricultura era praticada por esses imigrantes é, no mínimo, interessante:

\footnotetext{
${ }^{6} \mathrm{O}$ município de Cotia foi objeto de estudo de Ana Fani Alessandri Carlos em A (re)produção do espaço urbano. O bairro do Moinho Velho é citado, e ilustra como a mancha urbana da metrópole paulistana cresceu ao longo do século XX, alcançando outros municípios. Carlos conta que: "Pouco restou da paisagem das chácaras (estas se distanciam mais de São Paulo em direção a São Roque, Ibiúna) ou dos pioneiros japoneses (o local onde plantavam batatas, no Moinho Velho, se transforma numa área com indústrias e bairros operários)" (CARLOS, 2008, p. 70). Em outro trecho, ela também deixa claro como a mancha urbana se expandiu para Cotia: "A indústria, aos poucos, foi ocupando [...] o lugar da atividade hortifrutigranjeira. As transformações em Cotia, que ocorrem a partir dos anos [19]70, baseadas na atividade industrial, invertem o processo, levando a uma intensa valorização das áreas [...] e expulsando outras atividades para o interior, ou, ainda, para outros municípios" (CARLOS, 2008, p. 103). Essa constatação da autora indica o que Azevedo já havia indicado: a cidade se expandiu, principalmente, no eixo leste-oeste, devido à ausência de barreiras como as encontradas no eixo norte-sul do município.
} 
Onde quer que se localizem, imprimem os japoneses sinais iniludíveis de sua presença. São as culturas intensivas. É o cuidadoso arranjo de suas propriedades, caracterizadas pelas linhas geométricas dos canteiros, pelo terraceamento das encostas, pelas canaletas abertas nas várzeas, para a drenagem ou para a irrigação. As técnicas que empregam, que muito têm de jardinagem, contrastam de maneira evidente com as dos agricultores nacionais, sobretudo os caipiras, que não sabem compor suas propriedades, tudo fazem de maneira empírica e só utilizam processos atrasados e deficitários (1958, p. 116, grifo nosso).

Ainda sobre a forma como esses agricultores japoneses trabalhavam, Costa conta que o adubo era

[...] empregado abundantemente, quer o animal [...] quer o mineral [...] Comum é o uso de arados, de bico ou de discos, de propriedade do agricultor ou tomados de empréstimo da "Cooperativa Agrícola de Cotia". Além disso, generalizado é o emprego de medicamentos destinados ao combate às pragas ou à proteção das plantas cultivadas, como também a utilização de sementes selecionadas (1958, p. 117, grifo da autora).

As palavras de Costa deixam clara a participação da cooperativa na atividade agrícola dos japoneses. Também é importante observar como a autora enxerga a agricultura praticada por esses imigrantes, como algo feito com cuidado e com a utilização de técnicas modernas, ao contrário dos caipiras da região. Sua comparação é um tanto preconceituosa, deixando claro a sua visão de que os caipiras representavam o atraso no campo:

Chocante é o contraste existente entre as propriedades cultivadas por japoneses e as que estão sob a guarda de caipiras locais. [...] Em regra, o caipira, mesmo possuindo terra própria, prefere trabalhar como "agregado" dos japoneses, como "diarista" ou "caseiro" nos sítios de recreio, ou prestar serviços nas olarias e nas áreas de extração de madeiras ou fabrico do carvão.

É profundamente triste constatar que sua ignorância, seu fatalismo, sua inércia, falta de ambição e desconhecimento da técnica mais rudimentar refletem-se nas propriedades em que trabalham por conta própria. O caipira não sabe aproveitar convenientemente o solo, nem consegue auferir lucros com o que produz. Alega com frequência que a terra não presta ou está cansada, mesmo quando, ao lado, exista uma bem organizada e próspera propriedade de japoneses. Via de regra, suas lavouras não chegam para atender às necessidades da própria subsistência; em canteiros assimétricos e desalinhados, plantam pequena roça de milho, exíguo mandiocal, umas poucas verduras e flores; [...]

Sua técnica de cultivo é praticamente inexistente, pois, em regra, não emprega adubos, não utiliza o arado, desconhece remédios contra as pragas, não se preocupa em selecionar as sementes [...] (1958, p. 123). 
A diferença de agricultura praticada entre os japoneses e os caipiras da região também apareceu nas falas de alguns dos membros da Cooperativa Agroecológica dos Produtores Rurais e de Água Limpa da Região Sul de São Paulo (Cooperapas) entrevistados para esse trabalho ${ }^{7}$. Mauri da Silva e Ana Zilda Coutinho, conhecida como Ana do $\mathrm{Mel}^{8}$, comentaram nas entrevistas que seus avós e pais não usavam agrotóxicos nem adubos químicos. No caso de Ana do Mel, o principal motivo era o preço proibitivo dos produtos. Mauri trabalhou para um japonês e contou que começou a ter problemas, como irritações, e seu avô culpava o uso dos agrotóxicos da plantação. Já Ernesto Oyama, neto de japoneses e cujo pai chegou a ser cooperado da CAC, lembra de ajudá-lo a mexer com os agrotóxicos:

Eu lembro do meu pai, sabe aquelas capas amarela de chuva? Aí ele colocava um saquinho de plástico na cara, com um pedaço de pano... e ficava tacando [agrotóxico] no tomate. Lembro muito bem disso. Lembro dele passando mal, indo pro hospital. Mas não parava né... e não vencia, os bichos vinham, aí tinha que por mais e mais. Tacando herbicida. Ele passava muito mal quando tacava herbicida. Isso eu me lembro muito bem (informação verbal) ${ }^{9}$.

Ana do Mel relembra que seu avô arrendava terra para os japoneses:

Ele [seu avô] achava engraçado como os japoneses trabalhavam anos nessa terra, depois deixavam e arrendavam outra terra. E a que eles deixavam só nascia sapê.

Já naquela época eles [familiares e pessoas conhecidas] já comentavam: "nossa, que será que os japoneses fazem que planta, planta, e depois não nasce nada?".

Meu avô colocava animais, acabava recuperando a terra e depois arrendava de novo (informação verbal) ${ }^{10}$.

Ana do Mel ainda explica na entrevista que seu avô, no início, não sabia nem o que eram agrotóxicos e adubos químicos. Ela conta que as pessoas da época de seu avô, as quais desconheciam essas novas técnicas agrícolas, perguntavam-se: "Como japonês chega, planta... que japonês faz pra produzir tanto? Eles ficavam assustados porque japonês produzia muito" (informação verbal) ${ }^{11}$. Hoje, ela acha interessante que a agricultura a qual

\footnotetext{
${ }^{7}$ Sobre os agricultores e a cooperativa, esses temas serão tratados nos capítulos 2 e 3 respectivamente.

${ }^{8}$ Ao longo do trabalho, optei por citar as pessoas como são usualmente chamadas no meio em que vivem. Portanto, na maioria dos casos, elas aparecerão pelo primeiro nome ou apelido, e não pelo seu sobrenome.

${ }^{9}$ Entrevista concedida por Ernesto Oyama, na Casa de Agricultura Ecológica, na Subprefeitura de Parelheiros, em São Paulo, em 19 de janeiro de 2015.

${ }^{10}$ Entrevista concedida por Ana Zilda Coutinho em seu sítio, no município de Embu-Guaçu, em 20 de janeiro de 2015.

${ }^{11}$ Ibidem.
} 
sempre foi praticada por seu avô, pai e por ela mesma, é considerada como orgânica e agroecológica, e passou a ser valorizada como uma prática muito mais correta para gerar menos impacto negativo no meio ambiente e na saúde de quem consome esses alimentos.

Conforme o resgate histórico feito anteriormente, a agricultura ainda hoje encontrada em Parelheiros, Marsilac e nos municípios vizinhos, ganhou força no século XX, com a chegada dos imigrantes, especialmente os japoneses. Muitos se dedicaram à horticultura, porém, culturas como a batata também tiveram destaque. Um dos atuais cooperados, Zundi Murakami, foi um grande produtor dessa cultura na região de Parelheiros.

Se a agricultura ganhou força no século XX no município de São Paulo - ainda que não tenha se tornado uma atividade econômica tão expressiva como a indústria e os serviços a cidade também cresceu e se expandiu. O crescimento da mancha urbana tomou grandes proporções e, em décadas, conurbou-se com municípios vizinhos. A figura 1.1 e o mapa 1.3 após a figura deixam claro a que proporções chegou a mancha urbana da metrópole paulistana.

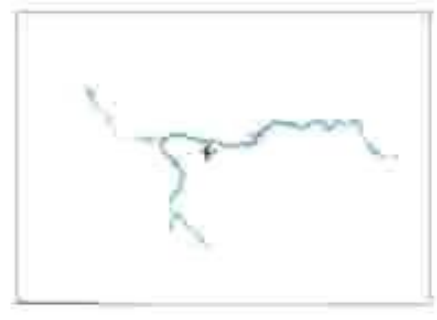

1881

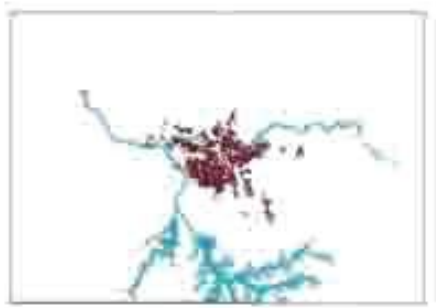

1930

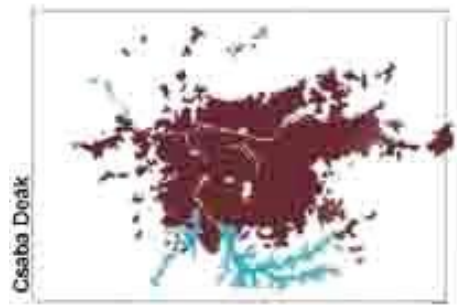

1972

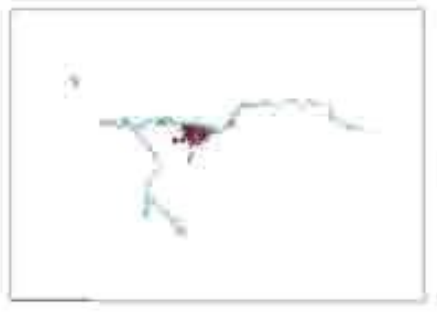

1905

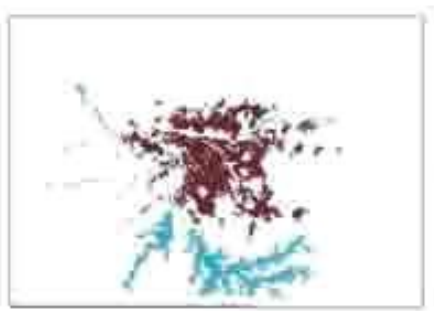

1952

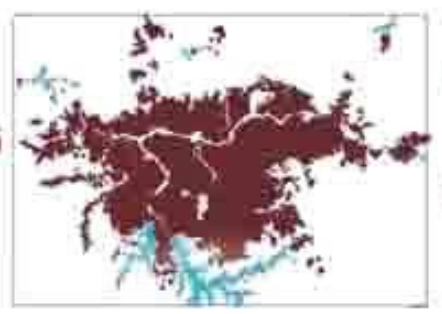

1983

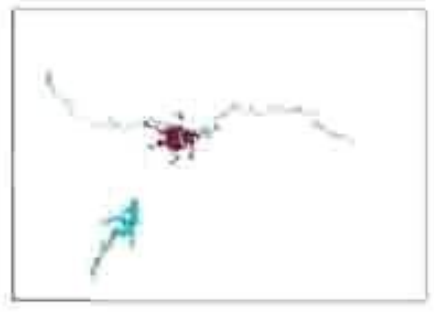

1914

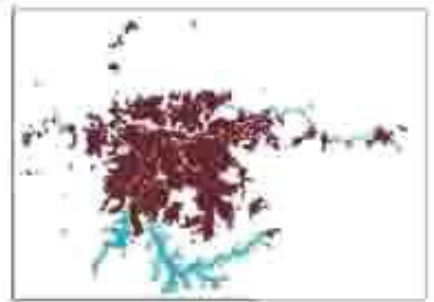

1962

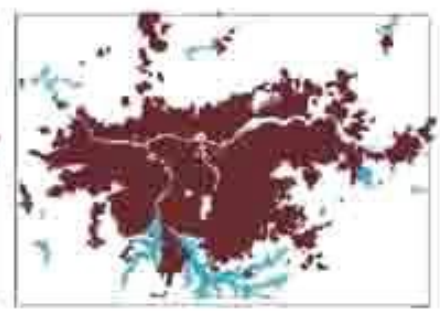

1995

Figura 1.1. Crescimento da mancha urbana de 1881 a 1995 de São Paulo, que alcançou municípios vizinhos. Fonte: DEÁK, Csaba (Org.). Evolução da mancha urbana 1881-1995. FAU-USP. Disponível em: 〈http://www.fau.usp.br/docentes/depprojeto/c_deak/CD/5bd/1rmsp/m02-evol/index.html>. Acesso em: 30 jun. 2016. 
Mapa 1.3. Mancha urbana da metrópole de São Paulo

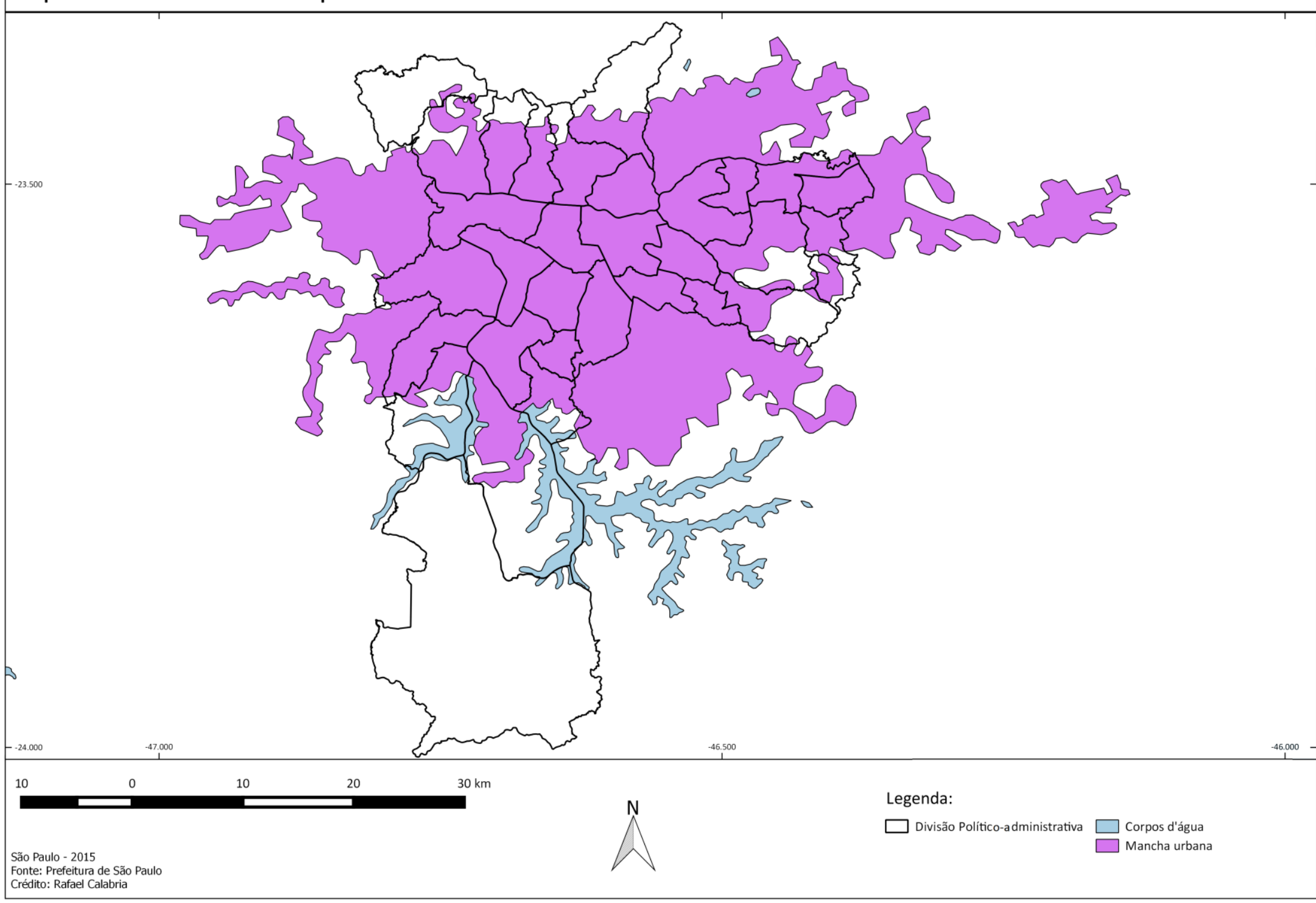


É interessante ressaltar, junto com a montagem das imagens e do mapa anteriormente, a leitura que Carlos faz a respeito da mancha urbana e seu crescimento:

O processo do espaço urbano cotidiano está inter-relacionado ao processo de reprodução espacial da metrópole, que, ao desenvolver-se, tende a ampliar seus limites territoriais formando uma mancha urbana, a qual apesar de concentrada, apresenta tendência a espalhar-se como se fosse uma mancha de óleo, através da incorporação de novos espaços e da transformação e reestruturação de "velhos". Todavia não se apresenta, necessariamente, como contínua. O desenvolvimento da mancha urbana da capital paulista dá-se principalmente no sentido leste-oeste - já que encontra duas barreiras: a Serra da Cantareira, ao norte, e as represas ao sul. [...] (CARLOS, 2008, p. 65).

Carlos, aqui, levanta o mesmo aspecto já apontado por Azevedo no início desse capítulo: a Serra da Cantareira, ao norte, e as represas, ao sul, foram barreiras para a expansão da mancha urbana paulistana.

Essa conurbação, observada na imagem e no mapa, gerou o que se conhece como a metrópole paulistana. Scarlato explica que:

[...] o termo metrópole se refere não somente à cidade-mãe mas a todo o espaço em conurbação com a mesma, formando um todo complexo e profundamente integrado, hoje conhecido como área ou região metropolitana.

As metrópoles são a forma mais aguda do processo de concentração espacial que o capitalismo engendrou neste século. Em nenhum outro momento da sua história o capital foi capaz de erigir formas de aglomeração urbana de tal magnitude e complexidade.

Os países capitalistas desenvolvidos foram os primeiros a apresentar esse tipo de espacialização do fenômeno urbano. Londres, Nova Iorque, Paris, Tóquio, mesmo antes da Segunda Guerra Mundial, já apresentavam intensos processos de conurbação. Porém, no Brasil somente com a industrialização, em decurso após os anos [19]50, a configuração de regiões metropolitanas consolidou-se. Ela resultou do intenso processo de concentração das atividades secundárias e terciárias em expansão nos centros urbanos que já representavam polos regionais de crescimento econômico e que se desenvolviam no interior da sociedade agroexportadora brasileira (2005, p. 432).

Sobre o papel da metrópole no processo de produção do urbano, Carlos fala que

[...] o processo de produção do urbano ocorre, hoje, a partir de um processo de universalização da divisão do trabalho e das trocas, em função das estratégias gerais no nível da formação econômica da sociedade capitalista. Trata-se de um espaço mundial dividido, diferenciado, hierarquizado e antagônico, onde a metrópole tem, estrategicamente, o papel de comando na 
articulação das parcelas desse espaço, na medida em que se concentra $o$ poder financeiro, político e econômico $(2008$, p. 98).

Para compreender como se deu essa intensa urbanização brasileira, especialmente São Paulo, é preciso pensar que "A reprodução do espaço brasileiro hoje é fruto de um processo histórico de desenvolvimento das forças produtivas que desde a sua origem repousa na “divisão internacional do trabalho [...]" (CARLOS, 2008, p. 47), pois a

[...] cidade é essencialmente o locus da concentração de meios de produção e de concentração de pessoas; é o lugar da divisão econômica do trabalho [...], é o lugar da divisão social do trabalho dentro do processo produtivo e na sociedade e é também um elo na divisão espacial do trabalho na totalidade do espaço (tanto no nível local, regional, nacional, como no internacional) (CARLOS, 2008, p. 83-84).

De acordo com Carlos, essa produção e reprodução, no caso do espaço urbano brasileiro, fundamenta-se nas desigualdades. Ela conta que:

[...] a produção do espaço urbano fundamenta-se num processo desigual; logo o espaço deverá, necessariamente, refletir contradições.

No caso do uso produtivo do espaço, este será determinado pelas características do processo de reprodução do capital; [...]

Entretanto, o modo de utilização será determinado pelo valor que, em seu movimento, redefine constantemente a dinâmica da utilização do solo.

Tal dinâmica conduz, de um lado, à redistribuição do uso de áreas já ocupadas, levando a um deslocamento de atividades e/ou dos habitantes, e de outro, à incorporação de novas áreas que importam em novas formas de valorização do espaço urbano. No caso das grandes cidades, por exemplo, ocorre geralmente a deterioração do centro e/ou das áreas centrais, que passam a ser ocupados por casas de diversão noturna, pensões, hotéis de segunda classe, zonas de prostituição. Isso faz com que os chamados "bairros ricos" localizados próximo às áreas centrais sofram uma mudança de clientela; os antigos moradores "fogem" para áreas privilegiadas mais afastadas, surgindo os bairros-jardins, as chácaras, os condomínios "fechados". É a moradia como sinônimo de status.

A população mais pobre também procura as áreas mais distantes, mas por outros motivos: os terrenos são mais baratos, pois há ausência de infraestrutura e existe a possibilidade da autoconstrução. [...] (2008, p. 51).

O desenvolvimento urbano da metrópole paulistana e suas desigualdades se intensificaram a partir do final da década de 1960, devido à expansão da economia brasileira:

É necessário que se diga que o período de 1968 a 1974 é marcado, no Brasil, por um período de expansão da economia brasileira, com aumento, a partir de 1970, das taxas de investimento e expansão do setor 
industrial, inclusive de bens de capital e das exportações. Todavia o processo de acumulação realizava-se de forma extremamente concentrada, espacial e socialmente; a época do milagre econômico é marcada pela compressão do piso salarial.

A paisagem urbana metropolitana refletirá assim a segregação espacial, fruto de uma distribuição de renda estabelecida no processo de produção. Tal segregação aparece no acesso a determinados serviços, à infraestrutura, enfim, aos meios de consumo coletivo. [...] (CARLOS, 2008, p. 55).

Ainda sobre as contradições que surgem na paisagem e no espaço urbano, Carlos explica que:

As contradições sociais emergem, na paisagem, em toda a sua plenitude, pois aqui os contrastes e as desigualdades de renda afloram, já que o acesso a um pedaço de terra, o tamanho, o tipo e material de construção vão espelhar mais nitidamente as diferenciações de classe. $\mathrm{O}$ acesso à habitação e aos meios de consumo coletivo serão diferenciados segundo a camada social que se localizará e morará de modo diferenciado na cidade. Teremos aqui suas características básicas. A primeira diz respeito à segregação espacial, tanto das pessoas de maior rendimento financeiro, como também das de menor poder aquisitivo. [...] (2008, p. 95).

Scarlato também fala sobre a relação infraestrutura e renda e como isso aparece no espaço urbano:

As discrepâncias quanto à existência de saneamento básico, de infraestrutura em transportes, iluminação, saúde e educação, registradas entre os bairros das cidades brasileiras, principalmente nas grandes metrópoles, estão associadas às diferenças nas rendas das famílias. Os bairros onde se registram as mais baixas rendas são sempre os menos bem equipados (2005, p. 400).

Essas discrepâncias do espaço urbano aparecem nos dados referentes à qualidade de vida da população. A tabela a seguir (1.1) traz o Índice de Desenvolvimento Humano Municipal (IDHM) do ano de 2010 no município de São Paulo. Esse índice leva em conta a longevidade, a educação e a renda. Os dados estão baseados a partir da divisão políticoadministrativa municipal. Os piores índices estão nas periferias.

Também é interessante observar os dados em mapas. Após a tabela, os mapas referentes à educação (1.4), rede hospitalar (1.5) e domicílios sem rede de esgoto (1.6) indicam as disparidades espaciais do município de São Paulo, e mostram, mais uma vez, como as regiões mais centrais têm melhores índices sociais e melhor infraestrutura. 
Tabela 1.1. Índice de Desenvolvimento Humano Municipal (IDHM) do município de São Paulo (2010)

\begin{tabular}{|l|c|}
\hline \multicolumn{1}{|c|}{ DIVISÃO POLÍTICO- } & IDHM \\
\hline Aricanduva / Vila Formosa & 0,822 \\
\hline Butantã & 0,859 \\
\hline Campo Limpo & 0,783 \\
\hline Capela do Socorro & 0,750 \\
\hline Casa Verde & 0,799 \\
\hline Cidade Ademar & 0,758 \\
\hline Cidade Tiradentes & 0,708 \\
\hline Ermelino Matarazzo & 0,777 \\
\hline Freguesia do Ó / Brasilândia & 0,762 \\
\hline Guaianases & 0,713 \\
\hline Ipiranga & 0,824 \\
\hline Itaim Paulista & 0,725 \\
\hline Itaquera & 0,758 \\
\hline Jabaquara & 0,816 \\
\hline Jaçanã / Tremembé & 0,768 \\
\hline Lapa & 0,906 \\
\hline M'Boi Mirim & 0,716 \\
\hline Mooca & 0,869 \\
\hline Parelheiros & 0,680 \\
\hline Penha & 0,804 \\
\hline Perus & 0,731 \\
\hline Pinheiros & 0,942 \\
\hline Pirituba / Jaraguá & 0,787 \\
\hline Santana / Tucuruvi & 0,869 \\
\hline Santo Amaro & 0,909 \\
\hline São Mateus & 0,732 \\
\hline São Miguel Paulista & 0,736 \\
\hline Sé & 0,889 \\
\hline Vila Mariana & 0,938 \\
\hline Vila Maria / Vila Guilherme & 0,793 \\
\hline Vila Prudente & \\
\hline
\end{tabular}

Legenda: O IDHM leva em conta a longevidade, a educação e a renda. Quanto mais próximo de 1,0, melhor o índice; quanto mais próximo de 0 , pior.

Fonte: ATLAS DO DESENVOLVIMENTO HUMANO NO BRASIL. Consulta. Disponível em: <http://www.atlasbrasil.org.br/2013/pt/consulta>. Acesso em: 28 set. 2016. 
Mapa 1.4. Taxas de analfabetismo da população de 15 anos e mais no municipio de São Paulo (2010)

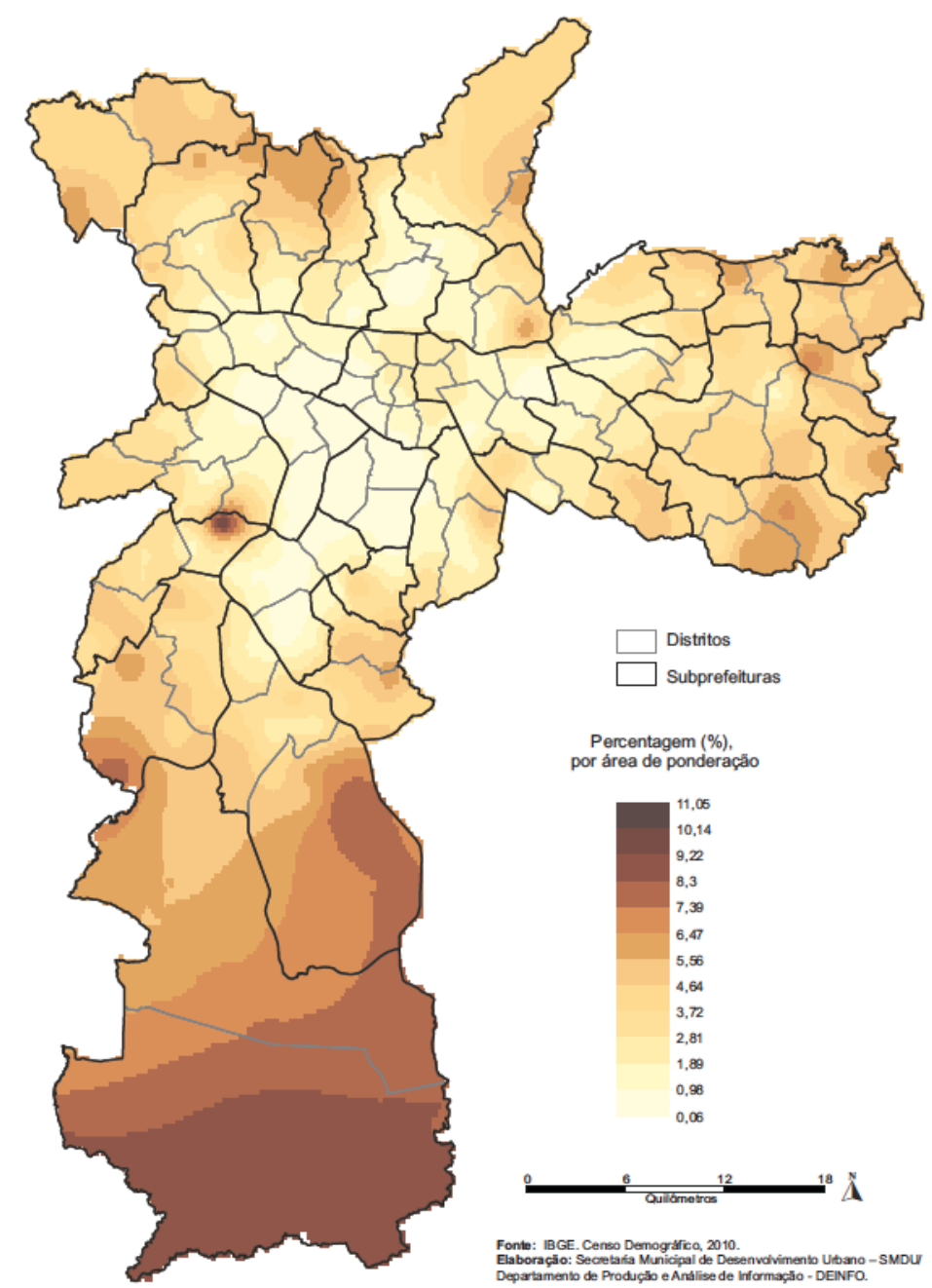

Mapa 1.5. Rede hospitalar do município de São Paulo (2014)

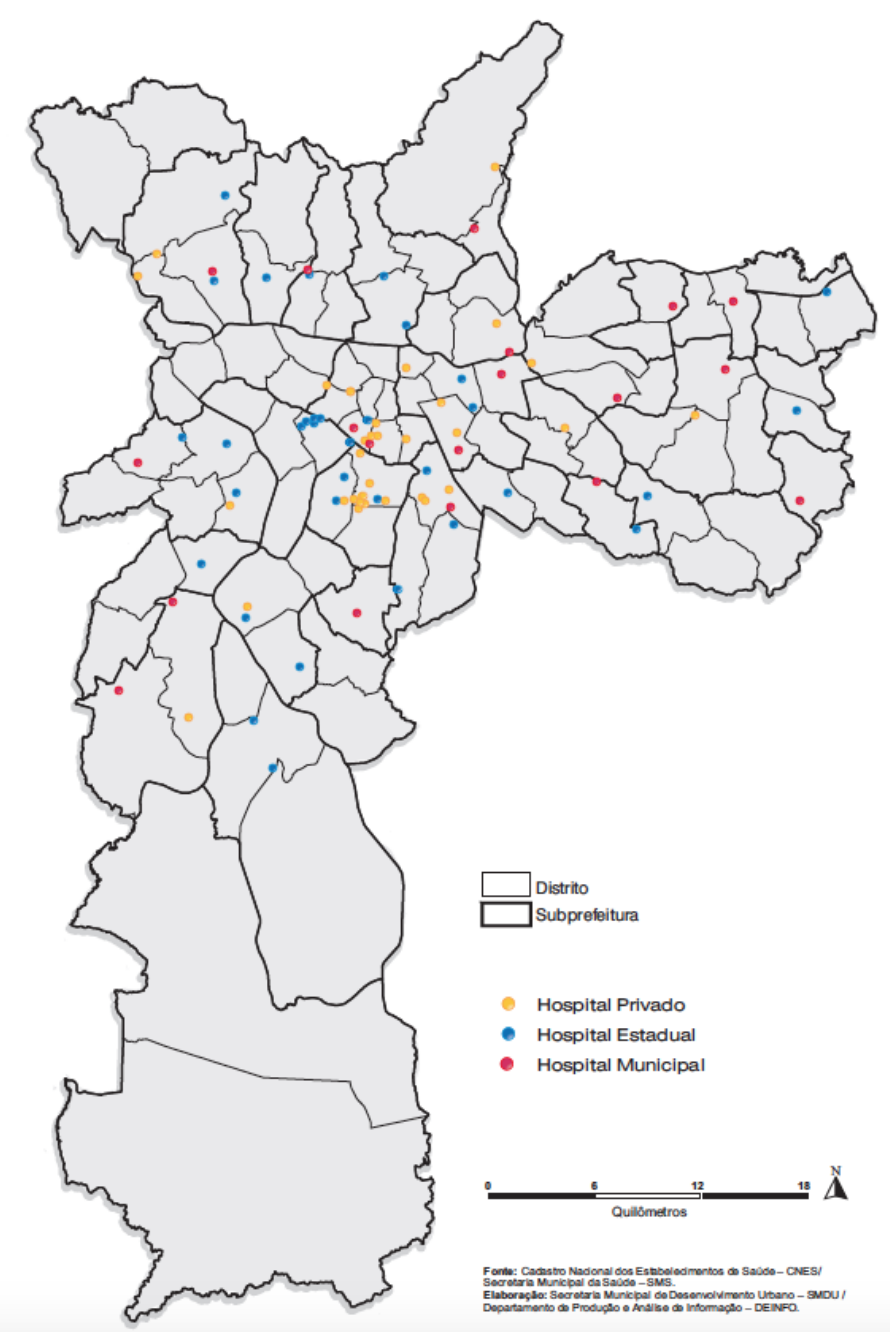


Mapa 1.6. Domicílios sem rede esgoto no município de São Paulo (2010)

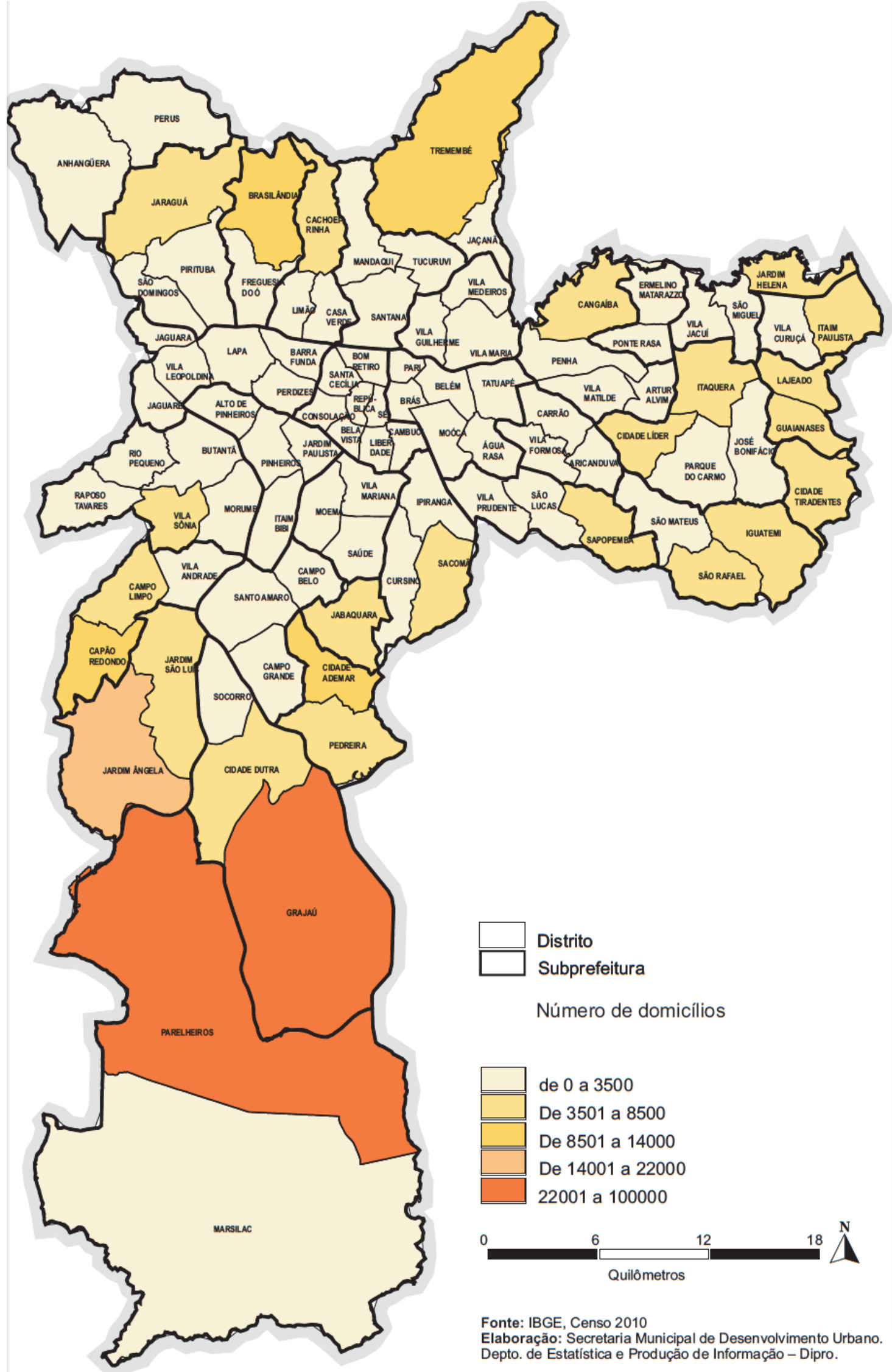


Assim, a produção e reprodução do espaço urbano brasileiro, além de se dar por meio da desigualdade e das contradições sociais, também ocorre com uma série de deficiências, como a falta de infraestrutura, habitação, emprego, transporte e saneamento, principalmente nas periferias pobres distantes dos centros. Porém é importante ressaltar que uma outra periferia rica também surge, de uma parcela da população com maior poder aquisitivo, a qual "foge" para áreas mais distantes em busca de uma vida com mais segurança e tranquilidade, geralmente dentro de condomínios de alto padrão: "No caso específico da região metropolitana, a mancha urbana que tem seu nó na capital apresenta na periferia dois fenômenos; se por um lado encontramos áreas destinadas a residências de uma classe de baixo poder aquisitivo, o contrário também é verdadeiro" (CARLOS, 2008, p. 172).

Ao mesmo tempo em que ocorre a produção e reprodução desigual desse espaço urbano, a mancha urbana se expande e as classes sociais de baixa renda vão em busca de terrenos baratos cada vez mais distantes do centro da cidade, em locais com precária infraestrutura. Por outro lado, nas zonas mais centrais ocorre a verticalização, a fim de aproveitar melhor os bairros com mais infraestrutura e transporte. Conforme Scarlato explica:

[...] nas áreas urbanas localizadas nos pontos centrais, o valor que os lotes vão adquirindo estimula a verticalização, ou seja, o surgimento do chamado solo criado, cada vez menos acessível às camadas de baixa renda, que são obrigadas a procurar a periferia das grandes cidades para adquirir a propriedade ou para pagar aluguéis mais baratos.

A verticalização nas áreas centrais das grandes cidades, em especial nas regiões metropolitanas, acaba beneficiando-se das infraestruturas urbanas existentes, como o sistema de saneamento, a drenagem das águas pluviais, a eletrificação, o abastecimento de água, as ruas pavimentadas, bem como da grande quantidade de atividades e de serviços públicos e privados.

Ao mesmo tempo em que ocorre a verticalização nos centros, as cidades expandem-se em direção às áreas periféricas, o que se chama expansão horizontal. Esta última geralmente é acompanhada de precárias condições de infraestrutura. [...] as periferias metropolitanas presenciam formas de assentamento nascidas de loteamento geralmente feito por empresas clandestinas que, iludindo a boa-fé das populações de baixa renda, vendem lotes grilados em áreas públicas e privadas. Hoje, grande parte dos bairros das periferias metropolitanas brasileiras encontra-se com problemas jurídicos em relação ao direito de propriedade sobre os lotes, nos quais, através do processo da autoconstrução, edificaram suas residências (2005, p. 435-436).

Scarlato ainda explana que esse processo de urbanização brasileiro com problemas jurídicos gerou uma cidade legal e outra ilegal (foto 1.1, na página a seguir): 
O processo de urbanização brasileira, que se desenvolveu desde a consolidação das relações capitalistas de trabalho, quando o trabalhador teve que negociar no mercado imobiliário sua moradia, acabou gerando no interior de cada cidade a existência de duas cidades: a legal e a ilegal.

A primeira resulta de um processo de apropriação e uso do solo urbano que se enquadra dentro das normas técnicas dos códigos de obras e que está garantido pelas formas regulares do direito de propriedade. A segunda resulta de formas de grilagem e loteamento feitos por empresas imobiliárias que atuam na clandestinidade, iludindo a boa-fé dos trabalhadores de baixa renda, ou então de ocupações de terrenos públicos e privados por pessoas impelidas pela necessidade de um lugar para morar. Em sua grande maioria, são precárias as construções desse segundo tipo de cidade, encontrando-se em geral fora das normas técnicas exigidas por lei.

Legalidade e ilegalidade representam o verso e o reverso de uma urbanização na qual a moradia representa a mais cara mercadoria, cuja posse e propriedade é a grande garantia de sobrevivência e que se adquire no jogo da especulação imobiliária (2005, p. 400-401, grifo do autor).

Carlos também ressalta que "As favelas localizam-se nas áreas onde a propriedade privada da terra em princípio não exerce seu poder, isto é, terras da prefeitura ou áreas em litígio" (2008, p. 53, grifo nosso).

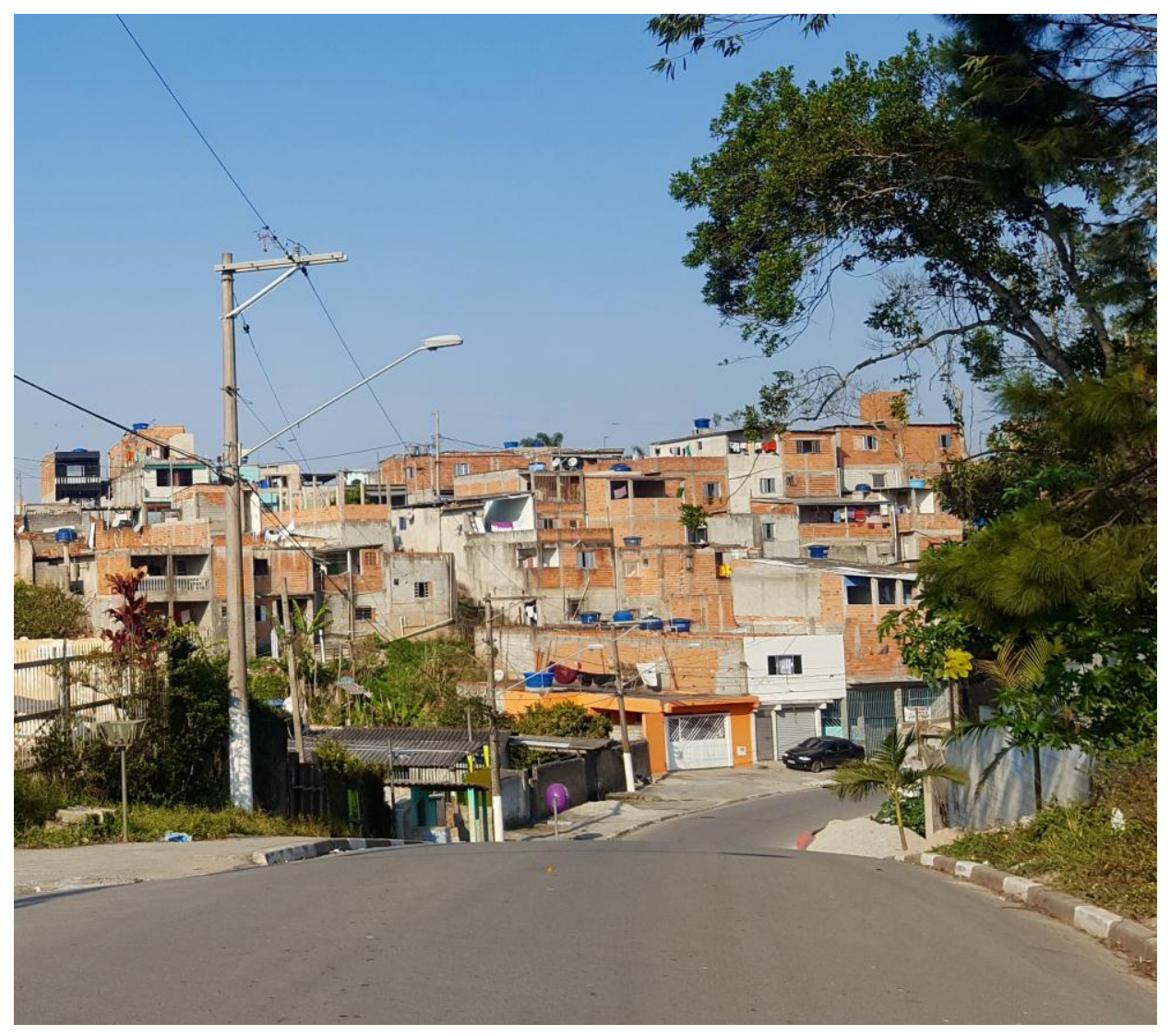

Foto 1.1. Bairro no distrito de Parelheiros que se formou a partir de invasões irregulares de terra. Foto de 4 de agosto de 2016. Crédito da foto: Angélica Campos Nakamura. 
A partir de Scarlato e Carlos, percebe-se que a questão da propriedade da terra no espaço urbano e a sua consequente especulação é um dos fatores determinantes na geração da desigualdade. Carlos afirma que “A ‘especulação' fundamenta-se no fato de que a habitação e a terra são componentes essenciais da reprodução dos homens (a necessidade de abrigo), além de ser símbolo de status e ascensão social, que tem um valor de troca" (2008, p. 96). Carlos ainda explica que

No urbano, a terra deixa de ser um instrumento de produção imediata, um bem da natureza, como o é no campo. E mesmo a questão da terra ser um bem finito, que não pode ser criado pelo trabalho, no contexto urbano, ganha um novo sentido, na medida em que a reprodução do espaço urbano não ocorre apenas através da incorporação de novas áreas, mas também a partir de espaços construídos. O processo de verticalização é um exemplo. [...]

O espaço geográfico, produzido pelo processo de trabalho, não é exterior à sociedade, mas um produto, feito à sua imagem e semelhança. $\mathrm{O}$ espaço geográfico nasce do processo de construção material da sociedade, no processo de trabalho, ao contrário da terra, que não é produto do trabalho (a terra "em si", terra matéria, será entendida como instrumento de produção) (2008, p. 169).

Sobre a questão da terra não ser produto do trabalho e sua valorização no espaço urbano, Carlos levanta um dilema:

As considerações sobre a terra urbana, do ponto de vista do processo de produção da cidade, nos colocam diante de um dilema, ou melhor, de uma contradição, que não parece ser apenas aparente.

a. De um lado, parece evidente (e até óbvio) que a terra não é produto do trabalho, logo não tem valor. [...]

b. Por outro lado, o espaço geográfico, como produto do trabalho geral da sociedade, aparece, através da cidade, como trabalho materializado.

O desenvolvimento dessa ideia, do ponto de vista geográfico, nos dirige para o perigoso caminho que as "parcelas" do espaço, apropriadas individualmente pela propriedade privada da terra, especialmente através da compra-venda, mediada pelo mercado, quer em função de sua utilidade como meio de vida -, quer da perspectiva da valorização do capital - como condição da produção material - ou ainda pela perspectiva da comercialização da terra, ocorrem pelo fato de a terra, como uma parcela do espaço, ter valor (de uso e de troca) (2008, p. 168-169).

Como a terra, que não tem valor por não ser produto do trabalho, passa a ter, a ponto de chegar a preços exorbitantes no espaço urbano? Martins traz uma explicação sobre como a terra passa a ter valor: 
A terra é, pois, um instrumento de trabalho qualitativamente diferente dos outros meios de produção. Quando alguém trabalha na terra, não é para produzir a terra, mas para produzir o fruto da terra. $\mathrm{O}$ fruto da terra pode ser produto do trabalho, mas a própria terra não o é.

A terra não pode ser confundida com o capital; não pode ser analisada em suas consequências sociais, econômicas e políticas como se fosse capital igual àquele representado pelos outros meios de produção. Nesse sentido, ocorre em relação à terra o mesmo que ocorre com o trabalho. Este também não é produto do próprio trabalho, não contém valor. No entanto, o capital, monopolizando os meios de produção, impede que o trabalhador trabalhe por sua conta; só lhe resta trabalhar para o capital. Assim, através da separação radical entre o trabalhador e os meios de produção de que ele necessita para trabalhar, o capital cria as condições para se apropriar do seu trabalho, para fazer com que o trabalho apareça como parte do capital quando é comprado pelo capitalista. Assim como o capital pode se apropriar do trabalho, também pode se apropriar da terra; [...] assim como o capitalista precisa pagar um salário para se apropriar da força de trabalho do trabalhador; também precisa pagar uma renda para se apropriar da terra. Assim como a força de trabalho se transforma em mercadoria no capitalismo, também a terra se transforma em mercadoria. [...]

A tendência do capital é dominar tudo, subordinar todos os setores e ramos da produção e, pouco a pouco, ele o faz. [...] Como o capital tudo transforma em mercadoria, também a terra passa por essa transformação, adquire preço, pode ser comprada e vendida, pode ser alugada. [...] (1981, p. 159-160).

Ou seja, o capital torna a terra uma mercadoria. Oliveira ainda diz que

[...] a terra, no Brasil particularmente, adquiriu o caráter de "reserva de valor", ou seja, a terra é apropriada apenas com fins especulativos e não para produzir. Ou seja, os capitalistas, em decorrência da inflação quase permanente em nossa economia, vêem na terra um "investimento seguro", que não se "desvaloriza". É assim que se retém terrenos urbanos vazios e latifúndios inaproveitáveis (1986, p. 85, grifo do autor).

Portanto, apesar de a terra não possuir valor por não ser produto do trabalho, o capital a torna uma mercadoria, pois tudo subordina. No Brasil, de acordo com Oliveira, a terra ainda adquiriu um caráter de reserva de valor, ou seja, possuir terra se tornou um investimento seguro, pois, com o tempo, ela se valoriza cada vez mais ${ }^{12}$. No caso do espaço urbano, a valorização da terra

[...] se expressa através da localização, papel e grau de inter-relação com o espaço global, produzido, mesmo que seja potencial, dentro de condições específicas. [...]

\footnotetext{
${ }^{12}$ Para se ter uma ideia da valorização dos preços dos imóveis na cidade de São Paulo, uma pesquisa realizada pela Fundação Instituto de Pesquisas Econômicas (Fipe), estimou que entre 1975 e 2015 os valores de venda de imóveis aumentaram 103\% (ÉPOCA NEGÓCIOS, 2015).
} 
O processo de formação do preço da terra, como manifestação do valor das parcelas, leva em conta desde processos cíclicos da conjuntura nacional (que incluem a forma de manifestação de processos econômicos mundiais) até aspectos políticos e sociais específicos de determinado lugar. Todos esses fatores vinculam-se ao processo do desenvolvimento urbano, que, ao realizar-se, redefine a divisão espacial, e com isso o valor das parcelas. Este valor será determinado em função do conjunto ao qual pertencem, e é nesta inter-relação entre o todo e a parte que ocorre o processo de valorização do real ou potencial de cada parcela do espaço

Nesse sentido, os terrenos mais bem situados em relação às vias de comunicação, aos sistemas de transporte, à infraestrutura teriam maior valor, declinando à medida em que nos distanciássemos do centro em direção à periferia. [...] (CARLOS, 2008, p. 170-172).

Ainda que a terra, quanto mais distante do centro, seja menos valorizada por ter menos infraestrutura e serviços ${ }^{13}$, sua demanda não diminui. Afinal, as populações mais pobres acabam se dirigindo para essas periferias, a fim de buscar um local para habitar, componente essencial para a sua reprodução. O urbano acaba por englobar terras até então ociosas ou rurais (CARLOS, 2008, p. 170).

Esse processo de incorporação de terras, aqui no caso rurais, pelo espaço urbano é visível no extremo sul de São Paulo, onde ainda existem sítios ${ }^{14}$ de agricultores. Há tanto uma pressão imobiliária por essas áreas para que se tornem chácaras de lazer, como para a construção de casas para moradia. Como pesquisadora, faço parte do grupo de Whatsapp da Cooperativa Agroecológica dos Produtores Rurais e de Água Limpa da Região Sul de São Paulo (Cooperapas), a cooperativa estudada nesse trabalho - a qual será tratada mais detalhadamente no capítulo 3 - e, além dos assuntos sobre a cooperativa, o grupo também compartilha reclamações. Uma, muito presente, é a venda de lotes pela região de Parelheiros e Marsilac (foto 1.2, na página a seguir). De acordo com os participantes do grupo, que são agricultores e moradores, muitas dessas vendas são ilegais. Eles denunciam essa prática para a Prefeitura de São Paulo e para a Secretaria do Meio Ambiente do Estado de São Paulo por ser uma região de APA (Área de Proteção Ambiental) ${ }^{15}$, porém, medidas reais nunca são tomadas.

\footnotetext{
${ }^{13}$ Os preços mais baixos do metro quadrado no município de São Paulo estavam nos distritos de Arthur Alvim, cujo valor chegava a $\mathrm{R} \$ 3.243,00$, e Itaquera, a $\mathrm{R} \$ 3.436,00$, ambos na zona leste. Já os mais caros estavam no Jardim Europa, cujo valor alcançava R \$10.749,00, na zona oeste, e Vila Nova Conceição, com R\$ 11.336,00, na zona sul. Ambos na região da cidade considerada parte do centro expandido (TERRA, 2016).

${ }^{14}$ Ao longo do trabalho, será adotado o termo sítio para se referir às propriedades agrícolas. Optou-se por adotar esse termo porque é como tanto os agricultores, como os técnicos que trabalham na região, referem-se às propriedades.

${ }^{15}$ Mais sobre as Áreas de Proteção Ambiental será tratado mais à frente nesse capítulo.
} 


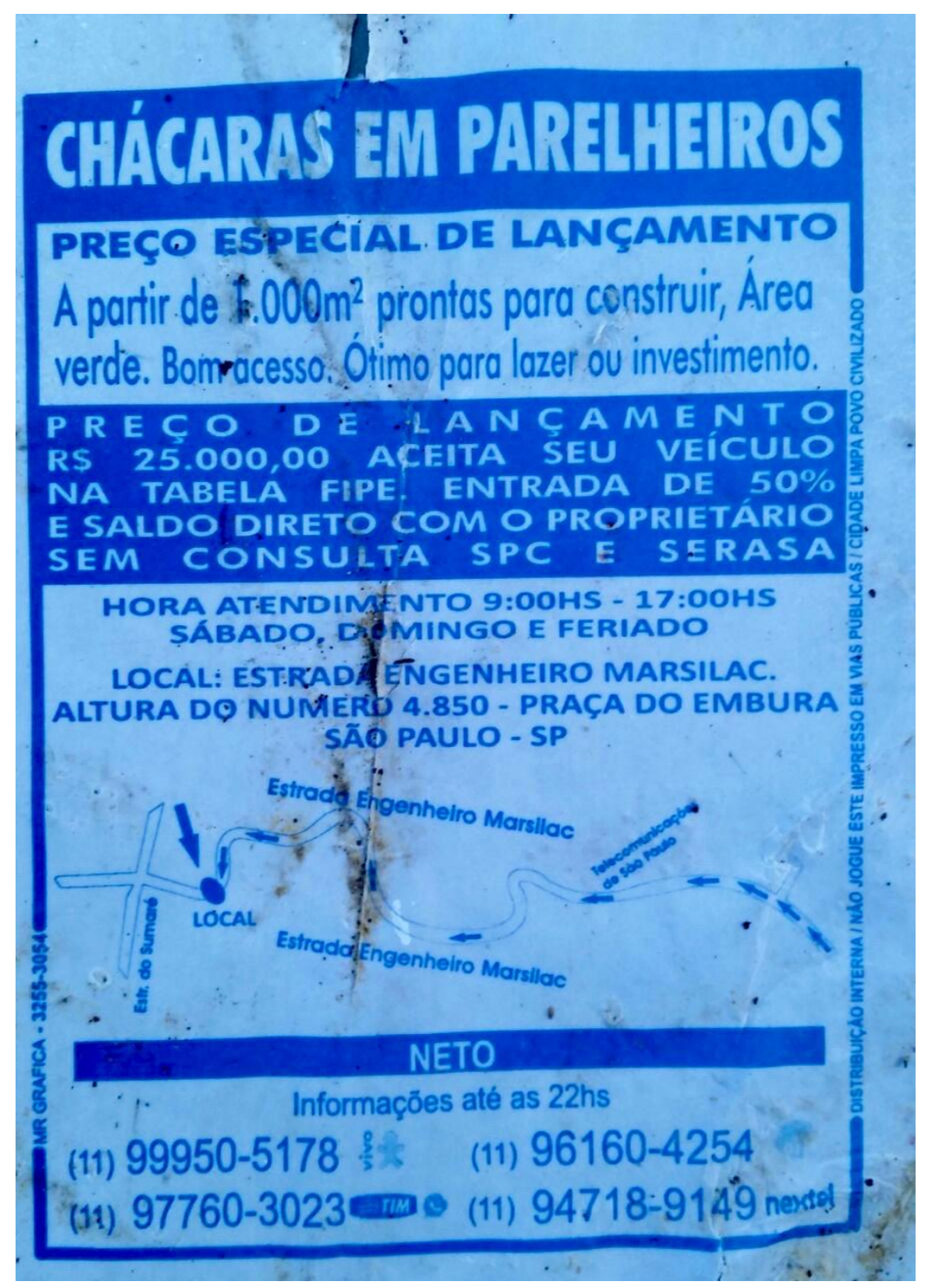

Foto 1.2. Foto de um panfleto recebido por um dos membros da Cooperapas e enviado para o grupo do Whatsapp, sobre a venda de chácaras em Parelheiros. Foto de 18 de fevereiro de 2016. Crédito da foto: foto recebida pelo grupo do Whatsapp da Cooperapas.

Um caso que exemplifica muito bem essa especulação imobiliária é o de Valéria Macoratti, presidenta da Cooperapas e agricultora. Valéria arrendava, até 2015, um sítio para produzir. O dono exigiu o terreno de volta, pois quer vendê-lo. Chegou a oferecê-lo para ela, por 13 milhões de reais.

Como foi apresentado até aqui, a região do extremo sul do município de São Paulo começou a ter uma atividade agrícola com mais destaque no início do século $\mathrm{XX}$, com a chegada dos grupos de imigrantes, principalmente dos japoneses. Apesar disso, uma agricultura tida como caipira já existia na região, a qual se diferenciava em muito das práticas adotadas pelos japoneses. Enquanto a primeira era vista como atrasada, rústica e com baixa 
produtividade, a dos nipônicos era considerada moderna, produtiva e organizada. Vale destacar que esse grupo de imigrantes teve apoio do próprio governo japonês, e um dos meios de incentivo foi a criação de cooperativas que ajudassem com insumos e técnicos agrícolas.

Porém, conforme será visto mais adiante nesse capítulo, a agricultura caipira voltou a ser valorizada, dessa vez com outra "roupagem", mas passou a ser vista como mais correta para a conservação do meio ambiente e para a saúde tanto dos produtores como dos consumidores.

Ainda, a mancha urbana da cidade de São Paulo cresceu em proporções gigantescas ao longo do século XX, gerando uma cidade extremamente desigual e excludente. Os locais que mais sofrem com a falta de infraestrutura e problemas sociais são as periferias pobres, distantes do centro da cidade. Essas periferias se expandiram alcançando regiões com agricultura no município, como o extremo sul. Os agricultores que lá vivem também enfrentam todos os problemas dessas periferias, além da especulação imobiliária sobre suas terras.

\subsection{Da ausência do Estado ao Estatuto da Cidade e a obrigatoriedade de um Plano Diretor}

Conforme visto no item anterior, o crescimento e o desenvolvimento das cidades brasileiras, aqui no caso com enfoque na metrópole de São Paulo, deu-se de forma desordenada, surgindo uma cidade com muitas desigualdades econômicas e sociais, além da carência de infraestrutura, principalmente nas periferias pobres. Scarlato faz uma crítica à posição do poder público em relação esse desenvolvimento, que se fez - e ainda faz - ausente ou desacertada:

A ação do Estado pouco variou enquanto se verificava a grande industrialização que comandava a produção do espaço metropolitano. Sua ação deu-se sempre no sentido de intervir para ajustar a desordem para o alto e para os lados de forma frenética, produzindo e reproduzindo novas e antigas formas de segregação espacial. O poder público, ao invés de atuar para superar a desordem urbana, limitou-se a "sacramentá-la" de forma paternalista, ou seja, urbanizando favelas e legitimando movimentos sociais urbanos $[\ldots]$

Pode-se assim dizer que a ação do Estado brasileiro em relação aos problemas da urbanização é marcada por profundas contradições nascidas de omissões e desacertos. A experiência das metrópoles brasileiras tem 
mostrado que tal ação está muito mais para o "caos urbano controlado", por mais contraditório que possa ser esta afirmação, do que para o planejamento urbano (2005, p. 460-461).

Porém, desde 1971, a lei federal obriga que os municípios com mais de 20 mil habitantes tenham um Plano Diretor:

Pela legislação federal há obrigatoriedade, desde 1971, da elaboração do Plano Diretor para municípios com mais de 20 mil habitantes. Em decorrência dele, os municípios criam as leis de zoneamento, com a finalidade de controlar a intervenção das imobiliárias e dos particulares nas áreas já assentadas e nas áreas passíveis de novos assentamentos. Com isso se orienta o processo de verticalização e as formas de uso do solo urbano, evitando seu grande adensamento. As leis de zoneamento urbano contribuem também para preservar as características paisagísticas, a qualidade de vida dos bairros nobres e a memória das cidades, ameaçadas pelo processo demolidor que o crescimento das empresas imobiliárias aciona (SCARLATO, 2005, p. 438).

Hoje, são os artigos 182 e 183, no capítulo II, da Constituição da República Federativa do Brasil de 1988, os quais estabelecem a política urbana brasileira. A Lei $\mathrm{n}^{0} 10.257$ de 10 de julho de 2001 é a que regulamenta tais artigos (BRASIL, 1988, 2001). Essa lei é denominada de Estatuto da Cidade e, em parágrafo único, "estabelece normas de ordem pública e interesse social que regulam o uso da propriedade urbana em prol do bem coletivo, da segurança e do bem-estar dos cidadãos, bem como do equilíbrio ambiental” (BRASIL, 2001). Ela está dividida em cinco capítulos, que tratam sobre as diretrizes gerais da lei, dos instrumentos da política urbana, do Plano Diretor, da gestão democrática da cidade e disposições gerais.

O capítulo III, que aborda o Plano Diretor, estabelece no art. 41 quando ele deve ser obrigatório:

Art. 41. O plano diretor é obrigatório para cidades:

I - com mais de vinte mil habitantes;

II - integrantes de regiões metropolitanas e aglomerações urbanas;

III - onde o Poder Público municipal pretenda utilizar os instrumentos previstos no $\S 4^{0}$ do art. 182 da Constituição Federal ${ }^{16}$;

\footnotetext{
${ }^{16} \mathrm{O} \S 4^{\circ}$ do art. 182 estabelece que: "É facultado ao Poder Público municipal, mediante lei específica para área incluída no plano diretor, exigir, nos termos da lei federal, do proprietário do solo urbano não edificado, subutilizado ou não utilizado, que promova seu adequado aproveitamento, sob pena, sucessivamente, de:

I - parcelamento ou edificação compulsórios;

II - imposto sobre a propriedade predial e territorial urbana progressivo no tempo;

III - desapropriação com pagamento mediante títulos da dívida pública de emissão previamente aprovada pelo Senado Federal, com prazo de resgate de até dez anos, em parcelas anuais, iguais e sucessivas, assegurados o valor real da indenização e os juros legais" (BRASIL, 1988).
} 
IV - integrantes de áreas de especial interesse turístico;

$\mathrm{V}$ - inseridas na área de influência de empreendimentos ou atividades com significativo impacto ambiental de âmbito regional ou nacional.

VI - incluídas no cadastro nacional de Municípios com áreas suscetíveis à ocorrência de deslizamentos de grande impacto, inundações bruscas ou processos geológicos ou hidrológicos correlatos (BRASIL, 2001).

No caso da cidade de São Paulo, até 1920, não existia nenhuma forma de controle voltado ao uso e ocupação do solo do município. De acordo com Nobre:

As edificações da cidade eram controladas pelo Código de Posturas de 1886, que definia, entre outras considerações, as alturas dos pavimentos e os tamanhos das aberturas das construções, sem de fato controlar a ocupação, visto que as limitações técnicas não possibilitavam a construção de edifícios em altura. Por outro lado, o Código estabelecia proibições de instalação de usos ditos "incômodos", como por exemplo os matadouros municipais, dentro do limite da área urbana. Contudo, não existia uma preocupação em se estabelecer regras gerais e extensivas a todo o município.

As inovações tecnológicas do inicio do século, mais especificamente o desenvolvimento do concreto armado e do elevador, possibilitaram o crescimento em altura das edificações, iniciando o processo de verticalização da área central da cidade [...]

Percebendo os problemas advindos de uma verticalização sem controle, a Prefeitura do Município incorporou o controle a altura das edificações no primeiro Código de Obras Municipal, promulgado na lei 3.427 de 1929. Esse controle se dava a partir da relação da altura do edifício com a largura da rua, que chegava a 2,5 vezes nas áreas centrais e ia decaindo em direção à periferia, enfatizando o processo de verticalização do Centro $[\ldots]$

A partir da década de 1940 a verticalização assume caráter residencial e passa a ocupar bairros próximos ao Centro, como Campos Elíseos e Higienópolis, enquanto que no Centro predominava a verticalização comercial. [...]

Na década de 1950, apesar dos esforços dos técnicos da Prefeitura na elaboração de um Plano Diretor, esse acabou não saindo do papel (2004, p. $1-2)$.

Mas foi apenas em 1972, com a promulgação da Lei 7.805, conhecida como Lei de Zoneamento, que ocorreu a primeira normatização do uso e ocupação do solo. Porém, em 1971, a Prefeitura já havia institucionalizado a Lei 7.688, regulamentando o Plano Diretor de Desenvolvimento Integrado (PDDI). Nobre explica que

Essa lei institui 8 zonas de uso e previu a redução dos coeficientes de aproveitamento ${ }^{17}$ ao máximo de 4 vezes a área do terreno, restrito apenas às zonas de uso misto centrais. A definição da compatibilidade dos usos e a

\footnotetext{
${ }^{17}$ Nobre, no mesmo texto, esclarece que o "Coeficiente de Aproveitamento - CA é o índice obtido pela divisão entre a área construída computável de uma edificação e a área do terreno onde ele se encontra” (2004, p. 2).
} 
adequação da situação proposta com a existente ficaram a cargo da Lei de Zoneamento.

Contudo, a crise do Petróleo pôs fim ao "Milagre Brasileiro", fazendo com que a construção das vias expressas propostas no PDDI nunca saíssem do papel. [...]

No decorrer dos anos o Zoneamento foi sendo modificado e moldado aos interesses do mercado imobiliário. Várias novas zonas foram sendo criadas para resolver as especificidades que o Zoneamento original não previra. [...]

Outro aspecto negativo foi o fato de que definindo coeficientes de aproveitamento variáveis dentro da cidade, o Zoneamento criou uma valorização artificial de terrenos, estimulando preços maiores nas áreas da cidade com potencial construtivo maior, aumentando o processo de exclusão sócio-espacial, que se intensifica a partir da década de 1970 (2004, p. 1-4).

Foi só com a aprovação do Estatuto da Cidade, em 2001, que finalmente instrumentos urbanísticos, os quais buscam uma cidade menos desigual e cujas propriedades cumpram sua função social, foram legitimados. Até então, vários Planos Diretores chegaram a ser elaborados, porém, sempre engavetados nas gestões posteriores à elaboração, como ocorreu com o Plano Diretor da gestão Mario Covas (1982-1985) para a de Jânio Quadros (19851989); e de Luiza Erundina (1989-1993) para a de Paulo Maluf (1993-1997). Apesar disso, alguns instrumentos urbanísticos importantes haviam sido estabelecidos anteriormente, como a Operação Interligada, criada pela Lei 10.209 em 1986 e alterada pela Lei 11.773 em 1995 . Ela estabelecia que a iniciativa privada poderia realizar modificações de seu interesse na propriedade e, em contrapartida, ela deveria doar à Prefeitura um certo número de Habitações de Interesse Social (NOBRE, 2004, p. 4-5).

Bonduki, ainda, pontua aspectos importantes que o Estatuto da Cidade trouxe para a discussão da cidade e do urbano, como: regulamentação de instrumentos que fazem valer a função social da propriedade; a descentralização de decisões e o aumento da importância dos municípios; obrigatoriedade de um Plano Diretor em mais de dois mil municípios brasileiros; exigência de processos participativos para elaborar programas, planos e projetos urbanos (BONDUKI, 2012).

Em 2002, o município de São Paulo aprovou um dos primeiros planos diretores após a criação do Estatuto da Cidade, por meio da Lei 13.430, na gestão de Marta Suplicy. Foi um plano com muitos avanços e abordou aspectos variados, como a função social da propriedade, a questão da mobilidade, da moradia, a agricultura urbana e a política ambiental etc. Várias ações ocorreram na cidade para articular com o novo Plano Diretor os objetivos ali propostos, como: a construção dos Centros Educacionais Unificados (CEUs) nas periferias (foto 1.3), a 
regularização fundiária de favelas, programas para morar no centro da cidade, a implantação do bilhete único, entre outros (BONDUKI, 2013).

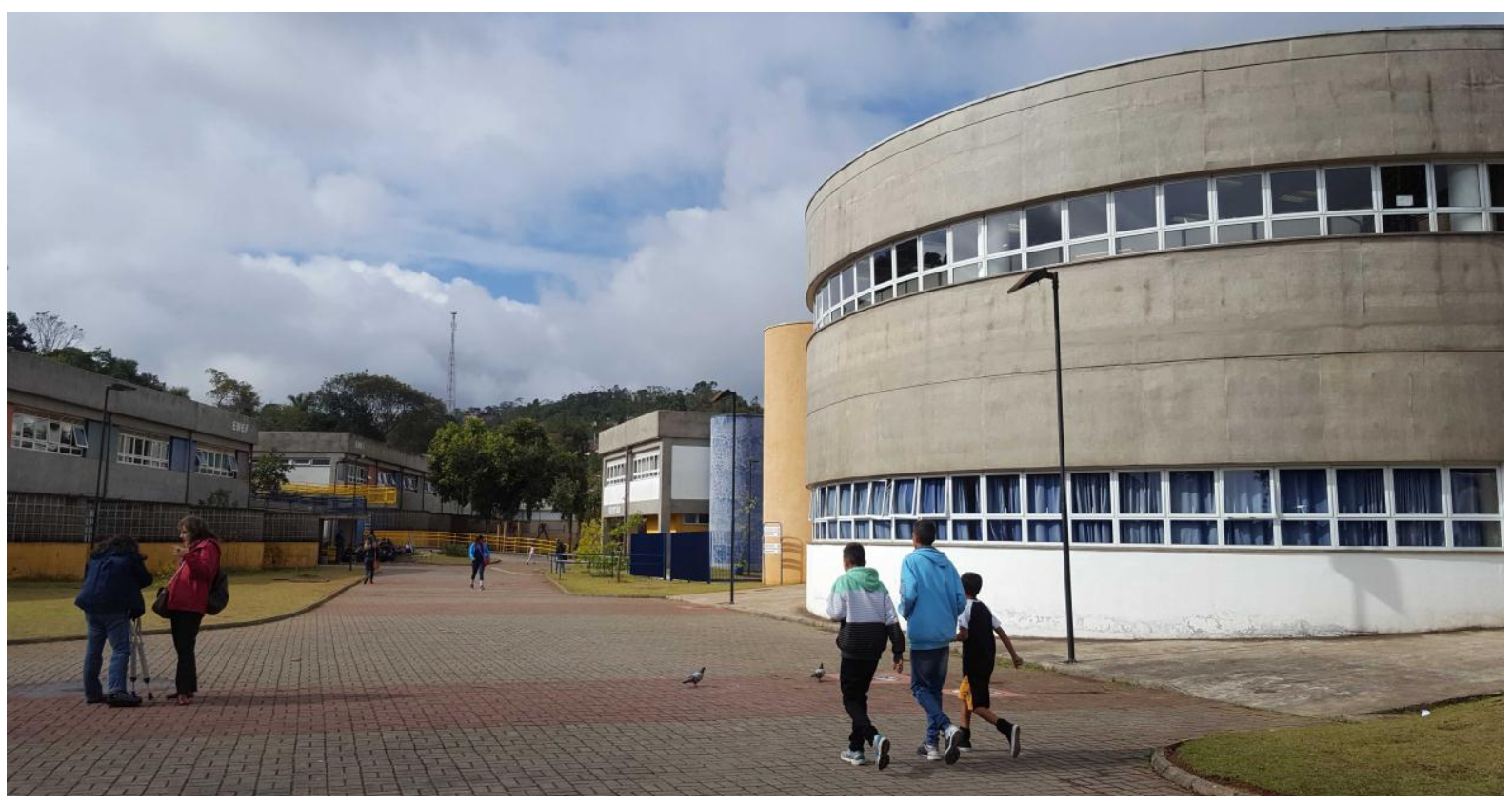

Foto 1.3. Os CEUs surgiram na gestão de Marta Suplicy e tiveram continuidade em outras gestões. O distrito de Parelheiros também conta com um CEU, entregue em 2008. Foto de 25 de abril de 2016. Crédito da foto: Angélica Campos Nakamura.

Finalmente, em 30 de junho de 2014, o Plano Diretor atualmente vigente no município de São Paulo foi aprovado pela Lei 16.050 e será ele que orientará o crescimento da cidade nos próximos 16 anos (PREFEITURA DE SÃO PAULO, 2014).

Para a elaboração desse plano, seguiu-se as diretrizes gerais do Estatuto da Cidade, que exige a gestão democrática, por meio da participação da população, de associações e segmentos da sociedade. De acordo com a Câmara Municipal de São Paulo, a partir de setembro de 2013 e durante os nove meses seguidos, houveram debates e formulação de propostas e soluções para se buscar a aprovação do Plano Diretor. A Câmara Municipal ainda ressalta que foram sessenta audiências públicas abertas a quem quisesse participar e opinar, além de consultas feitas pela internet. Houve participação da sociedade, de movimentos sociais e do Ministério Público. Todo o processo foi divulgado pela imprensa (CÂMARA MUNICIPAL DE SÃO PAULO, 2014, p. 8). 
Os objetivos gerais desse novo Plano Diretor podem ser resumidos nos seguintes pontos:

I. Reestruturar a mobilidade urbana, racionalizando o uso de automóvel e priorizando o transporte coletivo de alta e média capacidade e os modos não motorizados;

II. Conter o processo de expansão horizontal da cidade, contribuindo para preservar o cinturão verde metropolitano e fortalecer a zona rural;

III. Reduzir a necessidade de deslocamento, aproximando o emprego da moradia ao estimular a criação de postos de trabalho nas áreas periféricas e da implantação de habitação em áreas bem servidas de emprego;

IV. Dirigir o adensamento construtivo e populacional para as áreas bem servidas de infraestrutura e transporte de massa, de forma planejada e sustentável;

V. Planejar a reestruturação das áreas subutilizadas ao longo da orla ferroviária e dos rios e antigas áreas industriais, com proteção social e ambiental;

VI. Implementar uma política fundiária que combata a especulação, garanta a função social do solo e proteja o patrimônio ambiental e cultural;

VII. Reservar glebas e terrenos, em áreas dotadas de infraestrutura para atender ao déficit habitacional acumulado e às necessidades futuras;

VIII. Reduzir a desigualdade socioterritorial, garantindo a implantação da rede básica de equipamentos sociais e culturais em todos os distritos da cidade;

IX. Regularizar, urbanizar e qualificar loteamentos irregulares e favelas;

X. Contribuir para a minimização dos potenciais efeitos das mudanças climáticas, reduzir as emissões de poluentes e gases de efeito estufa e estimular a construção sustentável;

XI. Proteger as áreas verdes, as unidades de conservação, as áreas de proteção permanentes, os mananciais, as terras indígenas e a biodiversidade;

XII. Valorizar e qualificar os espaços públicos, ampliar as áreas verdes, os parques, a arborização e a permeabilidade do solo;

XIII. Contribuir para a universalização do abastecimento de água, a coleta e o tratamento ambientalmente adequado dos esgotos e dos resíduos sólidos;

XIV. Proteger o patrimônio histórico, cultural e religioso e valorizar a memória, o sentimento de pertencimento à cidade e a diversidade;

XV. Ordenar o processo imobiliário de acordo com os objetivos do planejamento da cidade;

XVI. Fortalecer uma gestão urbana integrada, descentralizada e participativa e a articulação com o planejamento metropolitano e com os planos diretores dos demais municípios da Região Metropolitana (CÂMARA MUNICIPAL DE SÃO PAULO, 2014, p. 9).

Conforme se pode perceber, o Plano Diretor aborda aspectos muito variados para se pensar a cidade e o urbano, como a questão da moradia, da mobilidade, da infraestrutura, do adensamento populacional, da cultura, do meio ambiente, do clima, da biodiversidade, do lixo etc. Entretanto, o presente trabalho focou para as questões voltadas para a agricultura e o meio ambiente, temas que perpassam diretamente a vida e o cotidiano dos membros da Cooperapas. Eles vivem em uma região da cidade que está no limite da mancha urbana ou que ainda não 
foi alcançada por ela. Também é uma região repleta de mananciais que abastecem a cidade de São Paulo e ainda possui resquícios de Mata Atlântica.

O item II dos objetivos gerais do novo Plano Diretor, citado anteriormente, merece uma atenção especial, pois afirma, entre os objetivos, que se espera conter a expansão horizontal da cidade para, dessa forma, preservar o cinturão verde e fortalecer a zona rural. Surge, assim, na discussão da cidade e do urbano, o rural.

O rural ganha tanto destaque nesse novo Plano Diretor que aparece como uma das zonas do município. Assim, tem-se a zona urbana e a zona rural. A zona rural compõe parte da Macrozona de Proteção e Recuperação Ambiental. As macrozonas são "áreas que têm características de ocupação semelhantes. O Plano dividiu São Paulo em duas macrozonas: Macrozona de Estruturação e Qualificação Urbana e Macrozona de Proteção e Recuperação Ambiental” (CÂMARA MUNICIPAL DE SÃO PAULO, 2014, p. 18). As macrozonas, por sua vez, estão divididas em macroáreas, entendidas como "áreas com características de urbanização semelhantes e que devem cumprir papeis específicos no futuro do município. $\mathrm{O}$ Plano definiu seis macroáreas situadas na Zona Urbana e duas Macroáreas situadas na Zona Rural” (CÂMARA MUNICIPAL DE SÃO PAULO, 2014, p. 18).

As duas macroáreas que compõem a zona rural são a de Contenção Urbana e Uso Sustentável e a de Preservação dos Ecossistemas Naturais. Essas macroáreas foram traçadas com os seguintes objetivos:

- Contenção Urbana e Uso Sustentável: conservar a paisagem e o meio ambiente, permitindo usos compatíveis com a proteção; conter a urbanização; promover o desenvolvimento da zona rural com sustentabilidade ambiental, econômica e social; proteger as áreas indígenas; conservar os fragmentos florestais, corredores ecológicos e as áreas de preservação permanente (CÂMARA MUNICIPAL DE SÃO PAULO, 2014, p. 19).

- Preservação dos Ecossistemas Naturais: manutenção das condições naturais; garantia da preservação das espécies; pesquisa, ecoturismo e educação ambiental (CÂMARA MUNICIPAL DE SÃO PAULO, 2014, p. 19).

Os mapas 1.7 e 1.8 a seguir, e a tabela 1.2 após os mapas, mostram mais detalhadamente como estão compostas as macrozonas, quais são as macroáreas, suas características e objetivos e qual a área da zona urbana e da zona rural. 
1.7. Macroáreas do Plano Diretor do município de São Paulo

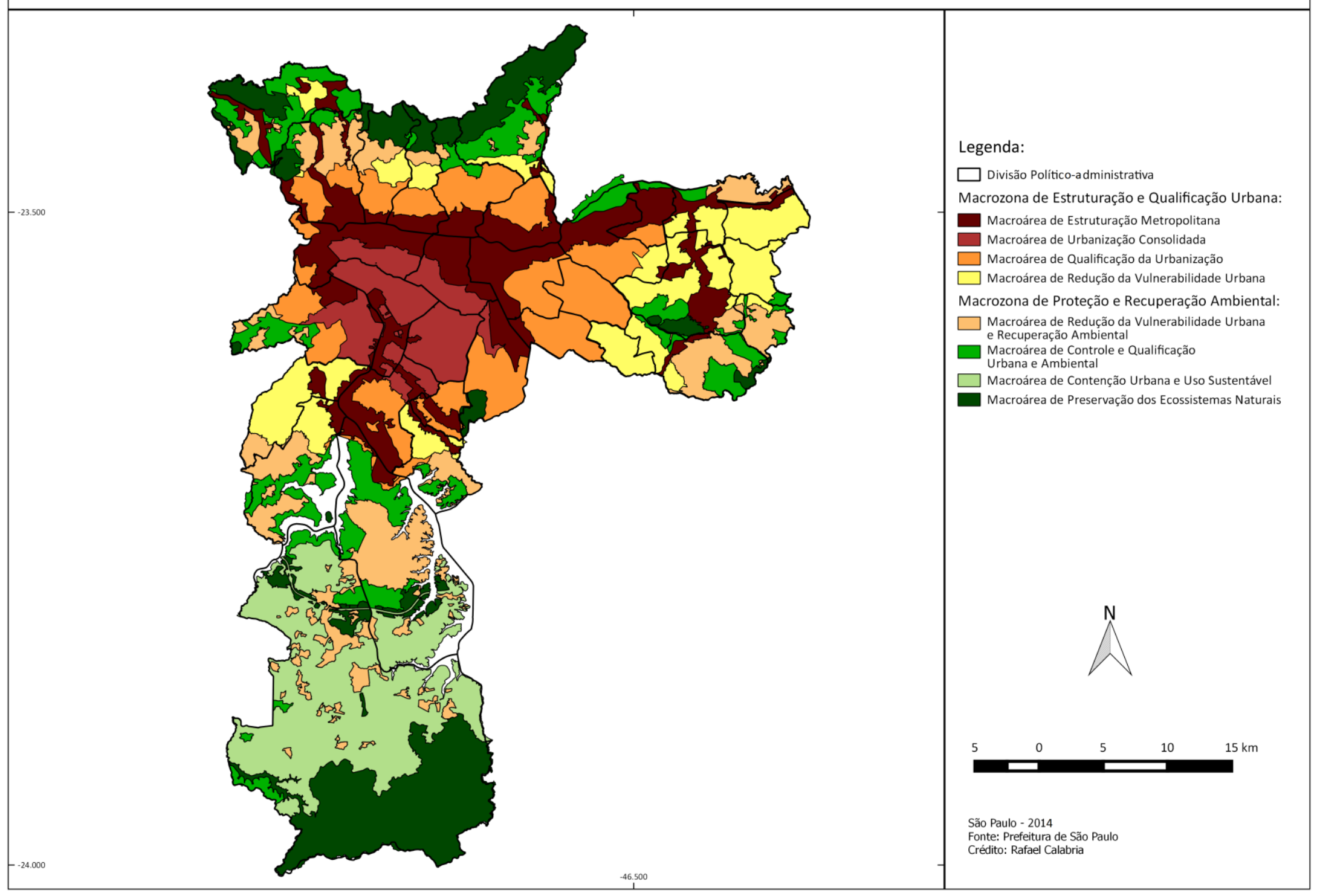




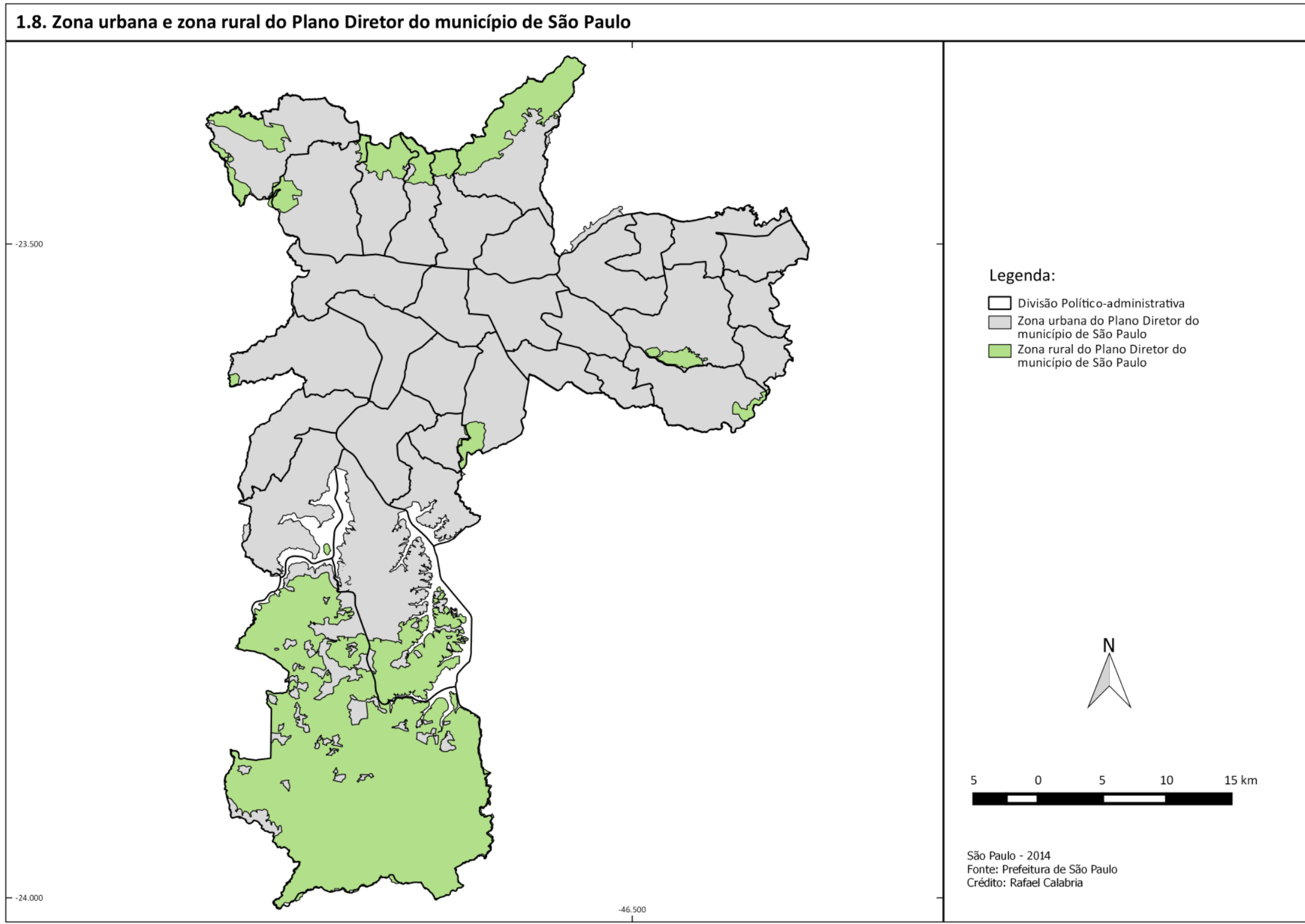


Tabela 1.2. Macrozonas e macroáreas no Plano Diretor do município de São Paulo (2014)

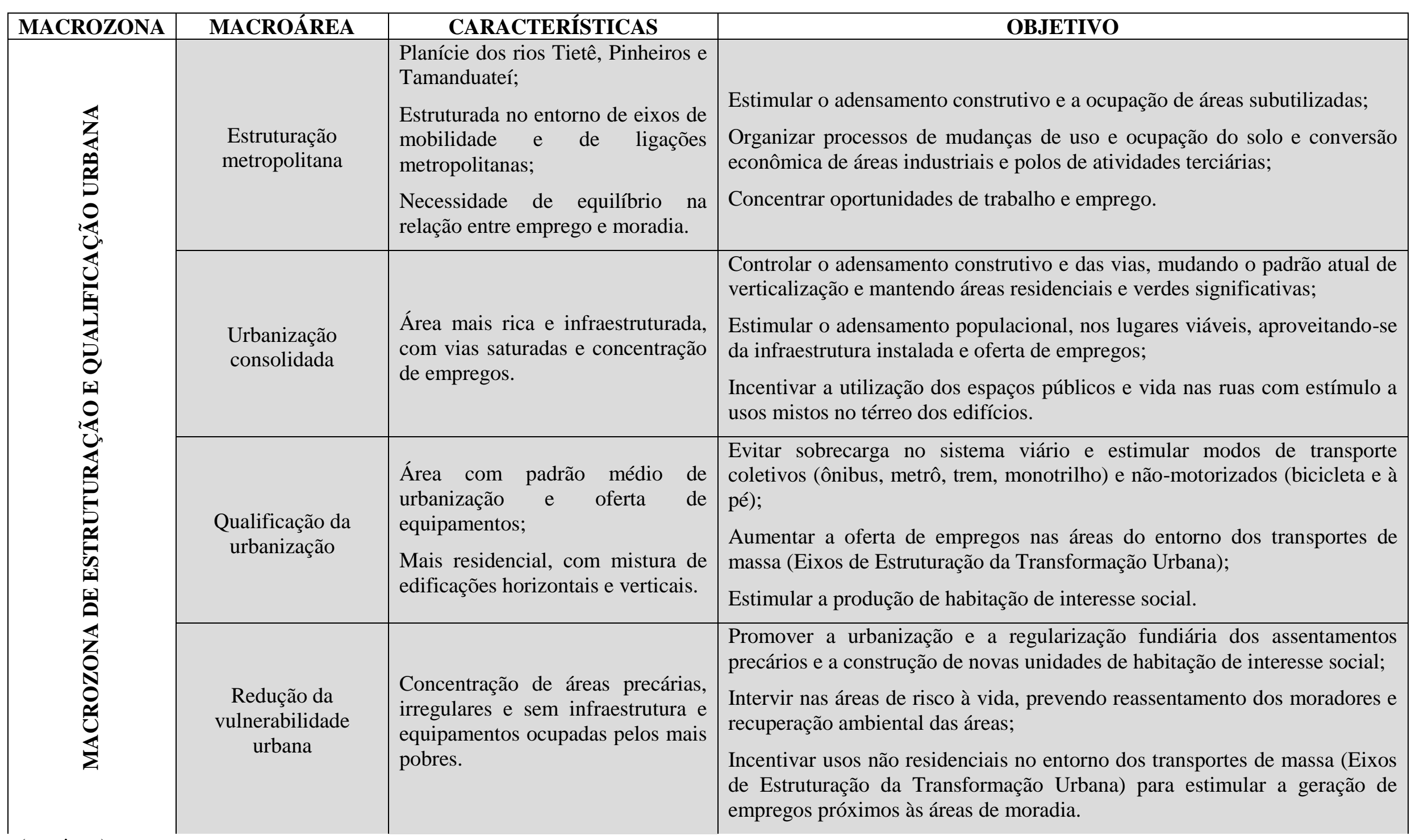


(conclusão)

\begin{tabular}{|c|c|c|c|}
\hline MACROZONA & MACROÁREA & CARACTERISTICAS & OBJETIVO \\
\hline \multirow{4}{*}{ 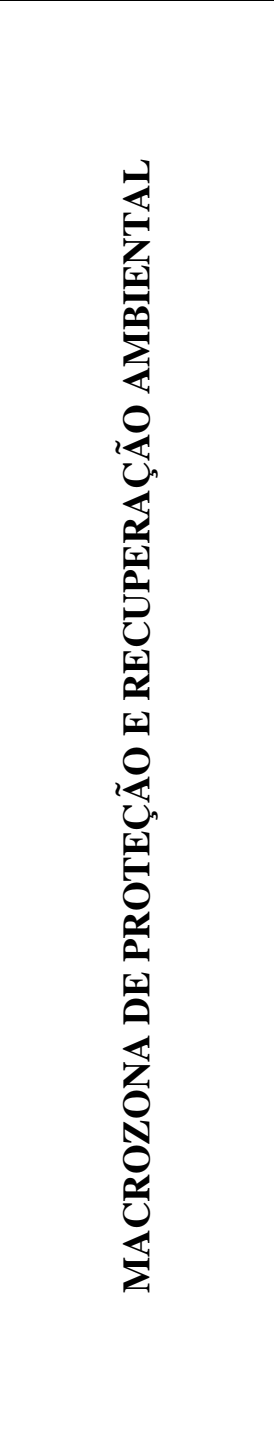 } & $\begin{array}{l}\text { Redução da } \\
\text { vulnerabilidade } \\
\text { urbana e } \\
\text { recuperação } \\
\text { ambiental }\end{array}$ & $\begin{array}{l}\text { Concentração de áreas precárias, irregulares e sem infraestrutura em } \\
\text { áreas de proteção de mananciais de água e outras que, como essas, } \\
\text { prestam serviços ambientais que não podem ser perdidos. }\end{array}$ & $\begin{array}{l}\text { Melhorar as condições urbanas e sociais, com } \\
\text { recuperação ambiental, dos assentamentos precários; } \\
\text { Universalizar o saneamento ambiental. }\end{array}$ \\
\hline & $\begin{array}{l}\text { Controle e } \\
\text { qualificação } \\
\text { urbana e } \\
\text { ambiental }\end{array}$ & $\begin{array}{l}\text { Região que contém áreas consideradas "vazias ou subutilizadas", sem } \\
\text { cobertura vegetal e áreas com reflorestamento; } \\
\text { Ocupação predominantemente horizontal, residencial (sem edifícios), } \\
\text { com áreas de exploração mineral e industrial. }\end{array}$ & $\begin{array}{l}\text { Qualificar a urbanização e o meio ambiente } \\
\text { permitindo a ocupação com habitação, } \\
\text { equipamentos e serviços, com controle e cuidados } \\
\text { ambientais; } \\
\text { Conter a expansão horizontal e o adensamento dos } \\
\text { assentamentos precários e irregulares existentes; } \\
\text { Universalizar o saneamento ambiental; } \\
\text { Recuperar áreas mineradas; } \\
\text { Apoiar e incentivar a agricultura urbana e } \\
\text { periurbana. }\end{array}$ \\
\hline & $\begin{array}{l}\text { Contenção } \\
\text { urbana e uso } \\
\text { sustentável }\end{array}$ & $\begin{array}{l}\text { Contém áreas com vegetação natural preservada entremeadas com } \\
\text { regiões de atividade agrícolas que protegem e, ao mesmo tempo, } \\
\text { impactam a qualidade dos recursos hídricos e da biodiversidade; } \\
\text { Integralmente em área de proteção dos mananciais preservados para } \\
\text { garantir o abastecimento de água na região; } \\
\text { Não inclui nenhum território atualmente ocupado por assentamentos } \\
\text { urbanos. }\end{array}$ & $\begin{array}{l}\text { Conservar a paisagem e o meio ambiente, } \\
\text { permitindo usos compatíveis com a proteção; } \\
\text { Conter a urbanização; } \\
\text { Promover o desenvolvimento da zona rural com } \\
\text { sustentabilidade ambiental, econômica e social; } \\
\text { Proteger áreas indígenas; } \\
\text { Conservar os fragmentos florestais, corredores } \\
\text { ecológicos e as áreas de preservação permanente. }\end{array}$ \\
\hline & $\begin{array}{l}\text { Preservação dos } \\
\text { ecossistemas } \\
\text { naturais }\end{array}$ & $\begin{array}{l}\text { Área com meio ambiente muito preservado que ainda conserva suas } \\
\text { características naturais; } \\
\text { Área rica em biodiversidade e farta em relação a águas, porque contém } \\
\text { as cabeceiras de rios, nascentes e cursos d'água ainda pouco } \\
\text { impactados pelo homem; } \\
\text { Não inclui nenhum território atualmente ocupado por assentamentos } \\
\text { urbanos. }\end{array}$ & $\begin{array}{l}\text { Manutenção das condições naturais; } \\
\text { Garantia da preservação das espécies; } \\
\text { Pesquisa, ecoturismo e educação ambiental. }\end{array}$ \\
\hline
\end{tabular}

Fonte: CÂMARA MUNICIPAL DE SÃO PAULO. Conheça o novo Plano Diretor Estratégico de São Paulo. Lei 16.050/14. São Paulo: Câmara Municipal de São Paulo, 2014. p. 19. 
Visto essa nova proposta de divisão do município, fica claro que o novo Plano Diretor vê na atividade agrícola uma forma de promover a conservação do meio ambiente, a promoção social e evitar a expansão da mancha urbana. Conforme a própria publicação da Câmara Municipal de São Paulo escreve:

O crescimento da cidade "para dentro" exige a contenção da expansão horizontal, por meio da promoção de usos economicamente sustentáveis, da conservação de áreas que prestam serviços ambientais para toda a cidade, e da recuperação das áreas da ocupadas. [...]

Este Plano Diretor recriou a Zona Rural ${ }^{18}$, preparando a região para uma política de desenvolvimento econômico voltada para atividades rurais, de turismo e outros usos sustentáveis, buscando porém, manter o modo de vida, a cultura e a paisagem rural do Sul do Município.

Para estas áreas, a localização em zona rural faz a diferença e viabiliza a inclusão social produtiva dos que ali habitam, facilita a obtenção de financiamentos para a produção e beneficiamento da produção agrícola, evita a expansão da mancha urbana sobre essas terras, e ainda, assegura a conservação dos serviços ambientais, sobretudo produção de água, que esta área presta (CÂMARA MUNICIPAL DE SÃO PAULO, 2014, p. 40, grifo do autor).

De acordo com o mesmo documento, ainda se prevê a definição de um Polo de Desenvolvimento Econômico Rural Sustentável, que pretende combinar atividades agrícolas e não agrícolas. Criar-se-ia, assim, uma zona rural multifuncional para que, dessa forma, evitese

[...] a pressão pela instalação de usos urbanos sobre o território [da zona rural], contribuindo para a preservação e recuperação dos recursos naturais, sobretudo a biodiversidade e, portanto, para a conservação dos serviços ambientais essenciais para a vida na cidade (CÂMARA MUNICIPAL DE SÃO PAULO, 2014, p. 40).

Essa zona rural multifuncional, além da atividade agrícola, prevê como atividade não agrícola o ecoturismo. A própria Prefeitura de São Paulo já apresenta o Polo de Ecoturismo de São Paulo, com atrações variadas e, nem todas, voltadas exatamente para o turismo na natureza.

Há cinco roteiros indicados no site: Mata Atlântica, história e cultura, religioso, cicloturismo e náutico. As atrações são variadas e vão, desde trilhas e cachoeiras, até visitação nas aldeias indígenas da região e em templos, como o Solo Sagrado ${ }^{19}$. Também é possível

\footnotetext{
${ }^{18}$ O Plano Diretor de 2002 havia extinguido a zona rural do município.

19 O Solo Sagrado é um complexo de templos da Igreja Messiânica, localizado às margens da Represa de Guarapiranga. É tido como um ponto turístico do município de São Paulo.
} 
baixar, do próprio site, um guia turístico, indicando os locais para visitação com endereços e telefones (figura 1.2).

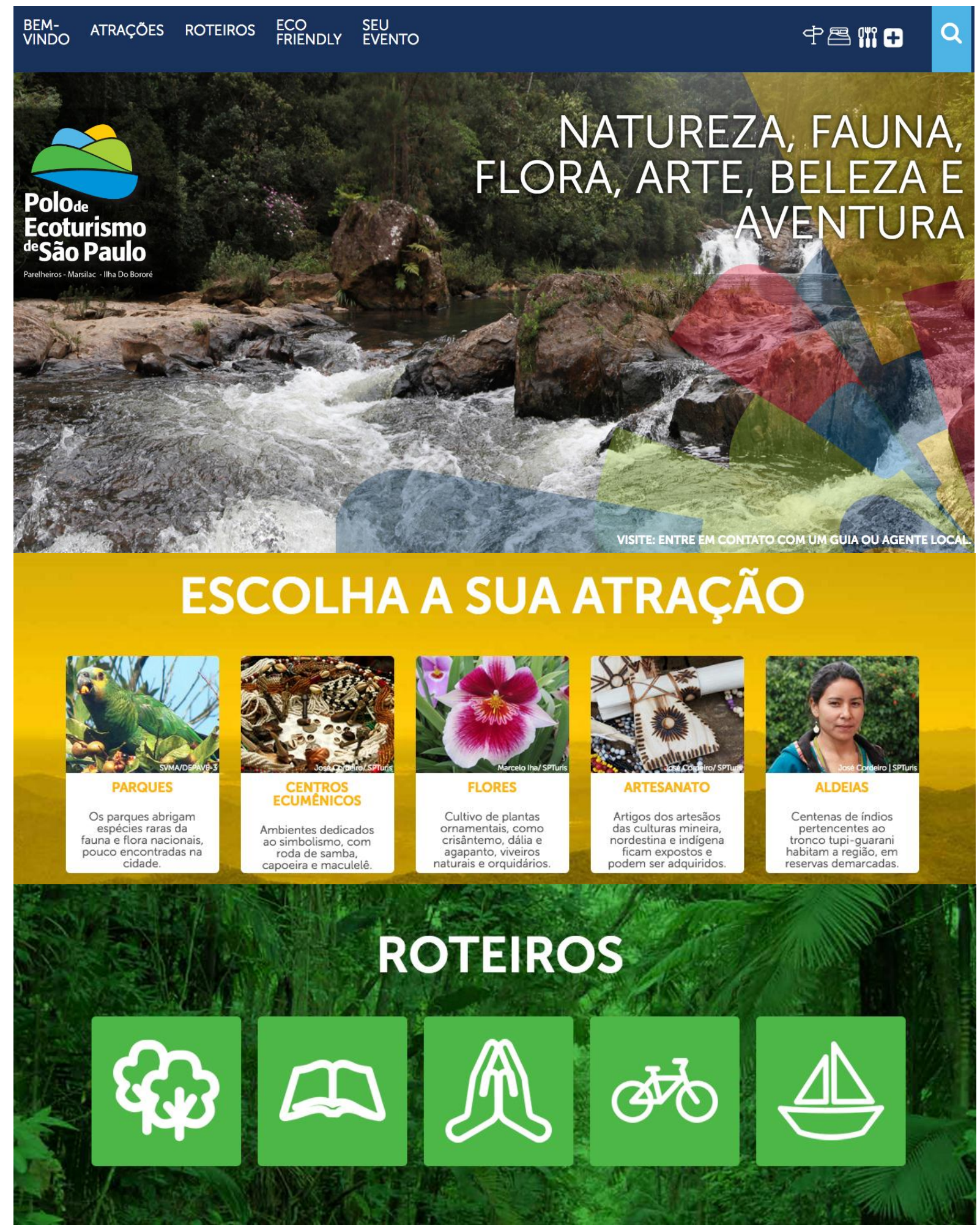

Figura 1.2. Página da internet do Polo de Ecoturismo de São Paulo. Disponível em: <http://www.cidadedesaopaulo.com/ecoturismo/?lang=>. Acesso em: 30 set. 2016. 
O Polo de Ecoturismo foi estabelecido com a Lei $\mathrm{n}^{\mathrm{o}}$ 15.953, em 7 de janeiro de 2014. É nessa lei que são delimitados os distritos abrangidos pelo polo, entre outros pontos:

Art. $1^{\circ}$ Fica criado na Cidade de São Paulo o Polo de Ecoturismo nos Distritos de Parelheiros e Marsilac até os limites da Área de Proteção Ambiental Bororé-Colônia.

Parágrafo único. Esta lei objetiva disciplinar e normatizar as atividades ecoturísticas desenvolvidas nos territórios administrativos das subprefeituras de Parelheiros e da Capela do Socorro, a fim de dar execução a um projeto gerador de recursos, negócios, renda, empregos e com total compromisso com o meio ambiente e as futuras gerações.

Art. $2^{\circ}$ Integram o Polo Ecoturístico criado por esta lei os seguintes distritos: Parelheiros, Marsilac e o território da APA Bororé-Colônia, denominado de Polo Ecoturismo Parelheiros/Marsilac/llha do Bororé. [...]

Art. $3^{\circ} \mathrm{O}$ Poder Executivo envidará esforços para que o Polo possa receber incentivo e benefícios fiscais destinados a estimular o desenvolvimento econômico e social das áreas atingidas, na forma prevista nesta lei, visando em especial às microempresas de hotelaria, pousada, artesanato, comércio, operadoras de turismo, agências receptivas, empresas de eventos, associações de guias e monitores, cooperativas, comércio e serviços voltados ao turismo em geral, instaladas ou que venham a se instalar nas localidades abrangidas por esta lei.

Art. $4^{\circ}$ Outros distritos ou/e bairro de interesses turísticos poderão compor e ampliar o polo de ecoturismo desta região ${ }^{20}$. [...]

Art. 10. O Poder Público poderá fazer a implantação de ônibus turístico regular, a ser explorado por empresa via processo de concorrência/licitação, proporcionando, assim, uma demanda perene de visitação aos atrativos turísticos do Polo Ecoturismo Parelheiros/Marsilac/llha do Bororé.

Art. 11. Ficam instituídos como Locais de Interesse Turístico as Estradas: Ponte Alta e Reserva, desde seu início, no bairro do Embura, até o seu fim, no limite do Núcleo Curucutu-PESM/Parque Estadual da Serra do Mar, ficando aqui consideradas e denominadas de Estrada Ecoturística (PREFEITURA DE SÃO PAULO, 2014).

A lei incentiva a atividade turística nos distritos de Parelheiros, Marsilac e até os limites da APA Bororé-Colônia. É importante destacar que a APA Bororé-Colônia abrange parte dos distritos de Parelheiros e do Grajaú, onde se encontra a referida "Ilha do Bororé" no trecho da lei anteriormente citada. Portanto, a lei inclui inteiramente os distritos de Parelheiros e Marsilac e, em parte, do Grajaú. Contudo, também se prevê a possibilidade de inclusão de outros bairros de interesse turístico na região.

Um dos pontos levantados pela lei é a implantação de um ônibus turístico por processo de concorrência/licitação. Esse ônibus, chamado de jardineira, já foi lançado e tem como ponto de partida o Posto de Atendimento ao Turista (PAT) de Parelheiros.

\footnotetext{
${ }^{20}$ Os bairros já incluídos pela lei são: Vargem Grande, Colônia, Barragem, Ilha do Bororé, Parelheiros, Embura, Engenheiro Marsilac, Vila Evangelista de Souza, Gramado, Jardim dos Eucaliptos, Embura do Alto, Mambu, Jaceguava, Nova América e Chácara Santo Amaro (PREFEITURA DE SÃO PAULO, 2014).
} 
Em 4 de junho de 2016, a Folha de Parelheiros noticiou a inauguração da jardineira ${ }^{21}$. A jardineira é um ônibus projetado especialmente para turistas (figura 1.3). De acordo com o site do Polo de Ecoturismo, os roteiros são variados e diferentes a cada fim de semana (POLO DE ECOTURISMO DE SÃO PAULO, 2016). Quem opera é uma agência de ecoturismo da região, a Toca da Onça (figura 1.4, na página a seguir).

Apesar da jardineira, há várias placas de pontos turísticos espalhadas ao longo das principais vias de circulação de veículos pelos distritos do extremo sul, como a placa na foto 1.4 (na próxima página) na Avenida Sadamu Inoue.

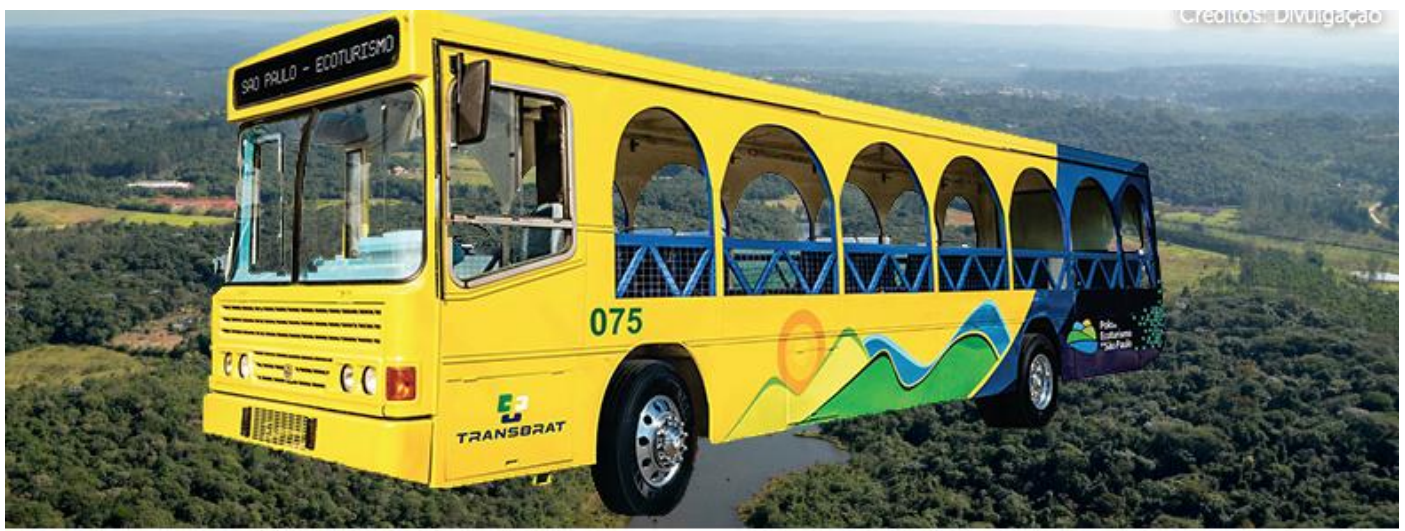

\section{JARDINEIRA}

O Polo de Ecoturismo de São Paulo ganhou uma nova opção de lazer. A agência Toca da Onça passa a oferecer um ônibus para quem quiser explorar a região, a Jardineira.

O veículo especial passará por diversos pontos turísticos locais, seguindo um roteiro diferente a cada fim de semana, levando seus passageiros com conforto e segurança.

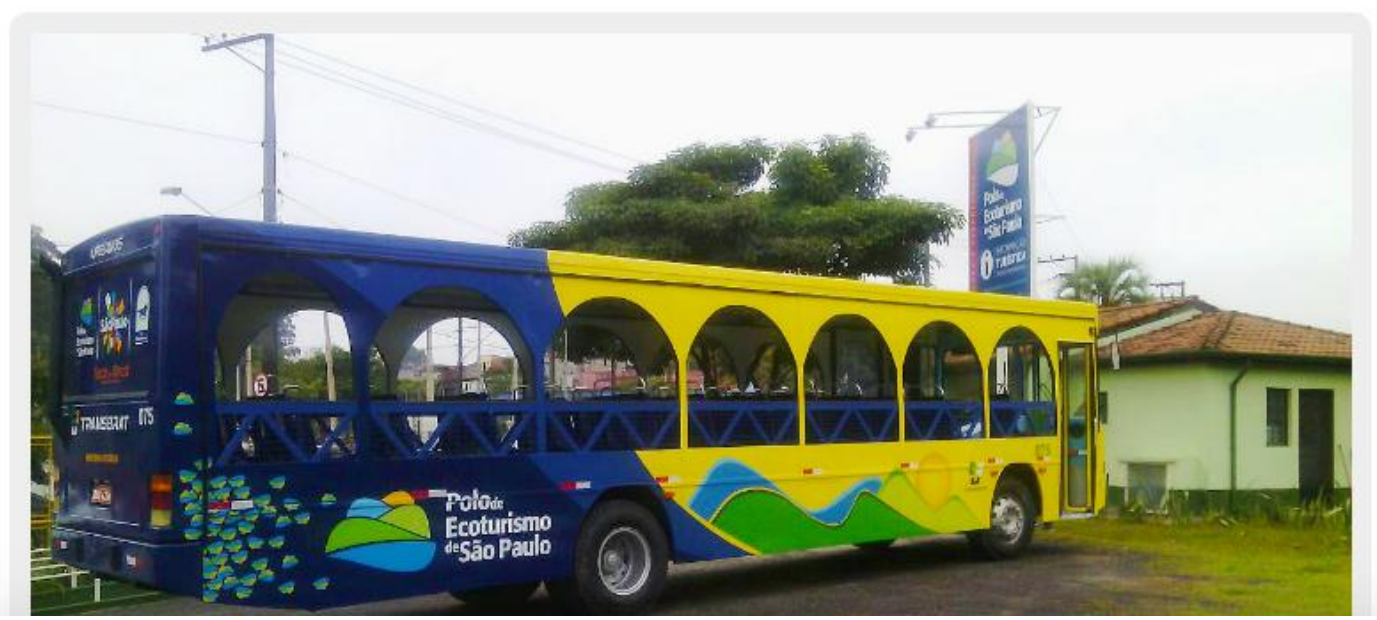

Figura 1.3. Divulgação da jardineira no site do Polo de Ecoturismo de São Paulo. Disponível em: <http://www.cidadedesaopaulo.com/ecoturismo/jardineira>. Acesso em: 30 set. 2016.

\footnotetext{
${ }^{21}$ A notícia divulgada pela Folha de Parelheiros se encontra no final desse trabalho, na seção "Anexos", como o anexo "A".
} 


\section{varapesasarcto \\ Jardineira

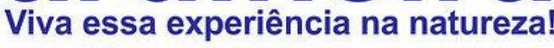
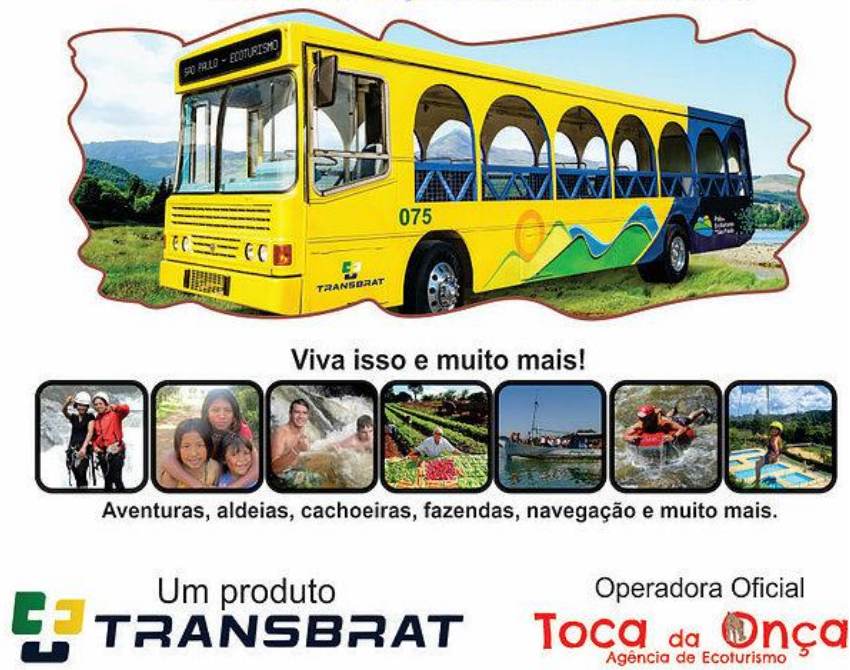

Figura 1.4. Divulgação da jardineira no site da operadora responsável, a Toca da Onça. Disponível em: <http://agtocadaonca.wixsite.com/site/jardineira>. Acesso em: 30 set. 2016.

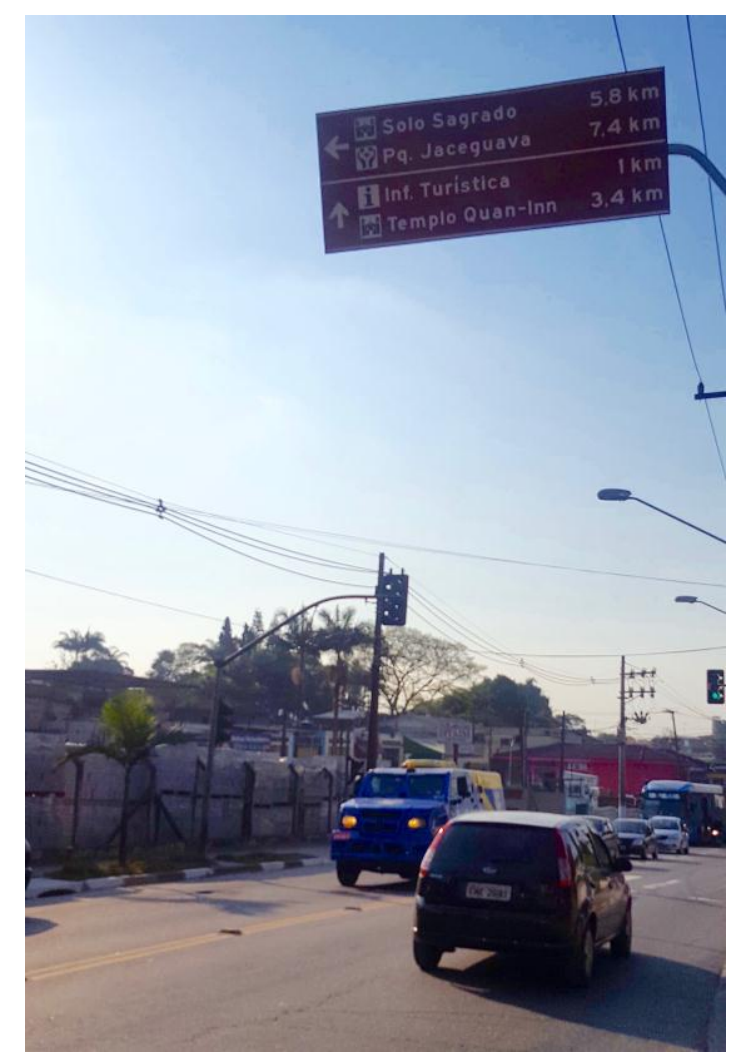

Foto 1.4. Placa na Avenida Sadamu Inoue, no distrito de Parelheiros. A placa indica a distância de alguns pontos turísticos da região (dois templos, o Solo Sagrado e o Templo Quan-Inn) e um parque (o Jaceguava), além do centro de informações turísticas. Foto de 4 de agosto de 2016. Crédito da foto: Angélica Campos Nakamura. 
A produção da agricultura orgânica na região também ganha destaque. Alguns agricultores aparecem no site, com seus contatos (telefones e e-mails), para caso alguém se interesse em conhecer mais sobre suas propriedades e produções e para comprá-las. A maior parte dos agricultores indicados participa da Cooperapas (figura 1.5).
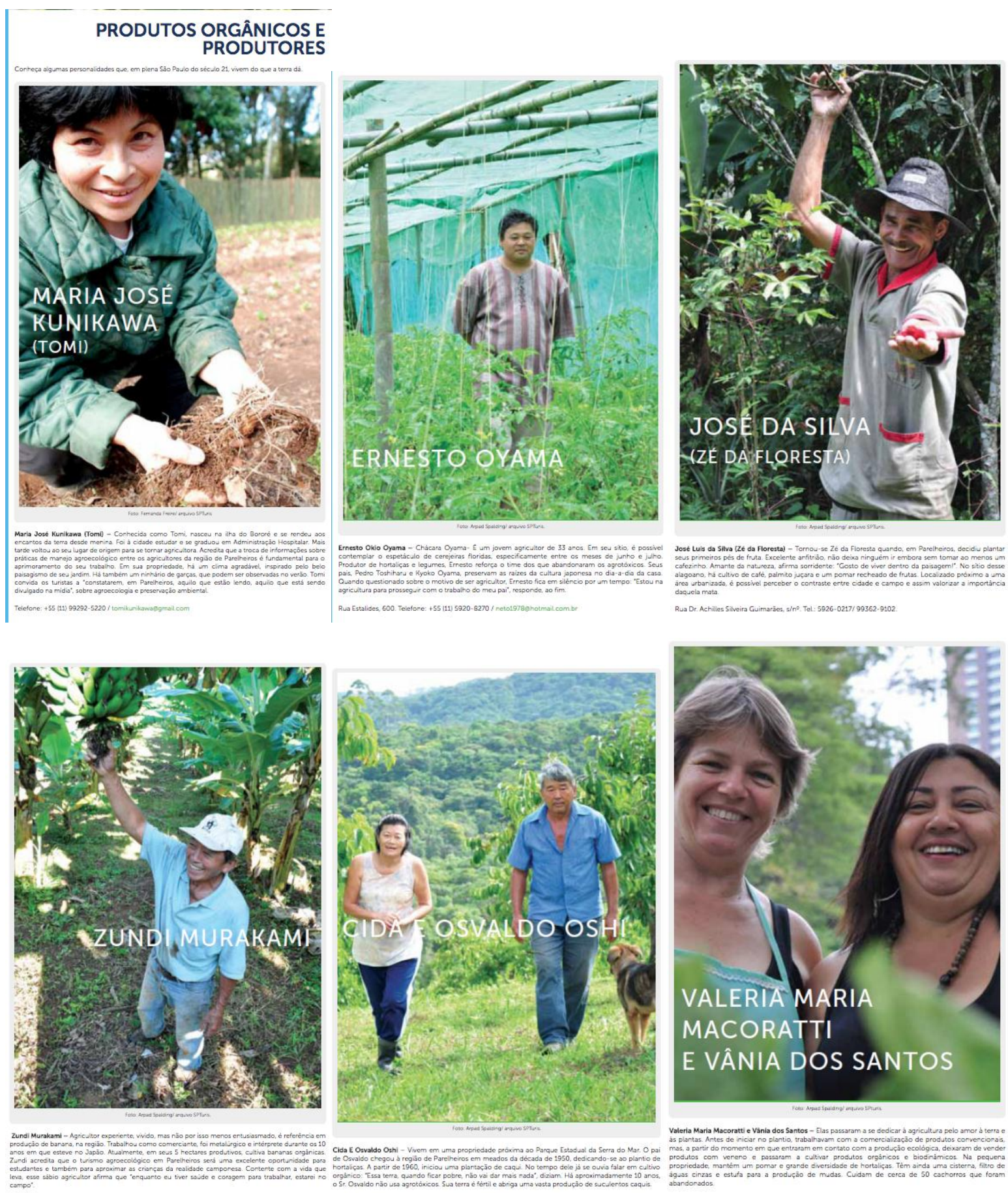

Figura 1.5. Alguns dos agricultores indicados no site do Polo de Ecoturismo de São Paulo. Disponível em: <http://www.cidadedesaopaulo.com/ecoturismo/consumoresponsavel/produtos-

organicos/?lang=pt $>$. Acesso em: 30 set. 2016. 
Apesar de a ideia de um polo turístico diversificado dentro do município de São Paulo ser interessante e uma forma de incentivar uma atividade econômica, há problemas na sua criação. Os agricultores e moradores da região contam que alguns locais, como as cachoeiras para visitação, não têm infraestrutura adequada para receber turistas. Esses locais, em certos casos, não possuem banheiros e lixeiras e não apresentam sinalização e indicação de pontos perigosos para se banhar ${ }^{22}$. Outro relato referente aos problemas, é a violência e os assaltos na região. Além de afetar os moradores, comércio e serviços, os turistas também correm riscos ${ }^{23}$.

$\mathrm{O}$ maior incentivo à atividade agrícola, vinculado à ideia de sustentabilidade e mais respeito com o meio ambiente, também vem ocorrendo desde o estabelecimento do novo Plano Diretor. Porém, esse incentivo não é tão recente. Apesar de o Plano Diretor de 2014 ter restituído as zonas rurais do município, as políticas voltadas para uma agricultura considerada urbana surgiram em 1980 e tiveram mais atenção com a instituição do Plano Diretor de 2002, conforme se verá a seguir.

\title{
1.3. Do Plano Diretor de 2002 às políticas públicas para a agricultura periurbana no município de São Paulo
}

De acordo com Giacchè e Porto,

\begin{abstract}
Os primeiros apoios governamentais à AU [Agricultura Urbana] na cidade de São Paulo surgiram na década de 1980, quando o então governador Franco Montoro implantou projetos de hortas em espaços públicos não utilizados, como os terrenos da ELETROPAULO, da TRANSPETRO e da SABESP na zona leste de São Paulo. Porém, não houve continuidade política dessa iniciativa. Somente em 2004 foi criado o PROAURP [Programa de Agricultura Urbana e Periurbana], instituído pela Lei n. 13.727/2004 (2015, p. 50).
\end{abstract}

Entretanto, antes de tratar do Proaurp, é importante destacar alguns aspectos no Plano Diretor de 2002. Nele, é possível encontrar pontos que já se voltavam para a atividade agrícola no município, como o item X do art. 29, na seção II. Essa seção era referente ao

\footnotetext{
${ }^{22}$ No primeiro semestre de 2016, em uma cachoeira, um banhista morreu afogado. Ele era morador da região e conhecido por alguns agricultores da Cooperapas. Alguns desabafaram no grupo do Whatsapp, criticando a criação do polo, feita sem muito planejamento e cuidado, pois nessa cachoeira, de acordo com alguns, já morreram mais de 50 pessoas afogadas.

${ }^{23}$ Em uma conversa informal, relataram a ocorrência de assaltos nas próprias cachoeiras, quando há mais movimento de pessoas nesses locais.
} 
trabalho, emprego e renda. O item previa a instituição de um "programa de agricultura urbana em terrenos subutilizados ou não utilizados". Outro item, o V no art. 56, previa a "orientação e o controle do manejo do solo nas atividades agrícolas" (PREFEITURA DE SÃO PAULO, 2002). Na subseção III, art. 170, o plano também levantava a importância da eliminação progressiva do uso dos agrotóxicos e o estímulo à prática da agricultura orgânica; a promoção do agroecoturismo e agroindústria familiar; valorização do espaço produtivo predominantemente agrícola e agroindustrial. Porém, no plano não foi encontrado, realmente, menção à uma zona rural e a atividade agrícola aparece definida como agricultura urbana. Aparentemente, o mais próximo que se chegou a uma zona rural foi ao destacar essa valorização do espaço produtivo predominantemente agrícola e agroindustrial (PREFEITURA DE SÃO PAULO, 2002).

É a seção X do Plano Diretor de 2002 que merece ser ressaltada. Ela se voltava inteiramente para a agricultura urbana:

Art. 51 - São objetivos da Agricultura Urbana:

I - estimular a cessão de uso dos terrenos particulares para o desenvolvimento, em parceria, de programas de combate à fome e à exclusão social, por meio da agricultura urbana;

II - aproveitar os terrenos públicos não utilizados ou subutilizados, em programas de agricultura urbana de combate à exclusão social. [...]

Art. 52 - São diretrizes da Agricultura Urbana:

I - o desenvolvimento de políticas que visem o estímulo ao uso dos terrenos particulares com o objetivo de combate à fome e à exclusão social, por meio de atividades de produção agrícola urbana;

II - o desenvolvimento de política de aproveitamento dos terrenos públicos não utilizados ou subutilizados, visando à implantação de programas de agricultura urbana que tenham como objeto o combate à fome e à exclusão social e incentivo à organização associativa.

Art. 53 - São ações estratégicas da Agricultura Urbana:

I - fomentar práticas de atividades produtivas solidárias e associativas;

II - criar mecanismos que possibilitem a implementação de programa de agricultura urbana, na forma da lei (PREFEITURA DE SÃO PAULO, 2002).

A agricultura urbana, portanto, já era vista como uma maneira de promover a inclusão social, de combater a fome, de utilizar terrenos ociosos ou subutilizados na cidade e, ainda, fomentar práticas solidárias e associativas. Vale lembrar que a criação de uma cooperativa é uma forma desse tipo de prática.

A citação da atividade agrícola, nesse Plano Diretor de 2002, também aparece vinculada à Macrozona de Proteção Ambiental, na subseção II, art. 152: 
Nas Macroáreas de Uso Sustentável, que abrangem as Áreas de Proteção Ambiental - APAs, as Reservas Particulares do Patrimônio Natural - RPPNs, e outras, cuja função básica seja compatibilizar a conservação da natureza com o uso sustentável de parcela dos recursos naturais existentes, são permitidos usos econômicos como a agricultura, o turismo e lazer e mesmo parcelamentos destinados a chácaras, desde que compatíveis com a proteção dos ecossistemas locais (PREFEITURA DE SÃO PAULO, 2002).

Assim, nota-se que desde o Plano Diretor de 2002, a atividade agrícola já foi vinculada com o uso sustentável dos recursos e a conservação da natureza. O turismo e o lazer também, porém, uma zona propriamente dita rural não foi estabelecida nesse plano. O plano até previa uma Zona Especial de Produção Agrícola e Extração Mineral (Zepag) na subseção III (PREFEITURA DE SÃO PAULO, 2002), e pretendia promover a atividade agrícola nessas áreas. Porém, não pensava em um território rural propriamente dito e multifuncional como o de 2014.

Aqui é importante compreender o conceito de agricultura urbana. Madaleno, em um breve histórico sobre esse tema de estudo, comenta que

Esta matéria foi negligenciada pelos estudos levados a cabo antes da década de [19]60, por se considerar que urbano e rural eram espaços não só totalmente diferentes mas também divergentes [...]. No entanto, alguns investigadores vêm enfatizando que, apesar de quase ausente das cidades pós Revolução Industrial, a agricultura prevaleceu dentro e na orla das mesmas desde tempos imemoriais (Mougeot 1994). Nos dias de hoje a agricultura urbana estabeleceu-se como temática importante e vem cativando um número crescente de adeptos na comunidade cientifica, investigadores preocupados com a sustentabilidade do desenvolvimento humano. [...]

De acordo com a organização americana The Urban Agriculture Network, na década de 1970 as atividades primárias em meio urbano ainda eram vistas como aberrantes, ou pelo menos conjunturais, resultantes do intenso êxodo rural então iniciado que se considerava insustentável a longo prazo. O tempo acabou por provar que estavam errados, pois a crise econômica resultante dos shocks petrolíferos perenizou-se, nós diríamos vulgarizou-se, e a agricultura urbana, considerada uma anomalia que a cidade acabaria por rejeitar, tornou-se numa solução possível para a resolução da pobreza urbana.

Nos anos 80 do século XX a agricultura urbana conheceu um período de rápido crescimento e de grande notoriedade entre algumas nações de países em desenvolvimento. Este processo foi estimulado por certas organizações internacionais, que nessa década iniciaram ou incrementaram programas de cooperação com países pobres no sentido de se investigarem as características da agricultura praticada em meio urbano, de se expandirem as terras cultivadas e se apoiarem tecnicamente os pequenos produtores. Foi decisiva a transferência de conhecimentos adquiridos nos âmbitos científico e tecnológico, onde a agricultura começava a ser vista como atividade importante para um desenvolvimento sustentado (2002, p. 2, 8-9). 
A partir desse breve histórico, pontos que Madaleno levanta a respeito da importância da agricultura urbana podem ser destacados, como: "uma possível resolução para a pobreza urbana" e "atividade importante para um desenvolvimento sustentado". Esses aspectos são encontrados no Plano Diretor de 2002 e, como será destacado, também no de 2014.

Madaleno também afirma que a agricultura urbana passou a ser incentivada por organizações internacionais. O Programa de Desenvolvimento das Nações Unidas (UNDP) ${ }^{24}$ é uma dessas organizações. Para o UNDP, a agricultura urbana é:

[...] uma atividade que contribui para a produção, o processamento e a comercialização de alimentos e energia, destinados à demanda dos consumidores urbanos ou metropolitanos, praticada em solos e com recursos hídricos dispersos pelo tecido urbano ou desenvolvida nas áreas periurbanas por meio da utilização dum sistema de produção intensivo, através do uso e reciclagem de recursos naturais e de resíduos sólidos urbanos, destinados a aumentar o rendimento das colheitas e a criação de gado (UNDP apud MADALENO, 2002, p. 3).

A Ruaf Foundation (Resource Centres on Urban Agriculture and Food Security Centro de recursos para a agricultura urbana e segurança alimentar), outra organização voltada para a agricultura urbana, define a atividade como

[...] o cultivo de plantas e a criação de animais dentro e no entorno da cidade. A característica mais marcante da agricultura urbana, que a distingue da rural, é que ela é integrada ao sistema econômico e ecológico urbano: a agricultura urbana é incorporada e interage com o ecossistema urbano. Isso inclui o uso de mão-de-obra dos próprios moradores urbanos, utilização de recursos da cidade (como resíduos orgânicos e águas residuais para a irrigação), ligação direta com os consumidores, impactos diretos sobre a ecologia urbana (positivos e negativos), integração com o sistema alimentar da cidade, disputa pela terra com outras funções urbanas, influência de políticas públicas e planos voltados para o urbano etc. (RUAF FOUNDATION, 2016, tradução nossa).

Um autor que estuda sobre agricultura urbana e apresenta seu conceito é Mougeot. De acordo com ele, a definição de agricultura urbana pode se basear em variáveis que envolvem o tipo de produção e produtos, a localização intra ou periurbana, as áreas em que é praticada a atividade - como residenciais, industriais ou comerciais -, o destino dos produtos e a escala de produção. Partindo disso, ele faz a seguinte definição:

\footnotetext{
${ }^{24}$ UNDP. Urban Agriculture: food, jobs and sustainable cities. New York: UNDP, 1996. p. 3.
} 
A agricultura urbana está localizada dentro (intra-urbana) ou na franja (periurbana) de uma pequena cidade, uma cidade ou uma metrópole; cultiva, processa e distribui uma diversidade de produtos alimentícios e nãoalimentícios $^{25}$; (re)usa amplamente recursos humanos e materiais, produtos e serviços encontrados na e no entorno da área urbana; e, em retorno, fornece recursos humanos e materiais, produtos e serviços para essa área urbana (MOUGEOT, 2000, p. 3, tradução nossa).

Madaleno também apresenta uma definição e explica como o uso de agricultura urbana pode ser tanto para a atividade agrícola intra ou periurbana. Ela, assim, diz que as

[...] atividades econômicas do setor primário, denominadas genericamente agricultura urbana, podem ser praticadas em pequenos espaços vazios existentes dentro do tecido urbano, ou em espaços mais abrangentes sitos na orla das cidades, conhecidos por cinturões verdes. Embora alguns autores segreguem os espaços cultivados apodando de periurbana a agricultura praticada na periferia das cidades e de urbana a desenvolvida nos espaços interiores não-construídos, a verdade é que se gerou um consenso entre as duas tendências generalizando-se a expressão urbana a ambos os espaços.

Consequentemente, a designação agricultura urbana abarca um sem número de formas de exploração agrícola que vão do cultivo intensivo dos quintais privados, ao plantio de uma associação de diversas espécies vegetais à beira das estradas e caminhos, passando pela ocupação, quantas vezes ilegal, de lotes urbanos vazios, pelo cultivo em vasos e recipientes dos mais diversos feitios nas varandas, em terraços, em pátios, nas caves, nas paredes de estruturas construídas, até à prática da agricultura hidropônica, da aquacultura e das mais ricas e variadas formas de criação de quase todos os tipos de gado (2002, p. 3, grifo da autora).

Como se pode perceber, a definição de agricultura urbana, apesar do termo "urbano", abrange tanto uma agricultura praticada dentro da cidade, como a feita em hortas comunitárias ou como a no entorno da mancha urbana. A própria definição de Mougeot é ampla, por considerar muitas variáveis diferentes. Aqui, será focado como uma atividade agrícola praticada em áreas intra e periurbanas. Assim, a região do extremo sul do município de São Paulo, onde se encontram os agricultores da Cooperapas e a ênfase desse estudo, pode ser estudada a partir de um novo viés: o da agricultura urbana.

Realmente, a agricultura praticada no extremo sul do município, ainda que tenha ganhado destaque no início do século XX como parte do cinturão verde da cidade, passou a ser referida como agricultura periurbana. O Plano Diretor de 2002 já dava indícios disso e, com a criação do Programa de Agricultura Urbana e Periurbana (Proaurp) no município de São Paulo, isso fica mais claro. Esse programa foi lançado pela Lei 13.727 em 2004 e

\footnotetext{
${ }^{25}$ Em seu texto, Mougeot não chega a definir o que ou quais seriam esses produtos não-alimentícios. Mas ele explica que excluir a categoria de produtos não-alimentícios da definição de agricultura urbana limita o entendimento desse conceito.
} 
regulamentado pelo Decreto 51.801 em 2010. O objetivo é "incentivar e apoiar a produção agroecológica e a comercialização na cidade de São Paulo" (PREFEITURA DE SÃO PAULO, 2016).

Como consequência do Proaurp, em 2006, por meio do Decreto 47.280, o então prefeito Gilberto Kassab oficializou a criação da Casa de Agricultura Ecológica (CAE) ${ }^{26}$ José Umberto Macedo Siqueira $^{27}$, localizada em Parelheiros ${ }^{28}$. Nele, decreta-se:

Art. $1^{\circ}$. Fica oficializada e denominada Casa da Agricultura Ecológica José Umberto Macedo Siqueira o serviço prestado pela Secretaria Municipal do Verde e do Meio Ambiente, instalado na Subprefeitura de Parelheiros, com a finalidade de dar apoio ao agricultor urbano e periurbano e implementar os objetivos do Programa de Agricultura Urbana e Periurbana - PROAURP no Município de São Paulo, que atenderá prioritariamente os agricultores, familiares e interessados dos Distritos de Parelheiros, Marsilac e Grajaú ${ }^{29}$. Parágrafo único. A Casa da Agricultura Ecológica mencionada no "caput" deste artigo funcionará como centro de referência técnica para políticas de desenvolvimento rural e periurbanas.

Art. $2^{\circ}$. A Casa da Agricultura Ecológica José Umberto Macedo Siqueira será gerenciada em parceria pelas Subprefeituras de Parelheiros e Capela do Socorro e pela Secretaria Municipal do Verde e do Meio Ambiente, que disponibilizarão os recursos humanos e materiais necessários ao seu funcionamento (PREFEITURA DE SÃO PAULO, 2006).

$\mathrm{Na}$ época, a CAE estava sob a gestão da Secretaria Municipal do Verde e do Meio Ambiente. Porém, ela foi passada para o Departamento de Agricultura, que até 2016, estava sob a Coordenadoria de Segurança Alimentar e Nutricional (Cosan). A Cosan "é o órgão responsável pela implementação de programas, projetos e ações, em Abastecimento e Segurança Alimentar e Nutricional, do município de São Paulo"30 (PREFEITURA DE SÃO PAULO, 2016). Essa, por sua vez, junto com a Coordenadoria de Desenvolvimento Econômico e a Coordenadoria do Trabalho, compunham a Secretaria Municipal do Desenvolvimento, Trabalho e Empreendedorismo. De acordo com Cristiano Mendes,

\footnotetext{
${ }^{26}$ Apesar de o nome oficial da CAE ser Casa de Agricultura Ecológica José Umberto Macedo Siqueira, ela é comumente chamada entre os cooperados e funcionários da Prefeitura de São Paulo e da Subprefeitura de Parelheiros de Casa de Agricultura ou apenas CAE. Esses nomes também serão adotados ao longo da dissertação.

${ }^{27}$ Ao longo da pesquisa, foram encontrados tanto "Casa de Agricultura Ecológica" como "Casa da Agricultura Ecológica". Para o trabalho, foi feita a opção por padronizar para "Casa de Agricultura Ecológica". Porém, nas citações, respeitou-se a maneira como foi referida a CAE.

${ }^{28}$ Posteriormente, com o Decreto 51.801, também foram estabelecidas mais duas Casas de Agricultura Ecológica no município, uma na zona leste, e outra na zona norte.

${ }^{29}$ Apesar de muitos agricultores residirem em Parelheiros e Marsilac, ainda existem agricultores no distrito de Grajaú. Inclusive, parte dos membros da Cooperapas residem e produzem dentro do território desse distrito, conforme será visto adiante no trabalho.

${ }^{30}$ O Decreto 56.399, de 9 de setembro de 2015, transformou a antiga Supervisão Geral de Abastecimento (Abast), na Coordenadoria de Segurança Alimentar e Nutricional (Cosan) (PREFEITURA DE SÃO PAULO, 2015).
} 
engenheiro agrônomo e funcionário da Supervisão Geral de Abastecimento da Prefeitura de São Paulo, a CAE (fotos 1.5, 1.6 e 1.7) foi transferida da Secretaria Municipal do Verde e do Meio Ambiente para a Cosan para ter um enfoque mais comercial (informação verbal) ${ }^{31}$.
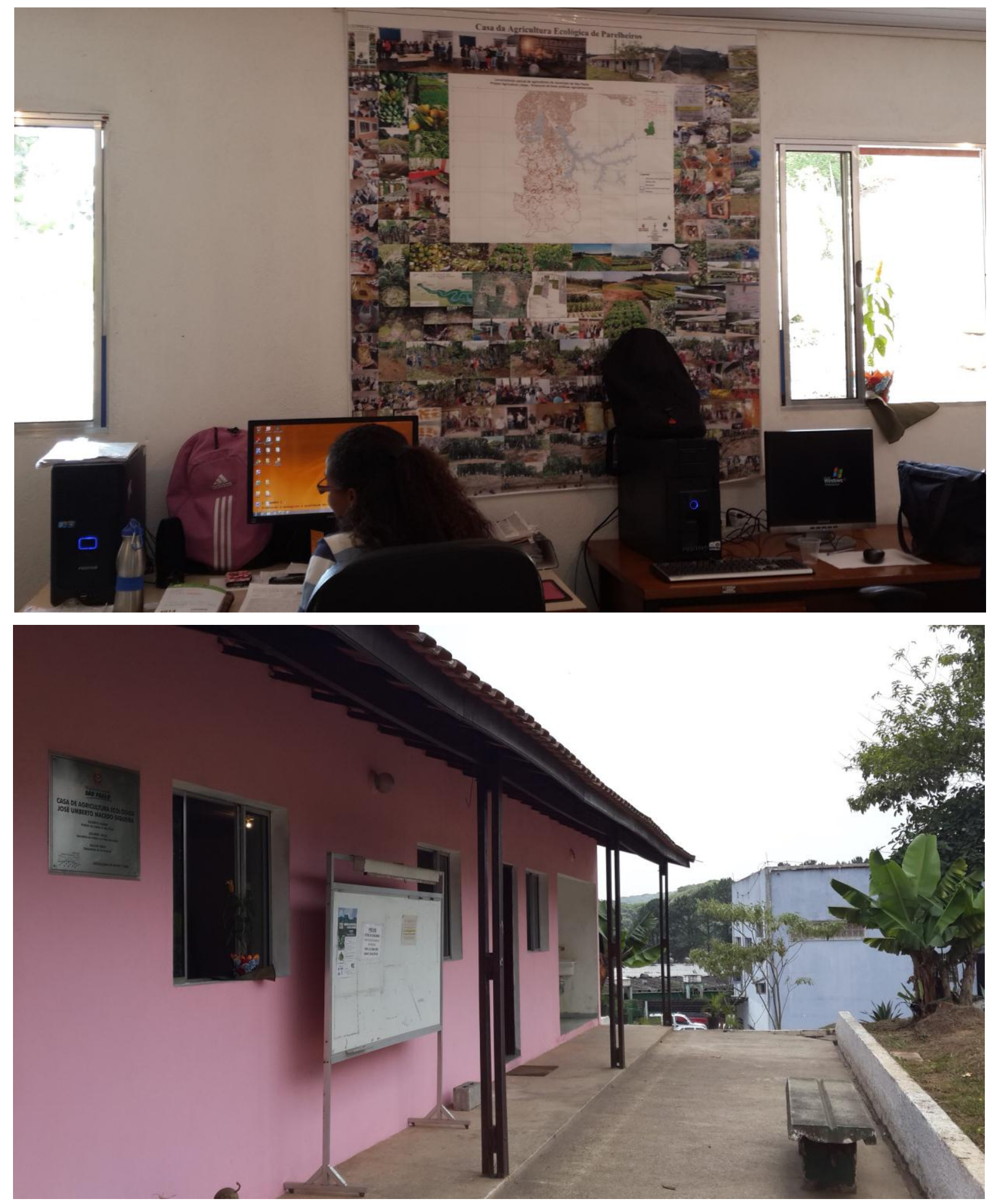

Fotos 1.5 e 1.6. Na foto acima (1.5), a sala onde trabalham os técnicos da CAE. Na foto abaixo (1.6), a CAE por fora, na Subprefeitura de Parelheiros. Fotos de 25 de novembro de 2014. Crédito das fotos: Angélica Campos Nakamura.

${ }^{31}$ Entrevista concedida por Cristiano Mendes, na Supervisão Geral de Abastecimento (Abast) em São Paulo, em 14 de setembro de 2015 . 


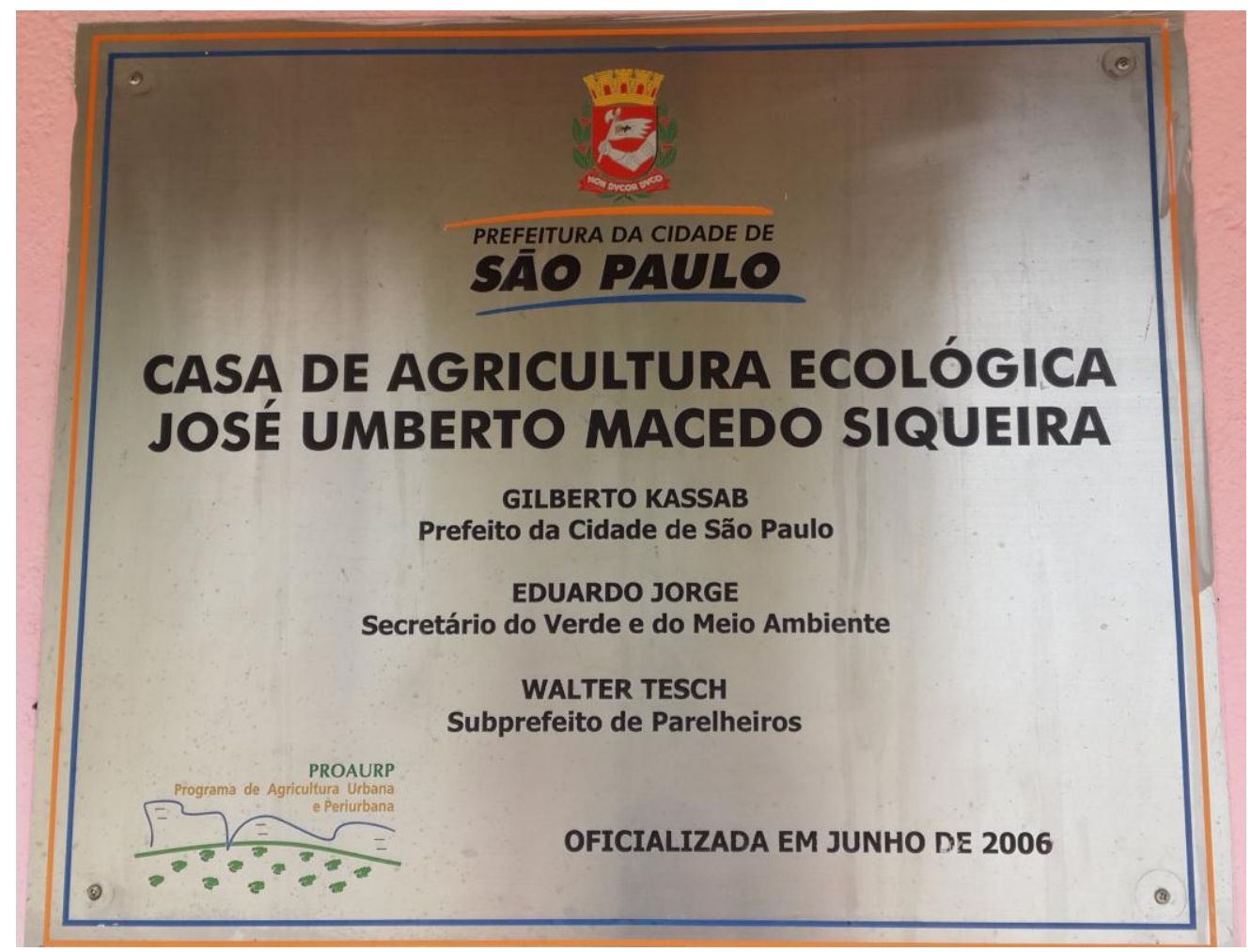

Foto 1.7. Placa da Casa de Agricultura Ecológica José Umberto Macedo Siqueira, a CAE de Parelheiros. Foto de 25 de novembro de 2014. Crédito da foto: Angélica Campos Nakamura.

Ainda sobre o Decreto 47.280, que oficializou a criação da Casa de Agricultura Ecológica, há considerações feitas no início dele. São elas:

CONSIDERANDO que devem ser observadas as especificidades locais na implementação da Política Municipal de Agricultura Urbana e Periurbana, priorizando-se a aptidão e a vocação agrícola regional;

CONSIDERANDO que a Lei $\mathrm{n}^{\circ} 13.706$, de 6 de janeiro de 2004, estabelece o Zoneamento Geo-Ambiental da Área de Proteção Ambiental Municipal do Capivari-Monos, que compreende extensas áreas classificadas como Zona de Uso Agropecuário - ZUA;

CONSIDERANDO que a agricultura, a pecuária e a silvicultura são importantes atividades econômicas exercidas no território das Subprefeituras de Parelheiros e Capela do Socorro;

CONSIDERANDO ainda que o cidadão José Umberto Macedo Siqueira, agricultor orgânico e líder comunitário local, recentemente falecido, teve destacado papel na luta pela construção de políticas públicas voltadas à agricultura [...] (PREFEITURA DE SÃO PAULO, 2006).

Por meio delas, entende-se a escolha do nome da CAE de Parelheiros, a relevância da atividade agrícola para a região e, contata-se mais uma vez, como a ideia da atividade agrícola junto com a conservação ambiental vêm caminhando juntas desde o Plano Diretor de 2002 e acaba retomada amplamente no Plano Diretor de 2014. 
Em 2004, o zoneamento de uma Área de Proteção Municipal foi estabelecido, a da APA Capivari-Monos. Essa APA, a primeira do município de São Paulo, havia sido criada pela Lei $\mathrm{n}^{\mathrm{o}} 13.136$ em 2001. Entre seus objetivos, tem-se:

I - promover o uso sustentado dos recursos naturais;

II - proteger a biodiversidade;

III - proteger os recursos hídricos e os remanescentes de Mata Atlântica;

IV - proteger o patrimônio arqueológico e cultural;

V - promover a melhoria da qualidade de vida das populações;

VI - manter o caráter rural da região;

VII - evitar o avanço da ocupação urbana na área protegida (JUSBRASIL, 2001).

Em 2006, uma outra APA municipal foi criada, a Bororé-Colônia, por meio da Lei $\mathrm{n}^{\mathrm{O}}$ 14.162. Seus objetivos são:

I - promover o uso sustentável dos recursos naturais;

II - proteger a biodiversidade;

III - proteger os recursos hídricos e os remanescentes de Mata Atlântica;

IV - proteger o patrimônio cultural;

V - proteger as sub-bacias hidrográficas do Taquacetuba e Bororé, contribuintes do reservatório Billings, e Itaim, contribuinte do reservatório Guarapiranga, importantes locais de captação de água;

VI - promover a melhoria da qualidade de vida das populações;

VII - manter o caráter rural da região;

VIII - evitar o avanço da ocupação urbana na área protegida;

IX - promover o resgate da memória histórica da imigração na região (PREFEITURA DE SÃO PAULO, 2006).

Assim, apesar das APAs serem áreas protegidas, elas preveem atividades econômicas e a presença de pessoas vivendo em seus territórios. O resgate desses decretos se faz importante para esse trabalho porque, conforme se verá adiante, o fato de esses agricultores viverem nas áreas de APAs (mapa 1.9 na página a seguir) influencia, em muito, sua atividade.

Cristiano Mendes, que teve um papel fundamental na criação da Cooperapas, entrou como funcionário de carreira na Prefeitura de São Paulo em 2009 e optou por trabalhar na Supervisão de Abastecimento (Abast). Apesar de já existir o Proaurp e a CAE, ele participou do início dos trabalhos da Prefeitura com os agricultores do extremo sul do município. De acordo com ele, até então os funcionários ficavam na central da Abast, no Mercado Municipal, no centro da cidade, e iam para Parelheiros para fazer as ações. Cristiano entrou para trabalhar em Parelheiros. 
Mapa 1.9. Parques e unidades de conservação no município de São Paulo (2012)

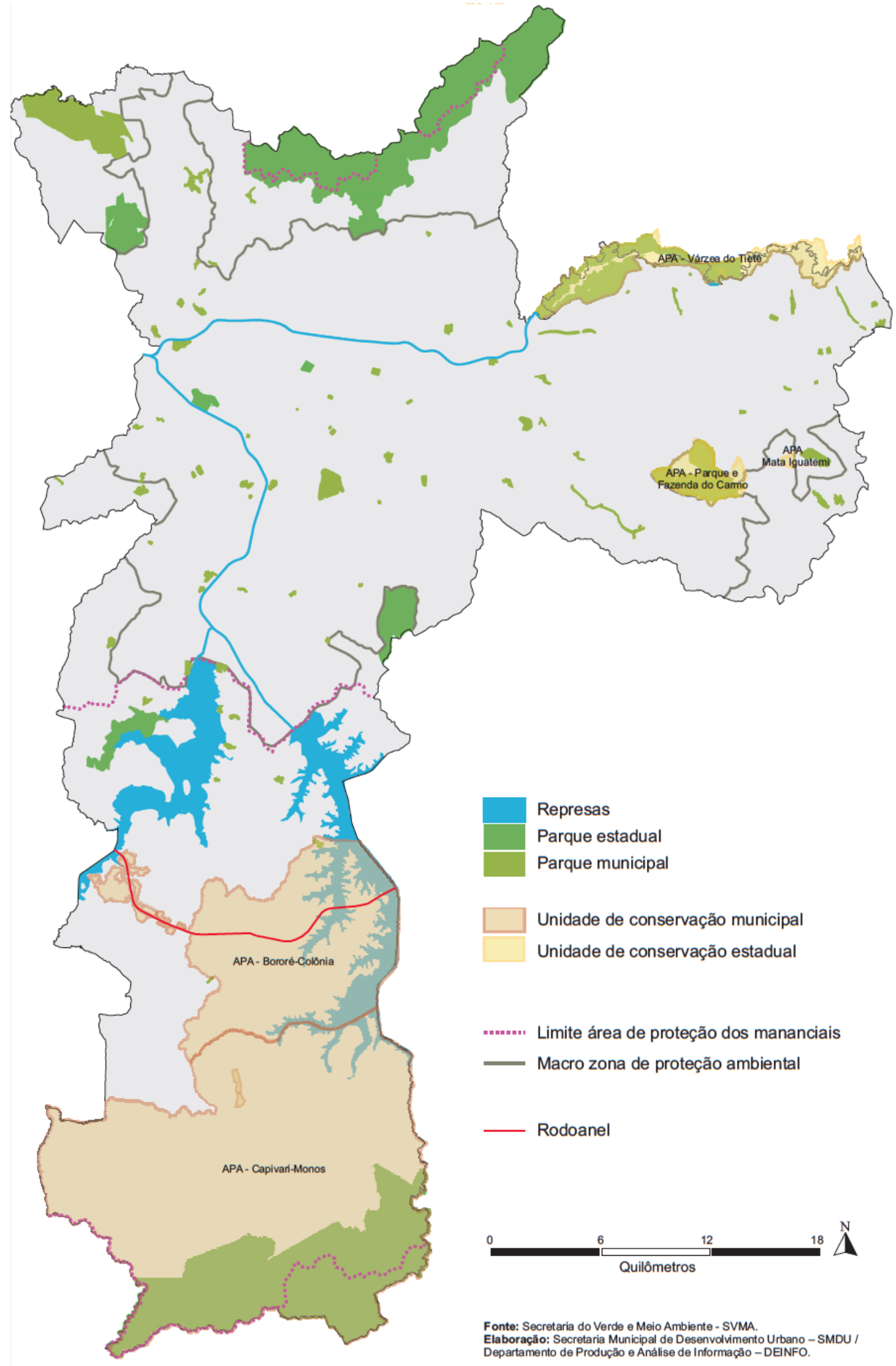


Cristiano pegou bem o início dos trabalhos e recorda:

Fizemos cadastro de produtores [...] fomos assumindo acompanhamento técnico pra esse pessoal. Também começamos a visitar outros produtores, sempre com a lógica de converter para a agricultura agroecológica.

$O$ pessoal foi se agregando, ia de porta em porta. [...] Fizemos várias ações, de cultivo, comercialização, individual... foi fazendo essas pequenas ações. Nisso também o governo do estado estava com um projeto na secretaria do meio ambiente chamado "Guarapiranga Sustentável",32 (informação verbal) $^{33}$.

E faz uma observação importante, que mostra o quanto as leis das APAs influenciam a atividade dos agricultores na região:

Até então, a agricultura lá na zona sul do município, por conta de algumas leis das APAs e dos mananciais, era uma atividade passiva de licenciamento. Tivemos problema com um agricultor que foi multado.

Essa lei, ela não tem regulamentação. Foi feita a lei dizendo que tinha que licenciar a agricultura na região, mas não tinha regulamentação. Então o pessoal da Cetesb $^{34}$, que tinha que licenciar isso, não tinha nenhum parâmetro de como licenciar [...]. Então veio essa multa do cara lá, o pessoal da Cetesb veio procurar a gente, [dizendo] "não sei o que fazer com isso, não vou aplicar multa nesse cara".

Foi dai que a gente começou a conversa com o Guarapiranga Sustentável, para criar boas práticas para que servisse [sic] como um ajustamento de conduta pra ser um instrumento para o pessoal da Secretaria do Meio Ambiente, para que o pessoal da Cetesb visse e tivesse um parâmetro. Mas decidimos fazer por um caminho de não imposição, então criamos um protocolo em parceria com o governo do estado e prefeitura com adesão voluntária, com incentivos, assistência técnica. A gente quer, paulatinamente, agregando [sic] o pessoal pra conversão voluntária (informação verbal) ${ }^{35}$.

Foi dessa necessidade de regulamentação e criação de parâmetros de como praticar uma agricultura com menos agrotóxicos ou livre deles que surgiu, em 2010, o Programa Agricultura Limpa e, por meio de decreto municipal, o Protocolo de Boas Práticas

32 O Projeto Guarapiranga Sustentável visava reduzir a degradação das águas causada pela agricultura convencional, colaborando com sua proteção e melhorando sua qualidade para o abastecimento público (SIGAM, 2016).

${ }^{33}$ Entrevista concedida por Cristiano Mendes, na Supervisão Geral de Abastecimento (Abast) em São Paulo, em 14 de setembro de 2015.

${ }^{34}$ A Companhia Ambiental do Estado de São Paulo (Cetesb) "é a agência do Governo do Estado responsável pelo controle, fiscalização, monitoramento e licenciamento de atividades geradoras de poluição, com a preocupação fundamental de preservar e recuperar a qualidade das águas, do ar e do solo" (CETESB, 2016).

${ }^{35}$ Entrevista concedida por Cristiano Mendes, na Supervisão Geral de Abastecimento (Abast) em São Paulo, em 14 de setembro de 2015. 
Agrícolas $^{36}$, em parceria com o governo estadual. De acordo com a Secretaria Municipal do Verde e do Meio Ambiente:

Em 2010, foi criado o Programa Agricultura Limpa [...] Tem o objetivo de incentivar a produção agrícola no município de São Paulo e orientar a conversão da agricultura convencional em orgânica.

Também foi criado, por meio de decreto municipal, o Protocolo de Boas Práticas Agrícolas, documento construído em parceria com o Governo do Estado, que dispõe de regras para produção sem danos ao ambiente.

Aderindo ao protocolo, os produtores recebem apoio da Prefeitura para converter sua produção, e o direito de utilização do Selo de Indicação de Procedência Guarapiranga - a Garça Vermelha [figura 1.6] - que identifica os produtos da agricultura paulistana cultivados segundo as boas práticas agroambientais (2012, p. 56).

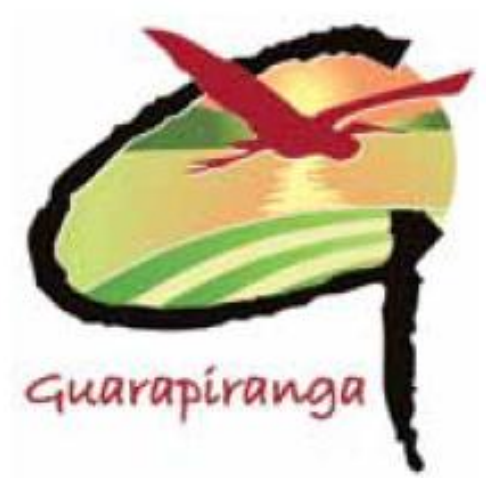

Figura 1.6. Selo de Indicação de Procedência Guarapiranga e Boas Práticas Agrícolas. Fonte: SECRETARIA DO MUNICIPAL DO VERDE E DO MEIO AMBIENTE. Ecoturismo e agroecologia no extremo sul de São Paulo. São Paulo: SVMA, 2012. p. 56.

Por meio do Protocolo de Boas Práticas Agrícolas, os agricultores se comprometiam a realizar a transição da produção convencional para a produção agroecológica. Por outro lado, o governo prometia fornecer apoio e assistência técnica agroecológica para esses produtores (SIGAM, 2010).

O estabelecimento do protocolo também visava ajudar esses produtores na comercialização de seus produtos. De acordo com os técnicos da Casa de Agricultura Ecológica, para que uma produção agrícola seja considerada totalmente limpa de agrotóxicos e biofertilizantes, a demora é de cerca de dois anos. Assinando o protocolo, o agricultor podia vender seus produtos considerados "em transição" e cobrar um pouco mais por eles do que o convencional, porém, ainda não o valor do orgânico.

\footnotetext{
36 O Protocolo de Boas Práticas Agrícolas (ou Agroambientais, como está no documento) se encontra no final desse trabalho, na seção "Anexos”, como o anexo "B”.
} 
Se em 2015 e 2016 a procura por orgânicos se tornou tamanha que os agricultores da Cooperapas não conseguem dar conta dos interessados que surgem para comprar seus produtos, a realidade nesses anos nos quais se iniciavam as políticas públicas no município, mais focadas nessa agricultura, era outra. Além de não haver muita procura por esse tipo de produto, os agricultores reclamavam de não existir muitos locais de comercialização de produtos orgânicos.

Esse contexto é muito importante, porque é daí que a ideia de uma cooperativa com agricultores da região surge, conforme será estudado no capítulo 3. Por meio de uma cooperativa, poder-se-ia participar de políticas públicas federais como o Programa de Aquisição de Alimentos (PAA) e o Programa Nacional de Alimentação Escolar (Pnae). Contudo, era necessário criar outros canais para a comercialização. Uma das saídas foi a criação de feiras orgânicas pela Supervisão de Abastecimento. A primeira a surgir foi no Parque Burle Marx em 2011, conforme relata Mendes:

A gente estava começando uma conversa com o Verde [a Secretaria Municipal do Verde e do Meio Ambiente] para colocar feiras agroecológicas. Conseguimos com o conselho do parque [Burle Marx], conseguimos lá. Tinha 4 barracas lá, mas uma de cooperativa [da Cooperapas]. Por que? Para uma feira ter opções de venda, diversidade pro consumidor, por isso ter mais barracas (informação verbal) ${ }^{37}$.

Apesar de apenas uma barraca ser da Cooperapas, todas as outras eram de agricultores da cooperativa. A da Cooperapas era para levar produtos de agricultores membros sem condições de ter um veículo para transportar seus produtos ou ter alguém que pudesse ir à feira.

Tiago Arpad Spalding Reiter ${ }^{38}$, funcionário do Instituto Kairós ${ }^{39}$, na época trabalhava para o Instituto 5 Elementos $^{40}$, que realizava um projeto na região pelo Fundo Especial de

\footnotetext{
${ }^{37}$ Entrevista concedida por Cristiano Mendes, na Supervisão Geral de Abastecimento (Abast) em São Paulo, em 14 de setembro de 2015.

${ }^{38}$ Tiago Arpad Spalding Reiter, mais conhecido por Arpad, é membro da Cooperapas e personagem importante na história dos agricultores e na constituição da cooperativa, conforme será visto no capítulo 3 .

39 "O Instituto Kairós - Ética e Atuação Responsável tem como foco prioritário de trabalho a educação, assessoria e pesquisa em consumo responsável e comércio justo e solidário, entendidos como estratégias para combater a desigualdade social e contribuir na transformação da relação da sociedade com a natureza. A instituição, fundada em 2000, adota a prática e o fomento da autogestão e desenvolve suas ações de acordo com os princípios e propostas da economia solidária, bem como da agricultura camponesa/familiar, agroecologia e soberania alimentar" (KAIRÓS, 2016).

40 "O Instituto 5 Elementos - Educação para a Sustentabilidade é uma Organização da Sociedade Civil de Interesse Público (Oscip) fundada em 1993, em São Paulo, com o propósito de semear conceitos e práticas voltadas à sustentabilidade, fomentar o debate e as ações sobre essas questões na sociedade e disseminar conhecimentos de modo a transformar a relação das pessoas com a natureza e o meio ambiente urbano" (INSTITUTO 5 ELEMENTOS, 2013).
} 
Meio Ambiente e Desenvolvimento Sustentável (Fema) ${ }^{41}$. Ele também relembra a criação dessa feira:

A gente criou a feira do Burle Marx, não existia feira lá. Isso foi parte do projeto. A gente criou política pública pra começar a abrir feiras, pra vender produtos da agricultura limpa e orgânicos. A barraca era em nome dos agricultores, mas era uma coisa para os agricultores da cooperativa. [...]

A gente conseguiu fazer a feira do Burle Marx, que foi uma grande vitória. Por quê? Porque foi a primeira feira dentro de um parque municipal. Existe uma lei do Jânio Quadros que proibia feira em parques. Ai a gente foi conversando com o secretário do verde, o Eduardo Jorge, com vereador, com o Abastecimento, "vamos fazer a feira no parque" [...] Aí foi feito um decreto ${ }^{42}$ (informação verbal) ${ }^{43}$.

Após a criação dessa feira, Arpad conta que se iniciaram trabalhos para o surgimento de mais uma, que se tornou uma das principais feiras orgânicas da cidade de São Paulo: a Feira de Produtos Orgânicos e da Agricultura Limpa no Modelódromo do Ibirapuera ${ }^{44}$, mais conhecida apenas como "Feira do Ibirapuera" ou "Feira do Modelódromo". Para a organização dessa feira, houve uma grande mobilização de grupos variados:

Pra abrir na feira do Ibirapuera, a gente montou um projeto de trabalho.

As feiras são do Abastecimento. A CAE se envolveu nisso, especialmente o supervisor de abastecimento, que era o José Roberto Graziano. Foi um envolvimento total, a gente se reunia uma vez por mês.

o Kairós também se envolveu pra montar a feira.

Todas as associações envolvidas com agricultura orgânica em São Paulo se reuniam uma vez por mês para pensar essa feira. A AAO [Associação de Agricultura Orgânica], $A B D$ [Associação Agricultura Biodinâmica], ANC [Associação de Agricultura Natural de Campinas e Região], Mokiti Okada, Kairós, Slow Food... (informação verbal) ${ }^{45}$.

\footnotetext{
${ }^{41}$ De acordo com o site da Secretaria Municipal do Verde e do Meio Ambiente, "O Fundo Especial de Meio Ambiente e Desenvolvimento Sustentável - FEMA - destina-se a apoiar projetos que visem o uso sustentável dos recursos naturais, manutenção, melhoria e/ou recuperação da qualidade ambiental, pesquisa e atividades ambientais de controle, fiscalização e defesa do meio ambiente" (SECRETARIA MUNICIPAL DO VERDE E DO MEIO AMBIENTE, 2016, grifo do autor).

${ }^{42}$ Tanto o decreto de Jânio Quadros que proibia, como o novo permitindo feiras em parques, não foram encontrados.

${ }^{43}$ Entrevista concedida por Tiago Arpad Spalding Reiter, em seu sítio, localizado no distrito de Marsilac, no município de São Paulo, em 27 de novembro de 2015.

${ }^{44}$ O Modelódromo do Ibirapuera foi inaugurado em 1969. É uma área separada do parque e "foi construído exatamente para congregar, num único espaço, as atividades do plastimodelismo, aeromodelismo, nautimodelismo, ferrorama e autorama" (GPPSD, 2016).

${ }^{45}$ Entrevista concedida por Tiago Arpad Spalding Reiter, em seu sítio, localizado no distrito de Marsilac, no município de São Paulo, em 27 de novembro de 2015.
} 
Até a feira estrear, em 2012, ocorreram alguns empecilhos. A feira iria acontecer dentro da área do parque, porém, o conselho do parque recorreu ao Ministério Público para "denunciar que estavam se apropriando do espaço público do parque e que iam ganhar rios de dinheiro" (informação verbal) ${ }^{46}$. Por isso, a feira ocorre, até hoje, no Modelódromo do Ibirapuera.

Mesmo com a mudança de local, em 2014 a feira passou novamente por problemas e foi proibida de acontecer no Modelódromo. Isso gerou uma grande mobilização de pessoas, desde os envolvidos com a agricultura orgânica no município de São Paulo, como os agricultores, até os consumidores. O episódio ficou conhecido por "A feira fica" e teve participação direta de Arpad e alguns membros da Cooperapas (foto 1.8). Felizmente, o episódio se resolveu e a feira voltou a ocorrer no Modelódromo. Hoje, ela é um dos pontos mais concorridos para a venda de produtos orgânicos na cidade.
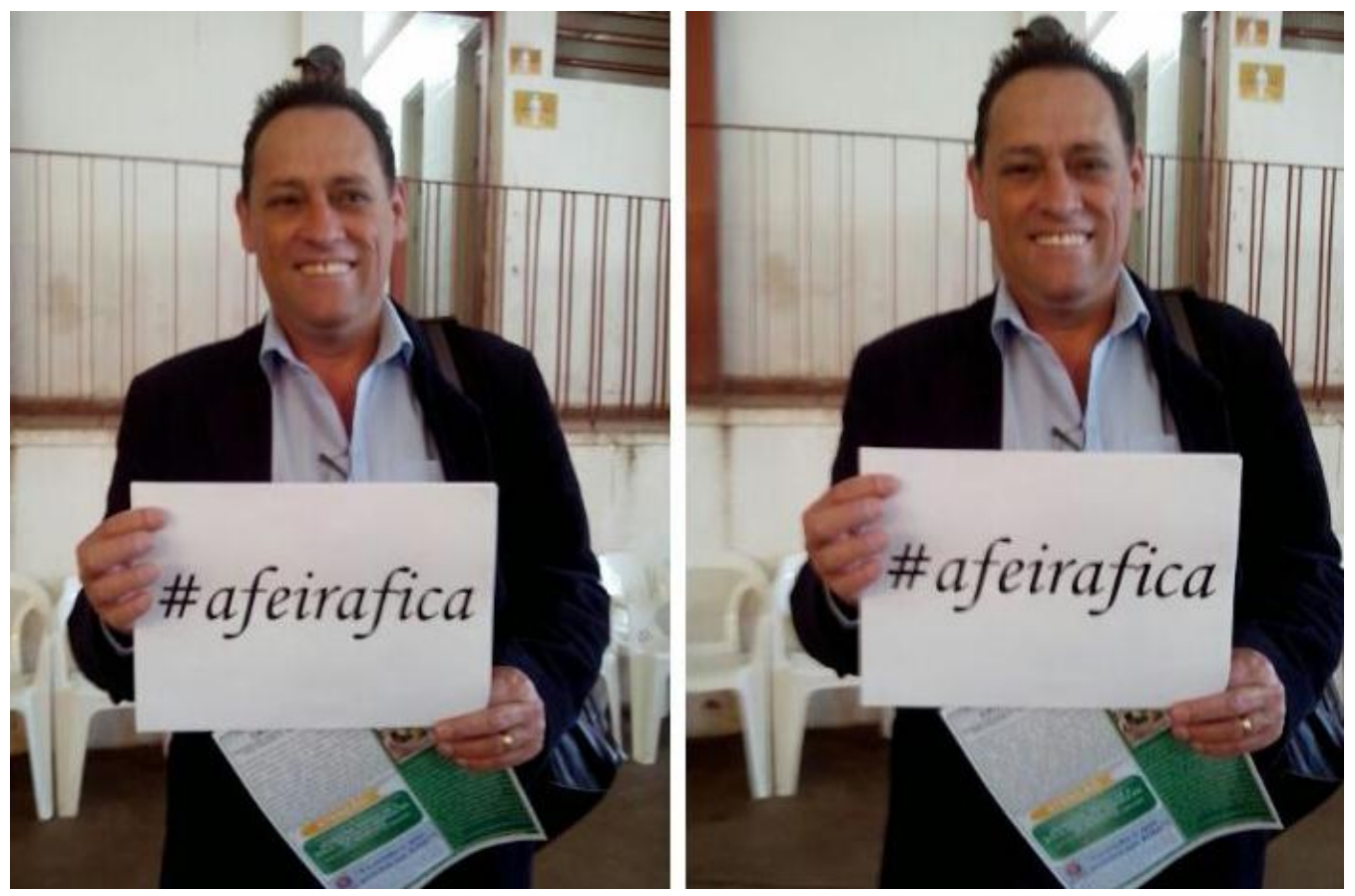

Foto 1.8. Foto recebida em 11 de agosto de 2016, pelo grupo de Whatsapp da Cooperapas. Na ocasião, alguns membros estavam relembrando o episódio "A feira fica". Na foto, o secretário municipal do Trabalho, Artur Henrique, posa pelo movimento. Foto sem data. Crédito da foto: foto recebida pelo grupo do Whatsapp da Cooperapas.

Atualmente, existem várias feiras orgânicas na cidade de São Paulo e, enquanto acompanhei os trabalhos da Cooperapas e da CAE ao longo de 2015, era muito comum ouvir um comentário de uma feira orgânica que estava por surgir, ou sobre algum evento ou cliente

\footnotetext{
${ }^{46}$ Entrevista concedida por Tiago Arpad Spalding Reiter, em seu sítio, localizado no distrito de Marsilac, no município de São Paulo, em 27 de novembro de 2015.
} 
interessado nos produtos da cooperativa. Ao longo dos últimos anos, o mercado consumidor de orgânicos e o interesse por eles cresceu. Por sempre surgir alguma novidade, é muito difícil acompanhar em tempo real quantas feiras e locais vendem produtos orgânicos. O Instituto Brasileiro de Defesa do Consumidor (Idec) mapeia as feiras e locais os quais comercializam produtos orgânicos pelo Brasil pelo Mapa de Feiras Orgânicas no site $<$ http://feirasorganicas.idec.org.br $>^{47}$ (figura 1.7).

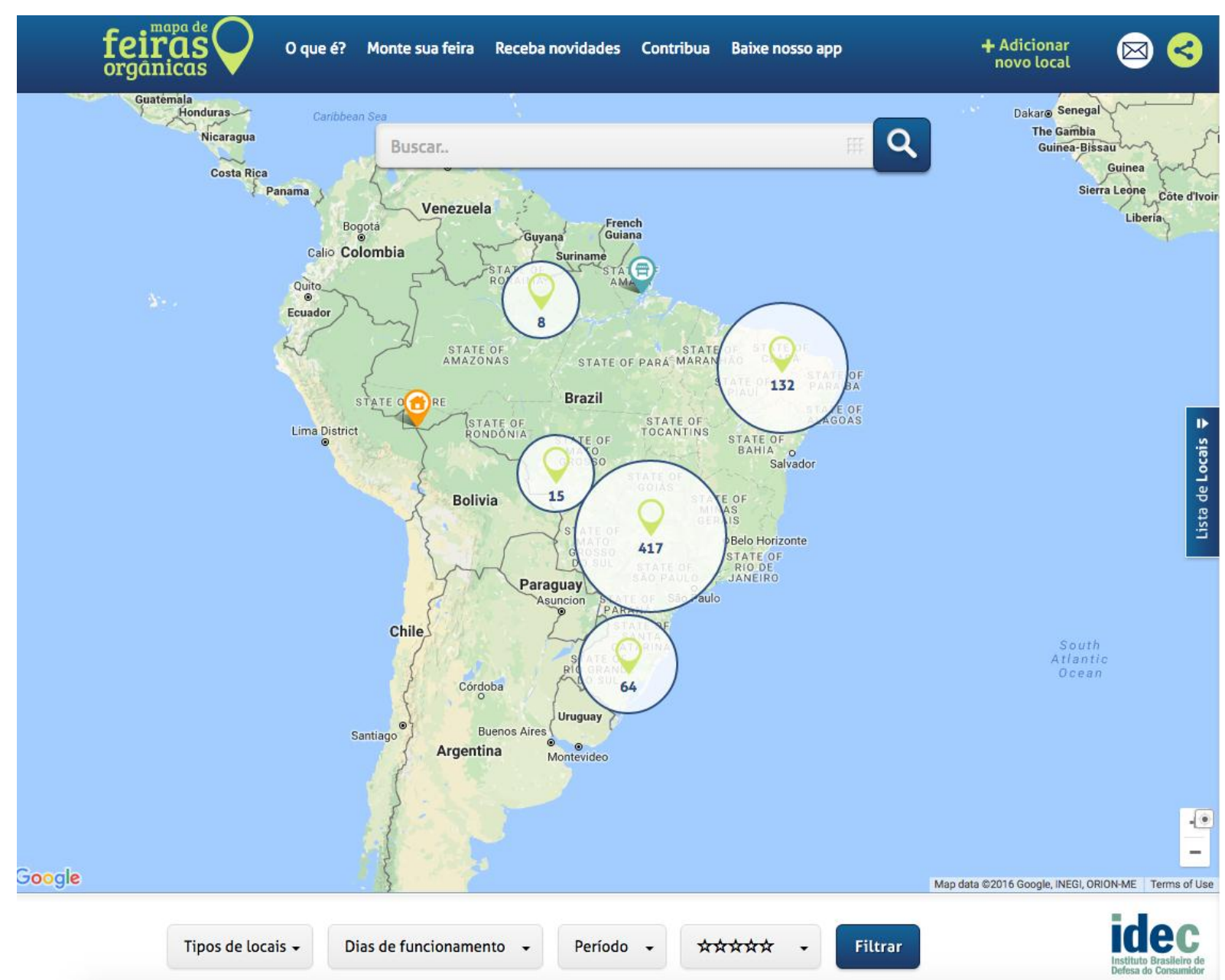

Figura 1.7. Página na internet do Idec, com o mapa de feiras orgânicas pelo Brasil. É possível filtrar as informações pelo tipo de local, dia de funcionamento e período. O Idec ainda disponibiliza um aplicativo para quem quiser acessar de forma mais prática do celular.

Conforme dito, o surgimento da Cooperapas, cuja história será tratada no capítulo 3, deu-se nesse contexto de surgimento de políticas públicas voltadas para a agricultura urbana e periurbana no município de São Paulo. Elas ganham força a partir do Plano Diretor de 2002 e, com a chegada do Proaurp em 2004 e o surgimento da CAE em 2006, as ações começam

\footnotetext{
${ }^{47} \mathrm{O}$ acesso foi feito em 8 de agosto de 2016.
} 
efetivamente a acontecer. O surgimento da cooperativa, portanto, tem ligação direta com essas políticas públicas e com o início da criação das feiras orgânicas na cidade. Com a aprovação do novo Plano Diretor em 2014 e o restabelecimento de uma zona rural no município, novas políticas voltadas para esses agricultores do extremo sul do município surgiram nos últimos anos.

\subsection{Novas políticas públicas para a agricultura periurbana e a questão da conservação ambiental e do desenvolvimento sustentável}

O Plano Diretor de 2014 se mostrou muito mais completo e pensado para o rural no município de São Paulo. Entre seus princípios, logo no início, ele traz a função social da propriedade rural, que é a utilização "racional e adequada [da propriedade], conservando seus recursos naturais, favorecendo o bem-estar dos proprietários e dos trabalhadores e observando as disposições que regulam as relações de trabalho" (PREFEITURA DE SÃO PAULO, 2014).

Apesar de ser afirmado que esse plano criou a zona rural, ela não tem uma seção voltada para ela no Plano Diretor. A zona rural aparece completamente vinculada da questão ambiental: "As macroáreas de Contenção Urbana e Uso Sustentável e de Preservação de Ecossistemas Naturais correspondem à zona rural do Município" (PREFEITURA DE SÃO PAULO, 2014). Essas duas macroáreas fazem parte da Macrozona de Proteção e Recuperação Ambiental, conforme citado anteriormente.

É a subseção III que define a Macroárea de Contenção Urbana e Uso Sustentável:

Art. 20. A Macroárea de Contenção Urbana e Uso Sustentável, [...] localizada ao sul do território municipal é caracterizada pela existência de fragmentos significativos de vegetação nativa, entremeados por atividades agrícolas, sítios e chácaras de recreio que protegem e/ou impactam, em graus distintos, a qualidade dos recursos hídricos e da biodiversidade, com características geológico-geotécnicas e de relevo que demandam critérios específicos para ocupação, abrigando também áreas de exploração mineral, ativas e desativadas.

§ 10 A Macroárea de Contenção Urbana e Uso Sustentável localiza-se integralmente na Área de Proteção de Mananciais definida na legislação estadual, abrangendo o território das Áreas de Proteção Ambiental CapivariMonos e Bororé-Colônia. 
§ $2^{\mathbf{0}}$ A Macroárea de Contenção Urbana e Uso Sustentável integra a zona rural, sendo vedado o parcelamento do solo para fins urbanos (PREFEITURA DE SÃO PAULO, 2014).

Entre alguns dos objetivos para essa área, pode-se citar:

I - contenção da urbanização do território;

II - proteção da paisagem rural considerando seu valor ambiental, histórico e cultural;

III - promoção do desenvolvimento da zona rural com sustentabilidade ambiental, econômica e social, e estímulo à agricultura orgânica;

IV - conservação e recuperação dos fragmentos florestais, corredores ecológicos e das áreas de preservação permanente; [...]

XI - manutenção e recuperação dos serviços ambientais prestados pelos sistemas ambientais existentes, em especial aqueles relacionados com a produção da água, conservação da biodiversidade, regulação climática e proteção ao solo (PREFEITURA DE SÃO PAULO, 2014).

A subseção IV define a Macroárea de Preservação dos Ecossistemas Naturais:

Art. 21. A Macroárea de Preservação de Ecossistemas Naturais, [...] é caracterizada pela existência de sistemas ambientais cujos elementos e processo ainda conservam suas características naturais.

$\S \mathbf{1}^{\mathbf{0}} \mathrm{Na}$ Macroárea de Preservação de Ecossistemas Naturais predominam áreas de remanescentes florestais naturais e ecossistemas associados com expressiva distribuição espacial e relativo grau de continuidade e conservação, mantenedoras da biodiversidade e conservação do solo, bem como várzeas preservadas, cabeceiras de drenagem, nascentes e cursos d'água ainda pouco impactados por atividades antrópicas e áreas com fragilidades geológico-geotécnicas e de relevo suscetíveis a processos erosivos, escorregamentos ou outros movimentos de massa.

$\S 2^{\circ}$ A Macroárea de Preservação de Ecossistemas Naturais integra a zona rural (PREFEITURA DE SÃO PAULO, 2014).

Apesar de integrar a zona rural, não há menção à atividade agrícola, pois é uma área considerada pouco ou quase nada explorada ou que não sofreu muita alteração do trabalho humano.

Há outros objetivos para as macroáreas, como a "VIII - garantia de proteção às terras indígenas, delimitadas e em processo de homologação, de forma a coibir a ocupação dessas áreas até que sua situação seja definida pelo Ministério da Justiça" (PREFEITURA DE SÃO PAULO, 2014) na Macroárea de Contenção Urbana e Uso Sustentável, ou a "VII - promoção de atividades ligadas à pesquisa, ao ecoturismo e à educação ambiental" (PREFEITURA DE SÃO PAULO, 2014) na Macroárea de Preservação de Ecossistemas Naturais. Todos esses objetivos deixam claro a ideia da criação de uma zona rural multifuncional. 
Apesar de não haver uma seção específica para a zona rural, na seção V o plano prevê um Polo de Desenvolvimento Econômico Rural Sustentável. Ele prevê as seguintes ações:

I - fortalecer a Assistência Técnica e Extensão Rural através das Casas de Agricultura Ecológica, dotando-as de recursos e infraestrutura suficientes;

II - apoiar a certificação orgânica dos agricultores familiares, em especial a certificação participativa;

III - estabelecer convênio com o Instituto Nacional da Colonização e Reforma Agrária para promover o recadastramento e a regularização fundiária das propriedades;

IV - firmar convênios com o Governo Federal objetivando implantar no Município as políticas e programas federais voltados à agricultura familiar e à agroecologia, de acordo com a Política Nacional de Agricultura Familiar e o Plano Nacional de Agroecologia e Produção Orgânica;

V - implantar, em parceria com os governos Estadual e Federal, uma Escola Técnica de Agroecologia e programas de melhoria das estradas vicinais rurais e de saneamento básico;

VI - viabilizar a construção de um entreposto de comercialização e distribuição de produtos agropecuários;

VII - garantir a introdução de alimentos orgânicos produzidos no Município de São Paulo na alimentação escolar;

VIII - implantar o Polo de Turismo de Parelheiros, nos termos da legislação em vigor;

IX - fortalecer e ampliar a fiscalização ambiental para proteger o uso e a paisagem rural, integrando e otimizando as ações dos órgãos estaduais e municipais competentes;

$\mathbf{X}$ - implementar o instrumento por pagamento por serviços ambientais às propriedades rurais, conforme o art. 158 desta lei, em especial, nas áreas prestadoras de serviços relacionadas à produção de água;

XI - criar mecanismos para a proteção e conservação da biodiversidade na zona rural;

XII - melhorar a oferta de equipamentos e serviços públicos de educação, saúde, assistência social, lazer, esporte e cultura à população moradora da região (PREFEITURA DE SÃO PAULO, 2014).

Entre os pontos em ação, pode-se citar a assistência técnica prestada pela CAE, o apoio desses técnicos com as certificações orgânicas participativas (as quais serão tratadas no item a seguir desse capítulo) e a implantação do Polo de Turismo de Parelheiros, aludido anteriormente nesse capítulo. Porém, outros passos foram dados, voltados para essas ações estabelecidas no Plano Diretor.

Em 2 de março de 2016, foi lançado o programa Agriculturas Paulistanas na Subprefeitura de Parelheiros (fotos 1.9 e 1.10 na página a seguir). Esse programa pretende realizar a regularização fundiária, a capacitação e a assistência técnica para os agricultores da região. O programa, ainda, trouxe para os agricultores o acesso gratuito a equipamentos para a atividade agrícola: um trator, um microtrator com kit encanteirador, uma enxada rotativa com encanteirador, uma carreta agrícola basculante, um sulcador, um perfurador de solo, um 
terraceador de arrasto, uma roçadeira hidráulica, uma pá agrícola traseira e um distribuidor de fertilizantes. De acordo com informações da Prefeitura de São Paulo, o programa também disponibilizará fertilizante orgânico produzido em uma central de compostagem no distrito da Lapa, na zona oeste da cidade (PREFEITURA DE SÃO PAULO, 2016).
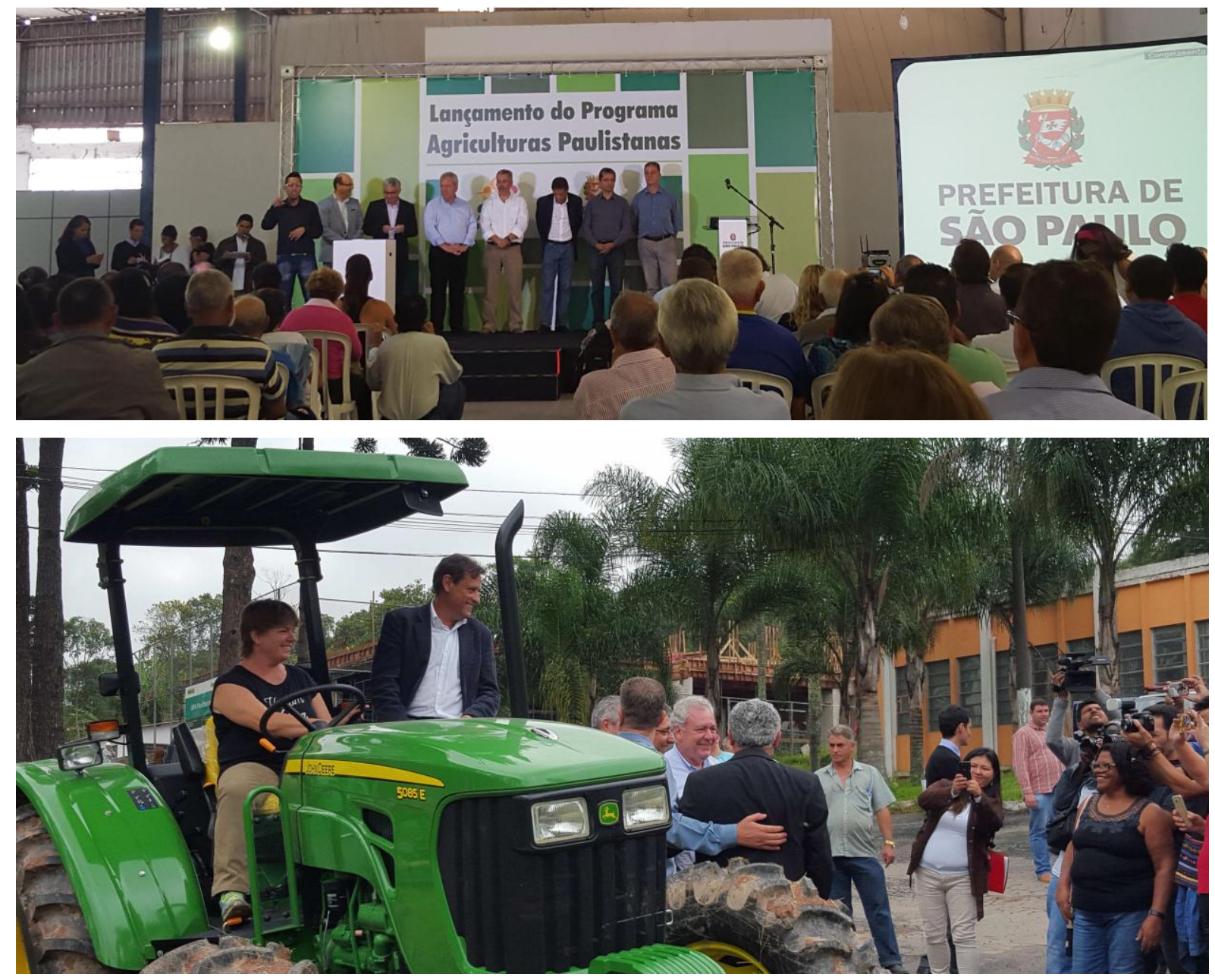

Fotos 1.9 e 1.10. Na foto acima (1.9), a cerimônia de lançamento do programa Agriculturas Paulistanas. Na foto abaixo (1.10), o trator doado pelo programa para uso dos agricultores da região. Fotos de 2 de março de 2016, na Subprefeitura de Parelheiros. Crédito das fotos: Angélica Campos Nakamura.

O programa também tem parceria com o Instituto Nacional de Colonização e Reforma Agrária. Na ocasião, uma Sala da Cidadania foi inaugurada (foto 1.11 na próxima página), com o intuito de realizar o georreferenciamento e o recadastramento das propriedades rurais da região, para que, assim, fosse feita a regularização fundiária de certas áreas (PREFEITURA DE SÃO PAULO, 2016). 


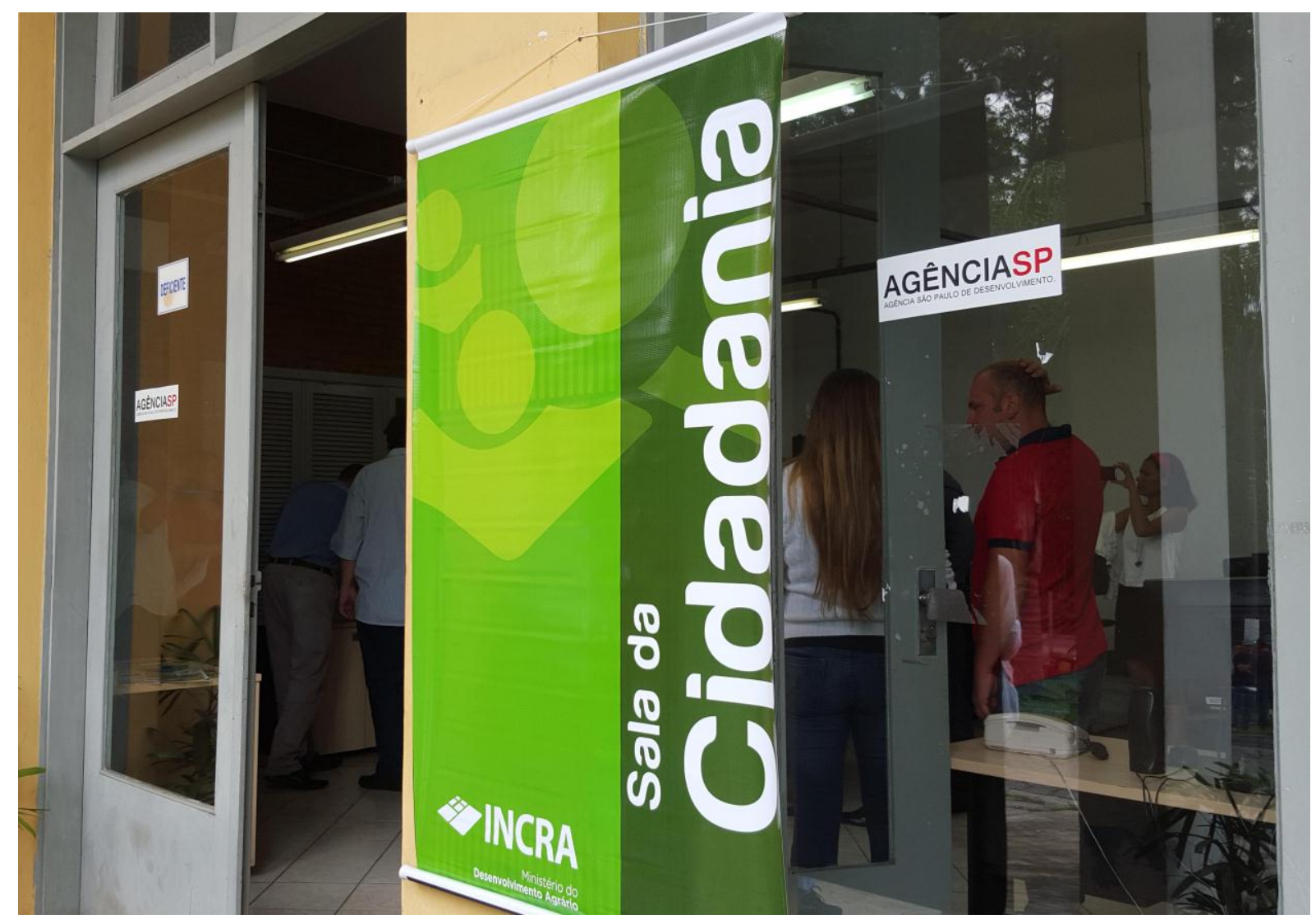

Foto 1.11. Sala da Cidadania, inaugurada na Subprefeitura de Parelheiros. Foto de 2 de março de 2016. Crédito da foto: Angélica Campos Nakamura.

Outro passo dado foi a regulamentação da Lei $\mathrm{n}^{0} 16.140$ em 5 de abril de 2016. Essa lei tornou obrigatória a inclusão de alimentos orgânicos ou de base agroecológica na alimentação escolar (PREFEITURA DE SÃO PAULO, 2016). Em 20 de maio, um outro decreto, com relação direta com essa lei, foi lançado. O Decreto $n^{0} 57.007$ instituiu a Política Municipal de Segurança Alimentar e Nutricional (PMSAN) e fixou diretrizes para o Plano Municipal de Segurança Alimentar e Nutricional (PREFEITURA DE SÃO PAULO, 2016). Vale destacar que essas políticas públicas voltadas para a alimentação e relacionadas com a agricultura, são resultado de um contexto muito maior, com o envolvimento da sociedade civil, ativistas, associações e organizações ligadas ao movimento de agricultura urbana na cidade de São Paulo, que participam de conselhos, como o Conselho Municipal de Segurança Alimentar e Nutricional de São Paulo (Comusan-SP) ${ }^{48}$.

\footnotetext{
${ }^{48}$ O Conselho Municipal de Segurança Alimentar e Nutricional de São Paulo (Comusan-SP) “foi instituído pelo Decreto $\mathrm{n}^{\circ}$ 42.862, de 13 de fevereiro 2003, e atualizado estruturalmente pelo Decreto $\mathrm{n}^{\circ}$ 50.126/08, com o objetivo de contribuir para a concretização do direito constitucional de cada pessoa humana à alimentação e à Segurança Alimentar e Nutricional.

As atividades do COMUSAN-SP envolvem a proposição, acompanhamento e fiscalização das ações do governo municipal nas áreas de segurança alimentar e nutricional; a articulação de áreas do governo municipal com as organizações da sociedade civil para a implementação de ações voltadas ao combate das causas da miséria e da
} 
Os agricultores da Cooperapas também participaram desses momentos de discussão para a elaboração de políticas públicas. Em maio de 2015, realizou-se uma pré-conferência do Comusan-SP no Centro Educacional Unificado (CEU) de Parelheiros, que contou com a presença de alguns membros da cooperativa (fotos 1.12 e 1.13).

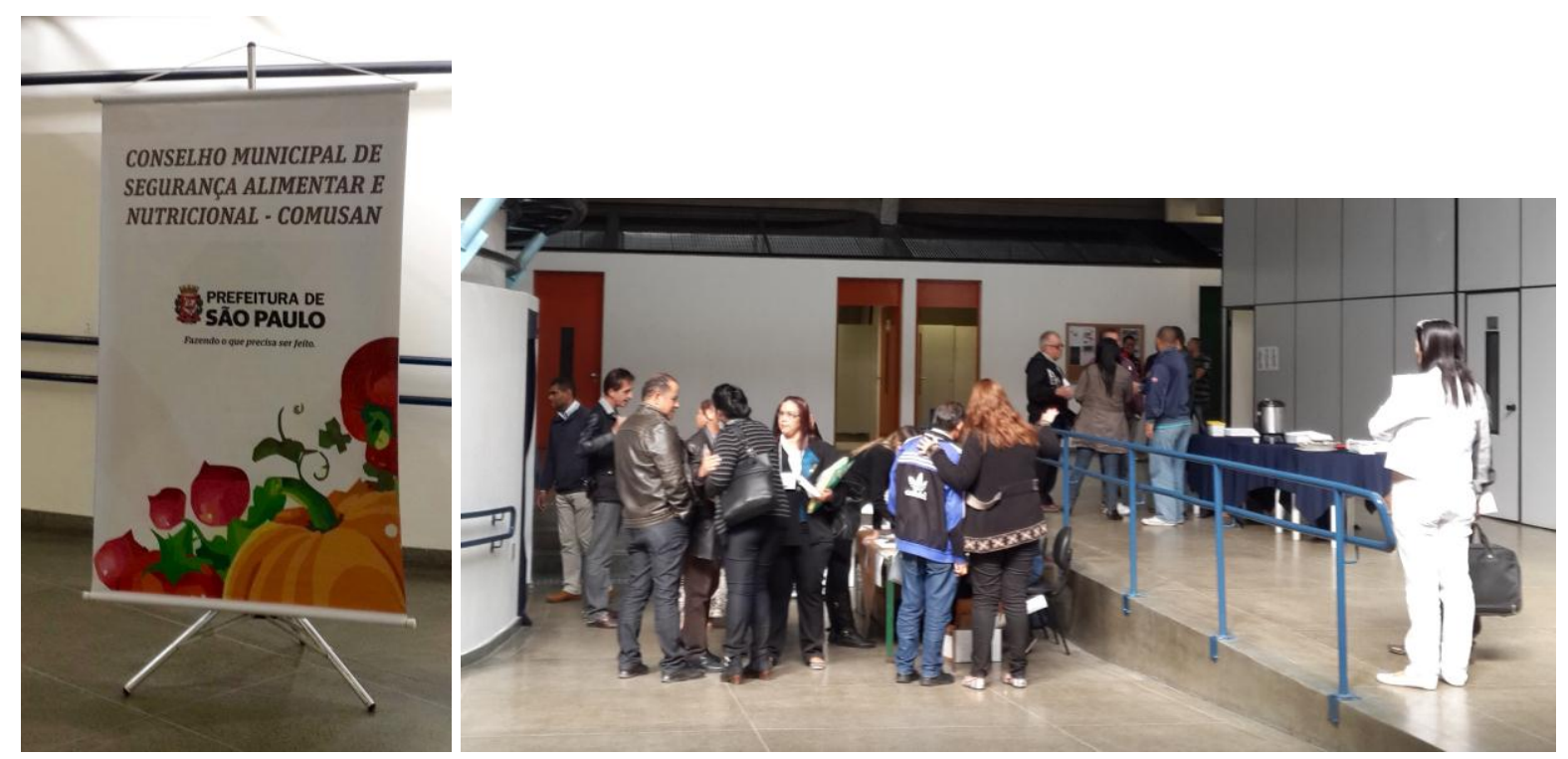

Fotos 1.12 e 1.13. Na foto à esquerda (1.12), placa indicando o evento do Comusan-SP, que ocorreu no CEU de Parelheiros. Na foto à direita (1.13), pessoas chegam para o evento e fazem o credenciamento. Fotos de 15 de maio de 2015. Crédito das fotos: Angélica Campos Nakamura.

Outra pré-conferência, essa com participação massiva dos cooperados e outros agricultores da região do extremo sul, técnicos da Casa de Agricultura Ecológica e funcionários da Secretaria Municipal do Verde e do Meio Ambiente e da Secretaria do Meio Ambiente, de indígenas e moradores, realizada também no CEU de Parelheiros, foi a de Desenvolvimento Rural Sustentável, ocorrida em maio de 2016. A $1^{\text {a }}$ Conferência Municipal de Desenvolvimento Rural Sustentável (figura 1.8, na página a seguir) ocorreu em junho, na Universidade Federal de São Paulo (Unifesp).

Os pontos discutidos nessa pré-conferência eram de total interesse para os agricultores (foto 1.14, após o cartaz de divulgação) e uma série de propostas foram levantadas, muitas em comum com o que a legislação e o Plano Diretor já preveem: mais assistência técnica, políticas públicas voltadas para a agricultura familiar, incentivo à produção orgânica,

fome, no âmbito do Município; o incentivo de parcerias de caráter regional que garantam mobilização dos setores envolvidos e racionalização do uso dos recursos disponíveis; a coordenação de campanhas de conscientização da opinião pública com vistas à união de esforços; a cooperação na formulação do plano municipal de segurança alimentar e nutricional; a proposição de estratégias, normatizações, projetos e ações que implementem o Código Sanitário do Município de São Paulo, no que concerne à segurança alimentar e nutricional, bem como opinar a esse respeito" (PREFEITURA DE SÃO PAULO, 2015). 
pagamentos por serviços ambientais, preservação da vegetação e mananciais, construção de um entreposto para comercialização na região do extremo sul, melhor fiscalização. Esse último item, inclusive, é alvo constante de reclamações dos agricultores. Afirmam que sempre entram em contato com as secretarias do Meio Ambiente, tanto municipal como estadual ou com a polícia, para denunciar invasões irregulares de terras, despejo de lixo no meio da vegetação de Mata Atlântica ou de resíduos nos mananciais e represas, entre outras infrações que a legislação das APAs não permite. Porém, de acordo com eles, de nada adianta.

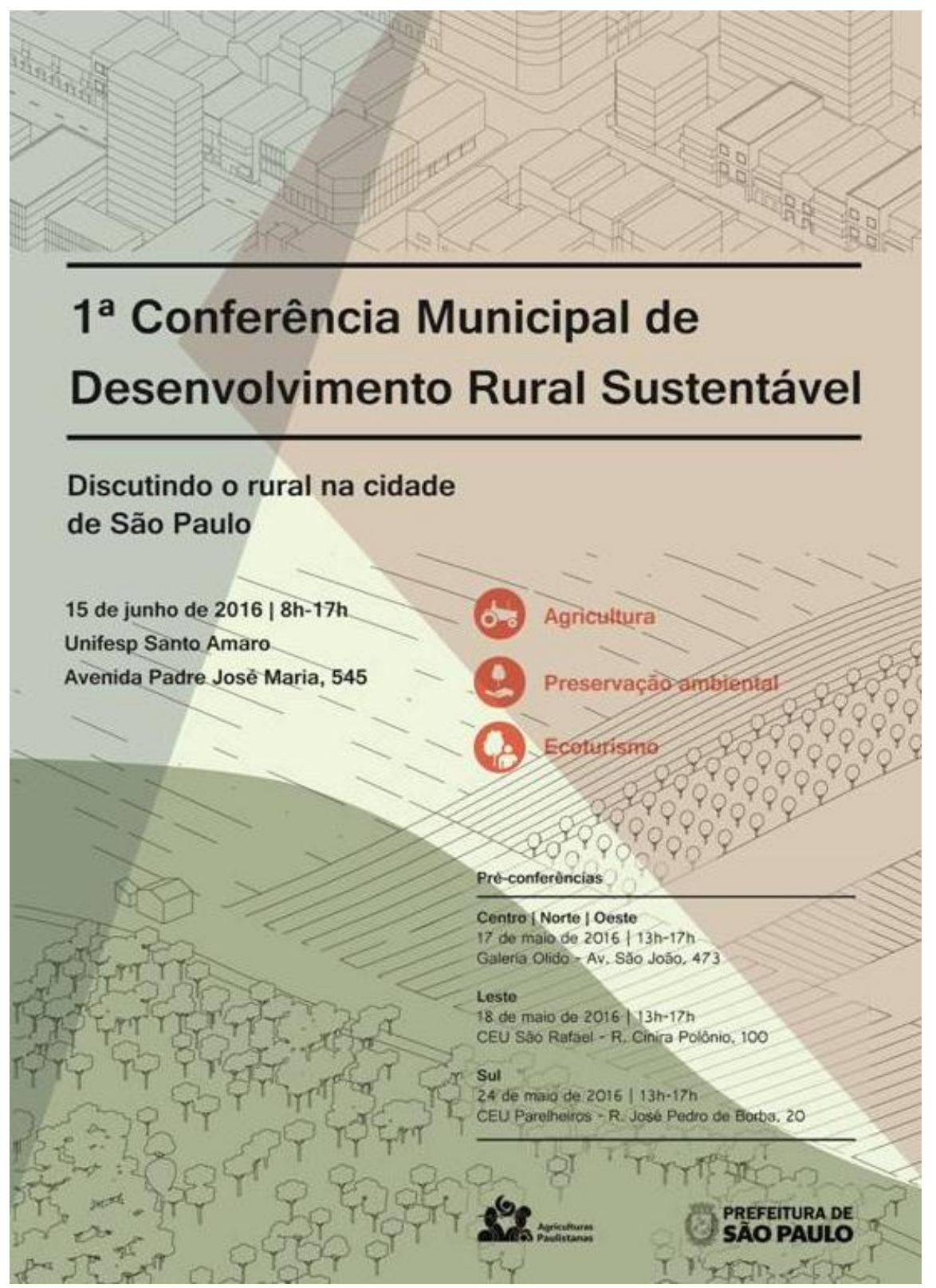

Figura 1.8. Cartaz de divulgação da $1^{\mathrm{a}}$ Conferência Municipal de Desenvolvimento Rural Sustentável e suas pré-conferências. 


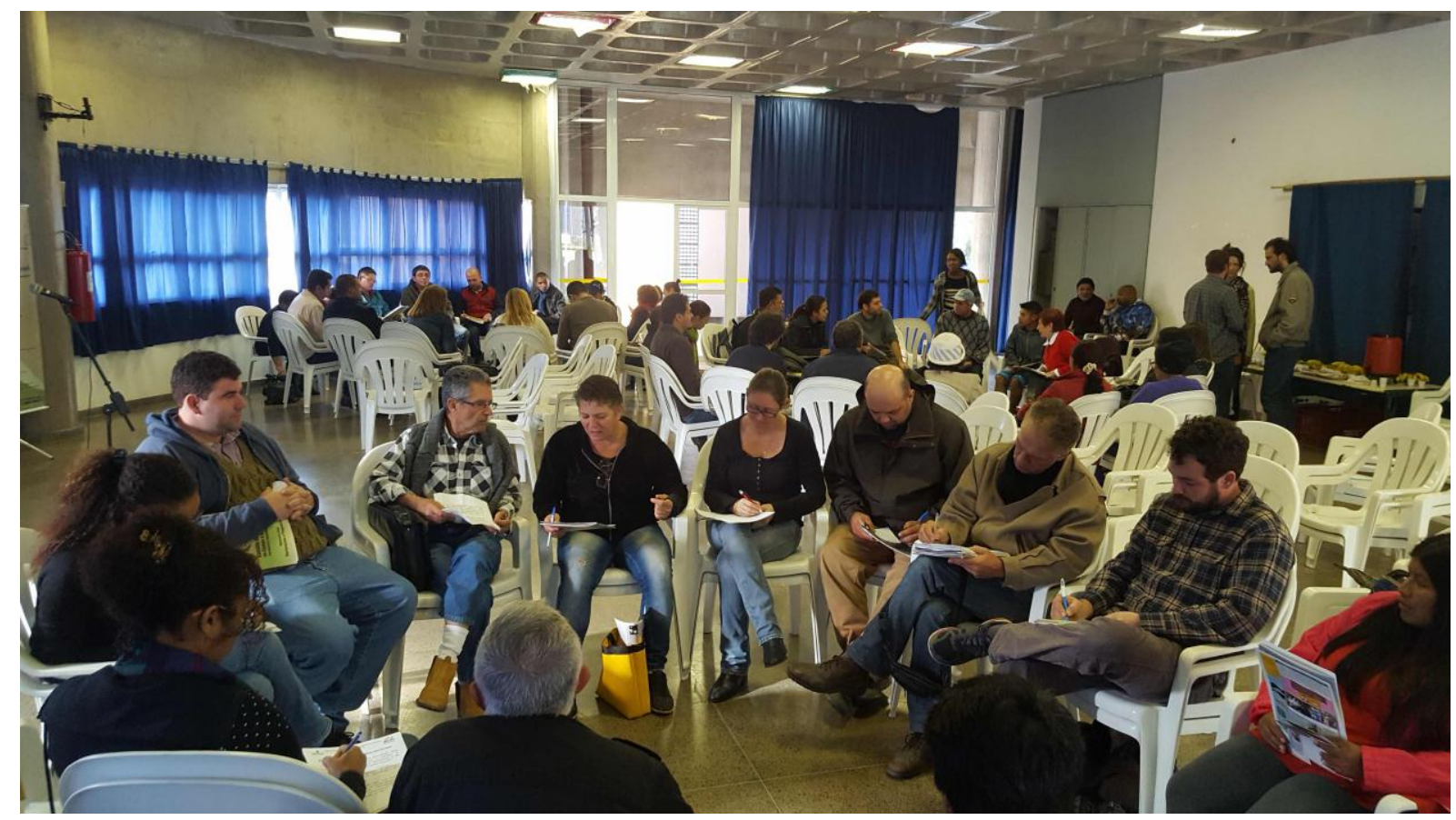

Foto 1.14. Na pré-conferência realizada no CEU de Parelheiros em 24 de maio de 2016, os presentes se organizaram em grupos para discutir quais as propostas importantes para serem levadas na conferência. Crédito da foto: Angélica Campos Nakamura.

Ainda que muito da legislação e do Plano Diretor do município de São Paulo não tenham sido apresentados aqui, é possível notar como a ideia de rural anda junto com a conservação ambiental e o desenvolvimento sustentável, pelo menos desde a criação da primeira Área de Proteção Ambiental, a Capivari-Monos, em 2001, e o Plano Diretor de 2002.

Diegues traz uma explicação sobre a origem desse tipo de valorização da natureza e do rural:

[...] no começo da revolução industrial, a vida nas cidades, antes valorizada como sinal de civilização em oposição à rusticidade da vida no campo, passou a ser criticada, pois o ambiente fabril tornava o ar irrespirável. A vida no campo passou a ser idealizada sobretudo pelas classes sociais não diretamente envolvidas na produção agrícola [...]

[...] nessa valorização do mundo natural selvagem é preciso ressaltar como faz Corbin (1989), o papel dos escritores românticos. Estes fizeram da procura do que restava de "natureza selvagem", na Europa, o lugar da descoberta da alma humana, do imaginário do paraíso perdido, da inocência infantil, do refúgio e da intimidade, da beleza e do sublime. [...]

Essas ideias, sobretudo a dos românticos do século XIX, tiveram, portanto, grande influência na criação de áreas naturais protegidas, consideradas como "ilhas" de grande beleza e valor estético que conduziam o ser humano à mediação das maravilhas da natureza intocada.

É nessa perspectiva que se insere o conceito de parque nacional como área natural, selvagem, originário dos E.U.A. A noção de "wilderness" (vida natural/selvagem), subjacente à criação dos parques, no final do século XIX, era de grandes áreas não-habitadas, principalmente após o extermínio 
dos índios e a expansão da fronteira para o oeste. Nesse período já se consolidara o capitalismo americano, a urbanização era acelerada, e se propunha reservarem-se grandes áreas naturais, subtraindo-as à expansão agrícola e colocando-as à disposição das populações urbanas para fins de recreação (2008, p. 25-26).

Sobre o conceito de parque nacional como área natural e sua origem nos Estados Unidos, é importante explicar:

A concepção dessas áreas protegidas provém do século passado, tendo sido criadas primeiramente nos Estados Unidos, a fim de proteger a vida selvagem (wilderness) ameaçada, segundo seus criadores, pela civilização urbano-industrial, destruidora da natureza. A ideia subjacente é que, mesmo que a biosfera fosse totalmente transformada, domesticada pelo homem, poderiam existir pedaços do mundo natural em seu estado primitivo, anterior à intervenção humana. [...]

Para o naturalismo da proteção da natureza do século passado, a única forma de proteger a natureza era afastá-la do homem, por meio de ilhas onde este pudesse admirá-la e reverenciá-la. Esses lugares paradisíacos serviriam também como locais selvagens, onde o homem pudesse refazer suas energias gastas na vida estressante das cidades e do trabalho monótono. [...]

A existência de um mundo natural selvagem, intocado e intocável faz parte, portanto, desses neomitos. Como afirma Ellen (1989), entretanto, a natureza em estado puro não existe, e as regiões naturais apontadas pelos biogeógrafos usualmente correspondem a áreas extensivamente manipuladas pelos homens (DIEGUES, 2008, p. 17, grifo do autor).

A preocupação em se criar áreas naturais protegidas se tornou uma estratégia para a preservação do meio ambiente:

A criação de parques e reservas tem sido um dos principais elementos de estratégia para conservação da natureza [...]

O objetivo geral dessas áreas naturais protegidas é preservar os espaços com atributos ecológicos importantes. Algumas delas, como parques, são estabelecidas para que sua riqueza natural e estética seja apreciada pelos visitantes, não se permitindo, ao mesmo tempo, a moradia de pessoas em seu interior. [...]

Segundo Ghimire (1993), há uma combinação de fatores que explicam esse aumento da preocupação mundial pelas unidades de conservação: a rápida devastação das florestas e a perda da biodiversidade, a disponibilidade de fundos internacionais para a conservação e a possibilidade de geração de renda pelo turismo em parques (DIEGUES, 2008, p. 17 e 20).

A partir da leitura de Diegues, percebe-se que o entendimento do rural e de natureza e o olhar que se tem sobre eles, passa por um tipo de valorização proveniente de ideias urbanas, nascidas na Revolução Industrial. As proposições e objetivos da legislação e dos Planos 
Diretores para a zona rural desse estudo, o extremo sul do município de São Paulo, deixam claro esse olhar sobre o rural. Além de fornecedor de produtos agrícolas, ele é visto como um refúgio para a busca da natureza, do sublime e da beleza e para o lazer dos citadinos. A criação de um polo de ecoturismo reflete bem isso.

Mas não é só isso que mostra essa concepção do urbano sobre o campo e a natureza. $\mathrm{O}$ neomito em manter o mundo natural, selvagem e intocado, aparece na fala do engenheiro agrônomo Cristiano Mendes, quando ele conta sobre a multa que foi aplicada a um agricultor. Esse tipo de postura tem origem em uma corrente denominada preservacionista, que pensa o ser humano separado da natureza e, para preservá-la, cria parques separados e afastados da sociedade urbano-industrial, que usa os recursos naturais até sua exaustão. Para explicar melhor do que se trata essa corrente, Diegues resgata vários autores:

A [corrente] preservacionista, pode ser descrita como a reverência à natureza no sentido da apreciação estética e espiritual da vida selvagem (wilderness). Ela pretende proteger a natureza contra o desenvolvimento moderno, industrial e urbano. [...]

$\mathrm{O}$ preservacionismo norte-americano foi muito influenciado pelos escritos e pela obra de Heny David Thoreau que, em meados do século XIX, se baseavam na existência de um Ser Universal, transcendente no interior da Natureza. [...]

[...] foi John Muir o teórico mais importante do preservacionismo, abraçando um organicismo pelo qual a base do respeito pela natureza era seu reconhecimento como parte de uma comunidade criada à qual os humanos também pertenciam. Para esse autor, não somente os animais, mas as plantas, e até as rochas e a água era fagulhas da Alma Divina que permeava a natureza (2008, p. 32 e 33$)$.

Esse modelo tem muitas críticas, conforme Diegues relata:

Rodman (1973) afirma que a criação dos parques obedeceu a uma visão antropocêntrica, uma vez que beneficiava as populações urbanas e valorizava, principalmente, as motivações estéticas, religiosas e culturais dos humanos [...] esse modo de preservação por meio de áreas naturais protegidas é inadequado e injustamente seletivo, pois privilegia áreas naturais que são apelativas do ponto de vista estético, segundo valores ocidentais, como as florestas, grandes rios, canyons, discriminando áreas menos "nobres", como pântanos, brejos etc., ainda que estas possam ser essenciais para o funcionamento dos ecossistemas.

Ademais, segundo Ekersley (1992), considerar as unidades de conservação como "ilhas" e colocar de lado pedaços de áreas selvagens, ignorando os problemas crescentes de superpopulação e poluição que, paulatinamente, apresentarão impactos negativos sobre as áreas naturais remanescentes, representa, de um ponto de vista ecológico, uma atitude derrotista. 
Baird Callicot (1991) criticou o conceito de wilderness, uma vez que marca uma separação entre humanidade e a natureza, considerando-o etnocêntrico, não levando também em consideração o manejo tradicional das áreas naturais do Novo Mundo (2008, p. 37).

E, ele esclarece usando os autores Gomes-Pompa e Kaus:

O conceito de 'wilderness' (mundo natural/selvagem) como terra intocada ou domesticada é, fundamentalmente, uma percepção urbana, uma visão de pessoas que vivem longe do ambiente natural de que dependem como fonte de matéria-prima. Os habitantes da zona rural têm percepções diferentes das áreas que os urbanos designam como wilderness, e baseiam seu uso da terra em visões alternativas. [...] Muitos agricultores entram numa relação pessoal com o meio ambiente. A natureza não é mais um objeto, mas um mundo de complexidade em que os seres vivos são frequentemente personificados e endeusados mediante mitos locais (GÓMEZ-POMPA; KAUS, 1992, p. 273 apud DIEGUES, 2008, p. 38) ${ }^{49}$.

Contudo, apesar de uma influência preservacionista, não se pode afirmar que a legislação e os planos diretores do município de São Paulo adotem completamente essa postura (grifo nosso). Prevê-se, conforme foi mostrado, a atividade agrícola, enfoque desse trabalho. Muito se fala sobre o desenvolvimento sustentável/sustentabilidade ambiental. Mostra-se, assim, a influência da corrente conservacionista, cuja origem e essência é explicada aqui por Diegues:

Gifford Pinchot, engenheiro florestal treinado na Alemanha, criou o movimento de conservação dos recursos, apregoando o seu uso racional. $\mathrm{Na}$ verdade, Pinchot agia dentro de um contexto de transformação da natureza em mercadoria. Na sua concepção, a natureza é frequentemente lenta e os processos de manejo podem torná-la eficiente; acreditava que a conservação deveria basear-se em três princípios: o uso dos recursos naturais pela geração presente; a prevenção de desperdício; e o uso dos recursos naturais para benefício da maioria dos cidadãos.

Essas ideias foram precursoras do que hoje se chama de "desenvolvimento sustentável". Como afirma Nash (1989), o conservacionismo de Pinchot foi um dos primeiros movimentos teóricospráticos contra o "desenvolvimento a qualquer custo". A grande aceitação desse enfoque reside na ideia de que se deve procurar o maior bem para o benefício da maioria, incluindo as gerações futuras, mediante a redução dos dejetos e da ineficiência na explotação e consumo dos recursos naturais nãorenováveis, assegurando a produção máxima sustentável.

[...] a essência da "conservação dos recursos" é o uso adequado e criterioso dos recursos naturais [...] (2008, p. 31 e 32).

${ }^{49}$ GÓMEZ-POMPA; KAUS. Taming the wilderness myth. BioScience, n. 42, p. 273, 1992. 
Assim, quando se faz referência ao desenvolvimento sustentável na legislação e nos planos diretores, busca-se o uso mais consciente dos recursos naturais, evitando o desperdício, a poluição e a ineficiência da exploração deles. Ao mesmo tempo, quer-se desenvolver atividades econômicas, como a agricultura e o ecoturismo, que exploram menos os recursos naturais ou não o destruam de vez, como a vegetação. Ainda, incentiva-se a transição da agricultura convencional para a orgânica, já que a convencional faz uso de insumos químicos, os quais poluem os solos e as águas.

Inclusive, é importante ressaltar que no Plano Diretor de 2014, é dado grande enfoque à agricultura orgânica e agroecológica e, o único momento em que se faz referência explícita à agricultura convencional, é na seção IV, intitulada "Dos instrumentos de gestão ambiental", na subseção VII. Essa subseção, chamada de "Do pagamento por prestação de serviços ambientais", prevê o pagamento por serviços ambientais, com retribuição, monetária ou não, de "proprietários ou possuidores de áreas com ecossistemas provedores de serviços ambientais, cujas ações mantêm, restabelecem ou recuperam estes serviços" (PREFEITURA DE SÃO PAULO, 2014). Entre as ações com possibilidade de retribuição, está, no item IV, a conversão da agricultura familiar convencional para a agricultura orgânica. Faz-se, ainda, referências à agricultura familiar, porém, não foi encontrado nenhum item pensado para a agricultura convencional, ainda muito praticada nessa região do extremo sul.

Apesar de o rural no município de São Paulo ser pensado a partir de uma visão urbana e conservacionista, conforme exposto com base em Diegues, não se pode tirar a importância de existir uma legislação e um planejamento preocupados em manter a agricultura nesse extremo sul do município. O novo Plano Diretor tem mérito ao definir uma zona rural para São Paulo, ainda que praticamente pautado sobre a ideia de conservação ambiental e desenvolvimento sustentável. Junto com a criação de outras políticas públicas as quais fomentam a agricultura, como o Agriculturas Paulistanas, a Lei $\mathrm{n}^{\mathrm{0}} 16.140$ a qual tornou obrigatória a inclusão de alimentos orgânicos ou de base agroecológica na alimentação escolar e, finalmente, a $1^{\text {a }}$ Conferência Municipal de Desenvolvimento Rural Sustentável, existe um esforço em valorizar o rural, sempre vinculado ao sustentável e à conservação da natureza. Portanto, um rural que produz alimento, conserva e mantém os recursos para usufruto do urbano. 


\subsection{A agricultura praticada pelos membros da Cooperapas e as certificações orgânicas}

Até o momento, muito se falou da agricultura orgânica e agroecológica e de como essas práticas aparecem e são incentivadas na legislação e nos planos diretores do município de São Paulo. O grupo de agricultores estudado, membros da Cooperapas, buscam essas práticas e, ainda, a agricultura biodinâmica.

Entretanto, antes de compreender um pouco mais sobre essas práticas agrícolas, é importante situar um pouco os dados a respeito dessa atividade e dos agricultores no município de São Paulo.

Em 2010, o IBGE indicou que o município possuía aproximadamente 11,2 milhões de habitantes, e sua população rural foi estimada em um pouco mais que 101 mil habitantes (IBGE, 2016). Porém, é preciso ponderação com a metodologia do IBGE para o levantamento desse dado da população urbana e, especialmente, da rural. No documento sobre a metodologia do Censo Demográfico de 2010, o IBGE define:

\section{Cidade}

É a localidade onde está sediada a Prefeitura Municipal. É constituída pela área urbana do distrito-sede e delimitada pelo perímetro urbano estabelecido por lei municipal. [...]

\section{Área urbana isolada}

Área definida por lei municipal e separada da sede municipal ou distrital por área rural ou por outro limite legal.

\section{Área rural}

É definida no IBGE como toda área externa ao perímetro urbano.

\section{Áreas urbanizadas de cidade ou vila}

São classificadas como áreas urbanizadas aquelas legalmente definidas como urbanas, caracterizadas por construções, arruamentos e intensa ocupação humana; as áreas afetadas por transformações decorrentes do desenvolvimento urbano; e aquelas reservadas à expansão urbana.

\section{Áreas não urbanizadas de cidade ou vila}

São classificadas como áreas não-urbanizadas aquelas legalmente definidas como urbanas, caracterizadas por ocupação predominantemente de caráter rural. [...]

\section{Aglomerado rural}

É um conjunto de edificações adjacentes e com características de permanência, situado em área legalmente definida como rural, que forma:

- Uma área continuamente construída com arruamentos reconhecíveis ou disposta ao longo de uma via de comunicação;

- Um agrupamento de edificações com mais de 50 unidades 
domiciliares, número que estaria relacionado com um montante de população superior a 250 habitantes.

Os aglomerados rurais estão classificados em dois grandes tipos:

- Aglomerados rurais do tipo "extensão urbana" que possuem caráter urbano por definição; e

- Aglomerados rurais "isolados", que podem ser de natureza urbana ou rural.

\section{Aglomerados rurais do tipo "extensão urbana"}

São assentamentos situados em áreas fora do perímetro urbano legal, mas desenvolvidos a partir da expansão de uma cidade ou vila, ou por elas englobados em sua expansão. Por constituírem uma simples extensão da área efetivamente urbanizada, atribui-se, por definição, caráter urbano aos aglomerados rurais deste tipo. Tais assentamentos podem ser constituídos por loteamentos já habitados, conjuntos habitacionais, aglomerados de moradias ditas subnormais ou núcleos desenvolvidos em torno de estabelecimentos industriais, comerciais ou de serviços.

\section{Aglomerados rurais isolados}

São assentamentos situados em área legalmente definida como rural, que atendam aos critérios de tamanho e densidade anteriormente estipulados e que se encontrem separados do perímetro urbano legal de uma cidade ou vila, ou de um aglomerado do tipo "extensão urbana" por uma distância igual ou superior a $1 \mathrm{~km}[\ldots]$ (IBGE, 2013, p. 297, 299, 301-302).

Oliveira já questionou as classificações do IBGE a respeito do que é rural. De acordo com ele, em 2000 o Censo apontou a existência de 621.065 habitantes na zona rural do município de São Paulo (20004, p. 50). Para ele,

É por isso que qualquer estudioso que vá analisar os dados sobre a população rural do Brasil fica literalmente assustado quando verifica que o município que tem a maior população rural do Brasil é São Paulo [...]. Quem conhece o município de São Paulo sabe de antemão que esse dado não corresponde à realidade dos fatos. É por isso, também, que qualquer um que analisa os dados sobre a população rural do Brasil verifica que grande parte dos municípios que possuem população rural elevada são cidades médias ou estão em regiões metropolitanas. [...]

Inclusive, é preciso também deixar registrado que o IBGE nunca negou essas questões, ao contrário, procurou sempre chamar atenção para elas. [...] (OLIVEIRA, 2004, p. 50).

Se em 2000, o dado de mais de 600 mil habitantes de população rural no município de São Paulo causava espanto, o de 2010 pode parecer algo mais próximo da realidade. Contudo, o conceito de cidade na metodologia do IBGE foi apresentado para mostrar que, para o IBGE, isso depende da legislação municipal. Sabendo disso, fica uma questão: será que no próximo levantamento do Censo Demográfico, em 2020, a população rural do município de São Paulo aumentará novamente? O quanto será? Afinal, no levantamento de 2010, ainda não havia o 
novo Plano Diretor, o qual estabeleceu uma zona rural no município. No Plano Diretor de 2002, anterior ao de 2014, a zona rural foi extinguida. O dado de 2000, trazido por Oliveira, foi antes do Plano Diretor de 2002. Talvez isso explique a tamanha queda do número de 2000 para 2010.

Os conceitos do que é urbano e rural para o IBGE também terão um embate com o que foi definido como zona rural no município. Dentro dessa zona rural há áreas completamente urbanizadas, como o centro do bairro de Parelheiros e o seu entorno. Além disso, o estabelecimento da zona rural no Plano Diretor, no extremo sul do município, coincide com as Áreas de Proteção Ambiental. O entendimento de rural no Plano Diretor de 2014 se dá com base na conservação ambiental, enquanto o rural do IBGE considera o que foi estabelecido fora do perímetro urbano pela lei municipal e com caráter rural, ou seja, sem características de áreas urbanizadas.

O IBGE também apresentou alguns dados a respeito de alguns itens de lavoura permanente e lavoura temporária da produção agrícola do município em 2014. Nas tabelas de dados da pesquisa, não há menção de hortaliças, que são os principais produtos dos agricultores acompanhados ao longo desse trabalho e, conforme se pode observar durante os trabalhos de campo realizados e conversas com os agricultores e técnicos da Casa de Agricultura Ecológica (CAE) José Umberto Macedo Siqueira, de muitos outros produtores também. Os dados do IBGE a respeito da agricultura no município em São Paulo, limitados a alguns produtos, são os apresentados na tabela 1.3.

Tabela 1.3. Produção agrícola municipal - algumas lavouras (2014)

\begin{tabular}{|c|c|}
\hline \multicolumn{2}{|c|}{ LAVOURA PERMANENTE } \\
\hline Caqui & 33 toneladas \\
\hline Banana & 840 toneladas \\
\hline LAVOURA TEMPORÁRIA \\
\hline Cana-de-açúcar & 200 toneladas \\
\hline Feijão & 30 toneladas \\
\hline Mandioca & 78 toneladas \\
\hline
\end{tabular}

Fonte: IBGE. Produção agrícola municipal 2014. Rio de Janeiro: IBGE, 2015. Disponível em: $<$ http://www.cidades.ibge.gov.br/xtras/perfil.php?lang=\&codmun=355030\&search=sao-paulo|saopaulo>. Acesso em: 30 jun. 2016. 
Apesar de o IBGE estimar em 101 mil habitantes a população rural, o número não indica quem nesse meio são realmente agricultores. A Prefeitura de São Paulo, por meio de dados da Supervisão de Abastecimento (Abast) e com a Secretaria do Verde e do Meio Ambiente (SVMA), tem um levantamento baseado na unidade produtiva, e afirma que existem 420 unidades de produção agrícola, sendo 320 na zona sul do município (POLO DE ECOTURISMO DE SÃO PAULO, 2016). Entretanto, esse número é uma estimativa, pois em conversas informais, foi admitido que o número não é proveniente de um levantamento detalhado e, além disso, abrange tanto produtores convencionais, como orgânicos e agroecológicos.

É importante fazer a distinção dos produtores orgânicos dos agroecológicos porque são práticas diferentes. Na legislação apresentada ao longo do capítulo, citou-se tanto a agricultura orgânica como a agroecológica. Ao se referir à uma agricultura mais sustentável, havia menção às duas, passando a impressão de que, em certos momentos, elas foram utilizadas como sinônimos.

De acordo com Altieri, a agroecologia

[...] é tanto uma ciência quanto um conjunto de práticas. Como ciência, baseia-se na aplicação da Ecologia para o estudo, o desenho e o manejo de agroecossistemas sustentáveis. Isso conduz à diversificação agrícola projetada intencionalmente para promover interações biológicas e sinergias benéficas entre os componentes do agroecossistema, de modo a permitir a regeneração da fertilidade do solo e a manutenção da produtividade e da proteção das culturas. Os princípios básicos da Agroecologia incluem: a reciclagem de nutrientes e energia; a substituição de insumos externos; a melhoria da matéria orgânica e da atividade biológica do solo; a diversificação das espécies de plantas e dos recursos genéticos dos agroecossistemas no tempo e no espaço; a integração de culturas com a pecuária; e a otimização das interações e da produtividade do sistema agrícola como um todo, ao invés de rendimentos isolados obtidos com uma única espécie. [...]

A Agroecologia se fundamenta em um conjunto de conhecimentos e técnicas que se desenvolvem a partir dos agricultores e de seus processos de experimentação. [...] Seu enfoque tecnológico está enraizado na diversidade, na sinergia, na reciclagem e na integração, assim como em processos sociais baseados na participação da comunidade. Para a Agroecologia, o desenvolvimento dos recursos humanos é a pedra angular de qualquer estratégia voltada para ampliar o leque de opções da população rural e, especialmente, dos camponeses que dispõem de parcos recursos. Também atende às necessidades alimentares a partir do fomento à autossuficiência [...] Trata-se de um enfoque que privilegia a esfera local ao direcionar seus esforços para o abastecimento dos mercados locais que encurtam os circuitos entre a produção e o consumo de alimentos, evitando assim o desperdício de energia gasta no transporte dos produtos de lugares muito distantes até a mesa do consumidor (2012, p. 15-17, grifo do autor). 
Petersen explica que a agroecologia assume três concepções:

1) como uma teoria crítica que elabora um questionamento radical à agricultura industrial, fornecendo simultaneamente as bases conceituais e metodológicas para o desenvolvimento de agroecossistemas sustentáveis;

2) como uma prática social adotada explícita ou implicitamente em coerência com a teoria agroecológica;

3) como um movimento social que mobiliza atores envolvidos prática e teoricamente no desenvolvimento da Agroecologia, assim como crescentes contingentes da sociedade engajados em defesa da justiça social, da saúde ambiental, da soberania e segurança alimentar e nutricional, da economia solidária e ecológica, da equidade entre gêneros e de relações mais equilibradas entre o mundo rural e as cidades.

Em sua essência, a Agroecologia articula sinergicamente essas três formas de compreensão, condensado em um todo indivisível o seu enfoque analítico, a sua capacidade operativa e a sua incidência política (2012, p. 7 8).

Portanto, a agroecologia vai muito além da prática de uma agricultura que não usa fertilizantes e agrotóxicos. Ela tem uma proposta voltada também para o social e o cultural, pois busca, entre outras coisas, a equidade de gêneros, a justiça social, a valorização de saberes de comunidades tradicionais, indígenas e campesinato, a economia solidária etc.

Já a agricultura orgânica é definida pela Embrapa como

[...] sistema de manejo sustentável da unidade de produção com enfoque sistêmico que privilegia a preservação ambiental, a agrobiodiversidade, os ciclos biogeoquímicos e a qualidade de vida humana. É um processo produtivo comprometido com a organicidade e a sanidade da produção de alimentos vivos para garantir a saúde dos seres humanos, razão pela qual usa e desenvolve tecnologias apropriadas à realidade local de solo, topografia, clima, água, radiações e biodiversidade própria de cada contexto, mantendo a harmonia de todos esses elementos entre si e com os seres humanos.

A agricultura orgânica aplica os conhecimentos da ecologia no manejo da unidade de produção, baseada numa visão holística da unidade de produção. [...] Na agricultura orgânica, a unidade de produção é tratada como um organismo integrado com a flora e a fauna.

Esse modo de produção assegura o fornecimento de alimentos saudáveis, mais saborosos e de maior durabilidade; não utilizando agrotóxicos preserva a qualidade da água usada na irrigação e não polui o solo nem o lençol freático com substâncias tóxicas; por utilizar preparo mínimo do solo assegura a estrutura e fertilidade dos solos evitando erosões e degradação, contribuindo para promover e restaurar a rica biodiversidade local; por esse conjunto de fatores a agricultura orgânica viabiliza a sustentabilidade da agricultura e amplia a capacidade dos ecossistemas locais em prestar serviços ambientais a toda a comunidade do entorno [...].

$\mathrm{Na}$ agricultura orgânica os processos biológicos são priorizados. As práticas monoculturais apoiadas no uso intensivo de fertilizantes sintéticos e de agrotóxicos da agricultura convencional são substituídas pela rotação de 
culturas e diversificação [...]. O manejo de pragas e mesmo das plantas espontâneas é fundamentalmente ecológico.

A agricultura orgânica busca criar ecossistemas mais equilibrados, preservar a biodiversidade, os ciclos e as atividades biológicas do solo. Esta é a razão pela qual o agricultor orgânico não cultiva produtos transgênicos, pois ele não quer colocar em risco a diversidade de variedades que existem na natureza (EMBRAPA, 2016).

Assim, a agricultura orgânica se refere a um sistema de manejo, o qual não utiliza agrotóxicos nem fertilizantes, que não polui os recursos naturais, como a água e o solo, impactando menos no meio ambiente e na biodiversidade.

No Brasil, a Lei n ${ }^{0} 10.831$ de 2003 é a que dispõe sobre a agricultura orgânica. A lei afirma que

$\S 1^{\circ}$ A finalidade de um sistema de produção orgânico é:

I - a oferta de produtos saudáveis isentos de contaminantes intencionais;

II - a preservação da diversidade biológica dos ecossistemas naturais e a recomposição ou incremento da diversidade biológica dos ecossistemas modificados em que se insere o sistema de produção;

III - incrementar a atividade biológica do solo;

IV - promover um uso saudável do solo, da água e do ar, e reduzir ao mínimo todas as formas de contaminação desses elementos que possam resultar das práticas agrícolas;

$\mathrm{V}$ - manter ou incrementar a fertilidade do solo a longo prazo;

VI - a reciclagem de resíduos de origem orgânica, reduzindo ao mínimo o emprego de recursos não-renováveis;

VII - basear-se em recursos renováveis e em sistemas agrícolas organizados localmente;

VIII - incentivar a integração entre os diferentes segmentos da cadeia produtiva e de consumo de produtos orgânicos e a regionalização da produção e comércio desses produtos;

IX - manipular os produtos agrícolas com base no uso de métodos de elaboração cuidadosos, com o propósito de manter a integridade orgânica e as qualidades vitais do produto em todas as etapas (BRASIL, 2003).

Porém, chama atenção o parágrafo dois dessa lei: "O conceito de sistema orgânico de produção agropecuária e industrial abrange os denominados: ecológico, biodinâmico, natural, regenerativo, biológico, agroecológicos, permacultura e outros que atendam os princípios estabelecidos por esta Lei” (BRASIL, 2003, grifo nosso). Logo, a lei brasileira de orgânicos abrange outros sistemas, inclusive o agroecológico, denominando todos como "agricultura orgânica". Explica-se, assim, o uso de agricultura orgânica e de agroecológica sem grandes distinções. Todas essas práticas agrícolas ficaram denominadas no senso comum como agricultura orgânica. 
Uma outra forma de produção orgânica, determinada pela lei, é a da agricultura biodinâmica. Sobre a agricultura biodinâmica, Assis explica:

Criada em 1924, a partir do trabalho de Rudolf Steiner, fundador da antroposofia, a agricultura biodinâmica apresenta um forte foco filosófico e espiritual, trabalhando com as energias que criam e mantém a vida, e com certos princípios que garantem solos e plantas sadios. Procura equilíbrio e harmonia entre cinco elementos básicos: terra, plantas, animais, influências cósmicas e o homem (KOEPF et al., 1983).

Relaciona-se com as demais correntes de agricultura não industrial, no que diz respeito à diversificação e integração das diferentes atividades da unidade de produção, à reciclagem de resíduos vegetais e animais e ao uso de adubos de baixa solubilidade e com baixa concentração de nutrientes. Apresenta ainda, mais do que na agricultura orgânica, ênfase a ideia de que a unidade de produção agrícola funcione como um "organismo vivo", buscando a maior autonomia possível em relação à insumos externos.

Utiliza preparados biodinâmicos aspergidos sobre as plantas ou adicionados aos adubos. Esse é o primeiro ponto que mais distingue este sistema das demais correntes [agrícolas] [...]. O segundo ponto relaciona-se ao fato de que as diferentes atividades agrícolas são realizadas de acordo com um calendário astrológico (DAROLT, 2000) (2005, p. 15).

É importante destacar aqui que essas práticas agrícolas vão contra a agricultura praticada em grande escala, como o agronegócio. Entretanto, o interesse em produtos orgânicos vem crescendo, criando uma verdadeira "indústria do orgânico", cuja diferença para o agronegócio "tradicional" é apenas o não uso de fertilizantes e pesticidas. Assis explica:

Atualmente, com o aumento da demanda dos consumidores por alimentos que não ofereçam riscos a sua saúde, tem se verificado, em grande medida, uma ruptura entre o produto em si e a forma como este é produzido. Isto tem determinado que o termo agricultura orgânica, enquanto mais difundido, esteja sendo reconhecido como sinônimo das demais correntes de agricultura não industrial. Essa (re)interpretação do que seja agricultura orgânica, com foco prioritário no chamado "mercado de produtos orgânicos", tem favorecido o estabelecimento de sistemas de produção tidos como orgânicos, baseados em tecnologias de produtos. Em outras palavras, sistemas de produção que evitam, ou excluem amplamente, o uso de fertilizantes, pesticidas, reguladores de crescimento e aditivos para a alimentação animal, compostos sinteticamente, na medida que esta é a demanda do mercado a ser atendido.

Nestes casos, a lógica de organização da produção mantém-se a mesma dos sistemas de produção industriais, como verifica-se em alguns casos de produções orgânicas monoculturais, que visam a alta produtividade, através do aporte de insumos externos à unidade de produção $(2005$, p. 14$15)$. 
Os agricultores da Cooperapas transitam por essas três práticas: a agricultura orgânica, a agroecologia e a agricultura biodinâmica (foto 1.15). Como foi exposto até aqui sobre elas, é possível perceber que as três buscam uma prática agrícola a qual respeite a natureza e seja sustentável e, portanto, são muito próximas entre si, daí a possibilidade de praticarem um pouco de cada uma.

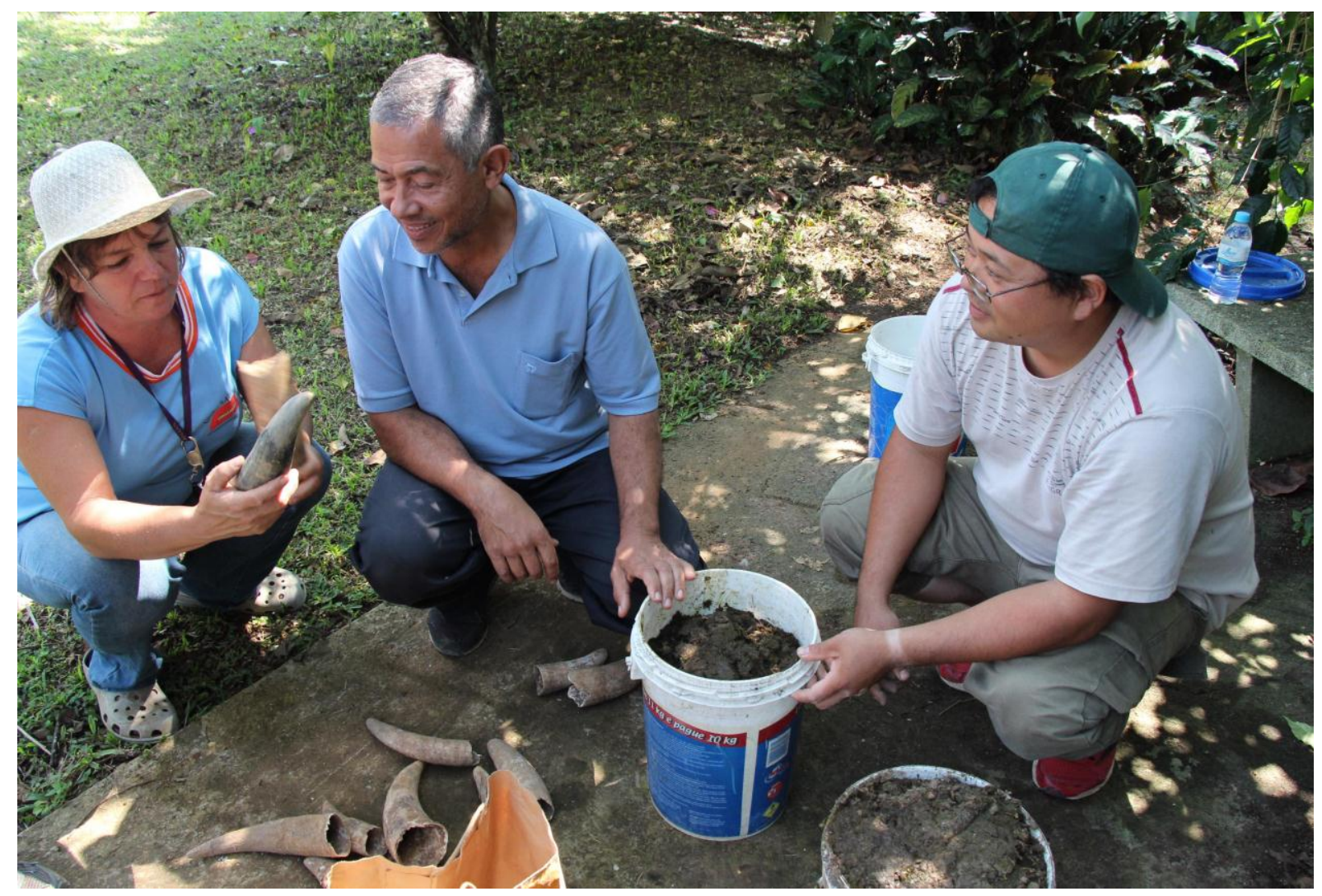

Foto 1.15. No encontro mensal do dia 25 de março de 2015, os agricultores se juntaram para fazer alguns preparados biodinâmicos em um sítio no distrito do Grajaú. Crédito da foto: Angélica Campos Nakamura.

É o Decreto $\mathrm{n}^{\mathrm{o}}$ 6.323, de 2007, o qual regulamentou a Lei $\mathrm{n}^{\mathrm{o}} 10.831$ sobre a agricultura orgânica. É nele que se encontram outras providências, entre elas, a exigência da certificação orgânica dos produtos para a sua comercialização. Existem três maneiras de conseguir a certificação orgânica (BRASIL, 2007).

Essas três formas foram encontradas entre os membros da Cooperapas. Contudo, uma parte do grupo ainda não realizou a transição completa para a agricultura orgânica, mas assinaram o Protocolo de Boas Práticas Agrícolas. Esse protocolo permite que o agricultor possa vender seu produto com um valor agregado um pouco mais alto em relação ao convencional, porém, não como orgânico ainda. É uma maneira de incentivar o agricultor a continuar na agricultura orgânica até, finalmente, chegar a um produto $100 \%$ limpo de 
agrotóxicos e fertilizantes. De acordo com técnicos da CAE, que acompanham esses agricultores, são cerca de dois anos para que a produção se torne limpa.

Já para quem pode ter a certificação orgânica, existem três meios distintos: a certificação por auditoria, pelo Sistema Participativo de Garantia (SPG) e pela Organização de Controle Social (OCS), todos esses reconhecidos pelo Ministério da Agricultura, Pecuária e Abastecimento (Mapa).

De acordo com o Mapa,

As Certificadoras por Auditoria atuam comercialmente na prestação de serviços de certificação a produtores individuais e grupos. Têm por obrigação avaliar e garantir a conformidade da produção orgânica sob sua responsabilidade. Devem estar regularmente constituídas para esta atividade e possuir mecanismos de resolução de conflitos, atendimento a denúncias e aplicação de sanções administrativas.

Devem manter os clientes atualizados quanto às normas vigentes e realizar visitas programadas e sem aviso prévio às unidades, ao menos uma vez ao ano. Segundo a complexidade e o grau de risco da produção, estas visitas deverão ocorrer com maior frequência.

A Certificadora por Auditoria deve possuir quadro profissional habilitado e registrado em seus conselhos profissionais (inspetores e auditores) que procederão, respectivamente, com as visitas de inspeção "in loco" às propriedades e com as análises de aceitação de certificação. Desta forma, os produtores não participam dos processos decisórios sobre certificação (MAPA, 2016).

A certificação por auditoria é mais cara de todas. De acordo com os agricultores, os preços variam um pouco dependendo da empresa contratada. Os valores giram em torno de $\mathrm{R} \$ 3.000,00$ a R \$ 3.500,00 por ano.

Para obter a certificação orgânica pelo Sistema Participativo de Garantia (SPG) ou pela Organização de Controle Social (OCS), os agricultores devem estar organizados em grupos. Portanto, existem dois grupos internos dentro da Cooperativa, os pertencentes à SPG intitulada Grupo Biodinâmico Água Limpa Billings Guarapiranga, e à OCS São Paulo.

O SPG funciona da seguinte forma:

O Sistema Participativo de Garantia (SPG) é formado pela reunião de produtores e outras pessoas interessadas em organizar a sua estrutura básica, que é composta pelos Membros do Sistema e pelo Organismo Participativo de Avaliação da Conformidade (OPAC). Os Membros do Sistema são pessoas físicas ou jurídicas que fazem parte de um grupo classificado em duas categorias, distribuidores, comercializadores, transportadores e armazenadores. Os colaboradores são os consumidores e suas organizações, os técnicos, as organizações públicas e privadas, as que representam as mais diferentes classes e os parceiros (colaboradores) que 
possam ajudá-los a dar garantia a seus produtos. Todos tomam conta de todos e se visitam, para garantir a qualidade orgânica (MAPA, 2016).

Assim, quando se realizam as reuniões, podem comparecer pessoas da sociedade civil, interessadas na certificação, como os consumidores; membros representantes da organização pública, como os técnicos da CAE; e os agricultores que fazem parte do grupo. Já os Opac, de acordo com o Mapa,

[...] são a parte do SPG que se organiza como Pessoa Jurídica e correspondem às certificadoras na certificação por auditoria. São os OPAC que avaliam, verificam e atestam que produtos, estabelecimentos produtores ou processadores atendem às exigências do regulamento da produção orgânica. O OPAC assume a responsabilidade formal pelo conjunto de atividades desenvolvidas pelo SPG. Devem estar regularmente constituídos para a atividade de certificação participativa e possuir mecanismos de resolução de conflitos, atendimento a denúncias e aplicação de sanções administrativas.

As atribuições do OPAC são:

--> Ser o representante legal do SPG;

--> Assumir a responsabilidade legal pela avaliação da conformidade orgânica, de acordo com a Lei Brasileira de Orgânicos;

--> Possuir obrigatoriamente uma Comissão de Avaliação e um Conselho de Recursos formados por representantes dos membros do SPG;

--> Emitir documentos relativos ao funcionamento do SPG;

--> Organizar e guardar os registros e documentos relativos à avaliação da conformidade;

--> Apontar as não conformidades e sugerir ações preventivas e corretivas necessárias aos fornecedores;

--> Possuir regimento interno que mostre a sua organização, o funcionamento participativo e como se responsabilizar pelo SPG (MAPA, 2016).

No caso dos agricultores da Cooperapas, a Opac responsável pela certificação deles é a Associação Brasileira de Agricultura Biodinâmica (ABD), cuja sede é em Botucatu, interior do estado de São Paulo. Para obter a certificação pela ABD, o agricultor paga a eles por área plantada. De 0 a 2 hectares, o valor em 2016, estava em $\mathrm{R} \$ 380,00$ ao ano.

Apesar da possibilidade de representantes "de fora", que seriam os consumidores, poderem acompanhar o SPG, até o final de 2015, o grupo do SPG realizava os encontros apenas duas vezes ao ano, uma vez em cada semestre, e sem visitantes de fora (fotos 1.16, 1.17 e 1.18 na página a seguir e o mapa 1.10 após as fotos). De acordo com os agricultores, 
tratava-se de um grupo ainda muito pequeno - com sete agricultores - para se realizar reuniões periódicas, como uma vez por mês, e com a presença de pessoas de fora ${ }^{50}$.
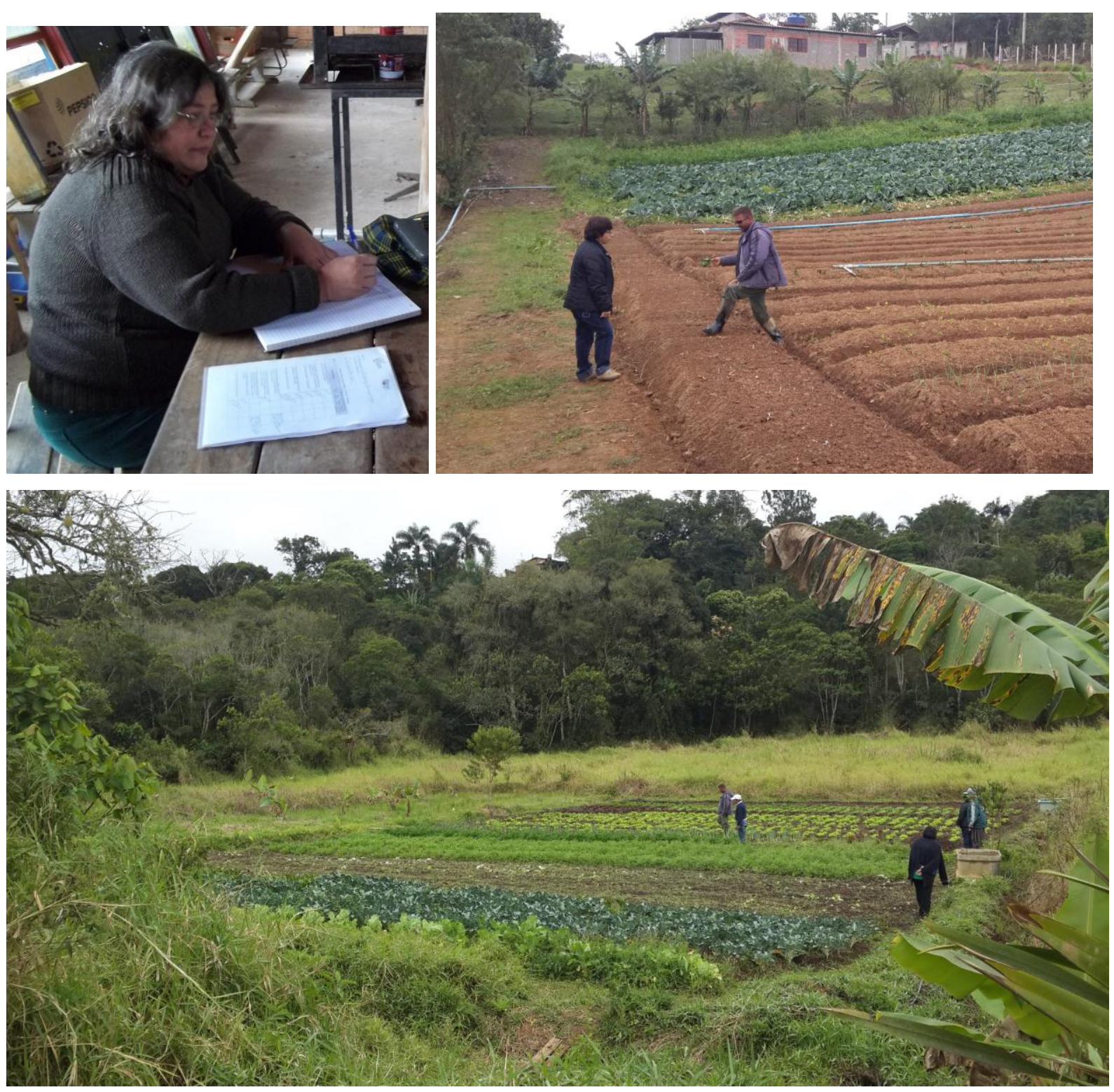

Fotos 1.16, 1.17 e 1.18. No encontro semestral da SPG em 2 de setembro de 2015, na foto à esquerda acima (1.16), uma das agricultoras preenche a documentação exigida. Na foto à direita acima (1.17) e, na foto maior embaixo (1.18), as visitas em dois sítios diferentes, dos membros do SPG, o primeiro no município de Embu-Guaçu e, o segundo, no município de São Paulo. Crédito das fotos: Angélica Campos Nakamura.

\footnotetext{
${ }^{50}$ Consegui acompanhar o SPG realizado no segundo semestre de 2015 porque, coincidentemente, marquei duas entrevistas com agricultores que fazem parte do grupo nos dois dias nos quais foram feitas as visitas nos sítios. De acordo com um dos agricultores do grupo, em uma conversa que tive por volta de março de 2016, mais três cooperados estavam entrando no grupo. Com esse aumento, eles pretendiam iniciar as reuniões com mais periodicidade e aberta aos consumidores interessados em acompanhar a certificação. Pedi para que me avisassem quando ocorresse uma, porém, até maio de 2016, nada havia sido realizado.
} 


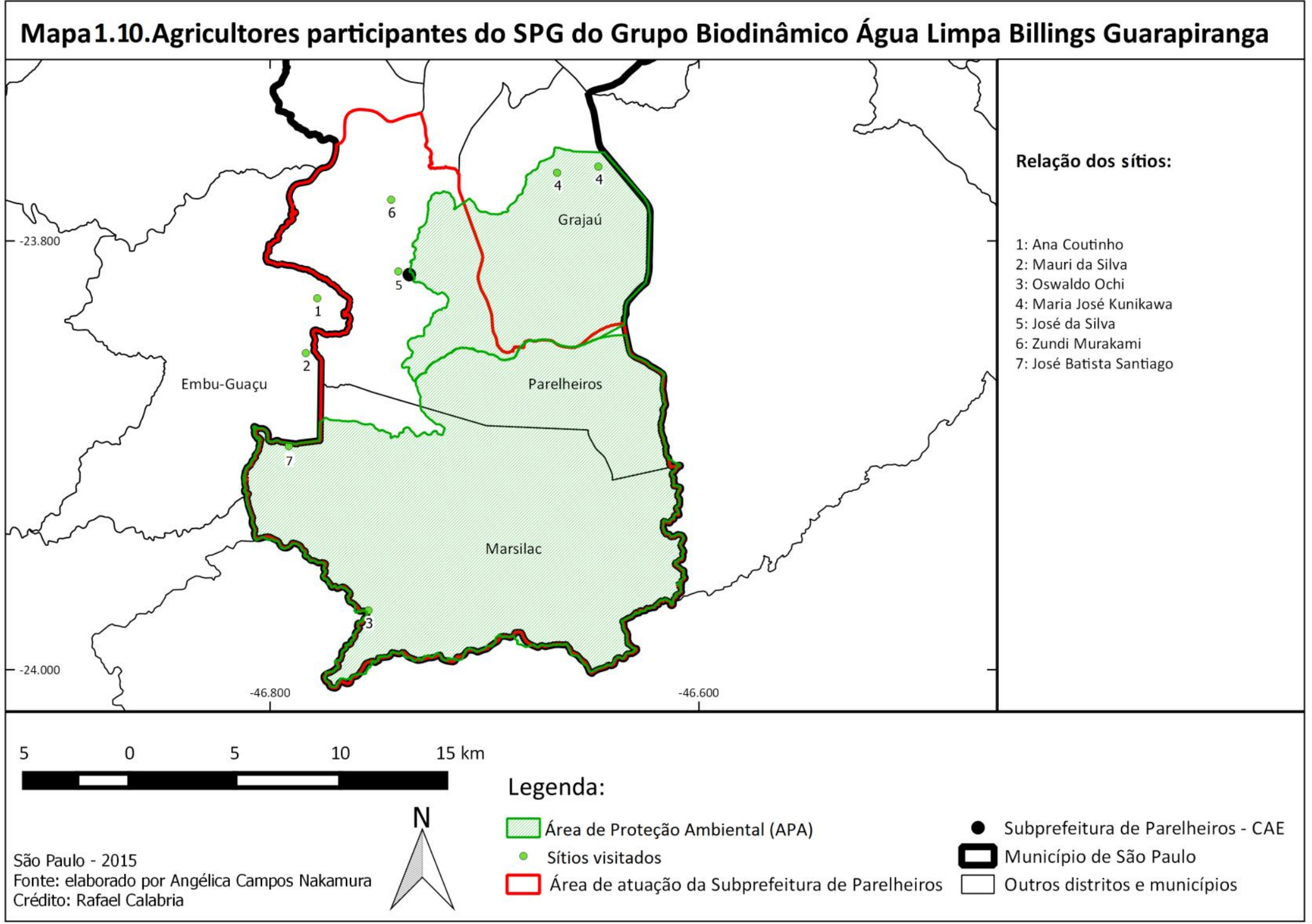


Finalmente, a OCS, está definida no Decreto ${ }^{\circ} 6.323$ de 27 de dezembro de 2007, no artigo $2^{\circ}$, alínea VIII:

[...] organização de controle social: grupo, associação, cooperativa ou consórcio a que está vinculado o agricultor familiar em venda direta, previamente cadastrado no Ministério da Agricultura, Pecuária e Abastecimento, com processo organizado de geração de credibilidade a partir da interação de pessoas ou organizações, sustentado na participação, comprometimento, transparência e confiança, reconhecido pela sociedade (BRASIL, 2007).

Ainda, de acordo com o Ministério da Agricultura, Pecuária e Abastecimento (Mapa):

Nessa forma de regularização, quem dá a garantia da qualidade orgânica é o produtor, acompanhado de perto pela sociedade. Ainda que o número de produtores ligados a uma OCS seja reduzido, se o controle da sociedade é exercido e registrado, ela cumpre sua finalidade. A garantia se baseia na relação de confiança entre quem vende e quem compra. Os produtores devem permitir que seus consumidores visitem sua propriedade, para que possam verificar o quê é produzido e de que forma. Também permitem a entrada dos órgãos de fiscalização, sempre que preciso.

Para poder comercializar seus produtos diretamente ao consumidor, as OCS devem se cadastrar junto à Superintendência Federal de Agricultura da unidade federada [...] As OCS só podem ser formadas por agricultores familiares legalmente reconhecidos; devem estar ativas, possuir formas de controle e registro de informações que sejam capazes de assegurar a qualidade orgânica dos produtos e identificar claramente que produtor é responsável por cada produto. Os produtores assinam um Termo de Compromisso juntos, comprometendo-se a atender ao Decreto $\mathrm{N}^{\circ} 6.323 / 07$ nos princípios e diretrizes da produção orgânica. Como grupo, todos se responsabilizam por todos.

Os produtores ligados às OCS não podem colocar o selo federal do SisOrg em seus produtos, uma vez que este mecanismo de controle não compõe o Sistema Brasileiro de Avaliação da Conformidade Orgânica SisOrg. Sua identificação se dá através da Declaração de Cadastro, que deve estar em local visível no ponto de comercialização. É permitida, apenas, a venda direta de seus produtos ao consumidor, à merenda escolar (através do Programa Nacional de Alimentação Escolar - PNAE) ou à CONAB (Programa de Aquisição de Alimentos - PAA) (MAPA, 2016, grifo nosso).

Até 2015, a OCS São Paulo estava composta por seis membros ${ }^{51}$. As reuniões são realizadas todos os meses, sempre na última quinta-feira, cada mês em um sítio de um dos participantes da OCS diferente (fotos 1.19 e 1.20 na página a seguir e mapa 1.11 após as fotos). Comparecem todos os agricultores, algum técnico da CAE e os consumidores

\footnotetext{
${ }^{51}$ No mapa 1.11, estão indicados apenas os sítios que foram visitados. Valéria Macoratti vive em um pequeno sítio e arrendava outro com um agricultor, também membro da OCS. Porém, o dono do sítio arrendado pediu ele de volta, pois quer vendê-lo por 13 milhões de reais. Esse caso foi contado no início do capítulo. No final de 2015, um novo agricultor entrou no grupo, porém, na ocasião da visita a seu sítio, não pude comparecer.
} 
interessados em conhecer mais sobre a produção orgânica, como ela funciona etc. Normalmente, são clientes das feiras orgânicas nas quais esses agricultores participam e vendem seus produtos. Também é possível comprar diretamente dos produtores nessas reuniões. Não há custo para se montar um grupo de OCS, apenas para enviar a documentação exigida pelo Mapa.
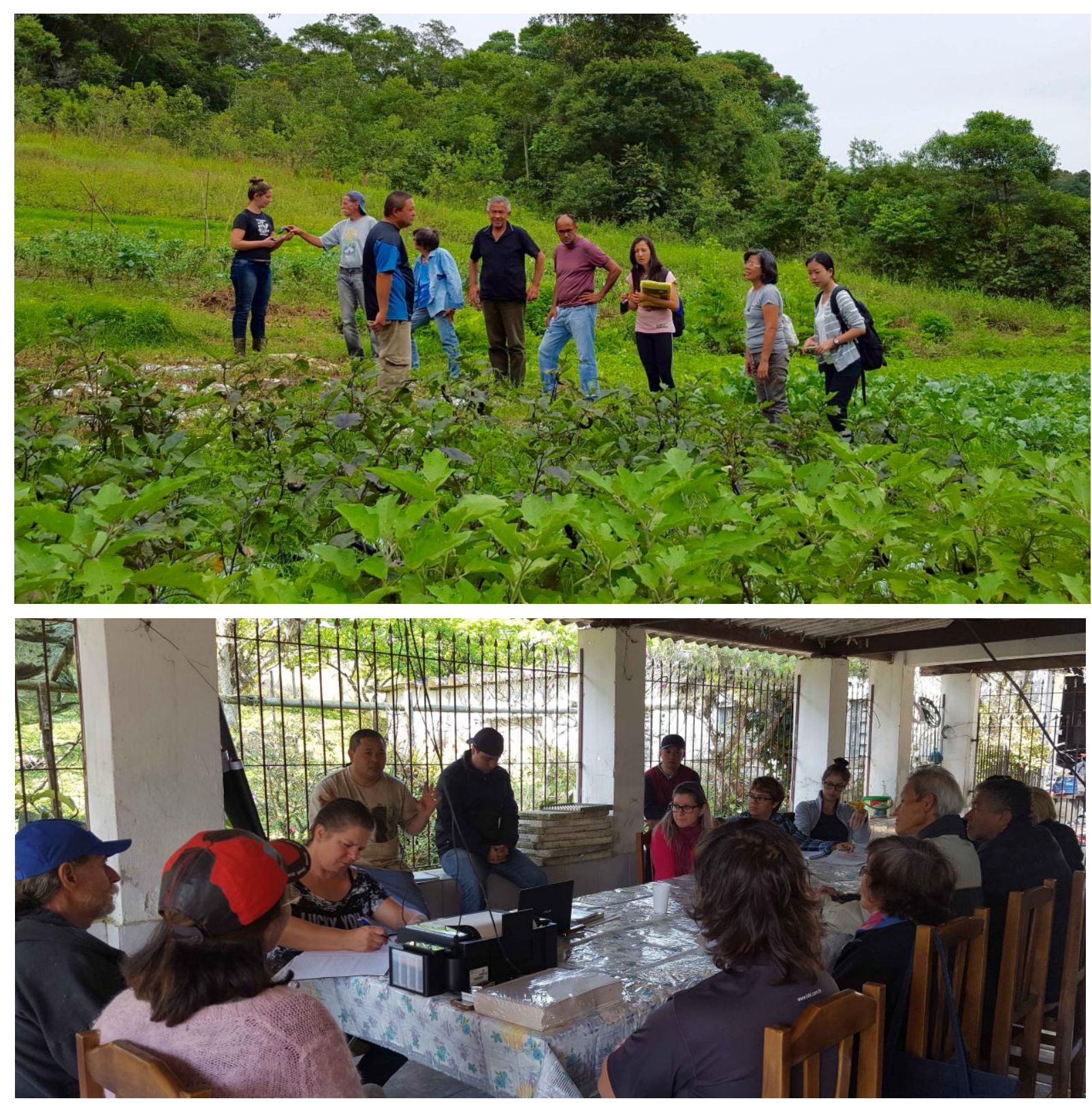

Fotos 1.19 e 1.20. Na foto acima (1.19), os participantes da OCS conhecem o sítio, no distrito de Parelheiros, e ouvem explicações a respeito da produção agrícola, em 25 de fevereiro de 2016. Na foto abaixo (1.20), no mesmo sítio, momento da OCS em que os presentes planejam os próximos passos do grupo, conversam sobre suas produções, recebem avisos etc, em 4 de agosto de 2016. Crédito das fotos: Angélica Campos Nakamura. 


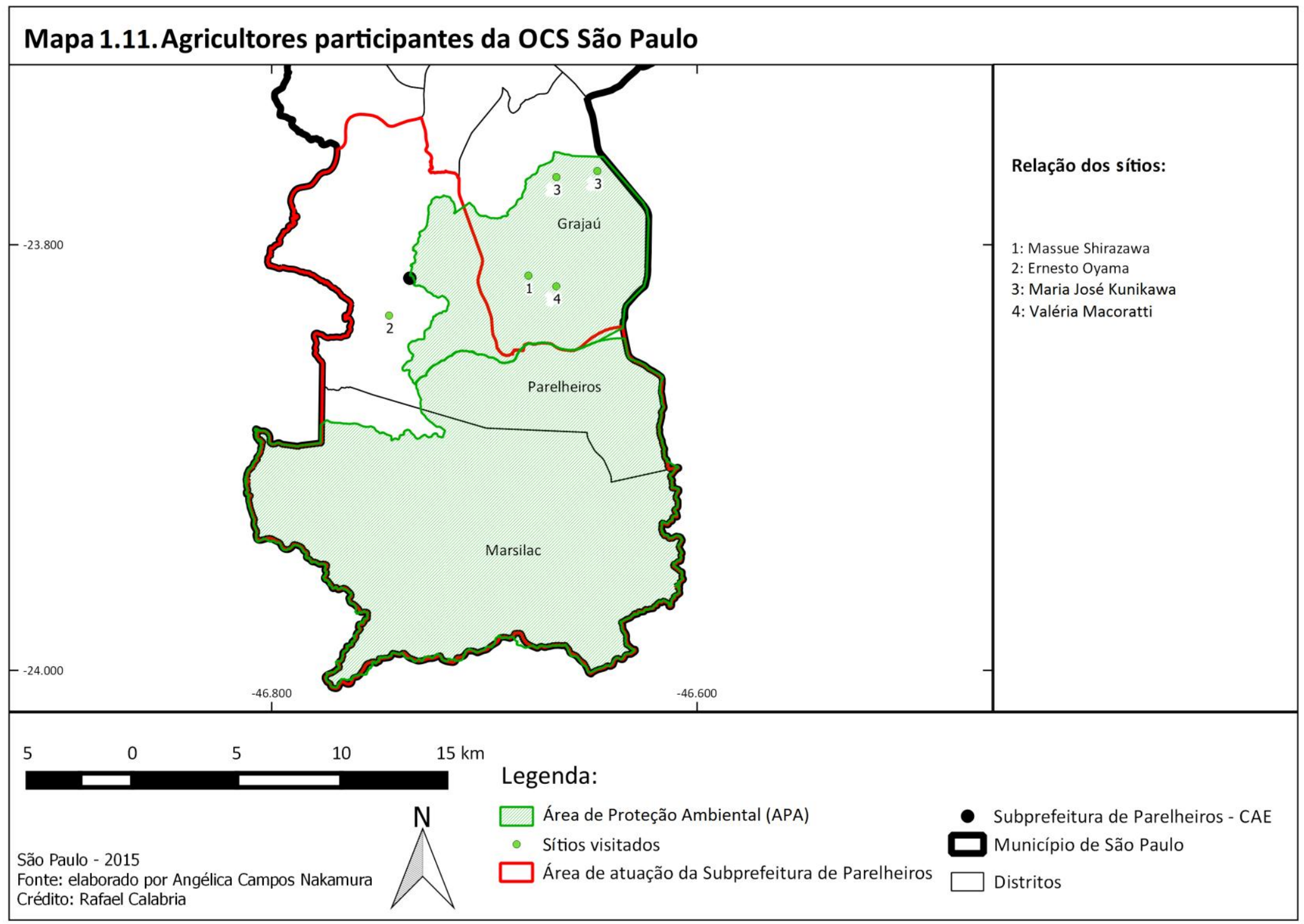


Desde o final de 2015, um dos participantes pedia para que o grupo passasse a ser um SPG, pois conforme destacado na última citação, os produtores participantes da OCS só podem realizar vendas diretas - como as feiras orgânicas - e participar do Pnae e PAA. Caso se tornem um grupo com certificação pelo SPG, esses agricultores poderiam começar a vender para clientes diferentes, como restaurantes. Finalmente, na reunião da OCS de julho de 2016, esse participante conseguiu outros interessados, pois os membros da OCS São Paulo não se interessavam em fazer um grupo de SPG. De acordo com ele, não há problemas em um agricultor participar de uma OCS e uma SPG ao mesmo tempo.

Até aqui, buscou-se apresentar um quadro geral do extremo sul do município de São Paulo e a agricultura lá praticada, a qual ganhou destaque no início do século XX graças aos imigrantes, especialmente os japoneses. A região não deixou de sofrer com a expansão da mancha urbana, porém, a cidade não chegou a se estender completamente sobre o extremo sul.

No início do século XXI, com o Estatuto da Cidade e o Plano Diretor de 2002, a atenção para a agricultura começou a crescer, agora vinculada à ideia de sustentabilidade e conservação do meio ambiente e o incentivo à prática de uma agricultura sem agrotóxicos e fertilizantes ganhou força. A agricultura antes praticada com o uso dessas substâncias químicas, até elogiadas nos relatos de pesquisadores no início do século $\mathrm{XX}$ trazidos no começo desse capítulo, agora passa a ser vista como poluidora do meio ambiente e nociva à saúde de quem produz e consome.

Políticas públicas começaram a surgir, voltadas para os agricultores da região, e a criação da Cooperapas se insere nesse contexto. Mais sobre quem são esses agricultores será tratado no capítulo 2 a seguir. A história dessa cooperativa e os desafios e problemas enfrentados por ela serão tratados no capítulo 3 . 
2. OS AGRICULTORES DA COOPERAPAS 


\subsection{Um perfil dos membros da Cooperapas}

Durante a realização do trabalho de campo, ao acompanhar os encontros dos membros da Cooperapas, como reuniões e assembleias, e entrevistar parte dos cooperados, sempre foi claro a forma como a maioria desses produtores se veem: são agricultores familiares. Valéria Macoratti, a presidenta da Cooperapas, até bate no peito ao afirmar que é uma agricultora familiar e tem muito orgulho disso.

Apesar de se identificarem como agricultores familiares, ao conhecer melhor os membros da cooperativa, é possível perceber como há perfis muito variados: pessoas cujos pais e avós trabalharam na roça; outras que quiseram sair do meio totalmente urbano para buscar uma aproximação com a natureza; ainda, há as que querem ser agricultoras para mudar de vida.

A fim de conhecer melhor quem são esses cooperados, um perfil foi traçado a partir de entrevistas, realizadas ao longo do segundo semestre de 2015, e de alguns dados fornecidos pela Casa de Agricultura Ecológica (CAE) José Umberto Macedo Siqueira.

As entrevistas realizadas consistiam em dois momentos: o primeiro, com perguntas baseadas em um cadastro de produtores rurais da Prefeitura de São Paulo. Esse questionário me foi repassado pelos funcionários da $\mathrm{CAE}$, a fim de me ajudar a elaborar as perguntas de caráter mais social e econômico ${ }^{1}$. Porém, os dados da CAE passados para mim tinham como base esses questionários, que foram aplicados por volta de 2010. Daí a necessidade em se realizar novamente essa parte da entrevista. Porém, foram utilizados apenas alguns dados desse questionário para esse trabalho. É importante ressaltar também que não foram todos os cooperados que consegui conversar.

O segundo momento das entrevistas consistia na história de vida da pessoa: quem eram seus avós e pais? Trabalhavam antes com a terra? Se não, que caminhos o levaram a se tornar hoje um membro de uma cooperativa de produtores rurais do município de São Paulo? Qual o envolvimento dela com a terra? Conforme a entrevista ocorria, novas perguntas poderiam ser feitas. Tudo dependia da trajetória de vida pessoal.

Para realizar as entrevistas, eu sabia que dificilmente conseguiria conversar com todos os cooperados. Primeiro, porque há os membros os quais não aparecem nas reuniões há muito tempo, inclusive, alguns desses constam no estatuto de fundação da Cooperapas e as pessoas

\footnotetext{
${ }^{1}$ O questionário da CAE se encontra no final desse trabalho, na seção "Anexos", como o anexo "C”.
} 
nem sabem quem são. Assim, priorizei os sócios mais ativos que se disponibilizaram a conceder uma entrevista e a me receber em seus sítios e casas. Segundo, porque alguns são realmente difíceis para se fazer uma entrevista. Cheguei a combinar dia e local, mas na hora de confirmar - algo que sempre fazia antes de ir e percorrer no mínimo cerca de 40 quilômetros e enfrentar o trânsito da cidade de São Paulo e estradas de terra - nunca conseguia. A pessoa tinha outro compromisso, ou não atendia a ligação, ou pedia para remarcar. Com quem consegui marcar, também não foi sem dificuldade. Alguns foram remarcados até haver compatibilidade de agenda, outros chegaram a esquecer o dia combinado, mas acabaram me atendendo. A maioria dessas entrevistas ocupou quase todo o meu dia. Eu evitava combinar mais de uma por dia por preferir uma entrevista qualitativa melhor. Os entrevistados gostaram de contar suas histórias e de como chegaram ali. Não queria apressá-los.

Do momento que realmente comecei a realizar essas entrevistas e visitas, o ano já estava no segundo semestre de 2015. Após as entrevistas, ainda viria todo o trabalho de ouvilas, rever as minhas anotações, refletir sobre tudo o que vi e ouvi, pensar nas leituras para, finalmente, escrever.

Também ressalto que, além do trabalho com as entrevistas e as visitas nos sítios, continuei a acompanhar as reuniões mensais, os encontros extras que ocorreram e as assembleias - todos da Cooperapas - e, ainda, as reuniões mensais da Organização de Controle Social (OCS) São Paulo e uma certificação realizada pelo grupo do Sistema Participativo de Garantia (SPG). Portanto, meu relato aqui se baseia nas entrevistas e na rotina que acompanhei desses agricultores. Ainda, tive muitas conversas informais. Nem sempre o que saía nessas conversas tinha relevância acadêmica, porém, elas colaboraram para entender melhor a realidade na qual esses agricultores vivem e como se dão as relações entre eles.

Para selecionar quem entrevistaria, tomei como base a lista dos 30 membros que fundaram a Cooperapas presente no estatuto da cooperativa. Dessa lista, cerca de seis nunca ou quase nunca compareceram nas reuniões. De acordo com técnicos da CAE e alguns membros, alguns abandonaram a atividade agrícola. Outros três, que aparecem na maioria das reuniões, tentei marcar entrevista, mas nunca consegui. Ainda, uma das antigas cooperadas que se desligou, não me respondeu. Até o início de 2016, havia 28 membros na cooperativa.

De meados de 2015 para frente, novos membros ingressaram. Desses, entrevistei quatro. No total, fiz 19 entrevistas as quais considero completas, ou seja, com o questionário fornecido pela CAE e com a história de vida desses cooperados. Entretanto, conforme 
relatado, muito da minha compreensão e entendimento proveio, também, do intenso contato que tive participando das reuniões, encontros e conversas informais.

Apesar de não ter conversado com todos os membros, procurei entrevistar uma quantidade que fosse razoável dentro desse grupo e a qual tivesse perfis e histórias diferentes para, assim, ter um quadro de quem são esses membros da Cooperapas.

Para iniciar, apresento a tabela 2.1 com os pontos das coordenadas dos sítios obtidos por GPS e indicados no mapa 2.1 (após a tabela), o nome dos proprietários e uma foto com a visão local. Apesar de ter realizado entrevista com 19 cooperados, há 16 sítios indicados, pois em três casos, os sítios são referentes a dois membros da Cooperapas.

Tabela 2.1. Pontos dos sítios apresentados no mapa 2.1

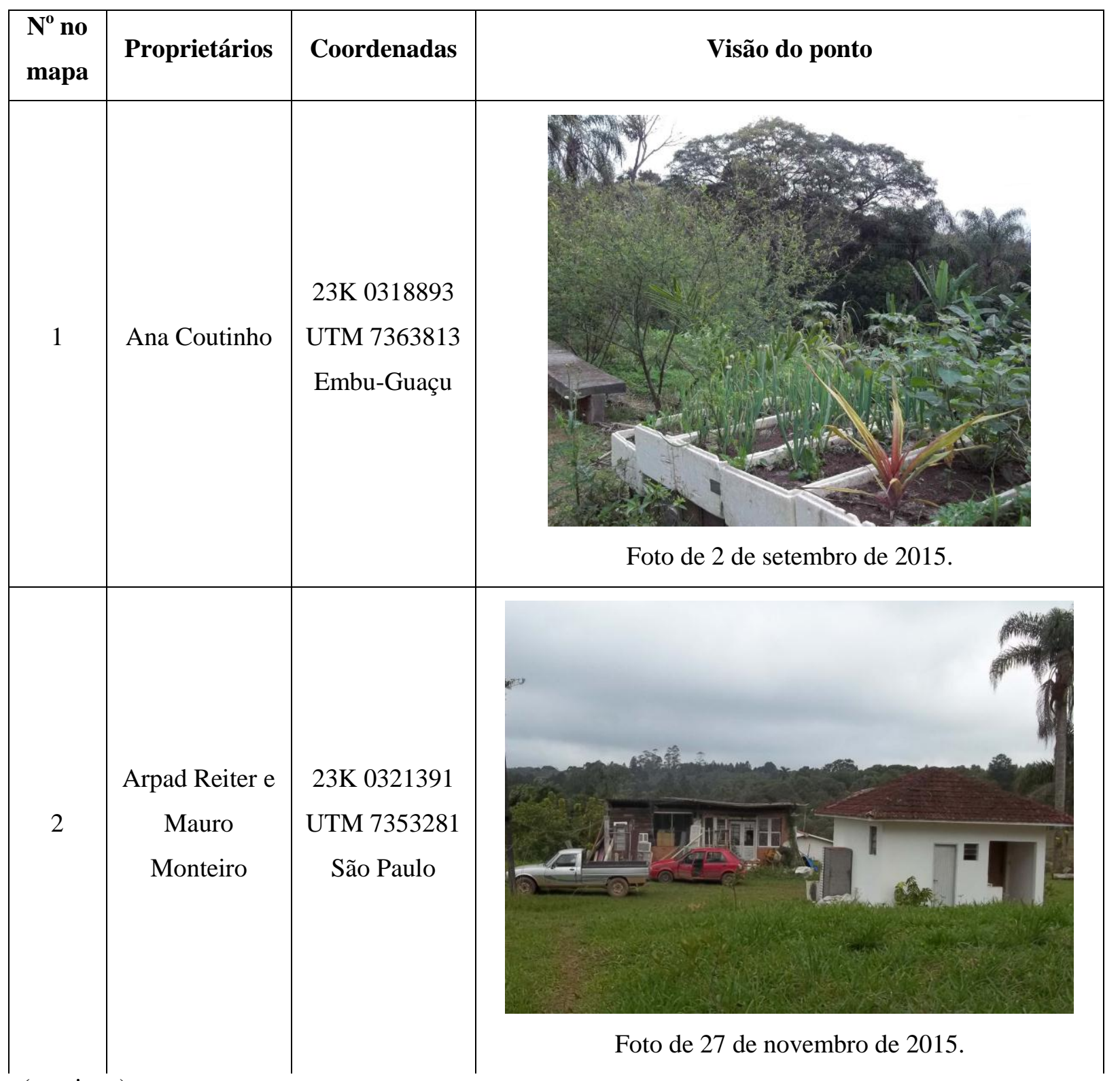

(continua) 
(continuação)

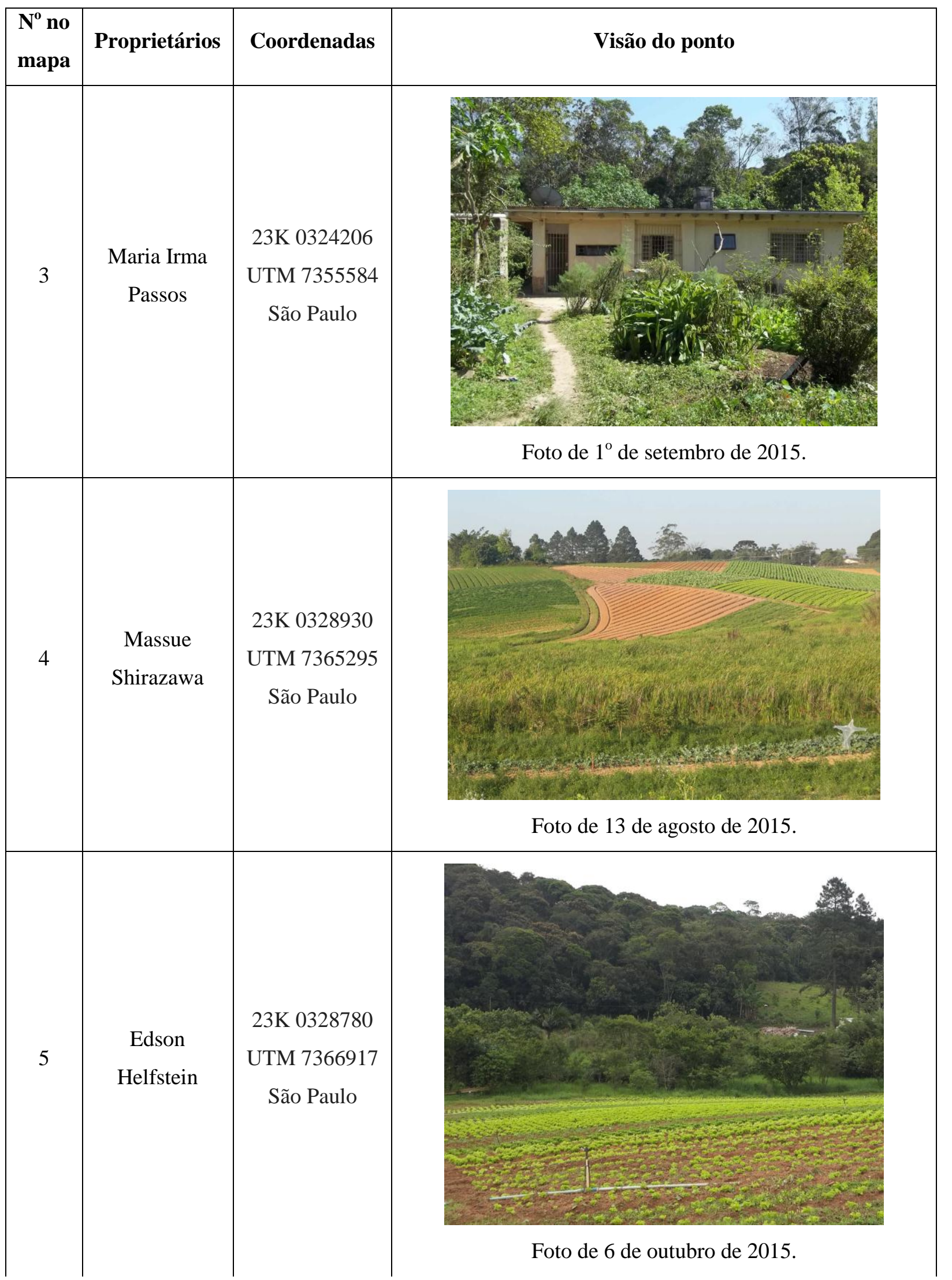


(continuação)

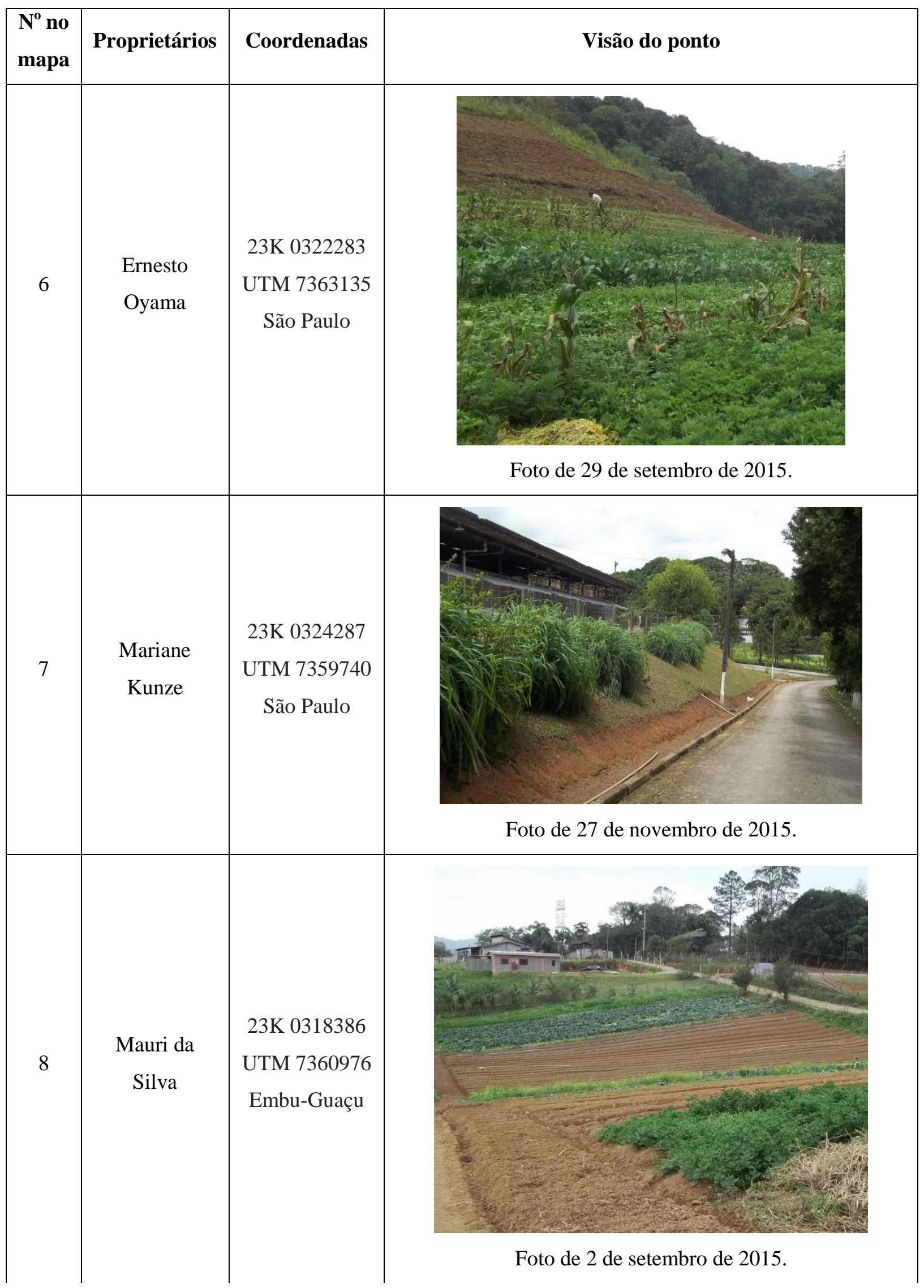


(continuação)

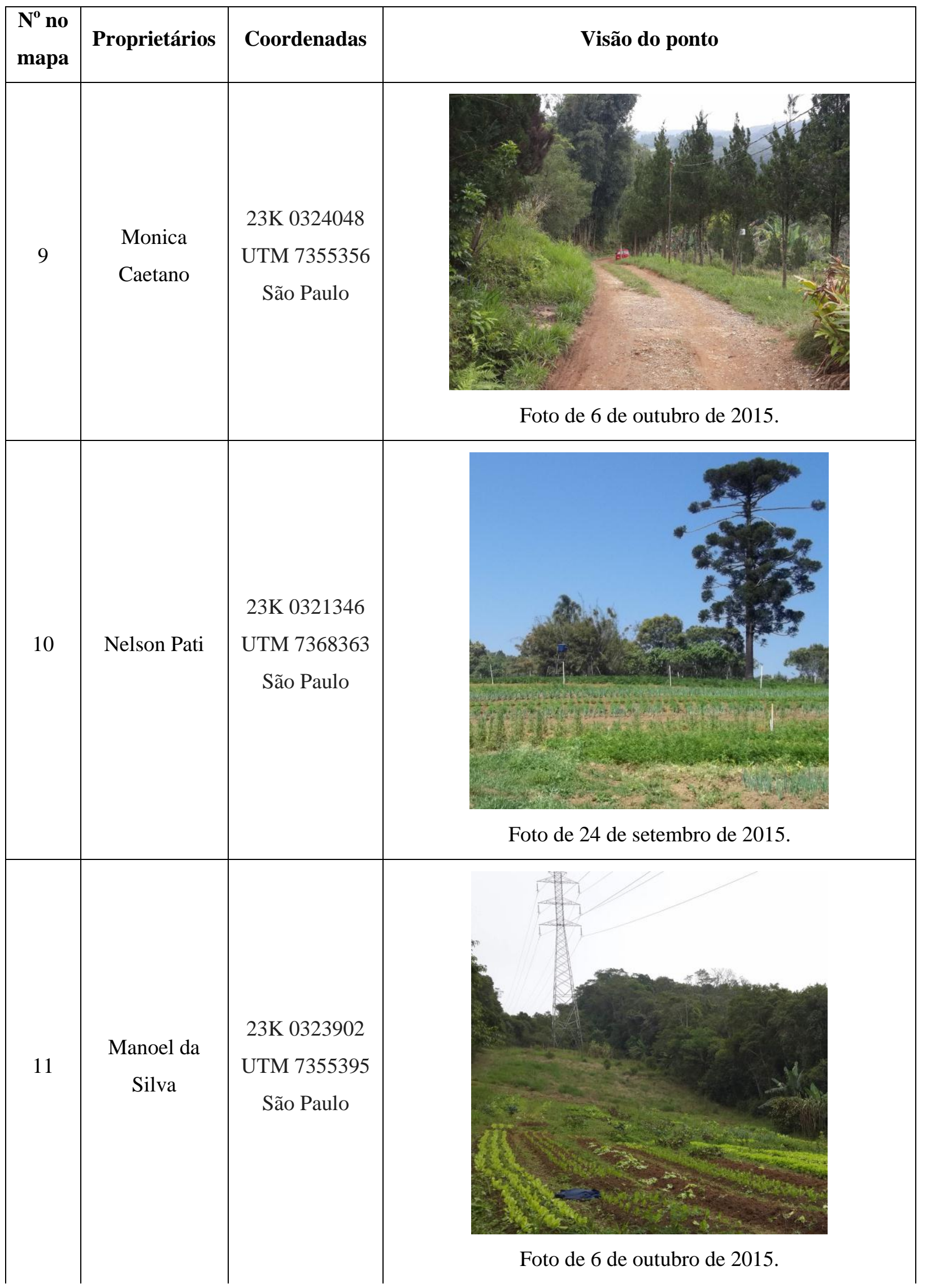


(continuação)

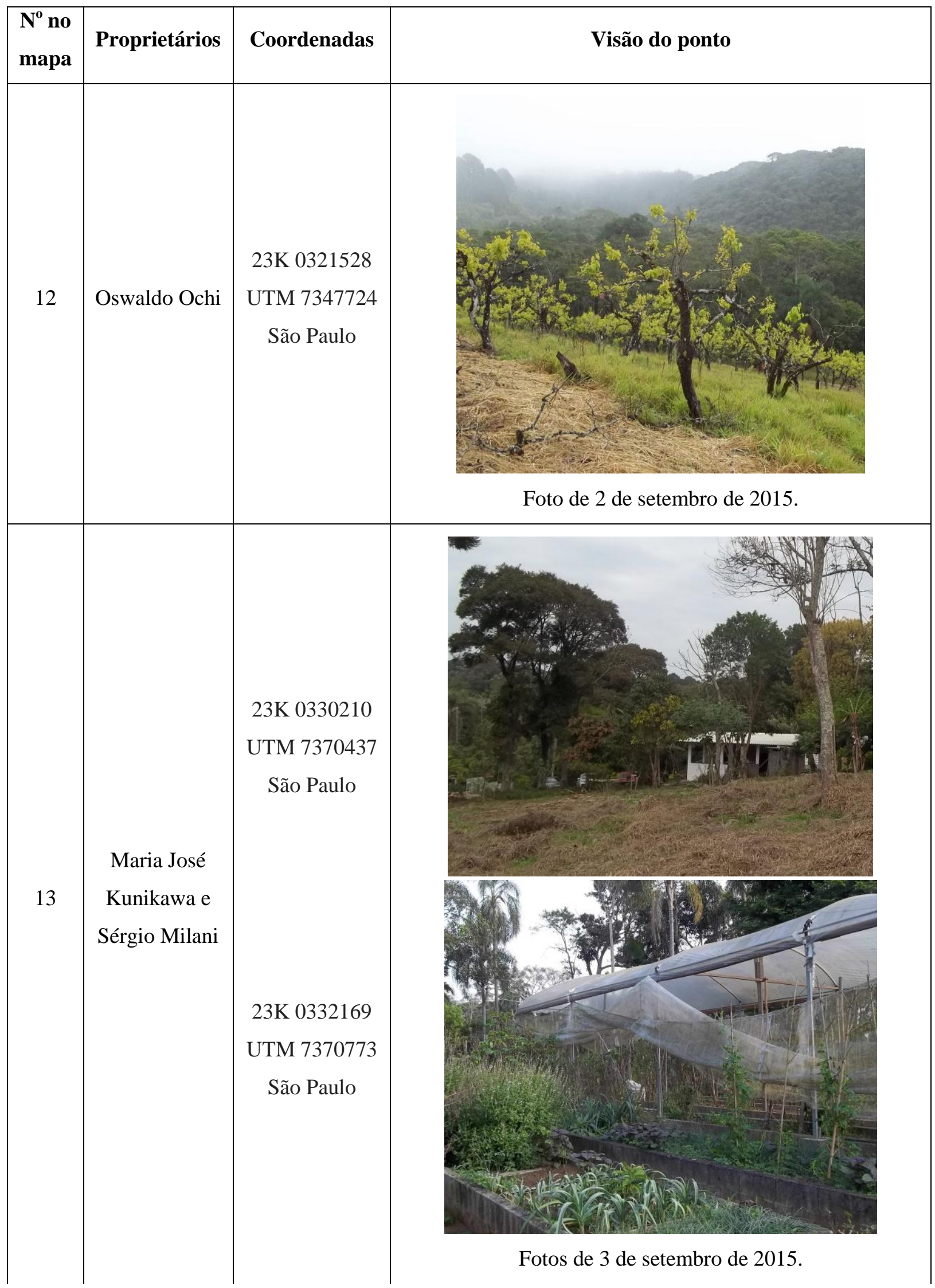


(conclusão)

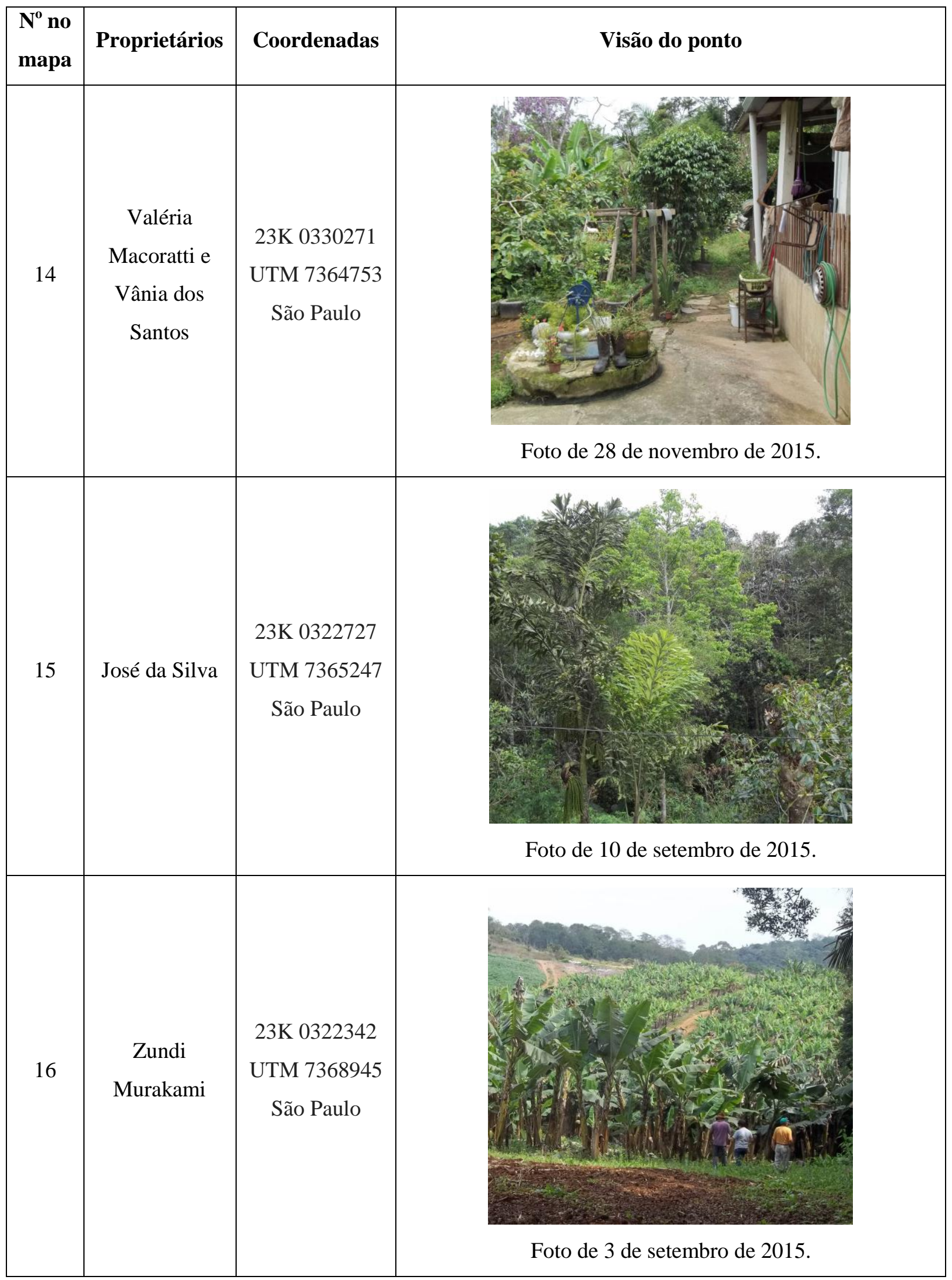

Fonte: Elaboração da autora a partir dos trabalhos de campo realizados durante a pesquisa. 
118

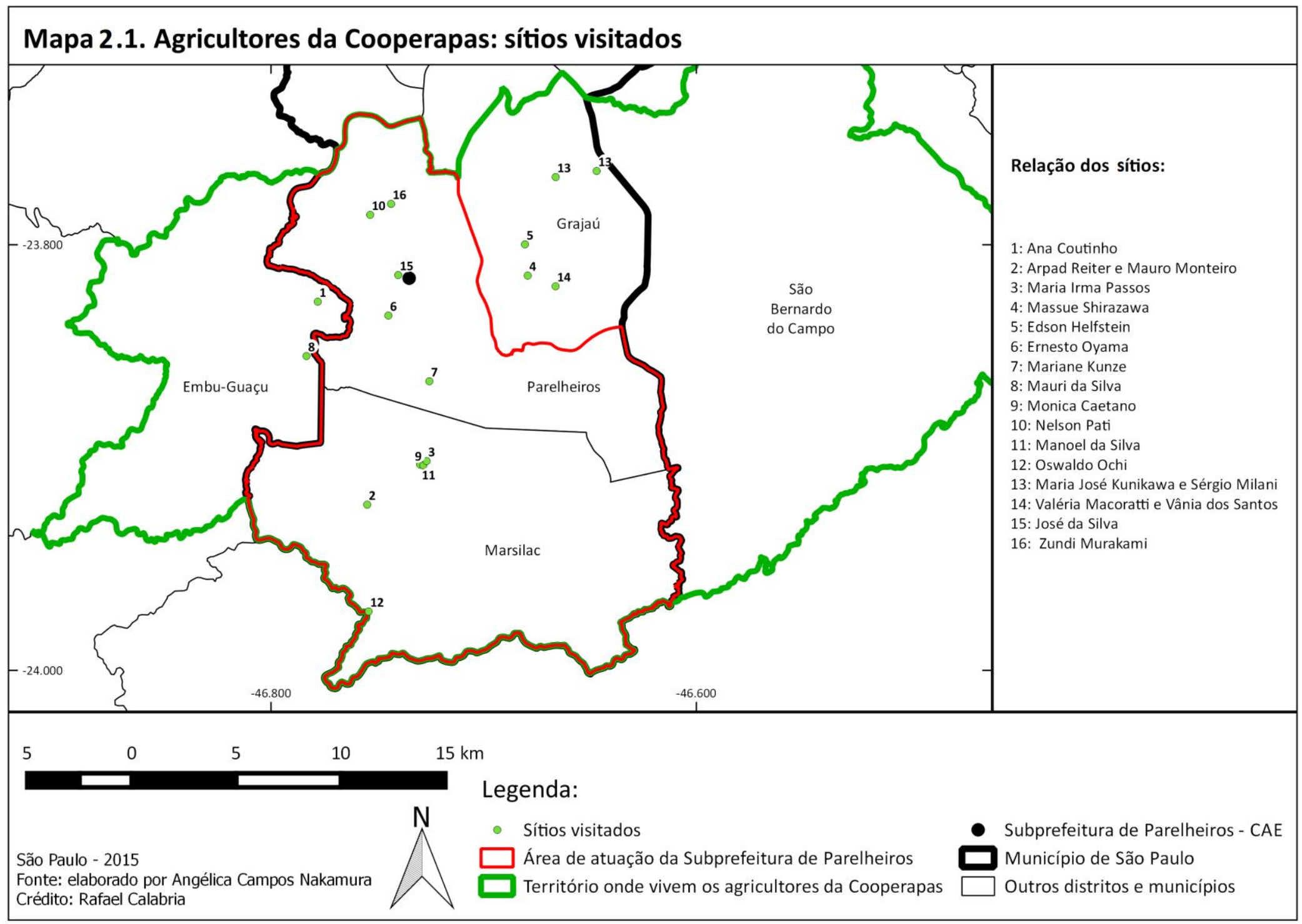


A partir do questionário de cadastro de produtores rurais da Prefeitura de São Paulo, alguns aspectos a respeito dos 19 agricultores foram levantados e trazidos para o presente trabalho. A começar, se possuíam a Declaração de Aptidão ao Pronaf (DAP)².

Gráfico 2.1. Agricultores entrevistados da Cooperapas que possuem DAP

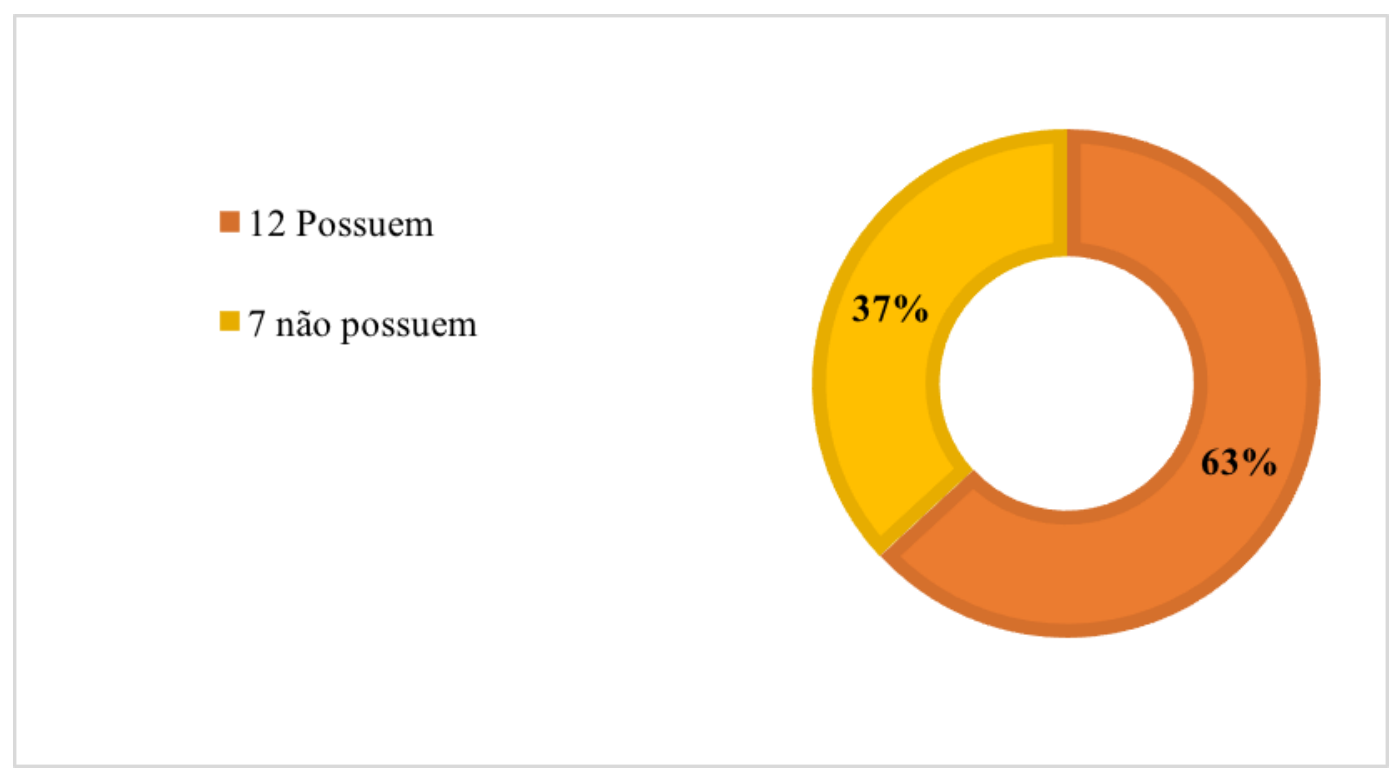

Fonte: Elaboração da autora a partir dos dados levantados durante a pesquisa ${ }^{3}$.

A DAP é importante para que esses membros tenham acesso às políticas públicas do governo federal, como o Programa Nacional de Fortalecimento da Agricultura Familiar (Pronaf $^{4}$. Apesar de a maioria possuir a DAP, até o final de 2015, apenas um cooperado afirmou já ter acessado o programa.

\footnotetext{
${ }^{2}$ A Declaração de Aptidão ao Pronaf (DAP) é um documento que identifica o agricultor familiar. De acordo com o Ministério do Desenvolvimento Agrário (MDA), "O documento [DAP] foi criado há 17 anos por meio de uma resolução do Conselho Monetário Nacional (CMN, RES 2191, de 24 de agosto de 1995). Até então, era específica para acesso ao crédito rural (Pronaf). De lá para cá, veio ganhando cada vez mais espaço e atualmente a DAP funciona como uma espécie de identidade dos agricultores familiares". Ainda, "O documento é exclusivo dos trabalhadores rurais que atuam em conjunto com a família. Quilombolas, povos indígenas, extrativistas, pescadores, assentados da Reforma Agrária, agricultores em geral, dentre outros produtores rurais, podem obter a DAP. Só a declaração comprova que o trabalhador é um agricultor familiar" (MDA, 2012). A DAP pode ser tirada por pessoa física ou jurídica. Sobre a questão de o produtor ser enquadrado como agricultor familiar perante ao Estado, ela será tratada mais à frente nesse capítulo.

${ }^{3}$ Um dos cooperados não se encaixava na definição de agricultor familiar de acordo com a legislação. Para ser agricultor familiar, a lei exige que a mão-de-obra familiar seja predominante na propriedade, o que não é o caso desse membro.

4 "O Programa Nacional de Fortalecimento da Agricultura Familiar (Pronaf) destina-se a estimular a geração de renda e melhorar o uso da mão de obra familiar, por meio do financiamento de atividades e serviços rurais agropecuários e não agropecuários desenvolvidos em estabelecimento rural ou em áreas comunitárias próximas" (BANCO CENTRAL DO BRASIL, 2015).
} 
Gráfico 2.2. Agricultores entrevistados da Cooperapas que conhecem o Pronaf

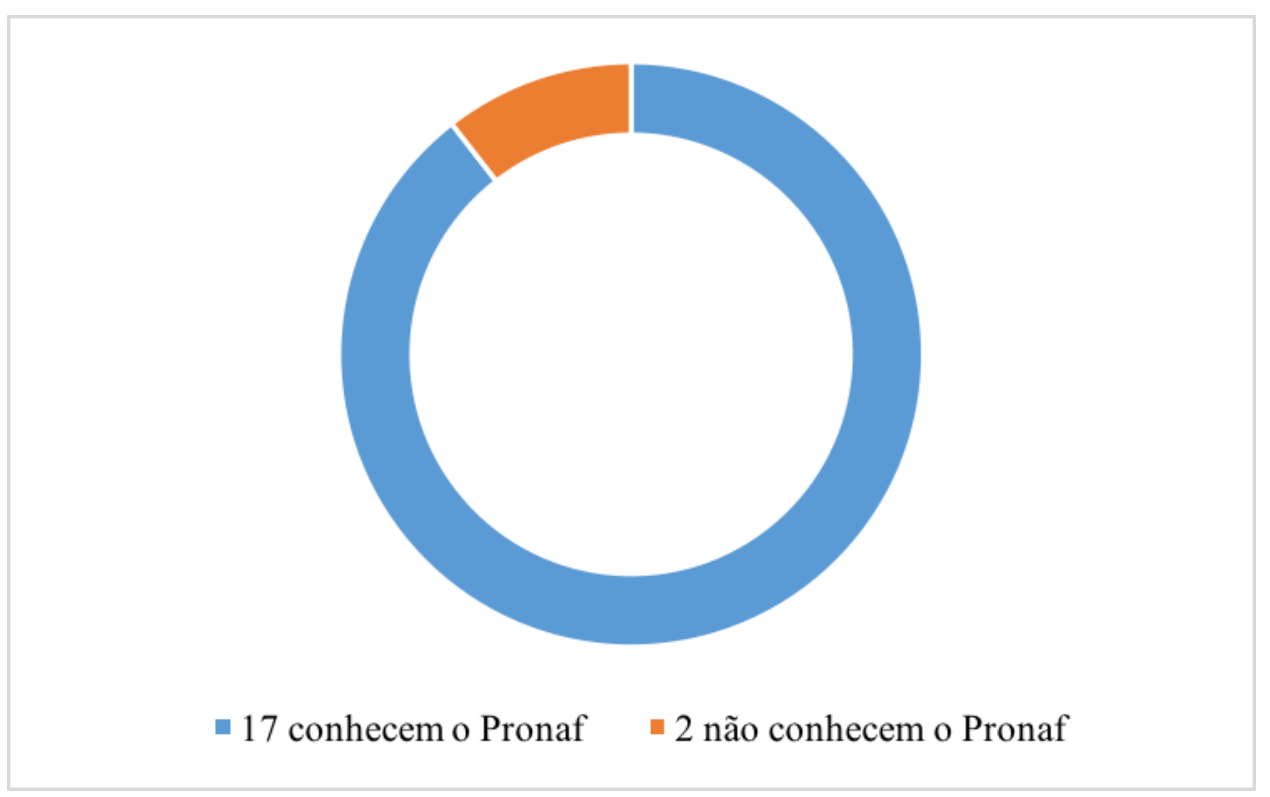

Fonte: Elaboração da autora a partir dos dados levantados durante a pesquisa.

O membro o qual afirmou já ter acessado o Pronaf, comprou um carro pelo Pronaf Mais Alimentos, que é uma linha de crédito voltada para financiar a infraestrutura produtiva da propriedade familiar. Quinze membros afirmaram conhecer o Pronaf mas nunca acessaram. Deles, um reclamou sempre tentar financiamento, mas nunca ter conseguido ${ }^{5}$.

É importante ressaltar aqui que de todos esses entrevistados, apenas dois afirmaram ter $100 \%$ de suas rendas provenientes da agricultura. Coincidência ou não, um deles foi justamente o que já acessou o Pronaf. Todos os outros possuem alguma renda externa, cuja proveniência é variada, como por exemplo: um dos entrevistados faz bicos, principalmente de cozinheiro; sete deles afirmaram ter uma propriedade alugada, na maioria dos casos era uma casa ou apartamento; dois cooperados usam o sítio (pois são irmãos), o qual possui uma área grande e com um belo paisagismo, para receber eventos e escolas (fotos 2.1 e 2.2 na página a seguir); três contaram que outros membros da família trabalham fora da roça; dois membros trabalham para o Instituto Kairós; quatro deles ou são aposentados, ou têm membros da

\footnotetext{
${ }^{5}$ Esse agricultor não entrou em detalhes dos motivos de não conseguir o financiamento. Porém, entre os membros da Cooperapas, é muito comum ouvir reclamações de como é difícil conseguir um financiamento ou crédito nos bancos. De acordo com eles, o banco não consegue compreender que a produção agrícola tem seus altos e baixos, épocas com mais produção do que outras e, portanto, não há como comprovar uma renda fixa estável. Com o estabelecimento de uma zona rural no município de São Paulo, muitos têm a esperança de que a postura dos bancos da região melhore, e que tragam gerentes os quais saibam lidar e entender a realidade de um agricultor.
} 
família que recebem aposentadoria; um dos cooperados possui uma escola de educação infantil; um tem boa parte da renda proveniente de ganho de capital.
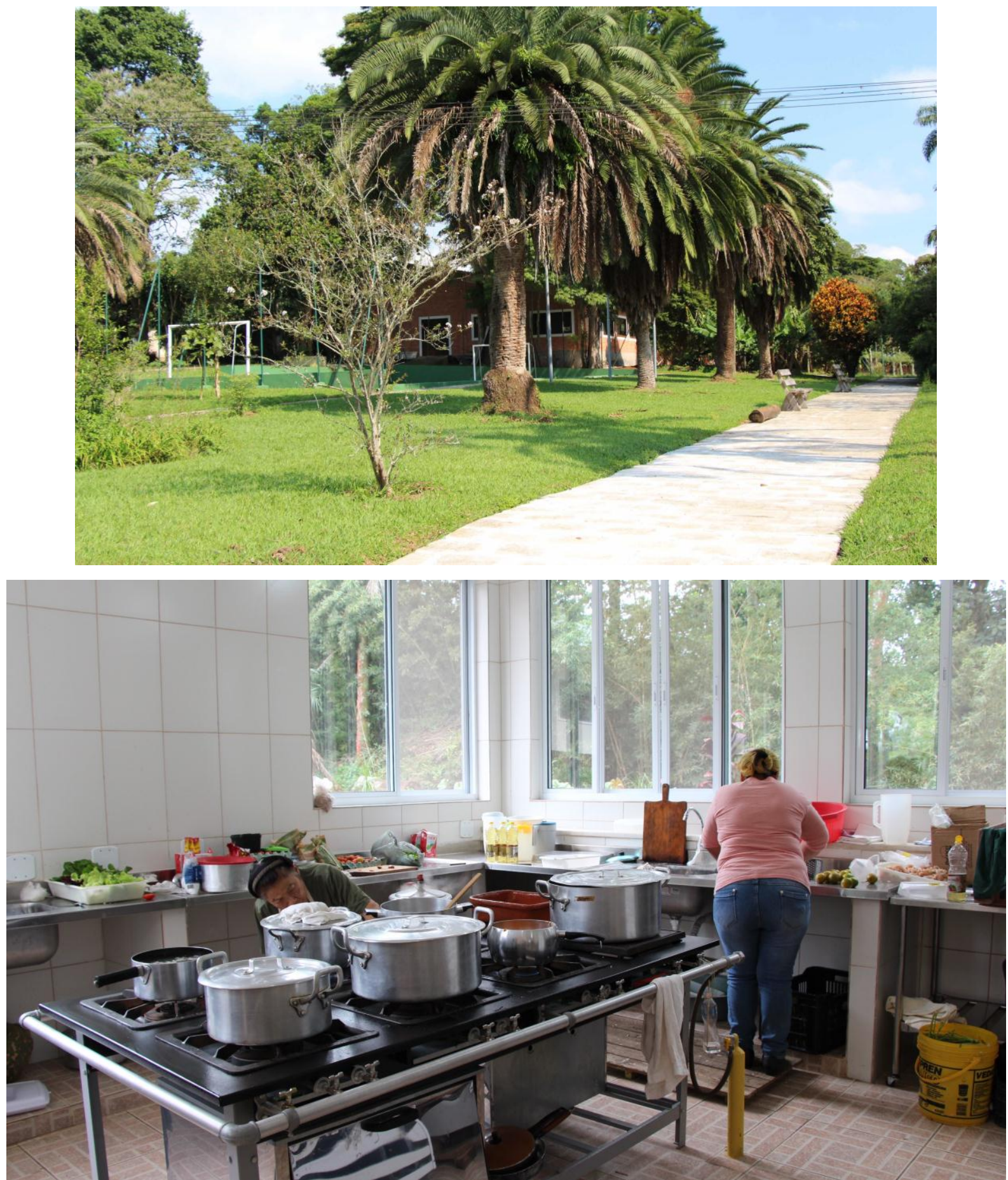

Fotos 2.1 e 2.2. Na foto acima (2.1), área externa do Sítio Paiquerê, no município de São Paulo. O local conta com quadra de esportes e, ainda, piscina. Foto de 25 de março de 2015 . Na foto abaixo (2.2) a cozinha para receber para eventos. Foto de 5 de maio de 2015. Crédito das fotos: Angélica Campos Nakamura. 
Dos entrevistados, quase todos são proprietários de seus sítios (gráfico 2.3). O único não proprietário é funcionário assalariado, responsável por cuidar do sítio de seu chefe e da horta. Ele é quem participa das reuniões da Cooperapas. Porém, seu chefe e proprietário do sítio é quem está com o nome entre os membros da Cooperapas. De acordo com o entrevistado, além de ele ser assalariado, ele também participa como meeiro na produção agrícola do sítio.

Entre esses 19 entrevistados, 15 viviam na unidade produtiva (fotos 2.3 e 2.4 ).

Gráfico 2.3. Proprietários entre os agricultores entrevistados da Cooperapas

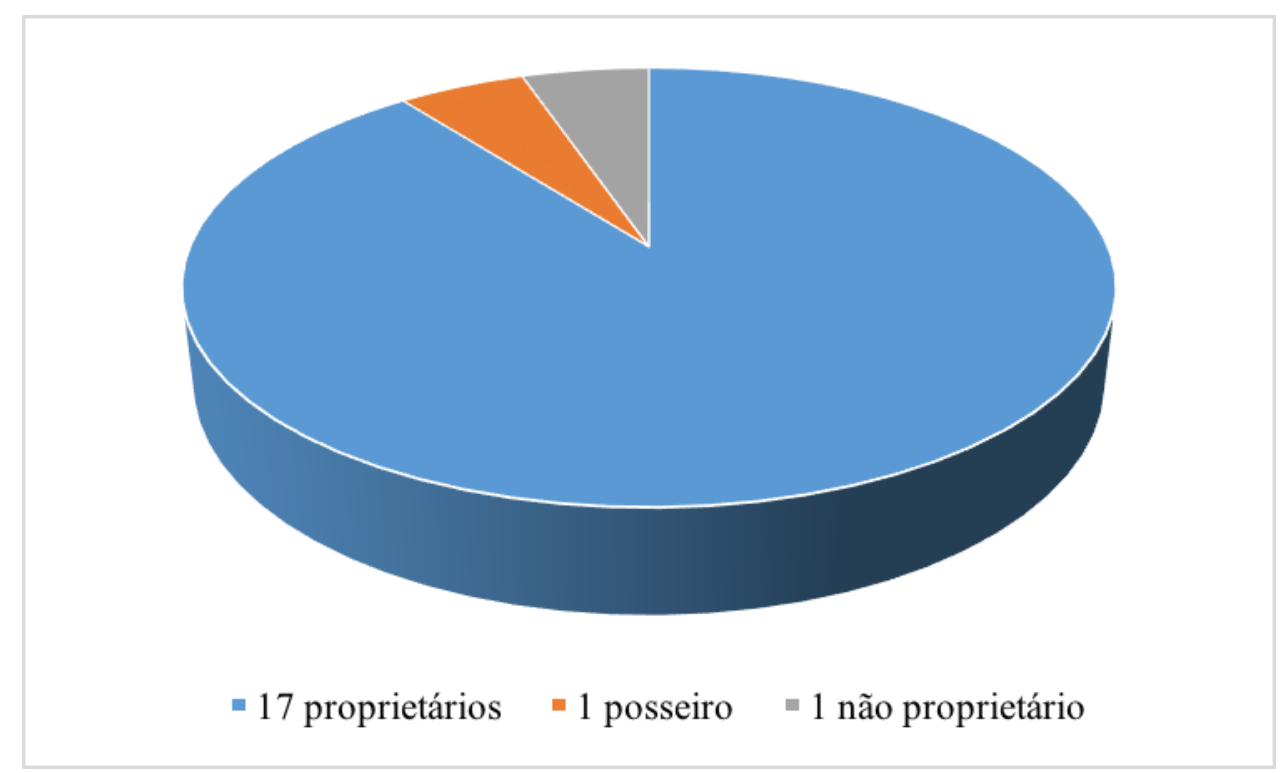

Fonte: Elaboração da autora a partir dos dados levantados durante a pesquisa.

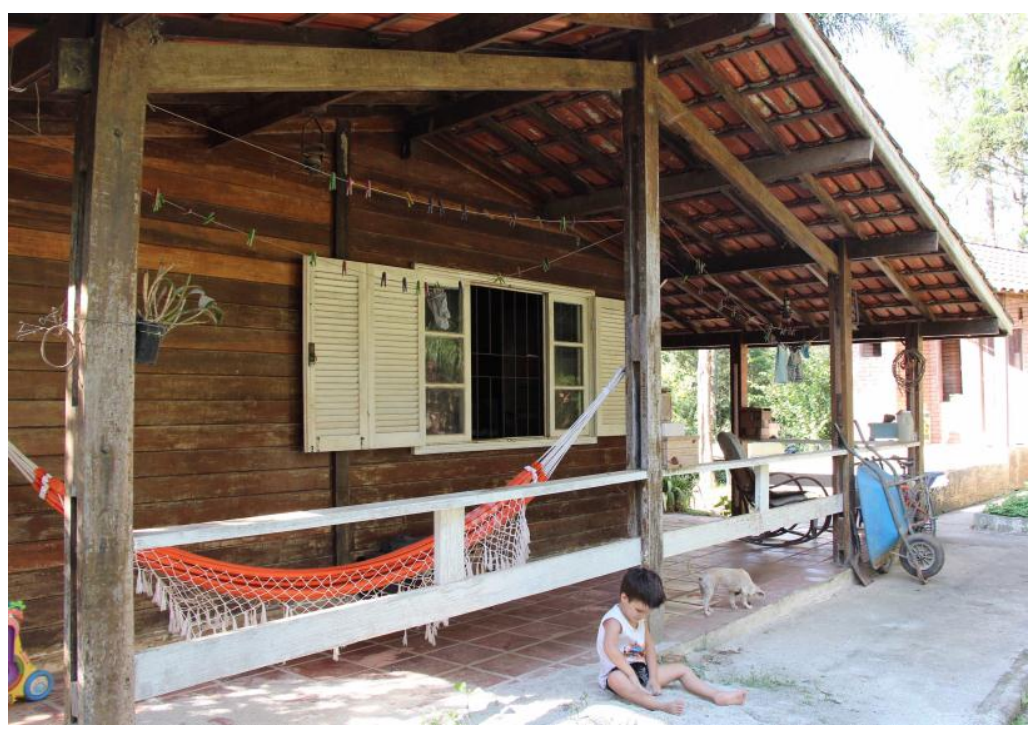

Foto 2.3. Casa da Ana do Mel, no município de Embu-Guaçu, em 20 de janeiro de 2015. Crédito da foto: Angélica Campos Nakamura. 


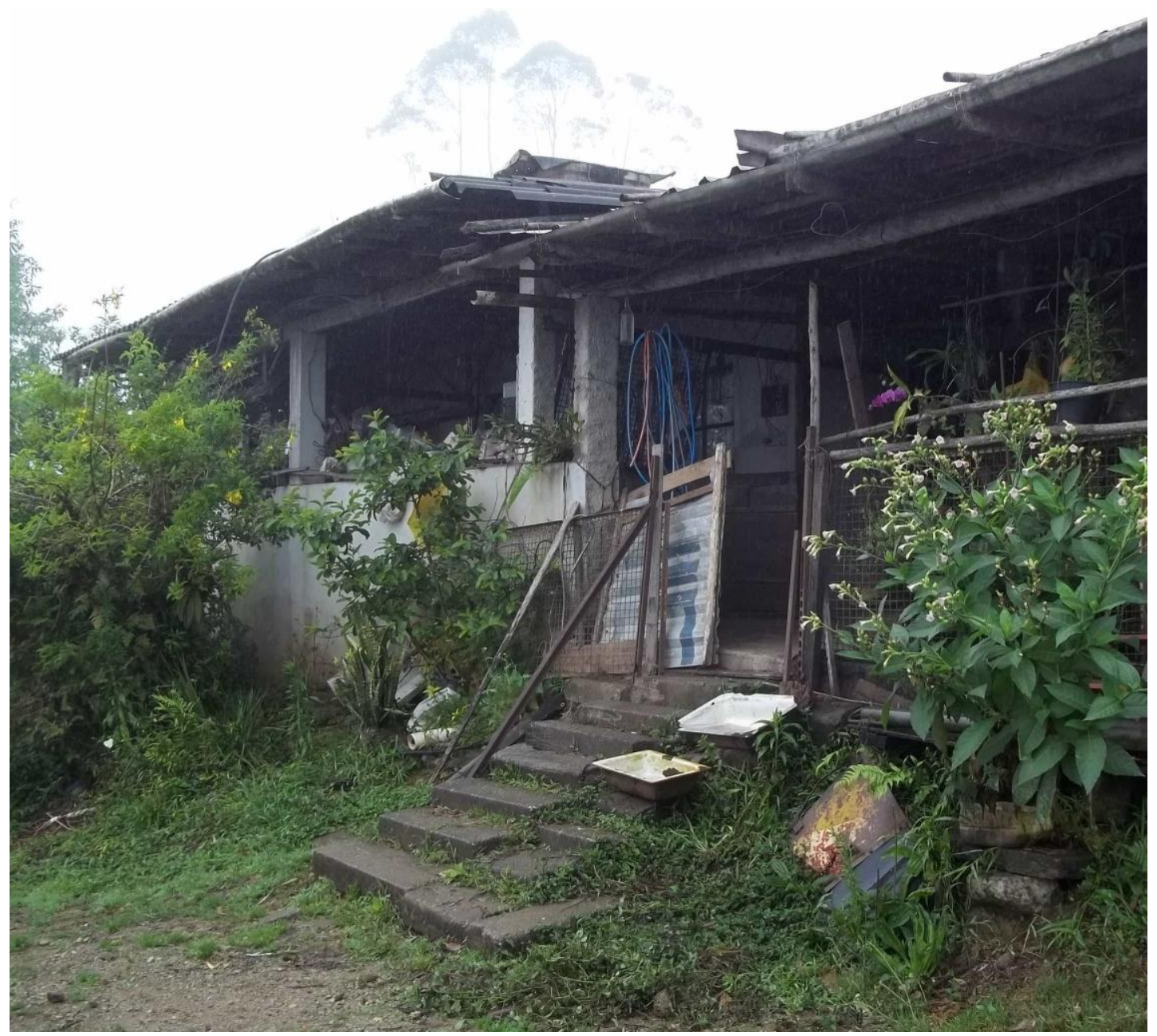

Foto 2.4. Casa de Seu Osvaldo, no distrito de Marsilac, no município de São Paulo, em 2 de setembro de 2015. Crédito da foto: Angélica Campos Nakamura.

Entre os proprietários membros da Cooperapas, um deles estava à procura de um novo sítio para arrendar na época da entrevista ${ }^{6}$. Apesar de produzir no sítio no qual vive, a área é muito pequena. Portanto, era necessário outro local para ampliar a produção.

No que se refere à força de trabalho utilizada, a maior parte são as próprias famílias e proprietários, porém, a maioria contrata temporários para ajudar ou possuem funcionários contratados (foto 2.5, na página a seguir). É muito comum ouvir reclamações dos cooperados da dificuldade em se encontrar pessoas dispostas a trabalhar na roça, pois o serviço é exaustivo. Em uma reunião, uma das cooperadas chegou a reclamar, inclusive, de valores exigidos por serviços. Na ocasião, ela necessitava de um tratorista e o preço dele, por hora, era de $\mathrm{R} \$ 100,00$, valor muito alto para ser arcado por ela.

\footnotetext{
${ }^{6}$ Esse é o caso de Valéria Macoratti, citado no capítulo 1. O dono do sítio o qual ela arrendava exigiu a área de volta para vendê-la pelo valor de $\mathrm{R} \$ 13$ milhões.
} 


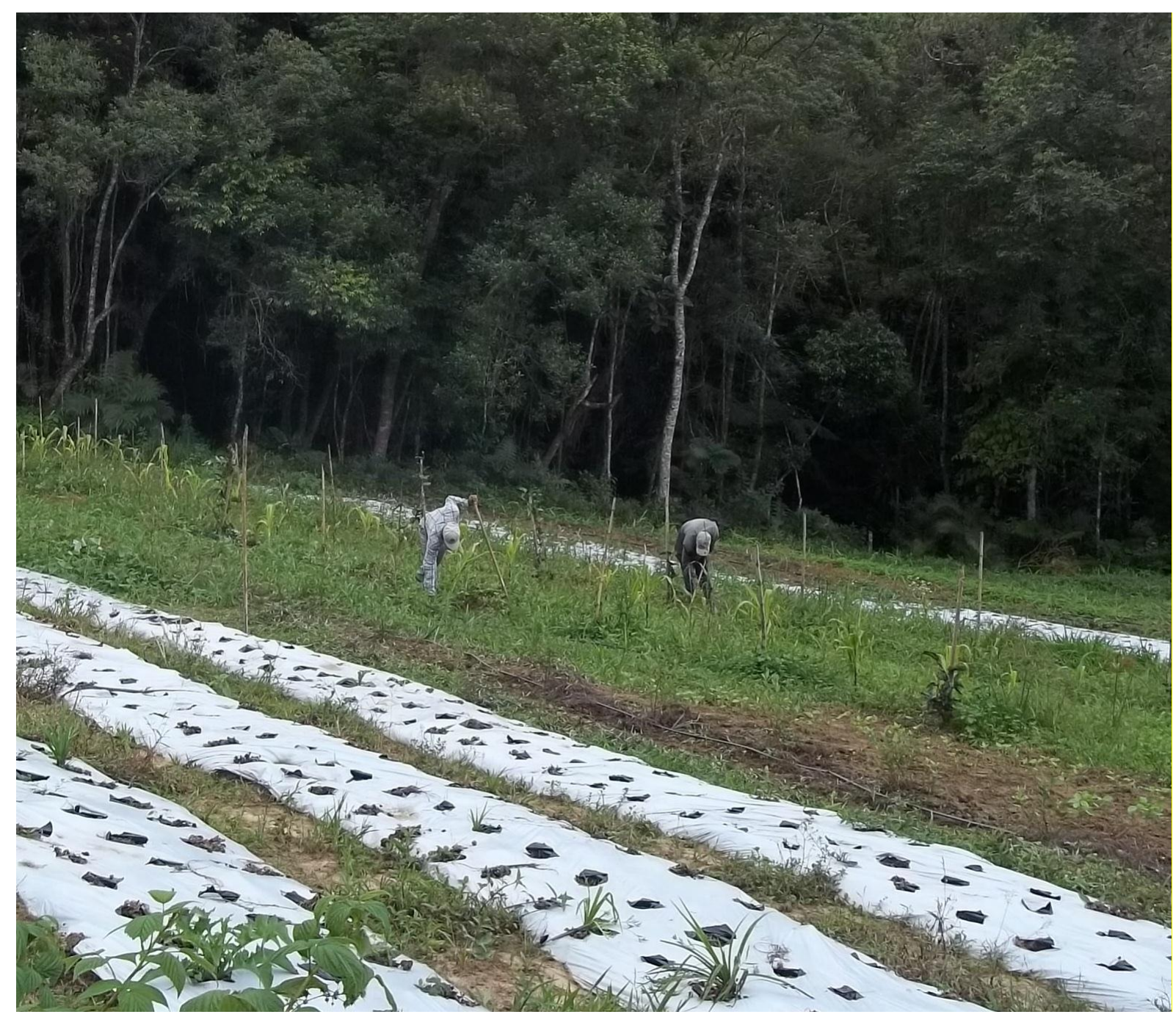

Foto 2.5. Funcionários trabalham em um dos sítios visitados em Marsilac, município de São Paulo, em 27 de novembro de 2015. Crédito da foto: Angélica Campos Nakamura.

Apesar de não ter entrevistado todos os agricultores da Cooperapas, de acordo com os técnicos da $\mathrm{CAE}$, a maioria dos cooperados possui sítios com uma média de 2 a 8 hectares. $\mathrm{O}$ dado levantado no gráfico 2.4 a seguir, evidencia como o recorte realizado na pesquisa foi variado. A maioria dos entrevistados possuem sítios com até 30 hectares de terra ${ }^{7}$.

É importante ressaltar que as áreas desses sítios, principalmente os maiores, possuem muita vegetação nativa preservada que não são usadas para a agricultura.

\footnotetext{
${ }^{7}$ A questão do módulo fiscal no município de São Paulo será tratada mais à frente nesse capítulo.
} 
Gráfico 2.4. Área dos sítios dos agricultores entrevistados da Cooperapas

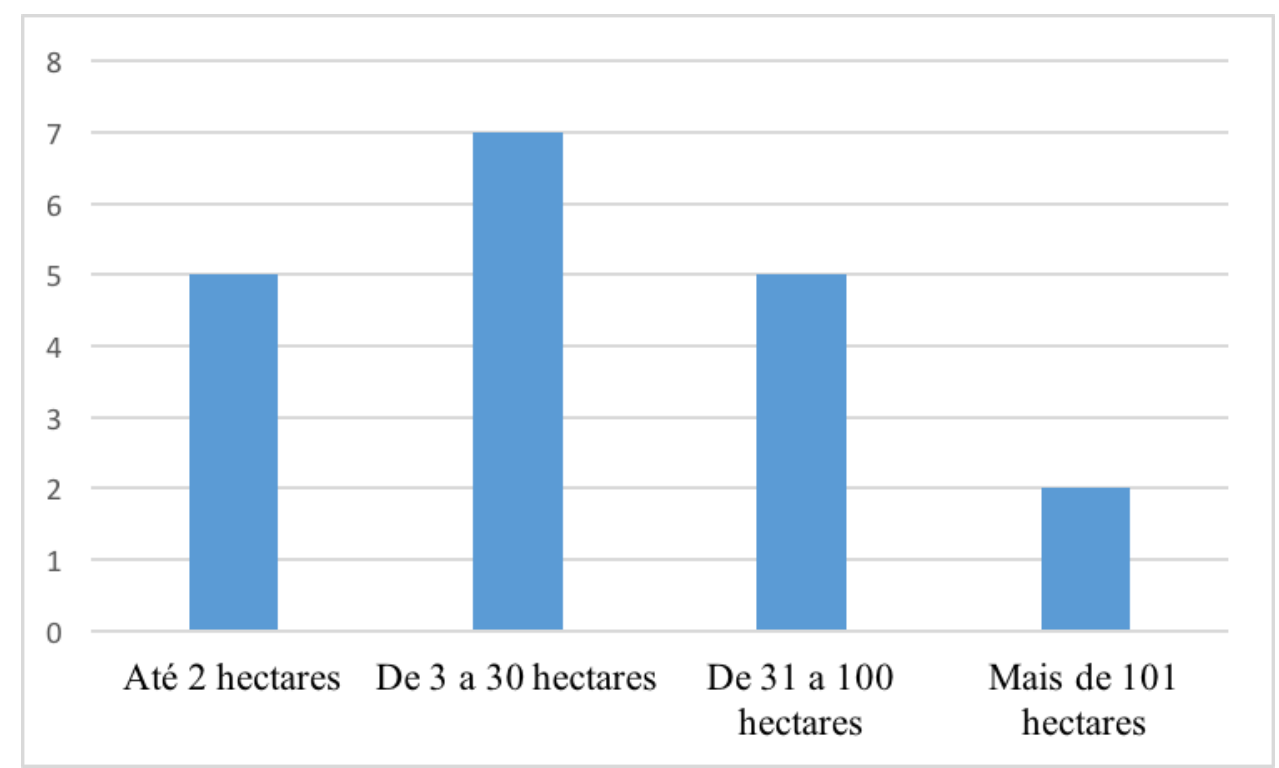

Fonte: Elaboração da autora a partir dos dados levantados durante a pesquisa.

A produção desses agricultores vai, em sua maioria, para o consumidor final, como se pode observar na tabela 2.2. Como um dos consumidores finais, foi considerado o Solo Sagrado, que compra produtos orgânicos de agricultores da região.

Tabela 2.2. Destino dos produtos vendidos pelos agricultores entrevistados da Cooperapas

\begin{tabular}{|l|c|}
\hline \multicolumn{1}{|c|}{ QUEM COMPRA } & QUANTOS VENDEM \\
\hline $\begin{array}{l}\text { Consumidor final (pode ser venda direta para } \\
\text { restaurante, vizinhos e conhecidos) }\end{array}$ & 10 \\
\hline Instituto Chão & 9 \\
\hline Feiras livres orgânicas & 8 \\
\hline Intermediário (atravessador) & 7 \\
\hline Mercado & 3 \\
\hline Sacolão & 1 \\
\hline
\end{tabular}

Fonte: Elaboração da autora a partir dos dados levantados durante a pesquisa.

O segundo comprador principal dos membros da cooperativa é o Instituto Chão ${ }^{8}$. Nota-se, aqui, como ele exerce um papel importante para a Cooperapas. Além de boa parte

\footnotetext{
${ }^{8}$ O Instituto Chão é uma associação sem fins lucrativos, com uma proposta de desenvolvimento sustentável e economia solidária, e foi aberto em maio de 2015. De acordo com o site do Instituto, "Tudo o que é vendido ou servido [...] é repassado ao consumidor diretamente pelo preço de compra. Os custos do Chão estão expostos [...] Nossa única fonte de financiamento são os frequentadores desse lugar" (INSTITUTO CHÃO, 2016). Os clientes do local podem, por exemplo, pagar uma porcentagem sobre a compra realizada, ou dar um valor aleatório como doação para os gastos. A abertura do Instituto Chão foi amplamente divulgada pela mídia, como na Veja São Paulo, na Folha de São Paulo, no site Terra e no Catraca Livre, entre outros, pois foi considerado uma novidade
} 
dos cooperados enviarem produtos para o instituto, foi finalmente com o Chão que a primeira venda coletiva ocorreu9 9 . Até outubro de 2016, era o carro-chefe da venda coletiva da cooperativa.

Depois vêm as feiras livres orgânicas. Os cooperados que vendem nessas feiras não escondem sua satisfação, pois conseguem repassar seus produtos com um preço mais alto, já que as feiras ocorrem em locais onde a população possui um maior poder aquisitivo e acaba pagando mais por um produto orgânico. Porém, não há vendas coletivas e existe o grande desafio de a Cooperapas conseguir se organizar para manter uma barraca na feira ${ }^{10}$.

Os agricultores, no geral, produzem principalmente hortaliças. A variedade é muito grande. Um deles, em entrevista, disse que eles sempre procuram variar a produção ao máximo porque, dessa forma, conseguem vender mais na feira, pois sempre têm algo diferente a oferecer.

Para se ter uma ideia do que plantam, de maneira geral, foram citados: alface crespa, romana, mimosa, lisa, roxa e americana; almeirão; alcachofra; açafrão; alecrim; alho poró; alho; agrião; azedinha; abobrinha; gengibre; catalônia; beterraba; brócolis e brócolis ninja; salsinha; coentro; cebolinha; hortelã; sálvia; inhame; nabo e nabo redondo; rabanete; jiló; couve, couve manteiga e couve chinesa; vagem; tomate; feijão; pepino e pepino caipira; maxixe; mandioca; mandioquinha; morango; pimentão amarelo; erva-cidreira; erva-doce; espinafre; escarola; manjericão; yacon; taioba; batata-doce, batata-inglesa; beterraba; milho; escarola; repolho; couve-flor; acelga; ervilha; berinjela; quiabo; jiló; banana; caqui; cenoura; uva (fotos 2.6, 2.7 e 2.8 na página a seguir).

Um produtor disse que pretende se dedicar a frutas vermelhas como amora, framboesa, mirtilo, amora silvestre e morango silvestre.

Para ajudar nas suas produções, os agricultores recebem assistência técnica, a maioria só pela CAE. Em um dos sítios o proprietário é engenheiro agrônomo, portanto, ele mesmo acompanha a produção e faz sua assistência. Dois entrevistados afirmaram que recebem assistência da CAE e da Coordenadoria de Assistência Técnica Integral (Cati) de EmbuGuaçu, do governo estadual. Um disse pagar um engenheiro agrônomo particular e um afirmou não receber nenhuma assistência.

com uma proposta inovadora de comércio. O Instituto Chão está localizado no bairro da Vila Madalena, zona oeste de São Paulo.

${ }^{9}$ Mais sobre a venda coletiva será tratada no capítulo 3 a seguir, sobre a Cooperapas.

${ }^{10} \mathrm{O}$ desafio de organização da cooperativa para vender coletivamente em feiras será tratado no capítulo 3 a seguir. 

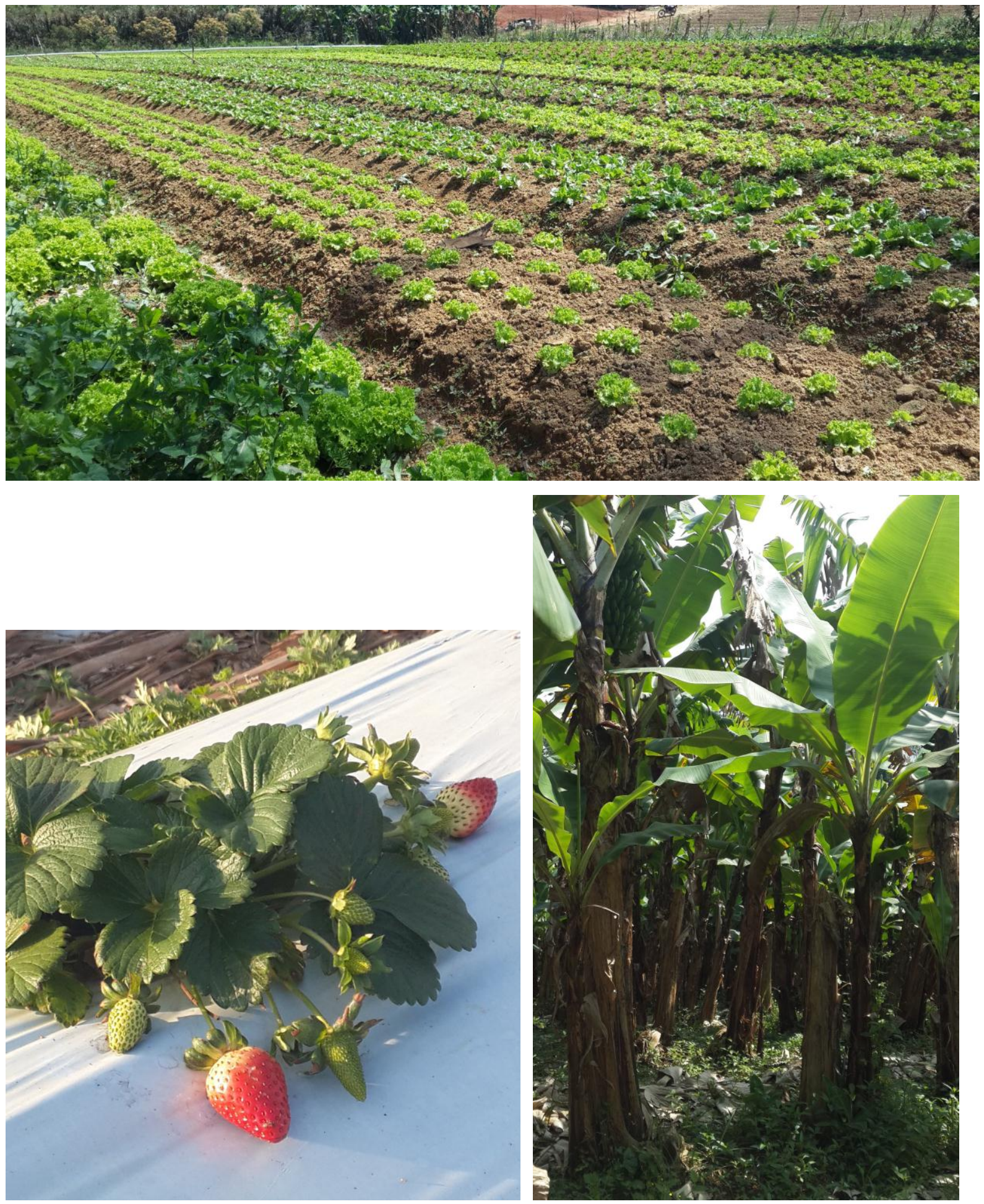

Fotos 2.6, 2.7 e 2.8. Na foto acima (2.6), canteiros com produção de hortaliças variadas, no sítio de Mauri da Silva, no município de Embu-Guaçu, em 16 de setembro de 2015. Na foto abaixo à esquerda (2.7), detalhe da produção de morangos no sítio de Massue Shirazawa, no município de São Paulo, durante o inverno, em 13 de agosto de 2015. Na foto à direita abaixo (2.8), plantação de bananas no sítio de Zundi Murakami, no município de São Paulo, em 3 de setembro de 2015. Crédito das fotos: Angélica Campos Nakamura. 
Para vender, os agricultores precisam de nota fiscal. Da parcela entrevistada, dez afirmaram possuir e nove não. Desses nove, na época da entrevista, dois disseram estar providenciando. Os agricultores os quais possuem ajudam quem não tem e repassam os produtos agrícolas na sua própria nota. Depois, pagam pelos produtos vendidos, descontando os gastos que tiveram no processo, como transporte e a porcentagem referente à cooperativa.

Os produtos agrícolas precisam ser transportados. Ainda que a cooperativa pague um motorista para levar até o Instituto Chão os produtos, circular pela região apenas com o transporte público e carregando sacolas ou caixas com verduras não é fácil e nem aconselhável, pois altera a qualidade e aparência do produto. Além disso, as estradas de terra são muito ruins, principalmente nos meses de verão, entre dezembro e março, quando mais chove. Dos 19 entrevistados, 17 possuíam ao menos um carro ou uma caminhonete. Desses, três possuíam carro e caminhão e, dois, carro, caminhão e caminhonete. Apenas dois afirmaram depender exclusivamente do transporte público, ou ter que pagar ou depender do favor de alguém para transportar seus produtos.

Além da Cooperapas, esses agricultores participam de outros grupos, no caso, a Organização de Controle Social (OCS) São Paulo e do Sistema Participativo de Garantia (SPG). Uma agricultura disse participar de um Grupo de Trabalho (GT) de Mulheres. Em 2016, um dos entrevistados entregou uma carta na CAE solicitando o desligamento da Cooperapas, porém, ele permanece um membro do SPG.

Uma parte dos agricultores é sindicalizada, conforme mostra o gráfico 2.5 na página a seguir.

Também foi levantado sobre o nível de instrução desses membros da Cooperapas (gráfico 2.6 na próxima página). A maioria possui ensino superior ou segundo grau completo. Em relação à cursos extras de formação, quase todos os entrevistados já fizeram cursos relacionados à agricultura orgânica, agroelógica e biodinâmica. Muito desses cursos foram dados pelo Instituto Kairós e pela Associação Biodinâmica (ABD), via projetos do Fema. Todos afirmaram se interessar em fazer mais cursos voltados, por exemplo, para agricultura ou gestão da propriedade. 
Gráfico 2.5. Agricultores entrevistados da Cooperapas que são sindicalizados

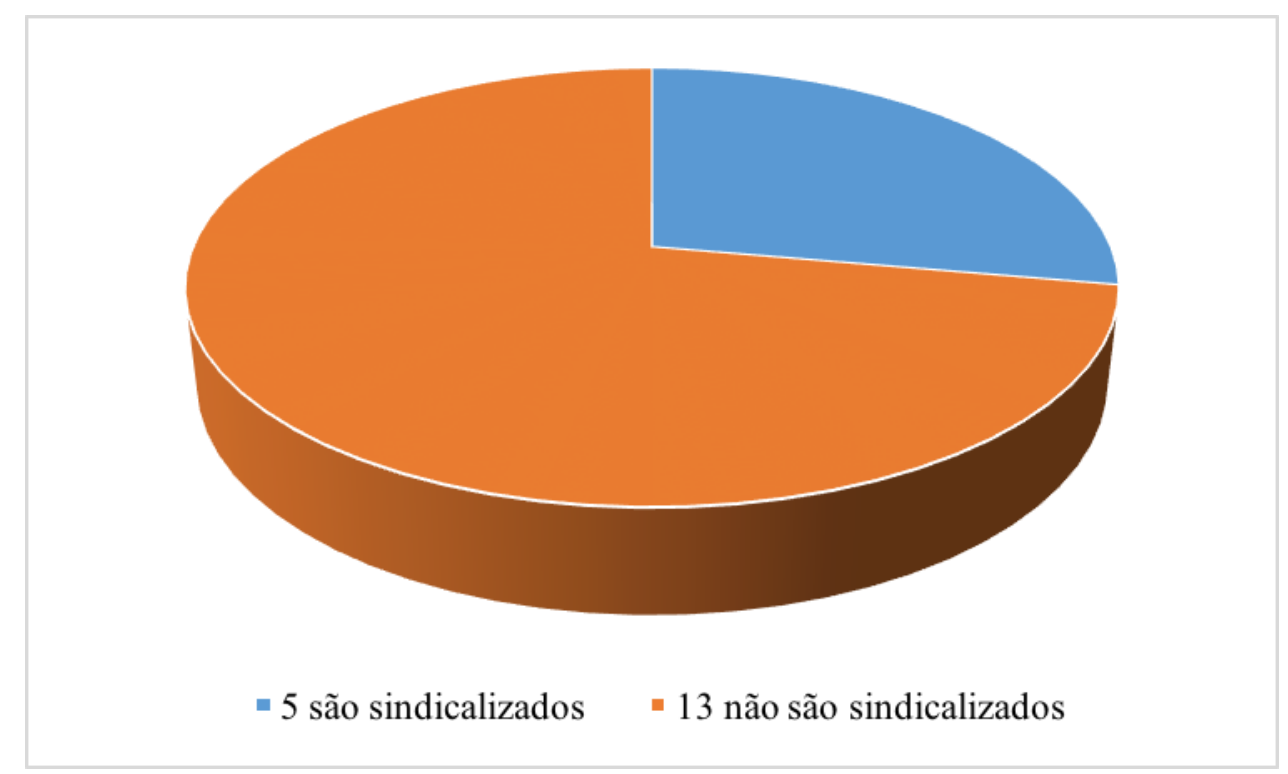

Fonte: Elaboração da autora a partir dos dados levantados durante a pesquisa.

Gráfico 2.6. Nível de instrução dos agricultores entrevistados da Cooperapas

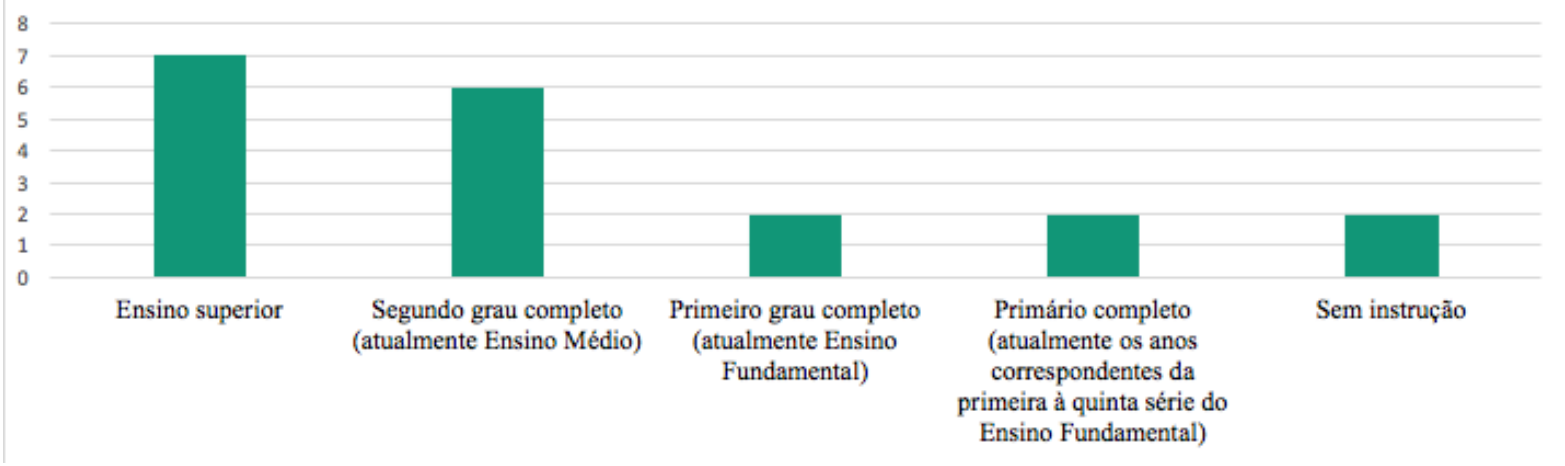

Fonte: Elaboração da autora a partir dos dados levantados durante a pesquisa.

Outro dado pesquisado, entre esse grupo, foi quem possui telefone e/ou celular, computador e internet (gráfico 2.7 na página a seguir), pois muito da comunicação entre os cooperados se dá através de telefonemas, SMS, e-mail ou o grupo do WhatsApp. Apesar disso, sempre há alguém que afirma não receber os avisos. Ainda que todos tenham alguma forma de contato, a região tem um sinal de celular e internet, seja móvel ou em casa, muito ruim. Telefonar em casa nem sempre é saída também: muitos passam o dia "na roça" trabalhando, e não escutam o telefone ou não chegam a tempo de atendê-lo. 
Gráfico 2.7. Agricultores entrevistados da Cooperapas com telefone, celular, computador e internet

6 possuem telefone e/ou celular

- 13 possuem telefone $\mathrm{e} / \mathrm{ou}$ celular, computador e internet

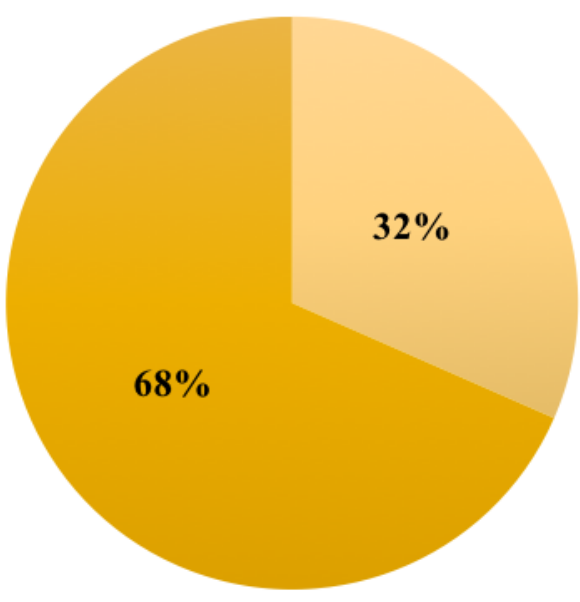

Fonte: Elaboração da autora a partir dos dados levantados durante a pesquisa.

Sobre a faixa etária dos cooperados entrevistados, o mais jovem nasceu em 1989 e, o mais velho, em 1940. Dos mais jovens, que se encontram na faixa dos 30 aos 40 anos, nenhum tem filhos. Os mais velhos que têm filhos, apenas um tem dois filhos ajudando na roça. Outro tem filhos e um neto os quais o ajudam, porém, não diretamente na agricultura, e sim na comercialização ou gestão da produção. Outro cooperado, cujo um dos filhos ainda é adolescente, diz que ele se interessa por agricultura e agroecologia e até pensa em aprender mais sobre isso. Porém, ele ainda está em idade escolar e, portanto, dedicando-se mais aos estudos formais. O restante afirmou que tanto parentes, como irmãos e primos, e filhos não ajudam com a agricultura e nem, no momento, pretendem seguir nesse ramo ou têm interesse.

Com os dados anteriormente expostos, já é possível ter uma ideia de quem são esses agricultores, membros da Cooperapas, e de certos aspectos de suas vidas. Porém, é necessário entender suas origens e como se envolveram com a agricultura, para se fazer uma análise mais aprofundada sobre esses sujeitos e compreender melhor seu papel no contexto da cooperativa e da agricultura no município de São Paulo. 


\subsection{Da legislação às correntes da Geografia Agrária e a agricultura familiar}

Para entender com mais profundidade esses sujeitos previamente analisados por meio de gráficos, tabelas e dados, é preciso tentar reconhecer qual é o papel que exercem em meio à realidade rural do sul do município de São Paulo. Conforme dito no início do capítulo, todos se identificam como agricultores familiares, e dão à sua atividade uma importância muito grande, pois sabem que, em primeiro lugar, produzem alimentos. Além disso, por serem produtores agroecológicos, veem-se como ajudantes com a conservação dos mananciais e da Mata Atlântica da região e, com a agricultura, dificultam a expansão horizontal da cidade.

Em um primeiro momento, necessita-se entender essa identificação com o conceito de agricultor familiar. A definição não vem só deles. Os funcionários da CAE e da Cati os chamam como tal. Isso se dá, principalmente, devido à disseminação do termo pela legislação e políticas públicas voltadas para pequenos agricultores, sendo esse termo utilizado para identificar tal público alvo.

É na Lei $\mathrm{n}^{\mathrm{o}} 8.171$, de 17 de janeiro de 1991, a qual dispõe sobre a política agrícola, que a agricultura familiar vem a ser citada, no art. 65-A, ao estabelecer que o Programa de Garantia da Atividade Agropecuária (Proagro) deverá operar o Programa de Garantia da Atividade Agropecuária da Agricultura Familiar (Proagro Mais). Porém, é em 1996, com o Decreto $\mathrm{n}^{\mathrm{o}} 1.946$, de 28 de junho, que se cria o Programa Nacional de Fortalecimento da Agricultura Familiar (Pronaf), no primeiro mandato de Fernando Henrique Cardoso. Esse decreto foi revogado e, nos anos seguintes, substituído por outros, até que, finalmente, foi estabelecido o Decreto $\mathrm{n}^{0}$ 8.735, de 3 de maio de 2016. Esse é muito mais abrangente em relação ao primeiro, de 1996, pois institui, entre outras providências, "a composição, a estruturação, as competências e o funcionamento do Conselho Nacional de Desenvolvimento Rural Sustentável (Condraf)". O Condraf ${ }^{11}$

tem por finalidade propor diretrizes para a formulação e a implementação de políticas públicas estruturantes, constituindo-se em espaço de concertação e de articulação entre os diferentes níveis de governo e as organizações da sociedade civil, para o desenvolvimento rural sustentável, a reforma agrária e a agricultura familiar (BRASIL, 2016).

\footnotetext{
${ }^{11}$ O Condraf fazia parte do Ministério do Desenvolvimento Agrário (MDA) e, no Decreto n ${ }^{\circ}$ 8.735, ainda consta como vinculado a esse ministério. Porém, o MDA foi extinto pela Lei $\mathrm{n}^{\circ} 13.341$, de 29 de setembro de 2016 . O MDA foi transformando na Secretaria Especial de Agricultura Familiar e do Desenvolvimento Agrário pelo Decreto $\mathrm{n}^{\circ} 8.865$, de 29 de setembro de 2016, fazendo parte da Casa Civil.
} 
Portanto, esse decreto, ao contrário do primeiro de 1996, estabelece várias outras diretrizes, e formaliza a busca por articular a sociedade civil, o desenvolvimento rural sustentável, a reforma agrária e a agricultura familiar nas políticas públicas. De acordo com Neves:

[...] emerge então no decorrer desses processos, a construção do agricultor familiar como sujeito de direitos, consagrados enfim pelo Pronaf - Programa Nacional de Fortalecimento da Agricultura Familiar (Decreto $\mathrm{n}^{\circ}$ 1.946, de 28 de junho de 1996; Resolução 2.310, de 29 de agosto de 1996). [...]

Em resumo, no Brasil, o termo agricultura familiar corresponde então à convergência de esforços de certos intelectuais, políticos e sindicalistas articulados pelos dirigentes da Confederação Nacional dos Trabalhadores na Agricultura, mediante apoio de instituições internacionais, mais especialmente a Organização das Nações Unidas para a Agricultura e a Alimentação (FAO) e o Banco Internacional de Reconstrução e Desenvolvimento (Bird). Consagra-se para dar visibilidade ao projeto de valorização de agricultores e trabalhadores rurais sob condições precárias de afiliação ao mercado e de reprodução social, diante de efeitos da interdependência entre agricultura e indústria e do processo de concentração da propriedade dos meios de produção no setor agropecuária [...] (2007, p. 230, grifo da autora).

Foi com a Lei $\mathrm{n}^{\mathrm{0}} 11.326$, de 24 de julho de 2006, que se instituiu as diretrizes para a Política Nacional da Agricultura Familiar e Empreendimentos Familiares Rurais. Ela é que define o que é ser um agricultor familiar e empreendedor rural:

Art. $3^{-}$Para os efeitos desta Lei, considera-se agricultor familiar e empreendedor familiar rural aquele que pratica atividades no meio rural, atendendo, simultaneamente, aos seguintes requisitos:

I - não detenha, a qualquer título, área maior do que 4 (quatro) módulos fiscais ${ }^{12}$;

II - utilize predominantemente mão-de-obra da própria família nas atividades econômicas do seu estabelecimento ou empreendimento; [...]

III - tenha percentual mínimo da renda familiar originada de atividades econômicas do seu estabelecimento ou empreendimento, na forma definida pelo Poder Executivo;

IV - dirija seu estabelecimento ou empreendimento com sua família (BRASIL, 2006).

Além disso, conforme já dito, para ser reconhecido como um agricultor familiar para se ter acesso às políticas públicas do governo, é necessário tirar a Declaração de Aptidão ao

\footnotetext{
${ }^{12}$ De acordo com a Lei $\mathrm{n}^{\mathrm{0}}$ 8.629, de 25 de fevereiro de 1993, o imóvel rural considerado como pequena propriedade deve ter área compreendida entre 1 (um) e 4 (quatro) módulos fiscais (BRASIL, 1993). Os módulos fiscais variam em cada município brasileiro. Em São Paulo e Embu-Guaçu, municípios nos quais estão os sítios dos entrevistados, um módulo fiscal equivale a 5 hectares (INCRA, 2013).
} 
Pronaf (DAP). De acordo com informações do extinto Ministério do Desenvolvimento Agrário (MDA):

A agricultura e o agricultor familiar têm à disposição diversas políticas públicas que auxiliam no desenvolvimento da produção e, consequentemente, na melhoria das condições de trabalho e qualidade de vida. Mas, para acessá-las é necessário requisitar a Declaração de Aptidão ao Pronaf (DAP). Criado para identificar o agricultor familiar nas áreas rurais, o documento dá acesso a políticas como o crédito do Programa Nacional de Fortalecimento da Agricultura Familiar (Pronaf) e aos programas de compra pública, como o de Aquisição de Alimentos (PAA) e o de Alimentação Escolar (Pnae).

Atualmente, existem mais de 5,1 milhões de DAP's ativas no Brasil. Com 700 mil DAP's, a Bahia é o estado com o maior número de adesão. [...]

A Declaração pode ser emitida por pessoa física ou jurídica e contempla públicos específicos como: jovens, mulheres e assentados da reforma agrária. Ainda existe a DAP que inclui os agricultores familiares com renda anual de até $\mathrm{R} \$ 20$ mil e é direcionada aos trabalhadores com renda anual superior a $\mathrm{R} \$ 20$ mil e até $\mathrm{R} \$ 360$ mil (MDA, 2015).

De acordo com Daniel Beluti, técnico da Cati de Embu-Guaçu e quem tira a DAP dos agricultores da região, para tirar a DAP

É mais declaratório, a gente só vai pra confirmar a informação se tiver alguma dúvida. [...]

Primeiro a gente faz um cadastro da propriedade. Aqui em São Paulo um módulo rural são cinco hectares. Então quatro módulos, são 20. Então se o produtor tiver mais de 20 hectares, ele está desenquadrado. Então ele não vai ter a DAP por ter mais de quatro módulos fiscais. [...]

A maior parte da renda tem que vir da agricultura [mais de 50\%]. [...] E a maior parte da força de trabalho tem que ser da família. Tem quatro pessoas na família, então pode ter três empregados.

A renda de enquadramento é até $R \$ 350$ mil por ano. [...] (informação verbal) ${ }^{13}$.

Há propriedades que ultrapassam os 20 hectares, porém, Daniel explica que muitas vezes a propriedade tem mais de um dono. Assim, a área é dividida pelo número de pessoas, resultando, assim, em uma quantidade de hectares dentro dos parâmetros do módulo fiscal do município. Ele também acrescenta que mesmo se a pessoa arrendar a terra, e não for proprietária, ela tem que arrendar dentro do limite do módulo fiscal do município para poder se enquadrar nas exigências da DAP (informação verbal) ${ }^{14}$.

\footnotetext{
${ }^{13}$ Entrevista concedida por Daniel Beluti na pré-conferência do Desenvolvimento Rural Sustentável, no CEU Parelheiros, no município de São Paulo, em 24 de maio de 2016.

${ }^{14}$ Ibidem.
} 
Para compreender quem é esse "agricultor familiar" ao qual a legislação e as políticas públicas fazem referência, tem-se que ir além das definições criadas pelas leis para se enquadrar esses agricultores. Assim, buscou-se as três correntes que tratam da questão agrária no Brasil. Oliveira ${ }^{15}$ explica que

há autores que defendem o ponto de vista de que no Brasil houve feudalismo, ou mesmo relações semifeudais de produção. Por isso, eles advogam a seguinte tese: "para que o campo se desenvolva, seria preciso acabar com essas relações feudais ou semifeudais e ampliar o trabalho assalariado no campo". Para esses autores, a luta dos camponeses contra os latifundiários exprimiria o avanço da sociedade na extinção do feudalismo. Portanto, a luta pela reforma agrária seria um instrumento que faria avançar o capitalismo no campo (2004, p. 34).

Para essa corrente, só há duas classes sociais possíveis: a burguesia e o proletariado. Entre os autores dessa corrente, destacam-se Inácio Rangel, Orlando Valverde, Nelson Werneck Sodré, entre outros.

Outra corrente entende

que "o campo brasileiro já está se desenvolvendo do ponto de vista capitalista, e que os camponeses inevitavelmente irão desaparecer, pois eles seriam uma espécie de 'resíduo' social que o progresso capitalista extinguiria". Ou seja, os camponeses, ao tentarem produzir para o mercado, acabariam indo à falência e perderiam suas terras para os bancos, ou mesmo teriam de vendê-las para saldar as dívidas. Com isso, "os camponeses tornarse-iam proletários" (OLIVEIRA, 2004, p. 34).

Para essa corrente, também só há duas classes sociais possíveis: a burguesia e o proletariado. Entre os autores dessa corrente, destacam-se Inácio Rangel, Orlando Valverde, Nelson Werneck Sodré, Ricardo Abramovay, José Graziano da Silva, entre outros.

Finalmente, a terceira corrente, a qual nega as anteriores, tem como ponto de partida que o desenvolvimento do capitalismo no território brasileiro é contraditório, combinado e desigual. Para essa corrente, o capitalismo avança produzindo e reproduzindo relações capitalistas no campo e, contraditoriamente, relações não-capitalistas de produção. Entre as relações não-capitalistas está a recriação do campesinato, aqui entendido como uma das classes sociais existentes, além do proletariado e da burguesia, no seio do capitalismo. Entre

\footnotetext{
15 As informações sobre as três correntes tiveram como base a leitura indicada de Oliveira (2004) e das informações anotadas em suas aulas da disciplina "Agricultura e capitalismo no Brasil", realizadas na pósgraduação em Geografia Humana na Faculdade de Filosofia, Letras e Ciências Humanas (FFLCH) na Universidade de São Paulo (USP), no segundo semestre de 2013.
} 
os autores dessa corrente, estão Teodor Shanin, José de Souza Martins, Margaria Maria Moura, José Vicente Tavares dos Santos, Ariovaldo Umbelino de Oliveira etc.

A corrente que analisa esses produtores como agricultores familiares é a segunda. Para essa corrente, esse agricultor passa a ser visto como uma categoria social da classe trabalhadora. Ele é um novo empreendedor, o qual se insere no sistema capitalista sem ir contra o seu desenvolvimento.

Para Abramovay, um dos autores referência da segunda corrente, não há como existir uma classe camponesa, pois

A impossibilidade de definir claramente a natureza e a origem de seus rendimentos demonstra que o conceito de camponês n'O Capital é logicamente impossível. A atividade produtiva que dá origem a sua reprodução não tem o estatuto de trabalho social [...]. As duas únicas classes que possuem a universalidade de incorporar nelas mesmas os elementos básicos de organização da sociedade contemporânea são a burguesia e o proletariado. [...]

É importante ressaltar, sob ângulo teórico, que não faz sentido para o marxismo a ideia de uma economia camponesa. [...] o mundo das mercadorias se define por sua sociabilidade contraditória - onde a ação de cada um é determinada de maneira não planejada pelo outro - será nesta alteridade que a vida social, e portanto as categorias econômicas centrais que lhe são sentido, se constituem. Cada segmento e cada classe da sociedade serão conhecidos, em última análise, pela maneira como se inserem na divisão do trabalho. Qualquer categoria social não imediatamente incorporada às duas classes básicas, só possuirá uma existência social fugaz, inócua de certa maneira. A relação do camponês com a sociedade, sob esse ângulo, o conduz fatalmente à auto-negação: seu ser só pode ser entendido pela tragédia de seu devir. Sua definição é necessariamente negativa: ele é alguém que não vende força de trabalho, mas que não vive basicamente da exploração do trabalho alheio. Neste plano, então, no mundo capitalista, o camponês pode ser no máximo um resquício, cuja integração à economia de mercado significará fatalmente sua extinção (ABRAMOVAY, 1990, p. 10, 32-33, grifo do autor).

Ainda que Abramovay afirme que só podem existir duas classes sociais, a burguesia e o proletariado, tomando como base "O Capital", isso não significa a abolição da produção agrícola familiar no campo: "O que Marx não podia antever, que estava totalmente fora de sua perspectiva teórica, é que o extermínio social do campesinato, não significaria fatalmente a eliminação de qualquer forma de produção familiar como base para o desenvolvimento capitalista na agricultura [...]” (1990, p. 142). 
Queiroz também faz um destaque acerca do desaparecimento do camponês no campo brasileiro, que ajuda a justificar a impossibilidade de existência dessa classe para Abramovay: "Na medida em que o meio urbano vai produzindo mercadorias cada vez mais cobiçadas, o consumo do sitiante tradicional se desequilibra, pois vê-se impelido a consumir muito mais mercadorias e muito mais caras, a fim de demonstrar seu prestígio econômico [...]" (QUEIROZ, 1976, p. 29).

A visão desses autores é evolucionista, pois para eles o camponês ou se torna um agricultor familiar, ou vai vender a sua força de trabalho em outra profissão. Fernandes deixa isso claro:

Dessa forma, a questão para o camponês é: ou ele se metamorfoseia em agricultor familiar e se integra ou se mantém como ele mesmo e se desintegra. Nestes referenciais não há futuro, porque não há perspectiva desse sujeito continuar sendo camponês. Na verdade, ele é visto como um estorvo para os que veem sua desintegração, considerando que do campesinato podem surgir o capitalista e o proletário (20--, p. 4-5).

Aqui, vale ressaltar a crítica de Marques a respeito dessa visão evolucionista e do uso do conceito de agricultor familiar:

Na última década do século XX, o conceito de agricultura familiar é proposto por alguns autores como substituto para o de camponês enquanto conceito-síntese e aceito sem maiores reflexões por muitos, seja na academia, na burocracia do Estado, ou também entre os próprios agricultores, seus sindicatos e movimentos sociais. Essa substituição se dá com base na adoção de uma abordagem evolucionista sobre o desenvolvimento da história e contribui para o empobrecimento do debate político em torno da questão agrária. [...] o emprego do conceito de agricultura familiar passa pela afirmação de sua diferença em relação ao de camponês, que não mais se aplicaria às novas realidades criadas a partir do desenvolvimento do capitalismo na agricultura (MARQUES, 2008, p. 61).

Para Abramovay e os estudiosos que seguem a corrente segundo a qual o camponês deixa de existir para se tornar um agricultor familiar, esse novo personagem do campo brasileiro, conforme já dito, é visto como um empreendedor, interessado em investir em sua produção e infraestrutura, em ampliar seu mercado, inserindo-se no sistema capitalista sem atritos. Essa agricultura familiar é "altamente integrada ao mercado, capaz de incorporar os principais avanços técnicos e de responder às políticas governamentais" (ABRAMOVAY, 1990, p. VI). Ainda, “o dinamismo técnico, a capacidade de inovação, a completa integração 
aos mercados são traços decisivos desta forma contemporânea de agricultura familiar" (ABRAMOVAY, 1990, p. 188).

Partindo da legislação brasileira e das políticas públicas voltadas para o pequeno agricultor, e após um maior aprofundamento da corrente que enxerga o fim do campesinato no campo brasileiro e a substituição dessa classe por uma nova categoria de trabalho, a agricultura familiar, é até possível realizar uma leitura desses agricultores da Cooperapas sob a ótica da segunda corrente.

Apesar de a maioria nunca ter acessado o Pronaf, quase todos afirmaram conhecer o programa. Para poder participar, é necessário possuir DAP, documento o qual mais da metade dos agricultores disseram possuir. Durante as reuniões acompanhadas da Cooperapas e nas falas dos membros, é muito comum os agricultores sempre se lembrarem da possibilidade de participar do Programa de Aquisição de Alimentos (PAA) e do Programa Nacional de Alimentação Escolar (Pnae). Nota-se como esses agricultores são bem informados sobre as possibilidades de comercialização e de integração com o mercado via políticas públicas. Ainda sobre a comercialização, foi justamente do desejo de maior integração com o mercado e de atrair mais compradores, que os agricultores se interessaram em organizar uma cooperativa de produtores rurais orgânicos no extremo sul do município de São Paulo, conforme se verá mais detalhadamente no capítulo a seguir.

Mais um aspecto a ser ressaltado a respeito desses agricultores familiares é como todos possuem, pelo menos, telefone e/ou celular. A maioria, entretanto, tem também internet e computador. Essas ferramentas são amplamente usadas por eles, pois os membros da Cooperapas combinam reuniões e assembleias, passam avisos, trocam dicas de agricultura, organizam compras coletivas de insumos agrícolas por Whatsapp, além de usarem telefone e e-mail. Outra ferramenta utilizada para trocar ideias e transmitir avisos é o Facebook, rede social na internet. $\mathrm{O}$ fato de possuírem celular e dependerem da internet, faz retomar a citação de Queiroz, de que o meio urbano produz mercadorias cobiçadas, inclusive, por quem vive no meio rural. Essas mercadorias vão muito além do celular, computador e um serviço de internet: durante a realização dos trabalhos de campo, algumas residências foram visitadas. Todos esses agricultores possuem itens como televisão, computador, notebook (foto 2.9 na próxima página), geladeira, fogão - alguns possuem o fogão mas também cozinham no fogão à lenha - aparelho de som, entre outros. Além disso, eles também possuem seus meios de transporte próprios, parte deles com carro e caminhão. 


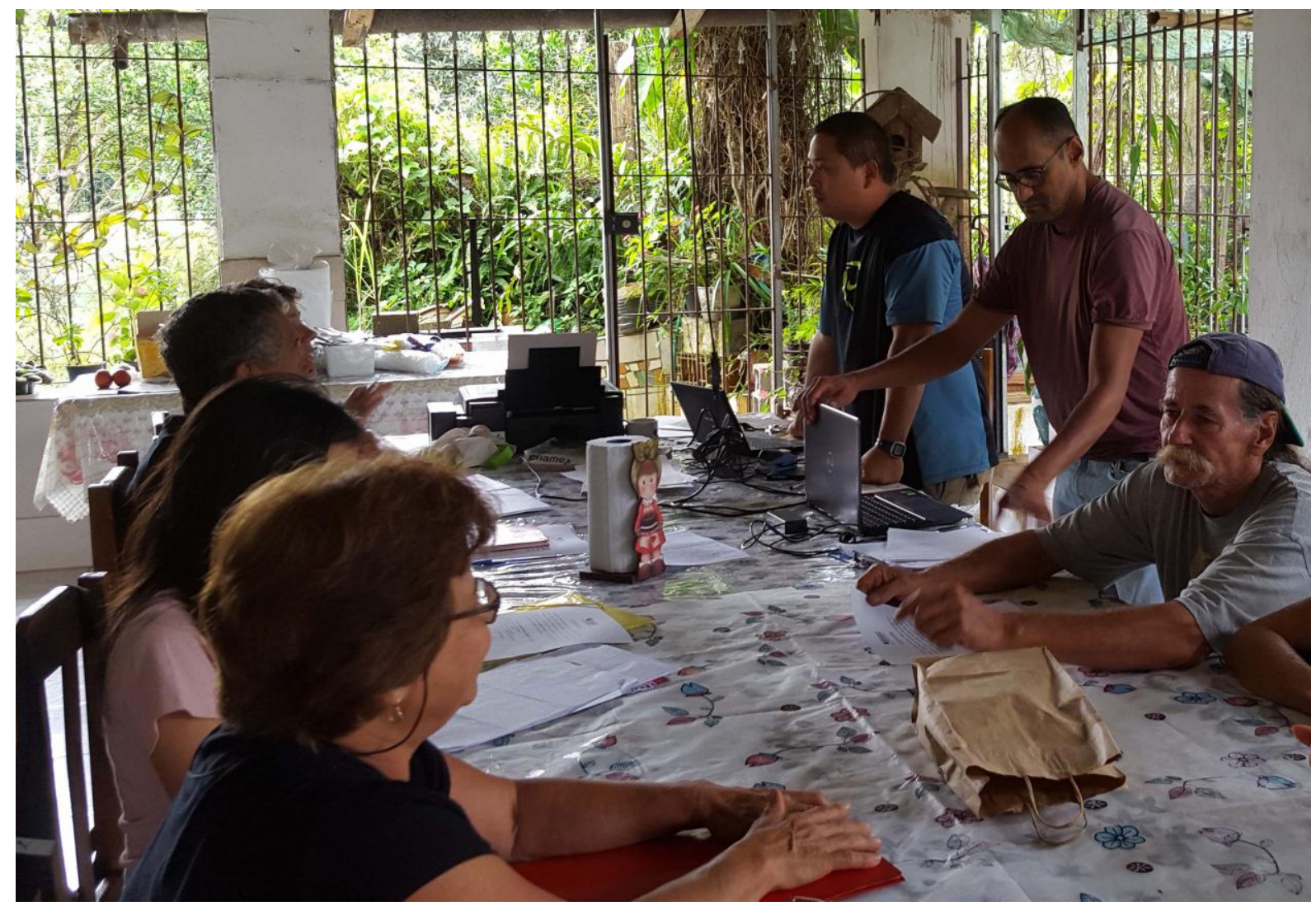

Foto 2.9. Em reunião da OCS de 25 de fevereiro de 2016, notebooks e impressora foram instalados para ajudar na organização. Crédito da foto: Angélica Campos Nakamura.

Esses agricultores também demonstraram ter interesse em realizar cursos de formação e ampliar seus conhecimentos a respeito da agricultura agroecológica, orgânica e biodinâmica. Ou seja, estão preocupados em melhorar a sua formação como agricultores.

Todos os aspectos levantados anteriormente, podem até sustentar a tese de que são agricultores familiares na visão de Abramovay. Afinal, para ele, trata-se de uma agricultura familiar integrada ao mercado, preocupada em incorporar os avanços técnicos e interessada nas políticas públicas governamentais. Ele ainda afirma que as

sociedades camponesas são incompatíveis com o ambiente econômico onde imperam relações claramente mercantis. Tão logo os mecanismos de preços adquiram a função de arbitrar as decisões referentes à produção, de funcionar como princípio alocativo do trabalho social, a reciprocidade e a personalização dos laços sociais perderão inteiramente o lugar, levando consigo o próprio caráter camponês da organização social (ABRAMOVAY, 1990, p. 124, grifo nosso). 
Abramovay concentra sua análise em aspectos como comercialização, participação em políticas públicas e avanços técnicos para falar da agricultura familiar. E, para ele, o modo desse grupo viver e se relacionar, e a história de seus pais e avós parece de nada influenciar sua realidade, pois o caráter camponês é perdido em um ambiente econômico onde imperam relações mercantis. Contudo, é questionável afirmar a perda desse caráter. Para Abramovay e autores da segunda corrente, é impossível a existência de um campesinato que comercialize seus produtos, participe de políticas públicas, seja integrado à novas tecnologias e as utilize e possua. O camponês, para eles, parou no tempo, não compreende as mudanças no seu entorno e não se integra e participa delas. Para eles, o caráter camponês é o atraso.

Porém, integrar-se ao mercado e também consumir mercadorias, utilizar e possuir equipamentos com novas tecnologias e participar de políticas públicas não elimina o caráter camponês. A origem camponesa persiste e, no segundo momento das entrevistas realizadas, que consistiu na história de vida da pessoa, no resgate de suas origens até os dias atuais, isso ficou claro.

As histórias desses camponeses serão tratadas no item a seguir.

\subsection{Uma agricultura camponesa}

O primeiro ponto da entrevista foi perguntar aos cooperados sobre seus pais ou, em alguns casos, avós, para saber se na família já houve alguma forma de relação com a terra e a agricultura. Se não, como essas pessoas chegaram na agricultura.

Para boa parte dos entrevistados, os avós tinham sua origem na agricultura. Ernesto Oyama é um deles. Em 1924, o avô de Ernesto, com cerca de 30 anos, chegou no Brasil, vindo da província de Kagoshima, no Japão. Trabalhou em um cafezal perto de Presidente Prudente, mas não aguentou devido ao excesso de trabalho e saiu fugido. Foi parando em cidades do interior até chegar, finalmente, no município de São Paulo. O avô já veio casado do Japão e teve nove filhos em terras brasileiras. Porém, a cada parada dele no trajeto para São Paulo, ele perdeu um filho, e apenas cinco chegaram ao destino final.

Na década de 1940, ele se instalou de vez em Parelheiros e começou com granja. Vendia seu produto na feira. Os filhos mais velhos começaram a ajudá-lo na agricultura até que ele se aposentasse. Assim, os tios e o pai de Ernesto assumiram a produção do seu avô. O 
pai de Ernesto nasceu em 1932 e nem Ernesto sabe ao certo se seu pai foi o quarto ou quinto filho a nascer.

O tio mais velho de Ernesto herdou a terra, mas seu pai também trabalhava no sítio. Em 2010, antes do tio de Ernesto falecer, ele fez a doação de sua parte para o pai de Ernesto (foto 2.10).

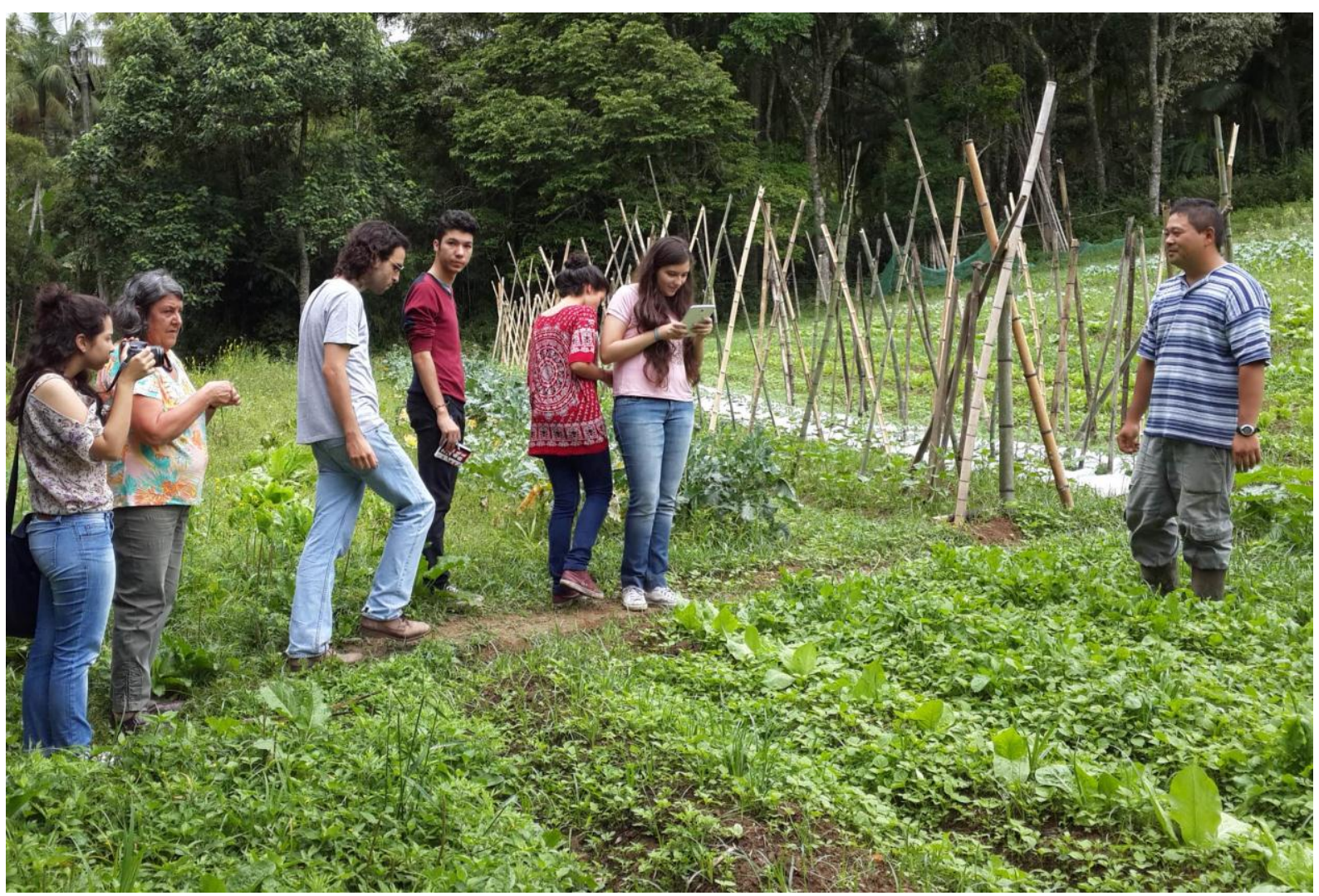

Foto 2.10. Ernesto, à direita, mostra canteiros de hortaliças em seu sítio em Parelheiros para visitantes, durante uma reunião da Organização de Controle Social (OCS) São Paulo, em 27 de novembro de 2014. Crédito da foto: Angélica Campos Nakamura.

Outra com uma história cujos avós e pais trabalhavam com a agricultura é Ana Zilda Coutinho, a Ana do Mel, que vive em Embu-Guaçu. Seus avós, tanto por parte de mãe, como de pai, eram agricultores, descendentes de europeus e indígenas, de acordo com ela. Seu pai veio do Vale do Ribeira, região sul do estado de São Paulo e, sua mãe, já residia em EmbuGuaçu, no sítio da família. A família da mãe de Ana era apicultora, mas sempre produziu mais para consumo próprio. De acordo com ela, era uma produção muito simples, a qual consistia em manter as colmeias no mato e, apenas duas vezes ao ano, tirava-se o mel. Ana conta como seu avô, por parte de mãe, fazia para vender os produtos: 
[o avô] era produtor de lima e mel e abastecia o mercado municipal de Santo Amaro. Na época ele carregava no lombo do burro as garrafas de mel. Eles [o avô e a família que ajudava] usavam as garrafas, lavavam e embalavam o mel. Colhiam os cestos de lima e levava para o mercado municipal de Santo Amaro.

Pra ir de Embu-Guaçu até lá gastava a semana toda. Iam devagar, parando, acampando, até chegar, comercializar. Lá recebiam dinheiro e já compravam os produtos que tinham necessidade. Compravam saca de açúcar, farinha, tecido. Faziam isso uma, duas vezes por ano. Mas meu avô já era sustentável, produzia uma boa parte da alimentação no sítio. Passava o resto do ano em Embu, quase não saía de lá (informação verbal) ${ }^{16}$.

Ainda jovem e solteiro, seu pai veio morar na região e conheceu a família da futura esposa. Trabalhava no sítio do avô de Ana, porém, como a renda não era suficiente para viver, também trabalhava como padeiro. O ofício de padeiro ele aprendeu com a própria família, descendente de portugueses. A família de Ana do Mel sempre produziu pensando no consumo próprio, inclusive ela mesma, que só começou a pensar em ter uma renda proveniente da agricultura por volta de 2004 (foto 2.11). Até então, ela plantava em casa para ela e sua família e, quando solteira, trabalhava como professora de educação infantil.

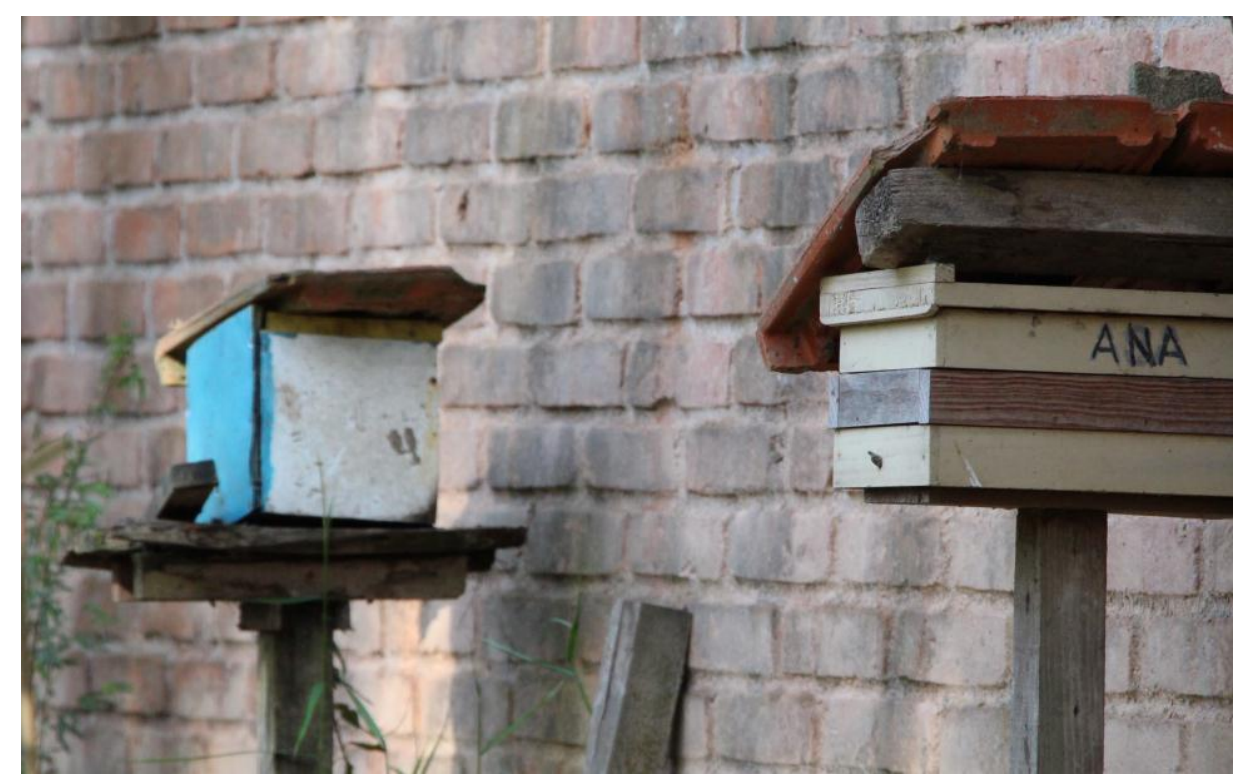

Foto 2.11. Caixas de abelhas no sítio de Ana do Mel, no município de Embu-Guaçu, em 20 de janeiro de 2015. Ana do Mel aprendeu com o pai como criar abelhas e possui uma pequena produção em seu sítio. Crédito da foto: Angélica Campos Nakamura.

Zundi Murakami, um filho de japoneses que já vieram casados do Japão, também cresceu na roça. Zundi e mais dois irmãos nasceram no Brasil, mas seus quatro irmãos mais

\footnotetext{
${ }^{16}$ Entrevista concedida por Ana Zilda Coutinho em seu sítio, no município de Embu-Guaçu, em 20 de janeiro de 2015.
} 
velhos nasceram no Japão. Apesar de o pai ter vindo para tentar a vida na agricultura, no Japão ele era pescador. Zundi conta que na família era o "Sistema japonês: primeiro filho fica com o pai, os outros casam e ficam independentes. Ficou só meu irmão mais velho. Ele morreu, agora o filho dele está lá, mas filho foi pra cidade e sitio ficou”" ${ }^{\text {"17 }}$ Assim, quando Zundi casou, em 1972, ele teve que sair de casa e ficou independente. Contudo, seu pai o ajudou, ao pagar o início do arrendamento de um terreno para o filho.

Zundi foi um grande produtor convencional de batata na região de Parelheiros e vendia tudo para o Ceagesp. Até outros produtores da Cooperapas já chegaram a comentar sobre seu passado de grande produtor na região. De acordo com ele

Foi crescendo a produção. Tudo em Parelheiros, arrendei vários terrenos. Onde tem a [igreja] Messiânica hoje, eu tinha 13 alqueires arrendados. Equivale a 30 hectares. Plantei muito tempo lá.

Levava essa vida, batata era o carro chefe, era tudo consignado. Produção era toda convencional (informação verbal) ${ }^{18}$.

Hoje Zundi é produtor de banana orgânica (foto 2.12) e o único que produz essa fruta em maior escala. Todos os outros agricultores orgânicos da região plantam e vendem pouca banana, pois no geral a produção é bem diversificada.

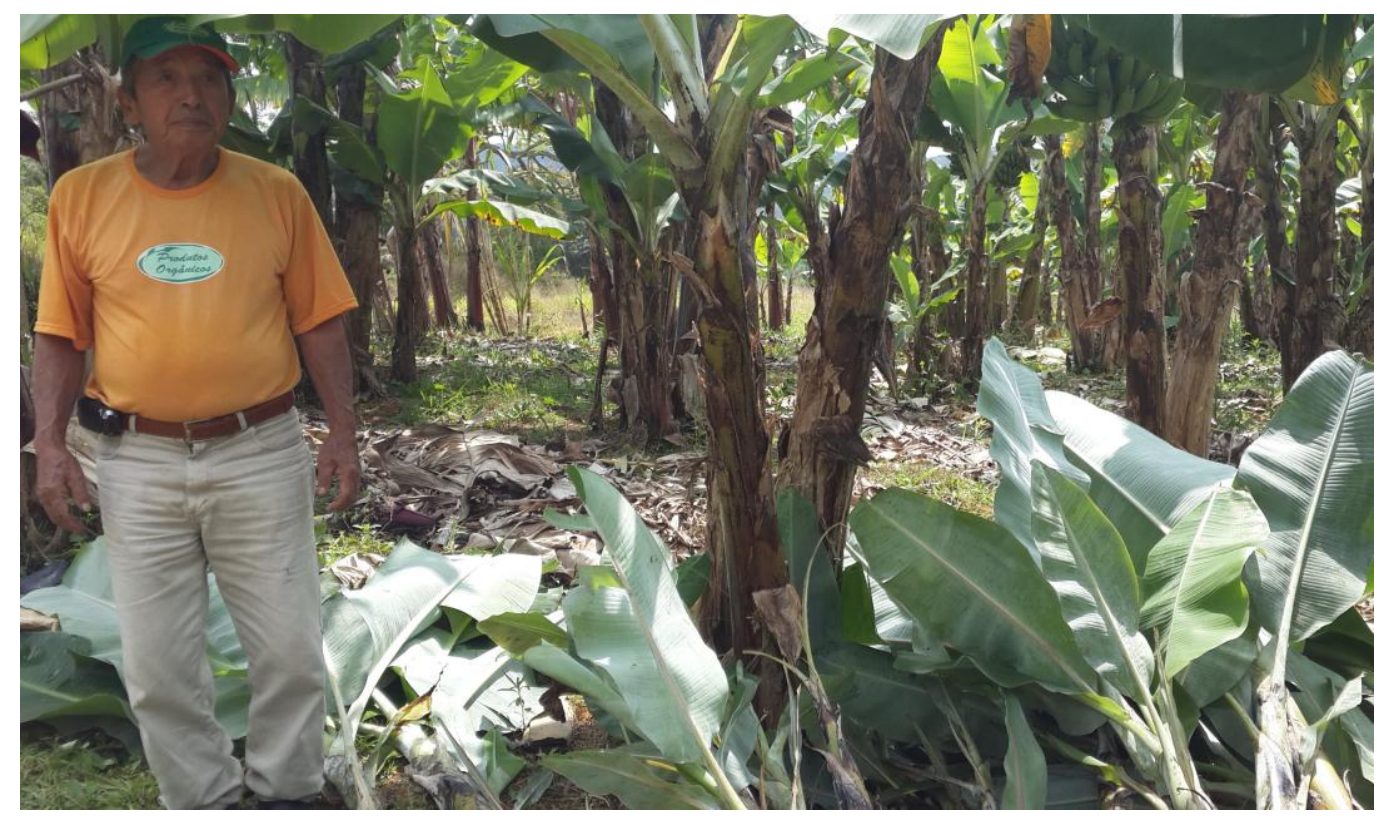

Foto 2.12. Zundi na plantação de bananas em seu sítio, no distrito de Parelheiros, em 3 de setembro de 2015. Crédito da foto: Angélica Campos Nakamura.

\footnotetext{
${ }^{17}$ Entrevista concedida por Zundi Murakami em $1^{\circ}$ de outubro de 2015, na Feira Biodinâmica, realizada em Santo Amaro, na zona sul do município de São Paulo.

${ }^{18}$ Ibidem.
} 
Outro que nasceu e cresceu na roça foi José da Silva, conhecido como Zé da Floresta, por ter preservado uma área de mata na região, próxima à subprefeitura de Parelheiros. Zé chegou na área em 1984 e tomou posse dela. Em uma parte do terreno, construiu sua casa e a de mais dois filhos. Em outra parte, preservou a vegetação. Para isso, cercou o entorno, devido ao aumento do número de casas no bairro. No meio da vegetação, passou a fazer alguns roçados de milho, mandioca, feijão, batata-doce, café, banana, limão entre outros (foto 2.13). Quando a entrevista foi feita, ele não estava mais vendendo produtos agrícolas, porque havia parado de plantar para comercializar, já que ele não conta com a ajuda dos filhos e netos e nem paga para alguém ajudá-lo. No final de 2015, ele pediu para sair da Cooperapas.

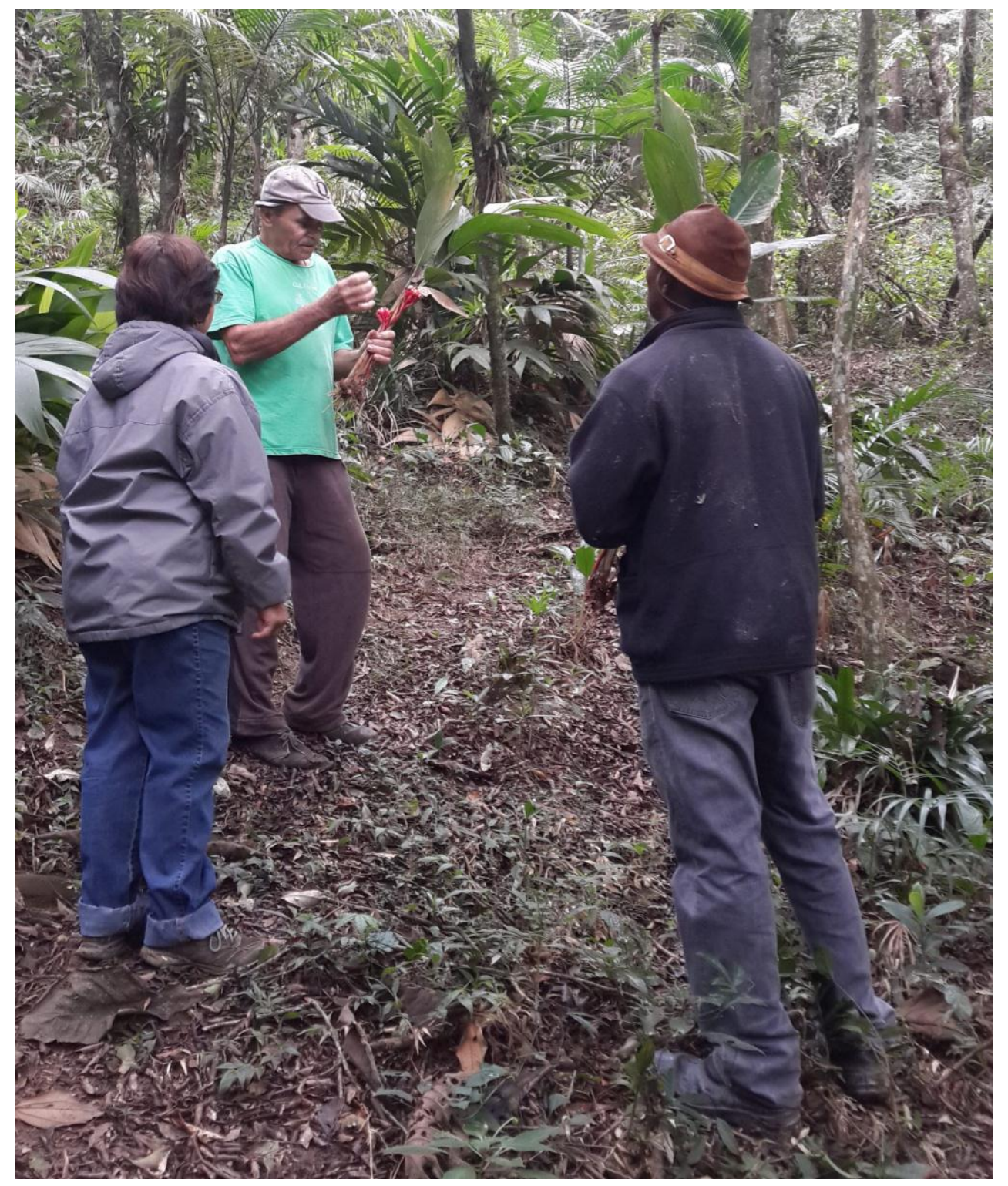

Foto 2.13. Zé da Floresta, no meio, explicando para outros agricultores como planta em meio à vegetação. Foto no seu terreno, no distrito de Parelheiros, em 3 de setembro de 2015. Crédito da foto: Angélica Campos Nakamura. 
Zé da Floresta nasceu em Capela, no estado do Alagoas. Morava no "interiorzão" do município, como ele conta: "Quando vim conhecer a cidade do meu município, eu tinha uns 20 anos. Era lá no interiorzão. Ficava mais perto das outras cidades dos outros municípios do que vim pra Capela. Aí os negócio de feira [sic], de venda de produto, a gente fazia nas outra [sic] cidade" ${ }^{19}$. Sua família - ele, seus pais e mais sete irmãos, três homens e quatro mulheres - vivia de arrendar terra em fazendas. Ficavam em uma e, depois de um tempo, se mudavam para outra. Ele explica:

Chegava e ia em outra fazenda, fazia um arrendamento lá. Não arrendava a fazenda, arrendava um pedaço de terra. Aquele pessoal no Nordeste, os fazendeiro [sic] às vezes tem 20, 30, 40, 50 morador [sic] arrendatário. Um pedaço pra um, um pedaço pra outro... aí chegava no fim do ano... pagava por ano. Não é que nem aluguel que paga por mês. Lá se fazia assim: ou você pagava a renda do terreno que você usava em dinheiro, ou pagava em serviço. Quando você pagava em dinheiro, chamava arrendatário. Quando você pagava em serviço, chamava morador de condição. [...] Você quando mora nesse regime, o patrão te dá a casa, um pedaço de terra pra trabalhar e toda segunda-feira, todos aqueles que são de condição, chega [sic] na casa do patrão de manhãzinha, o patrão leva pra roça dele e eles trabalha [sic] um dia de graça por semana pro patrão. O patrão não dá comida não. Naquela época não tinha jornada de trabalho. Era do dia amanhecê até o anoitecê [sic] (informação verbal) ${ }^{20}$.

Zé da Floresta ainda explicou que os patrões tinham um buzo, uma espécie de berrante para chamar os funcionários para o trabalho. Quando terminava a hora do almoço, esse instrumento era tocado para chamar de volta os funcionários. O buzo também servia para pedir socorro. De acordo com ele, naquela época não existia problemas com assalto, por exemplo, mas o patrão podia correr perigo de morte. Nessas horas, o buzo era tocado e todos que viviam na fazenda iam correndo para ver se algo aconteceu e ajudar.

Quando Zé da Floresta completou 16 anos, ele saiu da casa dos pais para trabalhar nas plantações de cana-de-açúcar da região e fazer um pouco de tudo: plantar e cortar cana, cavar sulco, carpir, derrubar mato, encher caminhão e carroça de trator. Ficou nessa vida por 13 anos. Nesse tempo casou e constituiu família. Em 1973, mudou-se para São Paulo com a esposa grávida e com mais seis filhos. No total teve nove, três nascidos no novo destino.

Outro agricultor que cresceu na roça é Mauri da Silva, cujo sítio é em Embu-Guaçu. Ele vive e planta no local que era de seu avô materno. A família toda vive ali até hoje. O terreno tem uma parte com cinco casas - a dele e as dos outros parentes - e, o restante, sua

${ }^{19}$ Entrevista concedida por José da Silva, no terreno em que vive, localizado no distrito de Parelheiros, no município de São Paulo, em 10 de setembro de 2015.

${ }^{20}$ Ibidem. 
plantação, quase toda de hortaliças. Mauri se recorda da infância, quando seus avós eram vivos:

meu vô fazia as pamonha, as paçoca, os caldo de cana, nós ficava tudo ali, era tudo feito na casa do meu vô [sic] [...] a vó fazia almoço, almoçava com eles. [Ela] Fazia paçoca no pilão, fruta tinha um monte, ameixa, caqui, banana... tudo aqui no sítio. [Ela] Fazia o café, torrava o café. [...]

Todo mundo ajudava na roça, minha mãe, alguns irmãos [de sua mãe] trabalhavam aqui ou em outras roças.

Tinha de tudo, tinha feijão, mandioca, abóbora, tinha porco, galinha, ovo. Vendia o que sobrava nos armazém [sic]. Comprava muito pouco (informação verbal) ${ }^{21}$.

Pelo relato de Mauri, tudo era centrado em seu avô e na família da mãe dele. Seu pai veio da Bahia, e ele nem faz maiores comentários sobre a família por parte paterna. Com cerca de 21 anos, seu pai faleceu. Era em torno de 1998, e, de acordo com ele, houve uma crise muito forte, em que tudo ficou muito caro para comprar e difícil para vender. Ele (foto 2.14), que na época ajudava o avô, resolveu "ir para a cidade".

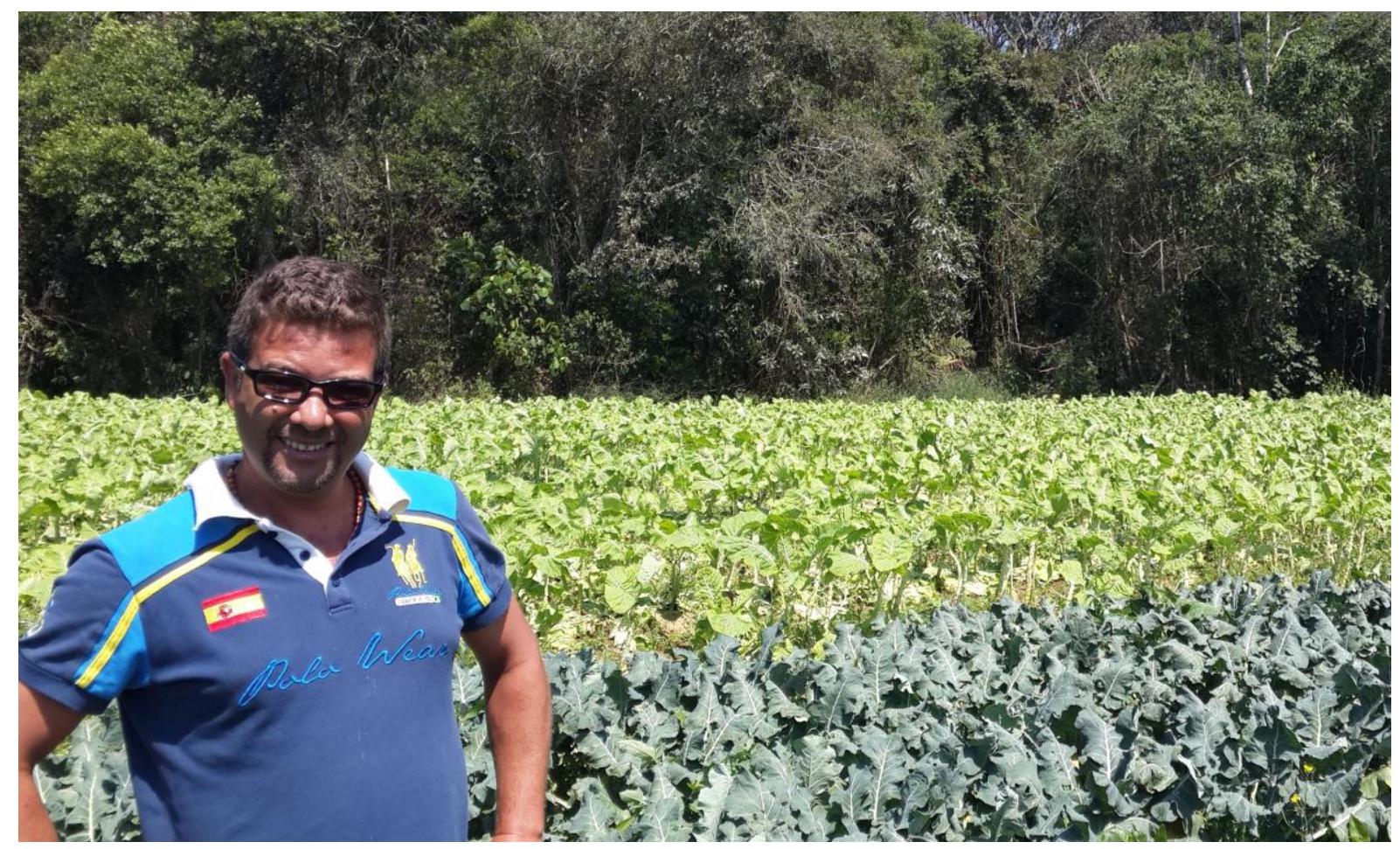

Foto 2.14. Mauri com a plantação de hortaliças, em seu sítio no município de Embu-Guaçu. Foto de 16 de setembro de 2015. Crédito da foto: Angélica Campos Nakamura.

\footnotetext{
${ }^{21}$ Entrevista concedida por Mauri da Silva em seu sítio, no município de Embu-Guaçu, em 16 de setembro de 2015.
} 
Ainda outros entrevistados também comentaram sobre suas origens na terra. Osvaldo Ochi e Massue Shirazawa, conhecidos mais como Seu Osvaldo e Dona Massue, ambos com avós e pais vindos do Japão, mas nascidos aqui, cresceram na roça e se mudaram para o município de São Paulo. Osvaldo nasceu em Bastos e, Massue em Quintana, municípios do interior do estado de São Paulo.

O avô de Osvaldo comprou terras da Bratac, a Sociedade Colonizadora do Brasil Ltda.. A Bratac era um

órgão destinado a administrar as colônias [nipônicas] Tietê (atual Pereira Barreto), Bastos, Alianças, Três Barras (atual Assaí) que, juntas totalizavam uma área de 80 mil hectares. O papel da Bratac era o de construir as instalações para a implantação das colônias, prestar orientações da parte agrícola e fixar os imigrantes nesses locais (BUNKYO, 2016).

No interior, a família plantava café e algodão. O pai de Osvaldo ficou com um pedaço dessa terra. Porém, ele comprou um sítio no município de São Paulo e se mudou com toda a família - Osvaldo e mais uma irmã, dois irmãos e a mãe -, após uma geada que dizimou toda a produção de café, em 1955. Hoje, apenas Seu Osvaldo e sua esposa vivem nesse sítio e plantam só caqui (foto 2.15). Seus irmãos foram trabalhar e viver no Japão e já estão lá há mais de 20 anos. Seus sobrinhos nasceram e cresceram lá. De acordo com Osvaldo, eles não pretendem voltar para o Brasil.

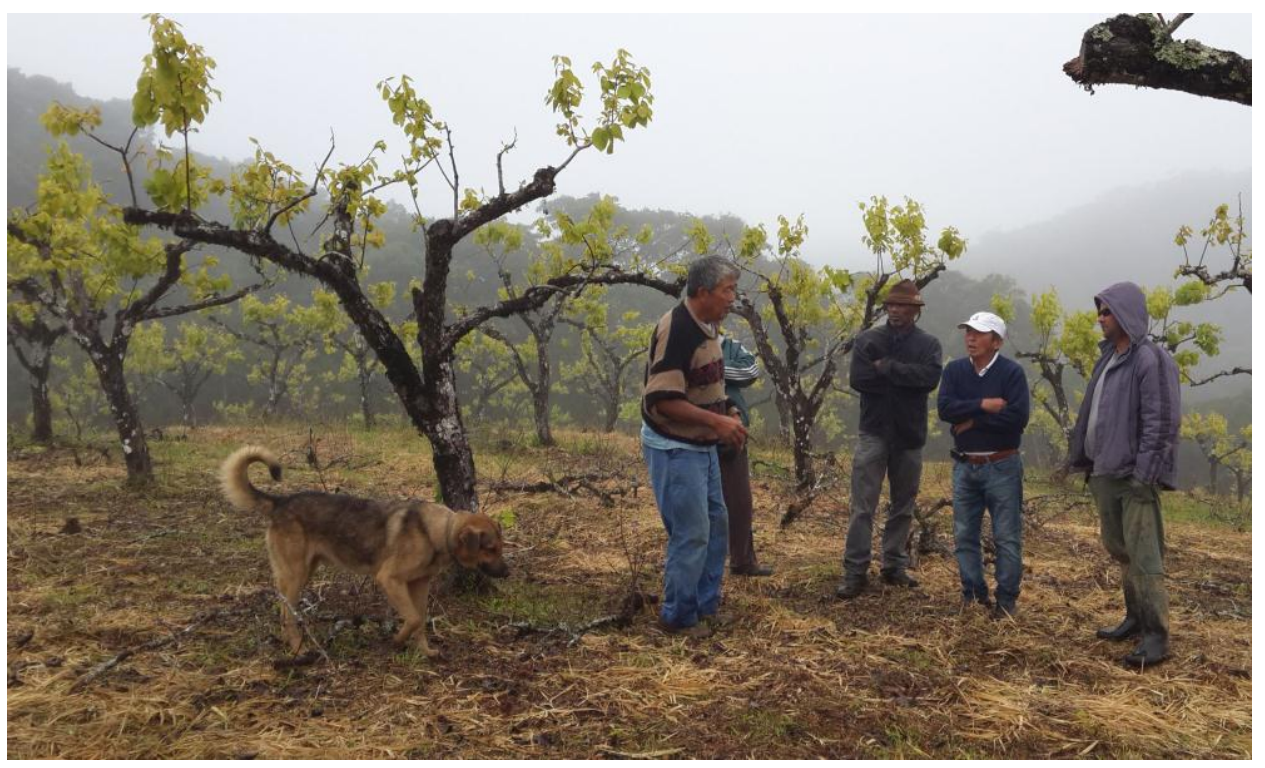

Foto 2.15. Seu Osvaldo, primeiro à esquerda, mostra sua plantação de caqui para os outros agricultores membros do SPG do Grupo Biodinâmico Água Limpa Billings Guarapiranga no seu sítio no distrito de Marsilac. Foto de 2 de setembro de 2015. Crédito da foto: Angélica Campos Nakamura. 
Já Dona Massue (foto 2.16) se lembra de trabalhar no interior, no sítio da família, fazendo horticultura e cuidando da granja que possuíam. Ela se mudou para o sítio no qual vive até hoje em São Paulo em 1971, quando casou. Teve quatro filhos e todos aprenderam a plantar. Hoje, dois vivem com ela e o marido no sítio e os outros dois estão trabalhando em fábricas no Japão. Os filhos vêm dando continuidade na produção agrícola de orgânicos da família e se interessam por essa agricultura.

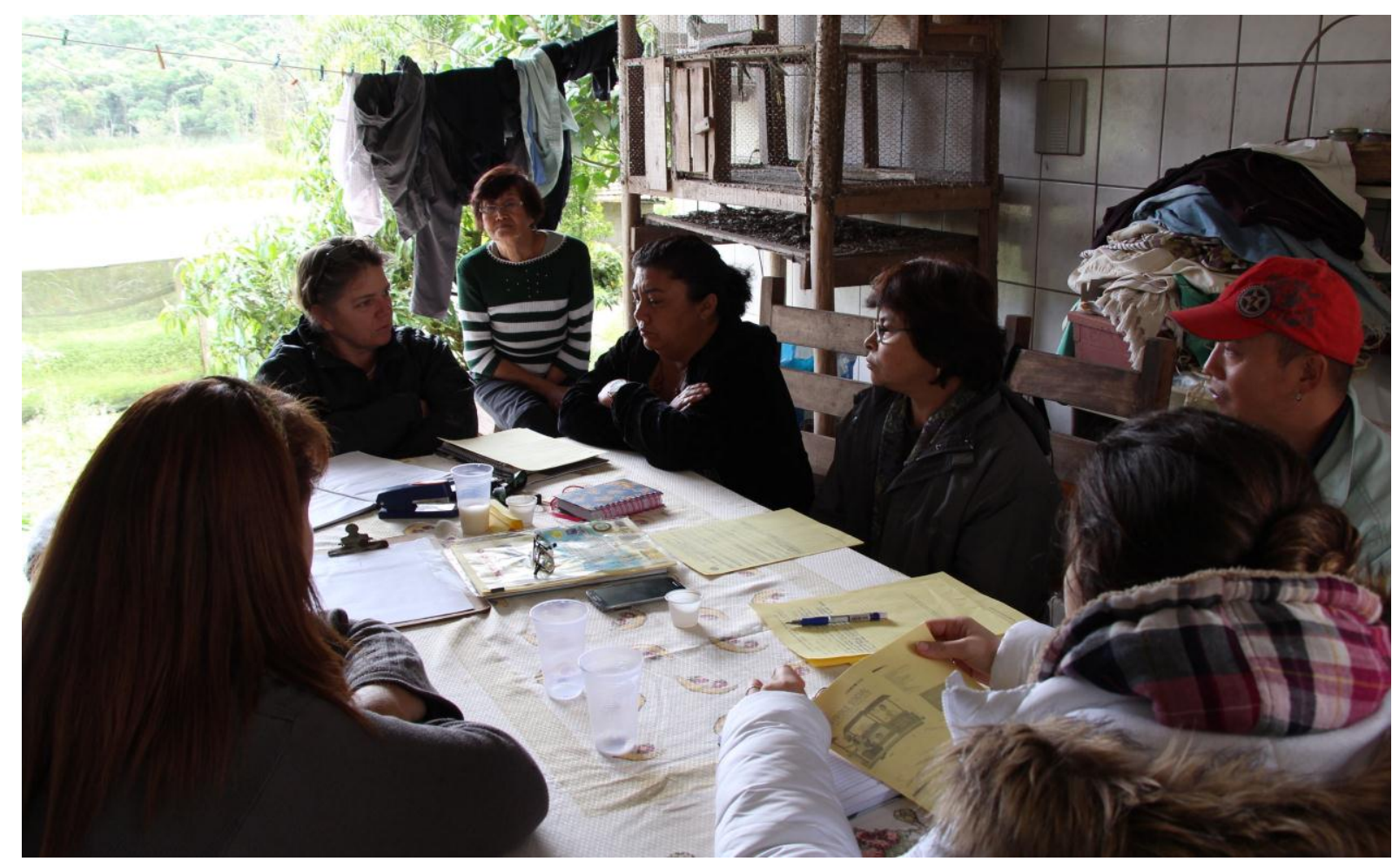

Foto 2.16. Dona Massue, sentada ao fundo (de óculos), acompanha uma reunião da OCS, realizada em seu sítio no distrito do Grajaú, em 25 de junho de 2015. Crédito da foto: Angélica Campos Nakamura.

Maria Irma Passos é mais uma das cooperadas que veio do interior, do município de Pedralva, no estado de Minas Gerais. De uma família grande - eram 11 filhos no total - e cujos pais são naturais de lá, Dona Irma, como é mais conhecida, relembra-se da vida na roça: “meu pai plantava de tudo, eu tenho meus irmãos lá, todo mundo planta. Meu pai tinha fábrica de rapadura, tinha criação de galinha, de porco, de vaca, minha mãe fazia queijo pra $v$ ender $^{, 22}$. Dona Irma acabou se mudando para a cidade de São Paulo em 1977 porque não tinha muitas opções de emprego em Pedralva. O sítio no qual hoje ela vive e planta foi comprado em 1985 com o marido, já falecido (foto 2.17, na página a seguir).

\footnotetext{
${ }^{22}$ Entrevista concedida por Maria Irma Passos em seu sítio, localizado no distrito de Marsilac, no município de São Paulo, em $1^{\circ}$ de setembro de 2015.
} 


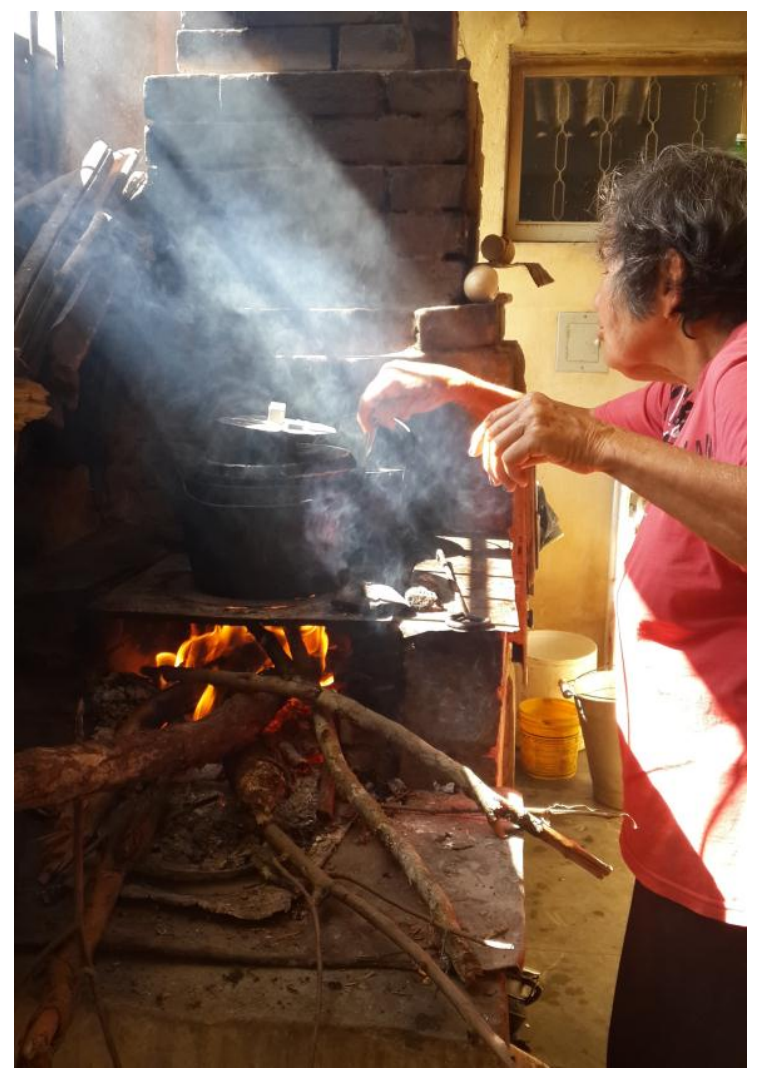

Foto 2.17. Dona Irma em casa, no distrito de Marsilac, preparando a comida no fogão a lenha. Foto de $1^{\circ}$ de setembro de 2015. Crédito da foto: Angélica Campos Nakamura.

Todos esses agricultores apresentados até aqui se recordam de terem trabalhado desde crianças na roça, ajudando seus pais. Alguns se lembram com mais detalhes e contam um pouco melhor de como era essa relação de trabalho. Ana do Mel se lembra de acompanhar o pai na roça:

Eu acompanhava meu pai. Ele fazia o buraquinho pra colocar o feijão, eu colocava o feijão. Fazia pro milho, eu colocava o milho. Então eu fui aprendendo, fui vendo como meu pai fazia, o que ele colocava na terra. Que ele puxava todo o capim. Ele não usava adubo químico e nem agrotóxico. $O$ adubo químico ele não usava porque não tinha acesso, era um produto caro. Ele usava esterco animal, dava certo (informação verbal) ${ }^{23}$.

Zé da Floresta também conta sobre sua infância na roça e, pelo seu relato, é possível perceber que ele não ou quase não frequentou a escola:

Eu comecei a trabalhar eu num dava conta nem do serviço que fazia. Era com enxadinha pequena e futucava aqui, futucava lá [...] aí quando meu pai achou que já dava pra eu [sic] e minha irmã aproveitar

\footnotetext{
${ }^{23}$ Entrevista concedida por Ana Zilda Coutinho em seu sítio, no município de Embu-Guaçu, em 20 de janeiro de 2015.
} 
alguma coisa... lá no norte a gente chama carreira. Aqui você planta uma carreira de milho, aqui você planta outra. Vamos dizer milho, ou mandioca, ou feijão. Seja lá o que for. [...] Aí ficava eu e uma irmã minha no meio dessa carreira aqui. O meu pai ficava de um lado aqui, o meu irmão mais velho do outro aqui. Cada um levava a carreira dele [...] Até que a gente ficou maiorzinho, aí cada um tomou conta de uma. Não tinha idade. Eu tenho muita pouca lembrança de quando já andava fazendo isso. [...] Naquele tempo amanheceu o dia você já tava [sic] na roça (informação verbal) $)^{24}$.

Ernesto e seus irmãos ajudavam seu pai com o trabalho no sítio. Ele se recorda de realizar um trabalho específico:

Quando era criança cheguei a ajudar, mas na verdade é brincar né. Mas era pesado... o meu pai tinha um tanque de uns 200 litros de água, aquelas caixas de água antiga. Não lembro o nome do material. Meu pai trazia o agrotóxico e jogava [na caixa], misturava o agrotóxico e meu pai tacava no tomate.

Esse era o meu serviço, pegar um pedaço de pau e ficar mexendo o agrotóxico (informação verbal) ${ }^{25}$.

Zundi lembra como foi difícil estudar e ainda ajudar seu pai:

Eu não consegui estudar porque faltava grana. Naquele tempo tinha escola mista, na minha sala tinha três séries. $4^{\circ}$ ano fiz em Santo Amaro, lá não tinha colegial. Só tinha escola mista. Tinha que fazer admissão pro Ginásio. Eu estudei até Ginásio [sic]. Eu pegava ônibus cinco da manhã, depois pegava outro, andava quase quatro quilômetros pra pegar o ônibus. Foi cinco anos nessa vida. Pra ir embora era três horas. [...]

Voltava ainda precisava ajudar o pai na roça. Antigamente tinha o burro que puxava a arara, precisava cortar capim, descascar milho pra ele comer. Eu que fazia isso (informação verbal) ${ }^{26}$.

Já Mauri conta que, quando era criança, acompanhava o avô na roça e que ia junto com ele para brincar, não para trabalhar. Porém, de acordo com ele, desde os sete anos sabia fazer alguma coisa. Ele fala que: "Meu vô plantava em tudo [...] Aí nós ia [sic] e ajudava eles [os adultos na roça]. E nós fomos pegando o gosto". Ele ainda lembra que

Com 12 anos comecei a trabalhar [...] fui trabalhar com um japonês. Tinha um salarinho, trabalhava por dia. Quando fui trabalhar pro japonês, ele plantava pimentão, tomate.

\footnotetext{
${ }^{24}$ Entrevista concedida por José da Silva, no terreno em que vive, localizado no distrito de Parelheiros, no município de São Paulo, em 10 de setembro de 2015.

${ }^{25}$ Entrevista concedida por Ernesto Oyama, na Casa de Agricultura Ecológica, na Subprefeitura de Parelheiros, em São Paulo, em 19 de janeiro de 2015.

${ }^{26}$ Entrevista concedida por Zundi Murakami em $1^{\circ}$ de outubro de 2015, na Feira Biodinâmica, realizada em Santo Amaro, na zona sul do município de São Paulo.
} 
[Eu: ele usava agrotóxico?] Nooooossa... foi a pior fase da minha vida. Eu não sabia de nada. Ele todo equipadão lá, parecia o cara da Guerra nas Estrelas e você lá puxando mangueira, de cara limpa. Aí começou a dar uns negócio, umas irritação [sic] e meu avô falava "tá vendo isso ai é o veneno". Aí não tinha jeito, comecei a trabalhar aqui dentro, ajudava meu $v \hat{o}$ (informação verbal) ${ }^{27}$.

A partir do exposto e das falas dos entrevistados, é possível identificar elementos da agricultura camponesa. Retomando as correntes já expostas anteriormente nesse capítulo, de acordo com Oliveira,

O desenvolvimento capitalista se faz movido pelas suas contradições. Ele é portanto, em si, contraditório e desigual. Isto significa que para seu desenvolvimento ser possível, ele tem que desenvolver aqueles aspectos aparentemente contraditórios a si mesmo.

Vamos encontrar no campo brasileiro, junto com o processo geral de desenvolvimento capitalista que se caracteriza pela implantação das relações de trabalho assalariado (os boias-frias, por exemplo), a presença das relações de trabalho não-capitalistas como, por exemplo, a parceria, o trabalho familiar camponês etc. (1991, p. 18).

Para compreender mais sobre o camponês e seu modo de produção, é preciso resgatar alguns dos elementos da produção camponesa. O primeiro deles é a propriedade da terra:

Aqui estamos diante da propriedade familiar, privada é verdade, porém diversa da propriedade capitalista, pois a propriedade familiar não é propriedade de quem explora o trabalho alheio. Estamos diante da propriedade direta de instrumentos de trabalho que pertencem ao próprio trabalhador. É pois, terra de trabalho. É portanto, propriedade do trabalhador, não é fundamentalmente instrumento de exploração [...] (OLIVEIRA, 1991, p. 60-61, grifo do autor).

Diferentemente da terra usada pelo capitalista, que a transforma em terra de negócio (MARTINS, 1991, grifo nosso), na qual existe a exploração do trabalho alheio, a terra, usada pelo camponês, é terra de trabalho, pois os ganhos do trabalho do camponês e de sua família não são ganhos de capital, por não serem provenientes da exploração de um trabalhador expropriado dos meios de produção (MARTINS, 1991, p. 54).

Ainda entre esse grupo de entrevistados, também se encontrou um posseiro, o Zé da Floresta, visto por Oliveira como um camponês-posseiro. Para ele, a “[...] posse deve ser vista

\footnotetext{
${ }^{27}$ Entrevista concedida por Mauri da Silva em seu sítio, no município de Embu-Guaçu, em 16 de setembro de 2015.
} 
como a negação da propriedade capitalista da terra, portanto como uma das contradições da propriedade privada [...]” (1991, p. 71, grifo do autor).

A terra, elemento presente em praticamente todos os casos citados, é, portanto, fundamental para essa produção e reprodução camponesa. Porém, em casos de famílias com mais de um filho, a partilha dela é inevitável, como aconteceu com a família de Ernesto. Tavares dos Santos fala sobre isso:

[...] a terra ainda é o meio de produção fundamental para o camponês. [...]

$\mathrm{Na}$ medida em que a terra é equivalente de mercadoria, a exigência de pagar o preço do solo também ocorre quando o camponês recebe a terra por herança. A cada divisão hereditária, o camponês precisa comprar os direitos de partilha dos irmãos que migraram (1978, p. 48 e 52)

Shanin também destaca que a “ [...] a propriedade da terra é uma condição necessária (e suficiente) para distribuir as ocupações [...]" (19--, p. 23, tradução nossa). Já Moura, M., ao falar sobre a terra, a vincula a outro elemento da produção camponesa: a força de trabalho familiar. Ela afirma que "O trabalho familiar caracteriza o vínculo social do camponês com a terra. Nuclear ou extensa, a família camponesa se envolve nas diversas tarefas produtivas, visando à reprodução física e social deste grupo de pessoas. [...]” (1988, p. 54).

Tavares dos Santos vem a explicar mais detalhadamente sobre a força de trabalho familiar dentro da unidade produtiva camponesa:

$\mathrm{Na}$ unidade produtiva camponesa, a força de trabalho é utilizada segundo seu valor de uso, pois é como atividade orientada de transformação de objetos que a capacidade de trabalho de cada membro possui significado para a família. Não se realiza a separação do trabalho da pessoa do trabalhador nem a consequente conversão da força de trabalho em mercadoria. Cada pessoa da família camponesa desempenha um trabalho útil e concreto, segundo o momento e a necessidade. Desse modo, estrutura-se no interior da família uma divisão técnica do trabalho, articulada pelo processo de cooperação, resultando numa jornada de trabalho combinada dos vários membros da família. Nesse sentido, a família camponesa transformase em um trabalhador coletivo (1978, p. 33-34).

Ainda sobre o trabalho familiar, Shanin diz que

A exploração camponesa forma uma pequena unidade de produção e consumo, que encontra seu principal sustento na agricultura e é mantida, principalmente pelo trabalho familiar. As necessidades de consumo familiar e as dívidas contraídas com os detentores do poder político-econômico definem em maior ou menor grau o caráter da produção (19--, p. 17, tradução nossa). 
Oliveira também fala da força de trabalho familiar e, ainda, de como existem outras relações de produção que também aparecem na unidade de produção camponesa, como a força de trabalho assalariada, elemento presente na maioria dos casos dos entrevistados, conforme apresentado no perfil no início do capítulo:

[...] a presença da força de trabalho familiar é característica básica e fundamental da produção camponesa. É pois derivado dessa característica que a família abre a possibilidade da combinação muitas vezes articulada de outras relações de trabalho no seio da unidade camponesa. É assim que o trabalho assalariado, ajuda mútua, e parceria aparecem como relações que garantem a complexidade das relações na produção camponesa. Porém, essa complexidade de relações estabelecidas é primeiro e fundamentalmente, articulada a partir da família, a partir da hegemonia que o trabalhador familiar exerce nessa unidade de produção e consumo. [...]

A presença da força de trabalho assalariada na unidade produtiva camponesa pode também aparecer como um elemento desta unidade. É evidente, que esse assalariamento no interior da unidade camponesa baseada fundamentalmente no trabalho familiar precisa ser muito bem entendido. [...] (OLIVEIRA, 1991, p. 56 e 58, grifo do autor).

Assim, dentro da unidade camponesa, pode-se encontrar a força de trabalho assalariada. É importante destacar que essa força não expropria a mais-valia do trabalhador. Paga-se alguém para complementar o trabalho dentro da propriedade, pois a família não consegue dar conta de realizar tudo sozinha. Oliveira explica que

Resulta desse processo que na unidade produtiva camponesa não se constitui o capital que depende da mais-valia gerada pela força de trabalho assalariada para se reproduzir em escala ampliada. Em outros termos, não se verifica o desenvolvimento do capital enquanto relação social entre as pessoas envolvidas no processo de trabalho camponês [...] (1991, p. 43).

O próprio camponês pode se tornar um assalariado em outra unidade produtiva, conforme aconteceu com Mauri, para complementar a renda da família. Esse trabalho é conhecido como trabalho acessório:

A presença do trabalho acessório do camponês é outro elemento componente da produção camponesa. Através do trabalho acessório o camponês pode se transformar periodicamente em trabalhador assalariado, recebendo salário por período de trabalho. Essa transformação periódica constitui-se em fonte de renda monetária que suplementa o rendimento com as culturas em suas propriedades [...] (OLIVEIRA, 1991, p. 57, grifo do autor). 
Dentro dessa unidade de trabalho familiar, observou-se como o papel dos homens, no caso os avôs e pais dos entrevistados, tinha um papel central na tomada de decisões. Geralmente, ao contar suas histórias, os entrevistados sempre faziam referência "ao avô que veio para o Brasil com a família" ou "o pai que comprou o terreno", por exemplo. A figura masculina é o referencial nas histórias. Sobre isso, Tavares dos Santos conta que

Os homens têm a responsabilidade de todas as tarefas produtivas, da direção do processo de trabalho e do contato com a cidade, aonde vão fazer "negócios". O chefe de família é a maior autoridade da unidade produtiva camponesa (1978, p. 31).

Em alguns exemplos, como no de Zundi Murakami, ele ainda tem papel central na tomada de decisões da família. Ainda, no caso dele, foi a partir do trabalho familiar que ele conseguiu aumentar sua produção, tornando-se um grande produtor da região e, portanto, um pequeno capitalista. Ele comenta até que seus filhos não trabalharam na roça quando pequenos e, como ele vendia muito, chegou a um ponto de se preocupar apenas em acompanhar a produção e fazer a comercialização. Sobre casos como ele, Oliveira especifica:

Através do trabalho familiar eles podem aumentar sua produção, mesmo sem ampliar suas terras. Dessa forma, uma família camponesa pode estar produzindo muito além do necessário à sua sobrevivência e com isso acumulando. Esse dinheiro poderá ser destinado a aumentar suas terras e/ou contratar trabalhadores assalariados para trabalhar para ela. Quando isso ocorre, seus membros (filhos, pai, mãe) deixam de trabalhar na produção, passando a cuidar apenas das tarefas da administração e comercialização da produção, tornando-se, pois, pequenos capitalistas (1991, p. 21).

Outro elemento observado, a partir dos relatos, foi a socialização camponesa. Ela se inicia com as crianças. Conforme dito anteriormente, todos afirmaram que começaram na roça cedo, "brincando", mas quem se lembrou com mais detalhes foram Ana do Mel, Zé da Floresta, Zundi, Ernesto e Mauri. Shanin destaca a importância dessa socialização ao explicar que "[...] o jovem aprende seu trabalho seguindo seu pai e o ajudando. Este procedimento de socialização reforça os laços familiares e realça o caráter tradicional da agricultura camponesa" (19--, p. 19, tradução nossa). Mas é Tavares dos Santos que melhor desvenda o assunto:

A reprodução da força de trabalho familiar efetiva-se pela procriação e complementa-se através do processo de socialização das crianças. Como a unidade produtiva camponesa condensa um núcleo familiar e um núcleo produtivo, nela vão confundir-se também a socialização primária, por meio 
da qual o indivíduo se converte em membro da sociedade, e a socialização secundária, através da qual o indivíduo adquire o conhecimento específico de papéis determinados pela divisão social do trabalho (1978, p. 44-45).

Ainda sobre a socialização, o mesmo autor fala sobre a figura do sexo masculino. Esse papel do jovem que ficará na propriedade para garantir a reprodução social de seus pais aparece no relato de Zundi, quando contou do irmão mais velho de seu pai, apesar de ele relacionar isso ao "sistema japonês". Tavares dos Santos explica mais detalhadamente sobre isso:

O jovem precisa permanecer porque é parte integrante da força de trabalho familiar e seu trabalho, principalmente o do jovem do sexo masculino, servirá para sustentar os pais quando ficarem velhos. Ficando na propriedade, o jovem garante a reprodução social do processo de trabalho camponês. Por outro lado, o processo de migração atinge sempre mais o campesinato [...] A valorização do estudo funciona como uma forma de preparar o jovem para o desempenho de tarefas urbanas, possibilitando uma "profissão" na cidade. [...]

Na realidade, o "estudo" é a preparação do jovem para o trabalho assalariado na cidade, seja na indústria, seja nos serviços [...] (1978, p. 47, grifo nosso).

Oliveira também destaca o papel da iniciação dos jovens na agricultura:

[...] as crianças são iniciadas como personagens da divisão social do trabalho no interior da unidade produtiva do camponês. Ao atingirem os 12, 14 anos, passam a desempenhar tarefas dos adultos, desenvolvendo dentro da unidade familiar o trabalho acessório. Nesse momento, desencadeia-se a contradição no seio da unidade familiar: o jovem precisa continuar na propriedade, pois é parte integrante da força de trabalho familiar; aí permanecendo, garante a reprodução social do processo de trabalho camponês. No entanto, com o aumento da família, a migração é inevitável.

A escola em geral contribui para aguçar esse processo no interior da produção camponesa, pois ela tem preparado o jovem para o trabalho assalariado na cidade. [...] (1991, p. 60).

Ambos os autores, Tavares dos Santos e Oliveira, destacam o papel do estudo e da escola nesses momentos, afirmando que estes servem para preparar os jovens para o trabalho assalariado na cidade. Realmente, isso ocorreu com praticamente todos os entrevistados, conforme se verá mais adiante.

Zé da Floresta, ao relembrar sobre sua infância e destacar que "Naquele tempo amanheceu o dia você já tava [sic] na roça”, acaba ressaltando outro elemento da produção camponesa: a jornada de trabalho. Durante a convivência com os entrevistados, foi sempre 
muito comum ouvi-los reclamar das condições do tempo, principalmente na época das chuvas do verão, e de como eram obrigados a parar, até por dias, o trabalho. Além disso, durante o verão, os dias são muito quentes, o que torna o trabalho muito mais cansativo e exaustivo. É comum vê-los dizer que chegam a trabalhar antes do Sol nascer e pararem por algumas horas, quando o Sol está alto. Outro aspecto da rotina deles que indica um pouco da jornada de trabalho são as vésperas de entrega de produtos e de feira. Geralmente, para eles, é inviável marcar uma reunião, pois eles gastam um dia para colher, embalar e preparar a produção para a comercialização.

Tudo isso mostra um pouco de como é essa jornada de trabalho. Oliveira diz que

A jornada de trabalho é outro elemento componente da produção camponesa. Nesse aspecto, a realidade é toda particular. Não há uma rigidez de horário diário como na produção capitalista; a jornada de trabalho do camponês varia conforme a época do ano e segundo os produtos cultivados. Assim, combinam-se períodos chamados de ociosos, quando o camponês está livre para assalariar-se através de trabalho acessório, com períodos de intenso trabalho quando, nem o nascer e o pôr-do-sol, às vezes, são os limites naturais da jornada de trabalho. Os trabalhos que envolvem o preparo da terra para o plantio são feitos até durante à noite. Essa aparente irregularidade da jornada de trabalho dos camponeses é que abre espaço para o desenvolvimento de uma série de tarefas artesanais domésticas, que eles realizam nos períodos de pouco trabalho agrícola (1991, p. 64, grifo do autor).

Um aspecto que ficou relevante durante as visitas aos sítios foi a propriedade dos meios de produção. Todos os entrevistados possuem, ao menos, equipamentos mais simples, como a enxada. Mas, boa parte deles têm tobata, compram adubos e outros preparados voltados para a agricultura orgânica, alguns compram plástico para fazer a plasticultura ${ }^{28}$, possuem estufas etc. (fotos $2.18,2.19$ e 2.20 na página a seguir).

Oliveira explica sobre a propriedade dos meios de produção:

[...] outro elemento da produção camponesa é a propriedade dos meios de produção, que na sua maioria, são adquiridos, portanto, são mercadorias. [...] É com relação ao acesso a essas mercadorias, meios de produção, que o camponês trava relação com o capital. É por esse processo que parte da renda vai ser drenada para o setor bancário e industrial, pois os empréstimos financeiros fazem parte da dinâmica de reposição desses meios de produção, e - por que não dizer? - do próprio acesso do camponês a essas mercadorias. Isso sem falar do processo de subsistência do camponês que se utiliza dos

\footnotetext{
${ }^{28}$ A plasticultura também é conhecida como cultivo em mulching. Tem várias vantagens para a agricultura, como diminuir o trabalho com capinas, manter a umidade do solo, poder utilizá-la em mais de um plantio, evitar a lixiviação do solo, reduzir o crescimento de plantas daninhas e regular a temperatura do solo. Essa informação foi fornecida em uma conversa com uma técnica da Casa de Agricultura (CAE) de Parelheiros.
} 
empréstimos para adquirir produtos de sua necessidade básica (1991, p. 63, grifo do autor).

Tavares dos Santos dá mais exemplos sobre quais são esses meios de produção:

A maior parte desses meios [de produção] têm a forma mercadoria. São mercadorias as matérias-primas intermediárias (fertilizantes, defensivos e corretivos agrícolas) e os meios de trabalho (arame, parte das estacas, motobomba pulverizadora, mangueira, arado de tração, animal, tesoura de podar, enxada, foice, faca, máquina manual de semear, máquina manual de pulverizar) [...] (1978, p. 54).
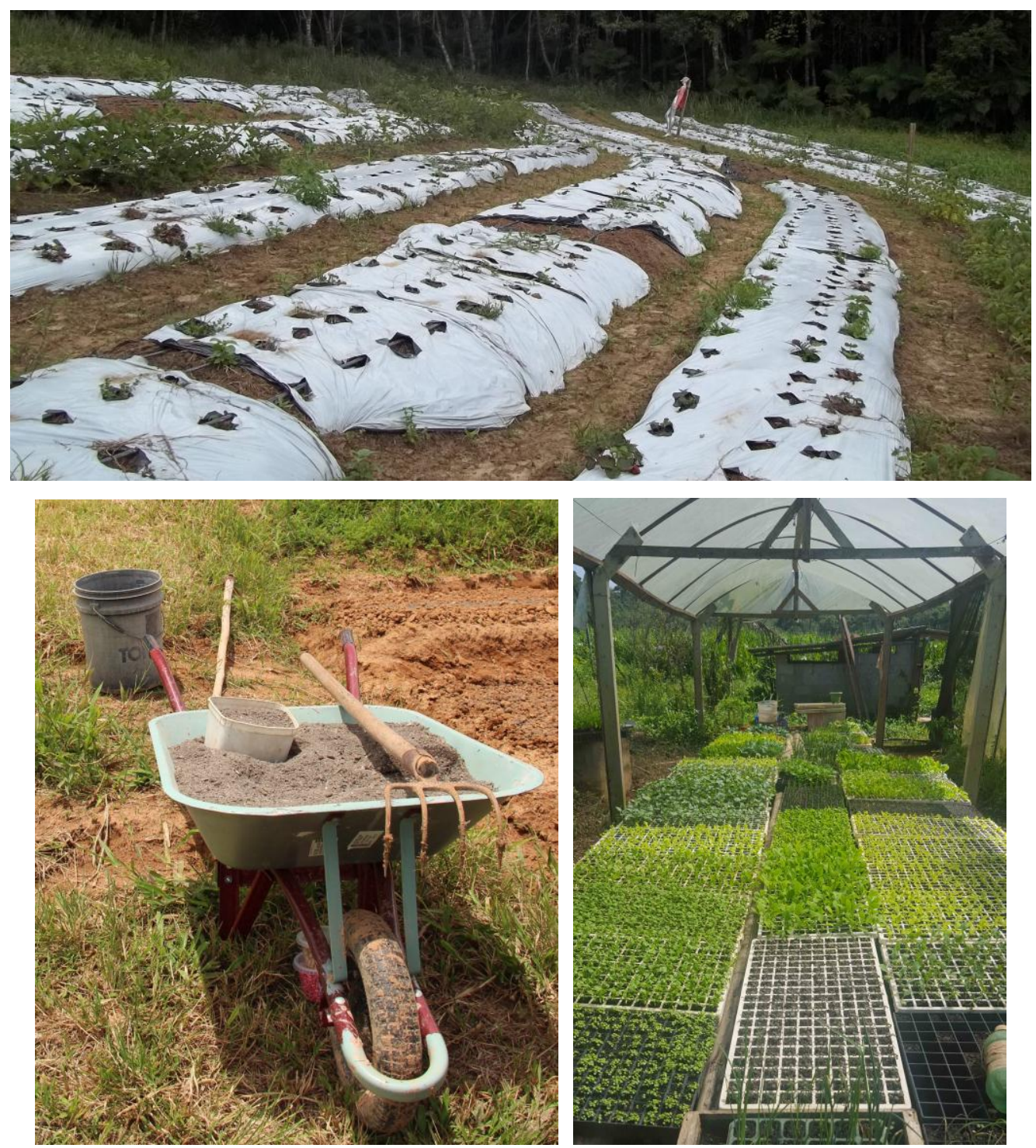

Fotos 2.18, 2.19 e 2.20. Na primeira foto, acima (2.18), plasticultura em um dos sítios visitados no distrito de Marsilac, em 27 de novembro de 2015. Nas fotos abaixo (2.19 e 2.20), equipamentos e utensílios utilizados na agricultura em um sítio no distrito do Grajaú. A foto à esquerda é de 29 de janeiro de 2015, e a foto à direita é de 31 de março de 2016. Crédito das fotos: Angélica Campos Nakamura. 
Assim, todas essas pessoas e suas famílias, apresentadas aqui, uma vez camponeses, são a

[...] personificação da forma de produção simples de mercadorias, na qual o produtor direto detém a propriedade dos meios de produção - (terra, objeto de trabalho e outros meios de trabalho) - e trabalha com estes meios de produção. Esta combinação de elementos faz com que o camponês se apresente no mercado como vendedor dos produtos do seu trabalho, como produtor direto de mercadorias. Como produtor, venderá seus produtos para adquirir outros, qualitativamente diferentes, que possam satisfazer suas necessidades de consumo individual ou produtivo. [...]

[...] seja diretamente, seja por meio do dinheiro obtido com a comercialização do "produto dos fatores de produção excedente", a "roça", ao garantir os meios de vida necessários, assegura a reprodução da força de trabalho familiar. [...] (TAVARES DOS SANTOS, 1978, p. 69-70)

Realmente, todos destacaram como viveram da agricultura, ainda que até um determinado período da sua vida, e vendiam seus produtos ou excedentes da roça. Alguns, ainda, confirmaram que mal saíam de seus sítios, como Ana do Mel, Mauri e Zé da Floresta, este último, no caso, das fazendas pelas quais sua família passou. $\mathrm{O}$ momento de sair era para realizar a comercialização e comprar produtos que não eram produzidos ou cultivados em casa.

De todos os entrevistados que foram apresentados nesse item, apesar de todos terem pais ou avós ligados à agricultura e terem crescido na roça, apenas Seu Osvaldo e Dona Massue se mantiveram a vida toda na agricultura. Todos os outros, em algum momento, ou deixaram de plantar ou, se plantavam, era apenas para consumo próprio e porque gostam de fazer essa atividade.

Entre os descendentes de japoneses, é notável como a possibilidade de ir para o Japão para trabalhar, na maioria dos casos em fábricas, e juntar dinheiro está presente na vida de todos eles. Osvaldo pode não ter ido, mas seus irmãos vivem lá. Dona Massue nunca foi para o país e sonha em conhecer, porém, todos os seus filhos já foram e, quando a entrevista se realizou, dois deles estavam no Japão. Todos ajudaram e ajudam financeiramente a família aqui.

Ernesto, quando terminou o segundo grau - hoje, Ensino Médio - foi para o Japão encontrar o pai, que já estava lá, e trabalhar. Ficou quase um ano, de janeiro a dezembro de 1997. Em dezembro, retornou com o pai. Porém, em janeiro de 1998, ele resolveu voltar para o Japão porque queria uma independência financeira. Ficou até 2007, sem voltar para o Brasil. Nesse mesmo ano, os pais de Ernesto, que tinham juntado dinheiro, foram visitá-lo no 
Japão e, de acordo com ele, foram buscá-lo também. Ele retornou para o Brasil e começou a trabalhar com agricultura:

Não aguentava mais a vida no Japão, estava muito estressado. No meu plano de vida não tinha nada programado pra trabalhar com agricultura, mesmo você não querendo o caminho me levou pra lá, acabei ficando. Precisa de alguém pra cuidar, tocar pra frente o negócio do meu pai. Hoje eu gosto (informação verbal) ${ }^{29}$.

Zundi também foi para o Japão com toda a família para trabalhar. Ele, que foi um grande produtor de batata, afirma: "Batata é igual loteria: quando dá fica rico, quando não dá, perde tudo" (informação verbal) ${ }^{30}$. Ou seja, Zundi perdeu suas produções de batata, entretanto, na entrevista, ele não explicou exatamente como perdeu tudo, apenas afirmou ter levado muitos tombos com a agricultura e que "batata era o carro chefe, era tudo consignado". Assim, para pagar suas dívidas, ele, a esposa e os quatro filhos - um menino e três meninas - partiram para o Japão em 1991, para a província de Tochigui, ao norte de Tóquio. Para pagar só a dívida para o Banco do Brasil, juntava 10 mil dólares por mês. Isso durou um ano.

Após três anos e meio, ele retornou para o Brasil com a mulher e o filho, que era o mais novo. As filhas continuaram a viver no Japão. De volta ao país, ele abriu uma loja de bicicletas e trabalhou nesse ramo por sete anos. Nesse período, foi assaltado cinco vezes. Cansado e com medo voltou, mais uma vez, para o Japão, já em 2001. Dessa vez, ficou até 2008. Na segunda vez, trabalhou mais para as empreiteiras que fazem a intermediação dos brasileiros com as fábricas japonesas. Ele era intérprete e acompanhava os brasileiros que não sabiam falar japonês em hospitais, na polícia, na prefeitura etc.

Novamente no Brasil, ele comprou um terreno em Osasco para alugar o qual hoje dá um dinheiro extra para ele. Além disso, ele voltou para a agricultura e resolveu plantar banana orgânica. Hoje Zundi conseguiu se estabelecer, muito devido ao dinheiro levantado ao longo dos anos no Japão. Ele até montou uma pequena fábrica para preparar biomassa, pasta e chips, tudo de banana. Pelo grupo do Whatsapp, algumas fotos foram enviadas das experiências com outros produtos de outros cooperados. No caso, tentaram desidratar os caquis produzidos pelo Seu Osvaldo (fotos 2.21 e 2.22, na próxima página).

\footnotetext{
${ }^{29}$ Entrevista concedida por Ernesto Oyama, na Casa de Agricultura Ecológica, na Subprefeitura de Parelheiros, em São Paulo, em 19 de janeiro de 2015.

${ }^{30}$ Entrevista concedida por Zundi Murakami em $1^{\circ}$ de outubro de 2015, na Feira Biodinâmica, realizada em Santo Amaro, na zona sul do município de São Paulo.
} 

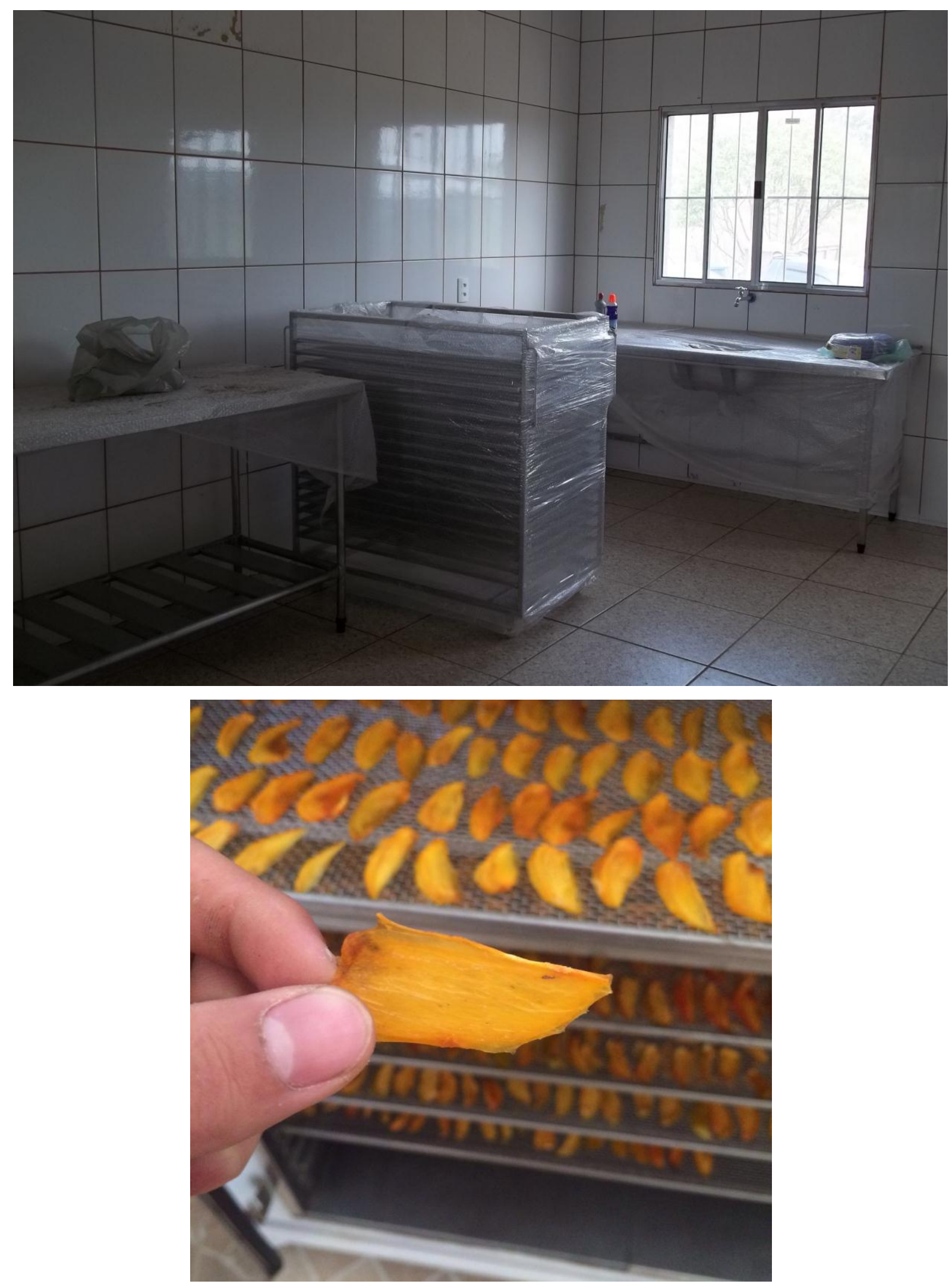

Fotos 2.21 e 2.22. Na primeira foto, acima (2.21), a pequena fábrica ainda em montagem no sítio de Zundi Murakami, no distrito de Parelheiros, em 3 de setembro de 2015. Crédito da foto: Angélica Campos Nakamura. Na foto abaixo (2.22), o teste da desidratação dos caquis de Seu Osvaldo. A foto foi enviada pelo grupo do Whatsapp da Cooperapas, em 12 de abril de 2016. Crédito da foto: foto recebida pelo grupo do Whatsapp da Cooperapas. 
Ana do Mel, Zé da Floresta, Maria Irma e Mauri também tiveram empregos fora da agricultura por muitos anos. Ana do Mel, na verdade, nunca perdeu o contato com a agricultura, mas durante anos a atividade serviu como complemento para sua renda e porque ela sempre gostou de plantar. Conforme já dito, ela foi professora de educação infantil até casar. Quando se casou, ela mudou para o sítio no qual vive hoje, e sair para trabalhar do local para a escola se tornou uma rotina puxada. Resolveu ficar em casa, plantando e fazendo mel, do jeito que aprendeu com a família. Ela diz que

Queria fazer algo aqui para ganhar um dinheirinho. Aí comecei a comercializar o mel. Comecei a vender pouquinho, eu tinha vergonha de vender. As pessoas falavam para mim "por que você não volta a estudar, fazer faculdade? Fica aí fazendo mel. Podia voltar a trabalhar em escola, ganhar mais dinheiro". As pessoas nunca apoiavam meu trabalho no sitio (informação verbal) ${ }^{31}$.

As coisas que plantava, como alface, começou a vender aos poucos. Foi só a partir de 2004 que ela resolveu levar a agricultura "mais a sério". Foi na Casa de Agricultura de EmbuGuaçu se informar mais e tinha uma amiga que conhecia os produtores orgânicos de Parelheiros. Aos poucos, foi se envolvendo, até voltar a viver só com a agricultura. Hoje, sua família depende $100 \%$ da agricultura. Vale lembrar que apenas dois entrevistados afirmaram ter a renda só dessa atividade.

Zé da Floresta, quando chegou em São Paulo em 1973, foi trabalhar em fábrica:

Cheguei no dia 6 de setembro. Já comecei a procurar serviço. Aí arrumei serviço aqui numa firma [...]. Eu sei que cheguei no dia 6 de setembro, no dia 18 comecei a trabalhar.

Era metalúrgica, tratamento térmico, temperamento de peça. Ali no Socorro [bairro]. [...] Naquele tempo tinha muitas né, hoje muitas já mudaram pro interior. [...] Aí eu trabalhei por dois anos, depois de dois anos eu resolvi sair, pedi e a firma mandou embora. Aí eu entrei em outra firma lá na Chácara Santo Antônio [bairro], era firma de plástico, desses de copo descartável. Continuei, aí depois fui saindo de uma e entrando em outra e por fim de conta hoje tô aqui [sic]. [...] Cheguei em [19]73, trabalhei em fábrica até [19]95, variando né, maioria de plástico (informação verbal) $)^{32}$.

Em 1984, quando ele chegou na área na qual hoje vive, começou a fazer roça, mesmo ainda trabalhando em fábrica. Ficou como operário até 1996 e, a partir daí, fez vários bicos,

\footnotetext{
${ }^{31}$ Entrevista concedida por Ana Zilda Coutinho em seu sítio, no município de Embu-Guaçu, em 20 de janeiro de 2015.

${ }^{32}$ Entrevista concedida por José da Silva, no terreno em que vive, localizado no distrito de Parelheiros, no município de São Paulo, em 10 de setembro de 2015.
} 
como o de pedreiro. Ele só foi se aposentar em 2001 e daí começou a se dedicar totalmente à agricultura. Como se trata de uma área com vegetação mais densa, ele aproveitava os locais mais abertos para plantar milho, mandioca, feijão, batata-doce, banana, café (foto 2.23), laranja, limão e abacate, por exemplo. Nos últimos meses, não vinha plantando mais para vender, pois não tem mais a ajuda dos filhos e dos netos, e o trabalho é cansativo.

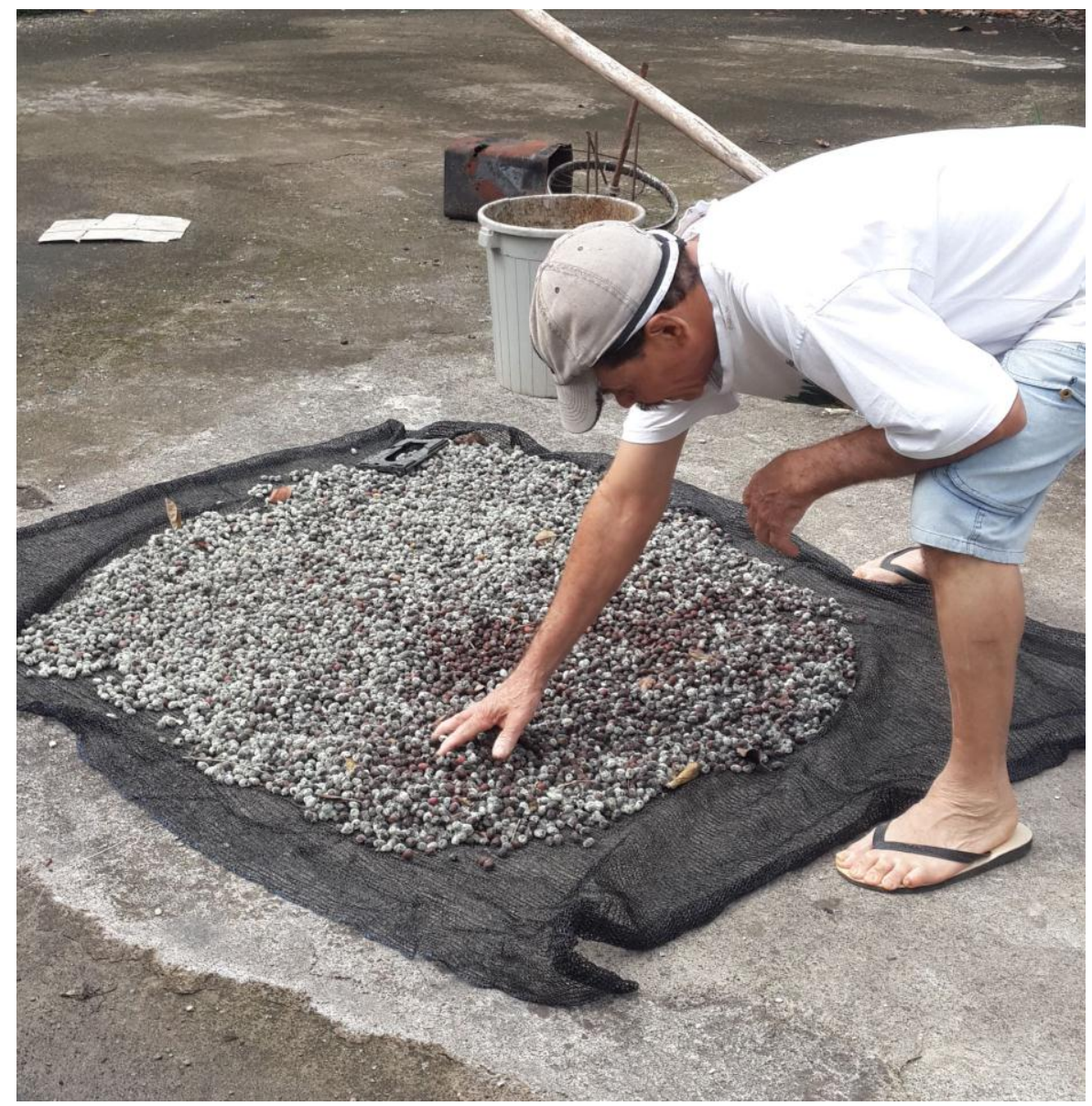

Foto 2.23. Zé da Floresta mostra o café que colheu e como deixa ele para secar na laje de sua casa, no distrito de Parelheiros. Foto de 10 de setembro de 2015. Crédito da foto: Angélica Campos Nakamura.

Maria Irma saiu de Minas Gerais, em 1977, para vir para a cidade de São Paulo porque não havia emprego onde morava. Em São Paulo, ela fez curso de técnico em enfermagem em São Bernardo do Campo, município vizinho a São Paulo, e trabalhou no Hospital Beneficência Portuguesa. Lá conheceu seu marido e, em 1985, compraram o sítio no qual ela vive hoje. Aposentada, produz pouco porque vive sozinha e uma ajudante vem alguns dias da semana (foto 2.24, na página a seguir). Vende alface, escarola, almeirão, chuchu e abóbora, principalmente, e tem criação de galinhas. Os ovos e alguns animais, vende para os vizinhos. 


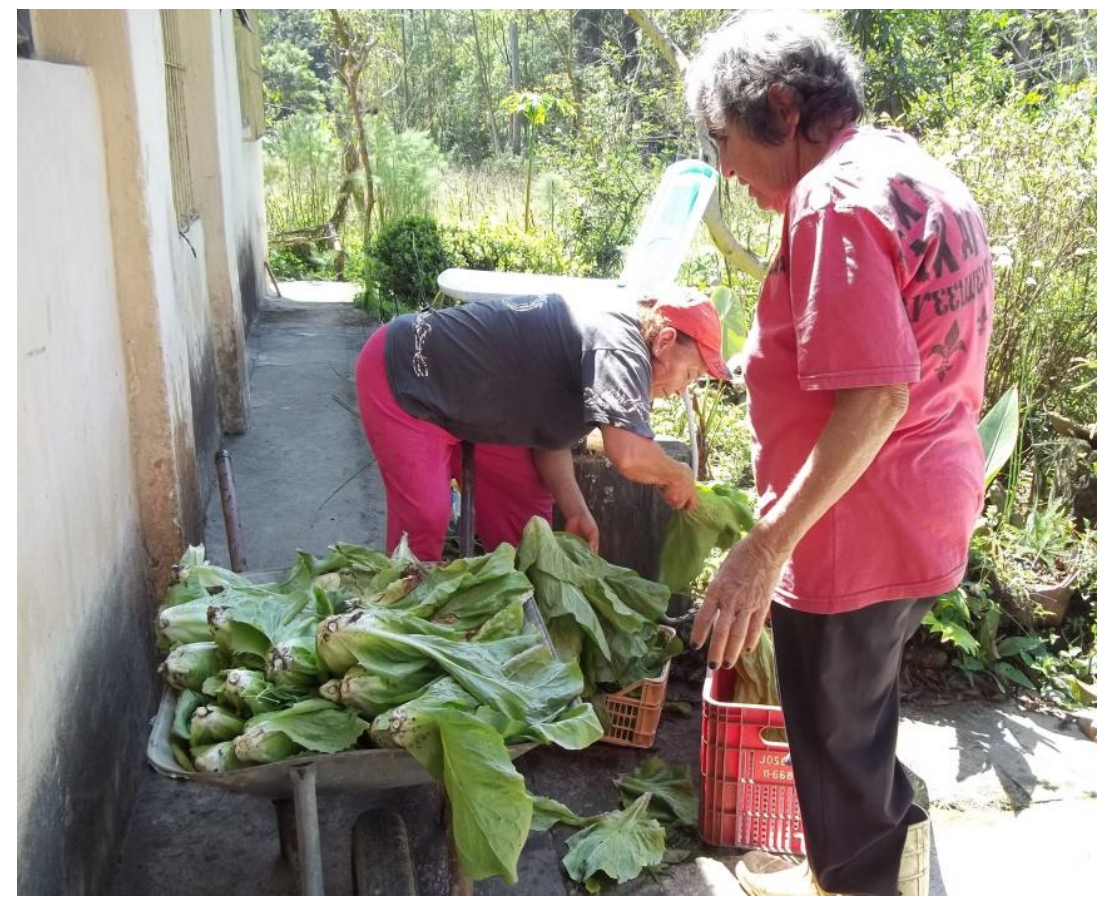

Foto 2.24. Dona Irma em seu sítio, no distrito de Marsilac, separando hortaliças para as vendas da cooperativa. Foto de $1^{\circ}$ de setembro de 2015. Crédito da foto: Angélica Campos Nakamura.

Mauri, quando resolveu ir para a cidade, começou a trabalhar para a Brasilwagen, uma rede de concessionária Volkswagen. Quem o indicou foi um amigo que já trabalhava lá. Ele conta que

Quando eu comecei a trabalhar nessa empresa lá, porque tem um começo né, eu comecei lavando carro. Eu trabalhei 30 dias. O que eu recebi em 30 dias na época era $R \$ 480,00$. Ou $R \$ 380,00$, não lembro direito. Mas quando saí da época ruim, da roça ruim, ruim já tirava uns $R \$ 800,00, R \$$ 700,00. Mas aí trabalhei uns três, quatro meses gostando daquela novidade, só carrão, gente diferente. Aí fui se [sic] empolgando. 21, 22 [anos], falei pro meu chefe: "meu, isso aqui não dá, ganho muito pouco". Ai ele falou "Mauri, você vai ter que seguir carreira". "Tá, então como é que faz esse esquema ai".

Aí comecei a ficar à noite, trabalhava das 8 às 6 [da tarde]. Aí ficava das 6 até 11, meia-noite pra começar a aprender. Eu chegava em casa uma hora da manhã. Aprendia mecânica, pra seguir carreira de mecânico. Mas estava empolgado na época.

Aí me passaram pra oficina. Já estava ganhando uns $R \$ 1.100,00$, $R \$ 1.200,00$. Tinha melhorado pra caramba né. Isso em 2000, 2001. Aí fui subindo, aí comecei a fazer dois cursos por ano na fábrica. Meu salário já estava quase dobrando, tava [sic] quase $R \$ 2.000,00$. Todo ano, um ou dois cursos. Só que me deu aquela agonia. Que saudade da roça. Eu fazia tudo aquilo ali, aprendendo, mas não estava gostando mais. Aí de domingo eu começava a roçar, de sábado, domingo, começava a fazer uns canteirinhos. [...] "Você vai largar o seu emprego pra voltar pra roça?". Minha mãe quase me internou. Porque a gente tava [sic] numa época tão difícil e aí 
começou a melhorar. Nossa, seguro de vida, plano de saúde, de segunda a sexta-feira [jornada de trabalho], dois cursos por ano (informação verbal) ${ }^{33}$.

Por volta de 2004, com 27 anos, Mauri largou o trabalho "na cidade" e voltou para a agricultura. Porém, no seu retorno, começou a produzir de maneira convencional. Chegou a fazer uma sociedade que não deu certo, perdendo dinheiro e sem receber pela sua produção agrícola. Ao que indica no seu relato, levou um calote, contudo, preferiu não entrar em detalhes. Sem dinheiro para comprar qualquer insumo agrícola, começou a relembrar que seu avô plantava sem nenhum agrotóxico ou fertilizante químico. Em 2007, descobriu que existia uma Casa de Agricultura em Parelheiros e foi verificar se a CAE oferecia alguma ajuda para os agricultores. Lá, contaram a ele mais sobre o que era agricultura orgânica. A partir daí, Mauri fez cursos e começou a plantar sem agrotóxicos ou insumos químicos.

Em todas as histórias, os entrevistados foram buscar um emprego urbano. Os motivos foram variados. Entretanto, todos eles voltaram para a agricultura. A saída temporária do campo, em boa parte dos casos, sem dúvida ajudou-os financeiramente. Mas o que explica esse desejo de retornar à terra?

Ainda é preciso pensar sobre uma outra parte dos entrevistados que fizeram o caminho contrário: vieram da cidade para viver no campo. E, nesses casos, como analisá-los? O próximo item tratará disso.

\subsection{A campesinidade e o urbano}

Uma parcela dos membros entrevistados da Cooperapas não tem um passado na agricultura, como os personagens apresentados no item anterior. A própria presidenta da Cooperativa, Valéria Macoratti, é uma delas. Sua companheira, Vânia dos Santos, também entrou com o nome na Cooperapas e a ajuda com as tarefas mais administrativas. Porém, é Valéria quem tem mais interesse na agricultura.

Valéria nunca havia trabalhado com agricultura, entretanto, seus avós vieram da Itália e da Alemanha para trabalhar na terra. Nasceu e cresceu no bairro de Guaianazes, na zona leste do município de São Paulo. Quando era criança, o bairro ainda "só era mato", tinha um

\footnotetext{
${ }^{33}$ Entrevista concedida por Mauri da Silva em seu sítio, no município de Embu-Guaçu, em 16 de setembro de 2015.
} 
riacho e a construção da escola na qual estudou era de madeira. Esse riacho, de acordo com ela, virou o esgoto da Cohab que lá foi construída.

Valéria sempre teve o desejo de não viver "na cidade". Até 2007, ela morou em uma parte do distrito do Grajaú mais urbanizada. Depois disso, comprou um pequeno sítio no mesmo distrito, porém, em uma área com sítios e onde ainda se desenvolve a agricultura, e se mudou com Vânia. Vivendo no novo endereço, ela conta:

fui conhecendo uns agricultores. As pessoas que a gente conhece no bairro [onde viva antes] pedia [sic] pra levar umas hortaliças, maço de couve, coentro... aí comecei a levar uns, depois de um tempo me vi levando 100 pés de alface... pegava tudo dos outros (informação verbal) ${ }^{34}$.

Em 2008, um dos vizinhos de Valéria apresentou seu irmão, Daniel dos Santos. O vizinho via que Valéria levava produtos agrícolas para vender e se aproximou dela, dizendo que seu irmão, Daniel, vivia da agricultura. Por intermédio do irmão, foram apresentados um ao outro, e Valéria teve uma forte empatia com Daniel. Assim, ela começou a vender os produtos agrícolas de Daniel.

Interessada cada vez mais pela atividade agrícola, Valéria fez três cursos sobre agricultura orgânica e biodinâmica. Depois de fazer os cursos, ela também começou a plantar. Junto com Daniel, chegaram a arrendar um sítio, pois Daniel não tem terra para plantar e o sítio no qual ela vive com Vânia é muito pequeno. Porém, até abril de 2016, eles estavam procurando um novo local, pois os donos do sítio querem vendê-lo, caso contado no primeiro capítulo (foto 2.25 ).

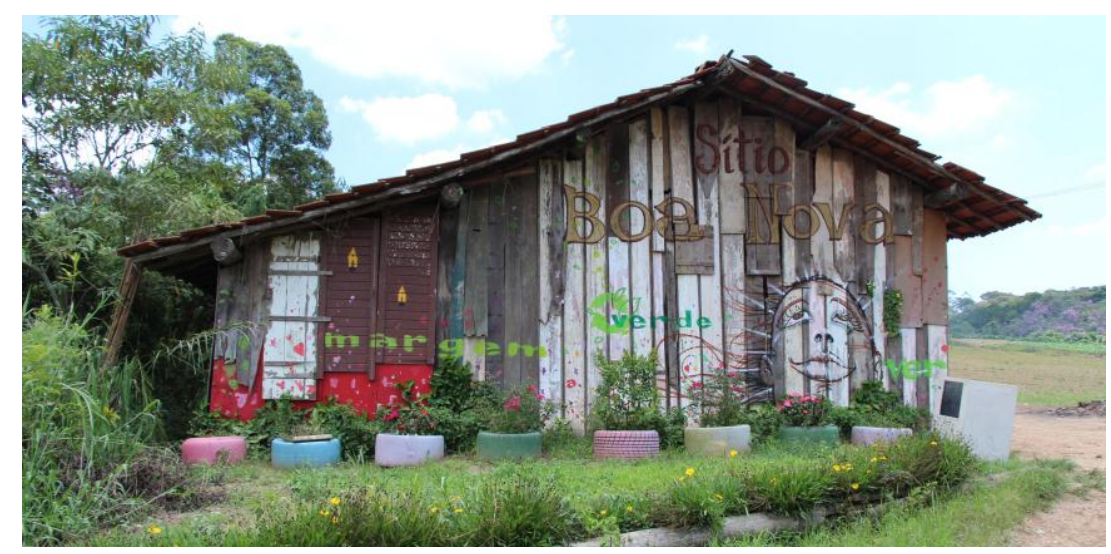

Foto 2.25. Entrada do sítio que Valéria e Daniel arrendavam, no distrito do Grajaú. Foto de 3 de fevereiro de 2015. Crédito da foto: Angélica Campos Nakamura.

\footnotetext{
${ }^{34}$ Entrevista concedida por Valéria Macoratti em seu sítio, localizado no distrito do Grajaú, no município de São Paulo, em 20 de fevereiro de 2015.
} 
Outro que afirma querer se tornar um agricultor é Tiago Arpad Spalding Reiter, o Arpad. Sua vontade de ir trabalhar na roça começou quando fez uma viagem, em 2007, após terminar a faculdade de Geografia, para Moçambique, pois ele tem família lá. Ele diz que passeava pelo campo e achava tudo muito mal aproveitado. Vendo aquilo, achou que podia trabalhar com isso, e tentar fazer uma agricultura mais responsável.

De volta ao Brasil, em 2008 começou um trabalho para o Instituto 5 Elementos. Foi assim que ele conheceu grande parte dos agricultores que hoje estão na Cooperapas, como Valéria, Mauri, Ana do Mel, Dona Massue entre outros. Ele visitava os sítios, batendo de porta em porta. Nas visitas, contava sobre o projeto desenvolvido pelo instituto, voltado para agricultura orgânica e comercialização, financiado pelo Fundo Especial do Meio Ambiente e Desenvolvimento Sustentável (Fema). Os projetos ofereciam cursos variados e acompanhamento técnico. Após explicar, convidava os agricultores a participarem. Foi por meio desses cursos que pequenos grupos se formaram. Esses grupos vieram a formar a Cooperapas, conforme se verá no próximo capítulo.

Dessa forma, Arpad se envolveu com os agricultores da região e conheceu a realidade e as demandas de quem vive no extremo sul do município de São Paulo. Acabou comprando um sítio em Marsilac com mais três sócios, um deles, seu primo Mauro Spalding Monteiro, que também entrou como membro da Cooperapas.

Arpad continua a trabalhar com projetos que surgem, seja pelo Instituto 5 Elementos, seja pelo Instituto Kairós, outro que também participa de projetos pelo Fema. Entretanto, sua intenção é se tornar um agricultor familiar, conforme ele mesmo define, e viver apenas da agricultura. Ele não tem uma produção em quantidade suficiente para conseguir viver apenas da terra, por isso, ainda trabalha com esses projetos que surgem na região.

Outra que vem tentando ganhar a vida com a agricultura orgânica é Mariane Kunze. Mariane é a mais jovem dos entrevistados - nasceu em 1989 - e, na época da entrevista, fazia aproximadamente cinco meses que vinha se dedicando só para a agricultura.

Mariane se formou em Rádio e TV e trabalhou com produção de vídeo até 2015. Em 2014, durante três meses, fez um mochilão para a Europa e, quando retornou, não conseguiu emprego, apenas alguns trabalhos como freelancer.

Durante esse tempo, começou a pensar na agricultura. A família dela possui uma empresa em Parelheiros, e desde criança ela frequenta o local, inclusive aos finais de semana. A família sempre plantou uma horta, mas um dos funcionários é quem era o responsável por cuidar. Ela conta que 
Tinha uma horta da família, tipo uma horta normal [...]. Aí comecei a observar a horta, achei legal. Aí teve uma vez que ele [o funcionário] plantou uma bandeja de alface, 200 pés, aí tinha muito alface. Aí coloquei no Facebook "nossa gente tem muito alface aqui, não quero que estrague, $R \$ 2,00$ cada um, quem quer" e bombou. As pessoas queriam muito, mó [sic] galera perguntando se ia ter sempre. E aí beleza, passou, vendi alguns e fiquei com isso na cabeça. [...] Aí comecei a observar, meu pai começou a falar "por que você não vende orgânico? O mercado tá meio parado, tá tudo meio difícil, as pessoas nunca vão parar de comer, é uma área boa, tá crescendo esse negócio de orgânico [sic]". E eu "não, não, quero trabalhar em Rádio e TV" (informação verbal) ${ }^{35}$.

Em 2015, o pai de Mariane, que faz parte da associação de empresários da região, conheceu Lia Moura, a vice-presidente da Cooperapas. Lia visitou o terreno da família e disse que poderiam desenvolver mais a atividade agrícola para comercialização. Mariane ainda esperou alguns meses, até que em julho de 2015 ela resolveu tentar de vez a agricultura.

Ela tem um funcionário que trabalha "na horta" (foto 2.26) - como ela mesma define a produção a qual possui - mas também está aprendendo sobre agricultura. Tira dúvidas com os funcionários da Casa de Agricultura Ecológica e afirma querer fazer cursos sobre agricultura orgânica. Enquanto isso, ela vai plantando e se descobrindo com a agricultura. De acordo com ela, “O coração já está muito aqui [a entrevista foi feita na propriedade onde está a produção]”. Ela diz que espera ter feito a escolha certa, porém, só o tempo dirá isso.

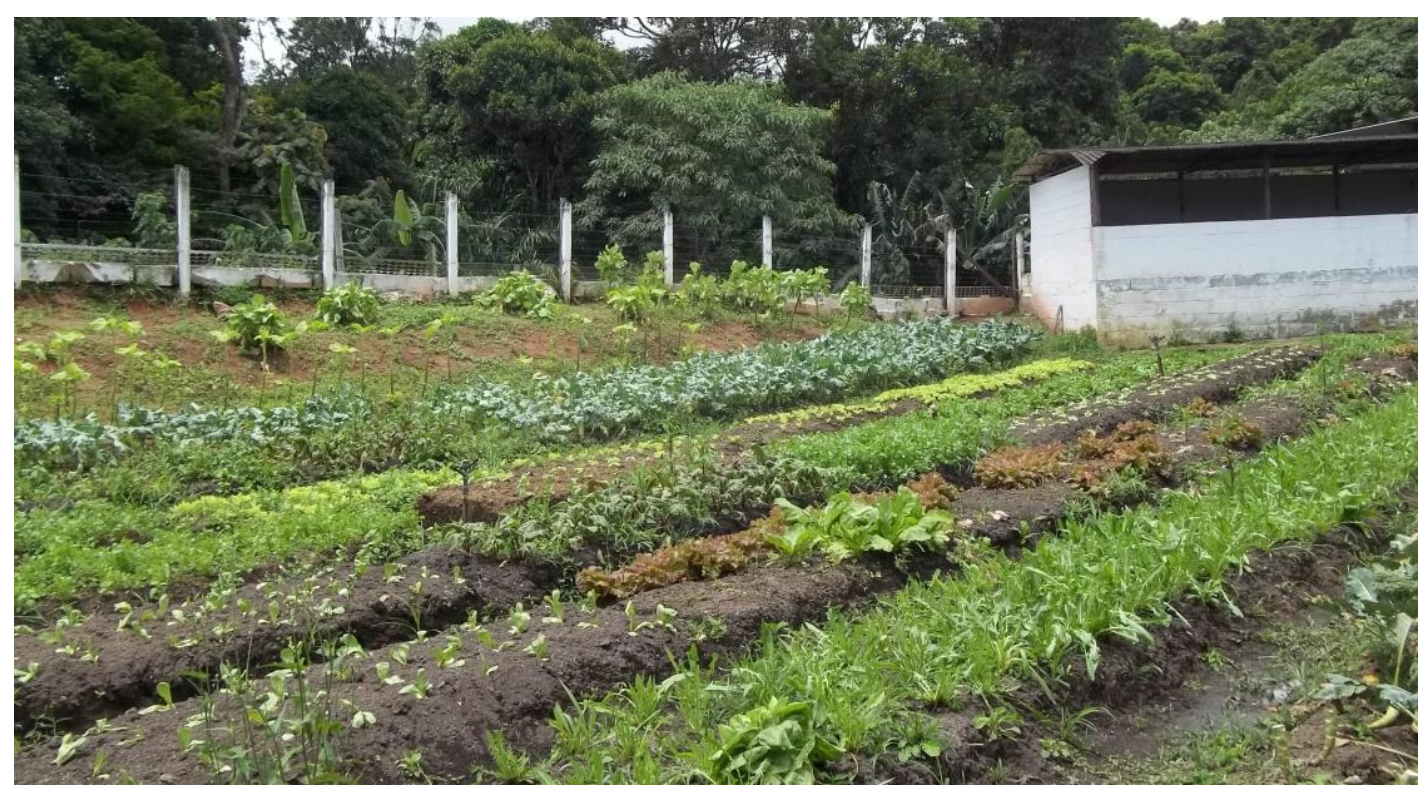

Foto 2.26. A horta com a produção agrícola de Mariane, no distrito de Parelheiros, em 27 de novembro de 2015. Crédito da foto: Angélica Campos Nakamura.

\footnotetext{
${ }^{35}$ Entrevista concedida por Mariane Kunze na propriedade da empresa da família, localizada no distrito de Parelheiros, no município de São Paulo, em 27 de novembro de 2015.
} 
Maria José Kunikawa e Sérgio Milani são irmãos de pais diferentes. Os dois fazem parte da Cooperapas, porém, quem se dedica mais à agricultura é Maria José, conhecida por todos como Tomi.

Eles possuem dois terrenos. Um é voltado totalmente para a agricultura e um caseiro toma conta. Outro, o Sítio Paiquerê, no qual vivem, há uma área com plantação e outra voltada para receber eventos. Esse sítio foi construído pelo padrasto de Tomi, pai de Sérgio, e quando crianças, servia como casa de campo para eles. Quem tomava conta era o avô deles, pai de sua mãe. Tomi, nessa época, já acompanhava o avô pelo sítio. Ele era caseiro e ajudava em um pouco de tudo, inclusive, com a agricultura, pois algumas coisas eram plantadas lá. Ela diz que sempre se interessou, mas nunca trabalhou com isso.

Tomi e Sérgio iam para esse sítio apenas aos finais de semana. Foram morar "na cidade" para estudar. Passaram por bairros diferentes, como Santo Amaro, Perdizes e Higienópolis. Ela estudou administração hospitalar e, ele, administração de empresas e economia.

Já adultos, Tomi conta que uma vez uma professora, de uma escola próxima ao sítio, foi visitar o local e perguntou: "Nossa, mas aqui é tão bonito, não dá pra gente trazer as crianças e fazer um piquenique? "(informação verbal) ${ }^{36}$. O local tem um belo paisagismo e uma área boa e uma infraestrutura com piscina, churrasqueira e salão (foto 2.27). Tomi achou uma boa ideia e, a partir daí, começou a receber escolas e eventos no sítio.

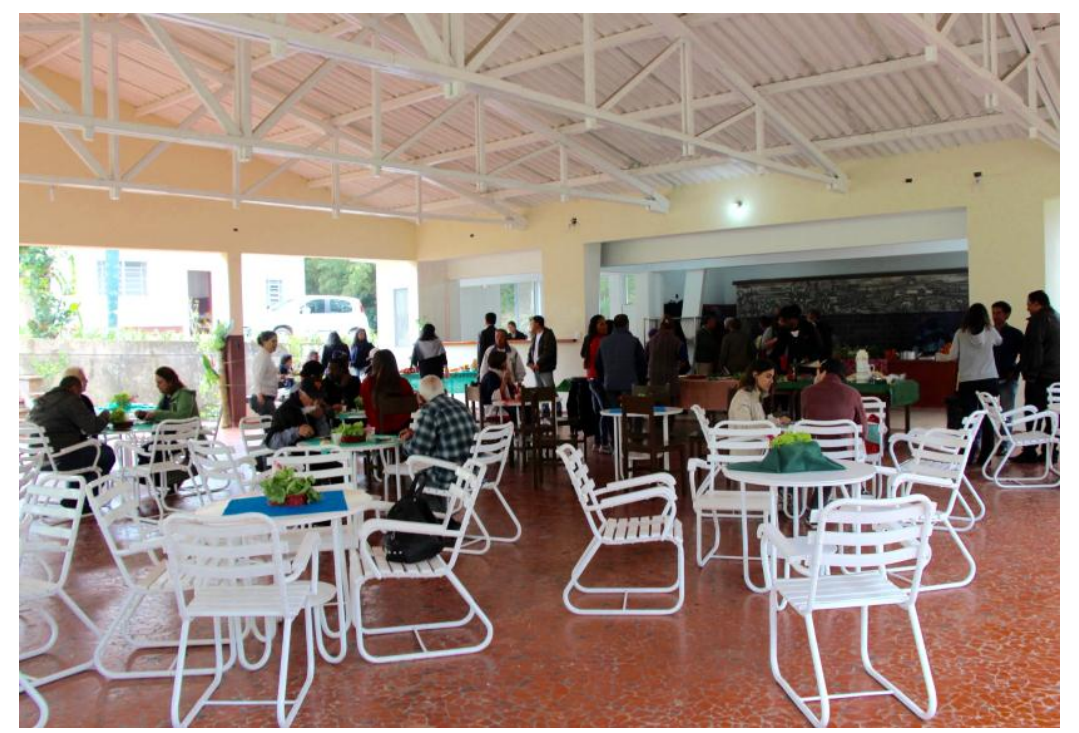

Foto 2.27. O salão com churrasqueira ao fundo para receber eventos no Sítio Paiquerê, no distrito do Grajaú. Foto de 5 de maio de 2015. Crédito da foto: Angélica Campos Nakamura.

\footnotetext{
${ }^{36}$ Entrevista concedida por Maria José Kunikawa em seu sítio, localizado no distrito do Grajaú, no município de São Paulo, em 15 de setembro de 2015.
} 
Sérgio, que é mais responsável por documentação e contratos, sempre participou de reuniões com pessoas da região e nas subprefeituras. Tomi acredita que foi dessa forma que ele conheceu Arpad. Por volta de 2009, ele ligou para Sérgio um dia, convidando-o a fazer um curso sobre agricultura orgânica biodinâmica. Sérgio não quis, mas perguntou se a irmã tinha interesse e ela aceitou.

Assim, Tomi começou a se envolver com a agricultura. Frequentando o curso, que durou de junho a dezembro de 2009, conheceu outras pessoas, como Valéria e Mauri. Hoje, ela acompanha as plantações (foto 2.28), mas não consegue muito plantar, já que ela ainda recebe escolas e eventos no sítio e é diretora financeira da Cooperapas. Tomi e Sérgio cuidam mais da parte de separar, limpar e embalar os produtos agrícolas.

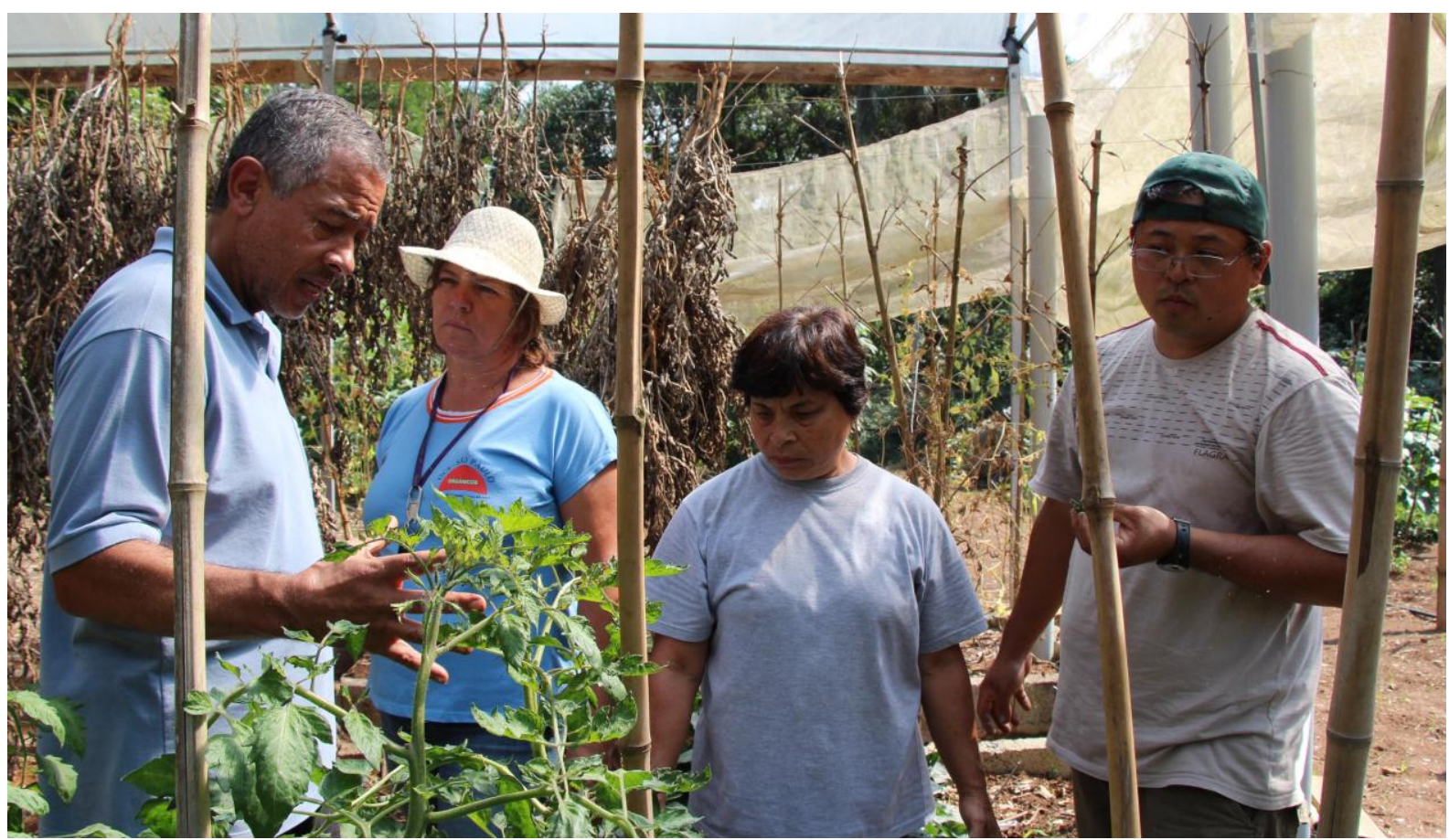

Foto 2.28. Encontro da OCS São Paulo no sítio de Tomi, no distrito do Grajaú. Foto de 23 de março de 2015. Crédito da foto: Angélica Campos Nakamura.

Nelson vive e produz no sítio que era do pai. O pai dele foi um advogado de "grandes indústrias, bem-sucedido" conforme ele relata. Ele comprou o sítio para ser um local de lazer e descanso aos finais de semana - Nelson diz que todo fim de semana seu pai ia com sua mãe para lá, era seu refúgio - e para investir. Lá, ele chegou a criar gado de leite holandês durante cerca de 10 a 15 anos. Largou esse negócio e investiu, por um tempo, na criação de cavalos de salto. Até importou raças da Europa, porém, desistiu depois de alguns anos, pois a produção era cara e dava pouco retorno. 
Nelson nunca havia trabalhado com agricultura. Ele mesmo se define como um empresário, pois se dedicou aos negócios a maior parte de sua vida. Ele conta que

Eu fiz direito, exerci advocacia por 10 anos no escritório do meu pai. Abri uma empresa com outros dois sócios pra dar consultoria pra investidor estrangeiro no Brasil. Tive bastante sucesso também. [...] Estamos falando de [19]90 a 2001. [...] 2002 estava muito difícil de atrair estrangeiro pro Brasil então a gente desistiu, fechamos a empresa (informação verbal) $^{37}$.

Depois de fechar essa empresa, Nelson abriu negócios variados, entre eles, uma empresa de tecnologia de acesso biométrico. Trabalhou alguns anos com isso, até que seu pai ficou doente.

Quando seu pai adoeceu, ele deixou de ir para o sítio. Durante anos, o local ficou largado, a cuidados de um caseiro. Até que por volta de 2007 e 2008, Nelson se dedicou a cuidar e reformar as benfeitorias construídas pelo pai. Finalmente, em 2009, ele se mudou para lá com a mulher. De acordo com ele

Nesse meio tempo, buscando uma vocação pra propriedade, nós [ele e a esposa] nos interessamos pela agricultura orgânica. Eu tinha acabado um negócio, fiquei um período meio de estudos, o que eu ia fazer. Tivemos contato, sempre com o estímulo da minha mulher, Helena, com a Associação de Agricultura Orgânica [AAO]. Começamos a estudar a filosofia da agricultura orgânica, que é muito mais que só agricultura, é um processo de integração da propriedade com a própria natureza, harmonia, relações sociais regulares, legais e comércio justo. Comecei a estudar biodinâmica também e pretendo a chegar biodinâmico, mas acho que tenho que passar muito tempo como orgânico [...] é uma segunda fase (informação verbal) ${ }^{38}$.

Com o incentivo da esposa, Nelson e ela começaram a desenvolver uma horta familiar, sem intuito econômico. Ele diz que "Naturalmente a coisa foi aumentando e resolvemos investir e entrar de cabeça na atividade agrícola" (informação verbal) ${ }^{39}$.

Como entender esses novos agricultores como Valéria, Arpad, Mariane, Tomi e Nelson? É importante destacar que todos esses entrevistados pagam alguém para ajudá-los no trabalho da roça. Porém, conforme pude acompanhar ao longo do trabalho, sempre que preciso, como na falta de algum funcionário, eles também realizam o que for necessário. Ou, responsabilizam-se por alguma etapa da produção, como a limpeza e embalagem dos

\footnotetext{
${ }^{37}$ Entrevista concedida por Nelson Pati em seu sítio, localizado no distrito de Parelheiros, no município de São Paulo, em 2 de outubro de 2015.

${ }^{38}$ Ibidem.

${ }^{39}$ Ibidem.
} 
produtos.

Valéria, Mariane e Tomi, apesar de não terem ajudado ou trabalhado na roça, tiveram um contato próximo com o meio rural. Valéria, quando criança, morou na zona leste do município, em uma época na qual ainda a mancha urbana não havia mudado a paisagem completamente. Ela ainda se lembra de como o bairro era "só mato", do riacho, da escola de madeira. Mariane cresceu indo para a propriedade da família em Parelheiros, na qual sempre plantaram uma horta. Até que começou a olhar com mais interesse para ela. Já no caso de Tomi, seu avô foi caseiro do sítio do padrasto, e ela acompanhava o avô no trabalho. Não morava no sítio, mas acabou voltando para trabalhar no local e, em uma oportunidade que apareceu de realizar um curso, resolveu aprender mais sobre agricultura.

Arpad, como dito, começou a pensar na agricultura quando viajou para Moçambique. Viu, na atividade, uma forma de tentar aproveitar melhor o espaço e seus recursos. Acabou se envolvendo com institutos que trabalham com agricultura na zona sul do município de São Paulo. Comprou um sítio e ainda pretende viver só da terra.

Nelson se envolveu com a agricultura por acaso, ao pensar em uma vocação para seu sítio. Junto com a esposa, começaram a estudar mais sobre a agricultura orgânica e a vê-la como uma possibilidade de realizar uma atividade integradora com a natureza, que busca uma sociedade melhor e um comércio mais justo.

Os personagens até aqui citados não tiveram tanta proximidade com a terra ao longo de suas vidas como Ernesto, Ana do Mel, Zé da Floresta, Zundi e Mauri, por exemplo. Mas o que pode os ter levado a se envolver com a agricultura e o meio rural, a ponto de participarem de uma cooperativa? Uma leitura possível é a feita por Woortmann, o qual busca a ideia de campesinidade.

A leitura de Woortmann também pode ser trazida para compreender melhor os primeiros entrevistados apresentados nesse capítulo e cuja análise se voltou para o campesinato. Afinal, quase todos acabaram indo para a cidade, porém, retornaram para o campo. Woortmann esclarece que sua intenção "não é o de surpreender o campesinato através de sua economia, mas está mais próximo da ideia de uma sociedade camponesa" $(1987$, p. 11, grifo do autor). Para ele, “Transita-se pela ordem econômica para realizar, como fim, a ordem moral e, com ela, a campesinidade" (1987, p. 19). Ainda sobre a perspectiva da campesinidade, ele expõe: 
produção, mas como algo pensado e representado no contexto de valorações éticas. Vê-se a terra, não como natureza sobre a qual se projeta o trabalho de um grupo doméstico, mas como patrimônio da família, sobre a qual se faz o trabalho que constrói a família enquanto valor. [...]

Estou tratando, pois, de valores sociais; não do valor-trabalho, mas do trabalho enquanto um valor ético. Esta tentativa se afasta, portanto, da tendência economicista que vê o campesinato como um modo de produção com sua lógica própria ou como o resultado de determinações impostas pela lógica do capital [...]

Ocupo-me de uma qualidade: a campesinidade, que suponho comum a diferentes lugares e tempos [...]

Prefiro então falar não de camponeses, mas de campesinidade, entendida como uma qualidade presente em maior ou menor grau em distintos grupos específicos.

A campesinidade pode ser apreendida de forma mais clara, em alguns casos, justamente nas situações menos camponesas, de um ponto de vista objetivo (1987, p. 12-13, grifo do autor).

Portanto, a leitura de Woortmann, que se volta para a ideia de campesinidade, não foca no aspecto econômico e, sim, no da ética e moral, pautando-se sobre aspectos como terra, família e trabalho. Ele diz que focaliza

[...] algumas categorias culturais centrais do universo camponês brasileiro, que são também centrais para a reconstrução da ética mais geral que elas representam: trabalho, família, liberdade, além de outras como comida. [...] [...] existem certas categorias comuns às sociedades camponesas em geral, como terra, família e trabalho. [...] Nas culturas camponesas, não se pensa a terra sem pensar a família e o trabalho, assim como não se pensa a terra sem pensar a família e o trabalho, assim como não se pensa o trabalho sem pensar a terra e a família. Por outro lado, essas categorias se vinculam estreitamente a valores e a princípios organizatórios centrais, como a honra e a hierarquia. Pode-se opor esse tipo de sociedade às sociedades modernas, individualizadas e voltadas para o mercado; em outras palavras, pode-se opor uma ordem moral a uma ordem econômica. Neste último tipo de sociedade, as três categorias acima referidas existem, naturalmente, mas elas podem ser separadas umas das outras; a terra não é pensada em função da família e do trabalho, mas em si mesma, como uma coisa, ou como uma mercadoria; a família é também pensada em si, sem relação com o trabalho ou a terra, o mesmo acontecendo com o trabalho, que pode ser pensado como uma abstração, como um "fator" (1987, p. 23, grifo do autor).

Ainda sobre a ideia de campesinidade, ele diz

[...] meu interesse não é dizer que o sitiante é camponês, mas sim extrair de sua fala e dos valores que ela revela uma ética que caracteriza o que chamo de campesinidade, expressão de uma ordem moral. Pessoas de carne e osso são como disse, ambíguas e se movem em dois mundos. [...] Disso resulta que a campesinidade não é uma prisão cultural. Enquanto pessoa concreta, o sitiante não é radicalmente distinto de pessoas "modernas". Afinal, se ele acha que todo comerciante é ladrão, ele sabe, por outro lado, dedicar-se ao 
negócio como prática e sabe investir dinheiro. [...] Se a campesinidade fosse uma prisão [...] a migração dos deserdados para a cidade, migração essa que reproduz o campesinato, resultaria na marginalização daqueles migrantes, e não, como ocorre, em sua ascensão social no meio urbano (1987, p. 69).

Pensar nesses valores justifica a postura de vários dos entrevistados. Nos primeiros casos, cujo passado foi muito mais ligado à terra e à agricultura, alguns tiveram uma postura clara em relação a certos valores. Conforme contavam suas histórias, a proximidade com os pais ou avós, ao acompanhá-los no trabalho na roça, influenciou em muito suas vidas, já que falavam com uma certa nostalgia. Já os novos agricultores, ao entrarem em contato com esse meio camponês e a agricultura, eles passam a incorporar certos valores desse meio. $\mathrm{O}$ trabalho com a terra tem um valor ético. Não à toa, eles buscam práticas agrícolas hoje enxergadas como mais éticas, por respeitar a natureza, o produtor e o consumidor, como a agricultura orgânica, a biodinâmica e a agroecologia.

Woortmann também levanta como a agricultura pode ser uma solução para o presente e uma possibilidade para o futuro:

Inversamente, o apego à tradição pode ser o meio de sobreviver à grande transformação: manter-se como produtor familiar em meio ao processo mais geral de proletarização ou de empobrecimento. A tradição, então, não é o passado que sobrevive no presente, mas o passado que, no presente, constrói as possibilidades do futuro (1987, p. 17).

Essa possibilidade de construção do futuro aparece praticamente na vida de todos eles: Ernesto, Mauri e os filhos de Dona Massue. No caso de Zundi, ele mesmo contou que só "faz tudo isso hoje" - em relação a ir para feiras, construir uma pequena fábrica - para os filhos e netos. Já Ana do Mel, pela sua fala, seu filho mais novo parece ter interesse em continuar com o sítio e a produção da mãe.

Porém, tanto no caso desses primeiros entrevistados, com o passado na terra, e o dos novos agricultores, como Valéria, Arpad, Mariane, Nelson e Tomi, também deve ser pensado em como o urbano influencia, e muito, a vida deles. Aqui, estamos falando de um grupo o qual vive em um município majoritariamente urbano com forte influência cultural urbana, cuja economia é voltada, principalmente, para os serviços, além de ser o centro econômico e financeiro do país. Para eles, não há dificuldades em circular entre o urbano e o rural. As diferenças existem, porém, complementam-se. Pode-se usar todos os serviços oferecidos e disponíveis de uma grande cidade - ainda que estejam em uma área periférica e mais carente da cidade, porém, existe mobilidade para eles, seja com seus próprios carros, seja com o 
transporte público, mesmo mais defasado. Acrescente-se a isso a proximidade desses agricultores com o maior mercado consumidor do país.

Os elementos da vida urbana podem aparecer por meio de objetos como geladeira, micro-ondas, computador etc. Woortmann justifica que esses elementos não tiram o traço camponês dessas pessoas:

A campesinidade, em sua rejeição do negócio e do lucro dele resultante, não significa que camponeses sejam, necessariamente, pobres. Certamente, não são magnatas, mas os colonos do Sul vivem bem e não deixam de ser camponeses por contarem em suas casas com comodidades tais como refrigerador, freezer ou aparelhos de TV [...] (1987, p. 70).

Mas não é apenas pelo consumo dessas "comodidades" que se constata o urbano no rural. Lefebvre vai além, e explica como o urbano invade o rural muito além da morfologia, ou seja, da mancha urbana. O urbano invade o rural, também, por meio de signos, significantes e significados. Isso se materializa pelo consumo de objetos, costumes e um certo modo de vida, no qual tudo se torna mercadoria:

[...] o interesse do "tecido urbano" não se limita à sua morfologia. Ele é o suporte de um "modo de viver" mais ou menos intenso ou degradado: a sociedade urbana. $\mathrm{Na}$ base econômica do "tecido urbano" aparecem fenômenos de uma outra ordem, num outro nível, o da vida social e "cultural". Trazidas pelo tecido urbano, a sociedade e a vida urbana penetram nos campos. Semelhante modo de viver comporta sistemas de objetos e sistemas de valores. Os mais conhecidos dentro os elementos do sistema urbano de objetos são a água, a eletricidade, o gás [...] que não deixam de se fazer acompanhar pelo carro, pela televisão, pelos utensílios de plástico, pelo mobiliário [...] Entre os elementos do sistema de valores, indicamos os lazeres ao modo urbano (danças, canções), os costumes, a rápida adoção das modas que vêm da cidade. E também as preocupações com a segurança, as exigências de uma previsão referente ao futuro, em suma, uma racionalidade divulgada pela cidade (2001, p. 19).

Carlos também aponta como o urbano vai muito além da mancha urbana e da cidade como local de concentração populacional e econômica:

[...] a ideia de urbano transcende a de mera concentração do processo produtivo stricto sensu. O urbano é um produto do processo de produção num determinado momento histórico, não só no que se refere à determinação econômica do processo (produção, distribuição, circulação e troca) mas também as sociais, políticas, ideológicas, jurídicas que se articulam na totalidade da formação econômica e social. Desta forma, o urbano é mais que um modo de produzir, é também um modo de consumir, pensar, sentir; enfim, é um modo de vida (2008, p. 84). 
O papel que o rural adquire diante da visão do urbano, é uma forma da invasão do urbano por meio de signos, significantes e significados que Lefebvre faz referência. Ele explica como:

\begin{abstract}
Muito estranhamente, o direito à natureza (ao campo e à "natureza pura") entrou para a prática social há alguns anos em favor dos lazeres. Caminhou através das vituperações, que se tornaram banais, contra o barulho, a fadiga, o universo "concentracionanista" das cidades (enquanto a cidade apodrece ou explode). Estranho percurso, dizemos: a natureza entra para o valor de troca e para a mercadoria; é comprada e vendida. Os lazeres comercializados, industrializados, organizados institucionalmente, destroem essa "naturalidade" da qual as pessoas se ocupam a fim de traficá-la e trafegar por ela. A "natureza", ou aquilo que é tido como tal, aquilo que dela sobrevive, torna-se gueto dos lazeres, o lugar separado do gozo, a aposentadoria da "criatividade". Os urbanos transportam o urbano consigo, ainda que não carreguem a urbanidade! Por eles colonizado, o campo perde as qualidades, propriedades e encantos da vida camponesa. O urbano assola o campo; este campo urbanizado se opõe a uma ruralidade sem posses, caso extremo da grande miséria do habitante, do habitat, do habitar (2001, p. 117).
\end{abstract}

O campo e a natureza acabam "comprados e vendidos" para o urbano como o espaço do lazer, do descanso, da contemplação. Esse assunto já foi tratado no capítulo 1, com Diegues, que conta como surgiu a ideia romântica do campo e da natureza, o mito da natureza intocada e as correntes que pregam a preservação e a conservação da natureza. Conforme ele esclarece, todas essas ideias tiveram origem no urbano, com a Revolução Industrial e o desenvolvimento das cidades.

Essa forma de enxergar o campo está presente, de maneira geral, na fala dos entrevistados. A ideia de conservação da natureza é muito forte entre os membros da Cooperapas e esse é um dos motivos de buscarem uma agricultura "limpa", ou seja, sem insumos químicos, além de conseguirem vender por preços melhores seus produtos agrícolas.

Outro ponto, é a busca de um lugar para viver, que seja mais próximo da natureza, tranquilo, com menos poluição e qualidade de vida na visão desses entrevistados. E essa forma de enxergar o campo não está presente apenas na fala dos membros que vieram "da cidade". Membros com um passado camponês também exaltam como é bom viver na roça, afirmando que estão mais perto da natureza e que ali têm mais qualidade de vida por respirar um ar mais puro, beber uma água limpa e produzir alimento sem veneno, ainda que tenham vizinhos próximos produzindo com agrotóxico. Um deles, Mauri, durante a visita em seu sítio, enquanto apresentava a área, falava da bela paisagem que circunda o terreno e como é 
bom observá-la enquanto se descansa sob a sombra de uma árvore (foto 2.29).

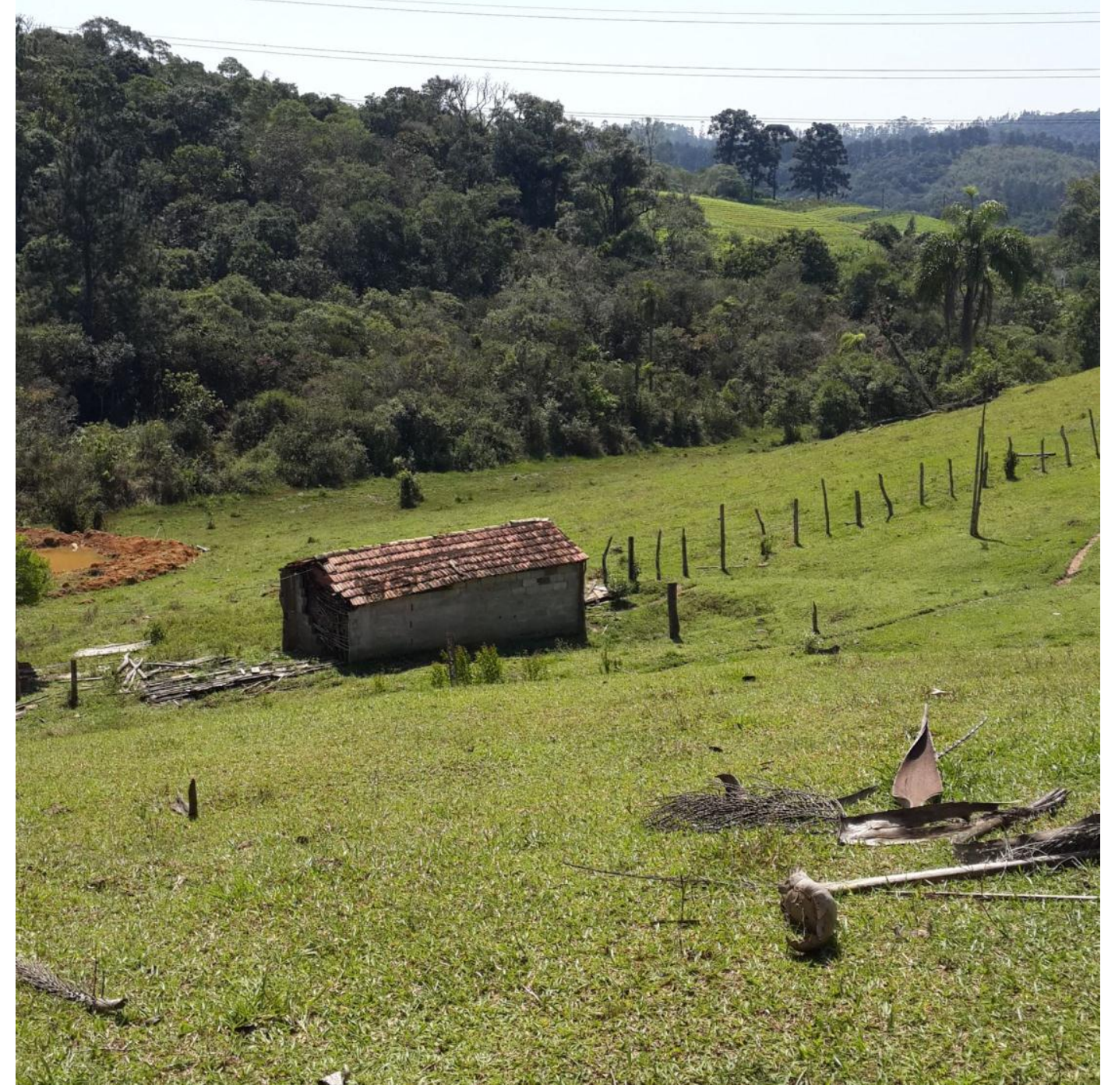

Foto 2.29. Paisagem rural no entorno do sítio de Mauri, no município de Embu-Guaçu. Foto de 16 de setembro de 2015. Crédito da foto: Angélica Campos Nakamura.

Sobre os novos agricultores, portanto, não se trata somente de vê-los como uma categoria de trabalho. Eles vão para o campo com seus valores urbanos, em busca de uma vida mais próxima da natureza. Ainda, todos esses, buscam práticas agrícolas tidas como mais corretas para o meio ambiente e as pessoas.

Aqui, vale ressaltar também a campesinidade proposta por Woortmann, derivada de uma moral e ética camponesa. Para os citadinos, o campo significa uma proximidade maior com a natureza, o respeito com ela e, nesses casos, a realização de uma atividade que respeita a terra e gera alimento, elemento essencial para a vida humana. Valéria, nas reuniões da Cooperapas, sempre gosta de lembrar que os agricultores ali não produzem só alimento, mas 
também água, outro elemento crucial para a vida humana, pois a região abriga mananciais que abastecem o município de São Paulo.

Portanto, para compreender quem são esses produtores da Cooperapas, em um primeiro momento, é muito fácil classificá-los como agricultores familiares. Porém, em uma análise mais aprofundada, percebe-se como o grupo é heterogêneo. Há uma parcela desses cooperados com origens na terra e que cresceram ajudando seus pais. Em suas falas, identificam-se elementos da produção camponesa, como: a propriedade da terra que não visa a exploração e, sim, o sustento da família; o trabalho familiar; a propriedade dos meios de produção; a socialização camponesa; a força de trabalho assalariada; o trabalho acessório.

Outros, vieram "da cidade" e acabaram se envolvendo com a agricultura mais tarde em suas vidas, e os motivos são os mais variados: a busca por uma proximidade com a natureza, a vontade de mudar de vida, o desejo de fazer uma atividade que gere dinheiro para viver e seja responsável e útil na sua visão.

Nas entrevistas realizadas, foi possível perceber como todos valorizam a agricultura orgânica, porque a enxergam como uma atividade com grande importância para a sociedade e o meio ambiente, seja para a alimentação e saúde das pessoas, seja para a preservação dos mananciais e dos resquícios de Mata Atlântica presentes na região.

Também é preciso ressaltar a influência e a relação muito próxima com o urbano. Essa realidade cria muitas possibilidades para esses agricultores, como a comercialização e a proximidade maior com serviços variados, como universidades e hospitais. A acessibilidade nem sempre é boa, pois enfrentam estradas de terra que nas épocas de chuva chegam a ter pontos quase intransitáveis, e o transporte público ainda é pouco. A distância e o trânsito que enfrentam também tornam mais cansativa a ida "à cidade", porém, eles não precisam sair do município - os que vivem em Embu-Guaçu estão muito próximos de São Paulo também.

Assim, tentar compreender esses agricultores pelo viés da agricultura familiar pode ser possível na visão de alguns pesquisadores, e até uma saída mais prática, já que todos se encaixam dentro dessa categoria. Contudo, ao se esmiuçar mais de perto a vida dessas pessoas, os elementos da produção camponesa estão presentes em suas falas e suas práticas, além de ser possível perceber uma ética e uma moral camponesa, definida por Woortmann como campesinidade. Essa campesinidade, porém, não fica restrita ao campesinato. Os novos agricultores, em contato com esse meio na nova profissão, também incorporam tais valores e éticas.

Falar sobre campesinato e campesinidade no município com a maior metrópole do país pode parecer um tanto contraditório, porém, é importante destacar que o 
[...] urbano tornou-se, assim, maior que a cidade e que o campo, tornou-se sua síntese contraditória. Mas essa síntese contraditória não eliminou a cidade nem o campo. As suas relações tornaram-se mais complexas. Um não pode ser entendido sem o outro (OLIVEIRA, 2004, p. 44).

Ainda que urbano e rural sejam contraditórios, eles em nenhum momento se eliminam. Portanto, para esse grupo, viver próximo da metrópole paulistana, na verdade, em nenhum momento os elimina como camponeses ou impossibilita um modo de vida mais próximo do campesinato. Pelo contrário, cria-se para eles mais possibilidades de integração e interação com o urbano, que se dá por meio do uso de equipamentos públicos, de políticas públicas voltadas para esse grupo e da comercialização com o maior mercado consumidor do país. Esses dois últimos aspectos tiveram um peso muito forte para a criação de uma cooperativa, a Cooperapas, conforme se verá no próximo capítulo. 
3. O COOPERATIVISMO: DAS ORIGENS À PRÁTICA DA COOPERAPAS 


\subsection{Cooperapas: como surge uma cooperativa de agricultores no município de São Paulo}

Desde 9 de junho de 2011, o município de São Paulo conta com uma cooperativa agrícola, a Cooperativa Agroecológica dos Produtores Rurais e de Água Limpa da Região Sul de São Paulo (Cooperapas). Ela é a única cooperativa de agricultores do município e, no início de 2016, contava com 28 cooperados, todos da região do extremo sul do município, que engloba os distritos de Grajaú, Parelheiros e Marsilac. Porém, há também cooperados de municípios vizinhos a esses distritos (mapa 3.1, na página a seguir).

Apesar de existir desde 2011, a Cooperapas só conseguiu iniciar suas vendas coletivas em 2015. Para se alcançar esse ponto, um longo caminho foi percorrido pelos cooperados, mas tanto são ainda os desafios para que essa comercialização em grupo se fortaleça e se efetive de verdade.

A compreensão do momento vivido pela Cooperapas, até meados de 2016, só é possível ao se recapitular sua história e sua formação. As versões dadas pelos entrevistados, sejam dos cooperados ou dos funcionários da Casa de Agricultura Ecológica (CAE) José Umberto Macedo Siqueira - localizada na Subprefeitura de Parelheiros - variam um pouco. Porém, é possível perceber em suas falas que, até se iniciarem as políticas públicas voltadas para a comercialização, como o surgimento de feiras livres orgânicas municipais conforme contado no capítulo 1, vivia-se um momento de muitas expectativas por parte desses produtores agrícolas, para que conseguissem vender para o mercado consumidor de produtos orgânicos no município de São Paulo.

Um dos cooperados, Zundi Murakami (informação verbal) ${ }^{1}$, conta que por volta de 2010:

Ah, Cooperapas quem começou fui eu! Eu tava entrando orgânico, nós não tinha certificação [sic], não tinha onde vender. Quem começou o Cristianó2, agrônomo, e eu. Aí nós andamos pra vender na escola, em umas cinco escolas [...] mas não deu pra concretizar porque não queriam picadinho, queriam o lote todo, arroz, feijão, tudo de uma vez só. Mas não tinha essa estrutura [...] Por isso que formou uma cooperativa [...]

\footnotetext{
${ }^{1}$ Entrevista concedida por Zundi Murakami em $1^{\circ}$ de outubro de 2015, na Feira Biodinâmica, realizada em Santo Amaro, na zona sul do município de São Paulo.

${ }^{2}$ Cristiano Mendes, já citado no capítulo 1, é engenheiro agrônomo e funcionário da Supervisão Geral de Abastecimento (Abast) da Prefeitura de São Paulo. Na época, trabalhava na CAE em Parelheiros.
} 


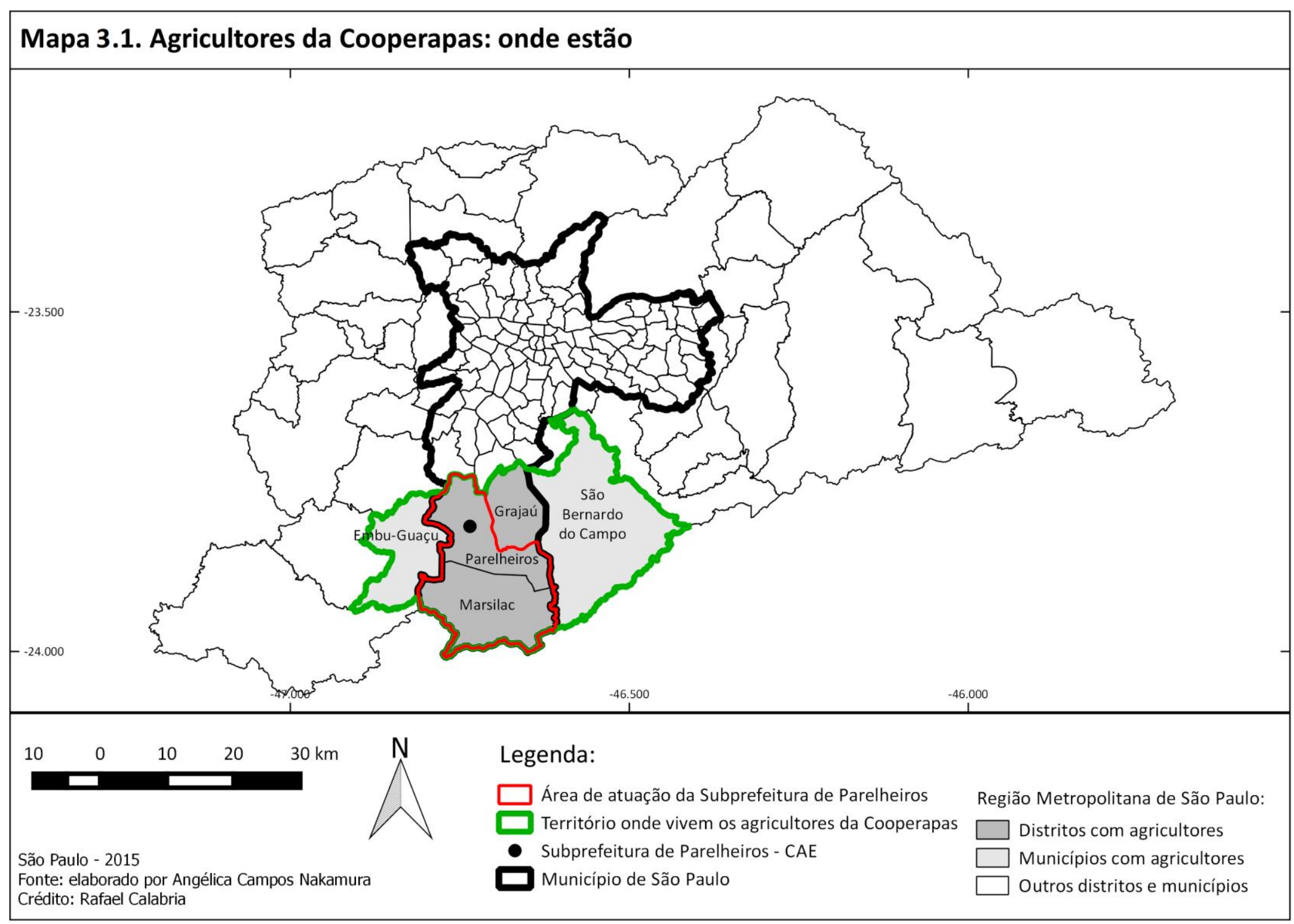


Já outra cooperada, Ana Zilda Coutinho (informação verbal) ${ }^{3}$, conhecida entre todos os cooperados e funcionários da CAE como Ana do Mel, afirma que a Cooperapas surgiu da necessidade de aumentar o tamanho de um grupo que se constituiu a partir de uma extensão universitária da Incubadora Tecnológica de Cooperativas Populares da Universidade de São Paulo (ITCP-USP), o Grupo Cultivar ${ }^{4}$, por volta dos anos de 2008 e 2009. De acordo com ela, outros agricultores os quais não faziam parte desse grupo, queriam entrar para trocar experiências sobre agricultura orgânica e agroecológica, além de conseguirem locais interessados em comprar produtos orgânicos.

Arpad (informação verbal) ${ }^{5}$, cooperado e funcionário do Instituto Kairós também citado no capítulo 1, relembra que por volta do ano de 2010, já existiam pequenos grupos formados devido a projetos desenvolvidos anteriormente na região. Um desses projetos era o citado por Ana do Mel, o Grupo Cultivar (figuras 3.1 e 3.2), composto por cerca de sete agricultores ${ }^{6}$.

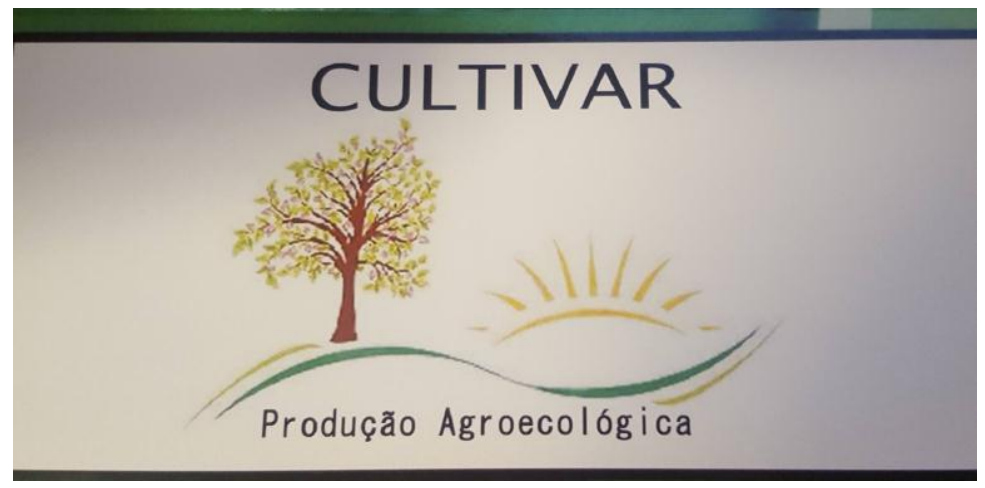

Figura 3.1. Capa de folder do Grupo Cultivar.

\footnotetext{
${ }^{3}$ Entrevista concedida por Ana Zilda Coutinho em seu sítio, no município de Embu-Guaçu, em 20 de janeiro de 2015.

${ }^{4}$ O Grupo Cultivar tinha como objetivo desenvolver "por meio de encontros participativos e do trabalho coletivo, uma rede de produção agroecológica no extremo sul paulistano. Destacam-se como resultados dessa parceria a resignificação e o resgate de valores e práticas rurais tais como solidariedade e cooperação, o autoreconhecimento dos agricultores enquanto trabalhadores dignos e fundamentais às cidades, e a consolidação de uma rede de consumo calcada nos princípios do comércio justo e solidário" (MARCELINO, Lucimara et al., 2009).

${ }^{5}$ Entrevista concedida por Tiago Arpad Spalding Reiter, em seu sítio, localizado no distrito de Marsilac, no município de São Paulo, em 27 de novembro de 2015.

${ }^{6}$ É interessante destacar que antes do surgimento do Grupo Cultivar, já haviam acontecido outras iniciativas da ITCP-USP na região de Parelheiros. Entre 2007 e 2010, realizou-se o projeto "Mãosementes conectadas: construindo a rede colaborativa agroecológica de Parelheiros", por meio de financiamento do CNPq e do extinto Ministério do Desenvolvimento Agrário (MDA), em parceria com o Laboratório de Geografia Agrária do Departamento de Geografia da Faculdade de Filosofia, Letras e Ciências Humanas (FFLCH) da USP. Este projeto, ainda, foi fruto de um anterior, denominado "Hortas Solidárias". No projeto "Mãosementes conectadas", um engenheiro agrônomo acompanhava as propriedades e oficinas eram realizadas, em esquema de rodízio entre os agricultores. O trabalho das oficinas era feito em mutirão (ITCP, 2013).
} 


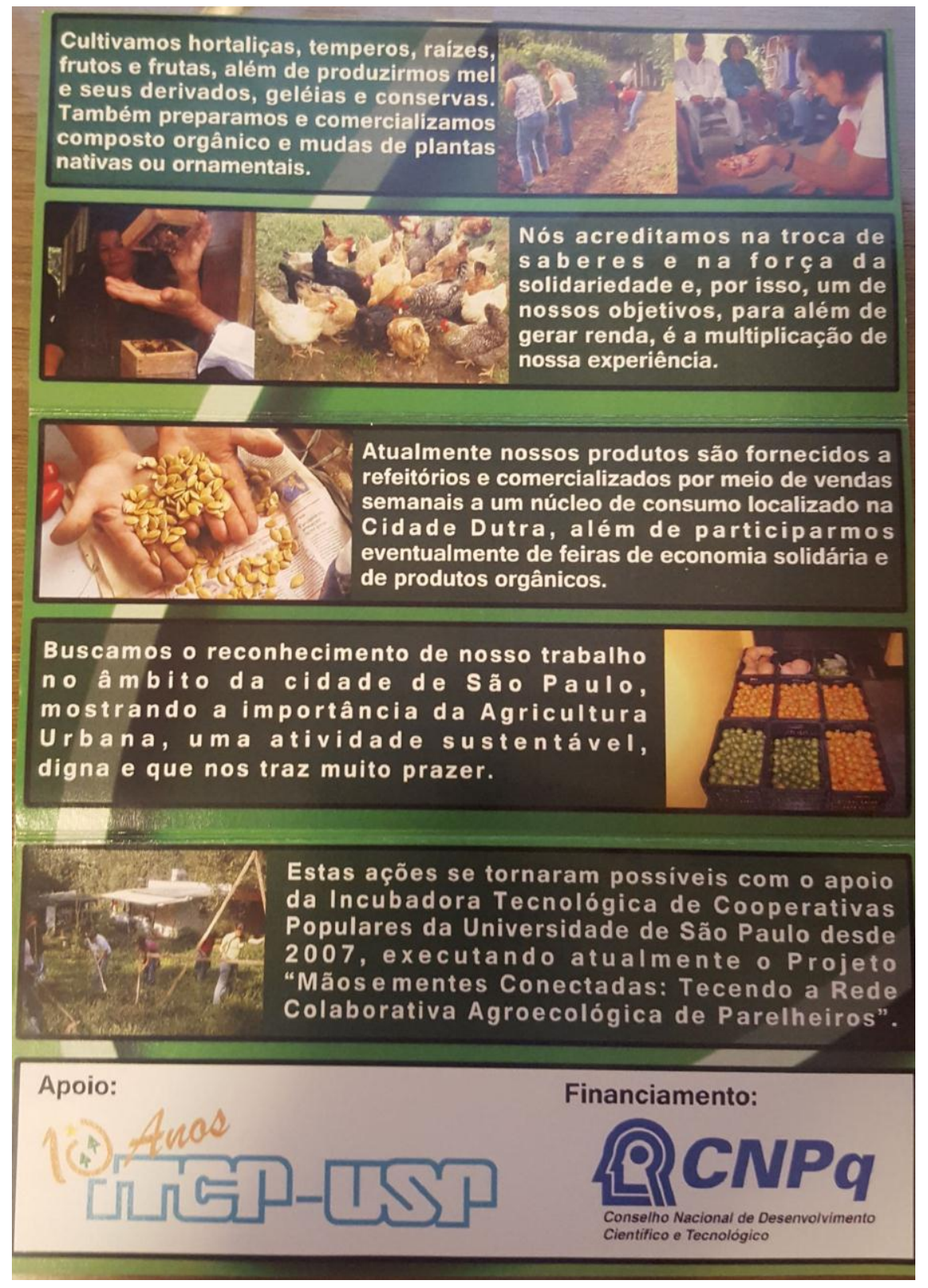

Figura 3.2. Folder do Grupo Cultivar, com as atividades e objetivos do grupo.

Outro grupo foi resultado de um projeto realizado pelo Instituto 5 Elementos em 2008, também financiado pelo Fundo Especial de Meio Ambiente e Desenvolvimento Sustentável (Fema). De acordo com Arpad, que trabalhou como coordenador para o instituto na época, o projeto do Instituto 5 Elementos consistia em dar assistência a um grupo de 10 a 15 agricultores, oferecendo cursos de agricultura orgânica e biodinâmica, visitas a uma fazenda de produção orgânica no interior do estado de São Paulo e em feiras orgânicas, bem como ajuda na comercialização de produtos orgânicos que, na época, tinha pouca procura e locais 
para venda. O Fema ainda financiou um outro projeto realizado pelo Instituto Pedro Matajs ${ }^{7}$ para cerca de 10 agricultores, o qual deu origem a mais um dos grupos citados por Arpad.

Apesar de os agricultores participarem de diferentes grupos, parte deles acabavam frequentando reuniões e cursos oferecidos por projetos diferentes dos seus. Normalmente, esses eventos não eram restritos a apenas os agricultores inscritos no projeto. Assim, aos poucos, eles foram se conhecendo e formando uma rede entre si.

Após o fim dos projetos, os quais duraram cerca de um ano e meio, Arpad conta que os grupos continuaram a se reunir e ele, mesmo desempregado, continuou a ir para Parelheiros se encontrar com os agricultores e acompanhá-los em suas reuniões. $\mathrm{O}$ ano era de 2010. Foi aí que nasceu um grupo que, para Arpad, foi a "sementinha da Cooperapas":

[...] a gente montou um grupo que chamava "Orgânicos das APAs", que era um grupo de agricultores que envolvia a Cultivar também. Todo mundo era junto, discutia coisa junto [...] fazia reunião de vez em quando. Então a gente manteve isso, pra além do grupo do projeto. Foi um grupo ampliado. Aí com esse grupo ampliado que surgiu a ideia de montar a cooperativa. Então juntou o Cultivar com o "Orgânicos das APAs" e mais outros agricultores que eram assistidos pela Casa de Agricultura (informação verbal) ${ }^{8}$.

Em meio a todos esses projetos ocorrendo, a Casa de Agricultura na Subprefeitura de Parelheiros também realizava visitas a sítios e acompanhava tudo o que acontecia. Até 2010, a CAE estava subordinada à Subprefeitura de Parelheiros e possuía um único funcionário. A partir desse ano, a Prefeitura de São Paulo passou a CAE para a Supervisão Geral de Abastecimento e colocou uma equipe com cinco pessoas para trabalhar. Entre elas, estava o engenheiro agrônomo Cristiano Mendes, citado por Zundi Murakami, e que o ajudou a buscar locais para venda e acabou por ser um dos incentivadores a formar uma cooperativa.

Mendes recorda do trabalho dessa época. Ele conta que existiam os projetos financiados pelo Fema os quais aconteciam pela região, e um trabalho paralelo da Casa de Agricultura. Além de acompanhar o que acontecia nos projetos, a CAE dava suporte técnico a alguns agricultores. Ele explica que (informação verbal) ${ }^{9}$

\footnotetext{
7 “O Instituto Pedro Matajs é uma organização não governamental, fundada em 20 de junho de 2004, tem grande preocupação com a preservação ambiental e com a melhoria da qualidade de vida dos moradores da comunidade local, que fazem uso dos recursos naturais" (INSTITUTO PEDRO MATAJS, 2016).

${ }^{8}$ Entrevista concedida por Tiago Arpad Spalding Reiter, em seu sítio, localizado no distrito de Marsilac, no município de São Paulo, em 27 de novembro de 2015.

${ }^{9}$ Entrevista concedida por Cristiano Mendes, na Supervisão Geral de Abastecimento (Abast) em São Paulo, em 14 de setembro de 2015 .
} 
Nós como Prefeitura atuamos como política pública permanente, tem outros instrumentos. Trabalhamos juntos em todos os projetos. [...] A gente não tinha como dar conta de todo esse pessoal, porque era tudo inicial. Sempre foi junto, ambos se auxiliando, nunca se sobrepondo. A gente continua com essa lógica, os projetos vêm fortalecer algum campo específico. Não tem concorrência.

A maioria dos agricultores que participaram dos projetos ou tinham apoio da CAE, ou foram encontrados por meio do "batendo de porta em porta". Tanto Arpad, como Mendes, contam que circularam muito por Parelheiros e Marsilac à procura de agricultores. Arpad diz que "onde tinha roça, ele parava". Os agricultores os quais não estavam em nenhum projeto foram definidos por Mendes como "mais alguns produtores perdidos aí, principalmente pessoais da ornamentais [sic]”.

Mendes relata que, na época, todos esses agricultores ou estavam em transição, ou seja, deixando a produção convencional para começar a de orgânicos, ou começando uma produção de orgânicos. O maior desafio, para eles, era encontrar um mercado disposto a comprar seus produtos, ainda que em transição. Além disso, não existia volume de produção. Todos esses agricultores eram pequenos produtores, fato já levantado por Zundi Murakami em sua fala. Ou seja, a comercialização era um grande entrave. Mendes conta mais detalhadamente:

Não tinha organização nenhuma [para fazer a comercialização]. Era um produtor numa feira... Era muito complicado, trabalhar individualmente. [...] Eles também começaram a ver, para comercializar nem sempre tinham produção suficiente. Não tinha essa interação entre os produtores de forma mais organizativa. Muitos tinham dificuldade de nota [fiscal]. Mas o pessoal tinha também muita resistência com esse negócio de cooperativa porque muitos tinham sido da Cotia [Cooperativa Agrícola de Cotia $-\mathrm{CAC}^{10}$ ] $e$ estavam meio traumatizados. O pessoal que era mais antigo tinha essa resistência. Só que o pessoal mais novo já estava querendo. [...]

A gente começou esse diálogo junto com esses produtores, 'precisa se organizar'. Aí uma associação? Uma associação atende? Não. Tem uma limitação para comercializar. Será que não rola uma cooperativa? Tinha uma vontade de se inserir nesses programas, PAA [Programa de Aquisição de Alimentos], merenda [do Programa Nacional de Alimentação Escolar Pnae]. [...] (informação verbal) ${ }^{11}$.

\footnotetext{
${ }^{10}$ A CAC chegou a ser considerada a mais importante cooperativa da América do Sul, cujo número de membros alcançou16.309 pessoas, e foi até desmembrada em várias cooperativas de segundo grau (PINHO, D., 2004, p. 25). Devido ao cenário econômico negativo na década de 1990, em 1994 ela encerrou suas atividades, levando muitos produtores à falência. Mais detalhes a respeito dela serão tratados ao longo do capítulo.

${ }^{11}$ Entrevista concedida por Cristiano Mendes, na Supervisão Geral de Abastecimento (Abast) em São Paulo, em 14 de setembro de 2015 .
} 
Conforme as conversas iam ocorrendo entre os agricultores e os técnicos da CAE, especialmente com Mendes, a vontade de criar uma cooperativa foi se fortalecendo. Até que finalmente uma assembleia foi marcada, durando o dia inteiro, com o intuito de criar a Cooperapas. Mendes relata que foi feito de tudo para facilitar a criação da cooperativa. A Supervisão Geral de Abastecimento (Abast) pediu para seu advogado assinar o estatuto e seu contador ajudar com a abertura da cooperativa, dando entrada no CNPJ e na inscrição estadual, entre outros documentos necessários.

Porém, uma das etapas necessárias para se criar uma cooperativa é realizar a integralização do capital. Essa integralização se dá pelo pagamento de quotas-partes - que pode ser em uma ou mais parcelas - por cada um dos cooperados, ou seja, cada um dos integrantes deve despender uma certa quantia, determinada pela cooperativa, a fim de formar um capital inicial. Esse capital é importante porque

Para tornar possível a manutenção e promover o desenvolvimento dos serviços que a empresa cooperativa deve prestar aos associados, é preciso incentivar a capitalização, pois como donos da sociedade os cooperados devem assumir de fato esta condição e aplicarem capital na empresa que lhes pertence, para investir, fortalecer o capital de giro e evitar a dependência de capital de terceiros (OCESP, 2016).

Ou seja, no começo, uma cooperativa dificilmente obterá divisas para pagar suas contas, daí a necessidade da integralização desse capital. Entretanto, a história da Cooperapas foi diferente. Não houve a formação de um capital inicial por parte dos cooperados e, sim, uma doação. Mendes conta que

Agora não me lembro quem é que foi, mas teve uma doação de uns $R \$$ 2.000,00 para as quotas-partes para eles não terem esse custo também. Então eles começaram com esse capital. [...] Esse recurso ajudou com algumas coisas que precisava pagar, cartório.... (informação verbal) ${ }^{12}$.

Mendes não foi o único questionado sobre a origem do dinheiro. Ao longo do desenvolvimento dos trabalhos de campo e entrevistas, quase ninguém soube afirmar de onde ou de quem veio esse capital inicial (grifo nosso). Alguns dos entrevistados afirmaram que o dinheiro veio de uma doação do próprio bolso do supervisor da Abast na época, José Roberto Graziano.

\footnotetext{
${ }^{12}$ Entrevista concedida por Cristiano Mendes, na Supervisão Geral de Abastecimento (Abast) em São Paulo, em 14 de setembro de 2015.
} 
Ao se levantar como a Cooperapas surgiu, é possível compreender melhor uma outra percepção dessa história, dada por Ernesto Oyama. Ele era um dos "produtores perdidos" indicado por Mendes, pois não participava de nenhum projeto. Seu sítio foi encontrado por meio dos trabalhos de campo realizados pelos técnicos da Casa de Agricultura. Acabou sendo trazido pela CAE para as reuniões e encontros que ocorriam entre os grupos já formados, derivados dos programas financiados pelo Fema. Ernesto relembra

[...] foi um lance de política, foi da política que nasceu a Cooperapas. Eles querem deixar em pé de qualquer jeito porque foram eles que lançaram, mas o agricultor não ajuda. Pelo menos pra mim não foi um pedido dos agricultores de formar a cooperativa. Chamaram pra fazer um curso de cooperativismo, umas 20 pessoas mais ou menos, aí a gente fez esse curso por uns 3 meses, uma vez por semana. Era sempre o mesmo grupo. Umas 3, 4 horas por dia de curso. Quando era pra gente fazer a viabilidade econômica de se construir a cooperativa, cortaram essa parte e foram direto para fazer uma assembleia geral e montar a cooperativa.

$\mathrm{Na}$ verdade, a cooperativa tem que nascer de uma pequena associação. Um tem que conhecer o outro. E trabalhar essa coisa de grupo, que não foi trabalhada no começo da cooperativa.

A CAE tenta empurrar isso, eles querem que a cooperativa fique nos trinque, mas precisa que os agricultores ajudem nisso. [...]

$O$ agricultor tem que ter na cabeça que ele faz parte de uma empresa. Ele tem que saber quais são os direitos e os deveres dele. Mas eles só querem os direitos e não querem fazer nada (informação verbal) ${ }^{13}$.

Ernesto ressalta que os futuros cooperados deveriam se conhecer melhor antes, montar uma associação, para daí chegarem na cooperativa. Nota-se no discurso dele como o fato de ser um dos "produtores perdidos" influenciou no seu entendimento da história da formação da Cooperapas. A maioria dos cooperados já era proveniente de um grupo constituído para um projeto. Ernesto era uma das exceções. Contudo, a avaliação de Ernesto a respeito da formação da Cooperapas não é equivocada. Existiam diferentes grupos de agricultores, porém, de distintos projetos, que foram juntados para a constituição da cooperativa.

Cristiano Mendes não discorda de a Cooperapas também ter nascido por influência da Prefeitura de São Paulo, mas rebate a percepção de Ernesto em sua fala:

A gente tinha realmente uma necessidade na Prefeitura por conta desses programas [do governo federal, como Pnae e PAA]. Mas a gente jamais quis impor qualquer coisa. Cooperativa você não chega lá, faz uma canetada, se isso não vier deles. Então a gente mostrou pra eles: 'ó, existem várias possibilidades aqui, de comercialização, tem PAA, tem a merenda, vocês como instituição, a gente tem como apoiar instituições também,

\footnotetext{
${ }^{13}$ Entrevista concedida por Ernesto Oyama, na Casa de Agricultura Ecológica, na Subprefeitura de Parelheiros, em São Paulo, em 19 de janeiro de 2015.
} 
legalmente constituídas. Então, pro nosso trabalho aqui, pra ajudar vocês, é interessante. Se pra vocês também for, então beleza'. [...] Então foi um pouco isso. A gente deu a possibilidade, mostrando a necessidade, mas a gente não forçou nada, isso eu posso garantir, porque eu estava lá e a gente sempre deixou muito claro. Que a gente puxou mesmo, como eles estavam desorganizados, alguém tinha que organizar. [...]

Não era a solução ideal, a gente prefere que esses grupos se constituam sozinhos. Foi o que foi possível na época. Mas foi mais nesse sentido mesmo, de assistência técnica, de assessoria [sobre a ajuda dada pela CAE]. Nunca decidimos nada por ninguém.

O negócio não foi "bonitinho", foi nos espaços que já estavam constituídos. O conselho gestor da APA [Ärea de Proteção Ambiental] tinha uma técnica de agricultura, existia as reuniões dos grupos, surgia nas discussões as demandas, a gente ia fazer palestra sobre PAA, crédito rural, aí surgia a demanda. Até que decidiram fazer (informação verbal) ${ }^{14}$.

Apesar de Mendes afirmar que não houve pressão por parte da Prefeitura para a criação da Cooperapas, é inegável o interesse do poder público para se criar uma cooperativa naquele momento. Afinal, houve uma doação de dinheiro para que os membros não tivessem que entrar com quotas-partes na criação da Cooperapas e, ainda, houve a ajuda gratuita de um contador e um advogado, funcionários da Prefeitura, para ajudar na parte burocrática e de legislação, como a criação do estatuto e a entrada do CNPJ na Receita Federal.

Assim, a Cooperapas surge em um momento de convergência de interesses: os agricultores da região em transição para a produção orgânica, que buscavam mercado para a venda de seus produtos, queriam um meio de conseguir mercado para realizar essa comercialização. Um dos meios era pelos programas federais, o Programa de Aquisição de Alimentos (PAA) e o Programa Nacional de Alimentação Escolar (Pnae). Porém, para se ter acesso a eles, os agricultores precisavam fazer parte de uma cooperativa. Além dos programas, por meio da cooperativa, eles poderiam obter volume de produtos para a venda, quesito exigido por certos locais de compra. Junte-se a isso o interesse da Supervisão Geral de Abastecimento (Abast) da Prefeitura de São Paulo de ter agricultores dentro do próprio município participando do PAA e do Pnae. Também é importante ressaltar o contexto apresentado ao longo do capítulo 1, que vem com o interesse do poder público, municipal e estadual, em desenvolver uma agricultura com menos agrotóxicos ou livre deles no município de São Paulo, e o incentivo dado a isso por meio do Programa Agricultura Limpa e do Protocolo de Boas Práticas Agrícolas. Consequentemente, despontam políticas públicas voltadas para a comercialização de produtos orgânicos e as feiras orgânicas municipais começam a surgir.

\footnotetext{
${ }^{14}$ Entrevista concedida por Cristiano Mendes, na Supervisão Geral de Abastecimento (Abast) em São Paulo, em 14 de setembro de 2015.
} 
Desse modo, nasceu a Cooperapas em junho de 2011 (foto 3.1), após uma assembleia cansativa, realizada o dia inteiro, como recorda Mendes. A partir dali, porém, a Cooperapas enfrentou muitos problemas e só em 2015 conseguiu, finalmente, começar sua comercialização em grupo.

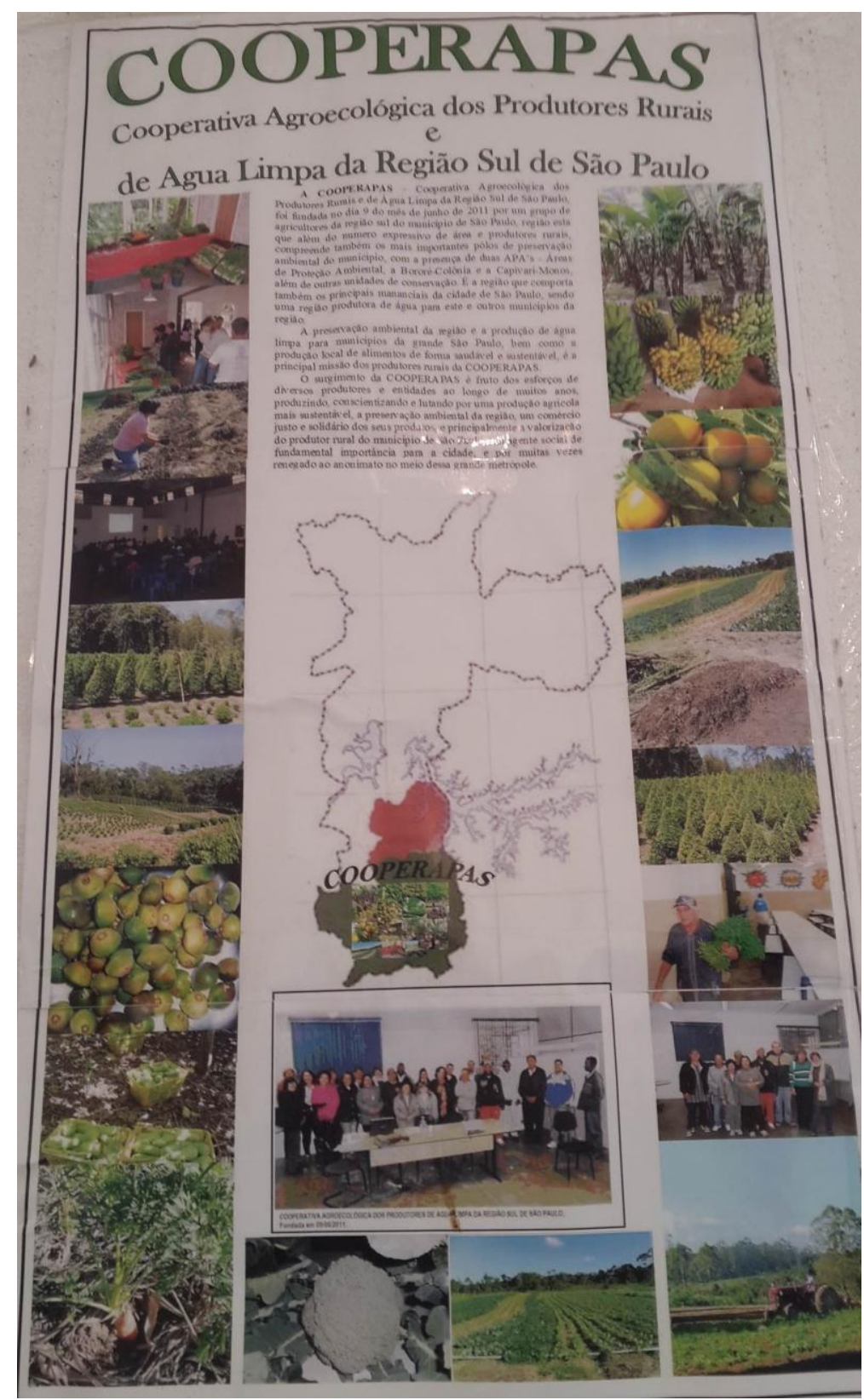

Foto 3.1. Cartaz fixado na CAE de Parelheiros, que conta um pouco sobre a história da Cooperapas. Nele, afirma-se que a cooperativa foi fundada "por um grupo de agricultores da região sul" e que ela "é fruto dos esforços de diversos produtores e entidades ao longo de muitos anos, produzindo, conscientizando e lutando por uma produção agrícola mais sustentável, a preservação ambiental da região, um comércio justo e solidário dos seus produtos e principalmente a valorização do produtor rural no município de São Paulo”. Foto de 25 de novembro de 2014. Crédito da foto:

Angélica Campos Nakamura. 
O andar da Cooperapas, desde a sua criação, será tratado ao longo do capítulo. Entretanto, antes disso, é importante compreender como essa forma de organização em grupo, conhecida como cooperativa, surge na história e no Brasil, até chegar nos seus moldes atuais, com influências do movimento cooperativista e da economia solidária. Tal história será tratada a seguir.

\subsection{O cooperativismo: das origens ao surgimento e desenvolvimento no Brasil}

O cooperativismo teve origem na Revolução Industrial, pois aí apareceram condições propícias para o surgimento das cooperativas. Elas foram consideradas uma resposta à exploração da classe operária. Como conta Souza (2003, p. 35):

O início do capitalismo industrial foi marcado por extrema exploração da classe trabalhadora que dedicava longas horas à atividade produtiva, recebia baixíssimos salários e vivia sob condições precárias. A Grã-Bretanha foi palco da primeira revolução industrial e também das primeiras reações da classe trabalhadora à exploração capitalista. As antigas corporações de ofício de artesãos qualificados geraram os sindicatos que por sua vez formaram as cooperativas. [...]

Assim, entender o surgimento das cooperativas é entender o

[...] contexto da imensa transformação das condições de vida e trabalho, além da própria natureza, alterando suas formas tradicionais e convertendo ambos, homens e ambiente, em mercadorias (Polanyi, 2000). É este momento específico de crise social estrutural que abre a possibilidade de novas formas de organização da produção e da distribuição com base em uma nova moral coletivista e solidária (FRANÇA et al., 2008, p. 45-46).

As primeiras experiências cooperativistas tiveram influência das teorias pioneiras do associativismo contemporâneo, tendo a contribuição de pensadores ingleses como Robert Owen no século XIX e, no século XX, Harold Laski, R. Tawney e G. Cole. Na França, tiveram influência Charles Fourier e Pierre Proudhon. De acordo com Santos e Rodríguez, (2002, p. 33), “o pensamento associativista e a prática cooperativa desenvolveram-se como alternativas tanto ao individualismo liberal quanto ao socialismo centralizado". Os autores afirmam que o associativismo como teoria social tem dois postulados: a defesa do mercado com base em princípios não capitalistas de cooperação e mutualidade e a crítica ao Estado 
centralizado, com políticas pluralistas e federalistas (HIRST, 1997 apud SANTOS; RODRÍGUEZ, 2002, p. 33). Já o cooperativismo, como prática econômica, tem como valores autonomia, democracia participativa, igualdade, equidade e solidariedade (BIRCHALL, 1997 apud SANTOS; RODRÍGUEZ, 2002, p. 33).

Robert Owen foi um que tomou iniciativas e realizou empreendimentos econômicos com princípios do cooperativismo. Em 1800, ele criou New Lanark, uma aldeia com 2.000 pessoas, entre elas, cerca de 500 crianças. Owen tentou melhorar a qualidade da alimentação e reduzir o uso de bebidas alcoólicas. Esse empreendimento obteve sucesso por um tempo, apesar de previsões pessimistas e afastamento de sócios (FRANÇA et al., 2008, p. 43-44). Além destes, há outros exemplos como “As chamadas pré-cooperativas, tais como a New Harmony, em Indiana (EUA), de iniciativa do próprio Owen em 1825, que resultaria em fracasso apenas dois anos depois, os Falanstérios idealizados por Charles Fourier; além das Colônias Icarianas inspiradas por Étienne Cabet” (FRANÇA et al., 2008, p. 45).

Singer (2002, p. 39), aprofunda melhor o surgimento das cooperativas, contando sobre a primeira que se tem conhecimento na História, que criou as diretrizes das cooperativas modernas:

[...] a famosa cooperativa dos Pioneiros Equitativos de Rochdale, considerada mãe de todas as cooperativas. Ela surgiu em Rochdale, um importante centro têxtil no norte da Inglaterra, em 1844. [...]

O impulso para a criação da cooperativa pode ter sido a derrota de uma greve de tecelões em 1844. Adotaram uma série de princípios, que seriam depois imortalizados como os princípios universais do cooperativismo: $1^{\circ}$ ) que nas decisões a serem tomadas cada membro teria direito a um voto, independentemente de quanto investiu na cooperativa; $2^{\circ}$ ) o número de membros da cooperativa era aberto, sendo em princípio aceito quem desejasse aderir. Por isso este princípio é conhecido como o da "porta aberta"; $3^{\circ}$ ) sobre capital emprestado a cooperativa pagaria uma taxa de juros fixa; $4^{\circ}$ ) as sobras seriam divididas entre os membros em proporção às compras de cada um na cooperativa; $5^{\circ}$ ) as vendas feitas pela cooperativa seriam sempre feitas à vista; $6^{\circ}$ ) os produtos vendidos pela cooperativa seriam sempre puros (isto é, não adulterados); $7^{\circ}$ ) a cooperativa se empenharia na educação cooperativa; $8^{\circ}$ ) a cooperativa manter-se-ia sempre neutra em questões religiosas e políticas. [...]

O princípio do controle democrático (ou uma pessoa = um voto) era a grande novidade, pois "não se tratava mais de contar com o esclarecimento e a benevolência de industriais ou reformadores sociais, como Owen, e sim em confiar na capacidade de organização dos próprios trabalhadores para transformar suas condições de vida" (FRANÇA et al., 2008, p. 47). 
Sobre os fundadores de Rochdale, é importante destacar que eles eram militantes políticos e já haviam participado das greves de 1842-1844. Conforme França et al. (2008) destacam, essas características dos tecelões de Rochdale faziam com que eles fossem privilegiados

[...] para captar os eventos profundamente transformadores da Revolução Industrial e seus contramovimentos, integrá-los em suas trajetórias pessoais, elaborando-os em uma reação coletiva e [...] para implementar esta reação em um sentido absolutamente novo e emancipatório (2008, p. 46).

Assim, o fato desses fundadores serem participantes ativos na política, fez com que eles se tornassem mais sensibilizados com os acontecimentos do momento na época e, dessa forma, questionassem a realidade na qual viviam e fundassem Rochdale.

Se na Europa as primeiras experiências cooperativistas começam a surgir por volta de 1800, até a fundação de Rochdale em 1844, no Brasil essas experiências também começam a aparecer no início do século XIX, com a chegada de imigrantes europeus. Segundo Pinho, D., a partir de 1824, surgem as primeiras experiências com princípios cooperativistas no Brasil. Ela conta que "imigrantes de origem germânica começaram a formar associações no Rio Grande do Sul, principalmente nas bacias do Guaíba, da Região da Serra, da Região das Missões e do Alto Uruguai” (2004, p. 16), devido à política imperial de ocupação do sul do Brasil. França et al. também ressaltam as tentativas de imigrantes europeus para a criação de estruturas comunitárias de compra e venda, como uma de 248 alemães que fundaram a Colônia Rio Negro em 1829, hoje município do estado do Paraná (2008, p. 50).

$\mathrm{Na}$ década de 1840, o médico e imigrante francês Benoit Jules de Mure foi apresentado, junto com um grupo de colonos pobres franceses, ao Imperador D. Pedro II. Ele expôs ao imperador suas ideias de colonização, influenciadas pelas proposições de Charles Fourier e Joseph Jacotot. Porém, a experiência criada na Baía de Babitonga, próxima a São Francisco do Sul, em Santa Catarina, fracassou (FRANÇA et al., 2008, p. 50). Outro francês que teve destaque no Brasil foi Jean Maurice Faivre:

[...] o cooperativismo no Brasil surgiu por iniciativa do também médico francês e fourierista Jean Maurice Faivre, tendo este recebido da Coroa uma grande quantidade de terras na região do atual município de Cândido Abreu, Paraná. A Colônia Tereza Cristina foi, então, fundada em 1847 em homenagem a Imperatriz, sua patrocinadora. Faivre, pesquisador naturalista, se instala na localidade com 87 famílias francesas e algumas outras brasileiras. No entanto, esse núcleo também não teria vida longa: doenças como malária e febre amarela vitimaram muitos colonos, e associadas a 
problemas de adaptação, fizeram com que muitas famílias buscassem novos locais de moradia, o que deu origem a outros núcleos de povoamento paranaenses (FRANÇA et al., 2008, p. 51).

Para França et al., "no limiar desta década [cerca de 1880], já estavam colocadas muitas das condições típicas de uma sociedade industrial [no Brasil], com uma estrutura urbana em processo de integração e a emergência de uma classe trabalhadora livre em substituição ao trabalhador escravo" (2008, p. 51). Essa mão-de-obra livre é a que vai reagir contrariamente às condições precárias de trabalho no Brasil e se organizar "politicamente (agrupamentos republicanos, positivistas, evolucionistas, socialistas utópicos, marxistas, anarquistas e outros) e associativamente (Uniões, Associações, Ligas e Sindicatos)" (PINHO, D., 2004, p. 20, grifo da autora).

Pinho, D. também ressalta o fim do trabalho escravo a respeito da implantação do cooperativismo no Brasil e ainda acrescenta outros fatores:

[...] diversos fatores marcaram os primórdios da implantação do Cooperativismo no Brasil, especialmente a abolição do escravismo e a legislação republicana assegurando a liberdade de associação, apoiada pela Constituição de 1891 (art. 72, parágrafo 8). Este último fato significou uma primeira abertura ao cooperativismo, já que a Constituição de 1824 proibia qualquer tentativa associacionista (art. 179, parágrafo 25).

Surgiram, então, condições para o aparecimento das primeiras cooperativas de modelo rochdaleano no Brasil, estimuladas por alguns idealistas brasileiros e imigrantes estrangeiros. No início, foram organizadas sobretudo cooperativas agrícolas na região sul do Brasil e, mais tarde, as cooperativas de agricultores japoneses em São Paulo (2004, p. 17).

França et al. citam alguns exemplos de cooperativas a partir da década de 1880, como: a Cooperativa de Consumo dos Empregados da Companhia Paulista (Campinas-SP, em 1887); a Cooperativa de Consumo de Ouro Preto e a Sociedade Econômica Cooperativa dos Funcionários Públicos de Minas Gerais (ambas em MG, em 1889); a Associação Cooperativa dos Empregados da Companhia Telefônica (Limeira-SP, em 1889); a Società Cooperativa delle Convenzioni Agricoli Industriali (na época, em Alfredo Chaves, hoje Veranópolis-RS, em 1892); a Cooperativa Militar de Consumo (Rio de Janeiro-RJ, em 1894); e a Cooperativa do Proletariado Industrial de Camaragibe (PE, em 1895) (2008, p.51).

Apesar de já na década de 1880 surgirem experiências cooperativistas, a Constituição Federal do Brasil só reconheceu o direito de associação dos trabalhadores em sindicatos e cooperativas em 1891, no parágrafo $8^{\circ}$ do art. 72, (PINHO, D., 2004, p. 20). 
No começo do século XX, em 1907, de acordo com Bulgarelli, surge na legislação brasileira o Decreto 1.637, de 15 de janeiro, voltado para as organizações cooperativas e para os sindicatos. De acordo com o autor, esse decreto foi

Profundamente influenciado pela lei francesa de 1867, não atribuía forma própria às cooperativas, devendo estas se constituírem sob a forma das sociedades comerciais, em nome coletivo, em comandita anônima. Dava-lhes porém ampla liberdade de constituição e funcionamento, sem subordinação a nenhum órgão estatal, bastando para funcionar validamente, que depositassem em duplicada, na Junta Comercial, os seus atos constitutivos, tendo apenas como obrigação posterior, a de semestralmente fazer o depósito da lista dos sócios e as alterações estatuárias verificadas (BULGARELLI, 1973, p. 141, grifo do autor) $)^{15^{5}}$.

É também no início desse século que aparecem cooperativas inspiradas em modelos trazidos por imigrantes estrangeiros com influências anarquistas e sindicalistas ou, ainda, de idealistas brasileiros (PINHO, D., 2004, p. 13). De acordo com França et al., mais cooperativas surgem: uma cooperativa de crédito rural, a primeira da América Latina (Nova Petrópolis-RS, em 1902); a Cooperativa de Produção Agropecuária (RS, em 1906); a Cooperativa Internacional da Lapa (São Paulo-SP, em 1908); no período de 1913 a 1929 muitas cooperativas surgem, devido à contratação do técnico italiano Giusepe Di Stefano Paternó, enviado ao Rio Grande do Sul para ajudar na criação de cooperativas de produção agrícola; a Cooperativa dos Empregados e Operários da Fábrica de Tecidos da Gávea ${ }^{16}$ (Rio de Janeiro-RJ, em 1913); a Cooperativa de Consumo dos Empregados da Viação Férrea COOPFER - (Santa Maria-RS, em 1913), que chegou a 18 mil membros e a ser a maior da América do Sul; em 1917, trabalhadores ferroviários brasileiros fundavam novas cooperativas; e a mais importante cooperativa da América do Sul, a Cooperativa Agrícola de Cotia - CAC - (SP, em 1927), que chegou a 16.309 membros (2008, p. 52-54) ${ }^{17}$.

Sobre esse início da constituição do cooperativismo, França et al. levantam uma questão importante:

\footnotetext{
15 Assim, as cooperativas brasileiras, até 1932, funcionavam como sociedades anônimas e tinham liberdade operacional. De acordo com Pinho, C., a crise de $1929 \mathrm{fez}$ com que isso mudasse, pois houve um abalo da economia brasileira, baseada no café. O Estado brasileiro viu então, nas cooperativas, uma das soluções para os problemas econômicos e sociais da época (1973, p. 108).

${ }^{16}$ Essa cooperativa foi criada com a ajuda de Custódio Alfredo Sarandy Raposo, personagem importante na história do cooperativismo no Brasil, pois fundou a Confederação Sindical Cooperativista Brasileira (CSCB) em 1921 e via, nas cooperativas, uma forma de transformação social e econômica.

17 "Sociedade Cooperativa de Responsabilidade Limitada dos Produtores de Batata em Cotia S/A - cooperativa singular; cresceu tanto que foi posteriormente desmembrada em várias cooperativas reunidas em uma cooperativa de segundo grau, a CAC-CC (Cooperativa Agrícola de Cotia - Cooperativa Central)" (PINHO, D., 2004, p. 25).
} 
Em traços gerais, pode-se afirmar que, em ambas as fases, a do précooperativismo e a da constituição do cooperativismo no Brasil, e em quase todas as experiências mais conhecidas, aparecem dois caracteres fundamentais: a relação com o Estado (Imperial ou Republicano) e a figura de um líder carismático inspirador (Weber, 2000). Na prática, o cooperativismo brasileiro, em seu início e nos desenvolvimentos que ainda viriam, nos segmentos de produção e consumo, agropecuário, crédito rural, de habitação e médico, sempre esteve ligado e tutelado pelo Estado, e quase nunca adquiriu um formato propriamente autogestionário (Singer, 2002: 122).

[...] o cooperativismo brasileiro demonstrou, desde suas origens, uma afinidade profunda com o controle do Estado. Possivelmente, os fluxos de criação e destruição de cooperativas corresponderam menos às tendências próprias da organização dos trabalhadores do que às facilidades e obstáculos oferecidos pelo Estado (FRANÇA et al., 2008, p. 54-55).

Para Pinho, D., foi no período de 1932-1964 que o cooperativismo no Brasil se consolidou parcialmente. Ela atribui essa consolidação

[...] ao Decreto 22.239, de 19 de dezembro de 1932, a primeira lei fundamental que arrolou as características principais das cooperativas, consagrou seu embasamento doutrinário rochdaleano e garantiu, às cooperativas, margem razoável de liberdade de constituição e funcionamento" (2004, p. 26-27, grifo da autora) ${ }^{18}$.

Bulgarelli também afirma que esse decreto

[...] dava às cooperativas razoável liberdade de constituição e funcionamento, e foi graças a ele (além, é claro, da própria fase histórica repleta de reformas na estrutura social e política do país, e a contribuição das grandes levas de emigrantes europeus e japoneses) que puderam as cooperativas desenvolver-se amplamente. [...]

De qualquer forma, o Decreto 22.239 de 1932 [...], foi a primeira lei "rochdaleana", consagrando muitos princípios doutrinários ${ }^{19}$, e apesar de certas falhas técnicas e de terminologia ${ }^{20}$, deu-lhe uma estrutura compatível com a sua verdadeira natureza cooperativa (1973, p. 142-143).

\footnotetext{
18 “1932 - Decreto 22.239 (19/12), de caráter rochdaleano, dispôs sobre a organização e o funcionamento da sociedade cooperativa; considerou as cooperativas sociedades de pessoas e não de capital, de natureza jurídica "sui generis", com características específicas (art. 2º)" (PINHO, D., 2004, p. 27).

${ }^{19}$ De acordo com Fleury, os princípios estabelecidos foram: adesão livre, gestão democrática, taxa limitada de juro do capital social, distribuição das sobras: ao desenvolvimento das cooperativas e serviços comuns, aos associados proporcionalmente às suas operações com a cooperativa, singularidade do voto (1983, p. 47).

${ }^{20}$ Uma das crítica de Bulgarelli faz é o fato do decreto ter "dificuldades em defini-las [as cooperativas], pois as considerava 'sui generis"” (1973, p. 143).
} 
O decreto também classificava 16 tipos de cooperativas, como as de produção agrícola, de produção industrial, de compras em comum, de vendas em comum, de consumo, de crédito etc. (FLEURY, 1983, p. 47). Ainda de acordo com Fleury:

Uma outra dimensão do movimento cooperativista o tornara muito atraente como instrumento da política econômica estatal: os seus princípios doutrinários, que revestiam o movimento de um caráter reformista, necessário para justificar as intervenções do Estado na economia, pois estas seriam feitas em nome das classes menos favorecidas.

Entretanto, esse "caráter reformista" do movimento se esgota, pelo menos a nível do setor agrícola, nas pretensões modernizantes de integração dos produtores ao mercado, não tocando por exemplo no problema da propriedade da terra, dos trabalhadores rurais, questões que entrariam em conflito com os interesses das classes dominantes agrárias (1983, p. 47).

Essa liberdade de organização e funcionamento que as cooperativas possuíam, a partir de 1941 com o Decreto-lei n 6.980 de 19 de março, ficou condicionada à fiscalização, controle e registro a um órgão junto ao Ministério da Agricultura (PINHO, C., 1973, p. 109).

Esse período se caracterizou pelo surgimento de mais cooperativas e mudanças na legislação voltadas ao cooperativismo. Grupos voltados para pensar o cooperativismo também surgiram. Uma delas, ocorrida em 1956, foi a

Criação da UNASCO (União das Associações Cooperativas), em São Paulo, e da ABCOOP (Aliança Brasileira de Cooperativas), no Rio de Janeiro, devido a divergências entre grupos de cooperativas. A divisão prosseguiu até 1969, quando o então Ministro da Agricultura - Cirne Lima, interessado na unificação do movimento, pediu ao Secretário de Agricultura de São Paulo, Dr. Antonio José Rodrigues Filho, que promovesse a harmonização das correntes antagônicas para a criação de um movimento cooperativista único, o que levou à constituição da OCB na década de 70 (Dec. 5.764/71) (PINHO, D., 2004, p. 33, grifo nosso).

Segundo Pinho, D., entre 1965 e 1970, o sistema cooperativista brasileiro entrou em crise, porém, após isso, ele voltaria a se reorganizar e se renovar. Em 1966, o estado voltaria a intervir mais fortemente, a partir do Decreto-lei $\mathrm{n}^{0} 59$, regulamentado pelo Decreto $\mathrm{n}^{\circ}$ $60.597^{21}$. Pinho, C. afirma que "O Estado chamou a si a incumbência de orientar a 'política nacional de cooperativismo' e a coordenação das iniciativas tendentes a dinamizar as cooperativas, 'para adaptá-las às reais necessidades da economia nacional e seu processo de

21 “1966 - Decreto-lei 59 (21/11) definiu a política nacional de cooperativismo, criou o CNC (Conselho Nacional de Cooperativismo), revogou o dec. $\mathrm{n}^{\circ}$ 22.239/32; criou um exagerado sistema de controle estatal e determinou outras providências" (PINHO, D., 2004, p. 37). 
desenvolvimento"' (1973, p. 109). Mesmo com forte intervenção estatal, a posição doutrinária rochdaleana estabelecida em 1932 com o Decreto 22.239 foi mantida. Ainda, de acordo com Pinho, D. esse decreto

[...] descentralizou a fiscalização das cooperativas estabelecendo que as cooperativas de crédito seriam fiscalizadas pelo Banco Central do Brasil; as cooperativas de habitação, pelo BNH (Banco Nacional de Habitação); e as demais cooperativas pelo então INDA (Instituto Nacional de Desenvolvimento Agrário), depois transformado sucessivamente em INCRA, SENACOOP e DENACOOP. Estes órgãos normativos podiam intervir nas cooperativas para "resguardar a lei e defender o interesse coletivo" (2004, p. 37).

Bulgarelli faz uma crítica a esse decreto-lei, afirmando que

Inaugurou-se assim o mau vêzo de se conceituar em lei a "política cooperativista", num sentido paternalista de orientação estatal, quando a política cooperativa deve ser o conjunto de diretrizes gerais que presidem e orientam a atividade do movimento, e não a sua própria atividade [...] o cooperativismo deve integrar-se aos planos governamentais - a sua subordinação total ao poder público não se justifica. A independência do movimento cooperativista é indispensável para o seu progresso, sobretudo a sua existência autêntica de acordo com seus princípios doutrinários (1973, p. 147).

França et al. também reforçam que nesse período houve um aprofundamento do cooperativismo tutelado, a partir da implantação da Ditadura Militar industrial-modernizadora em 1964 (2008, p. 54-55). Como exemplos de aprofundamento do controle do Estado sobre o cooperativismo brasileiro, tem-se a criação da Organização das Cooperativas Brasileiras (OCB) em 1969, a qual foi implantada em 1971. À OCB cabia

[...] fixar as diretrizes políticas do Sistema Cooperativo; contribuir para o aperfeiçoamento da legislação cooperativista; subsidiar o Governo na tomada de decisões e medidas referentes ao Sistema Cooperativo; estabelecer parâmetros e arrecadar a contribuição cooperativista; manter relações de integração e intercâmbio entre os Ramos e Órgãos Cooperativistas do País e do Exterior; exercer a representação sindical patronal das cooperativas, assumindo todas as prerrogativas de Confederação Patronal. Cabe-lhe, também, o registro e o cadastramento das cooperativas brasileiras (PINHO, D., 2004, p. 249-250).

Com a criação da Lei 5.764/71, a Lei do Cooperativismo, a OCB passou a monopolizar a representação do cooperativismo no Brasil. A lei, de acordo com Pinho, C. 
[...] apresentou-se concomitantemente liberal, paternalista e moderadamente intervencionista. [...] manteve a complexa ingerência estatal no processo de constituição e de funcionamento das cooperativas, através de múltiplos órgãos controladores.

Por outro lado, apesar de intensos reclamos de algumas áreas "progressistas", continuou a tradição doutrinária "ortodoxa", isto é, baseada nos Princípios Rochdaleanos. Mas destes "Princípios" se afastou ao "institucionalizar" a representação de cúpula do Movimento Cooperativo Brasileiro, criando registro obrigatório das cooperativas na OCB (Organização das Cooperativas Brasileiras) ${ }^{22}$ e "Contribuição Cooperativista" compulsória a seu favor ${ }^{23}$ [...] (1973, p. 109-110).

Além do registro obrigatório na OCB estabelecido pela Lei $\mathrm{n}^{\mathrm{o}} 5.764$, as cooperativas também eram obrigadas a fazer outros registros para funcionarem:

- na Junta Comercial, como qualquer sociedade econômica, com o fim de adquirir personalidade jurídica;

- no respectivo órgão executivo federal de controle $(\mathrm{BCB}, \mathrm{BNH}$ ou INCRA) - respectivamente para as cooperativas de crédito, de habitação ou demais categorias $[\ldots]^{24}$. (PINHO, C., 1973, p. 129).

A lei, ainda, estabeleceu o regime jurídico e normas, como: a constituição, os direitos e obrigações dos associados, fiscalização e ato cooperativo (FRANÇA, 2008, p. 55) ${ }^{25}$. Fleury

22 “A Organização das Cooperativas Brasileiras (OCB) é uma sociedade civil, sem fins lucrativos, sediada na Capital Federal (art. 105). É um órgão técnico-consultivo do governo e reúne todas as categorias cooperativas brasileiras. Cada uma tem um registro especial e é prestado uma assistência técnica, operacional, jurídica e outras. A OCB é central e está ligada a uma rede de filiais, as quais funcionam nos Estados, Territórios e Distrito Federal"' (PINHO, C., 1973, p. 128).

23 A contribuição cooperativista era "correspondente a $0,2 \%$ do valor do capital integralizado e fundos da sociedade cooperativa no exercício social do ano anterior, "sendo o respectivo montante distribuído, por metade, a suas filiadas, quando constituídas' (art. 108, $\S 1^{\circ}$ )” (Ibid., p. 128).

${ }^{24}$ De acordo com Pinho, C. (1973) sobre a Lei n ${ }^{\circ} 5.764$ :

“A legislação atual manteve, de modo geral, a estrutura de fiscalização e controle das sociedades cooperativas, tal como vinha sendo efetuado há vários anos:

- Banco Central do Brasil [BCB]: fiscaliza e controla as cooperativas de crédito e as seções de crédito das cooperativas agrícolas mistas;

- Banco Nacional de Habitação [BNH]: fiscaliza e controla as cooperativas habitacionais; e

- Instituto Nacional de Colonização e Reforma Agrária [INCRA]: fiscaliza e controla todas as demais cooperativas.

As cooperativas são obrigadas a remeter, anualmente, aos seus respectivos órgãos de controle: relação dos associados admitidos, demitidos, eliminados e excluídos no período considerado, bem como cópias de atas, balanços e relatórios do exercício social e parecer do Conselho Fiscal. São obrigadas, ainda, a permitir as verificações determinadas por seus órgãos controladores. [...] Além de fiscalização e controle, entretanto, o BCB, o BNH e o INCRA exercem também funções de assistência e fomento ao Cooperativismo" (Ibid., p. 125126). É interessante destacar que, até então, "historicamente, todas as cooperativas brasileiras, dos mais diferentes e heterogêneos tipos e categorias, sempre estiveram subordinadas ao Ministério da Agricultura, através de Serviço ou Divisão especializada" (Ibid., p. 127).

${ }^{25}$ Sobre a criação da OCB e da Lei 5.764/71, podemos citar Pinho, D., que detalha mais tais eventos:

“1969 - Criada a Organização das Cooperativas Brasileiras (OCB) com a unificação da UNASCO (União Nacional das Associações Cooperativas) e da ABCOOP (Associação Brasileira de Cooperativas). [...]

1971 - Lei 5.764, de 16 de dezembro, substituiu as legislações anteriores, teve longa vigência mesmo depois de derrogada em vários capítulos e artigos pela Constituição Federal de 1988. Ou seja, mesmo amputada, continuou 
também ressalta que essa nova lei restabeleceu as atividades de crédito nas cooperativas mistas, isentou as cooperativas de impostos (como não produzem renda, eram isentas do Imposto de Renda e do Imposto de Circulação de Mercadorias), eliminou a necessidade de autorização prévia para a constituição e funcionamento das cooperativas e permitiu que as cooperativas pudessem escolher sua área de operação e a admissão de novos sócios (1983, p. $50)$.

França et al. criticam a lei, afirmando que ela está "inserida na lógica de reprodução e acumulação capitalista e instituída pelos setores rurais conservadores, [e] é, de fato, voltada aos interesses de grandes empreendimentos, regulamentando, na prática, um 'cooperativismo' de ricos" (2008, p. 55). Outra crítica importante feita pelos autores é que

[...] a consolidação das relações capitalistas, com destaque para as conquistas trabalhistas e sindicais, permitiu o surgimento da expectativa de universalização do assalariamento, quando as demais formas de produção existentes, tais como comunitárias, artesanais, familiares e cooperativas, passaram a ser consideradas "resquícios atrasados" de relações do passado, a serem superadas. [...] Valores individualistas, concorrenciais e monetários hegemônicos deformaram importantes princípios cooperativistas historicamente conquistados, e o chamado cooperativismo tradicional passou, em muitos casos, após a década de 1970, a praticar alguma forma de exploração de seus associados ou de contribuir para a precarização do trabalho, isolando-se ainda mais o movimento sindical (FRANÇA et al., 2008, p. 55-56)

Quando a OCB foi criada, a intenção era a de copiar o modelo de outros países da América Latina, principalmente os agrícolas, como Peru e Bolívia. O objetivo era gerar emprego e renda para a população excluída do campo. O governo militar também esperava que, fazendo isso, os camponeses se desencorajassem a entrar nas ligas e associações camponesas. Porém, as cooperativas criadas eram distantes desses camponeses, especialmente os mais pobres, e grandes empreendimentos cooperativos surgiram e começaram a competir com empresas privadas em vários setores. Não havia, portanto, uma experiência prévia com movimentos sindicais e/ou partidários. Ainda, a OCB garantia ao governo o controle, funcionamento e legalização das cooperativas (FRANÇA et al., 2008, p. 58).

vigorando devido à dificuldade de se conciliar algumas questões polêmicas, entre as quais a representação única do Cooperativismo pela OCB (Organização das Cooperativas Brasileiras).

1971 - OCB (Organização das Cooperativas Brasileiras) criada pela Lei 5.764/71. Antonio José Rodrigues Filho, com apoio do ministro da Agricultura Cirne Lima, fundou a OCB, tornou-se seu primeiro presidente e promoveu a criação de OCE's (Organizações Estaduais de Cooperativas) em todos os Estados brasileiros. Deputados e senadores do PT (Partido dos Trabalhadores), bem como o MST (Movimento dos Sem-Terra), entidades sindicais e de apoio às cooperativas de microempreendedores, entre outras, sempre consideraram a OCB ilegítima e produto ‘espúrio’ do Governo Militar” (PINHO, D., 2004, p. 38-39, grifo da autora). 
Para Pinho, D., no período de 1971 a 1987, o cooperativismo se fortaleceu e se renovou, apesar da criação da OCB. Mas, em 1988, com a recessão pela qual o Brasil passava, uma crise se estabeleceu. Como pontos principais dessa crise, Pinho, D. (2004, p. 4647) levanta dois:

- $\quad$ primeiro resultava da própria falência do Estado brasileiro. Diante dos efeitos negativos e perversos da hiperestagflação que assolava a economia brasileira, o Cooperativismo Brasileiro não pode desfrutar da tão almejada autogestão conseguida com a Constituição/ $88^{26}$. Enfraqueceu-se e descapitalizou-se com a longa recessão econômica, produto direto dos sucessivos pacotes e "choques" heterodoxos e ortodoxos que vinham desmantelando o sistema produtivo do País, desde 1985. [...]

- o segundo resultava da própria crise de identidade do cooperativismo internacional, que não conseguira ocupar o vazio deixado pela implosão do socialismo aplicado e pela falência social do capitalismo que embasa a economia de mercado. No confronto com a empresa capitalista, acentuaramse as dificuldades de observação dos valores básicos e dos valores de referência do Cooperativismo, aprovados pela ACI, Aliança Cooperativa Internacional, e que se inspiraram no modelo rochdaleano. Enquanto a ACI debatia a possibilidade de mudanças nos "princípios" cooperativistas, as cooperativas entraram em uma séria crise de identidade quer em nível nacional, quer em nível internacional.

Ainda, pode-se somar a esse contexto, os

[...] problemas políticos e econômicos que culminaram na área do governo Federal e a grave indefinição do governo Itamar, que não conseguiu dominar a inflação, definir políticas econômicas, nem enfrentar as turbulências de seu período administrativo. [...]

Tudo isso significou, evidentemente, mais emperramento burocrático na área cooperativista, ainda regida por legislação em grande parte derrogada pela Constituição de 1988, já que em cada mudança ministerial era necessário reapresentar os projetos de interesse direto do Movimento Cooperativo (PINHO, D., 2004, p. 47-48).

É importante destacar o papel da Constituição de 1988 revogação parcial da antiga legislação cooperativista. Muitos dos artigos referentes ao controle estatal estabelecidos pela Lei $n^{0} 5.764$ foram, em parte, revogados na nova Constituição Federal de 1988 (PINHO, D., 2004, p. 50). Pinho, D. traz algumas das principais alterações:

\footnotetext{
26 “1988 - Constituição de 5 de outubro introduziu diversas inovações sobre Cooperativismo: não interferência estatal (art. $5^{\circ}$, inciso XVIII), garantiu a criação de associações e, na forma da lei, a de sociedades cooperativas; atribui à lei complementar estabelecer normas gerais em matéria de legislação tributária, com adequado tratamento ao ato cooperativo (art. 146, III, c); estabeleceu apoio e estímulo do Estado ao cooperativismo e a outras formas de associacionismo (art. 174, parágrafo $2^{\circ}$ ); [...] incluiu o cooperativismo entre os setores produtivos participantes do planejamento e da execução da política agrícola" (PINHO, D., 2004, p. 49-50).
} 
[...] não interferência estatal (art. $5^{\circ}$, inciso XVIII), garantiu a criação de associações e, na forma da lei, a de sociedades cooperativas; atribuiu à lei complementar estabelecer normas gerais em matéria de legislação tributária, com adequado tratamento ao ato cooperativo (art. 146, III, c); estabeleceu apoio e estímulo do Estado ao cooperativismo e a outras formas de associacionismo (art. 174, parágrafo $2^{\circ}$ ); lei complementar disporia sobre o funcionamento das cooperativas de crédito dando-lhes condições de operacionalidade e estruturação próprias das instituições financeiras (art. 192, VIII); [...] incluiu o cooperativismo entre os setores produtivos participantes do planejamento e da execução da política agrícola (2004, p. 49-50).

Também vale ressaltar que a Constituição de 1988 eliminou a obrigatoriedade de vínculo à OCB que a legislação de 1971 estabeleceu (CUNHA, 2003, p. 69). Ou seja, isso significava um menor controle por parte do estado, já que a vinculação obrigatória à OCB permitia a ela o controle, o funcionamento e a legalização das cooperativas, além de obrigálas a pagarem uma contribuição.

Na década de 1990, um movimento cooperativo paralelo de economia solidária passaria a ser mais visível. A partir de 1996, o Brasil começou a participar de representações internacionais (ACI [Aliança Cooperativa Internacional] e ACI-Américas), principalmente com o Mercosul e a União Europeia. Também se pode ressaltar, a partir desse ano, como eventos importantes na formação do cooperativismo brasileiro,

[...] (a) a criação da Sescoop $^{27}$, com sede em Brasília junto à OCB; (b) a organização de uma rede de Sescoop's estaduais junto às OCE's [Organizações Estaduais de Cooperativas]; (c) a fundação de sindicatos de cooperativas em todos os Estados, junto ao sistema OCB de Cooperativismo, porém, exceto no Estado de São Paulo; (d) a emergência da vertente cooperativista de economia solidária, funcionando paralelamente ao Sistema OCB (PINHO, D., 2004, p. 57).

Esse movimento cooperativo paralelo de economia solidária começou a questionar o registro das cooperativas na $\mathrm{OCB}$, o pagamento da contribuição cooperativista e a legitimidade da OCB ser a única representante do Movimento Cooperativo Brasileiro (PINHO, D., 2004, p. 250).

A possibilidade de formação de cooperativas de pequenos empresários, microempresários e microempreendedores de várias áreas, como indústria, comércio, prestação de serviços e atividades na área rural (PINHO, D., 2004, p. 60), que veio em

\footnotetext{
27 “1999 - Sescoop (Serviço Nacional de Aprendizagem do Cooperativismo), pessoa jurídica de direito privado, com sede e foro em Brasília - criado pela Medida Provisória 1.781, do mês de março; e regimento publicado no DOU de abril de 1999 (Decreto 3.017). [...]" (PINHO, D., 2004, p. 58-59).
} 
dezembro de 2002 com a resolução 3.058, já começou a indicar mudanças no cooperativismo brasileiro, até então restrito a um "cooperativismo de ricos" voltado a grandes empreendimentos, conforme crítica feita por França et al.. A partir de 2003, houve uma expansão do microcrédito cooperativo e surgiu uma multiplicidade de representações das cooperativas. Conforme Pinho, D. (2004, p. 61),

[...] a OCB, Organização das Cooperativas Brasileiras, perdeu a "representação única" do cooperativismo brasileiro mas continuou liderando a maioria do chamado "cooperativismo tradicional ou pioneiro". Por outro lado, passaram a buscar orientação na Secretaria Nacional de Economia Solidária (criada pelo Presidente Lula junto ao Ministério do Trabalho e Emprego) ${ }^{28}$, as cooperativas do Sistema de Economia Solidária (ECOSOL) e de outros movimentos paralelos, que já recusavam a liderança da OCB.

Essa multiplicidade de representações das cooperativas fez surgir diferenciações na academia:

O desenvolvimento do cooperativismo nos segmentos sociais de baixa renda tem estimulado reflexões de pensadores cooperativistas no sentido de distinguir as cooperativas sociais ou populares, das cooperativas econômicas, tradicionais ou pioneiras. Suas principais características podem ser assim esquematizadas: as cooperativas sociais ou populares são organizadas por pessoas de baixa renda ou portadores de deficiência física ou de outro tipo de limitação [...], com o objetivo de resolver seus próprios problemas econômicos [...]. Há casos em que essas cooperativas são incubadas em ITCP's (Incubadoras Tecnológicas de Cooperativas Populares), geralmente em universidades públicas, ou em outra cooperativa ou instituição de apoio ao cooperativismo. As cooperativas econômicas, tradicionais ou pioneiras, funcionam como empresas que buscam qualidade e produtividade para enfrentar a competição do mercado.

A emergência do "cooperativismo solidário" significa o reconhecimento de outra lógica gestionária na busca de uma nova economia que consiga abranger os micros (microcrédito, microempreendedores, microautogestores, clubes de troca e outros) e os excluídos (sem-teto, semterra, sem-conta bancária, sem-garantia patrimonial). Para isso, tenta formas de rearranjo econômico e social com base na cooperação espontânea e na solidariedade. Tentativa que fez surgir uma nova vertente cooperativa solidária, paralela ao cooperativismo tradicional, e embasada na ética, no caráter dos associados e em sua mútua confiança e espírito de solidariedade (2004, p. 7, grifo da autora).

\footnotetext{
28 “2003 - Criada pelo Presidente Lula a Secretaria Nacional de Economia Solidária, junto ao Ministério do Trabalho e Emprego. Seu primeiro dirigente, Paul Singer, prof. [de economia] da USP, especializou-se em economia solidária" (PINHO, D., 2004, p. 62).
} 
De acordo com Pinho, D., a vertente da cooperativa solidária não era reconhecida pela OCB, pois ela é "pouco viável, sobretudo do ponto de vista autogestionário cooperativo e econômico" (2004, p. 8). Para a autora, a OCB

[...] sempre foi quase exclusivamente presidida por produtores rurais. Seu relacionamento com o Estado, durante muito tempo, era predominantemente via Ministério da Agricultura e, nos Estados, via Secretarias de Agricultura elo que vinha dos primórdios do cooperativismo no Brasil, quando a economia brasileira era predominantemente rural e o Ministério da Agricultura, o grande incentivador governamental do cooperativismo entre os produtores rurais $[\ldots]$.

A não-representação única da $\mathrm{OCB}$, eliminada de fato pelos participantes da vertente cooperativa solidária e alguns de seus simpatizantes, foi confirmada pela vitória de Lula e por seus pacotes de medidas impactantes, destinados a marcar a "face social" de seu governo, no Dia Internacional do Cooperativismo, em julho de 2003 (2004, p.8-9, grifo da autora).

Para França et al., a partir de 2003, no governo Lula, a prática cooperativista volta a ser incentivada e, nesse movimento, a OCB, volta a se fortalecer. Mas eles notam que

[...] a OCB tem contribuído para a criação de cooperativas que pouco ou nada guardam dos princípios do cooperativismo, tal como foi proposto em suas origens. A maioria delas, na prática, reforça as condições de precarização do trabalho, tanto em situações onde há uma subordinação real do conjunto dos cooperados por uma minoria incrustada na diretoria e que os controla financeiramente, quanto por empresários que ajudam seus empregados a se constituírem como cooperativas para contratá-los, em seguida, como prestadores de serviços. [...]

Do ponto de vista da OCB, o cooperativismo que pratica é o legítimo, pois é ele que é capaz de influir economicamente, pela escala que pode alcançar, na geração de renda para uma população, em geral pouco ou nada qualificada, que, de outra maneira, não teria como se inserir ou reinserir no mercado de trabalho, em contração estrutural (2008, p. 59).

Essa prática e princípios da OCB também são encontrados no Serviço de Apoio às Micro e Pequenas Empresas (Sebrae) e no Serviço Nacional de Aprendizagem do Cooperativismo (Sescoop). França et al. fazem uma crítica a todas essas organizações, entendendo que o que fazem "resulta num cooperativismo conservador, destituído de qualquer proposta político-pedagógica ou, se preferirmos, um cooperativismo que confunde opiniões e reforça o sistema instituído" (FRANÇA et al., 2008, p. 59). Para criarem cooperativas, essas instituições juntam pessoas com afinidades e interesses comuns, realizam um curso de 120 horas e legalizam a cooperativa na Junta Comercial ou no Cartório de Pessoa Jurídica. O 
cooperativismo praticado por essas organizações, denominado por Pinho, D. como um cooperativismo tradicional, para França et al., pode ser denominado de pragmático.

Outra concepção é a do "novo cooperativismo" que, de acordo com França et al., é caracterizado por instituições que trabalham com a perspectiva da autogestão e dentro da proposta da economia solidária (2008, p. 60-61). Pinho, D., conta que o "novo cooperativismo" é uma denominação utilizada pela vertente brasileira de economia solidária. Essa vertente surge devido à crise ideológica da esquerda, à necessidade de enfrentar as consequências perversas do neoliberalismo nas relações de trabalho e às novas formas de luta do sindicalismo (2004, p. 246). A autora ainda afirma que

[...] o Novo Cooperativismo tem como base a democracia na produção e na distribuição, a desalienação do trabalhador e a luta direta dos movimentos sociais pela geração de trabalho e renda, contra a pobreza e a exclusão social. Para seus autores, trata-se de movimento que não se insere nos mesmos espaços institucionais do chamado cooperativismo tradicional, já que este, muitas vezes cooptado por órgãos governamentais, burocratizou-se ou mesmo se degenerou. [...]

Para os teóricos do Novo Cooperativismo, as coops (sic) do Movimento Cooperativo Tradicional nada têm em comum com a esmagadora maioria das cooperativas formadas por trabalhadores, já que estas procuram criar - para si e para toda a sociedade - propostas alternativas, democráticas e igualitárias ao capitalismo [sic]. [...] (2004, p. 246).

Singer complementa que “O que distingue esse 'novo cooperativismo' é a volta aos princípios, o grande valor atribuído à democracia e à igualdade dentro dos empreendimentos, a insistência na autogestão e o repúdio ao assalariamento" (2002, p. 111, grifo do autor).

Ainda existe um terceiro grupo de entidades, no geral ONGs, que procuram fortalecer o cooperativismo e empreendimentos populares, porém, sem a prática da autogestão e da economia solidária (FRANÇA et al., 2008, p. 62). Além das cooperativas, existem outros empreendimentos coletivos: associações e microempresas ou empresas de pequeno porte autogestionárias. A tabela 3.1 na página a seguir mostra aspectos gerais desses três tipos de propostas coletivas. 
Tabela 3.1. Associação, cooperativa e microempresa/empresa de pequeno porte

\begin{tabular}{|c|c|c|}
\hline ASSOCIAÇÃO & $\begin{array}{c}\text { COOPERATIVA } \\
\text { (AUTOGESTIONÁRIA) }\end{array}$ & $\begin{array}{c}\text { MICROEMPRESA E } \\
\text { EMPRESA DE PEQUENO } \\
\text { PORTE } \\
\text { (AUTOGESTIONÁRIA) }\end{array}$ \\
\hline $\begin{array}{l}\text { Sem fins lucrativos, busca } \\
\text { defender os associados e a } \\
\text { melhoria técnica, social e } \\
\text { profissional. } \\
\text { Considerada atividade não- } \\
\text { econômica. } \\
\text { Regulamentada pelo Código } \\
\text { Civil. } \\
\text { Registrada em cartório no } \\
\text { município em que estiver } \\
\text { localizada. }\end{array}$ & $\begin{array}{l}\text { Empreendimento de } \\
\text { propriedade coletiva, com no } \\
\text { mínimo } 20 \text { pessoas físicas, cuja } \\
\text { diretoria é eleita pelos } \\
\text { cooperados. } \\
\text { Sem fins lucrativos, mas } \\
\text { promove interesses econômicos } \\
\text { dos cooperados. } \\
\text { Precisa de "sobra" para } \\
\text { reinvestir. } \\
\text { Regulada pela Lei Federal } \\
\text { 5.764/71. } \\
\text { Registrada na Junta Comercial } \\
\text { do Estado. }\end{array}$ & $\begin{array}{l}\text { Empreendimento de } \\
\text { propriedade coletiva, com no } \\
\text { mínimo } 2 \text { pessoas físicas, cuja } \\
\text { diretoria é eleita pelos sócios. } \\
\text { Tem fins lucrativos, mas pode } \\
\text { funcionar como uma } \\
\text { cooperativa com autogestão e } \\
\text { mesmo valor para cotas/ações } \\
\text { dos sócios. } \\
\text { Regulada pela Lei 9.841/99, o } \\
\text { Estatuto da Microempresa e da } \\
\text { Empresa de Pequeno Porte. }\end{array}$ \\
\hline DESAFIOS & DESAFIOS & DESAFIOS \\
\hline $\begin{array}{l}\text { Dedicação intensa por, no } \\
\text { mínimo, dois anos. } \\
\text { Controle diário da produção. } \\
\text { Investimento diário na } \\
\text { comercialização de cada } \\
\text { associado, enquanto autônomo. }\end{array}$ & $\begin{array}{l}\text { Dedicação intensa por, no } \\
\text { mínimo, dois anos. } \\
\text { Controle diário da produção. } \\
\text { Investimento diário na } \\
\text { comercialização. }\end{array}$ & $\begin{array}{l}\text { Dedicação intensa por, no } \\
\text { mínimo, dois anos. } \\
\text { Controle diário da produção. } \\
\text { Investimento diário na } \\
\text { comercialização. }\end{array}$ \\
\hline $\begin{array}{c}\text { FORMAÇÃO, } \\
\text { PATRIMÔNIO E CAPITAL } \\
\text { SOCIAL } \\
\end{array}$ & $\begin{array}{c}\text { FORMAÇÃO, } \\
\text { PATRIMÔNIO E CAPITAL } \\
\text { SOCIAL } \\
\end{array}$ & $\begin{array}{l}\text { FORMAÇÃO, } \\
\text { PATRIMÔNIO E CAPITAL } \\
\text { SOCIAL } \\
\end{array}$ \\
\hline $\begin{array}{l}\text { Mínimo de duas pessoas. } \\
\text { Patrimônio formado por taxas } \\
\text { pagas pelos associados, doações } \\
\text { e fundos de reserva. } \\
\text { Dificuldade em obter } \\
\text { financiamento devido a } \\
\text { ausência de capital social. } \\
\text { Dirigentes recebem apenas } \\
\text { reembolso de despesas. } \\
\text { Sobras e lucros vão para a } \\
\text { associação. }\end{array}$ & $\begin{array}{l}\text { Mínimo de } 20 \text { pessoas. } \\
\text { Patrimônio formado por cotas- } \\
\text { partes, doações, empréstimos e } \\
\text { processos de captação. } \\
\text { Cotas-partes iguais para os } \\
\text { cooperados. } \\
\text { Mais facilidade em obter } \\
\text { financiamento por ter capital } \\
\text { social. } \\
\text { Dirigentes não ganham a mais } \\
\text { pela função. } \\
\text { Sobras podem ser divididas, } \\
\text { investidas na cooperativa ou ter } \\
\text { outro destino decidido em } \\
\text { Assembleia. }\end{array}$ & $\begin{array}{l}\text { Mínimo de duas pessoas. } \\
\text { Patrimônio formado por cotas- } \\
\text { partes, doações, empréstimos e } \\
\text { processos de captação. } \\
\text { Ações iguais para sócios. } \\
\text { Mais facilidade em obter } \\
\text { financiamento por ter capital } \\
\text { social. } \\
\text { Dirigentes não ganham a mais } \\
\text { pela função. } \\
\text { Sobras e lucros podem ser } \\
\text { divididas, investidas no negócio } \\
\text { ou ter outro destino decidido em } \\
\text { Assembleia. }\end{array}$ \\
\hline
\end{tabular}

(continua) 
(conclusão)

\begin{tabular}{|c|c|c|}
\hline ASSOCIAÇÃO & $\begin{array}{c}\text { COOPERATIVA } \\
\text { (AUTOGESTIONÁRIA) }\end{array}$ & $\begin{array}{c}\text { MICROEMPRESA E } \\
\text { EMPRESA DE PEQUENO } \\
\text { PORTE } \\
\text { (AUTOGESTIONÁRIA) }\end{array}$ \\
\hline $\begin{array}{c}\text { VANTAGENS E } \\
\text { DESVANTAGENS }\end{array}$ & $\begin{array}{l}\text { VANTAGENS E } \\
\text { DESVANTAGENS }\end{array}$ & $\begin{array}{c}\text { VANTAGENS E } \\
\text { DESVANTAGENS } \\
\end{array}$ \\
\hline $\begin{array}{l}\text { Pode auxiliar na organização e } \\
\text { planejamento do negócio. } \\
\text { Ajudar na capacitação social e } \\
\text { profissional dos associados e/ou } \\
\text { empregados. } \\
\text { Abre caminho para inovação } \\
\text { das técnicas de trabalho. } \\
\text { Não pode emitir Nota Fiscal. } \\
\text { Apoia a negociação conjunta de } \\
\text { crédito. } \\
\text { Reduz custos das compras. } \\
\text { Facilita entrada no mercado. } \\
\text { Contabilidade simplificada e } \\
\text { imunidade ou isenção de } \\
\text { impostos. }\end{array}$ & $\begin{array}{l}\text { Legislação atual não dá } \\
\text { vantagens na redução de } \\
\text { impostos. } \\
\text { Pagamento mensal de impostos } \\
\text { se der Nota Fiscal. } \\
\text { Pagamento mensal de contador, } \\
\text { mesmo sem emissão de Nota } \\
\text { Fiscal. }\end{array}$ & $\begin{array}{l}\text { Paga-se } 4 \% \text { até } 120 \text { mil reais } \\
\text { anuais e } 5,5 \% \text { até } 240 \text { mil reais } \\
\text { anuais, mas apenas para } \\
\text { atividades comerciais e } \\
\text { industriais. } \\
\text { Pagamento mensal de impostos } \\
\text { se der Nota Fiscal. } \\
\text { Pagamento mensal de contador, } \\
\text { mesmo sem emissão de Nota } \\
\text { Fiscal. } \\
\text { Formato jurídico mais aceito e } \\
\text { com menores ambiguidades } \\
\text { fiscais. } \\
\text { Linhas de crédito especiais. }\end{array}$ \\
\hline
\end{tabular}

Fonte: FRANÇA, Bárbara Heliodora et al. Parte II - formação da economia solidária. In:

Guia de economia solidária: ou porque não organizar cooperativas para populações carentes. Niterói: UFF, 2008. p. 79-81.

Apesar de todas as mudanças ocorridas nos últimos anos, especialmente após a década de 1990, é necessário destacar que a Lei $\mathrm{n}^{0} 5.764$ de 1971 ainda dita as regras cooperativistas no Brasil. Até setembro de 2016, tramitava na Câmara dos Deputados um novo projeto de lei, o PL 519/2015 (CÂMARA DOS DEPUTADOS, 2016). Esse projeto de lei pretende revogar a Lei $n^{\circ} 5.764$ de 1971 com novas disposições sobre as sociedades cooperativas.

Até aqui, foi traçado um histórico sobre o cooperativismo no Brasil e como a economia solidária surgiu na discussão e na prática cooperativista no país. Mas como essas práticas surgem em uma cooperativa? A Cooperativa Agroecológica dos Produtores Rurais e de Água Limpa da Região Sul também teve sua história contada. A seguir, o difícil início desse grupo e a tentativa da prática cooperativista e de economia solidária serão mostrados. 


\title{
3.3. O início da Cooperapas
}

Na prática, o momento da criação de uma cooperativa já se revela complicado. Quando a Cooperapas foi criada, pensou-se em uma cooperativa que se aproximasse, ao máximo, dos princípios da economia solidária ${ }^{29}$.

O estatuto da Cooperapas ${ }^{30}$ reflete um pouco dessa tentativa de criar uma cooperativa mais pautada para a economia solidária. No "Capítulo VI do conselho administrativo", o estatuto afirma que

\begin{abstract}
Art. $33^{\circ}$. - A COOPERATIVA será administrada por um Conselho Administrativo composto por 03 (três) membros, todos eleitos pela Assembleia Geral para um mandato de 02 (dois) anos, com direito a apenas uma reeleição, sendo obrigatória, a término de cada mandato, a renovação de, no mínimo, um dos seus componentes (ESTATUTO DA COOPERATIVA AGROECOLÓGICA DOS PRODUTORES RURAIS E DE ÁGUA LIMPA DA REGIÃO SUL DE SÃO PAULO, 2011).
\end{abstract}

Ou seja, no estatuto não há distinção entre os três membros do conselho administrativo. A ideia era que esses membros tivessem o mesmo peso de representação e de decisão quando preciso. Porém, na prática, a Cooperapas acabou definindo três cargos para o conselho administrativo: presidente, vice-presidente e diretor financeiro. Esses cargos estavam ocupados, até setembro de 2016, por três mulheres, respectivamente: Valéria Macoratti, Lia Moura e Maria José Kunikawa, essa última conhecida por Tomi. Elas foram escolhidas na assembleia geral ordinária de 17 de março de 2015 por aclamação ${ }^{31}$, ocasião em que a Cooperapas iniciou um processo de reorganização.

Essa reorganização foi necessária porque, após quase quatro anos da criação da Cooperapas, de 2011 a meados de 2015, nenhuma comercialização, compra de insumos ou participação de projetos do governo federal foram realizados. A situação da cooperativa,

\footnotetext{
${ }^{29}$ É importante ressaltar que, tanto o cooperativismo tido como o tradicional, como o "novo cooperativismo", com base na economia solidária, buscaram nos Pioneiros de Rochdale os mesmos princípios. Esses princípios foram citados nesse capítulo em "O cooperativismo: das origens ao surgimento e desenvolvimento no Brasil". Porém, conforme foi retomada a história do cooperativismo no Brasil, tais princípios ficaram cada vez mais distantes, até o movimento cooperativista se voltar apenas para os ricos e os grandes empreendimentos. O "novo cooperativismo" surge para retomar a proposta original e tornar possível uma prática mais justa, democrática e igualitária.

${ }^{30}$ O estatuto de 2011 completo da Cooperapas se encontra no final desse trabalho, na seção "Anexos", como o anexo "D".

${ }^{31} \mathrm{O}$ voto por aclamação está definido no estatuto da cooperativa, no Art. $28^{\circ} \S 1^{\circ}$ : "As votações poderão ser por voto secreto ou por aclamação" (ESTATUTO DA COOPERATIVA AGROECOLÓGICA DOS PRODUTORES RURAIS E DE ÁGUA LIMPA DA REGIÃO SUL DE SÃO PAULO, 2011).
} 
ainda, estava crítica: no início de 2015, ela tinha uma multa com a Receita Federal, a qual chegou a R\$ 11.350,00. Aline Dias Ferreira de Jesus, engenheira agrônoma e uma das funcionárias da Casa de Agricultura Ecológica (CAE), explica que

A cooperativa ficou em dívida porque não se registrou. Não tem nenhuma movimentação. Por mais que a cooperativa não tenha nada, renda, movimentação, ela tem que declarar Imposto de Renda. É um passivo que vai de um ano para o outro. É igual taxa de banco, se não vai pagando, vai juntando... é muito pouco, mas vai juntando. Gerou uma multa. Na Receita Federal você tem que declarar, senão, gera multa (informação verbal) $)^{32}$.

Após a criação da Cooperapas, em 2011, Cristiano Mendes, o engenheiro agrônomo da CAE que ajudou na fundação da cooperativa, foi transferido para a Casa de Agricultura Ecológica na zona leste do município, localizada no Parque do Carmo. Alguns cooperados acreditam que isso teve um peso grande nos rumos da Cooperapas, pois Mendes foi fundamental na sua criação e tinha noções da prática cooperativista.

O primeiro conselho administrativo eleito em 2011 foi composto por Ernesto Oyama (como presidente), Valéria Macoratti e Lia Moura (como diretoras). Entretanto, ao longo dos dois primeiros anos, a Cooperapas não realizou nada além de reuniões e assembleias. $\mathrm{O}$ mandato seguinte, porém, tornou-se um assunto tabu dentro da cooperativa.

Em 2013, um novo interessado em entrar para a cooperativa, Geraldino Moreira, começou a frequentar as atividades e reuniões. De acordo com relatos, ele era muito simpático, participativo, sempre se oferecendo a ajudar. Todos começaram a gostar dele. Contudo, com o tempo, de acordo com alguns cooperados, ele começou a reclamar de algumas pessoas, gerando brigas e desentendimentos internos. Alguns o acusam de fraudar as eleições para o segundo mandato que ocorreria na Cooperapas. Contam que ele marcou uma reunião para fazer uma revisão do estatuto e nova eleição da diretoria, sem avisar outros membros. Nessa reunião, ele foi eleito o novo presidente.

Há cooperados que rebaixaram Geraldino a ponto de o chamarem de "espertalhão" e "raposa velha", devido às acusações de fraude nas eleições e de geração de brigas e desentendimentos internos. Infelizmente, foram poucos os entrevistados que se abriram mais sobre o assunto, indicando como é um tabu. Dos poucos que falaram, quando cheguei a comentar da dificuldade em se conversar sobre isso e de como os entrevistados desviavam da história ou faziam poucos comentários dando a entender que é um passado superado, eles

\footnotetext{
${ }^{32}$ Entrevista realizada com Aline Dias Ferreira de Jesus em 29 de janeiro de 2015 em uma reunião da Organização de Controle Social (OCS), realizada no sítio Shirazawa, no município de São Paulo.
} 
chegaram a dizer que todos ali têm "culpa no cartório", pois "se deixaram levar por Geraldino". Apesar dessas palavras, houve quem rebatesse essas pessoas afirmando que ele era realmente uma pessoa participativa e disposta a ajudar e tudo isso foi dito por não gostarem dele.

Porém, a Cooperapas não teve problemas apenas com desentendimentos internos e, de acordo com alguns cooperados, eleições fraudadas. Por volta de 2014, a cooperativa queria se organizar para entregar para o Programa Nacional de Alimentação Escolar (Pnae) e, dessa forma, finalmente iniciar uma comercialização conjunta de produtos agrícolas. Quem conta mais detalhes é Tiago Arpad (informação verbal) ${ }^{33}$ :

Pouco antes do Geraldino sair, o pessoal começou a querer trabalhar pra entregar pra merenda [o Pnae]. Precisava da papelada, aí ele ficou enrolando, dizia que estava tudo certo. Aí a gente foi atrás e descobrimos...

Precisavam tirar nota fiscal da cooperativa e aí descobriram que não estava certo desde sempre.

Arpad e alguns cooperados resolveram ir por conta própria atrás da documentação para conseguir participar do Pnae. Foi aí que descobriram que a Cooperapas, desde sua criação, nunca esteve regulamentada corretamente. Como explicado por Aline na entrevista acima indicada, mesmo que a cooperativa não gere nenhuma renda ou movimente capital, ela deve declarar impostos, como o Imposto de Renda. Além disso, as reuniões e assembleias devem ser registradas em ata e, no caso de assembleia, a ata deve ser levada na Junta Comercial. Nada disso foi realizado.

Quando houve a troca de presidente, de Ernesto para Geraldino, e mudanças no estatuto, documentos novos foram feitos. Entretanto, nenhum desses documentos foi regulamentado. Com a descoberta desses problemas na documentação, os cooperados comentam que Geraldino prometeu que arrumaria a situação, porém, ele ficou na Cooperapas até o final de 2014 e, depois, nunca mais apareceu ${ }^{34}$. Levou consigo todos os documentos novos, como o estatuto com alterações feitas para que fosse eleito presidente, mesmo de nada valendo por nunca terem sido registrados.

\footnotetext{
${ }^{33}$ Entrevista concedida por Tiago Arpad Spalding Reiter, em seu sítio, localizado no distrito de Marsilac, no município de São Paulo, em 27 de novembro de 2015.

${ }^{34}$ Como pesquisadora, cheguei na Cooperapas na última reunião de 2014 , realizada em novembro. Foi a única ocasião na qual tive oportunidade de conhecer Geraldino, contudo, o contato foi breve e apenas nos cumprimentamos. Depois dessa reunião, ele nunca mais apareceu. Sempre que perguntava sobre ele, recebia respostas evasivas, dizendo que não sabiam mais nada dele e que havia sumido.
} 
Com uma cooperativa que nunca havia comercializado conjuntamente, que estava fora da regulamentação exigida e que nunca havia declarado à Receita Federal, os membros se viram com a seguinte questão: continuar ou não com a Cooperapas?

Assim, quando foi descoberta a situação real da Cooperapas - falta de regulamentação e dívidas geradas por multas por não declaração de impostos - alguns membros começaram a se reunir, em outubro de 2014, conforme relembra Ernesto Oyama :

Desde 2011, quando a gente constituiu a cooperativa, não tivemos um real trabalho de cooperativismo, não tivemos todo esse trabalho de grupo que na verdade a gente deveria ter tido [...]. E nisso aí foi passando 2011, 2012, 2013, 2014. Tivemos uma eleição de uma nova diretoria que eu prefiro não citar nomes e não pensar no que a gente passou nesses anos [...] até agora. Os trabalhos de regularização da cooperativa, quando começou em outubro do ano passado... Apesar da oposição de algumas pessoas de nós, da antiga diretoria, reassumir a cooperativa, a gente sabia que se não fossemos nós... porque na verdade tudo que tem a ver com papelada, na Jucesp [Junta Comercial do Estado de São Paulo], na receita, precisava da minha assinatura. Nesses três anos, a antiga diretoria deu entrada em alguns documentos mas não teve validade nenhuma porque precisava da minha assinatura, precisava ser registrado. Então nada foi feito nesses anos. Então perdemos a merenda escolar, que podíamos estar entregando, o PAA. [...] Nada tinha sido feito, nada tinha sido registrado. Na verdade, começou tudo a partir daí, da regularização da cooperativa. Em novembro tivemos o primeiro contato com o João contador e com o João do ICA ${ }^{35}$. [...] O João [do ICA] tentou fazer todo esse trabalho de grupo e não conseguiu. Chegou até ser quase que expulso, quase que chutado ${ }^{36}$. Mas a gente chamou ele de volta, o Jair chamou ele de volta. Eu, a Valéria e a Lia falamos 'não, ele vai ficar', os outros que estão contra, não tem jeito, ele precisa ficar com a gente para dar para gente esse caminho das pedras (informação verbal) ${ }^{37}$.

Quem encabeçou a ajuda com o processo de regulamentação da Cooperapas na CAE foi Jair Medeiro, citado na fala de Ernesto. Medeiro é engenheiro agrônomo e um dos técnicos que trabalham e dão suporte para os agricultores da região do extremo sul do município de São Paulo.

\footnotetext{
${ }^{35}$ A Cooperapas contava com a ajuda e assessoria de João Neto que passou a ser o contador da cooperativa até fevereiro de 2016, quando pediu para sair por problemas de saúde; e de João Belato, técnico do Instituto de Cooperativismo e Associativismo (ICA), que ficou conhecido entre os cooperados como João do ICA.

${ }^{36}$ Contam que João do ICA chegou a ser chamado para dar assessoria no início da Cooperapas, porém, houve muitos desentendimentos entre ele e os cooperados, o que o levou a ser "quase que chutado". Tentei várias vezes marcar uma entrevista com ele para conversar sobre esse início cheio de desentendimentos, mas a incompatibilidade de agendas não permitiu. Em reuniões realizadas em 2015, nas quais ele participou, ele chegou a "brincar" várias vezes que agora imploraram para que ele voltasse e ajudasse nas questões da cooperativa. Esse desentendimento inicial com João do ICA é outro assunto evitado pelos cooperados.

${ }^{37}$ Fala de Ernesto Oyama em assembleia geral da Cooperapas realizada em 17 de março de 2015 na Casa de Agricultura Ecológica (CAE) José Umberto Macedo Siqueira, na Subprefeitura de Parelheiros, zona sul do município de São Paulo.
} 
Comecei a acompanhar a Cooperapas logo após o momento de decidirem dar continuidade à cooperativa. Muitos contam que o desejo da maioria era de fechá-la de vez, história comentada em reuniões pela própria Valéria Macoratti. Porém, após muito diálogo, resolveram dar mais uma chance para a cooperativa. Uma, pela esperança de dar certo e um dia conseguirem comercializar e vender seus produtos para clientes variados e para os programas governamentais; outra, pelo reconhecimento que o nome Cooperapas traz a esses agricultores ${ }^{38}$ o qual, muitas vezes, atrai clientes interessados em seus produtos; e, finalmente, porque fechar uma empresa, de acordo com o contador contratado pela Cooperapas, sai mais caro do que regularizá-la novamente, além de demorar anos e ser um processo extremamente desgastante e burocrático. A meu ver, o fator financeiro foi o mais definitivo para continuarem com a Cooperapas.

$\mathrm{Na}$ fala de Ernesto, ele cita que a primeira diretoria reassumiu e tomou para si a tarefa de regulamentar a cooperativa porque, como nada foi registrado após sua criação, tudo o que foi realizado não teve validade. Assim, ele, Valéria e Lia ainda eram do conselho administrativo. Para piorar, como a cooperativa estava em dívida com a Receita Federal, eram eles que deveriam responder por ela. Daí, nada mais válido que o interesse deles em resolver, o mais rápido e da melhor forma possível essa questão.

Ernesto e outros membros chegaram a confirmar que Geraldino prometeu que arrumaria a situação, mas no fim nada foi feito:

Nessa nova administração, o nome do presidente, do tesoureiro, não foi dado entrada na Junta Comercial. Então nós [ele, Valéria e Lia] somos ainda presidente, diretores. Inclusive saímos, a nova diretoria teria que acertar e não acertou os problemas. Aí a bomba veio pra gente de volta. Que era acertar a legalização que não foi feita em dois anos de nova administração. Demos confiança pra um senhor [...] mas foi uma grande enrolação (informação verbal) ${ }^{39}$.

Depois de novembro de 2014, mais nenhuma reunião foi feita. Nos primeiros meses de 2015, a Cooperapas começou a se ajustar. Em 23 de fevereiro de 2015, foi realizada a primeira reunião do ano da Cooperapas (foto 3.2 na página a seguir). O contador João Neto foi trazido para explicar a situação da cooperativa para os membros presentes. Ele aproveitou para iniciar sua fala com uma boa notícia:

\footnotetext{
${ }^{38}$ Muitas pessoas que compram orgânicos ou que estão envolvidas com o movimento de agricultura urbana da cidade de São Paulo, por exemplo, conhecem ou já ouviram falar da cooperativa e veem com bons olhos uma organização coletiva desse tipo.

${ }^{39}$ Entrevista concedida por Ernesto Oyama, na Casa de Agricultura Ecológica, na Subprefeitura de Parelheiros, em São Paulo, em 19 de janeiro de 2015.
} 
A Receita Federal isentou a cooperativa desses $R \$ 11.050,00$ de multa.

Ficaram apenas com $R \$ 300,00$ de multa que não tem como tirar. Com a Receita Federal está tudo ok.

Hoje vocês têm uma certidão negativa de débitos e tributos federais conjunta a qual consta que vocês não têm débito com a Receita. E como ela é conjunta, já sai a do INSS.

Então vocês não têm pendência nem na Receita, nem no fundo de garantia, nem no INSS. Estão legalizados nos três. Agora o que vocês não podem deixar acontecer é "deixar a peteca cair", porque se ela cair de novo, vai complicar tudo de novo (informação verbal) ${ }^{40}$.

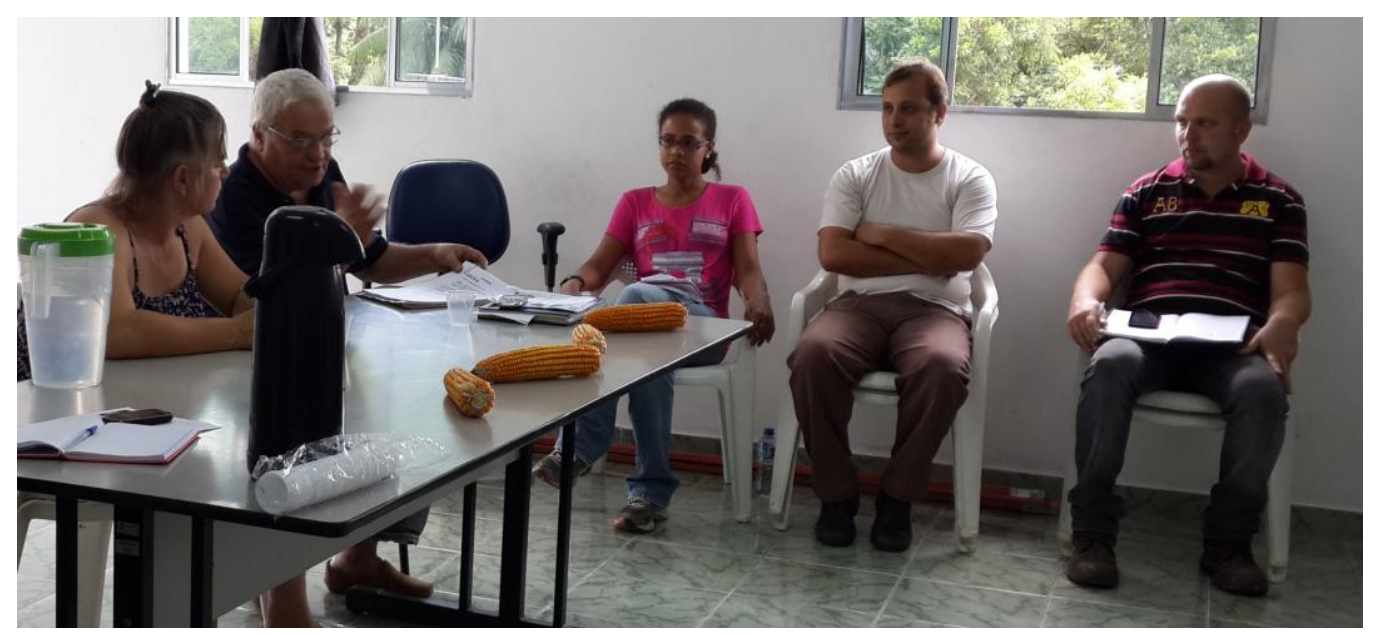

Foto 3.2. O contador João Neto, sentado à mesa, explica para os presentes a isenção das multas da Cooperapas na reunião realizada em 23 de fevereiro de 2015 na CAE. Crédito da foto: Angélica Campos Nakamura.

Quando a notícia foi dada, as pessoas presentes na sala até aplaudiram. Ernesto ergueu os braços para cima, pois caso eles tivessem que pagar a dívida, seu nome, o de Valéria e de Lia continuariam sujos até resolverem a questão. O contador até brincou que Ernesto não ia mais precisar vender seu caminhão. Finalmente, o Cadastro de Pessoa Física (CPF) dos três estava liberado. Ernesto até comentou que queria tirar o CNPJ rural e não podia por causa disso. João continuou, inclusive, dando conselhos para o futuro da Cooperapas:

O mal de todo empresário, qual é? Ah, o meu contador resolve. Mas ele não quer saber se foi resolvido ou se deixou de ser resolvido. Se ele quiser, pode arrebentar a sua empresa. Sempre tem que ter uma pessoa que acompanhe, que pegue no pé. Porque é muito fácil eu chegar aqui, falar bonito, e quando viro as costas a bomba aparece (informação verbal) ${ }^{41}$.

\footnotetext{
${ }^{40}$ Informação verbal fornecida por João Neto, durante reunião da Cooperapas na Casa de Agricultura Ecológica, na Subprefeitura de Parelheiros, em São Paulo, em 23 de fevereiro de 2015.

41 Informação verbal fornecida por João Neto, durante reunião da Cooperapas na Casa de Agricultura Ecológica, na Subprefeitura de Parelheiros, em São Paulo, em 23 de fevereiro de 2015.
} 
Outro conselho dado por João foi sobre a importância e necessidade de manter a organização dos documentos da Cooperapas. Ele reclamou da desorganização e de como foi difícil encontrar certos documentos. Caso qualquer pessoa queira verificar os documentos, uma vez organizados, ela conseguirá entender o que está ali e como está a situação da cooperativa. Ele chegou a se oferecer para ajudar nessa organização, e aconselhou a deixar esses documentos arquivados na CAE, pois a cooperativa não possuía uma sede própria até o encerramento deste trabalho.

Apesar da reunião de fevereiro, em 17 de março ocorreu a assembleia geral ordinária, ocasião já citada na qual foram eleitas as novas dirigentes do conselho administrativo: Valéria Macoratti, Lia Moura e Tomi. Nessa assembleia, o contador João Neto explicou em que situação a cooperativa se encontrava naquele momento:

A cooperativa tinha uma multa de $R \$ 11.350,00$ na Receita Federal por omissão. $O$ não nós sempre temos. Então vamos correr atrás do sim pra ver o que acontece. [...] É só entrar no site da Receita Federal e fazer essa busca. Tem todas as certidões negativas federais. A Cooperapas não tem mais nada. Tirou do FGTS [Fundo de Garantia do Tempo de Serviço] $e$ Ministério do Trabalho, que não consta nada. Está tudo na pasta. Balancete desde 2011 até hoje [março de 2015]. Houve um recebimento de $R \$$ $1.500,00^{42}$ para os cooperados. Tirou papelada na Junta Comercial. Sobrou um saldo de $R \$ 1.186,00$. [...] Até 2014 a Cooperapas tinha um saldo de $R \$$ 1.186,00. Daí pra frente face às despesas que tiveram com honorários, publicação de jornal, foi feito uma arrecadação de doação dos cooperados. Houve uma arrecadação [...], entrou como doação e não contribuição. Foi arrecadado $R \$ 100,00$ de cada cooperado. Fazendo uma contabilidade, chegou a um caixa de $R \$ 582,00$ [...]. Quem quiser verificar o balancete levantado eu tenho aqui 4 cópias (informação verbal) ${ }^{43}$.

Essa assembleia (foto 3.3, na página a seguir) também contou com a presença de João Belato, o João do ICA. Ele assessorou o encontro todo, dando informações de como gerir melhor a cooperativa, quais atitudes tomar no futuro, além de ajudar a organizar a assembleia.

Além dos membros votarem no conselho administrativo, um conselho fiscal foi escolhido. Ele é composto por seis pessoas, três como conselheiros fiscais, três como suplentes (organograma 3.1, na próxima página). Todos foram aprovados por aclamação.

\footnotetext{
${ }^{42}$ Provavelmente, esse recebimento foi a doação feita para dar início à cooperativa, em 2011. Cristiano Mendes afirmou que era por volta de $\mathrm{R} \$ 2.000,00$ o valor. Os valores, portanto, estão próximos.

${ }^{43}$ Informação verbal fornecida por João Neto, durante assembleia geral da Cooperapas na Casa de Agricultura Ecológica, na Subprefeitura de Parelheiros, em São Paulo, em 17 de março de 2015.
} 


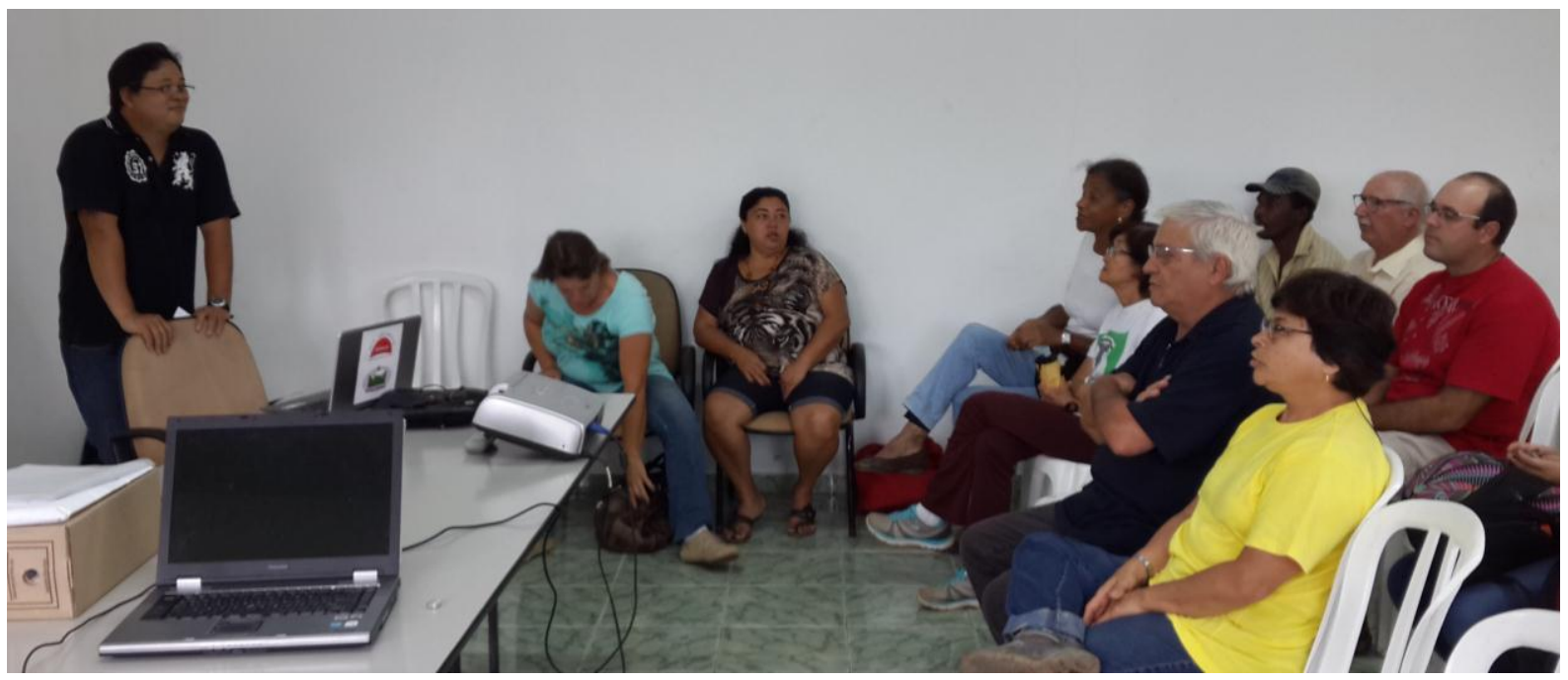

Foto 3.3. A assembleia realizada em 17 de março de 2015, na CAE, definiu os novos membros do conselho administrativo e fiscal. Crédito da foto: Angélica Campos Nakamura.

\section{Conselho \\ administrativo}

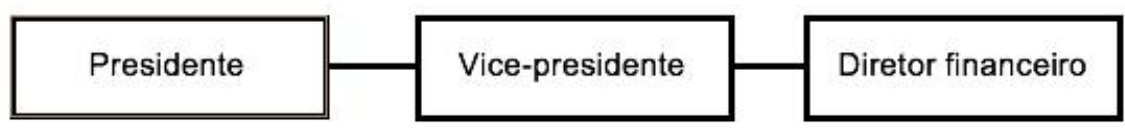

\section{Conselho \\ fiscal}

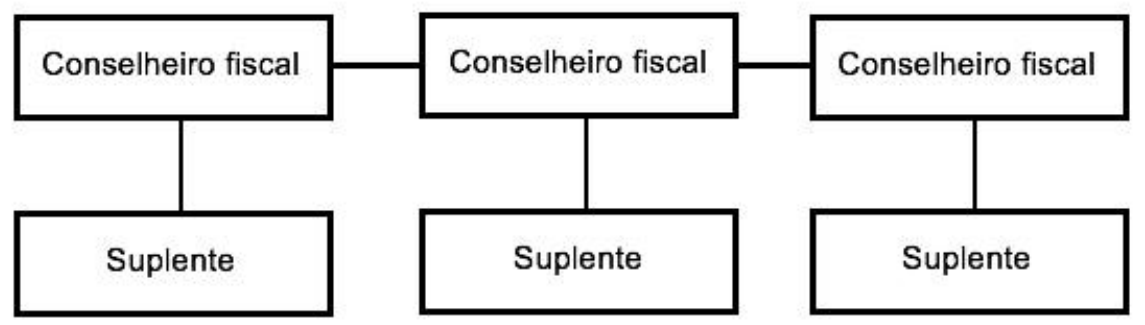

Organograma 3.1. O organograma acima mostra como ficou a organização interna da Cooperapas. Os três cargos do conselho administrativo estão no mesmo patamar porque, conforme explicado no capítulo, o estatuto não fez distinção dos três membros, para que tivessem o mesmo peso de representação e de decisão. O conselho fiscal acompanha as atividades da cooperativa e sua movimentação. Na ausência de um conselheiro, seu suplente o substitui.

Essa assembleia pode ser considerada o primeiro grande passo rumo à reorganização da Cooperapas. A começar pela forma como foi feita a chamada, dentro dos padrões exigidos para a gestão de uma cooperativa: publicação no jornal (figura 3.3, na página a seguir); avisos espalhados em locais por onde passam os membros da cooperativa; ligações, mensagens por SMS, e-mail, grupos como o Whatsapp (já que a Cooperapas possui um). Quem ajuda na divulgação dessas assembleias e reuniões da cooperativa são os funcionários da CAE. 


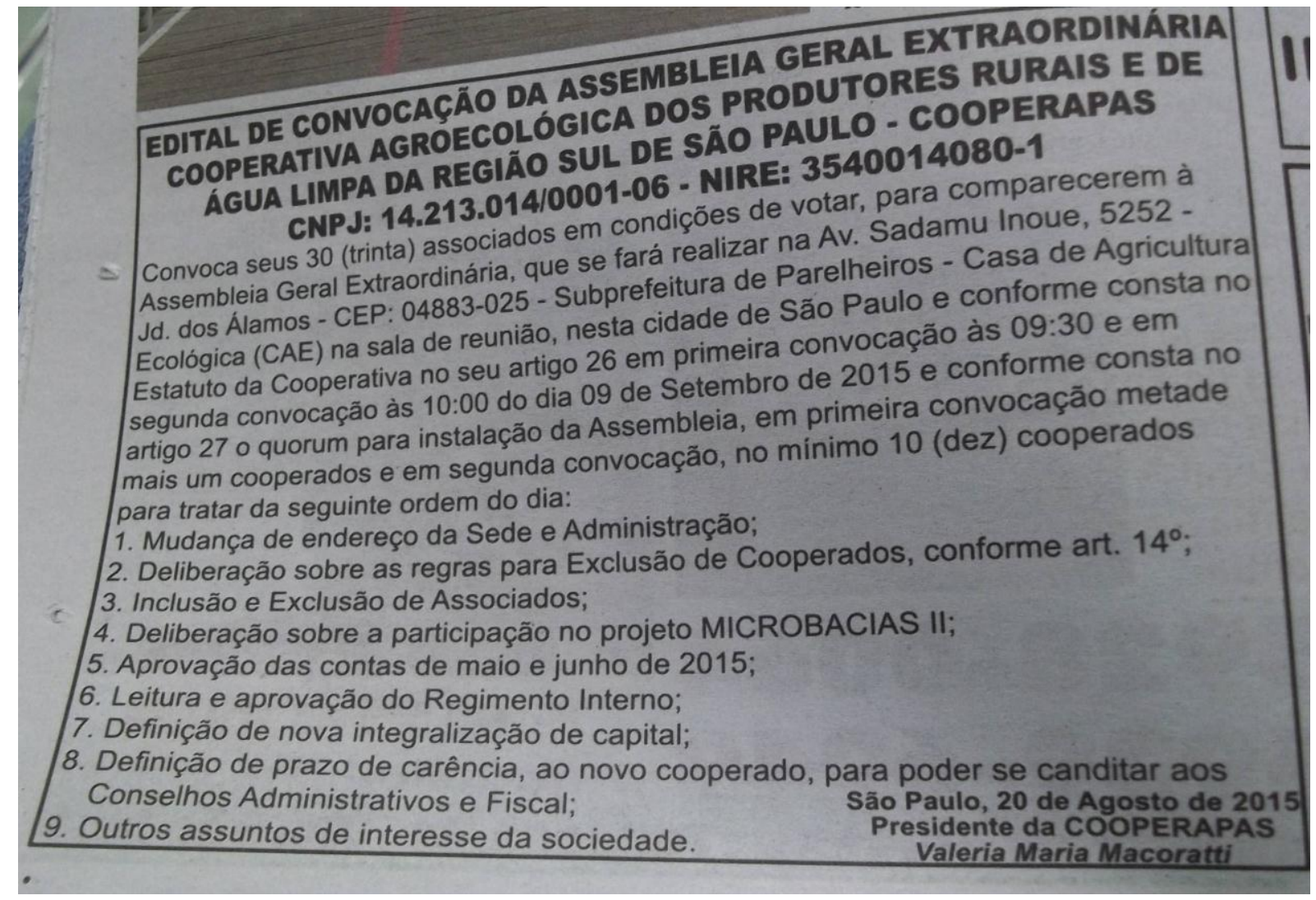

Figura 3.3. A partir da assembleia de 17 de março de 2016, as assembleias gerais passaram a cumprir as normas exigidas para a sua realização. Entre as normas, a publicação em um jornal com a data da assembleia e os pontos a serem tratados. A imagem acima mostra uma das convocações publicadas em um jornal da região.

Portanto, a partir de março de 2015, a Cooperapas começou a andar como deveria ter andado desde o início. Os membros até organizaram um churrasco para comemorar a ocasião e levantar fundos (foto 3.4, na próxima página). A festa ocorreu dia 5 de maio de 2015, no Sítio Paiquerê, pertencente à Tomi e a seu irmão, também um dos cooperados, Sérgio Milani.

$\mathrm{Na}$ ocasião, estavam presentes os cooperados e seus familiares, amigos e conhecidos, os técnicos da CAE, alguns funcionários da Supervisão Geral de Abastecimento (Abast) e o secretário municipal do Trabalho, Artur Henrique. Valéria conta mais sobre a intenção da festa:

A festa da Cooperapas foi para comemorar a nova fase que a gente entra e pra poder arrecadar fundos para pagar o que a gente deve. Com tudo que nós arrecadamos [...] marcamos tudo que nós conseguimos arrecadar com o que a gente devia, o que nós gastamos com carimbo... pagamos a mensalidade do João do mês cinco [maio], pagamos o mercado que a gente fez para a festa, o pão, o Sérgio que nós demos $R \$ 500,00$ na manutenção do sítio, porque foi usada a piscina, tinha que arrumar tudo. De 
tudo que nós arrecadamos e o que nós devíamos, a gente ainda fica com um saldo devedor de $R \$ 546,21$ [...] (informação verbal) ${ }^{44}$.

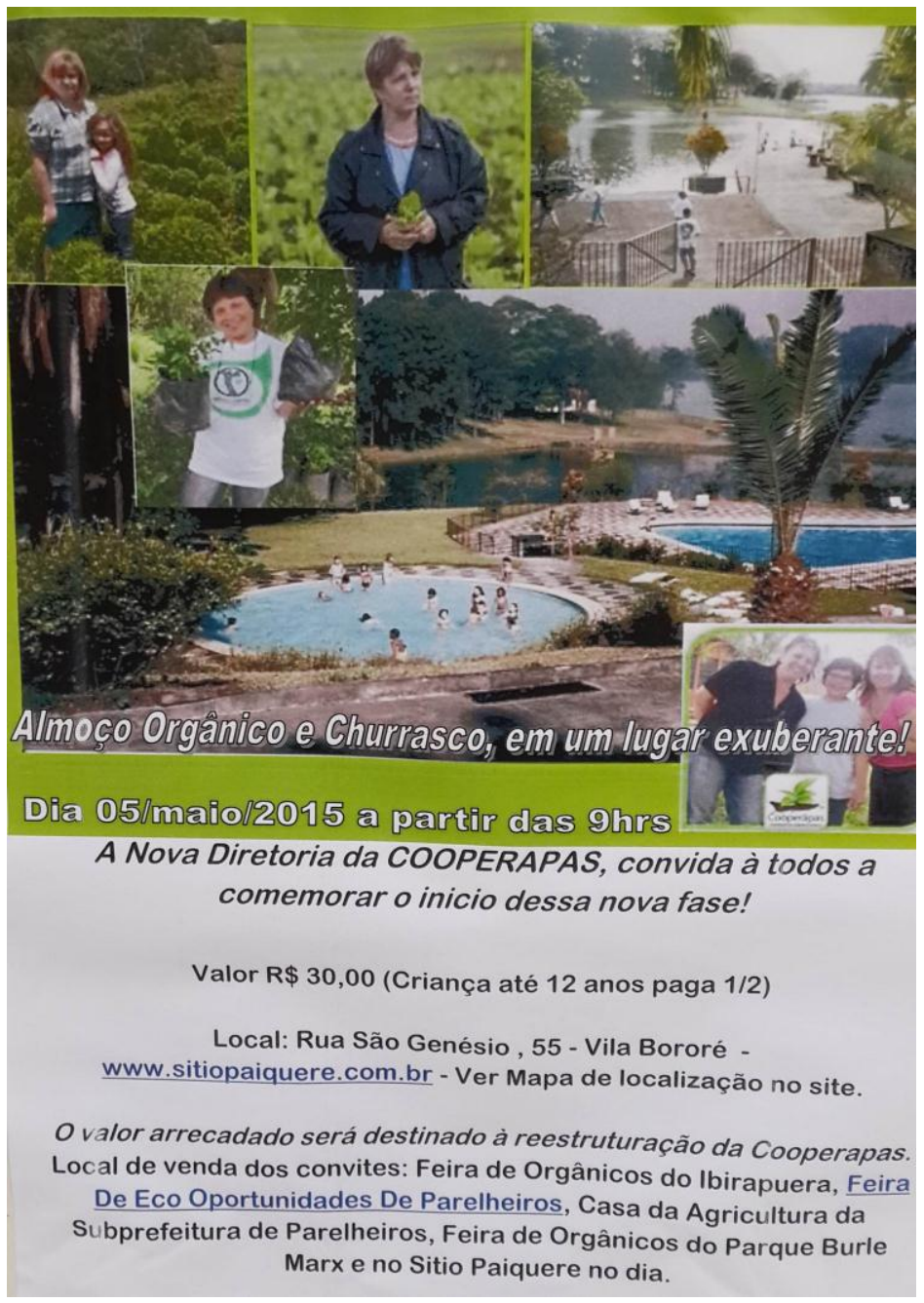

Foto 3.4. Foto de um dos cartazes que foram espalhados na Subprefeitura de Parelheiros, na CAE, anunciando o evento e a nova fase da Cooperapas. Foto de 29 de abril de 2015. Crédito da foto: Angélica Campos Nakamura.

Desde o início da reestruturação da Cooperapas, vieram outros gastos com documentação e pagamento pelos serviços e mensalidade do contador. Com isso, a cooperativa acumulou um débito de $\mathrm{R} \$ 3.000,00$. A festa realmente ajudou na arrecadação de dinheiro, mas também contou com a doação de produtos dos cooperados, pois cestas de produtos orgânicos foram doadas para as pessoas que ajudaram, direta e indiretamente, na regulamentação da Cooperapas (fotos 3.5, 3.6 e 3.7, na página a seguir). Para participar da festa, foram vendidos convites a um preço de $\mathrm{R} \$ 30,00$ (figura 3.4, após as fotos).

\footnotetext{
${ }^{44}$ Informação verbal de Valéria Macoratti, durante reunião da Cooperapas na Casa de Agricultura Ecológica, na Subprefeitura de Parelheiros, em São Paulo, em 26 de maio de 2015.
} 

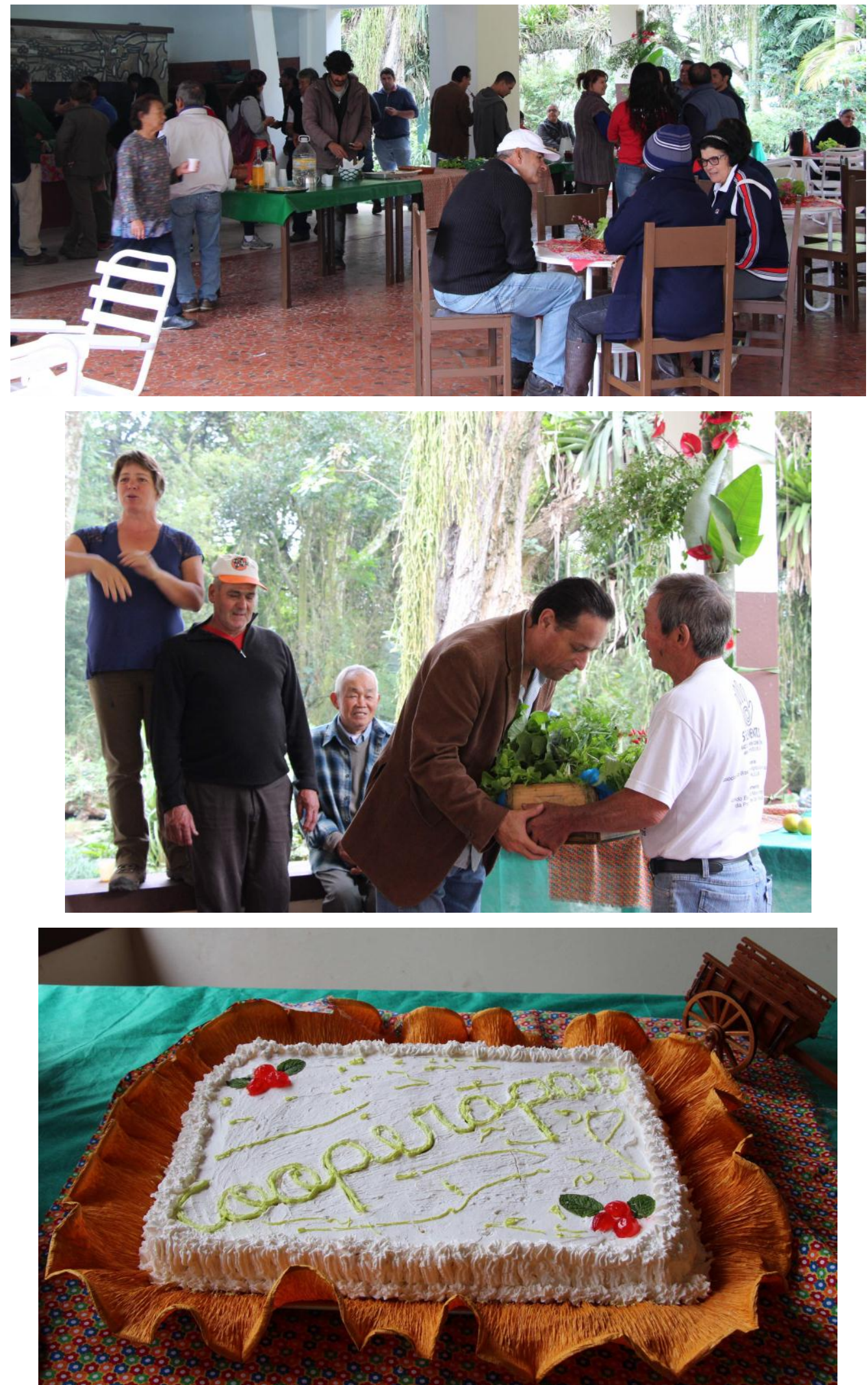

Fotos 3.5, 3.6 e 3.7. Na primeira foto (3.5), convidados reunidos na festa. Na segunda (3.6), o secretário municipal do Trabalho, Artur Henrique, agradece a cesta de produtos orgânicos que ganhou. Na última foto (3.7), o bolo com o nome da Cooperapas. Fotos de 5 de maio de 2015. Crédito das fotos: Angélica Campos Nakamura. 


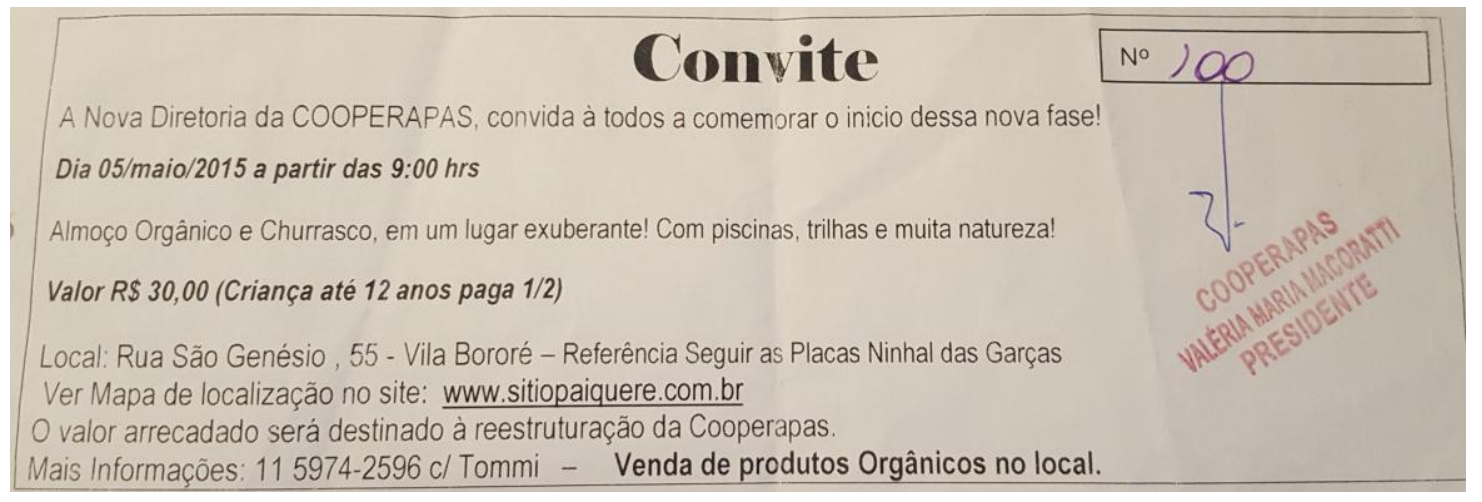

Figura 3.4. Convite da festa da Cooperapas realizada em 5 de maio de 2015.

Assim, com a documentação devidamente regulamentada, a Cooperapas poderia finalmente dar início a uma comercialização conjunta dos produtos agrícolas e orgânicos produzidos por seus membros. Porém, como veremos mais à frente, junto com as conquistas, mais desafios surgiram.

\subsection{Princípios e prática do cooperativismo na agricultura: o caso da Cooperapas}

Conforme contado no item anterior, a cooperativa quase terminou devido aos problemas de regulamentação e à forma como havia sido feita a sua gestão até 2014. Embora a dificuldade e o gasto para se fechar uma empresa tenham sido fatores determinantes para manter ou não a cooperativa, outras razões também pesaram na decisão final. Valéria Macoratti, atual presidenta, traz isso em uma fala sua na assembleia geral ordinária de 17 de março de 2015:

Mas e o nosso sonho? E tudo aquilo? E as pessoas que conhecem a Cooperapas? Porque nossos cooperados não sabem a importância que tem, mas a Cooperapas tem um nome lá fora, um nome muito mais forte do que as próprias pessoas daqui possam imaginar. A nossa cooperativa, queiramos nós ou não, ela já tem mais de 4 anos de fundação. Nós podemos participar de todos os projetos, de tudo que tem para nos oferecer, as portas estão escancaradas. Só cabe a nós. [...] Tomamos a frente, fomos resolver papelada atrás de papelada, está tudo certinho, só faltava fazer isso, até o final desse mês, a gente ter a nossa primeira assembleia correta, com ata, com anúncio no jornal, com tudo certinho, com convocação dos cooperados, com a fixação em todos os locais públicos onde os cooperados possam passar. [...] Então hoje a gente tá [sic] aqui, feliz, a Cooperapas vai ser 
fênix, para quem imaginava que a Cooperapas tava [sic] morta, enterrada, nós estamos aqui, e a gente vai dar um novo gás [...] (informação verbal) ${ }^{45}$.

É interessante destacar na fala dela sobre o início da cooperativa, "o nosso sonho". A palavra sonho remete a algo a ser alcançado, em um bom sentido, até utópico. Muitas vezes, relaciona-se o cooperativismo a uma utopia, pois essa prática é vista positivamente por muitas pessoas, já que a finalidade dela não é o lucro e, sim, o bem-estar de seus membros. Araújo (1982, p. 131) diz que, no Brasil, o cooperativismo "[...] tem sido considerado como a saída para inúmeros impasses de marginalização social em que se encontram largas faixas da população, face ao processo mais amplo de desenvolvimento".

O cooperativismo, de acordo com Silva e Holz (2008, p. 2 e 4),

[...] não visa ao lucro, mas sim a satisfazer as necessidades do grupo que dele faz parte, com acesso de bens e serviços a custos menores, gerando um melhor bem-estar social. Quando do excedente das transações realizadas com seu quadro social, este será investido e aplicado em seu local de atuação, permitindo assim uma melhor distribuição de renda e riqueza. [...]

As sociedades cooperativas são empresas cujo objetivo não é a busca desenfreada pelo lucro ou a ganância pela rentabilidade do capital, mas sim o uso comum do dinheiro do grupo de associados, que é transformado em bens e serviços, de acordo com o ramo da cooperativa, a custos mais acessíveis. Esta prática visa a estender um maior bem-estar social, pois permite o acesso de bens e serviços a pessoas que em uma estrutura capitalista tradicional não teriam acesso. [...]

$\mathrm{O}$ maior objetivo da cooperativa é atender e satisfazer às necessidades do grupo de associados que dela faz parte. Como este grupo assume o duplo papel de sócio e usuário, ele tem a autonomia de decidir o rumo da cooperativa de forma democrática.

Pinho levanta um ponto interessante acerca das definições existentes sobre cooperativas. Para ela, as diversas definições apresentadas pelos autores cooperativistas podem ser reunidas em dois grupos principais: no primeiro grupo, estão aquelas que consideram o fim dessas sociedades, ou seja, a correção dos problemas do meio social e a prestação de serviços; no segundo, estão as definições que colocam em relevo a forma dessas sociedades, descrevendo-as como organizações democráticas de pessoas que funcionam segundo os princípios rochdaleanos (PINHO, D., 2004, p. 124-125, grifo da autora). Ela ainda distingue a cooperativa de uma empresa não-cooperativa:

\footnotetext{
45 Informação verbal de Valéria Macoratti, durante assembleia geral da Cooperapas na Casa de Agricultura Ecológica, na Subprefeitura de Parelheiros, em São Paulo, em 17 de março de 2015.
} 
A cooperativa pode ser entendida como "uma empresa de serviço" cujo fim imediato é o atendimento das necessidades econômicas de seus usuários que a criam com seu próprio esforço e risco. Distingue-se da "empresa capitalista", porque nesta a satisfação das necessidades dos usuários não representa seu fim imediato, mas sim a multiplicação ou rendimento do capital investido.

[...] enquanto na empresa capitalista a prestação de serviços é o meio de obter o maior lucro possível, na cooperativa a satisfação das necessidades dos associados é o fim da atividade econômica. [...] (PINHO, D., 2004, p. 123-124).

Em uma tabela, ela lista as diferenças:

Tabela 3.2. Empresa cooperativa e não-cooperativa

\begin{tabular}{|l|l|}
\hline \multicolumn{1}{|c|}{ EMPRESA COOPERATIVA } & \multicolumn{1}{|c|}{ EMPRESA NÃO-COOPERATIVA } \\
\hline Uma sociedade de pessoas. & É uma sociedade de capital. \\
\hline Objetivo principal é a prestação de serviços. & Objetivo principal: lucro. \\
\hline Número ilimitado de associados. & Número limitado de acionistas. \\
\hline Controle democrático - um homem, um voto. & Cada ação um voto. \\
\hline $\begin{array}{l}\text { Assembleia: quórum baseado no número de } \\
\text { associados presentes. }\end{array}$ & Assembleia: quórum baseado no capital. \\
\hline $\begin{array}{l}\text { Não transferência das cotas-partes } \\
\text { estranhos à sociedade. }\end{array}$ & Transferência das ações a terceiros. \\
\hline Retorno proporcional ao valor das operações. & Dividendo proporcional ao valor das ações. \\
\hline
\end{tabular}

Fonte: PINHO, Diva Benevides. O cooperativismo no Brasil: da vertente pioneira à vertente solidária. São Paulo: Saraiva, 2004. p. 180.

Ou seja, apesar de ser importante para uma cooperativa alcançar o lucro, a sua finalidade é diversa daquela de uma empresa capitalista. Porém, a cooperativa não pode transformar a busca do lucro em seu único objetivo, pois assim de transforma em mais uma empresa capitalista disfarçada de cooperativa.

O lucro, em uma cooperativa, pode servir para melhorar as condições de produção e de vida dos cooperados. Singer dá um bom exemplo como isso se dá no meio rural:

Não é viável, por exemplo, que cada pequeno agricultor possa comprar trator, ceifadeira e outros equipamentos valiosos. Isso o impede de mecanizar sua lavoura e, portanto, de competir com grandes produtores, cujas dimensões justificam de competir com grandes produtores, cujas

\footnotetext{
${ }^{46} \mathrm{Na}$ Lei 5.764/71, em seu artigo 24, parágrafo $1^{\circ}$, o legislador fixa limites com o objetivo de preservar a igualdade entre os cooperados: nenhum associado poderá subscrever mais de 1/3 do total de cotas-partes, salvo nas cooperativas em que a subscrição deva ser diretamente proporcional ao movimento financeiro do cooperado, ou à área cultivada, ou ao número de plantas ou de animais em exploração. [...] (PINHO, D., 2004, p. 150).
} 
dimensões justificam e viabilizam o referido investimento. Para não serem expulsos do mercado, os pequenos e médios produtores têm de se unir e fazer o investimento em capital fixo em conjunto. $\mathrm{O}$ trator, a ceifadeira etc. adquiridos pela cooperativa são postos à disposição de cada membro, por um tempo, de modo que os seus custos de produção se equiparam aos dos grandes proprietários (2002, p. 84, grifo do autor).

Ainda, Singer também aponta a vantagem da cooperativa no momento da comercialização de produtos:

No caso da agricultura, há ganhos de escala importantes a serem realizados também mediante a venda em comum das colheitas. Geralmente, os compradores dos produtos agrícolas são grandes firmas atacadistas ou indústrias processadoras, que frequentemente adiantam dinheiro ao camponês em troca do compromisso de venda da sua colheita. Estas são transações altamente assimétricas, em que numerosos pequenos produtores se defrontam com poucos grandes adquirentes. Estes últimos alcançam grandes margens de lucros de intermediação, porque sua superioridade econômica lhes permite pagar o mínimo aos produtores e cobrar o máximo aos varejistas, que tendem a ser pequenos e numerosos também (2002, p. $84)$.

Dessa forma, as cooperativas se inserem no sistema capitalista sem realmente ameaçálo ou ir contra ele. Ao contrário, o cooperativismo surge, conforme dito acima, como uma forma de sobrevivência dentro do sistema capitalista, por ser uma alternativa mais justa, democrática e igualitária, que gera trabalho e inclui socialmente. Singer, mais uma vez, levanta a importância das cooperativas para o homem do campo:

[...] o cooperativismo agrícola [...] não passa de um modo de produção intersticial nas formações capitalistas. Isso significa que o cooperativismo de compras e vendas se insere em interstícios da economia em que a tendência centralizadora do capital, entregue a seu curso natural, destruiria a pequena produção de mercadorias. No caso da agricultura, isto significaria a eliminação total do campesinato, de sua cultura e do seu modo de vida, pelo agrobusiness, a grande empresa agrícola capitalista e seus trabalhadores assalariados e fornecedores contratados etc. A força do cooperativismo impediu esta eliminação, preservando para o camponês uma parcela importante da atividade agrícola (2002, p. 88, grifo nosso).

Realmente, a cooperativa pode ser uma saída para um agricultor com pequena produção no mercado. Há, na Cooperapas, casos desse tipo. Desde que a cooperativa começou a conseguir se organizar para vender, conforme se verá mais adiante mais detalhadamente, alguns pequenos começaram a se beneficiar com as vendas. É esse o "sonho" ao qual a presidenta, Valéria, refere-se muitas vezes. Ela tem consciência de que uma parcela 
dos cooperados têm mais dificuldades financeiras e a cooperativa traz, para eles, mais certeza da venda de seus produtos e, consequentemente, um retorno financeiro.

Porém, levar esse sonho para frente, desde o início da Cooperapas, não foi nada fácil. Ao mesmo tempo em que se propõe uma sociedade de pessoas a qual não busque exclusivamente o lucro, o que marca a grande diferenciação entre uma cooperativa e uma empresa, a cooperativa está dentro de uma sociedade capitalista e é gerida por leis pensadas no mercado. A começar pela obrigatoriedade da quota-parte, que é uma exigência excludente. A parcela mais marginalizada da sociedade, já sem condições de suprir suas necessidades básicas, não tem como direcionar uma parte de seu dinheiro para uma integralização de capital. Outro exemplo, que pode ser dado, é como a lógica de gestão de uma cooperativa também acaba caindo na lógica da de uma empresa, pois ainda que a cooperativa seja isenta de certos impostos, é preciso conhecimento de como declará-los e de como manter a documentação em dia. A Receita Federal não perdoa a falta de declaração.

Sobre esse conflito, Silva e Holz explicam:

As cooperativas [...] deverão estar atentas aos modernos modelos de estrutura e de gestão utilizadas pelas tradicionais estruturas capitalistas. Talvez seja esta característica que leva a gerar conflitos de entendimentos acerca do termo cooperativismo. Se, em determinados momentos utiliza-se uma filosofia de democracia, solidariedade e auto-ajuda, em outros, fala-se em adequação de mercado, otimização e racionalização de custos, gestão, enfim uma linguagem puramente capitalista. As cooperativas precisam utilizar-se destes mecanismos para sobreviver no mercado capitalista em permanente transformação (2008, p. 7).

Aqui talvez o melhor não seja falar em sobrevivência e, sim, de transformação da cooperativa, que aos poucos vai entrando na lógica capitalista. Pinho, D. afirma que

[...] as cooperativas são obrigadas a realizar esforços de modernização, e ao mesmo tempo, de adaptação ou acomodação aos sistemas, estruturas e regimes econômicos onde funcionam, mas quase sempre com esvaziamento de seu conteúdo doutrinário (1973, p. 27).

Desde a reorganização da Cooperapas, é muito comum Valéria afirmar que a cooperativa é uma empresa. Sua visão se explica tanto por todos os problemas os quais teve que resolver conforme se contou a história da cooperativa, como a necessidade de ter capital para pagar as despesas e funcionários que prestam serviços, como o contador. Mas há outros pontos, baseando-se em Silva e Holz, que indicam como a reorganização da cooperativa passou por uma forma de pensá-la como empresa cooperativa, indicados na tabela a seguir. 
Tabela 3.3. Pontos de Silva e Holz e reorganização da Cooperapas

\begin{tabular}{|c|c|}
\hline PONTOS DE SILVA E HOLZ & REORGANIZAÇÃO DA COOPERAPAS \\
\hline $\begin{array}{c}\text { Estruturação do processo de planejamento das } \\
\text { cooperativas: a cooperativa deve se organizar a } \\
\text { fim de saber como se encontra a sua situação no } \\
\text { mercado e o que pretende fazer, como vai se } \\
\text { inserir etc. }\end{array}$ & $\begin{array}{c}\text { Ao se reorganizar, a cooperativa ainda estava com } \\
\text { o objetivo de vender para programas } \\
\text { governamentais e aumentar suas vendas para } \\
\text { compradores interessados, pois o mercado de } \\
\text { orgânicos cresceu muito de 2010 para frente. }\end{array}$ \\
\hline $\begin{array}{c}\text { Estruturação organizacional das cooperativas: } \\
\text { nesta etapa, deve-se delinear quatro aspectos: as } \\
\text { responsabilidades, as autoridades, as } \\
\text { comunicações e as decisões da cooperativa. } \\
\text { administrativo e fiscal. Foi decidido continuar } \\
\text { com a cooperativa e, para isso, a documentação } \\
\text { foi acertada. A cooperativa passou a seguir as } \\
\text { normas para atas, registrar documentos na Junta } \\
\text { Comercial, anunciar no jornal as assembleias, } \\
\text { entre outras medidas. }\end{array}$ \\
$\begin{array}{c}\text { Estruturação do processo diretivo: é de grande } \\
\text { importância para a cooperativa, pois será } \\
\text { escolhida uma ou mais pessoas que serão as } \\
\text { líderes internas. Normalmente, é um cooperado } \\
\text { carismático e com forte influência sobre as } \\
\text { pessoas da cooperativa. }\end{array}$ & $\begin{array}{c}\text { O novo conselho administrativo foi eleito em } \\
\text { assembleia, porém, as três mulheres que o } \\
\text { compõem estavam entre as pessoas mais ativas e } \\
\text { comunicativas da cooperativa. }\end{array}$ \\
\hline $\begin{array}{c}\text { Estruturação do processo de acompanhamento, } \\
\text { avaliação e aprimoramento dos resultados das } \\
\text { cooperativas: é a etapa que consolida todas as } \\
\text { outras e as avalia. }\end{array}$ & $\begin{array}{c}\text { Os membros da cooperativa se reorganizaram } \\
\text { devido à avaliação feita das gestões anteriores, } \\
\text { nas quais muito pouco foi feito, e aprimoraram a } \\
\text { cooperativa colocando em ordem a } \\
\text { documentação, regulamentando-a. }\end{array}$ \\
\hline
\end{tabular}

Fonte: SILVA, Leonardo Xavier; HOLZ, Viviane Ratzmann. O cooperativismo e seu comportamento diante do capitalismo atual: aspectos teóricos e evidências empíricas. In: $\mathbf{V}$ Encontro de Pesquisadores Latino-americanos de Cooperativismo, Ribeirão Preto, SP, ago. 2008. p. 6-7.

Outra questão apontada para o bom andamento de uma cooperativa, é a compreensão da importância de sua natureza mútua. De acordo com Lamming,

[...] aqueles que formam uma cooperativa concordam em fundar e dirigir uma empresa ou um grupo de empresas, em conjunto [...]; de que o objetivo central dessa empresa conjunta seja capacitar os sócios para atender as suas necessidades recíprocas ou procurar interesse mútuos, por ação conjunta, baseada em compreensão comum; de que pertencer a uma cooperativa significa trabalhar como grupo, com a empresa comum e por ela, e que as normas do grupo devem ser observadas por todos, enquanto permanecerem como membros do grupo; de que o acordo de trabalhar em conjunto não funciona só entre cada sócio individual e a cooperativa, mas também multilateralmente, entre os próprios associados, de modo que operam como uma equipe econômica [...] (1973, p. 290, grifo do autor).

O início da Cooperapas foi bem diferente. Ainda que existisse uma vontade de pequenos grupos de agricultores se juntarem para formar uma cooperativa, que a Casa de Agricultura Ecológica tenha ajudado e prestado assessoria e que reuniões tenham sido 
realizadas para esse fim, nenhuma dessas etapas de estruturação inicial foi pensada de fato. $\mathrm{O}$ pensar em conjunto só ocorreu quando a desregulamentação da cooperativa gerou uma grande multa que deveria ser paga por todos com o nome na Cooperapas. Ernesto Oyama, em sua fala no início do capítulo, quando se conta a história da cooperativa, já apontava para a dificuldade de juntar agricultores provenientes de grupos distintos.

Após a reorganização da Cooperapas e a anulação de grande parte da multa da Receita Federal, a falta de dinheiro na cooperativa começou a pesar. Todos os meses, no mínimo, havia a mensalidade do contador. Sabendo das dificuldades financeiras que a cooperativa enfrentaria após a reorganização, foi acordado entre os membros que o conselho administrativo e o fiscal não receberiam nada pelo trabalho, ainda que este, muitas vezes, tome um tempo precioso do trabalho na agricultura.

Dinheiro é um assunto delicado a ser tratado entre os membros. É muito comum nas reuniões surgir comentários de que há pessoas devendo sua parte em algum gasto da cooperativa. Em uma reunião, por exemplo, reclamaram que havia pessoas as quais ainda não tinham pago o valor de $\mathrm{R} \$ 14,50$ referente à gastos gerais, como documentação. Os nomes dos devedores nunca são citados.

Se há dificuldades em se pagar um valor baixo, integralizar a quota-parte é um grande desafio para a cooperativa. Conforme contado na história da Cooperapas, houve uma doação do chefe da Supervisão Geral de Abastecimento para dar início à cooperativa. Porém, esse dinheiro foi usado durante a reorganização e outros gastos surgiram. Como a quota-parte não saiu do bolso dos cooperados na fundação da cooperativa, eles começaram a integralizá-la após a reorganização, já por meados de março de 2015.

A quota-parte é importante porque ela permite que a cooperativa tenha viabilidade econômica no seu início. João do ICA explica:

Cooperativa tem um tempo de amadurecimento. Tem dinheiro no bolso? Tem que ter viabilidade econômica. Primeiro faz o capital, primeiro tem que ter o dinheiro. Aí sim vai se ter dinheiro pra ter funcionário, ter coisas. [...] Falou em cooperativa, primeiro faz o patrimônio. Aí depois vai pensar em cooperativa. (informação verbal) ${ }^{47}$.

\footnotetext{
${ }^{47}$ Informação verbal fornecida por João Belato, durante assembleia geral da Cooperapas na Casa de Agricultura Ecológica, na Subprefeitura de Parelheiros, em São Paulo, em 17 de março de 2015.
} 
Em outra reunião, também com a presença de João do ICA, ele explica:

Na realidade, quando se pensa em cooperativa, se pensa primeiro em montar o capital [...]. Nosso grupo aqui foi feito ao contrário: de cima para baixo, nunca de baixo para cima. [...] A cooperativa vive de taxa de serviço, do serviço prestado pela cooperativa ao cooperado. Então o cooperado entrega o produto na cooperativa, a cooperativa vende, e tira uma porcentagem disso para pagar a despesa. Cooperativa não é como clube de futebol que precisa pagar mensalidade, isso não existe. Mas aqui como ela foi feita de uma forma diferente, a gente precisa cotizar as nossas dividas. O que é cotizar? A gente tem o contador, algumas vias que precisam ser emitidas [...]. Então a gente está pagando o contador. Só que até agora, parece que o pessoal não entendeu ainda, que a cooperativa tem as despesas dela. Não somos nós que estamos fazendo despesa, é ela própria. Por quê? Porque nós não entregamos produto direito ainda (informação verbal) $^{48}$.

As falas anteriores de João do ICA ocorreram antes da cooperativa iniciar suas vendas coletivas. Portanto, não havia nenhuma entrada de dinheiro no caixa da Cooperapas. A única entrada possível, naquele momento, era por meio da integralização das quotas-partes.

Para realizar essa integralização, cada membro deve pagar vinte parcelas de $R \$ 50,00$, totalizando $\mathrm{R} \$ 1.000,00$. Nas últimas entrevistas realizadas com Tomi, a diretora financeira responsável por receber esses valores, perguntada sobre o andamento dessa integralização, ela afirmou, com um certo desânimo, que não eram todos que estavam pagando.

Pode-se questionar como a cooperativa sobreviveu até então sem quota-parte integralizada pelos membros e sem nenhuma comercialização, pois algum gasto, ainda que pequeno, sempre surgia. No início da reorganização, mais gastos vieram, com o contador e a documentação. Esses gastos foram cobertos por doações de variados membros, sem reembolso a eles. Quem podia, dava mais para ajudar a pagar as contas. Nas primeiras reuniões de 2015, quando ainda não havia comercialização coletiva e quota-parte, foi comum presenciar essas doações "espontâneas”.

O início da comercialização conjunta era essencial para a entrada de dinheiro no caixa da Cooperapas. Porém, esse assunto só começou a surgir em reuniões em junho de 2015, com o surgimento de uma possibilidade de venda de hortaliças para um evento da Prefeitura de São Paulo, que ocorreria no mês seguinte. A venda se confirmou e, finalmente, em julho de 2015, a Cooperapas realizou sua primeira venda coletiva ${ }^{49}$.

\footnotetext{
48 Informação verbal fornecida por João Belato, durante reunião da Cooperapas na Casa de Agricultura Ecológica, na Subprefeitura de Parelheiros, em São Paulo, em 26 de maio de 2015.

${ }^{49}$ O evento foi o Encontro Nacional de Estudantes de Design (N SP 2015), que ocorreu em julho de 2015 na cidade de São Paulo. A Cooperapas forneceu "950 maços de couve, 1 tonelada de mandioca, $200 \mathrm{~kg}$ de batata,
} 
Contudo, essa primeira venda foi apenas para essa ocasião. No mesmo mês, após o evento, a Cooperapas conseguiu fechar com o seu primeiro comprador frequente, com entregas semanais: o Instituto Chão (fotos 3.8 e 3.9). Até setembro de 2016, o Instituto continuava seu cliente.

Dessa forma, o Instituto Chão vende produtos agrícolas orgânicos pelo preço pago aos produtores. $\mathrm{O}$ resultado é um valor mais baixo a ser pago pelo consumidor final e um valor mais alto e justo pago aos produtores agrícolas que vendem para eles. De acordo com os agricultores da Cooperapas, o preço ainda é mais baixo do vendido em feiras orgânicas na cidade de São Paulo, porém, muito melhor do que o pago em vendas por atacado a supermercados e sacolões.
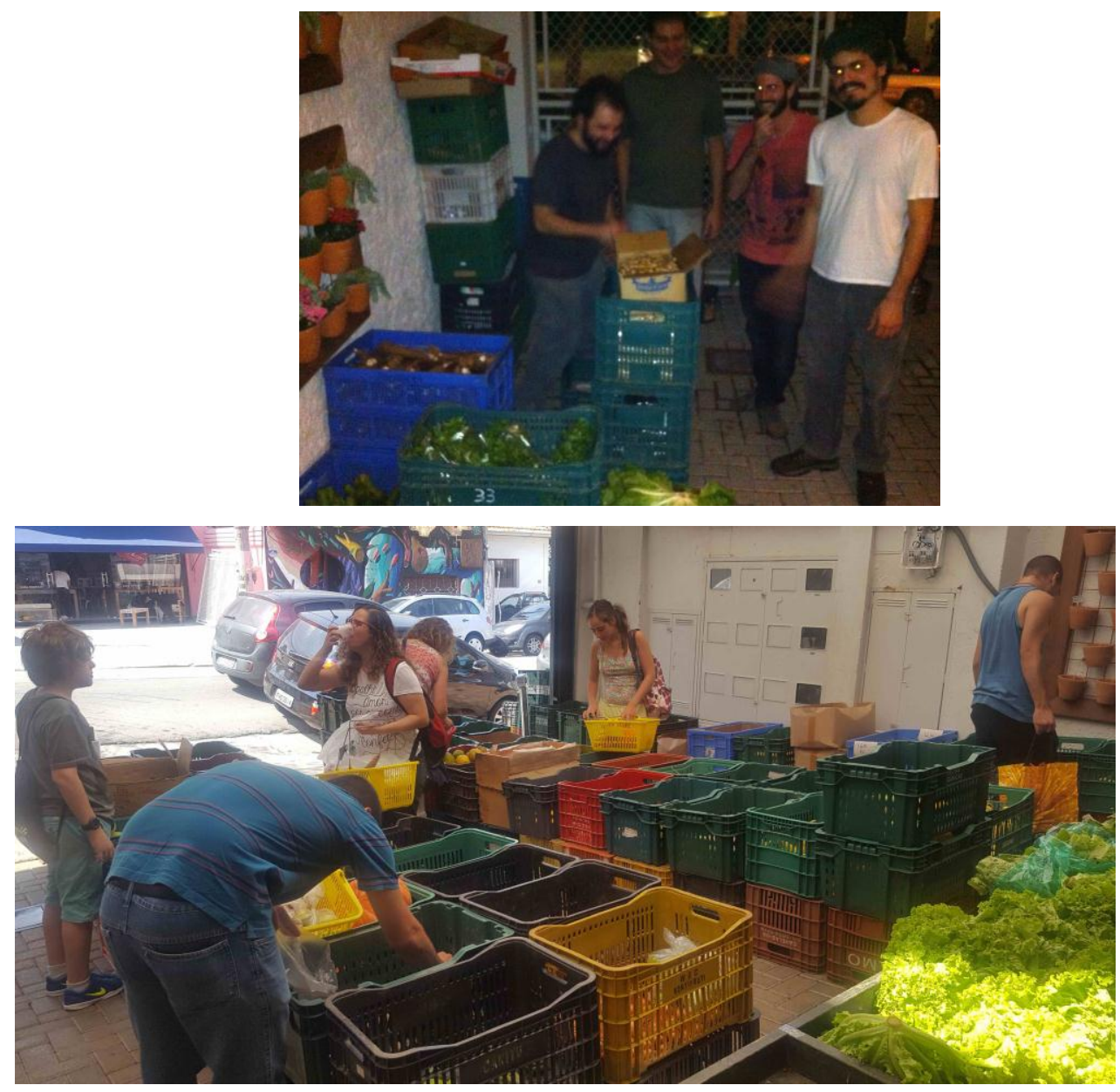

Fotos 3.8 e 3.9. Na foto acima (3.8), a primeira entrega para o Instituto Chão, em 10 de julho de 2015, foi tão importante que uma foto pelo grupo do Whatsapp da Cooperapas foi enviada, para registrar o momento. Crédito da foto: foto recebida pelo grupo do Whatsapp da Cooperapas. Na foto abaixo (3.9), clientes fazendo compras no Instituto Chão. Foto de 8 de abril de 2015. Crédito da foto: Angélica Campos Nakamura.

$300 \mathrm{~kg}$ de cenoura, 600 maços de cheiro verde, 3.000 pés de alface, 1.300 pés de escarola” (ECOSOL SP, 2015). Os produtos foram utilizados nas refeições diárias oferecidas pelo evento. 
Para se ter uma ideia dos valores dos produtos vendidos para o Instituto Chão, em uma reunião do dia 28 de julho de 2015, uma lista foi passada com os preços (tabela 3.4).

Tabela 3.4. Preços pagos pelo Instituto Chão em julho de 2015

\begin{tabular}{|l|l|l|l|}
\hline \multicolumn{1}{|c|}{ PRODUTO } & \multicolumn{1}{c|}{ PREÇO } & \multicolumn{1}{c|}{ PRODUTO } & \multicolumn{1}{c|}{ PREÇO } \\
\hline Abacate & $\mathrm{R} \$ 4,00$ o quilo & Chicória & $\mathrm{R} \$ 1,50$ a unidade \\
\hline $\begin{array}{l}\text { Abóbora limpa e } \\
\text { descascada }\end{array}$ & $\begin{array}{l}\mathrm{R} \$ 3,50 \text { o pacote } \\
\text { embalado }\end{array}$ & Coentro & $\mathrm{R} \$ 2,00$ o maço \\
\hline Açafrão & $\mathrm{R} \$ 20,00$ o quilo & Couve & $\mathrm{R} \$ 2,50$ a unidade \\
\hline Alface baby & $\mathrm{R} \$ 1,00$ a unidade & Escarola & $\mathrm{R} \$ 2,00$ a unidade \\
\hline $\begin{array}{l}\text { Alface crespa ou } \\
\text { mimosa }\end{array}$ & $\mathrm{R} \$ 2,00$ a unidade & Ervilha-torta & $\mathrm{R} \$ 15,00$ o quilo \\
\hline Almeirão & $\mathrm{R} \$ 1,50$ & Feijão carioca & $\begin{array}{l}\mathrm{R} \$ 4,00 \text { o pacote de } \\
\text { meio quilo }\end{array}$ \\
\hline Banana prata & $\mathrm{R} \$ 3,00$ o quilo & Inhame & $\mathrm{R} \$ 5,00$ o quilo \\
\hline Batata doce & $\mathrm{R} \$ 5,00$ o quilo & Laranja & $\mathrm{R} \$ 3,00$ o quilo \\
\hline Batata yacon & $\mathrm{R} \$ 7,00$ o quilo & Limão cravo & $\mathrm{R} \$ 3,00$ o quilo \\
\hline Brócolis & $\mathrm{R} \$ 3,00$ o maço & Mandioca com casca & $\mathrm{R} \$ 3,00$ o quilo \\
\hline $\begin{array}{l}\text { Cana-de-açúcar limpa } \\
\text { e embalada }\end{array}$ & $\mathrm{R} \$ 3,00$ o pacote & Mandioca limpa & $\mathrm{R} \$ 5,00$ o pacote \\
\hline Catalônia & $\mathrm{R} \$ 2,50$ a unidade & Milho verde & $\mathrm{R} \$ 1,00$ a espiga \\
\hline Cará-moela & $\mathrm{R} \$ 5,00$ o quilo & Mostarda & $\mathrm{R} \$ 2,00$ o maço \\
\hline Cenoura & $\mathrm{R} \$ 3,50$ o quilo & Repolho & $\mathrm{R} \$ 4,00$ a unidade \\
\hline Cheiro-verde & $\mathrm{R} \$ 2,00$ o maço & Rúcula & $\mathrm{R} \$ 3,00$ a unidade \\
\hline
\end{tabular}

Fonte: Informação verbal fornecida durante reunião da Cooperapas na Casa de Agricultura Ecológica, na Subprefeitura de Parelheiros, em São Paulo, em 28 de julho de 2015.

Ainda nessa reunião, Arpad informou que haviam vendido cerca de R \$10.000,00 em produtos só naquele mês e isso ainda poderia crescer, pois eram poucos os agricultores os quais estavam entregando.

Com o início da comercialização conjunta, a cooperativa estabeleceu uma porcentagem de $10 \%$ sobre o valor da venda de cada agricultor destinada ao caixa da Cooperapas. Desses $10 \%$, $5 \%$ vai para o pagamento do frete dos produtos - quem faz a entrega é um motorista pago à parte -, e 5\% para o fundo da cooperativa. Esse fundo paga outras despesas, como a documentação que sempre precisa estar em dia.

Essa primeira comercialização conjunta trouxe à tona várias questões as quais, até então, os cooperados nunca tinham pensado. A começar pela produção. Para atenderem uma demanda como essa, que é contínua - eles entregavam duas vezes por semana até o início de 2016 - eles precisavam saber quem tinha produto, quais disponíveis para o momento e futuramente. Ou seja, a primeira demanda que aí surge é o do planejamento da produção feito em conjunto. Ele é um grande desafio, pois os agricultores não têm o costume de registrar a 
quantidade produzida, nem de planejar exatamente o que vão plantar e, muito menos, de contabilizar a produção final. Até então, a escolha dos gêneros a serem cultivados levava em consideração apenas as estações do ano: as mais quentes e úmidas, e as mais secas e frias. De acordo com essas estações, eles escolhem o que vão plantar.

Mesmo após quase um ano de início de comercialização conjunta, a necessidade do planejamento aparece nas reuniões. Somente alguns cooperados vêm fazendo isso. Nesse período, sempre surgem nas reuniões alguém comentando de um potencial cliente. Porém, esbarra-se nesse problema logo de primeira: quem tem produto? Qual? Daqui alguns meses, quem terá determinado produto? A importância do planejamento em grupo aparece, mas nunca é realmente efetivado. Os agricultores com maior produção já vendem praticamente tudo, portanto, fica difícil eles assumirem mais uma venda.

Depois do momento do planejamento, é hora de juntar os produtos em um local para que alguém os busque e realize a entrega. O ponto de coleta é a Casa de Agricultura Ecológica (CAE), porque ela possui uma câmara fria, especialmente pensada nessa demanda dos agricultores.

Essa câmara fria é crucial para a Cooperativa, pois ela não tem um escritório, muito menos um armazém para o depósito de produtos. No caso de uma cooperativa, é essencial um local desse tipo. Seabra (1973, p. 87), em seu trabalho sobre a Cooperativa Agrícola de Cotia (CAC), aponta como foi necessário criar depósitos para o armazenamento dos produtos, veículos, equipamentos etc., além de uma rede de sistema de transportes da CAC. Ou seja, locais para armazenamento, e a necessidade de transporte próprio, são aspectos importantes e que devem ser pensados dentro da cooperativa ${ }^{50}$.

As entregas, até o início do ano de 2016, eram feitas duas vezes por semana, às quartas e sábados de manhã. Os agricultores se organizaram da seguinte maneira: às segundas e quintas, os agricultores entravam em contato, por e-mail ou telefone, com a pessoa responsável da cooperativa por anotar todos os produtos e a quantidade disponíveis para a venda. Essa pessoa, uma vez recolhida todas as informações, enviava para o Instituto Chão um e-mail informando os produtos e quantidades disponíveis. No mesmo dia, eles respondiam dizendo o que queriam. A pessoa responsável dava o retorno para os outros cooperados, para que se organizarem.

\footnotetext{
${ }^{50}$ Por não possuir uma central, a Cooperapas, na época de sua abertura, indicou o endereço do Centro Paulus, um local que abrigava cursos, eventos da região, hotel, albergue, galeria de arte etc., para promover o turismo na região (CENTRO PAULUS, 2016). Contudo, o local se tornou um parque municipal e a Cooperapas teve que mudar seu endereço. Uma das cooperadas, Tomi, ofereceu o endereço do seu sítio em substituição. Uma assembleia geral extraordinária teve que ser realizada em 9 de setembro de 2015 para oficializar a mudança de endereço da sede da Cooperapas.
} 
Quem levava os produtos até a câmara fria na CAE era o próprio agricultor. Normalmente, eles eram colhidos no dia anterior à entrega e levados à tarde ou à noite, nas terças e sextas-feiras. No dia seguinte, por volta das 4 h30 da manhã, o motorista passava na CAE para buscar os produtos.

Esse é um dos momentos o qual reflete como o trabalho em grupo, muitas vezes, é difícil. Apesar do combinado, muitos que deveriam entrar em contato com o responsável por anotar os produtos, não ligavam ou mandavam e-mail. O responsável, preocupado em cumprir com uma entrega, acabava entrando em contato com os agricultores. Cansado de correr atrás, ele chegou a levar esse problema para uma das reuniões. Acabaram acertando que, se o interessado em vender os produtos não entrasse em contato com o responsável pela ponte entre a Cooperapas e o Instituto Chão, até meio-dia da segunda e da quinta-feira, ficaria de fora daquela venda.

Outro percalço no caminho enfrentado pelos cooperados era que muitas vezes, entregavam em quantidades diferentes da prometida, por vezes a mais, por vezes a menos. A segunda opção acabava causando problemas, pois o pedido do Instituto Chão era fechado e combinado previamente, inclusive por conta dos valores a serem pagos. Para piorar, a quantidade citada por quem entregou era a prometida. O problema só era constatado quando um dos cooperados, que se encarregou de ir um dia antes da entrega contar e verificar os produtos, realizava esse serviço.

Finalmente, no momento da entrega, outro entrave também surgiu. Certos produtos não chegavam com a qualidade desejada pelo cliente. Vários eram os problemas: produtos amassados, folhas machucadas ou muito murchas, o produto estava muito pequeno e não valia o preço combinado. Nesse momento, a cooperativa percebeu que precisava aprender a padronizar seus produtos, mesmo provenientes de diferentes agricultores, e isso deveria começar desde o momento da produção, colheita e cuidados com o recebimento e o armazenamento.

Quem aponta a importância de se ter uma série de procedimentos ao longo de todo esse processo, que se inicia na produção e vai até a comercialização, é Utumi. Ele detalha melhor como essa organização e produção são influenciadas pela própria competição no mercado capitalista e, principalmente, pela mudança no comércio de produtos agrícolas:

Desde a colheita, sua entrega à cooperativa, até a comercialização final, existe um complexo de serviços destinado a preparar o produto para o seu ingresso no mercado. Aliás, esses serviços foram se tornando necessários à medida que, nos últimos anos, se foi modificando o comportamento do 
comércio de produtos agrícolas, em decorrência da mudança de hábitos e de costumes da população. A elevação do "status" social e o engrossamento de famílias que compõem a classe média determinaram essa mudança [...]

$\mathrm{E}$ as cooperativas agrícolas, ao ingressarem neste campo precisam, invariavelmente, adaptar-se às exigências requeridas por esse tipo de comércio, somente possível mediante vultosos investimentos $(1974$, p. 186187).

Apesar de Utumi fazer referência a cooperativas maiores, com mais agricultores e produção, sua fala é aplicável nesse entrave que a Cooperapas chegou. Afinal, a Cooperapas está negociando com compradores em um mercado capitalista. O Instituto Chão era apenas o primeiro cliente, e outros que viessem também fariam tais exigências.

As etapas citadas a seguir foram adaptadas de Utumi (1974, p. 187-200). Ele as enumera e comenta sobre cada uma delas:

a) Recebimento: a cooperativa pode tanto construir depósitos ou armazéns coletores para que os cooperados levem seus produtos em locais de mais fácil acesso ou ela pode comprar um veículo o qual vá até as propriedades buscar seus produtos. $\mathrm{O}$ veículo também pode levar mercadorias aos cooperados, como alimentos, material e máquinas para a produção agrícola etc.

b) Classificação: o produto recebe uma classificação quando é entregue na cooperativa. De acordo com Utumi, existem três tipos: quando a classificação é em função do cooperado, avalia-se o produto pela cor, tamanho, peso, sabor, paladar etc. Quem tem os melhores produtos sai beneficiado; quando a classificação é em função do cliente, a seleção dos produtos é feita de acordo com os hábitos dos consumidores; quando a classificação é legal, ela ocorre de acordo com leis e decretos, como os produtos que são exportados.

c) Padronização: a homogeneização dos produtos é importante na cooperativa, para que eles atendam as exigências das empresas compradoras. Mesmo que os produtos sejam heterogêneos, a cooperativa os separa, de acordo com os padrões estabelecidos. Utumi acredita que isso é positivo, pois "os cooperados são altamente favorecidos, pois a uniformização oferece a orientação e o estímulo para bem conduzir os seus trabalhos, visando colher quantidades maiores de produtos, que alcancem preços cada vez mais altos” (1974, p. 189). Para os consumidores, também há vantagens, pois os produtos chegam com mais qualidade. 
Em grandes cooperativas agrícolas, com muitos cooperados, Utumi (1974, p. 190) afirma que existe um sistema chamado de "pooling". Esse sistema é de recebimentoclassificação-padronização. Seabra explica:

Consiste o "pooling" em venda coletiva que visa, através da padronização e da classificação dos produtos, facilitar a sua comercialização e a fixação de preços de acordo com a qualidade. Deste modo, o produto chegado ao depósito etc., é examinado e classificado segundo a qualidade e vendido, permitindo o sistema de vendas por lotes de amostragem. A importância das vendas é distribuída aos consignatários de acordo com a quantidade e a classificação obtida pelos produtos (1973, p. 127).

d) Embalagem: com as mudanças no padrão de comercialização dos consumidores, foi necessária uma alteração na maneira de vender os produtos agrícolas. Para compreender melhor, Utumi exemplifica:

A batata, anteriormente exposta nos armazéns, coberta de terra, em sacos de 60 quilos, é hoje embalada em atraentes saquinhos enredados de 2 quilos, após haver passado por um processo de lavagem e limpeza. Os ovos são vendidos em pequenos invólucros de polietileno, de isopor ou de papelão, assim como os demais produtos: frutas, legumes etc., num esforço de motivar e interessar o comprador (1974, p. 191).

Todo esse trabalho com a embalagem cria uma nova necessidade como a de instalações e mão-de-obra que, para um pequeno produtor, só é viável por meio de uma cooperativa.

e) Transporte: a distribuição se dá por meio de veículos da cooperativa ou fretados de terceiros.

f) Vendas: finalmente os produtos são encaminhados para a comercialização. As grandes cooperativas no geral possuem uma ampla rede de abastecimento, com agentes e representantes em variados lugares, como supermercados, centrais de abastecimento, feiras livres etc. A cooperativa, aqui, aparece como uma grande empresa que defende seus associados.

Utumi ressalta, ao final, que esse modo de comercialização é o "normalmente adotado, podendo haver variações no 'modus operandi' de uma para outra sociedade” (1974, p. 200).

Seabra faz uma observação sobre esse sistema de vendas:

A aplicação deste sistema de vendas é sem dúvida um dos problemas mais complexos destas sociedades cooperativas [...]. Mesmo assim, o sistema, diga-se o único compatível com o manuseio de grandes volumes de 
produção, por tocar enfim no problema crucial da atividade comercial, isto é, quanto vai receber o cooperado, não tem deixado de ser um ponto de atritos entre este e a organização (1973, p. 127, grifo nosso).

Apesar de Utumi e Seabra terem estudado grandes cooperativas, essas etapas se mostraram importantes na gestão e planejamento da produção da Cooperapas. Tamanha a necessidade disso que, em 24 de setembro de 2015, a cooperativa marcou uma reunião para tratar exclusivamente desse tema. Ela foi realizada no Sítio 33, de Nelson Pati, um dos cooperados e foi divulgada para todos os membros.

O sítio de Nelson foi o escolhido porque ele paga um engenheiro agrônomo para acompanhar a sua produção. Sabendo da dificuldade da Cooperapas em estabelecer padrões para os produtos, ele ofereceu um dia de palestra com seu funcionário para todos os outros cooperados. O engenheiro explicou as etapas de colheita, cuidados na pós-colheita como a lavagem e armazenamento dos produtos, padronização e embalagem e o que é rastreabilidade dos produtos (fotos 3.10, 3.11, 3.12, 3.13 e 3.14). Infelizmente, não foram todos os cooperados que apareceram, foram apenas os principais fornecedores de produtos e os técnicos da CAE.

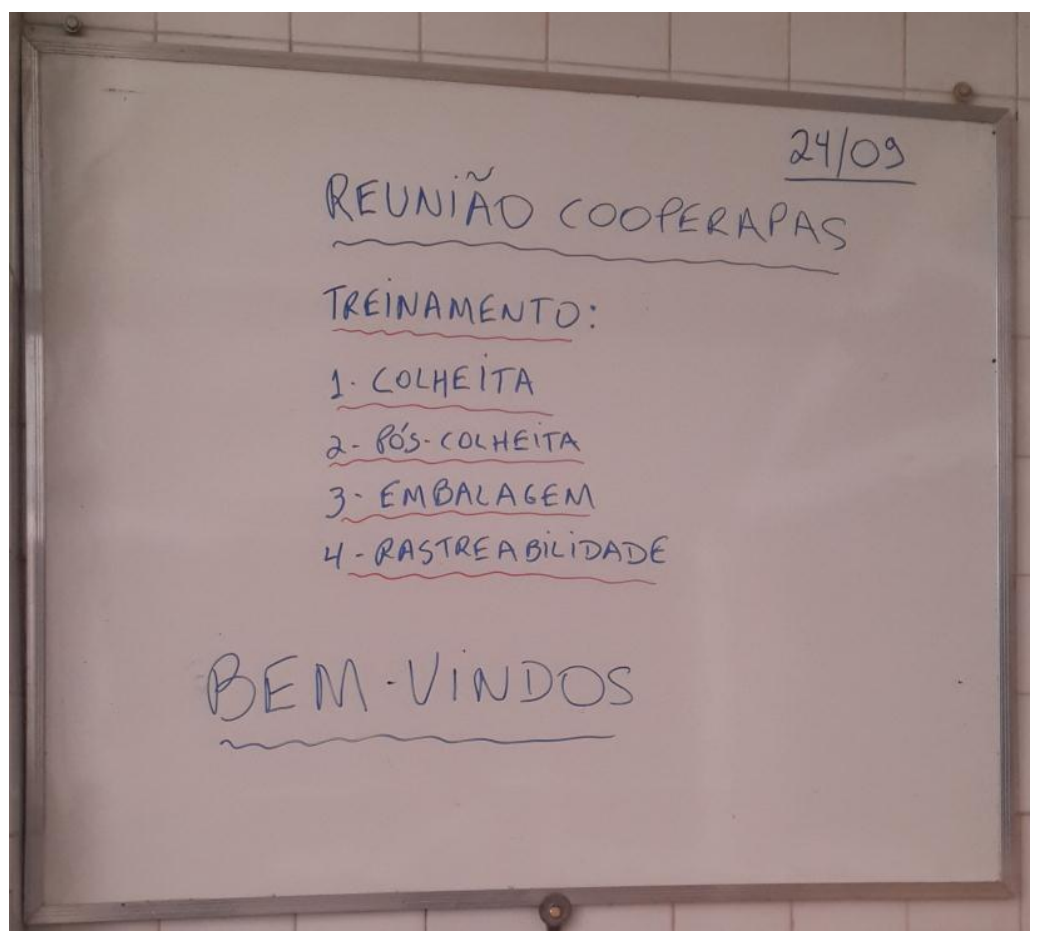

Foto 3.10. Quadro com os pontos que seriam explicados na reunião pelo engenheiro agrônomo. Foto de 24 de setembro de 2015. Crédito da foto: Angélica Campos Nakamura. 

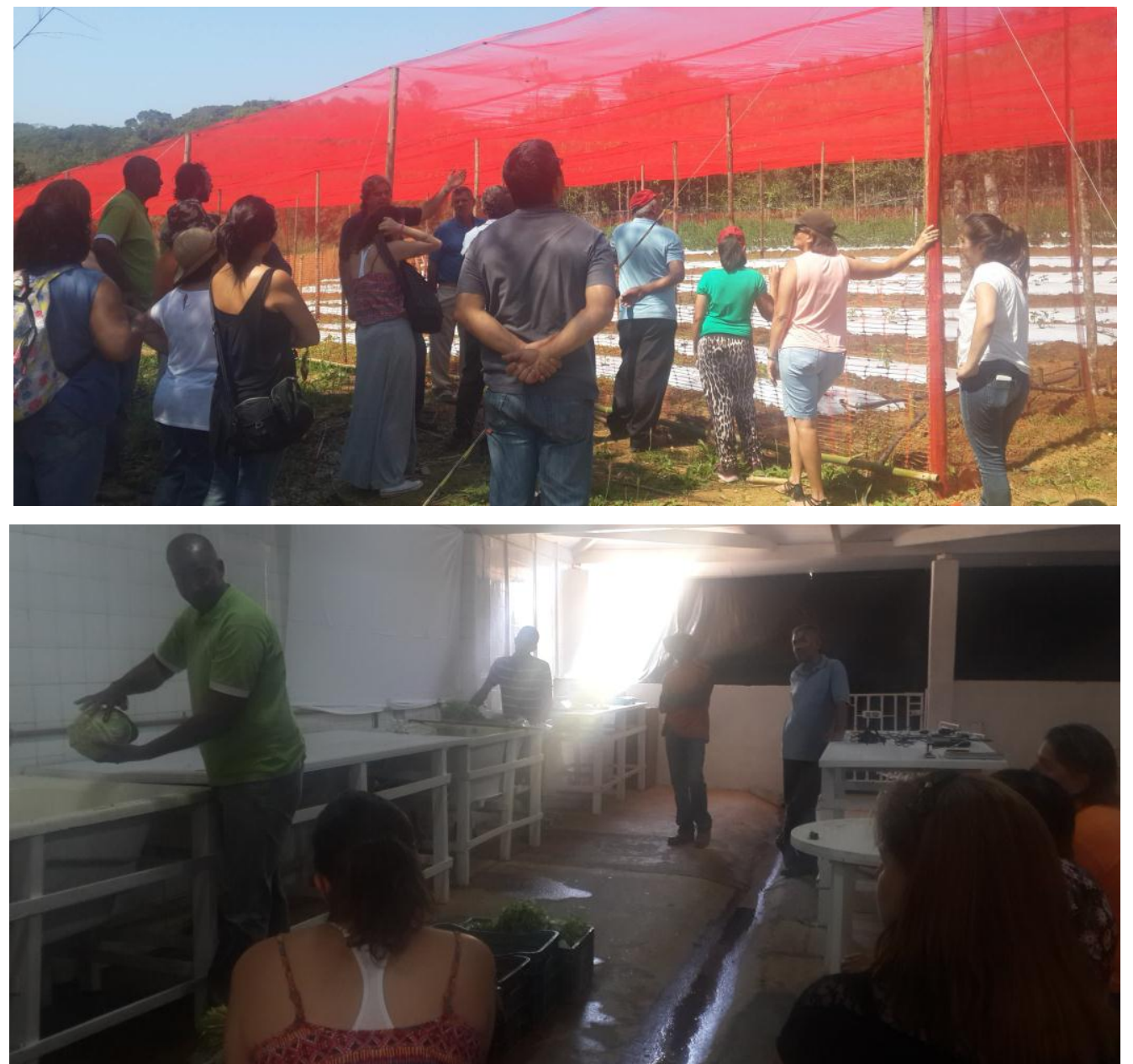

Fotos 3.11 e 3.12. Na foto acima (3.11), visita que foi feita ao sítio, para mostrar como estava a produção e já com algumas explicações sobre colheita. Na foto abaixo (3.12), o engenheiro agrônomo explica os cuidados no momento da lavagem e armazenamento de um produto. Fotos de 24 de setembro de 2015. Crédito das fotos: Angélica Campos Nakamura.
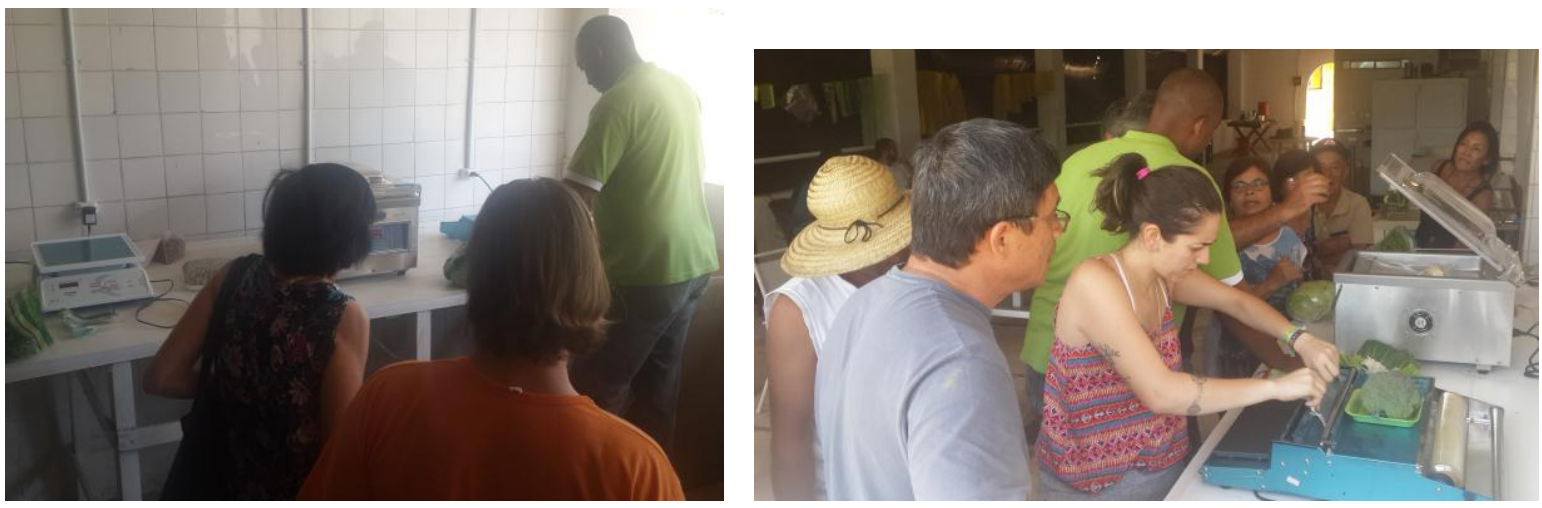

Fotos 3.13 e 3.14. Na foto à esquerda (3.13), o engenheiro agrônomo mostra como embalar os produtos. Na foto à direita (3.14), os cooperados colocam em prática as explicações do engenheiro agrônomo. Fotos de 24 de setembro de 2015. Crédito das fotos: Angélica Campos Nakamura. 
Por último, e não menos importante, o momento da entrega é outro nó na comercialização coletiva. Desde o início até setembro de 2016, Cláudio Miyaki era quem realizava as entregas da Cooperapas. O motorista sempre se mostrou muito solícito e interessado nas atividades da cooperativa, pois desde o início de seu trabalho com os cooperados, ele compareceu em todas as reuniões. Além disso, ele nunca falhou em nenhuma entrega. Todos ali reconhecem como é difícil encontrar um profissional como ele.

O serviço realizado por Cláudio consiste em ir de madrugada até a CAE, na Subprefeitura de Parelheiros, para buscar os produtos na câmara fria. Ele carrega todas as caixas para o caminhão e parte para a Vila Madalena. No início, ele cobrava $R \$ 150,00$ por entrega, entretanto, a quantidade de produtos ainda era pequena.

Com o tempo, a quantidade de produtos cresceu, pois aumentou o número de agricultores entregando os produtos e, os que já entregavam, ampliaram a produção. Em fevereiro de 2016, a Cooperapas estava fazendo três dias de entrega para o Instituto Chão e, ainda, tinha acabado de iniciar suas vendas para o restaurante Arturito, da chef Paola Carosella $^{51}$. Consequentemente, houve aumento do trabalho. Na reunião de 23 de fevereiro de 2016, Cláudio expressou seu descontentamento:

Desde o início das entregas [...] eu estava recebendo muito pouco tirando as despesas que tinha, despesas operacionais. [...]

Sempre falei que as condições de trabalho eram precárias. Me esforcei ao máximo e realizei todas as entregas até agora com responsabilidade e êxito. Porém, agora, eu deixo aberto a vocês, a todos vocês pra avaliarem quanto vale esse trabalho que eu estou fazendo. Porque tudo tem um preço justo. [...] O que aconteceu foi isso aí, falta de condições de trabalho. [...]

É caro o transporte em São Paulo, é caro. Infelizmente o custo operacional dentro de São Paulo é caro. [...] Não é fácil fazer esse trabalho. [...] (informação verbal) ${ }^{52}$.

Realmente, Cláudio cobrava mais barato quando começou a trabalhar para a Cooperapas, pois sabia da sua ruim situação financeira e já dava indícios de que, com o tempo, aumentaria o preço. Com o aumento do número de entregas e do volume de produtos, ele fez esse pedido nessa reunião.

O custo do frete, até setembro de 2016, subiu para $\mathrm{R} \$ 300,00$ por entrega. Caso Cláudio tenha algum gasto extra, como um ajudante por exemplo, isso já está incluso no

\footnotetext{
${ }^{51}$ A parceria de Paola Carosella com a Cooperapas saiu em reportagem na Folha de São Paulo. Ela se encontra no final desse trabalho, na seção "Anexos", como o anexo "E”.

${ }^{52}$ Informação verbal fornecida por Cláudio Miyaki, durante reunião da Cooperapas na Casa de Agricultura Ecológica, na Subprefeitura de Parelheiros, em São Paulo, em 23 de fevereiro de 2016.
} 
valor. Apesar de a Cooperapas ter estabelecido que dos $10 \%$ que estão destinados à cooperativa, $5 \%$ é para o frete, o valor das quantidades vendidas não chega a cobrir a despesa e sempre ultrapassa o estabelecido. Até setembro de 2016, a Cooperapas ainda estava com dificuldades em conseguir cobrir os gastos do transporte, mesmo com o aumento das vendas.

Outro aspecto relacionado à comercialização é a gestão das barracas das feiras nas quais os agricultores participam e vendem seus produtos. Hoje, essa venda ainda se dá de forma muito individual. Alguns produtores têm suas próprias barracas e vendem diretamente aos consumidores na feira. É o caso de Ernesto Oyama, Zundi Murakami, Massue Shirazawa (chamada por todos por Dona Massue) e Ana do Mel. Ernesto (foto 3.15) e Ana do Mel (foto 3.16, na próxima página) vendem na Feira de Produtos Orgânicos e da Agricultura Limpa, no Modelódromo do Ibirapuera, no bairro do Ibirapuera (ela ficou mais conhecida mais como Feira do Modelódromo ou do Ibirapuera). Zundi vende na Feira Orgânica do Shopping Villa Lobos, no bairro do Alto de Pinheiros, na Feira Biodinâmica e Orgânica no bairro de Santo Amaro (foto 3.17, na página a seguir) e na Feira do Produtor Orgânico no Parque da Água Branca, no bairro da Água Branca. Dona Massue vende na Feira Orgânica do Parque Burle Marx (foto 3.18, na próxima página), no bairro do Morumbi e na Feira da Cetesb (Companhia Ambiental do Estado de São Paulo), no bairro do Alto de Pinheiros.

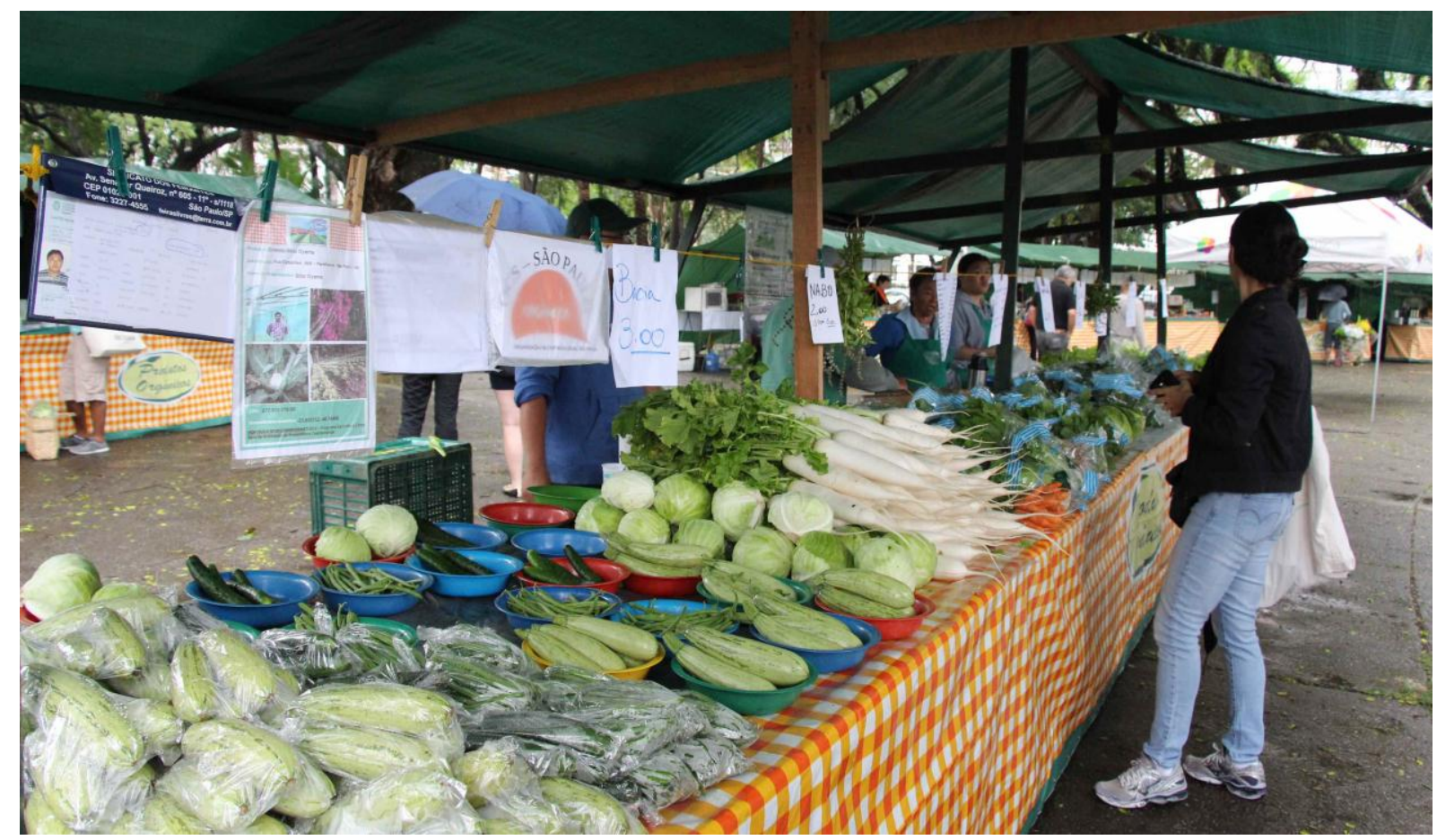

Foto 3.15. Barraca de Ernesto Oyama na Feira de Produtos Orgânicos e da Agricultura Limpa, no Modelódromo do Ibirapuera. Foto de 13 de dezembro de 2014. Crédito da foto: Angélica Campos Nakamura. 

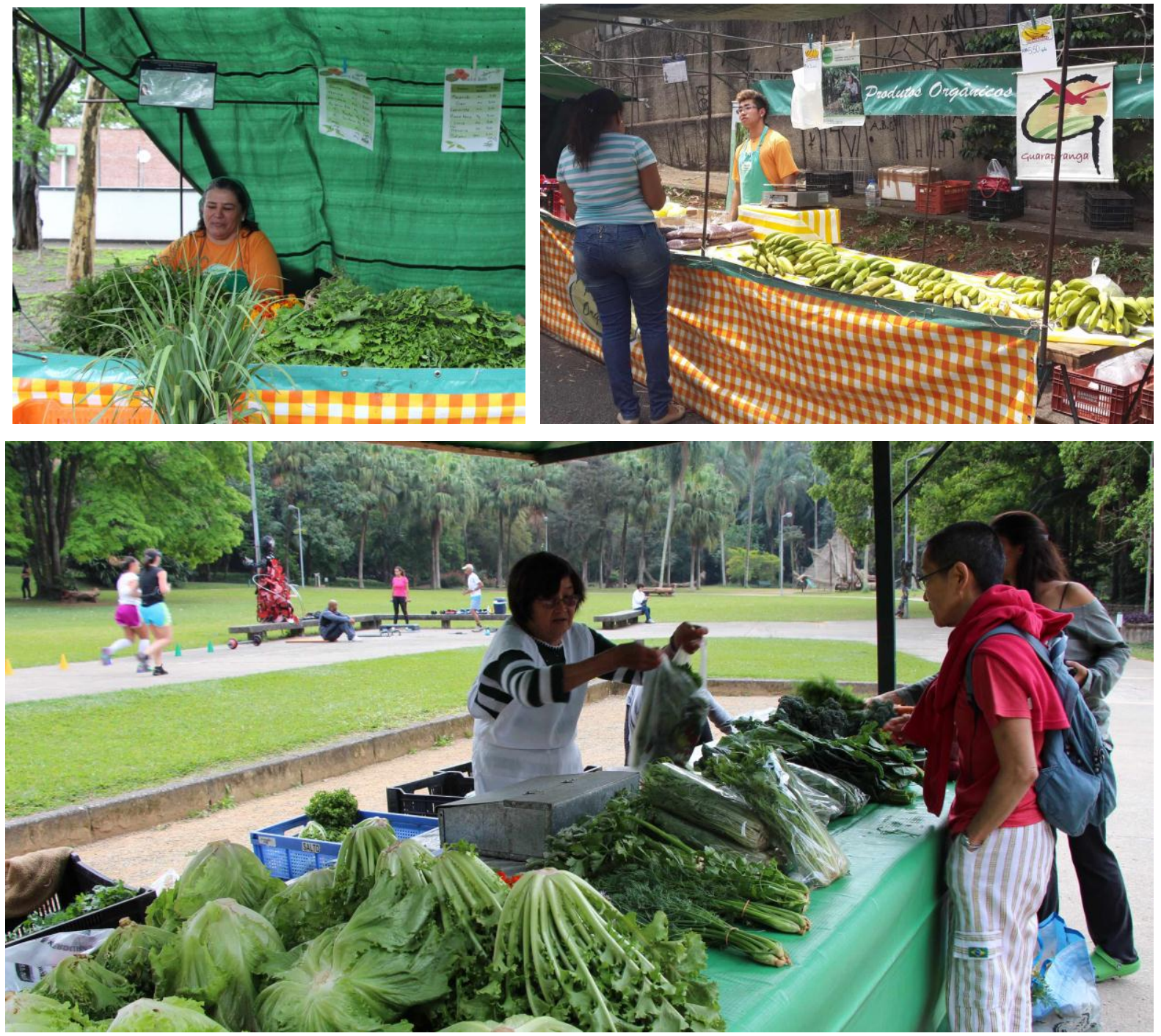

Fotos 3.16, 3.17 e 3.18. Na foto superior à esquerda (3.16), Ana do Mel em sua barraca na Feira do Modelódromo, em 13 de dezembro de 2014. Na foto superior à direita (3.17), barraca de Zundi Murakami na Feira Biodinâmica e Orgânica no bairro de Santo Amaro, em $1^{\circ}$ outubro de 2015. Na foto inferior (3.18), Dona Massue em sua barraca da Feira Orgânica do Parque Burle Marx em 22 de agosto de 2015. Crédito das fotos: Angélica Campos Nakamura.

Entretanto, nem todas essas barracas foram conseguidas por eles próprios. De acordo com relatos, a barraca de Ana do Mel na feira no bairro do Ibirapuera, de Zundi na feira da Água Branca e as duas feiras nas quais Dona Massue frequenta, eram para ser da cooperativa. Quando questionado sobre se a matrícula foi mudada, já que inicialmente era para ser um ponto de venda da Cooperapas, as informações são desencontradas e ninguém sabe ao certo. Ao que tudo indica, a barraca de Ana do Mel e a da feira do Burle Marx frequentada por Dona Massue estão em seus nomes.

Mas por quê eles acabaram assumindo? Isso é um dos pontos presentes nas reuniões da Cooperapas que precisam ser resolvidos, mas ainda não conseguiram. Esses locais foram oferecidos para a Cooperapas, porém, a cooperativa nunca conseguiu se organizar para levar 
os produtos para a feira, colocar uma pessoa para cuidar da barraca e fazer a gestão financeira disso. Zundi já ofereceu mais de uma vez a barraca na feira do Parque da Água Branca, mas nunca ninguém se ofereceu a ajudar. Inclusive, é ele quem arca com todas as despesas dessa feira, pois ela é gerida pela Associação de Agricultura Orgânica (AAO) e tem custos mais altos do que os das feiras municipais.

O ponto da feira na Cetesb foi oferecido à Cooperapas, mas também não houve uma movimentação conjunta. O único interessado foi o filho de Dona Massue, Cícero Shirazawa, que vende os produtos do sítio da família.

Apesar disso, a Cooperapas ainda possui mais um ponto, esse considerado importante: uma barraca na Feira de Produtos Orgânicos e da Agricultura Limpa, que é a Feira do Modelódromo. Essa feira é considerada, entre os agricultores orgânicos, a melhor para venda na cidade de São Paulo, além de ser a mais famosa. O local chegou a ficar vazio por meses, pois ninguém assumia, até que Jair Medeiro chamou a presidenta para avisar que iriam perder o ponto. Valéria sempre afirma que assumiu a barraca "por livre e espontânea pressão" até dezembro de 2015. Quem assumiu depois disso, temporariamente, foi Nelson Pati. Nas reuniões dos primeiros meses de 2016, ele expressou querer continuar na feira, porém, ele sabe da importância da comercialização coletiva e quer levar produtos dos outros cooperados.

As feiras orgânicas para os cooperados são tidas como os melhores pontos de venda. Os produtos orgânicos têm muita procura e, por serem feiras realizadas em bairros nobres, com população de melhor poder aquisitivo, eles conseguem vender por preços mais altos do que quando vendem para o Instituto Chão ou para algum supermercado ou sacolão. Os agricultores não contam o quanto tiram, mas em conversas informais, já admitiram tirar facilmente $\mathrm{R} \$ 3.000,00$ por feira. No caso da feira no bairro do Ibirapuera, há barracas que conseguem de $\mathrm{R} \$ 7.000,00$ a $\mathrm{R} \$ 10.000,00$, podendo ainda passar desses valores. Por isso, tamanho interesse em manter o ponto da Cooperapas.

A comercialização coletiva e a dificuldade em se gerir as barracas na feira, trouxeram à tona a necessidade de criar um regimento interno para a Cooperapas. Esse regimento também se faz importante devido às outras demandas surgidas ao longo desse tempo.

Uma dessas demandas veio com a doação de equipamentos da empresa Virada Sustentável $^{53}$ em parceria com a empresa Husqvarna ${ }^{54}$. Como essa doação aconteceu? Em

\footnotetext{
${ }^{53}$ A Virada Sustentável Eventos é uma empresa que faz parceria com o poder público, com outras empresas e com organizações da sociedade civil. Ela não tem fins lucrativos e promove atrações gratuitas e abertas ao público (GOVERNO DO ESTADO SÃO PAULO, 2013).

${ }^{54}$ A Husqvarna é uma empresa sueca que existe desde 1620. Ela fabrica equipamentos variados, entre eles, os agrícolas (HUSQVARNA, 2016).
} 
junho de 2015, um dos cooperados, Osvaldo Ochi, conhecido como seu Osvaldo por todos, sofreu um assalto em seu sítio. Levaram equipamentos para a agricultura, eletrodomésticos e objetos da casa. Todos os cooperados se mobilizaram, contaram para amigos e conhecidos. Fizeram uma vaquinha e conseguiram a doação de objetos, como um fogão, para seu Osvaldo. No meio dessa rede solidária, Mariana Belmont, uma moradora da região e amiga dos agricultores, e mais dois conhecidos, entraram em contato com a empresa Virada Sustentável e pediram uma doação de equipamentos agrícolas para seu Osvaldo e, quem sabe, para a Cooperapas. Eles montaram uma lista e enviaram à Virada Sustentável.

Para a surpresa de todos, a lista foi atendida e a Cooperapas ganhou os seguintes equipamentos (fotos 3.19 e 3.20 ):

- 5 motocultivadores;

- 8 roçadeiras;

- 7 motosserras;

- 3 sopradores;

- 2 podadores de cerca-viva;

- 2 cortadores de grama;

- um kit com timer para controlar irrigação;

- 10 computadores de irrigação;

- seu Osvaldo ainda ganhou, só para ele: uma motosserra, uma serra de poda e uma roçadeira.

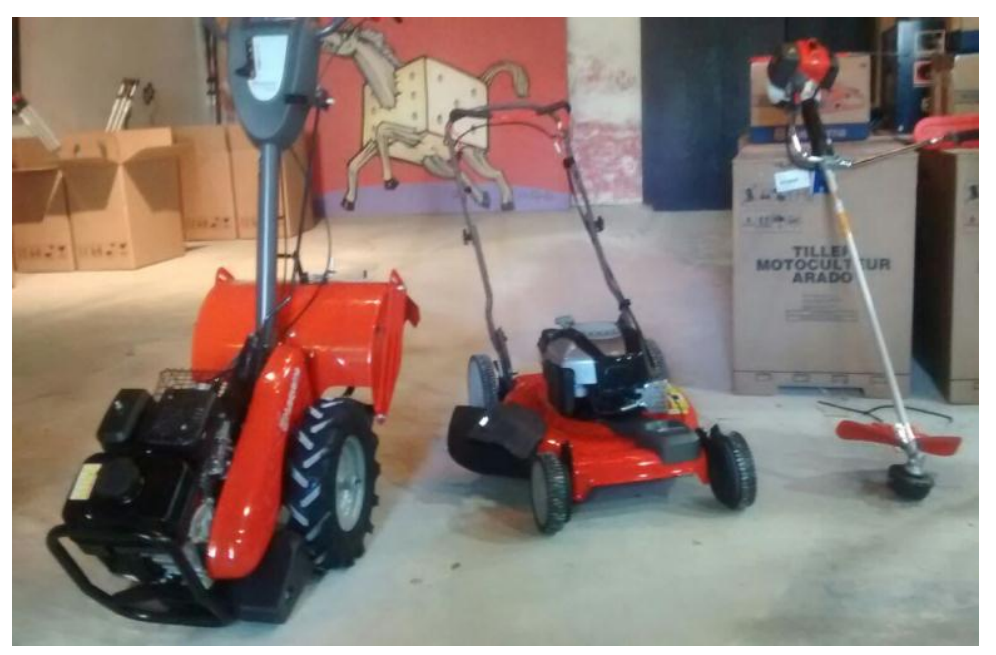

Foto 3.19. Alguns dos produtos doados para a Cooperapas. Foto de 15 de julho de 2015. Crédito da foto: foto recebida pelo grupo do Whatsapp da Cooperapas. 


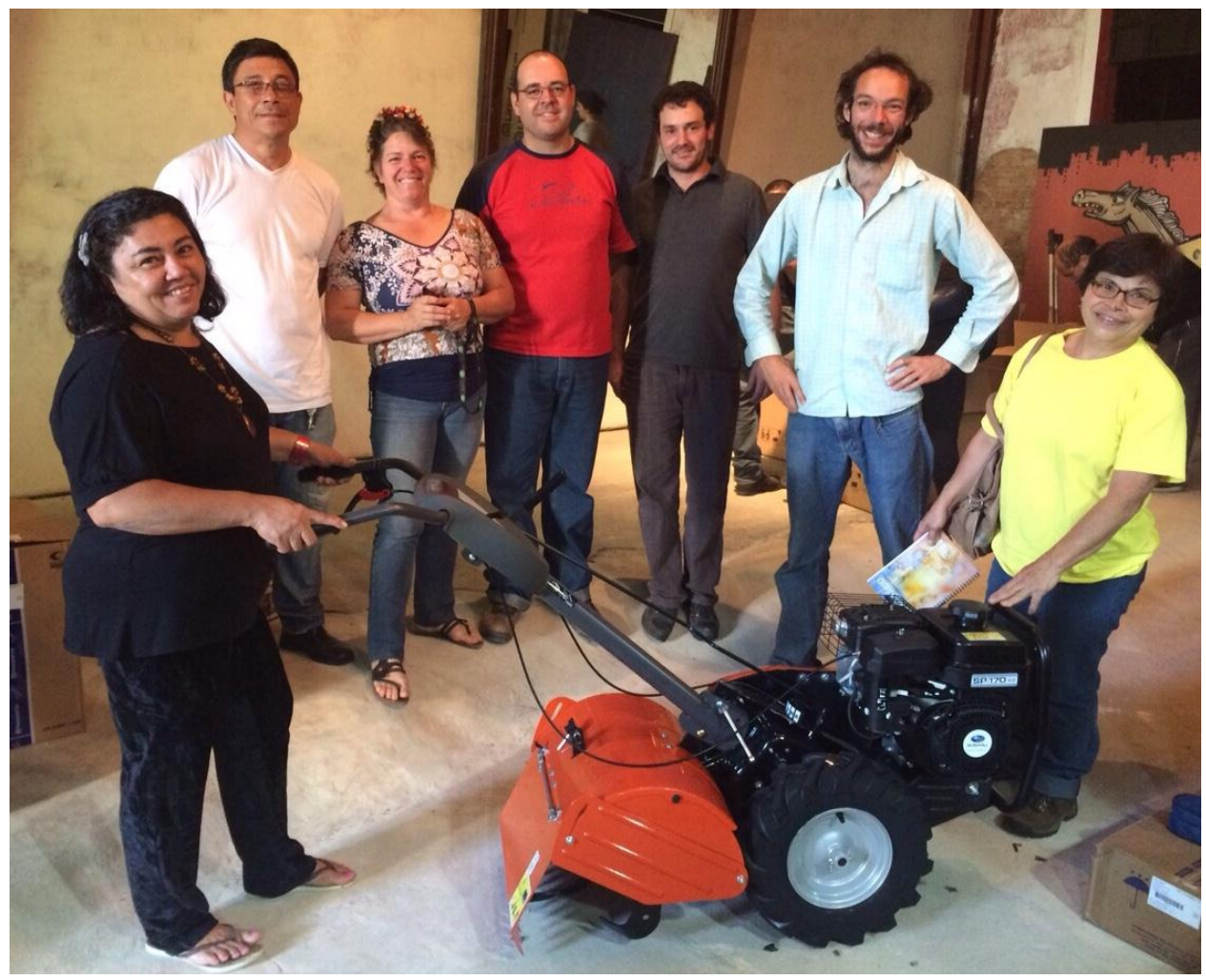

Foto 3.20. Cooperados que foram receber os produtos doados. Foto de 15 de julho de 2015 . Crédito da foto: foto recebida pelo grupo do Whatsapp da Cooperapas.

Na reunião de 29 de julho de 2015, a alegria foi geral, pois os equipamentos se tornaram parte do patrimônio da cooperativa ${ }^{55}$. Entretanto, veio o problema: como gerir seu uso coletivo? Onde guardá-los? Como transportá-los? Os equipamentos foram guardados nas casas de alguns dos cooperados, até que se decidisse seu uso e destino. Esses cooperados não usam os equipamentos.

Muito se conversou e uma reunião para definir o regimento interno foi realizada em 18 de agosto de 2015. A reunião durou cerca de cinco horas e pretendia-se discutir, além da gestão dos equipamentos, a gestão das barracas das feiras, a inclusão e exclusão de membros da cooperativa, as vendas coletivas no geral. Entretanto, avançou-se muito pouco em todos esses itens.

Na questão do uso dos equipamentos, decidiu-se que haveria um protocolo de cadastro dos interessados em seu uso. Em cima deles, ir-se-ia cobrar uma taxa de manutenção e recomposição devido ao desgaste. Além disso, o interessado pagaria um aluguel diário. A motosserra seria $R \$ 20,00$, a roçadeira $R \$ 28,00$, o podador $R \$ 20,00$ e o motocultivador $R \$$

\footnotetext{
${ }^{55}$ Como a Cooperapas ganhou uma boa quantidade de equipamentos e mantém contato com os agricultores de São Mateus, que têm uma associação na zona leste do município de São Paulo, foi decidido em votação, na reunião do dia 29 de julho, de doarem uma roçadeira e um motocultivador para eles.
} 
70,00. Quem guardasse algum dos equipamentos, seria o responsável por controlar o uso, além de verificar seu estado.

Apesar da definição de como usar os equipamentos, a gestão disso se mostrou difícil. Primeiro, pela logística: não são todos os cooperados que possuem um veículo para buscar e devolver o item. Segundo, porque cada um ficou em uma casa diferente, até por medo de assaltos, os quais ocorrem com certa frequência na região. Terceiro: ninguém quer ficar com a responsabilidade. Os que ficaram com os equipamentos em casa, foram os que buscaram no dia da entrega. Estavam com eles apenas temporariamente, até a Cooperativa decidir o que fazer com eles.

A Cooperapas chegou a pesquisar em como assegurar os itens, mas seus valores são muito baixos para se fazer um seguro. No final, decidiu-se vender os equipamentos para quem se interessasse, pois também seria uma maneira de melhorar o caixa da cooperativa. Pesquisaram os preços e, para os cooperados, oferecia-se um desconto de $30 \%$ do valor de mercado.

Tabela 3.5. Preços dos equipamentos estipulados pela Cooperapas

\begin{tabular}{|l|c|}
\hline \multicolumn{1}{|c|}{ EQUIPAMENTOS } & VALOR UNITÁRIO \\
\hline Motosserra 61 & $\mathrm{R} \$ 1.918,00$ \\
\hline Motosserra 236 & $\mathrm{R} \$ 729,00$ \\
\hline Roçadeira 525LK & $\mathrm{R} \$ 1.199,00$ \\
\hline Roçadeira 533RS & $\mathrm{R} \$ 899,269,00$ \\
\hline Soprador & $\mathrm{R} \$ 2.050,00$ \\
\hline Podador de cerca viva & $\mathrm{R} \$ 635,55$ \\
\hline Podador de galho & $\mathrm{R} \$ 1.749,00$ \\
\hline Cortador de grama & $\mathrm{R} \$ 3.959,00$ \\
\hline Motocultivador & $\mathrm{R} \$ 398,00$ \\
\hline Kit com timer para controlar irrigação & $\mathrm{R} \$ 349,00$ \\
\hline Computador de irrigação & \\
\hline
\end{tabular}

Fonte: Tabela de preços elaborada pela Cooperapas.

Essa dificuldade enfrentada reflete pontos indicados por Singer anteriormente nesse capítulo: a necessidade de uma cooperativa possuir um local para armazenamento de produtos, equipamentos e veículos e, ainda, possuir uma rede de transportes. Infelizmente, a cooperativa não tem um caminhão próprio para levar seus produtos. 
Todos os problemas e desafios enfrentados pela Cooperapas foram sempre discutidos em reunião. Tudo que trouxe aqui, nesse capítulo, é resultado do acompanhamento das reuniões realizadas ao longo do ano de 2015. Houveram poucas ocasiões nas quais não compareci, por serem assuntos muitos específicos que seriam discutidos. Além das reuniões mensais e assembleias, outras reuniões extras ocorreram, como a da discussão do regimento interno. Todos esses encontros sempre foram anunciados e todos os membros presentes convidados a participar. Quem não estava, normalmente era avisado pelo grupo do Whatsapp ou, caso o cooperado não possua acesso a esse aplicativo, a CAE ou algum cooperado entrava em contato para avisá-lo do próximo evento. Sempre há alguém que reclama de não ter sido avisado, porém, os esforços para isso sempre ocorrem, pois os presenciei e fiz parte de muitas dessas reuniões por ter sido avisada. Infelizmente, ocorre que alguns avisos são dados na véspera e não com dias de antecedência. Apesar disso, as reuniões contam com boa parte dos cooperados. No mínimo, metade chega a comparecer, mas sempre são os mesmos que vão e os mesmos que faltam.

Isso indica a preocupação em se realizar uma gestão, ao máximo, democrática e transparente. Fleury afirma que "A cooperativa se estrutura segundo um modelo organizacional que se pretende democrático, no qual as políticas e estratégias a serem adotadas são definidas por um processo decisório baseado em conflito e consenso entre as partes interessadas" (1983, p. 33). Realmente, isso ocorre, pois nem sempre todos concordam nas reuniões com as decisões tomadas, e as questionam. Entretanto, do que pude observar, as reuniões sempre estiveram abertas a todas as opiniões e as decisões são votadas por maioria nesses encontros.

Ainda que as reuniões sejam abertas, não são todos que se manifestam. Na maioria das reuniões, são sempre os mesmos a falar, a questionar e a opinar. Por mais que exista uma abertura nas reuniões, a igualdade de representação nunca ocorre de fato. Quem comenta sobre essa relação interna é Araújo. Segundo a autora,

Uma cooperativa, ao viabilizar o conteúdo doutrinário, compõe, de um lado, uma teia de relações internas, requeridas pela própria natureza da organização, que transcende em muito o mero exercício das normas reguladoras e os mecanismos de agregação; por outro lado, um conjunto de transações constantemente mantidas com o mundo exterior, garantia de sua sobrevivência.

Na consideração destes dois aspectos, delineia-se a especificidade de um tipo de participação - a participação cooperativa. [...]

Em qualquer agrupamento social, o fenômeno participativo está muito em função da maneira como se articulam os grupos dentro da associação e, mais além, como os diferentes grupos e/ou categorias sociais 
se combinam e são vistos no sistema global. Daí a necessidade de se fazer menção à participação social (ARAÚJO, 1982, p. 130).

Para Araújo, essas diferenças se dão porque o controle da cooperativa fica nas mãos dos grandes produtores e proprietários, enquanto os menores, mesmo que maioria, ficam excluídos de participarem mais efetivamente nas decisões e na autogestão da cooperativa. Isso pode não vir à tona em um primeiro momento, porque os princípios do cooperativismo, as leis e as normas ajudam a destacar o caráter democrático e, as estratégias justas e igualitárias das atividades desenvolvidas dentro da cooperativa, deixam transparecer a imagem de uma cooperativa ideal. Entretanto, é necessário ressaltar que esse estudo de Araújo faz referência a uma grande cooperativa, com produtores com alto poder aquisitivo e outros com baixo poder aquisitivo. Nessas cooperativas, muitas vezes, há reuniões separadas entre os conselhos gestores e cooperados com maior participação nas vendas. $\mathrm{O}$ abismo entre grandes e pequenos é muito maior.

Dentro da Cooperapas há, com certeza, diferença entre os membros, apesar de não ser uma grande cooperativa como o exemplo de Araújo. Alguns estão muito bem estabelecidos, enquanto outros são muito pequenos e com uma produção agrícola mínima. Essa diferença de representação no momento da reunião também pode ser atribuída a outros fatores, apontados por Esteves:

Como as diferentes formas de acesso à linguagem constituem diferentes formas de pensar e de enunciar o conteúdo do pensamento e da fala, nas cooperativas tais diferenças entre os cooperados, advindas de diferentes experiências de trabalho prévias, de regiões geográficas distintas, de pertencimento a grupos sociais, culturais, religiosos, políticos, desportistas etc. distintos, constitui um rico arcabouço de opções culturais para o uso da linguagem $[\ldots]$

Entretanto, por vezes tais diferenças tornam-se desigualdades, criando uma situação em que uma parcela dos cooperados torna-se impedida de comunicar-se com a outra, impedida de compreender aquilo que é dito e de se fazer compreender. Quando isso ocorre [...] dá-se ou torna-se evidente uma ou diversas cisões no grupo, revelando a todos a existência de dois ou mais grupos de interesses distintos, não apenas diferentes mas desiguais e contraditórios, isolados por uma barreira invisível e aparentemente insuperável [...] (2003, p. 284).

Ou seja, a diferença de vivências, de formação, de facilidade para se falar em público, muitas vezes, faz com que surja essa desigualdade de representação. Ainda, ele ressalta um ponto importante: 
Para poder entender como tais desigualdades são reproduzidas no interior de empreendimentos que se auto-intitulam democráticos ou autogestionários, faz-se necessária a compreensão de que não é na formalidade da assembleia, e sim na organização cotidiana e micropolítica das cooperativas, que acontece a vida do grupo. É nessa organização que se dão as relações ora ambíguas e contraditórias entre os cooperadores, destes com o mundo exterior e com a base técnica que possuem; é aí que acontecem as resistências e as ameaças à igualdade de fato. Os momentos de assembleia (compreendidos aqui de maneira ampla com toda e qualquer reunião da maioria dos cooperados), geralmente esporádicos, afastados do cotidiano e ainda estranhos aos trabalhadores, "são como a ponta de um iceberg sustentada por sua base submersa no cotidiano" (Sato \& Esteves, 2002) (ESTEVES, 2003, p. 272).

Para Esteves, deve-se ao máximo compreender as relações fora das reuniões e assembleias, pois a vida dos cooperados tem continuidade fora dali, e seus problemas externos nem sempre aparecem visíveis no momento do encontro mensal.

Até aqui, nota-se como fazer a gestão de uma cooperativa não é fácil. Além de todos os desafios e problemas que surgem no caminho, e da dificuldade de se discutir tudo em grupo, há uma série de burocracias a serem cumpridas. A começar pelas assembleias. $\mathrm{O}$ estatuto define que as assembleias gerais, sejam as ordinárias ou extraordinárias, devem ser “convocadas com antecedência mínima de 10 (dez) dias, mediante editais afixados em locais apropriados das dependências mais frequentadas pelos cooperados, publicação em jornal e comunicação aos cooperados por meio de circulares" (ESTATUTO DA COOPERATIVA AGROECOLÓGICA DOS PRODUTORES RURAIS E DE ÁGUA LIMPA DA REGIÃO SUL DE SÃO PAULO, 2011). Os cooperados também são avisados por telefone, e-mail ou Whatsapp. Além disso, na chamada, deve constar a(s) pauta(s) a ser(em) tratada(s). A assembleia geral ordinária é realizada uma vez ao ano, logo no primeiro ou segundo mês, pois ela faz um balanço do ano anterior. A extraordinária, trata de assuntos urgentes e específicos, como a ocorrida em 9 de setembro de 2015 (fotos 3.21 e 3.22, na página a seguir), cuja pauta consistia em: 1. Mudança de endereço da sede e administração; 2. Deliberação sobre as regras de exclusão dos cooperados; 3. Inclusão e exclusão de associados; 4. Deliberação sobre a participação do projeto de Microbacias 2; 5. Aprovação das contas de maio e junho de 2015; 6. Leitura e aprovação do regimento interno; 7. Definição da nova integralização de capital; 8. Definição dos novos prazos de carência ao cooperado para poder se candidatar aos conselhos administrativo e fiscal; 9. Outros assuntos de interesse da sociedade. 

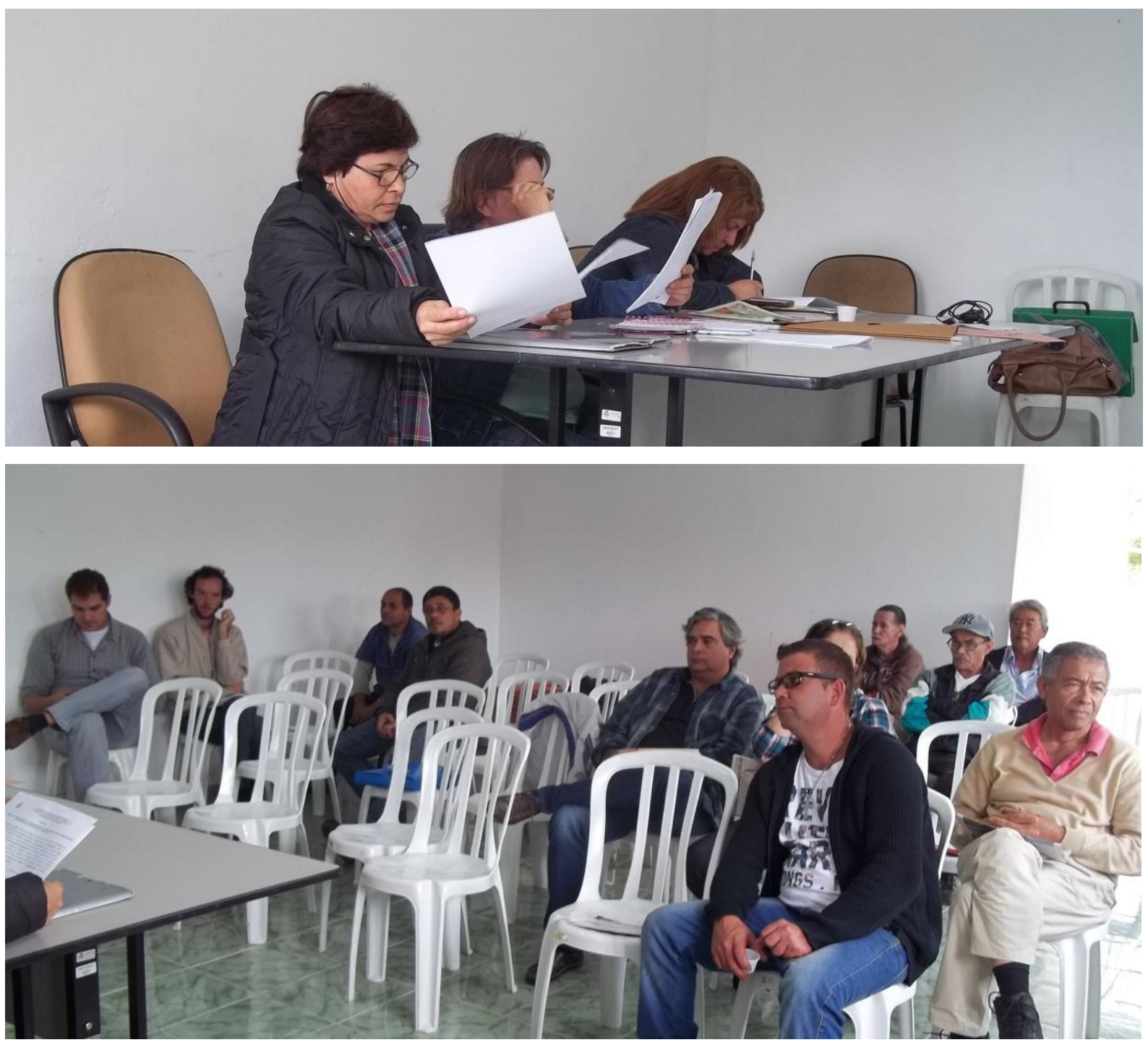

Fotos 3.21 e 3.22. Assembleia extraordinária realizada em 9 de setembro de 2015 . Na foto acima (3.21), o conselho administrativo. Na foto abaixo (3.22), os membros presentes na assembleia. Crédito das fotos: Angélica Campos Nakamura.

Todas as assembleias e reuniões precisam de uma lista de presença e de ata. No caso das assembleias, a ata deve ir para a Junta Comercial, no bairro da Barra Funda. A ata contém as assinaturas do conselho administrativo com firma reconhecida. Anexado à ata, envia-se uma cópia do anúncio no jornal no qual foi publicado o chamado e a lista de presença. Tudo deve ir em três vias. O documento é protocolado e deixado na Junta Comercial. Deve-se esperar de 10 a 15 dias para saber se ele foi ou não aprovado. Caso não seja aprovado, tem que buscar novamente o documento, rever os pontos errados, para devolver à Junta Comercial. O documento, uma vez aceito, é assinado, carimbado e uma cópia é devolvida à cooperativa. Para realizar todo esse procedimento na Junta, precisa-se pagar o Documento de Arrecadação de Receitas Estaduais (Dare) e o Documento de Arrecadação de Receitas Federais (Darf). Esse trabalho é tarefa do contador. 
Como se pode perceber até aqui, são muitos detalhes a serem cuidados em uma gestão cooperativa. Pude acompanhar uma cooperativa que teve um início difícil e incomum, cheio de problemas, por desconhecimento de como gerir uma empresa, ainda que ela não tenha como finalidade o lucro. Iniciei a pesquisa de campo logo após um momento crucial, de decisão dos cooperados em seguir em frente e de buscar adequar a documentação da cooperativa às exigências legais. Acompanhando as reuniões, pude aprender mais sobre detalhes burocráticos e de gestão e compreender melhor o funcionamento de uma cooperativa e as questões envolvidas no seu processo de constituição e gestão.

Muitos pesquisadores tentaram apontar quais os motivos levam uma cooperativa a ter problemas e dificuldades, como Moura V.. Ele levanta os seguintes pontos (1973, 84, 85 e 89):

a) A ausência de uma liderança ativa: para ele, é necessário que um líder se afirme pelo conjunto de suas qualificações, que saiba conduzir os negócios e as oportunidades, e aja no momento adequado. Ainda, ele diz que um bom líder consegue transmitir a mensagem de mutualidade e confiança a seus cooperados, além de ele ser um coordenador da vontade coletiva que ele representa. Ele tem que ser ativo e criar um estado permanente de organização socioeconômica, e não apenas mobilizar a cooperativa "nas emergências para tapar buracos". Assim, nesse aspecto, Moura, V. se mostra negativo, pois entende que as cooperativas no geral estão "condenadas a viver entre as omissões e inaptidões de uns e a indiferença passiva de outros, quando o desejável seria uma convergência do pensamento construtivo e da ação dinâmica" (1973, p. 84).

b) O desinteresse pela capacitação: Moura, V. critica o desinteresse que existe pela capacitação cooperativa. Ele aponta a necessidade da dedicação de estudos na área, pois "ao contrário de se dedicar a estudos que imponham um método de aprendizagem, preferem geralmente o recurso da tentativa, para verem se dá certo" (1973, p. 85).

c) As falhas institucionais e operacionais: muitas vezes, as cooperativas não dão certo devido à despreparação dos cooperados em relação à concepção doutrinária e jurídica e ao funcionamento.

Ora, aqui cabem críticas a esses pontos levantados por Moura, V.. Para ele, o líder de uma cooperativa parece mais um profissional de administração. Apesar das dificuldades, Valéria conseguiu conduzir a cooperativa, ainda que não saiba detalhes de gestão e negócios. Porém, ela sabe falar muito bem nas reuniões, e consegue deixar mensagens positivas, sempre 
relevando a importância da agricultura orgânica para o município de São Paulo e o meio ambiente. Apesar de Valéria ser a presidenta, ela não é a única a tomar iniciativa, e outros cooperados também participam das decisões e ações da Cooperapas. Entretanto, há membros que quase não aparecem nas reuniões e parecem indiferentes com o andar da cooperativa, indicando a "indiferença passiva" de Moura, V..

Moura, V. pode ter alguma razão ao criticar que se prefere o recurso da tentativa ao invés da dedicação a estudos na área cooperativista, visto o início cheio de erros da Cooperapas. Talvez com mais conhecimento sobre cooperativismo, gestão de empresas, administração e leis, muitos problemas teriam sido evitados. Isso nos conduz ao terceiro ponto levantado por Moura, V.. Porém, são muitos detalhes burocráticos e de legislação para se saber. De acordo com Jair Medeiro, o técnico da CAE que encabeçou a reorganização da Cooperapas, muitos contadores e advogados não sabem certos aspectos da legislação que são específicos para uma cooperativa. Portanto, a visão de Moura, V. é um tanto preconceituosa, pois parece que apenas "ter estudo", algo que muitos agricultores não têm, resolve grande parte dos problemas, o que não é verdade. Uma assessoria de profissionais dessa área é aconselhável, porém, qualquer membro interessado e com tempo para aprender tem condições de entender esse funcionamento. Muitas perguntas que tinha a respeito de burocracias e legislação foram tiradas com os próprios agricultores, que aprenderam essas questões ao longo desse processo de reorganização.

Criticar o despreparo e desconhecimento sobre cooperativismo é recorrente em autores que tratam sobre o tema e não é exclusivo de Moura, V.. Araújo é outra autora a qual insiste sobre isso. Ela questiona por quê as cooperativas têm tantos problemas, como a dificuldade em se pensar conjuntamente a produção e entrega, por exemplo. Os pontos a seguir foram adaptados dela (1982, p. 143-144):

1) Falta de conscientização e doutrinação cooperativista, baixo nível de instrução e educação, ausência de tradição nessa área;

2) Os produtores não são ligados uns aos outros e não desempenham tarefas especializadas. Eles têm contato com outros produtores que realizam um processo produtivo semelhante esporadicamente, ou seja, eles continuam indivíduos isolados e com seus interesses particulares;

3) Os produtores têm uma visão individualista e familista; 
4) A cooperativa é uma estrutura organizativa "moderna", enquanto os produtores têm um caráter e ideologia "camponesa" 56.

Apontar justificando, principalmente, o baixo nível de instrução e educação é questionável, além de me parecer uma saída fácil para indicar os porquês dos problemas de uma cooperativa. Como disse anteriormente, é crucial a assessoria de um contador e um advogado. Se ainda um técnico com vasta experiência na prática cooperativista puder ajudar, como João Belato, melhor para a cooperativa. Jair Medeiro chegou a reclamar da dificuldade em se encontrar um contador que entenda de cooperativas. Ou seja, não basta ter instrução: entender o funcionamento do cooperativismo passa por leis, conhecimentos contábeis e, principalmente, vivência e experiência na área.

\subsection{Uma cooperativa de economia solidária?}

Muito se falou aqui sobre a Cooperapas como uma empresa. A própria presidenta, Valéria Macoratti, desde o início da reorganização, vem falando que a cooperativa é uma empresa, porém, sempre ressalta que é a "nossa empresa", ou seja, do grupo de cooperados.

Realmente, ao longo do ano de 2015, período que acompanhei praticamente todas as reuniões e assembleias do ano, e vi como foram todas as discussões, as dificuldades e os problemas passados pela Cooperapas e a forma como foram tratados, é difícil não a ver como uma empresa. A bibliografia usada nesse capítulo para explicar e sustentar a prática cooperativista explica as cooperativas com uma visão administrativa, preocupada com o sucesso da gestão desse grupo.

Por que, no entanto, tanto se fala de economia solidária quando se entra no assunto cooperativismo? Uma cooperativa pode ser de economia solidária, porém, a economia solidária vai muito além disso. Souza explica que

\footnotetext{
${ }^{56}$ Aqui vale lembrar de alguns elementos estruturais da produção camponesa que vão gerar um embate com a estrutura "moderna" da cooperativa: a produção familiar, na qual é a família a responsável pela produção dentro da propriedade agrícola; é ela quem detém os meios de produção e a força de trabalho. No entanto, apesar de Araújo ressaltar essa visão individualista e familista, de caráter e ideologia camponesa, é interessante relembrar que dentro dos elementos estruturais da produção camponesa também encontramos a ajuda mútua, que não é de caráter individualista; pelo contrário, as famílias camponesas fazem mutirões ou realizam entre si trocas de dias de trabalho para ajudar famílias que precisem de ajuda com a sua produção. Assim, a visão de Araújo é outra visão preconceituosa a respeito desses camponeses que se envolvem em uma cooperativa, provavelmente, por não "terem estudo", ou seja, uma educação formal, com ensino superior. Porém, há muitos valores morais que não se aprende na escola ou em um curso.
} 
Segundo os pesquisadores e os adeptos da causa da economia solidária, ela não se resume ao cooperativismo, mas esse é sua forma principal, pois tem fundamentos éticos de organização e uma tradição histórica. Nessa perspectiva, a economia solidária vai além, portanto, do cooperativismo, abrangendo outras formas de organização econômica, mas com a mesma orientação igualitária e democrática. Ou seja, são experiências baseadas em valores coletivistas, não individualistas (2003, p. 38).

Outras formas de organização, dentro da economia solidária, são os clubes de troca por exemplo. Singer esclarece o que são esses clubes:

Os clubes de troca são uma inovação recente na economia solidária. Eles foram inventados mais ou menos ao mesmo tempo no Canadá, na ilha de Vancouver, e na Argentina, em Bernal, em meados da década de 1980. São, em ambos os casos, respostas ao desemprego e à queda da atividade econômica provocada por recessões. Os clubes de troca reúnem pessoas desocupadas que têm possibilidades de oferecer bens ou serviços à venda $\mathrm{e}$ precisariam comprar outros bens e serviços, mas não podem fazê-lo porque para poder comprar têm antes de vender e no seu meio não há quem tenha dinheiro para poder comprar sem ter vendido antes (2002, p. 105-106).

Porém, são as cooperativas a forma principal de economia solidária. O que pude observar ao longo da pesquisa é que se convencionou relacionar, no senso comum, cooperativismo com economia solidária, parecendo que quando se fala em um, o outro vem indissociavelmente. Contudo, conforme resgate histórico feito nesse capítulo sobre o movimento do cooperativismo no Brasil, duas correntes surgiram, uma voltada mais para o cooperativismo que ficou tido como o tradicional ou pragmático, e a outra, voltada para a economia solidária que ficou conhecida como "novo cooperativismo". A primeira corrente se distanciou, inclusive, dos princípios cooperativistas, pois a história do cooperativismo no Brasil levou esse movimento a se tornar algo pensado para grandes empreendimentos e, os princípios cooperativistas em si, serviam apenas como fachada. O "novo cooperativismo" veio para resgatar esses princípios.

Apesar de a Cooperapas ser vista como empresa pelos próprios membros, como Valéria afirma nas reuniões, ela é a empresa "de todos". Nas reuniões, os informes a respeito da cooperativa são passados, desde a situação do caixa, aos acontecimentos do último mês e as decisões que devem ser tomadas. Essas últimas, sempre são votadas pelos presentes, todos com o mesmo poder de voto. Existe, ali, uma tentativa clara de fazer a Cooperapas ser uma cooperativa de autogestão.

Essa forma de gerir tem a influência da economia solidária. Se no cooperativismo tradicional as cooperativas se tornaram empresas tão grandes, a ponto de se distanciar cada 
vez mais o pequeno agricultor, em uma ponta, ao do gestor ou presidente da cooperativa, no topo dela, cada um com um poder de voto diferente, o "novo cooperativismo" busca trazer de volta uma organização na qual todos tenham, ao máximo, um poder igual de voto e decidam em grupo os próximos passos da cooperativa. Singer explica:

A heterogestão, para atingir seus objetivos, tem de suscitar o máximo de cooperação entre os empregados, agrupados em seções, departamentos e sucursais. Competição e cooperação são, a rigor, incompatíveis entre si [...]. Dentro dessa contradição a heterogestão funciona, sempre à procura de novas fórmulas que lhe permitam extrair o máximo de trabalho e eficiência do pessoal empregado.

A empresa solidária se administra democraticamente, ou seja, pratica a autogestão. Quando ela é pequena, todas as decisões são tomadas em assembleias, que podem ocorrer em curtos intervalos, quando há necessidade. Quando ela é grande, assembleias-gerais são mais raras porque é muito difícil organizar uma discussão significativa entre um grande número de pessoas. Então os sócios elegem delegados por seção ou departamento, que se reúnem para deliberar em nome de todos. [...] (2002, p. 18).

Singer afirma que, dentro de uma empresa solidária, que pode ser uma cooperativa, tenta-se ao máximo eliminar as diferenças entre os sócios. Não existe um salário, mas uma "retirada", que varia conforme a receita da empresa. Mesmo que dentro de uma empresa solidária exista retiradas com valores diferentes, procura-se ao máximo minimizar as desigualdades internas de pagamento. Outro aspecto levantado sobre uma empresa solidária é o excedente anual, que em uma empresa capitalista é chamado de lucro. O destino desse dinheiro é decidido por todos os sócios, por meio de uma assembleia (2002, p. 11-14). Como exemplos práticos da Cooperapas, na tentativa de seguir uma prática mais próxima da economia solidária, pode-se citar: a não distinção dos três membros do conselho administrativo no estatuto para que tivessem o mesmo peso de representação e decisão; a transparência das reuniões, em que falam como está o caixa da cooperativa e como se pretende usar o dinheiro; nenhum dos membros do conselho administrativo ou fiscal recebem um salário e, ainda, devido ao início sem dinheiro em caixa, nem a "retirada" ocorre.

A autogestão, assim, torna-se um desafio, pois depende da participação e interesse dos sócios sobre os rumos de uma cooperativa. Singer vê como essencial a participação das pessoas nos processos de decisão de uma cooperativa, pois a torna "mais realizada, autoconfiante e segura" (2002, p. 21).

Se na autogestão a Cooperapas está no caminho da economia solidária, por que ainda é difícil enxergá-la como uma cooperativa voltada totalmente para essa prática? 
Aqui é importante destacar que a economia solidária vai além dessa autogestão. Ela pensa a economia com base na solidariedade, ou seja, ela só pode ser realizada se for “organizada igualitariamente pelos que se associam para produzir, comerciar, consumir ou poupar. A chave dessa proposta é a associação entre iguais em vez do contrato entre desiguais" (SINGER, 2002, p. 9, grifo do autor). Assim, a economia solidária pretende eliminar a competitividade gerada pelo sistema capitalista, que se pauta na polarização da sociedade entre ganhadores e perdedores. Ainda, de acordo com Singer:

A economia solidária é outro modelo de produção, cujos princípios básicos são a propriedade coletiva ou associada do capital e o direito à liberdade individual. A aplicação desses princípios une todos os que produzem numa única classe de trabalhadores que são possuidores de capital por igual em cada cooperativa ou sociedade econômica $(2002$, p. 10).

Ou seja, a economia solidária pensa em toda uma cadeia pautada sobre a solidariedade e a igualdade de produção, comércio e consumo. A Cooperapas está inserida em uma realidade baseada no sistema capitalista. E é aí que não só ela, mas também a prática da economia solidária, encontram seus limites.

O próprio estado, que possibilita por meio de políticas públicas a prática da economia solidária, a restringe. Sem dúvida, foi essencial certas medidas tomadas, como a não obrigatoriedade de se vincular à Organização das Cooperativas Brasileiras (OCB), fruto de uma política da Ditadura Militar, ou a criação da Secretaria Nacional de Economia Solidária e, ainda, a possibilidade de formação de cooperativas de pequenos empresários, microempresários e microempreendedores com a resolução 3.058. Porém, ao mesmo tempo que esse estado abre essas possibilidades, as cooperativas são obrigadas a seguir uma legislação e um processo extremamente burocrático, como qualquer outra empresa, e precisam ter CNPJ, inscrição estadual e municipal, atas registradas na Junta Comercial, declaração anual à Receita Federal, entre outros processos até mais específicos por se tratar de uma cooperativa.

Ainda que a autogestão venha funcionando dentro da Cooperapas, os limites também estão postos internamente entre os membros. A dificuldade em se organizar para conseguirem ir à feira vender os produtos coletivamente, de fazer uma gestão dos equipamentos em que todos conseguissem usar e usufruir dessa doação e até de pagar a quota-parte, indicam que ainda não existe uma coesão interna do grupo. Até onde as pessoas estão dispostas a serem solidárias para além de realizar suas vendas coletivamente? 
Aqui não se trata de apontar se há pessoas "boas" ou "ruins" por colaborarem mais ou menos pelo coletivo, e sim de compreender que se trata de um grupo muito diverso, com vivências e entendimentos diferentes, e isso traz limites pois, afinal, o que é o coletivo para cada uma delas? É apenas participar das reuniões e votar quando preciso? É cumprir com a entrega prometida para a cooperativa? É doar uma parte de seu tempo para ajudar na documentação e fechamento de contas ao invés de plantar? É pagar a quota-parte e nada mais? Não creio que um curso de formação cooperativista vai resolver essa situação.

Outro ponto a ser ressaltado é a maneira como a cooperativa foi criada. A Cooperapas surgiu em um momento de criação de políticas públicas voltadas para a agricultura e, ela mesma, foi resultado disso, conforme se pode compreender a partir do capítulo 1 e desse capítulo. Os envolvidos, que viviam ainda em um momento de não muita procura por produtos orgânicos no mercado, sem dúvida devem ter visto como uma ótima oportunidade para a venda de seus produtos. A intenção de se criar a cooperativa pode ter sido boa, mas juntar grupos de pessoas tão variadas se revelou um desafio.

Finalmente em 2015, quatro anos depois de sua criação, a Cooperapas conseguiu realizar sua primeira venda coletiva. Do que acompanhei de 2015 para 2016, algumas coisas avançaram, como o aumento da produção e das vendas. O número de presentes nas reuniões também aumentou: mais cooperados começaram a comparecer com mais frequência nos encontros mensais e agricultores da região, interessados em saber mais da Cooperapas, também começaram a vir para ver se ingressam ou não na cooperativa. Outra novidade é que, é muito comum nas reuniões, algum cooperado comentar sobre o surgimento de um potencial cliente interessado em comprar os produtos da Cooperapas. Às vezes o próprio cliente aparece na reunião para conversar (fotos 3.23 e 3.24 na próxima página).

Também é importante ressaltar como o estabelecimento da zona rural no Plano Diretor de 2014 trouxe mais políticas públicas pensadas para a agricultura. Em 2016, por exemplo, houve o lançamento do programa Agriculturas Paulistanas e o estabelecimento da Lei $\mathrm{n}^{\mathrm{o}}$ 16.140, que tornou obrigatória a inclusão de alimentos orgânicos ou de base agroecológica na alimentação escolar (assuntos tratados no capítulo 1). Essas iniciativas deram mais ânimo para os membros da Cooperapas continuarem com seus trabalhos e com a cooperativa. 

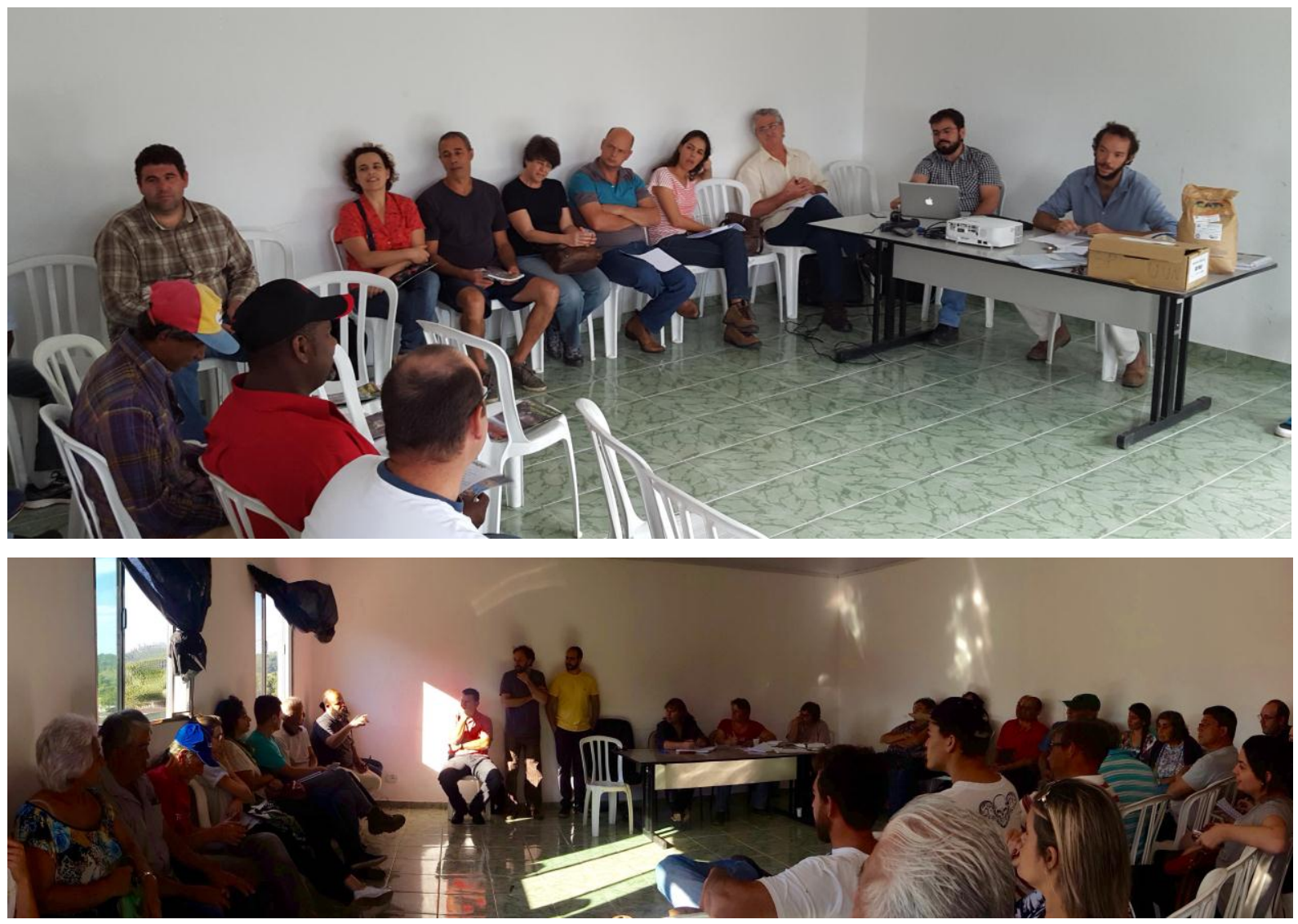

Fotos 3.23 e 3.24. Reuniões da Cooperapas em 2016. Na foto acima (3.23) a reunião realizada em 23 de fevereiro de 2016. Na foto abaixo (3.24), reunião de 26 de julho de 2016. Durante o ano de 2016, mais interessados começaram a surgir nas reuniões, como se pode observar na segunda foto. Crédito das fotos: Angélica Campos Nakamura.

Portanto, afirmar que a Cooperapas é uma empresa, tem sua verdade, afinal, certos aspectos da gestão, como a parte da regularização, legislação, tributação e fluxo de caixa, são pensados como uma empresa. O momento de se pensar em uma comercialização coletiva também traz a necessidade de se tratar, por exemplo, sobre a padronização dos produtos, desde a sua colheita até a embalagem. Aqui, surge uma exigência que a Cooperapas crie a "sua cara", que seus produtos tenham "um padrão" para ser lembrado no mercado. Porém, todos esses aspectos aqui levantados, surgem devido a um estado com exigências burocráticas e um mercado com determinados padrões de consumo que se refletem no momento da compra dos produtos.

Apesar disso, a economia solidária, que trouxe novamente os princípios cooperativistas, não deixou de influenciar o momento da autogestão da Cooperapas. Busca-se, nas reuniões, a transparência e a igualdade de representação e de votos. Inclusive, as portas da Cooperapas, estão sempre abertas a todos. 
Aqui não se trata se apontar para a Cooperapas e dizer se é uma cooperativa estritamente tradicional ou de economia solidária e qual opção é a melhor, se começou errado por ser uma iniciativa muito mais de "cima para baixo" do que "de baixo para cima" e, portanto, fora dos padrões citados na literatura e na teoria cooperativista. Conforme pude acompanhar as reuniões, assembleias e parte do cotidiano dessas pessoas, a realidade é muito mais complexa. Aqui é entender que há, ainda, muitas questões a serem discutidas e resolvidas, seja pelos problemas burocráticos, financeiros e de comercialização, seja pelo entendimento de todos os seus membros de até onde vai o individual e se inicia o coletivo. 
CONSIDERAÇÕES FINAIS 
Quando iniciei meu contato com a Cooperapas, não sabia se conseguiria ir adiante com a pesquisa, pois senti que ainda havia incertezas em relação ao seu futuro. Cheguei logo após o momento de decidirem continuar com a cooperativa. Na primeira visita à Casa de Agricultura Ecológica (CAE), em conversa com os técnicos, já me contaram das dificuldades que a Cooperapas passou desde o início com a regulamentação e a documentação e que, tudo aquilo, havia pesado em muito no desenvolvimento da cooperativa. Com o tempo, outros detalhes surgiram, como o tempo de presidência de Geraldino e o início sem muito rumo afinal, nada foi falado sobre avanços e tomadas de decisões na primeira gestão, composta por por Ernesto Oyama (como presidente), Valéria Macoratti e Lia Moura (como diretoras). A Cooperapas só começou a se movimentar quando tomou um "susto" de R\$ 11.350,00. Ao descobrirem a dívida com a Receita Federal e verificarem que fechar uma empresa é muito mais complicado e oneroso, resolveram dar uma chance a esse grupo.

A tentativa desse trabalho foi mostrar como se deu esse processo de reconstrução da Cooperapas. Para isso, foi feito um breve resgate da sua história, até chegar no momento o qual comecei a acompanhá-los, no final de 2014 e início de 2015.

A cooperativa, como a própria Valéria gosta de contar, "foi fundada de trás para frente", ou seja, foi uma decisão muito mais de "cima", do poder público, do que uma iniciativa de organização dos próprios agricultores. Mesmo não obrigando ninguém a dar o nome e assinar o estatuto na fundação da Cooperapas, a Prefeitura fez tudo que era preciso.

A criação da Cooperapas vem de um contexto de criação de políticas públicas voltadas para a agricultura no município de São Paulo. A própria cooperativa deve ser vista e entendida como o resultado de uma. Era um momento com muitas novidades positivas para esses agricultores: criação de feiras municipais orgânicas; projetos do Fundo Especial de Meio Ambiente e Desenvolvimento Sustentável (Fema); possibilidade de obter um selo de agricultura limpa, até então uma ideia inédita, que permite um agricultor vender seu produto em transição para o orgânico, sem ser considerado um convencional. Some-se a esse contexto a ideia de uma cooperativa, que possibilitaria o acesso a políticas públicas como o Programa Nacional de Alimentação Escolar (Pnae), o Programa de Aquisição de Alimentos (PAA) e, ainda, entrar mais fortalecido no mercado consumidor da cidade de São Paulo. Com a Prefeitura ajudando financeiramente e auxiliando com a documentação inicial necessária, sem dúvida, deixar de participar da primeira cooperativa agrícola do município, naquele momento, podia parecer uma má decisão.

Porém, cuidar dessa empresa coletiva se revelou mais trabalhoso e complicado do que parecia. Cristiano Mendes, o técnico da CAE na época que ajudou os agricultores na criação 
da Cooperapas, foi transferido de local de trabalho. Todos os entrevistados que estavam desde o início, só falam de como a partida de Mendes da CAE dificultou o andamento da cooperativa, pois ele era o único ali a entender um pouco melhor o funcionamento de uma. Desse período são lembrados os desentendimentos, como o ocorrido com o Geraldino, sem menção a alguma iniciativa maior, que realmente resultasse em algo para o grupo, como uma comercialização coletiva.

É comum culparem a pressão e influência do poder público pelos insucessos da Cooperapas. Com certeza, se a iniciativa tivesse surgido exclusivamente dos agricultores, a história seria diferente. Mas também não é possível saber se hoje a situação da Cooperapas estaria melhor. Afinal, normalmente teóricos e estudiosos de cooperativismo apontam que a iniciativa vem do grupo e a maioria dos casos são assim, mas isso não é regra e nem garantia de sucesso.

A cooperativa ainda não consegue garantir totalmente a venda e o sustento dos agricultores. A maioria, vende para vizinhos, clientes próprios e há os que possuem a própria barraca em alguma feira de produtos orgânicos na cidade de São Paulo. Porém, ela precisa superar uma série de entraves que fazem parte do vender coletivamente: o planejamento para plantar os produtos; a organização dos produtos para enviar para os clientes; a padronização dos produtos para a comercialização coletiva; o pagamento do transporte, que ainda consome quase todo o dinheiro que fica para a Cooperapas.

Mas a cooperativa não tem só a questão da comercialização para melhorar. As questões internas ainda são muitas: a documentação, em 2016, ainda tinha algumas pendências a serem resolvidas para a Junta Comercial aceitá-la. No segundo semestre do mesmo ano, os cooperados começaram a discutir sobre a necessidade de alterar certos pontos do estatuto e estavam para marcar uma reunião. Outro ponto que não avançou mais nas discussões foi a necessidade de se criar um regimento interno, que dê diretrizes como a gestão das barracas nas feiras. Uma questão que também ficou em aberto foi a venda dos equipamentos doados à Cooperapas. Depois de decidirem vender, ainda que de preferência para os membros da própria cooperativa, voltaram atrás. No fim, ninguém realmente sabe o que fazer com os equipamentos, se vendem ou se criam diretrizes em um regimento interno para seu uso coletivo.

Discutir todos esses assuntos demanda tempo e paciência de todos os membros. Conseguir marcar a melhor data possível, para que o máximo de pessoas possa comparecer, é sempre difícil. Além disso, nessas reuniões, para que elas sejam produtivas, o ideal é certas ideias já estarem pautadas, para guiar a discussão. 
Mesmo com tudo isso ainda a ser acertado, e outras questões que sempre surgem no caminho, é importante apontar a preocupação da cooperativa em sempre chamar todos os membros para que esses pontos sejam discutidos e avancem. Dificilmente todos os cooperados conseguem comparecer nas reuniões, principalmente nas marcadas fora da mensal (toda última terça-feira do mês), mas existe um grande esforço em sempre incluir os membros e ter o maior número possível de pessoas para acompanharem as decisões, opinarem e votarem.

Portanto, pude observar a busca pela autogestão dentro da Cooperapas. Nesse aspecto, ela se aproxima da economia solidária. Porém, conforme indiquei no final do terceiro capítulo, há, ainda, muitos limites que impedem a prática da economia solidária totalmente. O Estado, com toda a burocracia e legislação imposta, praticamente obriga a cooperativa a ter um contador e, ainda, a ajuda de um advogado também pode ser valiosa em muitos momentos. Como qualquer outra empresa, por exemplo, a Cooperapas tem que levar sua documentação para ser submetida à Junta Comercial.

Outro entrave que indiquei é a compreensão por parte dos próprios cooperados sobre o que significa fazer parte de uma cooperativa. Autores apontados no capítulo 3 e outros que cheguei a ler, gostam de indicar a falta de "educação cooperativista", como se realizando um curso certos valores e práticas pudessem ser apreendidos. Grande parte das questões da Cooperapas a serem resolvidas só surgiram quando realmente se preocuparam em arrumar a documentação para vender seus produtos, e outros tantos problemas podem ainda aparecer. Portanto, a cooperativa é uma construção que se dá todos os dias, em cada reunião e assembleia realizada.

Já sobre os membros da Cooperapas, eles se mostraram com perfis muito variados. Contudo, achei possível dividi-los em dois grupos: os com origem na produção camponesa e os "da cidade". Pelo relato dos membros cujo pais e avós eram "da roça", foi possível identificar elementos da produção camponesa e, ainda, de uma agricultura caipira, conforme indicado no capítulo 1. Essa agricultura caipira, para autores do início e meados do século $\mathrm{XX}$, significava o atraso no campo. Hoje, pelo contrário, esses saberes ganharam outro valor e significado, sendo apontados como melhores para o meio ambiente e a saúde de quem planta e consome.

Os membros "da cidade" vieram em busca de uma nova atividade econômica, a agricultura, que pudesse ajudá-los economicamente ou ainda os possibilitasse a viver só dela. Porém, não iniciaram uma agricultura com um retorno o mais rápido possível. Buscaram a agricultura orgânica (aqui no sentido geral que o termo adquiriu no Brasil), a qual tem um 
valor mais alto no mercado, porém, ela respeita os ciclos da natureza e o que a terra da região possibilita produzir. Portanto, não se trata de plantar "qualquer coisa" a "qualquer custo".

Ao trazer a campesinidade para explicar certos valores camponeses, ela ficou mais restrita a alguns aspectos, como a ligação com a terra, o trabalho com a terra, a construção de vida para um futuro. Mas visto as dificuldades da cooperativa, em conseguir tratar diversas questões, a moral e a ética camponesas embutidas nessa qualidade não necessariamente aparecem quando se trata do coletivo.

Devido à dificuldade em conseguir definir esse grupo tão diverso, optei por chamá-los, de maneira geral, de agricultores. Apesar de ter cogitado defini-los como agricultores urbanos, preferi não os abordar dessa maneira, pois há casos variados de agricultura urbana no município e isso, a meu ver, acarretaria uma necessidade de abordar esses outros exemplos para se compreender melhor tal definição e se ela é realmente possível para esse meu caso de estudo. Entretanto, essa abordagem até pode ser uma possibilidade.

A agricultura orgânica, praticada pelos agricultores da Cooperapas, ganhou mais destaque nos últimos anos. Isso se reflete nos dois últimos Planos Diretores do município. Especialmente no de 2014, essa atividade acaba vista como uma grande aliada da conservação ambiental do município de São Paulo. Não à toa, na zona sul do município, quase toda a área da zona rural coincide com a Área de Proteção Ambiental Bororé-Colônia e a CapivariMonos.

Mas o Plano Diretor de 2002 já indicava uma atenção maior voltada para a atividade agrícola dentro do município. A seção X se voltou inteiramente para a agricultura, porém, tratando-a como agricultura urbana. Como consequência, em 2004, o Programa de Agricultura Urbana e Periurbana (Proaurp) foi instituído.

Assim, a agricultura praticada nesse extremo sul também passa a ser vista como uma agricultura periurbana. Aos poucos, ao longo dos anos, as políticas públicas voltadas para essa atividade e para os agricultores da região vão surgindo, como a inauguração da Casa de Agricultura Ecológica, o surgimento de feiras orgânicas, o Protocolo de Boas Práticas Agrícolas e a Cooperapas. Após o novo Plano Diretor e o restabelecimento de uma zona rural, iniciativas como o programa Agriculturas Paulistanas, a $1^{\text {a }}$ Conferência Municipal de Desenvolvimento Rural Sustentável e a lei que tornou obrigatória a inclusão de alimentos orgânicos ou de base agroecológica na alimentação escolar, são indicativos de que há interesse na agricultura no município. O próprio Polo de Ecoturismo de São Paulo também deve ser destacado, pois em seu site há o contato de vários agricultores da região, 
incentivando a visitar seus sítios. Entretanto, quase não há menção à agricultura convencional praticada na região, que ainda é muito presente e significativa.

Para compreender, portanto, a Cooperapas, foi necessário ir além de comparecer nas reuniões e assembleias. Apesar de ter surgido "de cima para baixo", o papel do poder público vai além, com outras políticas públicas que não podem ter sua importância descartada e influenciam na vida desses agricultores. Fazer um resgate dos dois últimos planos diretores de São Paulo foi essencial para perceber isso e entender as políticas públicas que vêm surgindo desde o Proaurp.

Também conversei muito com as pessoas sobre a cooperativa e sobre suas vidas. Foi preciso tentar entender um pouco sobre suas origens e motivações para fazerem parte da Cooperapas. Mesmo com os problemas pelos quais passaram, esse grupo está persistindo e, ainda que esteja na busca de uma cooperativa mais rentável e que lhe garanta mais seu sustento, parece que o lucro a qualquer custo ainda não é o fator principal. Querem construir esse grupo e fortalecê-lo, mesmo que o caminho seja muito difícil e envolva interesses diversos

Encontrar a Cooperapas e esse grupo para realizar meu Mestrado me trouxe uma visão mais ampla sobre o município de São Paulo. Muitas vezes, essa cidade me pareceu cinza e só de concreto. Para minha surpresa, encontrei uma região em que a vegetação e os mananciais ainda estão mais conservados, e existem agricultores na busca de uma prática agrícola mais preocupada com os recursos naturais e o bem-estar do ser humano. A própria iniciativa da cooperativa, ainda que vinda de cima para baixo, também é importante, afinal, ali se tenta, ao máximo, praticar-se uma alternativa mais justa, democrática e igualitária. Ainda há muito a construir, seja com a Cooperapas ou com a agricultura na região, mas o caminho já foi iniciado, fazendo o espaço do município de São Paulo ser mais diverso e menos desigual. 


\section{REFERÊECIAS ${ }^{1}$}

ABRAMOVAY, Ricardo. De camponeses a agricultores: paradigmas do capitalismo agrário em questão. 1990. 354 f. Tese (Doutorado em Ciências Sociais) - Instituto de Filosofia e Ciências Humanas, Universidade Estadual de Campinas, Campinas, 1990.

ALTIERI, Miguel. Agroecologia: bases científicas para uma agricultura sustentável. São Paulo: Expressão Popular, 2012.

ARAÚJO, Silvia Maria P. de. Eles: a cooperativa. In: . Eles: a cooperativa; um estudo sobre a ideologia da participação. Curitiba: Projeto, 1982. p. 129-169.

ASSIS, Renato Linhares de. Agricultura orgânica e agroecologia: questões conceituais e processo de conversão. Seropédica: Embrapa Agrobiologia, 2005. Disponível em: <http://www.infoteca.cnptia.embrapa.br/bitstream/doc/628360/1/doc196.pdf>. Acesso em: 13 ago. 2016.

ASSOCIAÇÃO BRASILEIRA DE AGRICULTURA BIODINÂMICA (ABD). Disponível em: <http://www.biodinamica.org.br>. Acesso em: 24 maio 2016.

ATLAS DO DESENVOLVIMENTO HUMANO NO BRASIL. Consulta. Disponível em: <http://www.atlasbrasil.org.br/2013/pt/consulta>. Acesso em: 28 set. 2016.

BANCO CENTRAL DO BRASIL. FAQ - Programa Nacional de Fortalecimento da Agricultura Familiar - Pronaf, jul. 2015. Disponível em: <http://www.bcb.gov.br/?PRONAFFAQ>. Acesso em: 19 abr. 2016.

$\mathrm{BIO}$

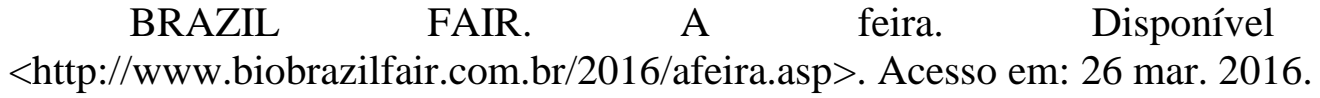

BONDUKI, Nabil. AUP 266 Planejamento de Estruturas Urbanas, $1^{\circ}$ sem. 2012. Disponível em:

<http://www.fau.usp.br/cursos/graduacao/arq_urbanismo/disciplinas/aup0266/Aup266_2012_Estatuto_da_Cidade_e_Plano_Diretor_Estrategico_de_Sao_Paulo__Aula_Nabil.pdf $>$. Acesso em: 25 jul. 2016.

\footnotetext{
${ }^{1}$ De acordo com a Associação Brasileira de Normas Técnicas. NBR 6023.
} 
SP: Plano Diretor e desigualdades urbanas. Carta Capital, 12 jun. 2013. Disponível em: <http://www.cartacapital.com.br/sociedade/rever-o-plano-diretor-para-reduzir-asdesigualdades-urbanas-3549.html>. Acesso em: 25 jul. 2016.

BRASIL. Constituição da República Federativa do Brasil de 1988. Disponível em: <http://www.planalto.gov.br/ccivil_03/Constituicao/Constituicao.htm>. Acesso em: 14 jul. 2016.

Decreto $\mathrm{n}^{\mathrm{o}}$ 1.946, de 28 de junho de 1996. Cria o Programa Nacional de Fortalecimento da Agricultura Familiar - PRONAF, e dá outras providências. Disponível em: <http://www.planalto.gov.br/ccivil_03/decreto/D1946.htm>. Acesso em: 22 abr. 2016.

Decreto $\mathrm{n}^{\mathrm{o}} 3.508$, de 6 de outubro de 1999. Dispõe sobre o Conselho Nacional de Desenvolvimento Rural - CNDR e sobre o Programa Nacional de Fortalecimento da Agricultura Familiar - PRONAF, e dá outras providências. Disponível em: <http://www.planalto.gov.br/ccivil_03/decreto/D3200.htm\#art15>. Acesso em: 22 abr. 2016.

Decreto $\mathrm{n}^{0} 3.508$, de 14 de junho de 2000. Dispõe sobre o Conselho Nacional de Desenvolvimento Rural Sustentável - CNDRS e dá outras providências. Disponível em: <http://www.planalto.gov.br/ccivil_03/decreto/D3508.htm>. Acesso em: 22 abr. 2016.

Decreto $\mathrm{n}^{\mathrm{o}} 3.992$, de 30 de outubro de 2001. Dispõe sobre o Conselho Nacional de Desenvolvimento Rural Sustentável - CNDRS e dá outras providências. Disponível em: <http://www.planalto.gov.br/ccivil_03/decreto/2001/D3992.htm>. Acesso em: 22 abr. 2016.

. Decreto $n^{0} 4.854$, de 8 de outubro de 2003. Dispõe sobre a composição, estruturação, competências e funcionamento do Conselho Nacional de Desenvolvimento Rural Sustentável - CONDRAF e dá outras providências. Disponível em: <http://www.planalto.gov.br/ccivil_03/decreto/2003/D4854.htm\#art14>. Acesso em: 22 abr. 2016.

Decreto $\mathrm{n}^{0}$ 6.323, de 27 de dezembro de 2007. Regulamenta a Lei $\mathrm{n}^{\mathrm{o}} 10.831$, de 23 de dezembro de 2003, que dispõe sobre a agricultura orgânica, e dá outras providências. Disponível em: <http://www.planalto.gov.br/ccivil_03/_ato20072010/2007/Decreto/D6323.htm>. Acesso em: 24 maio 2016.

Decreto $n^{\circ} 8.735$, de 3 de maio de 2016. Dispõe sobre a composição, a estruturação, as competências e o funcionamento do Conselho Nacional de Desenvolvimento Rural Sustentável - CONDRAF. Disponível em: 
<http://www.planalto.gov.br/ccivil_03/_Ato2015-2018/2016/Decreto/D8735.htm>. Acesso em: 10 set. 2016.

Decreto $\mathrm{n}^{\circ}$ 8.865, de 29 de setembro de 2016. Transfere a Secretaria Especial de Agricultura Familiar e do Desenvolvimento Agrário para a Casa Civil da Presidência da República e dispõe sobre a vinculação do Instituto Nacional de Colonização e Reforma Agrária - INCRA. Disponível em: <http://www.planalto.gov.br/ccivil_03/_Ato20152018/2016/Decreto/D8865.htm\#art6>. Acesso em: 10 set. 2016.

Lei $\mathrm{n}^{\circ}$ 8.171, de 17 de janeiro de 1991. Dispõe sobre a política agrícola. Disponível em: <http://www.planalto.gov.br/CCIVIL_03/leis/L8171.htm>. Acesso em: 22 abr. 2016.

Lei $\mathrm{n}^{0}$ 8.629, de 25 de fevereiro de 1993. Dispõe sobre a regulamentação dos dispositivos constitucionais relativos à reforma agrária, previstos no Capítulo III, Título VII, da Constituição Federal. Disponível em: <http://www.planalto.gov.br/ccivil_03/leis/L8629.htm>. Acesso em: 22 abr. 2016.

Lei $\mathrm{n}^{\mathrm{O}} 10.257$, de 10 de julho de 2001. Regulamenta os arts. 182 e 183 da Constituição Federal, estabelece diretrizes gerais da política urbana e dá outras providências. Disponível em:

<http://www.planalto.gov.br/ccivil_03/leis/LEIS_2001/L10257.htm>. Acesso em: 14 jul. 2016.

Lei $\mathrm{n}^{\mathrm{o}} 10.831$, de 23 de dezembro de 2003. Dispõe sobre a agricultura orgânica e dá outras providências. Disponível em: <http://www.planalto.gov.br/ccivil_03/leis/2003/L10.831.htm>. Acesso em: 13 ago. 2016.

Lei $n^{0} 11.326$, de 24 de julho de 2006. Estabelece as diretrizes para a formulação da Política Nacional da Agricultura Familiar e Empreendimentos Familiares. Disponível em: <http://www.planalto.gov.br/ccivil_03/_Ato2004-2006/2006/Lei/L11326.htm>. Acesso em: 22 abr. 2016.

Lei $\mathrm{n}^{0} 13.341$, de 29 de setembro de 2016. Altera as Leis $\mathrm{n}^{\mathrm{os}} 10.683$, de 28 de maio de 2003, que dispõe sobre a organização da Presidência da República e dos Ministérios, e 11.890, de 24 de dezembro de 2008, e revoga a Medida Provisória $\mathrm{n}^{\mathrm{o}}$ 717, de 16 de março de 2016. Disponível em: <http://www.planalto.gov.br/ccivil_03/_Ato20152018/2016/Lei/L13341.htm>. Acesso em: 10 set. 2016. 
BULGARELLI, Waldírio. A nova legislação cooperativista brasileira. In: et al. A problemática cooperativista no desenvolvimento econômico. São Paulo: Artegráfica, 1973. p. 133-165.

BUNKYO. Sociedade Brasileira Japonesa de Cultura Japonesa e de Assistência Social. Expresidentes: Kunito Miyasaka. Disponível em: <http://www.bunkyo.org.br/pt-BR/expresidentes/83-kunito-miyasaka-3-presidente-03-1965-ate-03-1971>. Acesso em: 28 abr. 2016.

CÂMARA DOS DEPUTADOS. Projetos de Lei e outras proposições. PL 519/2015. Disponível em: <http://www.camara.gov.br/proposicoesWeb/fichadetramitacao?idProposicao=953932> . Acesso em: 16 set. 2016.

CÂMARA MUNICIPAL DE SÃO PAULO. Conheça o novo Plano Diretor Estratégico de São Paulo. Lei 16.050/14. São Paulo: Câmara Municipal de São Paulo, 2014.

CARLOS, Ana Fani Alessandri. A (re)produção do espaço urbano. São Paulo: Edusp, 2008.

CENTRO PAULUS. Disponível em: <http://www.centropaulus.com.br>. Acesso em: 28 mar. 2016.

COMPANHIA AMBIENTAL DO ESTADO DE SÃO PAULO (Cetesb). Histórico. Disponível em: <http://www.cetesb.sp.gov.br/institucional/historico>. Acesso em: 8 ago. 2016.

COSTA, Emilia Viotti. Cotia e Itapecerica da Serra, subúrbios agrícolas. In: AZEVEDO, Aroldo de (Org.). A cidade de São Paulo: estudos de Geografia Urbana. São Paulo: Companhia Editora Nacional, 1958. v. IV: Os subúrbios paulistanos. p. 109-152.

CUNHA, Gabriela Cavalcanti. Dimensões da luta política nas práticas de economia solidária. In: __ et al. (Org.). Uma outra economia é possível: Paul Singer e a economia solidária. São Paulo: Contexto, 2003.p. 45-72.

DEÁK, Csaba (Org.). Evolução da mancha urbana 1881-1995. FAU-USP. Disponível em: <http://www.fau.usp.br/docentes/depprojeto/c_deak/CD/5bd/1rmsp/m02evol/index.html>. Acesso em: 30 jun. 2016. 
DIEGUES, Antonio Carlos. O mito moderno da natureza intocada. 6. ed. São Paulo: Hucitec/Nupaub, 2008.

ECONOMIA SOLIDÁRIA SP (ECOSOL SP). Economia Solidária mobiliza estudantes de Design, 30 out. 2015. Disponível em: <http://www.ecosolsp.com.br/materia/economiasolidaria-mobiliza-estudantes-de-design>. Acesso em: 23 set. 2016.

EMPRESA BRASILEIRA DE PESQUISA AGROPECUÁRIA (EMBRAPA). Agricultura orgânica. Disponível em: <http://www.cnph.embrapa.br/organica/agriorganica.html>. Acesso em: 13 ago. 2016.

ÉPOCA NEGÓCIOS. Preço dos imóveis em São Paulo dobrou nos últimos 40 anos, 17 set. 2015. Disponível em:

<http://epocanegocios.globo.com/Informacao/Resultados/noticia/2015/09/imoveis-emsao-paulo-valorizaram-103-nos-ultimos-40-anos.html>. Acesso em: 30 set. 2016.

ESTATUTO DA COOPERATIVA AGROECOLÓGICA DOS PRODUTORES RURAIS E DE ÁGUA LIMPA DA REGIÃO SUL DE SÃO PAULO, 2011.

ESTEVES, Egeu. Os desafios à igualdade nas cooperativas autogestionárias. In: SOUZA, André Ricardo de. et al. Uma outra economia é possível. São Paulo: Contexto, 2003.

FERNANDES, Bernardo Mançano. Agricultura camponesa e/ou agricultura familiar. Disponível em:

<http://www.geografia.fflch.usp.br/graduacao/apoio/Apoio/Apoio_Valeria/flg0563/2s2 012/FERNANDES.pdf>. Acesso em: 5 mar. 2016.

FLEURY, Maria Tereza Leme. Cooperativas agrícolas e capitalismo no Brasil. São Paulo: Global, 1983.

FRANÇA, Bárbara Heliodora et al. Parte II - formação da economia solidária. In:

Guia de economia solidária: ou porque não organizar cooperativas para populações carentes. Niterói, RJ: UFF, 2008. p. 43-105.

GIACCHÈ, Giulia; PORTO, Lya. Políticas públicas de Agricultura Urbana e Periurbana: uma comparação entre os casos de São Paulo e Campinas. In: Informações Econômicas, São Paulo. v. 45, n. 6, nov./dez. 2015. Disponível em: <http://www.iea.sp.gov.br/ftpiea/publicacoes/ie/2015/tec3-1215.pdf>. Acesso em: 7 ago. 2016. 
GOVERNO DO ESTADO DE SÃO PAULO. Sistema ambiental paulista. Virada Sustentável. Disponível em: <http://www.ambiente.sp.gov.br/virada-sustentavel>. Acesso em: 28 mar. 2016.

GRUPO DE PLASTIMODELISMO E PESQUISA SANTOS DUMONT (GPPSD). O Modelódromo. Disponível em: <http://gppsd.com.br/novo/?page_id=320>. Acesso em: 9 ago. 2016.

HUSQVARNA. Sobre a Husqvarna. Disponível em: <http://www.husqvarna.com/br/support/about-husqvarna/four-centuries-of-husqvarna>. Acesso em: 28 mar. 2016.

INCUBADORA TECNOLÓGICA DE COOPERATIVAS POPULARES DA UNIVERSIDADE DE SÃO PAULO (ITCP-USP). Mãosementes conectadas: tecendo a rede colaborativa agroecológica de Parelheiros. São Paulo: ITCP-USP, 2013. 201 p. Relatório técnico final.

INSTITUTO BRASILEIRO DE DEFESA DO CONSUMIDOR (IDEC). Mapa de Feiras Orgânicas. Disponível em: <http://feirasorganicas.idec.org.br>. Acesso em: 8 ago. 2016.

INSTITUTO BRASILEIRO DE GEOGRAFIA E ESTATÍSTICA (IBGE). Cidades@. São Paulo. Censo demográfico 2010: sinopse. Disponível em: $<$ http://www.cidades.ibge.gov.br/xtras/temas.php?lang=\&codmun=355030\&idtema $=1 \&$ search=sao-paulo|sao-paulo|censo-demografico-2010:-sinopse- $>$. Acesso em: 30 jun. 2016.

Cidades@. São Paulo. Histórico. Disponível em: <http://cidades.ibge.gov.br/painel/historico.php?codmun=355030>. Acesso em: 8 jun. 2016.

Cidades@. São Paulo. São Paulo. Disponível em: <http://www.cidades.ibge.gov.br/xtras/perfil.php?lang=\&codmun=355030\&search=sao -paulo|sao-paulo>. Acesso em: 30 jun. 2016.

INSTITUTO BRASILEIRO DE GEOGRAFIA E ESTATÍSTICA (IBGE). Metodologia do Censo Demográfico 2010. Rio de Janeiro: IBGE, 2013.

INSTITUTO 5 ELEMENTOS. Disponível em: <http://www.5elementos.org.br>. Acesso em: 29 fev. 2016. 
INSTITUTO AGRONÔMICO (IAC). Solos do estado de São Paulo. Disponível em: <http://www.iac.sp.gov.br/solossp>. Acesso em: 7 jun. 2016.

Cambissolos. Disponível em:

<http://www.iac.sp.gov.br/solossp/pdf/Cambissolos.pdf>. Acesso em: 7 jun. 2016.

INSTITUTO CHÃO. Disponível em: <http://www.institutochao.org>. Acesso em: 28 mar. 2016.

INSTITUTO KAIRÓS. Disponível em: <http://institutokairos.net>. Acesso em: 11 mar. 2016.

INSTITUTO NACIONAL DE COLONIZAÇÃO E REFORMA AGRÁRIA (INCRA). Sistema Nacional de Cadastro Rural - índices básicos de 2013. Disponível em: $<$ http://www.incra.gov.br/sites/default/files/uploads/estrutura-fundiaria/regularizacaofundiaria/indices-cadastrais/indices_basicos_2013_por_municipio.pdf >. Acesso em: 22 abr. 2016.

INSTITUTO PEDRO MATAJS. Disponível em: <http://www.institutopedromatajs.org.br>. Acesso em: 29 fev. 2016.

JUSBRASIL. Lei $13.136 / 01$ de 9 de junho de 2001. Disponível em: <http://cm-saopaulo.jusbrasil.com.br/legislacao/814931/lei-13136-01>. Acesso em: 7 ago. 2016.

LAMMING, Goodwin Norman. Eficiência em administração de cooperativas. In: . et al. A problemática cooperativista no desenvolvimento econômico. São Paulo: Artegráfica, 1973. p. 281-314.

LEFEBVRE, Henri. O direito à cidade. 5. ed. São Paulo: Centauro, 2001.

MADALENO, Isabel Maria. A cidade das mangueiras: agricultura urbana em Belém do Pará. Lisboa: Fundação Calouste Gulbenkian, 2002.

MARCELINO, Lucimara et al. Mão sementes conectadas: tecendo a rede colaborativa agroecológica de Parelheiros. Revista Brasileira de Agroecologia, v. 4, n. 2, nov. 2009.

MARQUES, Marta Inez Medeiros. A atualidade do uso do conceito de camponês. In: Revista Nera, ano 11, n. 12, jun. 2008. 
MARTINS, José de Souza. Expropriação e violência: a questão política no campo. 3. ed. São Paulo: Hucitec, 1991.

Os camponeses e a política no Brasil. Petrópolis: Vozes, 1981.

MINISTÉRIO DA AGRICULTURA, PECUÁRIA E ABASTECIMENTO. Certificação por auditoria. Disponível em: <http://www.agricultura.gov.br/portal/page/portal/InternetMAPA/pagina-inicial/desenvolvimento-sustentavel/organicos/regularizacao-producaoorganica/certificacao-por-auditoria-rpo>. Acesso em: 24 maio 2016.

Controle Social. Disponível em:

$<$ http://www.agricultura.gov.br/portal/page/portal/Internet-MAPA/paginainicial/desenvolvimento-sustentavel/organicos/regularizacao-producaoorganica/controle-social-rpo>. Acesso em: 24 maio 2016.

Sistemas participativos. Disponível em:

$<$ http://www.agricultura.gov.br/portal/page/portal/Internet-MAPA/paginainicial/desenvolvimento-sustentavel/organicos/regularizacao-producaoorganica/sistemas-participativos-rpo>. Acesso em: 24 maio 2016.

MINISTÉRIO DO DESENVOLVIMENTO AGRÁRIO (MDA). DAP: saiba como funciona a identidade do agricultor familiar, 27 mar. 2012. Disponível em: <http://www.mda.gov.br/sitemda/noticias/dap-saiba-como-funciona-identidade-doagricultor-familiar>. Acesso em: 19 abr. 2016.

Saiba como ter a DAP: documento que dá acesso às políticas públicas para agricultores familiares de todo o Brasil, 5 mar. 2015. Disponível em: <http://www.mda.gov.br/sitemda/noticias/saiba-como-ter-dap-documento-qued\%C3\%A1-acesso-\%C3\%A0s-po1\%C3\%ADticas-p\%C3\%BAblicas-para-agricultores>. Acesso em: 23 abr. 2016.

MOUGEOT, Luc J. A. Urban agriculture: concept and definition. Disponível em: <http://www.ruaf.org/urban-agriculture-concept-and-definition>. Acesso em: 7 ago. 2016.

MOURA, Margarida Maria. Camponeses. 2. ed. São Paulo: Ática, 1988. 
MOURA, Valdiki. Caráter e tendências do movimento cooperativo no Brasil. In: . et al. A problemática cooperativista no desenvolvimento econômico. São Paulo: Artegráfica, 1973. p. 73-105.

NEVES, Delma Pessanha. Agricultura familiar: quantos ancoradouros! In: FERNANDES, Bernardo Mançano; MARQUES, Marta Inez Medeiros; SUZUKI, Júlio César (Orgs.). Geografia Agrária: teoria e poder. São Paulo: Expressão Popular, 2007. p. 211-270.

NOBRE, Eduardo Alberto Cusce. Novos instrumentos urbanísticos em São Paulo: limites e possibilidades. Disponível em:

$<$ http://www.fau.usp.br/docentes/depprojeto/e_nobre/instrumentos_urbanisticos_sao_pa ulo.pdf $>$. Acesso em: 14 jul. 2016.

OLIVEIRA, Ariovaldo Umbelino de. A agricultura camponesa no Brasil. São Paulo: Contexto, 1991.

Geografia Agrária: perspectivas no início do século XXI. In:

; MARQUES, Marta Inez Medeiros (Orgs.). O campo no século XXI. São Paulo: Casa Amarela/Paz e Terra, 2004. p. 29-70.

OLIVEIRA, Ariovaldo Umbelino de. Modo capitalista de produção e agricultura. São Paulo: Ática, 1990.

. Renda da terra absoluta. Renda da terra de monopólio. Renda da terra pré-capitalista. Preço da terra. Revista Orientação. São Paulo: Instituto de Geografia USP, n. 7, dez./1986. P. 77-86.

\section{ORGANIZAÇÃO DAS COOPERATIVAS DO ESTADO DE SÃO PAULO (OCESP).}

Perguntas e respostas. Disponível em:

<http://ocesp.org.br/default.php?p=texto.php\&c=perguntas_e_repostas\#R16>. Acesso em: 2 mar. 2016.

PENTEADO, Antonio Rocha. Os subúrbios de São Paulo e suas funções. In: AZEVEDO, Aroldo de (Org.). A cidade de São Paulo: estudos de Geografia Urbana. São Paulo: Companhia Editora Nacional, 1958. v. IV: Os subúrbios paulistanos. p. 5-60.

PINHO, Carlos Marques. O estado brasileiro e as cooperativas. In: . et al. A problemática cooperativista no desenvolvimento econômico. São Paulo: Artegráfica, 1973. p. 107-132. 
PINHO, Diva Benevides. O cooperativismo no Brasil: da vertente pioneira à vertente solidária. São Paulo: Saraiva, 2004.

A doutrina cooperativa e a problemática do desenvolvimento econômico. In:

et al. A problemática cooperativista no desenvolvimento econômico. São Paulo: Artegráfica, 1973. p. 15-47.

POLO DE ECOTURISMO DE SÃO PAULO. Disponível em: <http://www.cidadedesaopaulo.com/ecoturismo>. Acesso em: 5 ago. 2016.

PREFEITURA DE SÃO PAULO. Conselho Municipal de Segurança Alimentar e Nutricional de São Paulo (Comusan-SP). Disponível em: <http://www.prefeitura.sp.gov.br/cidade/secretarias/trabalho/abastecimento/comusan/in dex.php?p=26221>. Acesso em: 9 ago. 2016.

Decreto $\mathrm{n}^{0}$ 47.280, de 16 de maio de 2006. Oficializa a Casa da Agricultura Ecológica José Umberto Macedo Siqueira. Disponível em: <http://www3.prefeitura.sp.gov.br/cadlem/secretarias/negocios_juridicos/cadlem/integr a.asp?alt=17052006D\%20472800000>. Acesso em: 7 ago. 2016.

Decreto $\mathrm{n}^{\mathrm{0}}$ 56.399, de 9 de setembro de 2015. Transforma a Supervisão Geral de Abastecimento - ABAST, da Secretaria Municipal do Desenvolvimento, Trabalho e Empreendedorismo, na Coordenadoria de Segurança Alimentar e Nutricional COSAN, bem como transfere cargos de provimento em comissão para os órgãos que especifica. Disponível em:

<http://www.prefeitura.sp.gov.br/cidade/secretarias/upload/trabalho/DECRETO\%20N $\% 2056 \% 20399$.pdf $>$. Acesso em: $1^{\circ}$ out. 2016.

. Decreto $\mathrm{n}^{0}$ 57.007, de 20 de maio de 2016. Institui a Política Municipal de Segurança Alimentar e Nutricional - PMSAN, bem como fixa as diretrizes para o Plano Municipal de Segurança Alimentar e Nutricional, conforme previsto na Lei $\mathrm{n}^{\mathrm{o}} 15.920$, de 18 de dezembro de 2013.

Infocid@de. Disponível em: <http://infocidade.prefeitura.sp.gov.br>. Acesso em: 25 jul. 2016.

Lei $\mathrm{n}^{\circ}$ 13.430, de 13 de setembro de 2002. Plano Diretor Estratégico. Disponível em: <http://www.prefeitura.sp.gov.br/cidade/secretarias/upload/infraestrutura/sp_obras/arqu ivos/plano_diretor_estrategico.pdf>. Acesso em: 25 jul. 2016. 
Lei ${ }^{\circ}$ 14.162, de 24 de maio de 2006. Cria a Unidade de Conservação Área de Proteção Ambiental Municipal Bororé-Colônia. Disponível em:

<http://www.prefeitura.sp.gov.br/cidade/upload/lei_14_162_1254941048.pdf >. Acesso em: 8 ago. 2016.

Lei $n^{0} 15.953$, de 7 de janeiro de 2014. Dispõe sobre a criação do Polo de Ecoturismo nos Distritos de Parelheiros e Marsilac até os limites da Área de Proteção Ambiental Bororé-Colônia, e dá outras providências. Disponível em: <http://www3.prefeitura.sp.gov.br/cadlem/secretarias/negocios_juridicos/cadlem/integr a.asp?alt=08012014L\%20159530000>. Acesso em: 2 out. 2016.

. Lei $\mathrm{n}^{\mathrm{o}}$ 16.050, de 31 de julho de 2014. Aprova a Política de Desenvolvimento Urbano e o Plano Diretor Estratégico do Município de São Paulo e revoga a Lei $n^{0}$ 13.430/2002. Disponível em:

<http://www.prefeitura.sp.gov.br/cidade/secretarias/upload/chamadas/2014-07-31__lei_16050_-_plano_diretor_estratgico_1428507821.pdf>. Acesso em: 8 ago. 2016.

Notícias. Lei que insere alimentos orgânicos nas escolas municipais é regulamentada, 5 abr. 2016. Disponível em: <http://www.capital.sp.gov.br/portal/noticia/10746\#adimage-0>. Acesso em: 9 ago. 2016.

Notícias. Prefeitura lança programa de incentivo à agricultura familiar, 2 mar. 2016. Disponível em: <http://www.capital.sp.gov.br/portal/noticia/9619\#ad-image-0>. Acesso em: 9 ago. 2016.

Secretaria Municipal do Desenvolvimento, Trabalho e Empreendedorismo. Organização: conheça a estrutura da SDTE. Disponível em: $<$ http://www.prefeitura.sp.gov.br/cidade/secretarias/trabalho/organizacao/index.php?p= 597>. Acesso em: 7 ago. 2016.

Secretaria Municipal do Verde e do Meio Ambiente. Proaurp. Disponível em: $<$ http://www.prefeitura.sp.gov.br/cidade/secretarias/meio_ambiente/servicos/proaurp/in dex.php?p=30091>. Acesso em: 7 ago. 2016.

QUEIROZ, Maria Isaura Pereira de. O campesinato brasileiro. Petrópolis: Editora Vozes, 1976.

ROSARIO, Ricardo Pedro Guazzelli. Estágios sucessionais e o enquadramento jurídico das florestas montanas secundárias na Reserva Florestal do Morro Grande. 2010. 153 f. Dissertação (Mestrado) - Instituto de Botânica da Secretaria de Estado do Meio Ambiente, São Paulo, 2010. 
RESOURCE CENTRES ON URBAN AGRICULTURE AND FOOD SECURITY (Ruaf Foundation). Urban agriculture: what and why? Disponível em: <http://www.ruaf.org/urban-agriculture-what-and-why>. Acesso em: $1^{\circ}$ out. 2016.

SANTOS, B.; Rodríguez, C. Introdução: para ampliar o cânone da produção. In: SANTOS, Boaventura de Sousa (Org.). Produzir para viver: os caminhos da produção não capitalista. Rio de Janeiro: Civilização Brasileira, 2002.

SCARLATO, Francisco Capuano. População e urbanização brasileira. In: ROSS, Jurandyr L. Sanches. Geografia do Brasil. 5. ed. São Paulo: Edusp, 2005. p. 381-463.

SEABRA, Manoel Gonçalves. As cooperativas mistas do estado de São Paulo: estudo de Geografia Econômica. 1973. 270 f. Tese (Doutorado em Geografia) - Faculdade de Filosofia, Letras e Ciências Humanas, Universidade de São Paulo, São Paulo, 1973.

SECRETARIA DO MUNICIPAL DO VERDE E DO MEIO AMBIENTE. Ecoturismo e agroecologia no extremo sul de São Paulo. São Paulo: SVMA, 2012. Disponível em: $<$ http://www.cidadedesaopaulo.com/ecoturismo/wpcontent/themes/ignacio_abiaru_wordpress_theme/guia_ecoturismo.pdf $>$. Acesso em: 5 ago. 2016.

Fema. Disponível em:

<http://www.prefeitura.sp.gov.br/cidade/secretarias/meio_ambiente/confema/index.php ?p=3299>. Acesso em: 29 fev. 2016.

SESC SÃO PAULO. Pétala por Pétala 2015. Disponível em: <http://www.sescsp.org.br/programacao/57071_PETALA+POR+PETALA+2015>. Acesso em: 26 mar. 2016.

SHANIIN, Teodor. Naturaleza y lógica de la economía campesina. [S.1.]: Anagrama, [19-]. p.15-39.

SILVA, Leonardo Xavier; HOLZ, Viviane Ratzmann. O cooperativismo e seu comportamento diante do capitalismo atual: aspectos teóricos e evidências empíricas. In: V Encontro de Pesquisadores Latino-americanos de Cooperativismo, Ribeirão Preto, SP, ago. 2008.

SINGER, Paul. Introdução à economia solidária. São Paulo: Perseu Abramo, 2002. 
SISTEMA INTEGRADO DE GESTÃO AMBIENTAL (SIGAM). Guarapiranga Sustentável. Disponível em:

<http://www.sigam.ambiente.sp.gov.br/sigam3/Default.aspx?idPagina=7611>. Acesso em: 8 ago. 2016.

Protocolo de cooperação que celebram entre si, o governo do estado de São Paulo, por intermédio da Secretaria Estadual do Meio Ambiente e da Secretaria Estadual de Agricultura e Abastecimento, o município de São Paulo, por intermédio da Secretaria Municipal de Coordenação das Subprefeituras, e da Secretaria Municipal do Verde e do Meio Ambiente e os agricultores e suas organizações para a adoção de práticas e ações destinadas a consolidar o desenvolvimento rural sustentável no município de São Paulo. Disponível em:

<http://www.sigam.ambiente.sp.gov.br/sigam3/Repositorio/259/Documentos/Protocolo. pdf $>$. Acesso em: 8 ago. 2016.

SOUZA, André Ricardo de. Economia solidária: um movimento nascente da crise do trabalho. In: et al. (Org.). Uma outra economia é possível: Paul Singer e a economia solidária. São Paulo: Contexto, 2003.p. 27-44.

TAVARES DOS SANTOS, José Vicente. Colonos do vinho: estudo sobre a subordinação do trabalho camponês ao capital. São Paulo: Hucitec, 1978.

TERRA. Economia. Preço do metro quadrado em São Paulo. Disponível em: $<$ https://economia.terra.com.br/preco-do-metro-quadrado-em-sao-paulo>. Acesso em: 30 set. 2016.

TOCA DA ONÇA. Agência de ecoturismo. Disponível em: <http://agtocadaonca.wixsite.com/site>. Acesso em: 30 set. 2016.

UTUMI, Américo. Comercialização de produtos agrícolas por intermédio das cooperativas. In: _ et al. A problemática cooperativista no desenvolvimento econômico. São Paulo: Artegráfica, 1973. p. 185-200.

WOORTMANN, Klaas. "Com parente não se neguceia". O campesinato como ordem moral. In: Anuário Antropológico, 1987. Disponível em: <http://www.dan.unb.br/anuarioantropologico-listagem-dos-numeros/133-anuario-antropologico-sumario-1987> . Acesso em: $1^{\mathrm{o}}$ abr. 2016. 


\section{ANEXOS}

ANEXO A - Notícia sobre a inauguração da jardineira no Polo de Ecoturismo de São Paulo, publicada na Folha de Parelheiros, em 4 de junho de 2016. A versão a seguir foi retirada do digital. Disponível em: <http://www.folhadeparelheiros.com.br/singlepost/2016/06/04/INAUGURA\%C3\%87\%C3\%83O-DA-JARDINEIRA-DO-POLO-DEECOTURISMO>. Acesso em: 30 set. 2016.

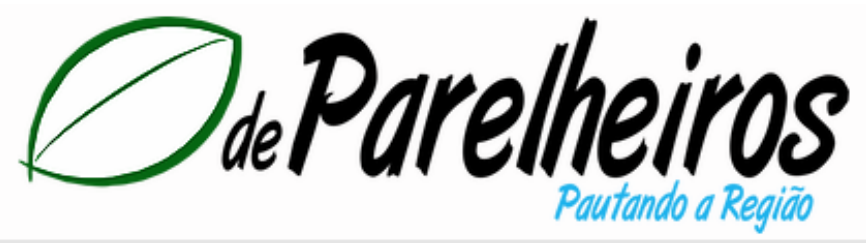

INICIO NOTICIAS QUEM SOMOS ANUNCIANTES FALE CONOSCO VOCÊ REPÓRTER TELEFONES UTEIS

\section{Ecoturismo \\ INAUGURAÇÃO DA JARDINEIRA DO POLO DE ECOTURISMO}

June 4, 2016 | Vagner Fernandes

Imagens Vagner Fernandes

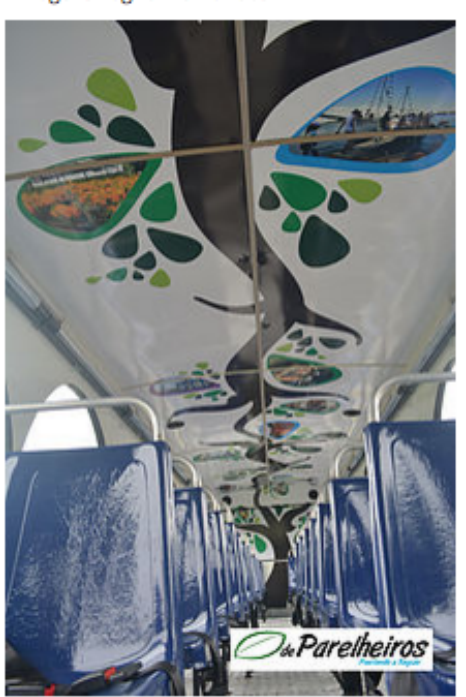

nauguração da jardineira do polo de ecoturismo aconteceu nesse sábado as 10:00 no PAT - Ponto de Atendimento ao Turista.

Com direito a estouro de champagne para comemorar mais uma conquista para o Polo de Parelheiros, Marsilac e Ilha do Bororé.

Com a presença de diretoria da AMTECI-PA, Associados, Empreendedores e diretoria da Transbrat.

Uma grande conquista e apoio para todos os empreendedores da Região.

A jardineira e um produto da Transbrat em Parceria com a Amteci-Pa.

Os Passeios de Jardineira terá seu ponto de partida do PAT - Ponto de Atendimento ao Turista aos atrativos turísticos da Região.

A JARDINEIRA INAUGURA SUAS ATIVIDADES OFICIALMENTE NO II FESTIVAL DE INVERNO DO POLO DE ECOTURISMO DE SÃO PAULO - Parelheiros, Marsilac e llha do Bororé

QUE ACONTECERÁ DO DIA 11/06 À 31/07.

Folha de Parelheiros cobertura total das atividades do II festival acompanhe as proximas notícias.

Clique aqui curta nossa pagina e fique por dentro dos acontecimentos de nossa região.
Posts Em Destaque

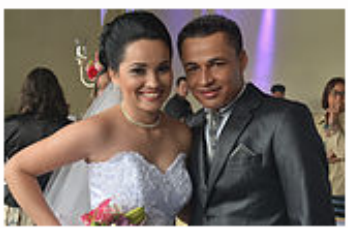

WORKSHOP DE NOIVOSE

DEBUTANTES SITIO SĀO

FRANCISCO 2016

September 25, 2016

Posts Recentes

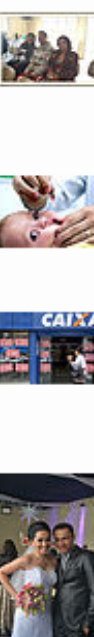

ASSOCIAÇÃO BENEFICENTE JARDIM

DE DEUS - RECANTO

DA BENÇÃO

September 2B, 2016

CAMPANHA DE

MULTIVACINAÇÄO VAI

ATE ESTA SEXTA-FEIRA September 28, 2016

Greve dos bancários

chega a 21 dia sem

previsão para

normalizar.

September 26, 2016

WORKSHOP DE

NOIVOSE

DEBUTANTES SITIO

SĀO FRANCISCO 2016

September 25, 2016

MARTA SUPLICY DIZ À

FOLHA DE 
ANEXO B - Protocolo de Boas Práticas Agrícolas.

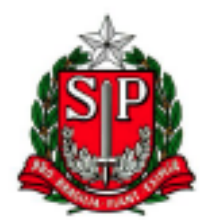

Estado de São Paulo

PROTOCOLO DE COOPERAÇÃO QUE CELEBRAM ENTRE SI, O GOVERNO DO ESTADO DE SÃO PAULO, POR INTERMÉDIO DA SECRETARIA ESTADUAL DO MEIO AMBIENTE E DA SECRETARIA ESTADUAL DE AGRICULTURA E ABASTECIMENTO, O MUNICÍPIO DE SÃO PAULO, POR INTERMÉDIO DA SECRETARIA MUNICIPAL DE COORDENAÇÃO DAS SUBPREFEITURAS, E DA SECRETARIA MUNICIPAL DO VERDE E DO MEIO AMBIENTE E OS AGRICULTORES E SUAS ORGANIZAÇỖES PARA A ADOÇÄO DE PRÁTICAS E AÇÖES DESTINADAS A CONSOLIDAR O DESENYVOLVIMENTO RURAL SUSTENTÁVEL NO MUNICIPIO DE SÃO PAULO.

O ESTADO DE SÃO PAULO, por intermédio de sua SECRETARIA ESTADUAL DE MEIO AMBIENTE, doravante denominada SMA, com sede na Avenida Frederico Hermann Junior, $n^{\circ} 345$, Alto de Pinheiros, CEP: 05459-010, São Paulo/SP, inscrita no CNPJ/MF sob o $n^{\circ}$ 56.089.790/0001-88, representada neste ato, por seu Secretário de Estado, Pedro Ubiratan Escorel de Azevedo, e da SECRETARIA ESTADUAL DE AGRICULTURA E ABASTECIMENO, doravante denominada SAA, com sede na Avenida Miguel Stefano, $n^{\circ} 3.900$, Água Funda, CEP: 04301-903, São Paulo/SP, inscrita no CNPJ/MF sob o $n^{\circ} 46.384 .400 / 0001-49$, representada neste ato, por seu Secretário de Estado, João de Almeida Sampaio Filho, o MUNICíPIO DE SÃO PAULO, com sede no Viaduto do Chá, $n^{\circ} 15$, Centro, CEP: 01002-020, São Paulo/SP, inscrito no CNPJ/MF sob $n^{\circ}$ 46.395.000/0001-39, doravante denominado simplesmente MUNICiPIO, representado neste ato por seu Prefeito, Gilberto Kassab, por intermédio das SECRETARIA MUNICIPAL DA COORDENAÇÃO DAS SUBPREFEITURAS, e da SECRETARIA MUNICIPAL DO VERDE E DO MEIO AMBIENTE, e OS AGRICULTORES E SUAS ORGANIZAÇŐES DENTRO DO MUNICÍPIO DE SÃO PAULO, 


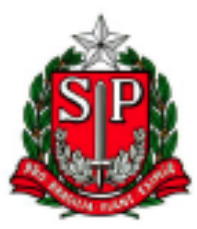

Estado de São Paulo

Considerando a necessidade da preservação das áreas de mananciais e a conseqüente manutenção da capacidade de produção de água potável para abastecer o Município de São Paulo;

Considerando a necessidade de promover o desenvolvimento rural sustentável no Município de São Paulo, minimizando os impactos negativos da agricultura convencional e da expansão urbana desordenada;

Considerando a necessidade de desenvolvimento de ações articuladas que aumentem a competitividade da agricultura familiar por meio da transição do atual padrão produtivo para o sistema agroecológico;

Considerando a Lei Estadual $\mathrm{n}^{\circ}$ 12.233, de 16 de janeiro de 2006, que define a Área de Proteção e Recuperação dos Mananciais da Bacia Hidrográfica do Guarapiranga; a Lei Estadual $n^{0}$ 13.579, de 13 de julho de 2009, que define a Área de Proteção e Recuperação dos Mananciais da Bacia Hidrográfica do Reservatório Billings - APRM-B, e a Resolução Conjunta SAA/SMA $n^{\circ} 08$, de 21 de dezembro de 2009, que estabelece diretrizes para incentivar as práticas de agricultura sustentável em Áreas de Proteção e Recuperação dos Mananciais da Unidade de Gerenciamento dos Recursos Hídricos do Alto Tietê, e

Considerando a Lei Municipal $n^{0} 13.136$, de 09 de junho de 2001, que cria a Área de Proteção Ambiental Municipal do Capivari-Monos - APA Capivari; a Lei Municipal $n^{\circ}$ 13.430, de 13 de setembro de 2002, que institui o Plano Diretor Estratégico e o Sistema de Planejamento e Gestão do Desenvolvimento Urbano do Município de São Paulo; a Lei Municipal n 13.727, de 12 de janeiro de 2004, que cria o Programa de Agricultura Urbana e Periurbana - PROAURP no Município de São Paulo e define suas diretrizes, e a Lei Municipal $\mathrm{n}^{\circ}$ 14.162, de 24 de maio de 2006, que cria a Unidade de Conservação Área de Proteção Ambiental Municipal Bororé-Colônia,

Firmam o presente Protocolo de Boas Práticas Agroambientais do Município de São Paulo, doravante denominado Protocolo, mediante as cláusulas e condições que seguem:

\section{CLÁUSULA PRIMEIRA - DAS DIRETRIZES GERAIS}

1.1 - Na execução do objeto do presente Protocolo, as partes observarão as seguintes diretrizes gerais:

\subsection{1 - As condutas governamentais e do setor produtivo devem ser transparentes;}

1.1.2 - Os produtos oriundos da agricultura praticada nesta região devem ter qualidade compatível com o seu uso e com a legislação aplicável; 


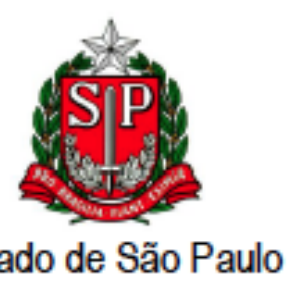

1.1.3 - Agricultura sustentável é a atividade que harmoniza o processo produtivo com a conservação ambiental, por meio de técnicas apropriadas de manejo dos recursos naturais, conservacionistas e não degradadoras do solo, da água, dos recursos genéticos animais e vegetais, de modo a assegurar a obtenção e a satisfação contínua das necessidades humanas para as gerações presentes e futuras;

1.1.4 - A produção agrícola deve ser realizada dentro dos princípios da agricultura sustentável e com responsabilidade social.

\section{CLÁUSULA SEGUNDA - DO OBJETO}

2.1 - O presente Protocolo tem por objeto promover a cooperação técnica e institucional entre as partes de forma a criar condições que viabilizem o desenvolvimento de um conjunto de ações para a consolidação do processo de desenvolvimento rural sustentável no município de São Paulo.

2.2 - Os agricultores, mediante adesão voluntária ao Protocolo, comprometem-se a respeitar as diretivas técnicas descritas na Cláusula Terceira, de acordo com termo de adesão (ANEXO 1).

\section{CLÁUSULA TERCEIRA - DAS DIRETRIZES TÉCNICAS}

\section{1 - Os agricultores que aderirem ao Protocolo deverão:}

3.1.1 - Adotar práticas de conservação do solo e de controle de erosão através de planejamento e distribuição racional dos caminhos, plantio em contomo, terraceamento, sulcos, camalhões, canais escoadouros, bacias de retenção e plantio em nível, de forma integrada e não isolada, com manutenção de boa cobertura do solo, uso de adubação orgânica em suas várias formas: verde, compostagem, biofertilizantes e estercos bioestabilizados;

3.1.2 - Utilizar práticas que aumentem a proporção de matéria orgânica no solo por meio da eliminação de queimadas, rotação de culturas, reposição de matéria orgânica, manutenção de boa cobertura do solo, utilização de adubos verdes e outras formas de adubos orgânicos, implantação de cercas vivas, manejo da vegetação espontânea, preferencialmente por meios manuais ou mecânicos e redução do revolvimento do solo;

3.1.3 - Diversificar o uso do solo por meio de rotação e consórcio de culturas comerciais e para consumo próprio, uso de cobertura viva, integração da produção animal e vegetal, quando possível, implantação de Sistemas Agroflorestais e de florestamento e reflorestamento; 


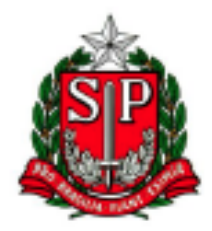

Estado de São Paulo

3.1.4 - Utilizar adequadamente os fertilizantes com base em análises periódicas de solo para subsidiar o programa de calagem e adubação, reduzir o uso de fertilizantes sintéticos de alta solubilidade e incrementar o uso de compostos orgânicos e adubos verdes;

3.1.5 - Promover o uso racional da água por meio do aumento da eficiência da irrigação e de sistemas de irrigação adequados, da manutenção de cobertura do solo e da utilização de quebra-ventos;

3.1.6 - Realizar controle de pragas e doenças privilegiando o uso de métodos de controle menos agressivos, como os biológicos e físicos, objetivando a redução do uso de agrotóxicos até a sua eliminação;

3.1.7 - Promover a recuperação, reposição e manutenção da mata ciliar e proteger as nascentes;

3.1.8 - Destinar corretamente os dejetos humanos por meio de fossa séptica, fossa seca, fossa biodigestora ou afastamento do esgoto doméstico pela rede pública de esgoto, quando houver, $\mathrm{e}$

3.1.9 - Destinar corretamente os residuos sólidos por meio da separação dos resíduos recicláveis e da compostagem dos resíduos orgânicos, incluindo os dejetos animais. Os demais resíduos devem ser destinados à coleta pública. Destinar corretamente as embalagens vazias de agrotóxicos, de acordo com legislação específica.

3.2 - Dentro do prazo de 90 (noventa) dias da data de adesão ao Protocolo o produtor deverá apresentar um Plano de Conversão para o Sistema Agroecológico, com base nessas diretivas (ANEXO 2).

\section{CLÁUSULA QUARTA - DO APOIO GOVERNAMENTAL}

4.1 - A Administração Pública por sua vez atuará no sentido de:

4.1.1 - Fomentar a pesquisa para desenvolvimento de índices ambientais com fins de validar a capacidade das práticas agroecológicas resultarem em melhor qualidade do solo e água;

4.1.2 - Fomentar pesquisas que visem ao uso de tecnologias de base ecológica e atividades produtivas mais apropriadas à região;

4.1.3 - Orientar a extensão rural no sentido de estimular o associativismo, o registro dos trabalhadores e do produtor rural, o controle e planejamento da produção entre os agricultores; 


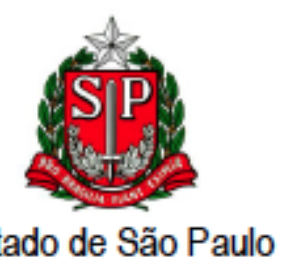

4.1.4 - Estimular a adequação ambiental das propriedades mediante mecanismos de apoio ao agricultor familiar, prioritariamente;

4.1.5 - Elaborar o Manual de Boas Práticas Agroambientais;

4.1.6 - Executar ações em prol de maior divulgação e informação dos conceitos e benefícios da produção agroecológica, em suas diferentes vertentes;

4.1.7 - Capacitar os técnicos envolvidos com Assistência Técnica e Extensão Rural em agroecologia;

4.1.8 - Fomecer assistência técnica agroecológica aos agricultores;

4.1.9 - Criar e fortalecer Centros de Referência em Agroecologia;

4.1.10 - Apoiar a criação de canais altemativos de comercialização, como as feiras agroecológicas e solidárias, as compras institucionais e o turismo rural sustentável, e

4.1.11 - Outorgar o Selo de Indicação de Procedência da Guarapiranga aos agricultores que obtiverem o Certificado de Conformidade ao Protocolo, mediante comprovação da execução do Plano de Conversão para o Sistema Agroecológico.

\section{CLÁUSULA QUINTA - DA OBRIGAÇÃO DAS PARTES}

\section{1 - Compete às partes:}

5.1.1 - Dar apoio para a realização dos objetivos do presente Protocolo e oferecer transparência às informações e ações decorrentes de seu cumprimento;

5.1.2 - Participar conjuntamente da formulação e análise de possíveis convênios de interesse para o desenvolvimento do presente Protocolo, e

5.1.3 - Constituir uma comissão executiva composta de 3 ( três) técnicos e seus respectivos suplentes, indicados pelas duas Secretarias de Estado e pela Prefeitura Municipal de São Paulo, com mandato de dois anos, que terá a responsabilidade, de acordo com seu Regulamento Interno, de zelar pela operacionalidade das ações, definir critérios para a expedição e renovação de Certificado de Conformidade ao Protocolo, outorgar o Selo de Indicação de Procedência da Guarapiranga, estabelecer metodologia para avaliação e acompanhamento das metas, podendo, inclusive, propor ajustes e adequações do presente Protocolo. 


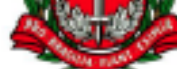

Estado de São Paulo

\section{CLÁUSULA SEXTA - DOS PRAZOS}

6.1 - O presente Protocolo entra em vigor na data de sua assinatura, com prazo de vigência de 60 meses, prorrogáveis por meio de Termo Aditivo, com participação de todas as partes.

E por estarem justos e acordados quanto às cláusulas e condições estabelecidas, firmam os partícipes o presente Protocolo de Boas Práticas em 04 (quatro) vias de igual teor e forma.

São Paulo, 23 de setembro de 2010.

PEDRO UBIRATAN ESCOREL DE AZEVEDO

SECRETÁRIO ESTADUAL DO MEIO AMBIENTE

JOÃO DE ALMEIDA SAMPAIO FILHO

SECRETÁRIO ESTADUAL DE AGRICULTURA E ABASTECIMENTO

GILBERTO KASSAB

PREFEITO DO MUNICÍPIO DE SÃO PAULO

RONALDO SOUZA CAMARGO

SECRETÁRIO MUNICIPAL DE COORDENAÇÃO DAS SUBPREFEITURAS

EDUARDO JORGE MARTINS ALVES SOBRINHO

SECRETÁRIO MUNICIPAL DO VERDE E DO MEIO AMBIENTE 


\begin{abstract}
Estado de São Paulo
ANEXO 1 - MODELO DE TERMO DE ADESÃO AO PROTOCOLO DE BOAS PRÁTICAS AGROAMBIENTAIS
\end{abstract}

TERMO dE ADESÃO AO PROTOCOLO DE BOAS PRÁTICAS AGROAMBIENTAIS (N

Pelo presente instrumento, o (nome do agricultor), (CNPJ/CPF), com domicílio na (endereço, cidade, estado, CEP), (telefone, fax, email), ADERE a todos os termos, cláusulas e condições do PROTOCOLO DE BOAS PRÁTICAS AGROAMBIENTAIS (Nº ), obrigando-se a cumpri-lo e respeitá-lo fielmente, assumindo todas as obrigações e direitos dele decorrentes.

Ao assinar o presente TERMO DE ADESÃO, (nome do agricultor) declara que teve acesso a uma cópia do PROTOCOLO DE BOAS PRÁTICAS AGROAMBIENTAIS (N ) e está ciente de seu teor.

Declara ainda, que (acertos locais):

$1-x x x x$

$2-x x x x$

$O$ presente TERMO DE ADESÃO foi lavrado em 4 (quatro) vias, com a seguinte destinação: $1^{a}$ Via: PMSP; $2^{a}$ Via: SMA; $3^{a}$ Via: SAA; $4^{a}$ Via: aderente (agricultor ou sua organização).

Local e data de assinatura do Termo de Adesão

Nome e assinatura do aderente (nome do agricultor)

"Reconhecimento de firma"

Nome e assinatura do representante da Comissão Executiva do Protocolo

"Reconhecimento de firma" 
ANEXO C - Questionário aplicado com os agricultores entrevistados no trabalho.

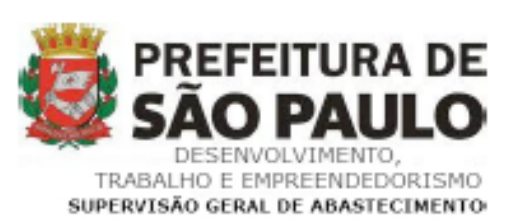

\section{Cadastro de Produtores Rurais}

Data: / /20

Código da Propriedade: CPRS-0000

1- Dados do Produtor:

$\square$ Arrendatário

Meeiro sitio

Outro

$\square$ Posseiro

( ) Proprietário

Nome ou Razão Social:

End. para Correspondência:

Bairro:

CEP:

Comodatário

Ponto de Referência:

E-mail:

DAP:

\section{2- Dados da Propriedade}

Nome ou Razão Social:

. UTM: E /N

Endereço:

Bairro:

. CEP:

Cidade: SP Telefone:
Complemento:

Celular:

CCIR:

Reside na Propriedade?

( ) Sim

Tem energia elétrica?

( ) Monofásica

Tem gerador?

$\square \operatorname{Sim}$

( )Bifásica

( ) Trifásica

( )Não

3- Dados do Proprietário:

Nome ou Razão Social:

Endereço para Correspondência:

Complemento: Bairro:

Telefone:

Fax: ( )

Cidade:

CEP:

E-mail:

4- Nivel de Instrução:

$\square \mathrm{S} /$ instrução/Analf.

$\square$ Primário Completo

$\square 1^{\circ} \mathrm{Grau}$ Completo

()Outros

Telefone:

( )Não
$\square$ Solteiro
Viúvo
$\square$ Divorciado
Outros.
( )Casado

6- Dados Pessoais e Histórico Familiar:

A familia é originária de Parelheiros?

$$
\square \operatorname{Sim}
$$

Especifique:

( )Não

Ano da chegada da familia na região: 


\title{
7-Grupo familiar:
}

\begin{tabular}{|l|l|l|}
\hline Nome & Idade & Escolaridade \\
\hline Filhos & & \\
\hline & & \\
\hline & & \\
\hline & & \\
\hline & & \\
\hline
\end{tabular}

\section{8- Mão de Obra}

\begin{tabular}{|l|l|}
\hline Tipo & Quantidade de Funcionários \\
\hline Familiar & \\
\hline Temporário & \\
\hline Permanente & \\
\hline Meeiro & \\
\hline
\end{tabular}

9- Estudo Socioeconômico do Produtor

Recebe algum beneficio governamental?
$\square$ aposentadoria
$\square$ bolsa familia
)outros

Tem acesso a saúde:
$\square$ pública
( )privada Qual:

Possui:

( )Computador

( )Internet

()Telefone

Faz uso de transporte:

( )público ( )privado Qual(is)? .

Possui: ( )carro ( )bicicleta ( )moto ( )caminhão ( )outros.

Há crianças em idade escolar? ( ) Não ( ) sim

Estão freqüentando a escola? ( ) Não ( ) sim

\section{9- Gestão Sócio Econômico da Atividade Produtiva}
Possui algum crédito?
( ) Não
( ) Sim
Qual:.
Conhece PRONAF?
( ) Näo
() $\operatorname{Sim}$
Já acessou?
Tem seguro rural?
( ) Não ( ) Sim
Qual:.

Tem nota fiscal do produtor? ( ) Näo ( ) Sim

Faz escrituração agricola? ( ) Não ( ) Sim

Utiliza a informática para a gestăo da propriedade ? ( ) Não ( ) Sim

É sindicalizado? ( ) Não ( ) Sim Qual (is) sindicato (s)?.

Recebe alguma assistência técnica ou privada? ( ) Não ( ) Sim

Participa de alguma associação ou cooperativa? ( ) Não ( ) Sim. Qual?

Qual a \% da renda familiar da atividade agropecuária?

A familia tem outras fontes de renda? ( ) Näo ( ) Sim Qual:....

Participa /gostaria de participar de cursos? ( ) Sim ( ) Não

Quais?...

\author{
( ) Sim
}

Qez/ faz

Sabe o que é produçăo orgânica? ( ) Não ( ) Sim

Faz produção orgânica ou tem interesse em fazer? ( ) Não ( ) Sim

10- Área total da propriedade:

\begin{tabular}{|l|l|}
\hline Área total (ha): & \\
\hline Cultura perene: & \\
\hline Cultura temporária: & \\
\hline Pastagens: & \\
\hline Reflorestamento: & \\
\hline Vegetação Natural: & \\
\hline Área em descanso: & \\
\hline Área complementar: & \\
\hline
\end{tabular}


Vegetação de brejo e várzea:

11- Dados da Produção:

\begin{tabular}{|l|l|l|l|}
\hline Produção & Área & Produtividade & Valor \\
\hline & & & \\
\hline & & & \\
\hline & & & \\
\hline & & & \\
\hline & & & \\
\hline & & & \\
\hline & & & \\
\hline & & & \\
\hline
\end{tabular}

12- Benfeitorias, instalações e Máquinas

\begin{tabular}{|l|l|l|}
\hline Descrição do item & Quantidade & Finalidade \\
\hline & & \\
\hline & & \\
\hline & & \\
\hline & & \\
\hline & & \\
\hline & & \\
\hline
\end{tabular}

\section{3- Fertilidade do Solo}

Presença de Plantas Indicadoras? ( ) Năo ( ) Sim

Matéria orgânica (visual): ( ) pouca ( ) média ( ) muita

Granulometria: ( ) argiloso ( ) arenoso ( ) misto

Estrutura: ( ) pouca ( ) boa

Compactação: ( ) sim ( ) não

Vida (visual): ( )ausente ( ) presente

Cobertura morta: ( ) sim ( ) não

Operaçöes de preparo do solo (descrever):

Possui análise de solo? ( ) Não ( ) Sim

Resultados:

Matéria orgânica Micro-nutrientes:

Fósforo: Cálcio:

Potássio: Acidez:

\section{Adubação/nutrição:}

Fontes utilizadas (descrever):

Adubaçăo de plantio (descrever):

Adubação de cobertura (descrever):

Recomendações: 
Quais práticas de controle (descrever):

\begin{tabular}{|l|l|l|l|}
\hline Planta & Praga & Doença & Controle \\
\hline & & & \\
\hline & & & \\
\hline & & & \\
\hline & & & \\
\hline
\end{tabular}

Tem local apropriado para armazenamento de produtos químicos (insumos agrícolas, produto de limpeza e medicamentos)? ( ) Não ( ) Não se aplica ( ) Sim. Onde?.

Faz triplice lavagem das embalagens? ( ) Năo ( ) Sim. Onde?

Faz descarte correto? ( ) Não ( ) Sim. Onde?.

15- Produção Animal

Tipo de criação animal $n^{\circ}$ de animais

\begin{tabular}{|l|l|l|}
\hline Animais & Quantidade & Produtividade \\
\hline & & \\
\hline & & \\
\hline & & \\
\hline & & \\
\hline & & \\
\hline
\end{tabular}

16- Comercialização da Produção
( )Consumidor Final
$\square$ Intermediário
$\square$ Feira-Livres
$\square$ Mercados

$\square$ Central Atacadista

$\square$ Restaurantes

$\square$ Programas Governamentais

( ) Outros.

Quais?

17- Quais os principais produtos processados na propriedade:

\begin{tabular}{|l|l|l|}
\hline Produto & Quantidade & Cotação do preço no mercado interno / unidade \\
\hline & & \\
\hline & & \\
\hline & & \\
\hline & & \\
\hline
\end{tabular}

\section{8- Aspectos Ambientais da Propriedade}

Recursos Hidricos

Utiliza recursos hídricos subterrâneos? ( ) Não

Possui equipamento de bombeamento? ( ) Não

Possui outorga? (X) Não ( ) Sim

Presença de barramento de água superficial? ( ) Não

Há nascentes /olho d'água na propriedade? ( ) Năo ( ) Sim

( ) Sim. Qual?

( ) Sim Qual: Elétrica

( )Não sabe o que é outorga

( ) $\operatorname{Sim}$

Tem áreas desprotegidas ( $\mathrm{s}$ / vegetação) nas nascentes e beira dos rios? ( ) Năo ( ) Sim

Saneamento
$\square$ Fossa séptica
( )Fossa negra
$\square$ Sumidouro

$\square$ A céu aberto

$\square$ Joga nos recursos hídricos

Lixo 
$\square$ Enterrado

$\square$ Joga no rio

$\square$ Queimado

$\square$ Outros:

$\square$ Lixão

( ) Coleta de lixo pública

Realiza reciclagem?

( ) Não

( ) Sim

Que tipo?

Faz compostagem?

$$
\text { ( )Năo }
$$

( ) Sim

Qual material?

\section{9- Gestão Ambiental da Propriedade}

Tem reserva legal?

$$
\text { ( )Não }
$$

( ) Sim

Faz averbaçăo de área? ( ) Não

Se não, tem interesse em fazer? ( ) Não ( ) Sim

Já fez limpeza de rio e/ou espelho d’água: ( ) Não

$\square \operatorname{Sim}$

20- Manejo de recursos naturais

Mineração? ( ) Não ( ) sim ( )Outros.

21- Manejo de recursos florestais e flora em geral (não madeireiros)

Utiliza madeira, lenha? ( ) Näo ( ) Sim

Coleta sementes da mata? ( ) Näo ( ) Sim

Produz mudas de espécies nativas ? ( ) Năo ( ) Sim

Faz o manejo do reflorestamento? ( ) Não ( ) Sim

22- Atividades Econômicas Complementar

Ecoturismo ou Turismo Rural? ( ) Não

Artesanato? ( ) Näo ( ) Sim.

Outras ?

\section{Observaçōes:}

Assinatura do Entrevistador

Assinatura do Entrevistado 
ANEXO D - Estatuto da Cooperativa Agroecológica dos Produtores Rurais e de Água Limpa da Região Sul de São Paulo.
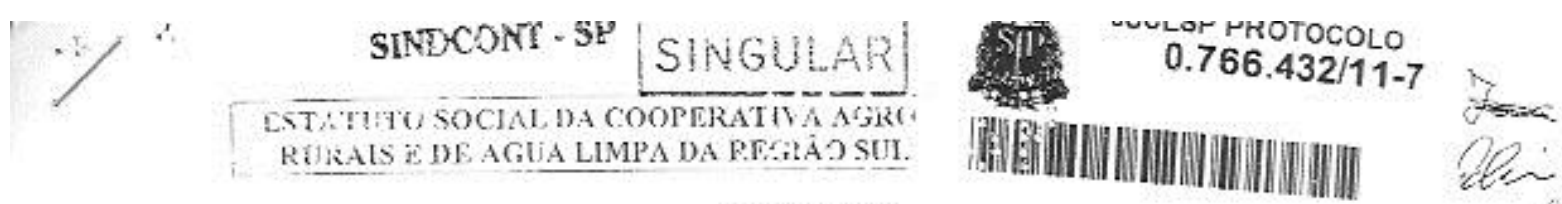

CAPITULO 1

DO NOME, SEDE, FORO, PRAZO DE DURAC IO, AREA DE ACAO E ANO SOCLAL

N.1. 1". - Com a denomintęato de COOPERAFAS, Cooperativa Agrocenlógica dos Produtores Rurais e de Agua L impa da Regiao Sul de Sào P. ulo, foi constituida na data de 09 de junlio de

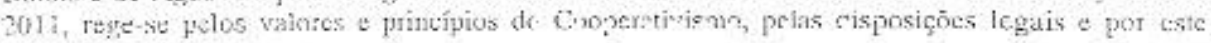
Estanutro, tendu:

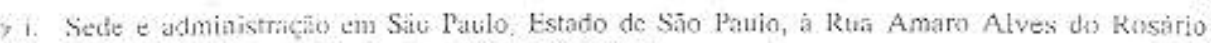
1) iol2 Finclieiros Paciheiros, CIE1': 04884-000.

ii. Foro jurídico na Comarca de Sáo Paulo, Estado de Sau Paulo;

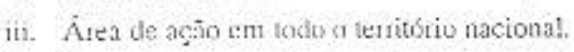

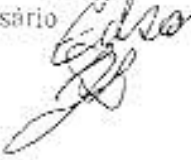

iv. Prazo de duraçấo indeterminado c ano social comprecndido no periodo de 01 de janciro a 31 de dezenihro.

\section{CAPITULO II \\ DOOBJETO E DOS OBJETIVOS SOCLAIS}

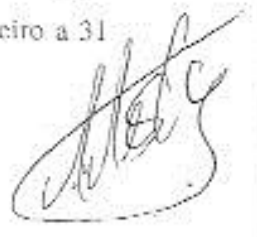

Arr. $2^{2}$ - A coOPFRATIVA tem por objeto i prestaça de serviços, produçăo, tevenda, processamento, distribuiçio e comercializaçăo de produtos agropecuários e artesanato, bem cumo at compra c venda de insumos, materiais c cquipamentos necessários à produçāo.

$\S 1^{\prime \prime}$ - revenda só será permitida mediante a indisponibilidade de produtos dos prúpnos cooperados.

A $\rightarrow 1.3^{u}$. - A COOPTRATIVA tem por objetivo principal proporcionar o exercício c o

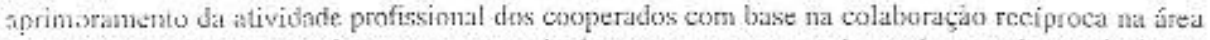
da agtonecuária to em todus us assuntos de interesse comum c de caráter socioeconômico c anilvienta!.

\$ $1^{\prime \prime}$ Para a consccuģon de scus nhjetivos, de acordo com os recursus disponiveis e prévial
programaçatu, a COOPERATIVA poderá:

i. Visbilizar e desenvolver a atividade produtiva dos seus associados.

ii. Divulgar, disiritsuia te comercinlizar a produçio $c$ a prestaça de serviços de seus cooperados

iii. Beneliciar c processir produtos de urigem ugropecuária, tendo em vista agregaçäo de valur aus produlus dos associados:

iv. Reprtstntar o cunjunto de sócios que integram a COOPERATIVA, cm assuntos de interesse: commin a de cariter sociceconomico e ambiental, perante quaisquer outras entidades de direito púhlicos uu privado nacional ou internacional;

(v.) Manıjar, athtat e exccutar açöes, programas c projotos destinados a promover e acelcrar

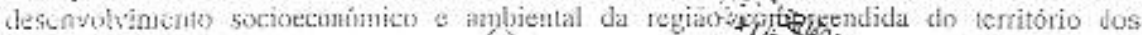

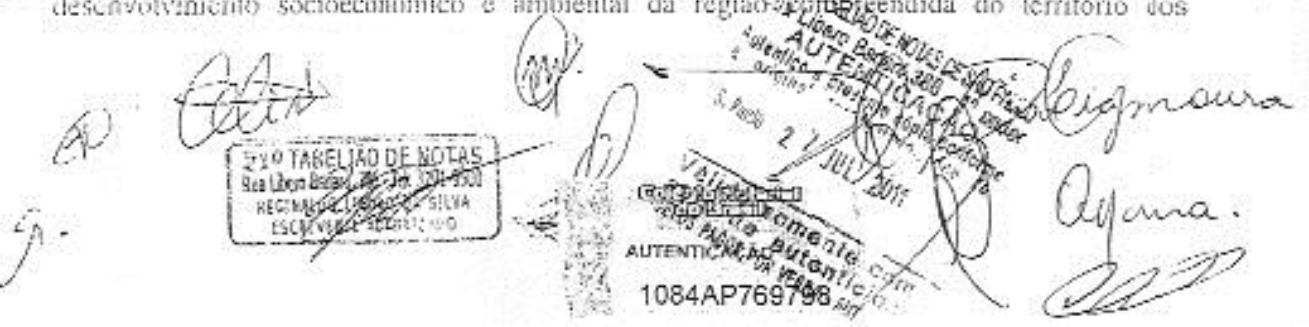


Municipios Parlicipantes, preconizando .4 solfite, oen estar e gualidade de vida dos coopetados e da populaçan.

(vi) Fomentar a criaçio, pesquisa e aplicagano de tecnokngias sustentávcis.

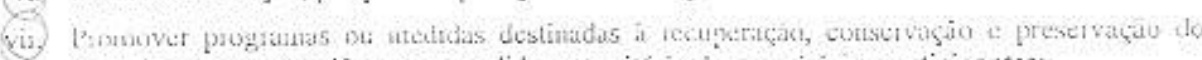
neio ambiente na tegiâo comprecndida no territóio diss municipos participantes;

viii. Contribuit a integracio das açies, programas s projetos desenvolvidos pclos órgäos nau. guvernamentais, úgios governamentais e enupuesis privadas voltadas para o desenvolvinento rutal sustentivel;

ix. Ptancjar apoiat o desenvolvimento rual xittade ne agricultura familar;

x. Promover à melnoria da qualidade de vid. da populaçat resiuente nos municípios compreendides pelit COOPRRAPAS - COOPERATIVA AGROECOLOGICA DOS TRODUTORISS RURASE DE AGIUA IIMPA DA REGIX̃O SUL DE SAO PAULO

xi. Reptescntar os cooperadus, junte a outras Associncicus, Entidades, Conselhos, Grgảos Públicers e demais Instilutçoss, respeitando o prescnte Fstatuto, mediante a aprovaçāo do Conselho Administrativo;

xii. Contratia e adquirir produtus e servigos para scus conperados em candiqués convenientes

xiii. Proporcionar apoto ass cupputados no que for necessirio para melhor execução da produçio e Hus serviços oferecidos;

xiv. Providenciar e brganizar os serviços aptoveitando a capacidade dos cooperados, distribuindous sempre conforme suas aptidócs e interessc coletivo;

xv. Promover assistencia sucjal e educacional ans conperados e respectivos familiares, utilizandose o FATES-Fundo de Assistência Técnica, Folucacional e Social;

|xvi. Ptomover cursos de capacitaçäo cooperativista c aprimoranentu técnico profissional para seu quadro social, tependentes e funcionários;

xvii. Promover, defender e divulgat os ideais conperativistas contribuindo para a expansào do conperntivismo e da organizaçüo popular e cconomia solidária.

xviii Plansar e apoiar o desenvolvimento de Turismo rumal sustentável.

ixix. Plancjar e apuia o desenvolvimento t comercializaçac do artesanato realizado pelos cooperados. $\$ 2^{\circ}$ Nos contratos coicbrados, a COOPERATIVA represcntara os cooperatos, colctivamente.
agindo como mandatário.

$\S 3^{0}$ Os cooperados executario as serviços contratados pela COOPERATIVA. ent conformidade com esse Estatutu e o Regimento Interne.

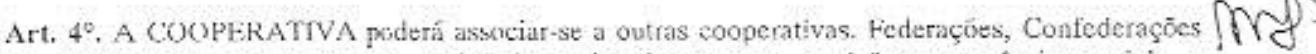
de cooperalivas on a outras socicdades, visanco sempre a defesa cconomicu-sucial, o desenvolvimento ham ontoco e a consecuçio plena dos objelivos da COOPERATIVA c. do seu quidio social.

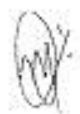

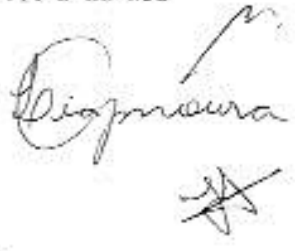

6
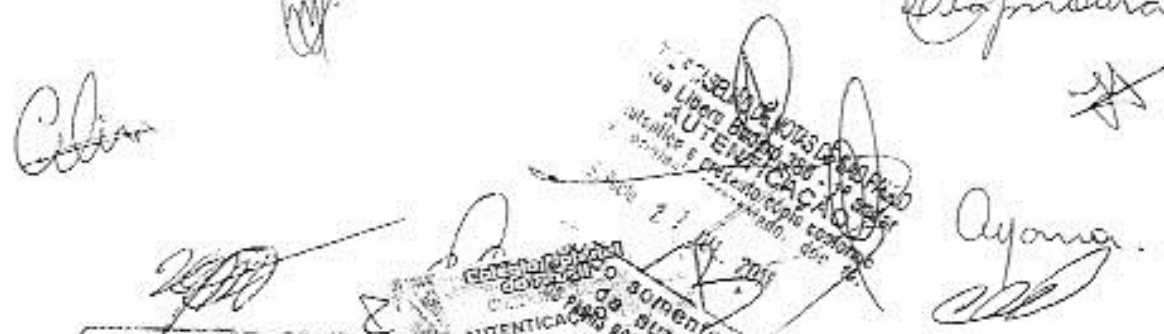


\section{CAI'1:L1: II: \\ DOSASSOCLADOS \\ Seça I}

Da Adinissino, Direitos, Deveres e Pesponsabilidades

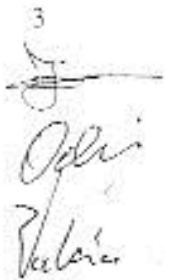

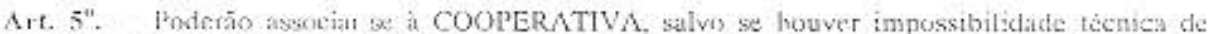

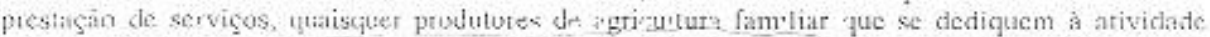

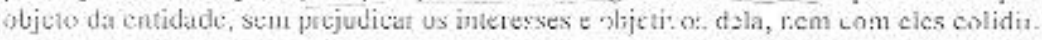

P’arágrafa única - () nimero de congetados $e$ ilimitado ụuanto a máximo, não podendo entretanto o numero minina se; inferion a 20 (viale) pessoss fisicas, conforme legislaço etu vigor.

Art. $6^{\circ}$. - Para cficito de admissaio na COOPERATIVA, candidato a súcio, deve ser profissumal de um dos scrviços objetu dat suctedade su se propor cspecializat-se constantemente na prática $c$ execuçàn the lais serviços.

$\S l^{a}$. - Para ser admitido o cundidato a sócio deveri ser indicado por no mínimo 03 (trés) coopenados, preencherí proposta fornecida pela COUPERATIVA assinando-il como um cooperado proponentc.

$\$ 2^{\circ}$ - - Conselhn Ariministrativo analisuá a propusta e a deferirí, se for a casn, contorme critćrins definidos em Regimento Intemo.

Art. $7^{n}$. Cunupiindis o que dispue o art. $6^{\circ}$, o conperado adquire todos os direitos e assume todos os deveres decorrentes da lei, deste Fstatuto c. das delibetaçoes tomadas pela COOPERATTVA devendo o cooperado subscrever quotas-partes do capital, nos termos destc Fstatuto e assinar o livro de inatrícula.

Art, $8^{\prime \prime}$ - Sato direitos do cooperado:

i. Patrticipar das Assembléias (jerais, discutindo e votando os assuntos que nelas forem tratados;

ii. Tarticipar de todils as alividades que constitucm objeto da COOPERATIVA;

iii. Votar e ser votados para cargos administrativos, fiscais e de coordenador de setor;

iv. Paticipar dus atividades econòmicas, sociais e educativas da COOPERATIVA;

v. Opinar e defender suas idéias, propondo no Consclho Administrativo, Conselho Fiscal ou à (he Assemhléia (ieral, medidas de interesse da COOPERATIVA;

vi. Solicitat esclanecimentos sobre as atividades da COOPERATIVA, incluindo neste ponte balanços firancciros, demonstrativos e relatórios;

vii. Desligar-se da (OOOPERATTVA quando quiser, retirando seu capital, de acordo com a cstabclecido nestc Estatuto;

viii. Receber sua produçî́o cmperativista calculado proponcionalnuente a proxduto e serviço realizado.
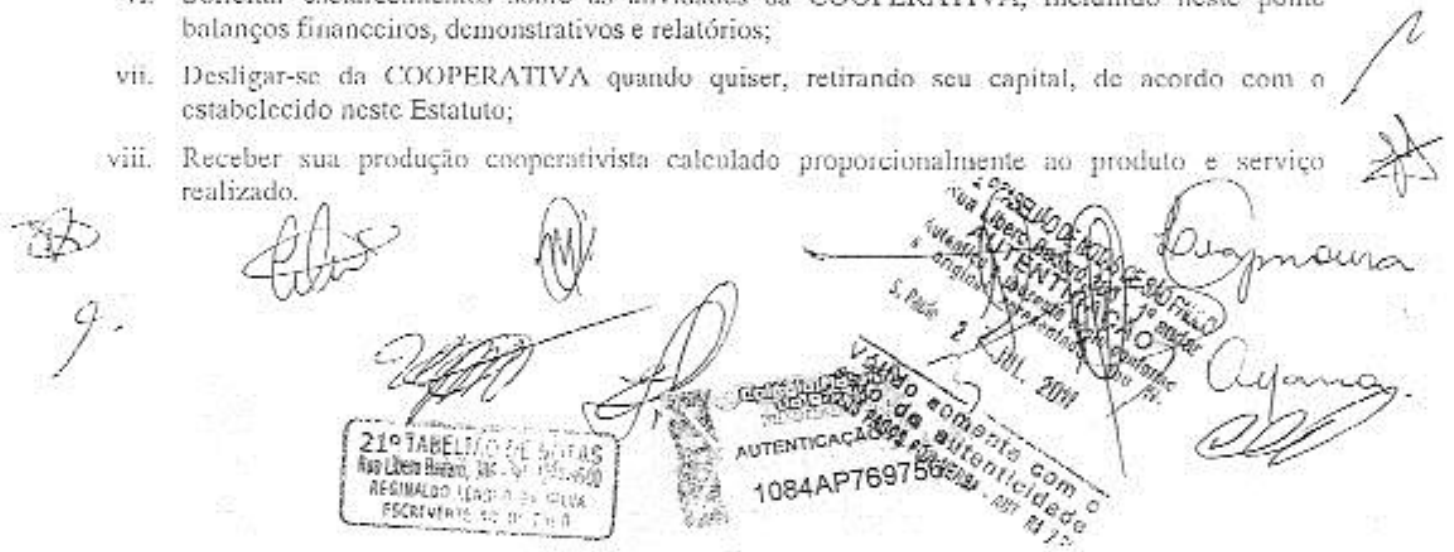
ix. Lixencer atividades fora da COOPERAII va, despe que nion prejudigue contratos com ar sociedade. e desde que o trabalho näo seja zon a nesma crtidide contratante dos scrvigos da COOHERATIVA.

81". A fim dis serem apreciadas pela Asscmbicit Genal, as propostas dos sooperados, neferidas en " $v$ " e "vi" deste artigo, deverko ser wresentadas as Conselho Administralivo, com a neccssária antecedencia e constar do respectivo edital de convocação.

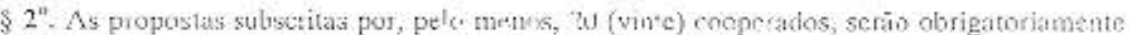

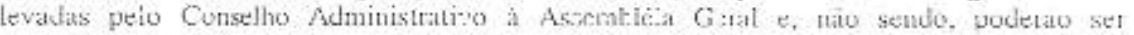
itpesemlidas ditelanente petos coojerititos proponenter.

Art. 9" - Säo deveres do cooperado:

i. Subscrever e integralizas as quotas-partee do capital nos temos deste Estatuto e contribuir com as taxas de serviços e encargos uperacionais quic forem estabelecidos:

ii. Participar das Asscmblétas Geráis, culaborando no planejamento, funcionamento fiscalizaçao das atividales da COOPERATIVA;

iii. Satistazer pontualuente seus compromissos com a COOPERATTVA dentre ns quais o de patticipar ativanente de sua vida socictírią c cmpresarial;

iv. Cobrit perdas dos exercicins, quando houve!, proporcionaimente às operaçnes que realizou. com a COOPERATIVA, se o fundo de rexervia não for suficiente para cobui-las:

v. Empenhar-se para criar estruturas e canais de comunicaçio que propiciem o diálogo e a livte circulaça das informaçócs essenciais ao grupo, permitindo que cada um dos sócios da COOPliRATIVA sinta-se informadi, integrado, tesponsável e solidário;

vi. Zelin pelá ética, putrimônio moral e material da COOPER $\Lambda$ TIV $A$;

vii. Cumprir disposiçōes Ja lei, do Estatuto e as delibcraçōes tomadas pela Assembléia Geral.

Art. 10". - O cooperado responde subsidiariamente pelos compromissos da COOPERATIVA até ó valor do Capital por ele subscrito e o montante das perdas que llie couber.

Art. 11": - A responsabilidade do couperado por compromisso da COOPERATIVA perante tercciros, perdurará, para os cooperados desligados c excluídos até quardo forem aprovadas a: contas dic exercício em que se deu o destigamento ou exclusio.

Art. $12^{\circ}$. - As obrigaçōes dos cooperados falecidis, conntraidas com a COOPERATIVA, éa oriundas de suas responsabilidades camo cooperado, perante terceincs, passam aos herdeiros, prescrevenco, porén, após $1(u m)$ ano do dia da abertura dia sucessīo.

\section{Seçิ๋ II}

Da Demissảo, Eliminaçũo e Exclusăo
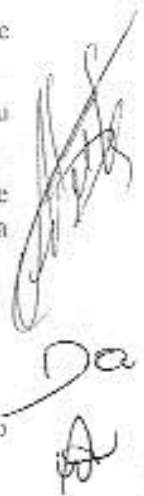

Art. 13". - A demissa do conperado dar-se-á a seu pedido, fornulmente dirigido ao Conselho Adninisirativo da COOPERATIVA, e nao poderá ser negado.

Art. 14". - A eliminaçáo do cooperado, será aplicada em virłude de infração legal ou estatutária por resoluçáo do Conselho Administrativo. Constitui-se motivo de eliminaçio, entre vutros:

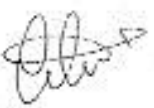<smiles>C1=Cc2cc1ccc1cccc2-1</smiles>

(ब)
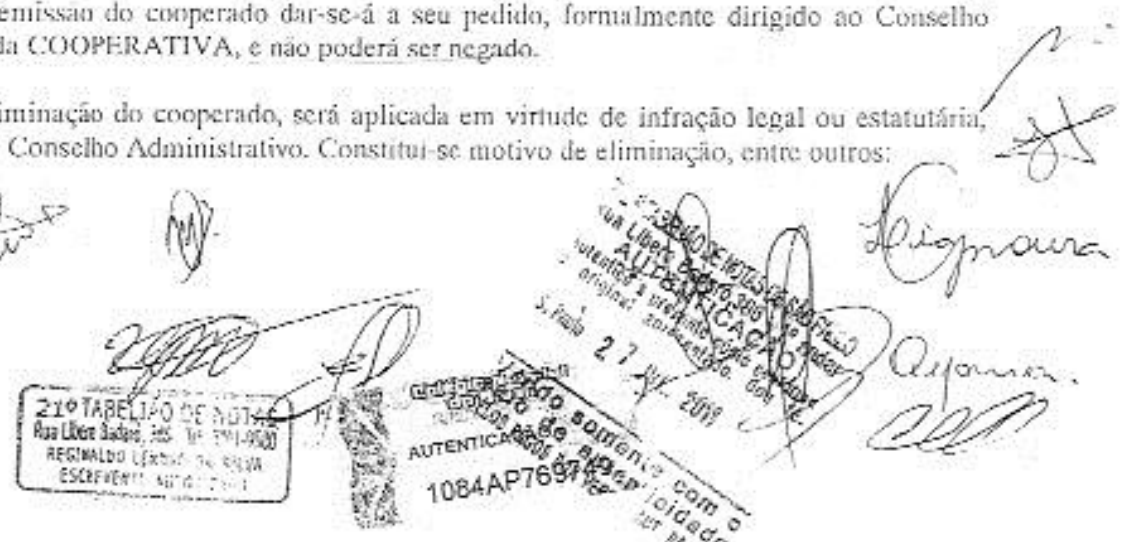

9.

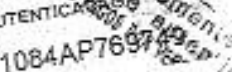

$4 \%$
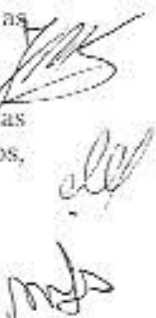
- Manter qualouer atividade gue conflite Lem us obietivus suciais da COOPERATIVA ce as cstabelecidos em reginento interno;

ii. 1)escumprir este Estituto e seus regulamentos accssirins;

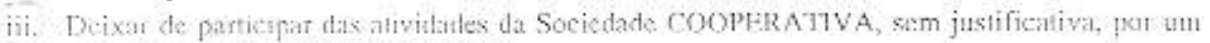
perícdo superiot a. 90 (nowenta) dias;

iv. Detxar de realizar, com a COOPERATIVA, as op raçors que constiluem seu ubjetivo social,

v. Voltit a infringi, depois de notificado, disposicries de lei deste Lstatuto e das resulucoues e delaberaçes regulanmente tomadas pela COOPFRATTVA:

vi. Cansir danos monais tru financeiros à COOOFERATHV 4 ou ciesrespeite colegas de trabalho ou ciientes.

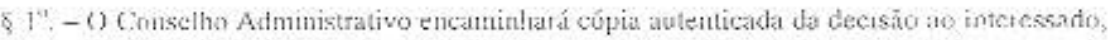
num prazo if 30 dias for processo que conprove as dutas de remessa e do recebimento.

$\$ 2^{\circ}$. - O atumide pouiera uo piazo de 30 (trinta) dias, a contar da data do recebimento da nolificugas, tutenpot tecurso, que terí cfeito atć a primeira Asscmbléia (ieral.

Art. $15^{\circ}$. - A exclusao do coxoperado será feita:

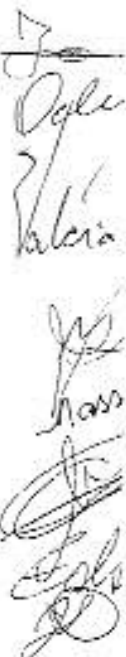

a) Pot dissuluço da COOPERATTVA;

1) Por morle da pessoa física;

c) Por ancapacidade civid nầ suprida :

d) Por deixar de atender aus teyuisitus estatutátios de ingtesso ou permansencia na COOPERATTVA

Art. $16^{\circ}$. - $\mathrm{O}$ ato de climinaça do cooperado e aquele que promover a sua exclusão inciso " $\mathrm{d}^{n}$ do artign anterior serâs efetivados por decisáo do Conselho Ndministrativo, com os motivos que dereminaram remessa de comunicaçio ao interessido, no prazo de 30 (trinta) diats, por processo que comprove as datas de remessa c recebimento.

\$ $1^{\circ}$. - Caso o conperado não scja encontradry, a notilicação será procedida alravés de edital publisado $\mathrm{cm}$ jornal de ampla circuiacin, boletins, informalivos lixados ma sede da COOPERATTVA e lnciis cstrategicos de movimento.

$\$ 2^{\prime \prime}$ - Denuo do prazo de 30 (tuinta) dias da data do recebimento cha notificaçãn a cooperado climinado e o excluído nos termos do artigo anterior, poderāo interpor recurso, com cfeito? suspensivo, até a primeira Assemblëia Geral.

Art. $17^{\circ}$. - lim qualquer caso de demistâu, eliminaçio ou exclusão o cooperado só terá dircito à restituiçâio do Capital que intcgralizou, devidamente corrigido, das sobras e de outros créditos que lhe tivetem sido registuadus, nito llue cabendo nenlam outro direito.

$\S 1^{\circ}$. - A restiluiço de que irata este at tigo somente poderá ser exigida depois de aprovado, pela Assembléia (jeral, o Balanço do exercício em que o couperado tenha se desligado da COOPERATIVA.

$\$ 2^{\circ}$. - O Consello Administrativo da COOPERATIVA poderá determinar que a restituiçao desse capital seja feita ena parcelas, a partir do exercício funanceiro que se scguir an em que se deu o desligamento.

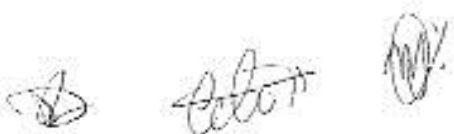

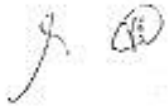

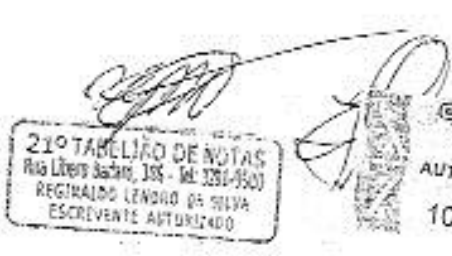




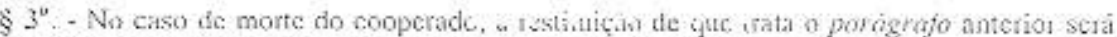
t:teruada aos herdeiros legais em uma si frarcelia mediante a apresentaçuo do sespectiva fomal de partilla ou alvarái judicial.

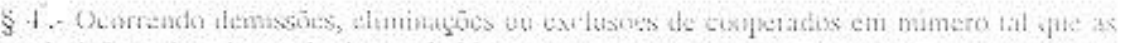

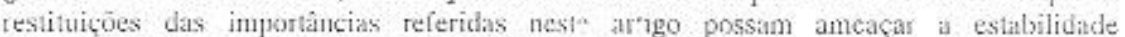
cconômica c finanocira da COOPERATIVA, esta poulerá restitui-las nediante critérios que resguardem ai st:a continuidade:

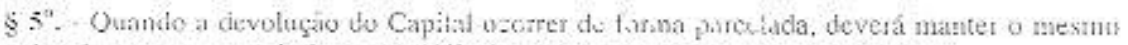

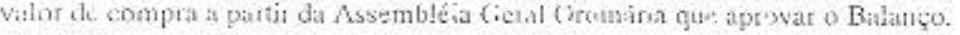

$\$ 6$ 6". No caso de teadmiksto do cooperndo, ressalvadds als disposiçes contrarias deste Fstatito, is cooperado integralizará à vista e atualizuá o Capital correspontente ao valor retirido da COOPERATTVA por ocasino do seu desligamentล.

Art. $18^{\circ}$. - Os atos de demissaes, elinimaçấo ou exclusāo acastetam o vencimento e pronta cxigibilidade das dívidas do cooperado na COOPERATIVA, wobre cuja liquidaşo caberá au Consello Administrativo decidir.

\section{CAPITULOIV}

\section{DO CAPITAL SOCIAL.}

Art. 19". - O Canital Sncial da COOPERATIVA, representado por quotas partes, náo terá limite quanto ao máximo e vaijái conforme o número de quotas-partes sulsscrilas, mas nao poderá scr inferiot as R\$ $1.350,00$ (um mil quinhentos c cincquenta reais).

$\$$ I". O Capital é subdividido en quolas-partes no valor de $R \$ 50,00$ (cinquenta reais) cadal uma, tem numere minimo de 1 (uma) yuuti-parle para cada associado.

$\$ 2$ ". A quotn-parte $c$ indivisível e intransferivel a nāo cooperados, tâ podendo ser negociada de modo algum, nem dada em garantia, e a sua subscriçäo, integralizaçá, transferência ou restituiçăo será scmpre cscriturada no livro de matricula, mediante termo que conterá as assinaturas, do cedeute, du cessionário e do Coordcnador Geral.

$\S 3^{\circ}$. As quotas-partes, depois de integralizadas, poderāo ser transferidas entre associaden, mediante auturizaçan do Consciho Administrativo, observando o limitc máximo de $1 / 3$ (um terço) do valor do Capial total subscrito por todos os associados.

$>\$ 4^{a}$. Sempre que o capilal social ficar inferior ao valor mínimo estipulado neste Estatuto, o Conselho Adrinistrativo em conjunto com o Consellı Fiscat promoveri chamada de capital parat elelivar o reslatielecimento do seu valur mínimo.

Art. 20". - Para ingresso e permanência na Sociedade, o associado é obrigado a subscaever, no mínimo, 1 (uma) guola-parte c, tio máximo, tantas quantas, cujo valor táo exceda a $1 / 3$ (um terço) do total do Capital subscrito.

Art. $21^{\circ}$. - O coopcrado poderá integralizar suas quotas partes de uma só vez, ou $\mathrm{cm}$ até 5 (cinco) prestaçōes mensais suctessivas mediante retenģo de valores do movimento fïlanceiro do conperado.
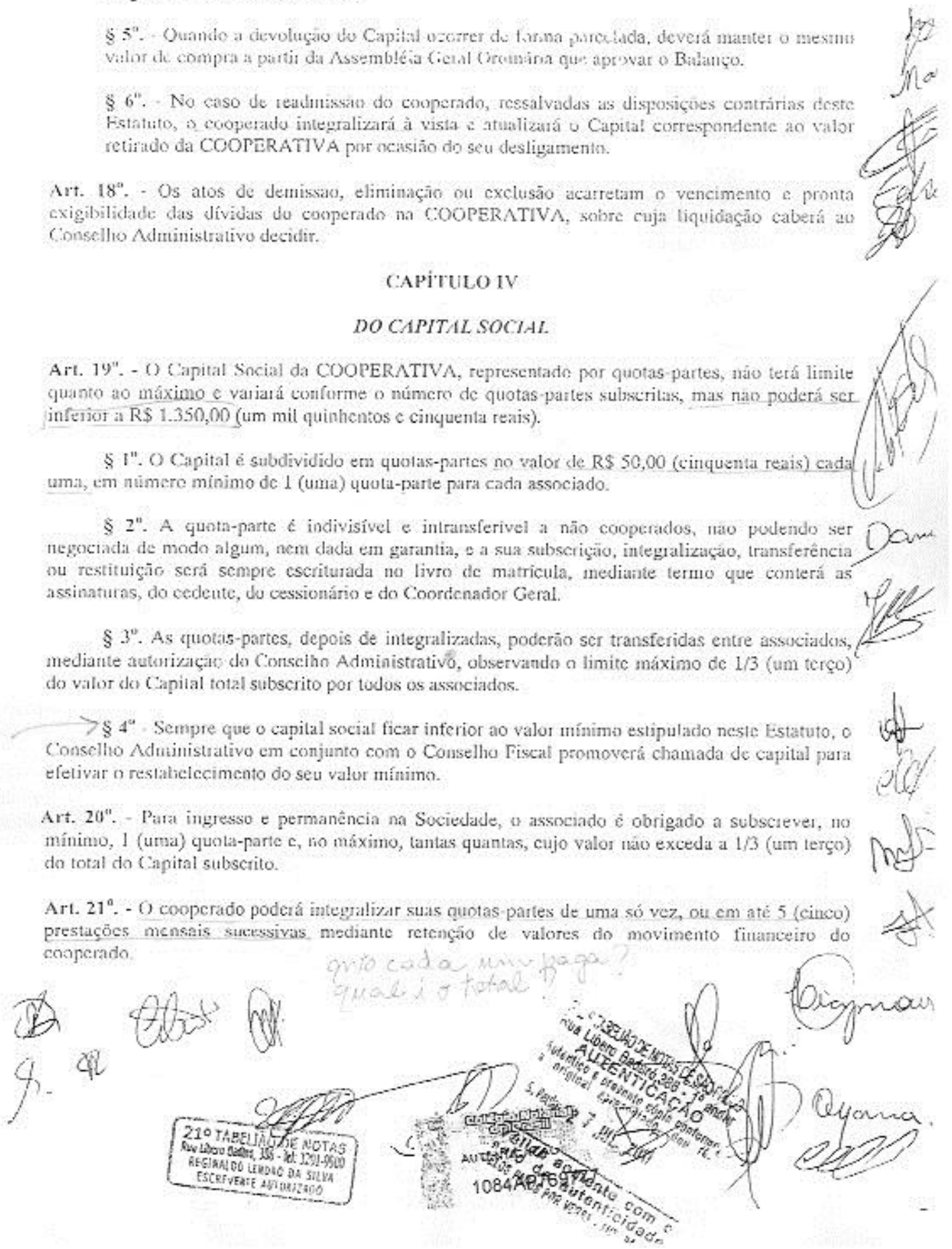
Art. $22^{\text {n. }}$ - A (COOPLRATVA distribuira juros je a $12 \%$ (doze por cento) ao ano, que sâ) coniados sobre a parte integralizada do capital, se houver sobras.

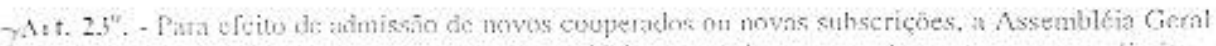
alualizatu anual mente, com a aprovação de $2 / 3$ (divis terçus) ilos cooperados presentes cum dieito a voto, o valor da quota-parte, conshante proposiçāo to Conscl ho Adninistrativo, respeitados os indiccs de desvalorizaça da moeda puhlicados por entáiade oficial do Governo.

\section{CAPITHLOV}

\section{DA ASSEMBLELA GERAT DUS CUOPTRALOS}

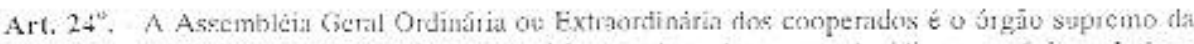
Suciedade, dentro dos limites legais o estatutários, lendo poderes para decidir us negúcius : elativos ao seu ubjeto, c tomat resnluçōes convenientes ao seu desenvolvimentn, sendo que suis deliberaçoes vinculem a todas, ninda que ausentes ou discordantes.

Art. $25^{\prime \prime}$. - A Axsombléia Geral será habitualmente convocada e dirigida por un membro do Conselho Administrativo. Poderá, tumbém, scr dirigida por qualquer cooperado desde que a Aiscunbleia nssim o decidat.

$\$ 1^{\circ}$. - Poderi tambem ger convectit pelo Cansellu Fiscal, caso ocorram motivas graves e urgentes vu pur $1 / 5$ (un yuinto) dos cooperados, em pieno gozo de seus diteitos sociais.

\$ $2^{\circ}$. - No cuso da convocaçäo ser leita por couperados, o edital será assinaro no mínimo petos .5 (enco) primeinos signatários do documento alravés do qual foi solicitadia.

$\$ 3^{\circ}$. Nào podetá participar da Assembléta geral o coopcracio que:

a) tcula sido admitido após à convocaçás; on

b) infringi qualquer disposiçuo desie Estatuto

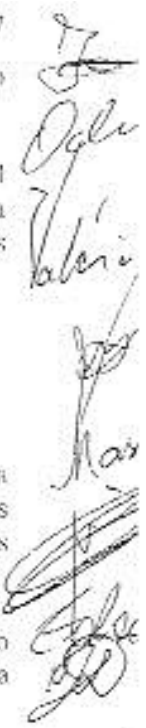

Art. $26^{\circ}$. - Em quaisqucr das hipóteses, referidits no untigo anterior, as Assembléas Gerais serào convoctadias com untecedência minima de 10 (dez) dias, mediante editais afixados em locais apropriados das dependências mais freqüentadas pelos cooperados, publicaçåo em jornal to comunicaçäo aus couperados por meio dic circulares.

\$ 1". - Nāo havenda, nu horário estabclecido, "quorum" de instalaçăo, as assembléias poưerảo ser realizadis cm segunda convocaçāo com intervalo minimo de 30 (tiinta) minutos cnire cauda cumwcaçáo, descle que assim conste do respectivo edital.

- $>$ Art. 27". - Nas Assembléias Gerais, o "quorum" de instalaçăo será o seguinte:

a) Mctide (1/2) mais um (1) Jos cooperados, cm primeira convocaçăo;

b) No minimo de dez (10) esouperados ua segunda convocaçño;

Art. $28^{\circ}$. - NaLs Assembléius Gerais, cada conperado presente só terá dircito a um voto, qualquer ulie seja u número de suas quotas-partes e as deliberaçōes scrāo tomadas por maioria dos votos dos cooperados presentes.

$\downarrow_{\S} 1^{\prime \prime}$. As votaçōes porderāo ser por voto secreto ou por açamação.
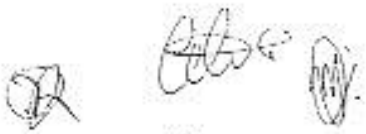<smiles>CC(C)C</smiles>
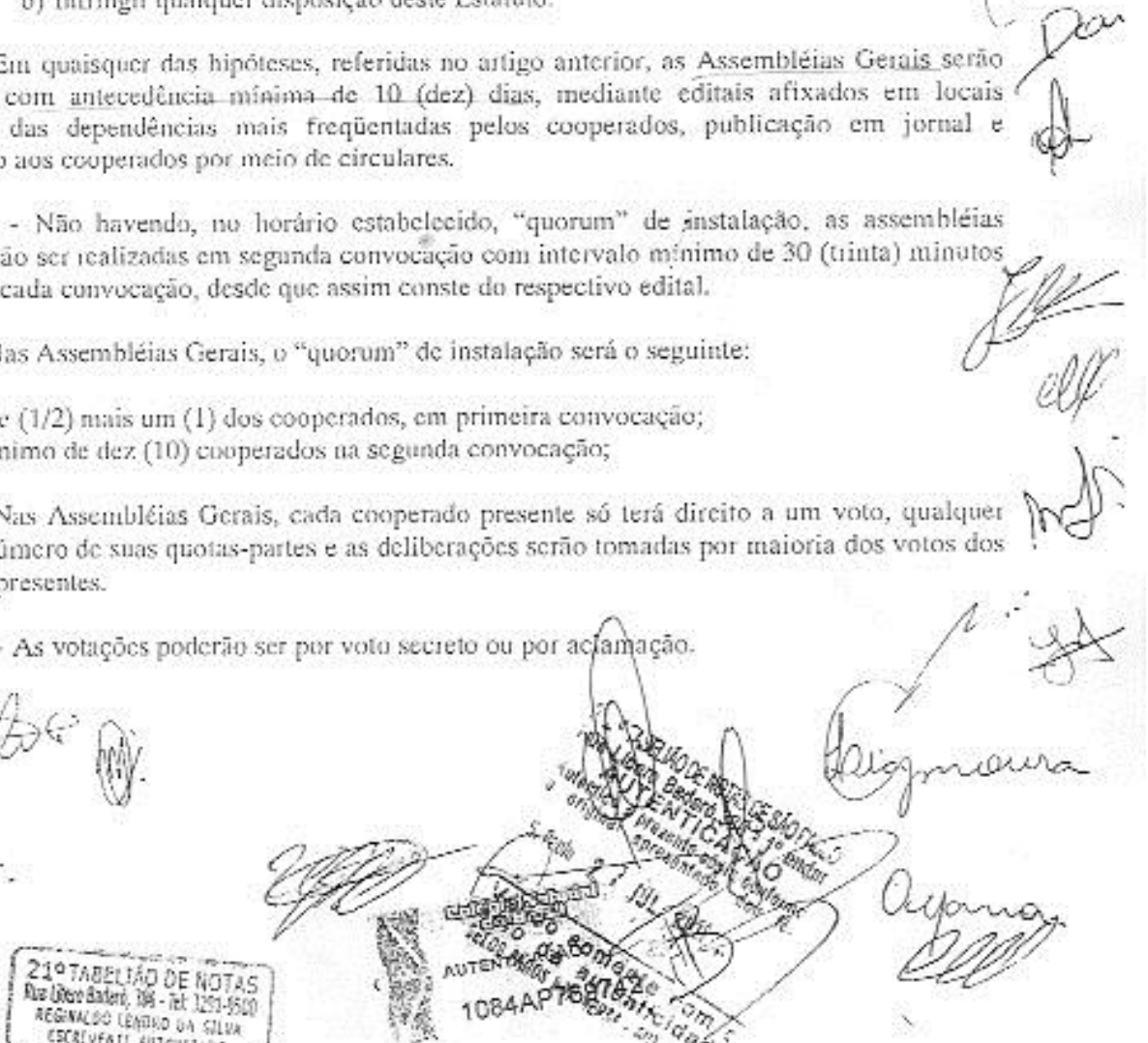


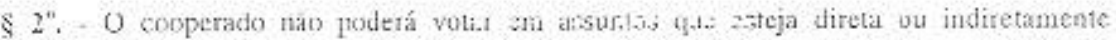
c:nvolvidu, exceto caso de elciçāo, calendı-line actisat o seu impedimento, nào ficando, cutretanto privado a participals de debates.

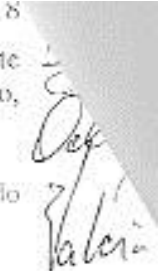

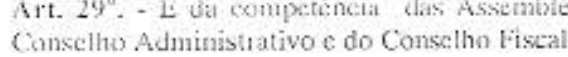

$\$ 1^{\circ}$. Ocorrendo una destituigao co ienuncia que possa cventuaimente afetar a regularidade

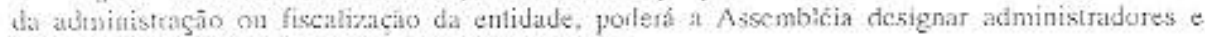
cunse] heitos num prazio mixime de 30 (trinis) dia:.

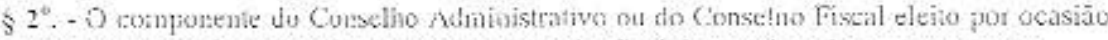
da destătugio ou renuncia exerceri o cargo sounente até $u$ final do mandato do scu antecessor.

$\$ 3^{n}$ - Em caso de impnssilviliade temporaria de an membro do Conselho Adtuinistrativo dedicat- a 5 cu cargo por um periodo inferior a 90 (novenal) dias caberí ao próprio Conselbo viganikar entre scus componentes sua substituiçăo provisória.

\section{Sę̧à̀o I \\ DA.S ASSIMMLEIAS GERAIS ORDINARIAS}

Art. 30". A Asscmblćia (icral Ordinára, gue se realizará olvigitoriamente umia vez por ano, no decotrer tos 3 (tês) primeitos meses após o término do excrcicio social, deliberará subre as stgumes assumlok, que deveraso consiar da Otden do Dia:

1) Prestaça de contas dus ógious de administraçio, acompanhada do parecer do Consello Fiscul, comprecndido:

a) Relatório da zestāo;

b) Balanço geral;

c) Demonstativo das sohras apuradas ou das perdas, e parecer do Cunselho Fiscal;

d) Plano de atividade da COOPERATIVA para o excrcicio seguinte;

II) Destinaçấo das sobras apuradas on o ratcio das perdas, deduzindo-se, no primeiro caso, $h$ as parcelas para os fundos obrigatórios; its parcelas para os fundos obrigatórios;
uutros, quando for o caso;

IV) Fixaçầ de homrários, gratificaçao e da cédula de presença para os componentes do Conselho Administrativo e Consclho Fiscal;

V) Quaisquet assuntos de interesse social, excluidos e enumerados nestc Estatuto.

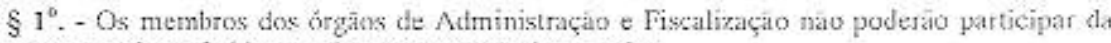
volação das materias referidas nos itens "l" e "IV" deste artiggo.

$\$ 2^{\prime \prime}$. - $A$ aprovaçî̀o do relatório, balanço e contas dos órgáos de administraçĩo não desonerará scus componentes da responsabilidade por erro, dolo, fraude ou simulaçăo, bem como por infraçió da lei desle Estatuto.

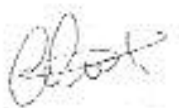<smiles>O=S1(=O)C2C3C=CC(C3)C21</smiles>

㘿<smiles>CCCC[GeH3]</smiles>
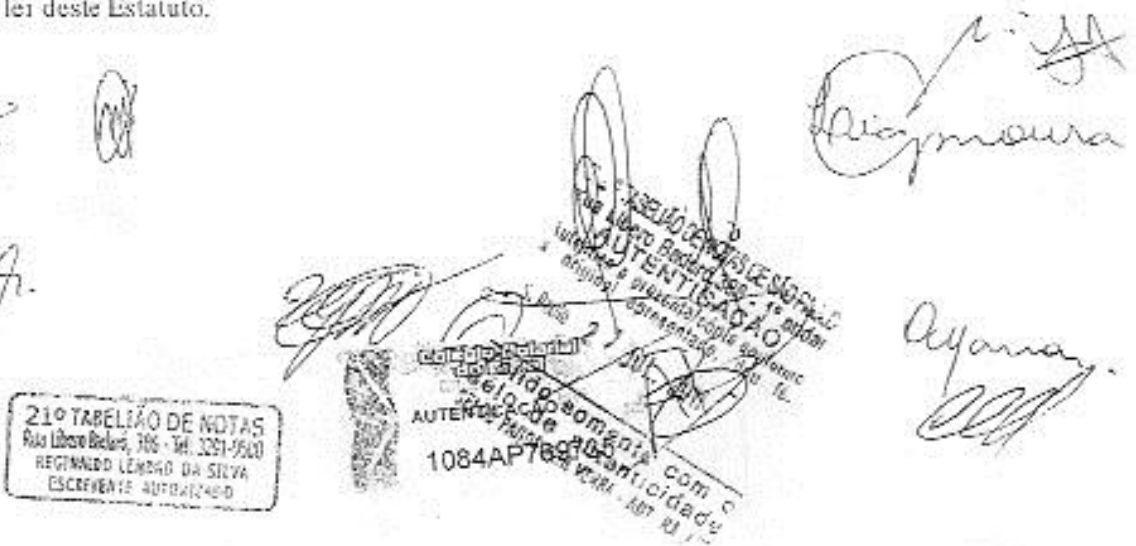


\section{Secrio II \\ DAS ASSFMBLFLAS GEFA'S EXIZAORDIYARLAS}

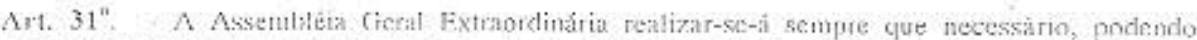

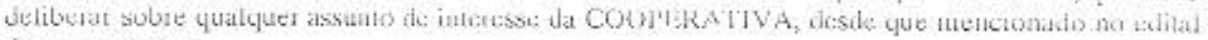
de convociaçao.

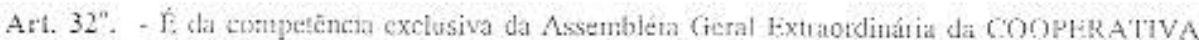

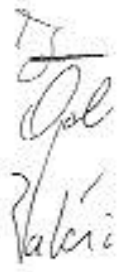
deliberar swhe os seguintes assuntus:
a) reforma do Eistntuto;
b) lusus, inconotaçio ot desmembrametuto;
c) mudanca de objetivo:
d) dissolução voluntátia e nomençño de liquidantes;
c) crntas do liçuidante

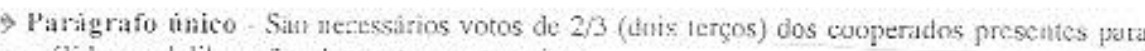
tornat vílibis as deliberaçōos de gue trata este artign.

\section{CAPITULO VI DO CONSELHO ADMINISTRATIVO}

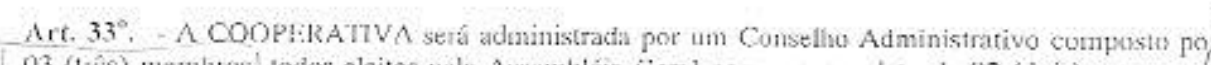
03 (tres) membros, todos cleitos pelis Assembléia Gicral pata un mandato de 02 (dois) anos, cond direitu a apenas uma reclciço, sendo obrigatríria, ao términu de cada mandato, a tenovaça de, do minimo, um dos scus componentes.

$\$ 1^{\circ}$. - () mandato dos membros do Conselho Administrativo inicia sc com a suil posse no órgio de Administraças.

$\$ 2^{\circ}$. Nao podem compor o Curselho, parentes cntre si, até o segundo grau cm linha reta ou colaterat, hen como patentes afins e cônjuge;

\$ $3^{\prime \prime}$ - A permanência no exercicio das funçces a que se refere este artigo termina por motivo de recumposiçäo dó Conselho ou por renúncia, admitida sempie a reconduçāo.

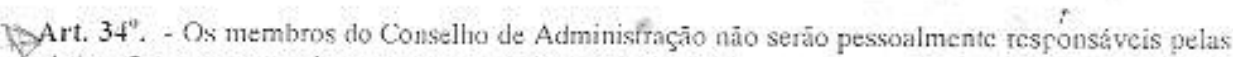
obrigą̧ōes que contuaírem em nome da COOPERNTIVA, mas responderīo solidariamente pelos prejuizos resultantes de scus atos, se agiren com culpa ou dolo.

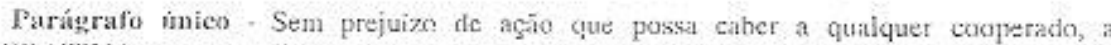
COOPIRATIVA, por seus dirigentes ou representadi pelo cooperado escolbido em Asscmbléia Geral, terá direito de aţäo contra os admiaistradues para promover a sua responsahilidadc.

Art. $35^{\circ}$. - O Conselho Administrativo rege-se pelas seguintes normas:

i. Reủne-se ordintriamente una vez por mês c cxtraordinariamente sempre que neccssârio, por cunvocaçâo da maioria dat própria adiministraçăo, ou, ainda, por solicitacto do Conselho Fiscal;

ii. Delibera validamente com at presença da maioria dos seys mufnłpros, proibida rcpresentaçao,
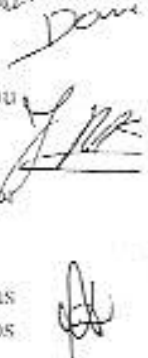

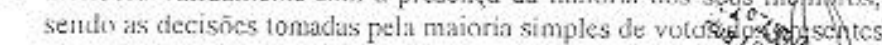
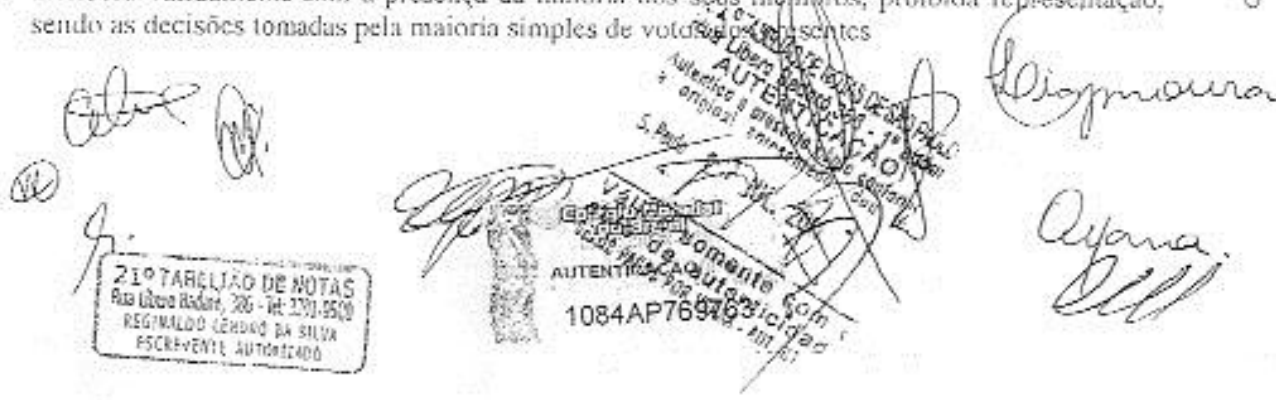
Art. $36^{\circ}$. Competem ao Consclho Adminisicarivo, dentru dos imsies da tei e desite Estatuto, as
seguntes atribuiçoes:

i. Programar as operaçeses es serviços da Sociedauls estaholecendo o fixando quantias, valores, $3 / / 6$ prazos, taxas e servigos e demais condiçoes necessírias a atividade social;

i2. Avaliat e providenciat o montante dos recursos financeitos e dos meicos necessárius ats atendimento dias operacecss e serviços;

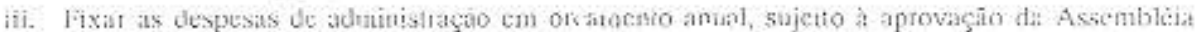
Geral Ordiuaria, indicando as tontes do cecurso para sur coberturq;

iv. Avatias a comventencia e fixar st limite da fiança ou segurn de fidelidade para os cooperados que manipulcen dinheim on valors:

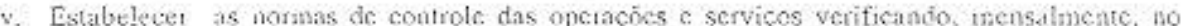
minimo, v estado econónico fitanceiro da Sociedade COOPERATIVA c o desenvolvimento dos negcicios e atividades en geral, através de baiancetes dir contabilidade e demonstrativos especificos;

vi. Acompanhar o cstado cconómico da Suciedade tumamdu, quandis necessárto, as medidas cabiveis para cveniuais correçuss.

vii. Convocar as Assembleias (ierais, toda vez que se apresentaten motivos para tai;

viii, Zclar palo cumprimente das lets do Couperativismo to tods as demais aplicaveis;

ix. Contrair obrigaçūes, transigir, atquirir, alienar e merar bens e doreitos com autorizaçio prévia c. expressa da Asscmblèia Geral;

x. Organizar c atualizar o Regimento Interno, apôs deliberaçōes da Assembléta Cieral;

xi. Cuntair obrigạ̧ōes de venda da produção da sxciedade 'ad referendum' "na Axsemblema Geral":

xii. Deliberar sobire admissão, demissî́n, eliminaçĭo e exclusàn de cooperados $c$ suas implicaçces, bem como as aplicaçio ou tevaçao de mulas;

xiii. Fstabelecer sançoses ou penalidades a sesem aplicadas nos cabos de violaça ou abuso cometidos contra disposiçōes de lei, deste fislatuto, ou das regras de relacionamento com a chtidade que venham a scr cstabclccidas;

xiv. Fimnenhar-se para criar estruluras e canais de comunicaçăo que, propictem o dálogro e a livre circulaçăo das informaçŏ̀es essenciaîs an grupo. permilindo que cada um dos sócius da cooperativa se sintam informados, integrados, responsâveis e soliclários.

$\$ 1$. - () Conselho Administrativo solicitart, sempre que julgar conveniente, 0 asscssoraumento de técnicos para auxiliá- lo no esclarecimento dos assuntos a decidir, podendo determinar que os mesmos apresentem, previamente, projelos sobre questós especificas;

$\$ 2^{\circ}$. - As normas funcionais estabelecidas pelo Conselho Administrativo e respaldadas pela Assembléa Geral serao fixadas em forma de instruçoes que seräo incorpuradas ao Regimento Interno da Socitedade COOPERATIVA;

8 $3^{\circ}$. - 0 Conselho Administrativo poderá criar departamentos e setores especticos, permanentes ou transitórios, fixatudo-lhes a forma de representaçäo, normas de funcionamento e atividades para estudar, planejar, coordentr e acompanha a saluçato de moblemas específicos.
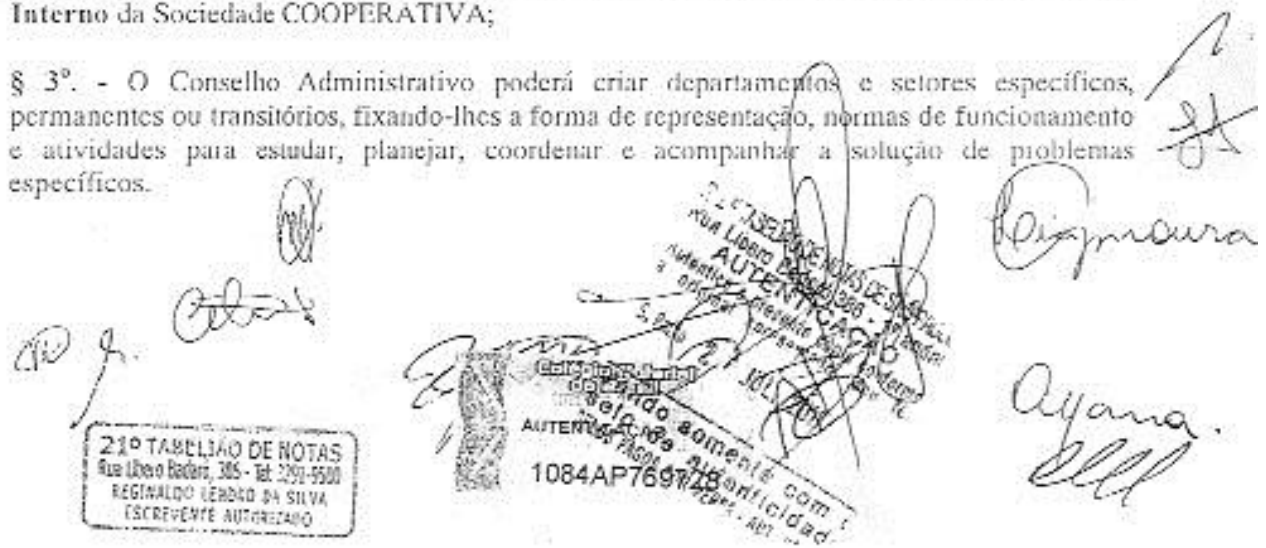


\section{CAPITLLO VII}

\section{DOCONSELHO FISCAI.}

Art. 37". - A COOPLRATV $\Lambda$ sesé fiscalizada, assidu e minuciosamente, por um Conselho Fiscal constituids por 03 (três) membros efetivos c. 03 (irēs) suplentes, iudos cooperados, clcitos

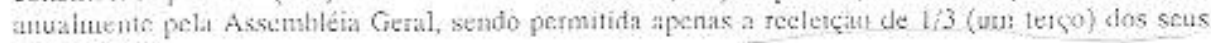
componentes.

$\rightarrow \$ 1^{\prime \prime}$. Näe podem fazer parte do Conseiho Fiwal us parentes dos dretores, até o $2^{\prime \prime}$ grau, bem como as parentes cutre si ate ess? grau.

\& $2^{4}$. - Os conperados mas podem exerces cunuhativamente cargos no Conselio Adminisinativo e Fiscal;

Art. 38". - Ao Conseihn Jiscal compele exerver as seguintes nutribuiçves:

a) Verificar sc os extratos das conlas taicárias conferen cum a escriluração contábil;

b) Examina se do montante das despesas e inversoves realizadas está em conformidade com os planos, orçatentus e decisóes do Consclho;

c) Verilica se as operaģōes rcalizadas e os serviçus prestados correspundem em volune, qquantidade, qualidade e valù às previsōes feitus c as conveniências econônico financeitas da COOPFRATIVA;

d) Orservat a regulatidade das reuniōes do Conselho, alertando, caso seja necessitrio, para

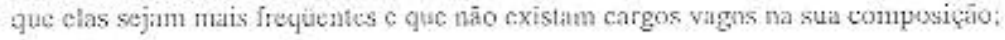

c) Verificar se or recebimento dos créditos ti feito com regularidade es se os compromissos säto atendidos com pontuaidacke;

6) Apurar se existem exigencias a comprir junto às auturidades fiscais, trabalhistas previdenciárias;

g) Averiguat se us estoques de matcriais, cquipamentos a outros estato contetos, \& sc os inventários periúdicos ou anuais são feitos com observancia das regras próprias;

h) Analisur e assinar o balancete trimestral, bem como verificar os documentos contíbcis;

i) Emitir parecer sobre o Balanço Patrimenial e Relatúrio do Conselho, para votaçầo ta Assembléia Geral;

j) Intormar D Conselho Administrativo sobre as conclusobes dos seus tratxalhos, denunciando as inegularidades constatadas e convocando a Assembjéia Geral se ocorrerem motivos graves e urgenles;

k) Reunii-se ordinariamente, una vez por mès e, extraordinariamente, sempre que necessário, com a participaça de 03 (trés) dos scas membros.

Paraigrafo único - O Conselho Fiscal poderát contratar serviços de auditora e lécnicos especializados, para exames dos livros de contabilidade $\mathrm{c}$ de documentus, nos termos do arligo 112 , da lei $5.764 / 71$.
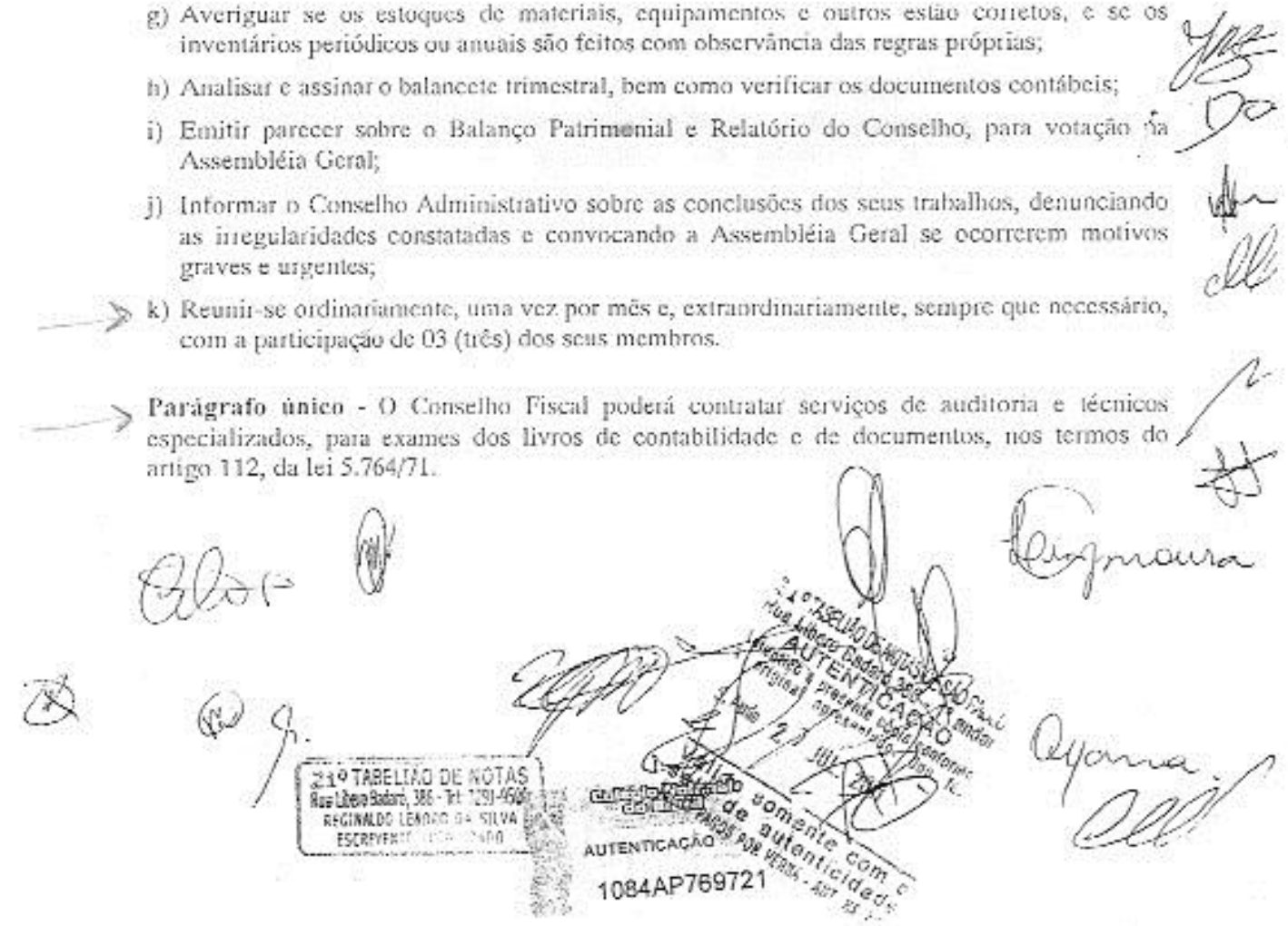


\section{CAPIIUT,O VII}

\section{DOS I.IFROS}

Art. $39^{\circ}$. - A COOPERATIVA deveri, além de outros, ter os seguñates livros:
i) de Malriculis
b) de Presença de couperados nas Assembileins Gerais:
c) de Atits das Assembléas Gerais;
d) de Anas do Consello Adminislrative;
e) de Alats du Conselho Fiscai.
a) Livios fiscais;
b) Ijvros contíbeis-

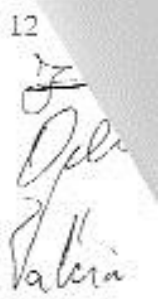

Paragrafo unico - f: facultada a adocate de hvess de folhas soltas ou fichas, tevidamente numeradas.

Art. $40^{\circ}$. - No livro de Malriculit us cooperados seräo inscrilos por orcén cronológica de admissão, diele constantio:

a) on nome, idade, estado civil, nacionalidade, profissaty e residencia dos couperadus;

b) at da a de suil admissao, e quando for o casse de sua dennissas a pedido, eliminaçao ou exclusio;

c) a conti corrente das respectivas yuotas partes do Capital Social.

\section{CAPITULO IX}

\section{DO BALANCO GERAL, DESPESAS, SOBRAS, PERDAS E FUNDOS}

Art. 41 . A COOPERATIVA é ohrigada a conslituir:

1. Fundo de Reserva, destinado a reparar as perdas e atender ao desenvolvimento do Stas atividades, constituido de, pelo monos, $10 \%$ (dez por cento) das sobras liquidas do exercicio.
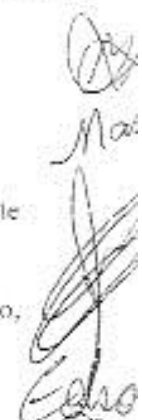

II. Fundo de Assistência Técnica Educacional e Social (FATFS), constituido de, pelo menos, 5 \% (ciico por cento) das sobras liquidas do exercicio, destinado à prestaçăo de assistencia atis cooperudos seus familiares e aos empregados da $\_$. COOPERATIVA, nos temos e normas traçados pelo Conselho Administrativo.

$\S 1^{\circ}$. Os serviços do FATES poderâo ser execulados mediante convénio com entidades especializadaı, oficiais ou nân.

$\$ 27$. - Além da taxa de $10 \%$ (dez por cento) das sohras liquidas apuradas no halanço do exercicio, revertem con tavor do Fundo de Reserva:

a) Os créditos nāo reclamados, decorridos 3 (trẻs) anos, após o encerramento do exerciciu social;

b) Os auxilios e doaçōes sem destimarä́ especial.
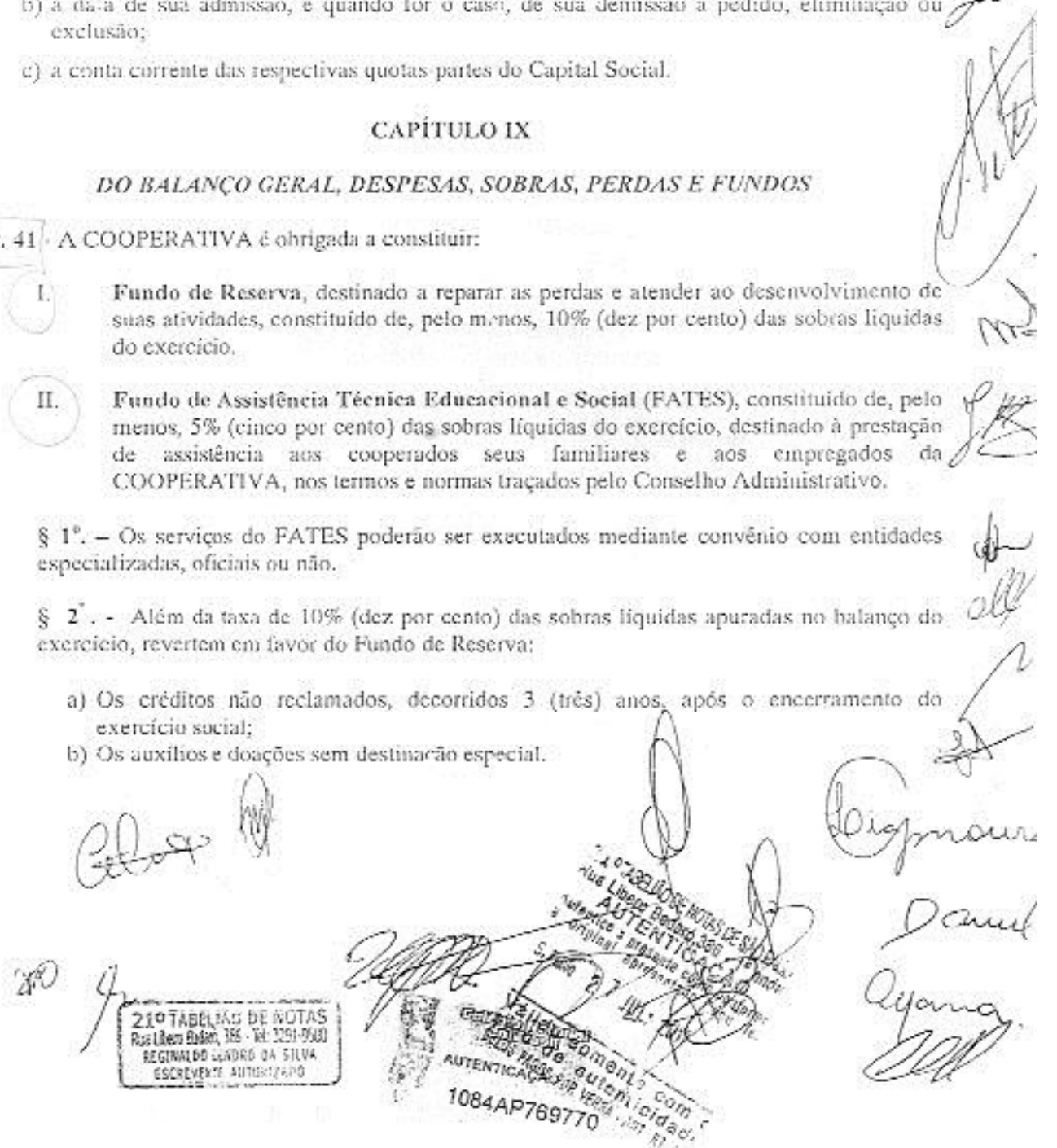
Art. 42". - A Assembléia cieral poderá criar outros fundos, inclusive rotativos, con recursos

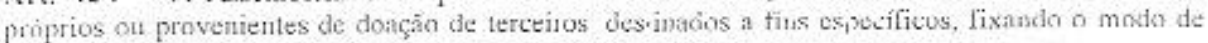
formaça, aplicação e liquidauga.

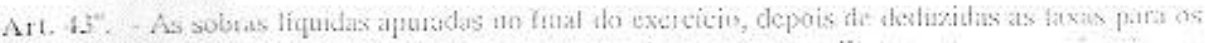
fundos mdivisiveis, serio atcadis entre os cooperados, em partes dietamente proporcionats aus servisos executados por eles, no periodo, salvo deliberaçes tiversis da Assembléia Geral.

Paragrafo unico - Do saldo que couber a cada cooperado, referente al retomo serân printeiramente deduzidos possiveis detitos na corta de "capital a integralizar".

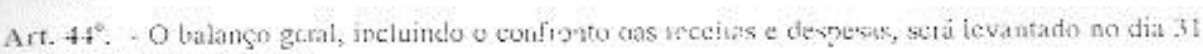
de Dezumbro de catit ano.

Paragrafo único - Os resulgados serio apurados seglingo á naturcza das operaçoes e serviços.

Art. $45^{\circ}$. As despesas di COOPLRATIVA scräo cohertas por uma taxa administrativa quó incidirá subre os servięn cxecutados por tados os omperados, pendendo, a criterio do Conscho Aduninstralivo, ser incluida no preçe cobradu ao cliente.

Art. $46^{\circ}$. Os prejuizos de cada exercicio, apuradns em halanįo, serio cobertos com o saldo do Findo de Reserva

Paragrafo único - Sc, porem, os recursos do Fundo forcm insuficientes para cobtir as perdas de que trata o presente artigo, caberá à Asscmbléia Geral Ordinátia decadir sohre a forma pela quall estes serño rateados entre us cooperados.

\section{CAPITULO $\mathrm{x}$}

\section{DA DISSOLUCAOO, FUSAOA E DESMEMBRAMENTO DA SOCTEDADE}

Art. $47^{\mathrm{n}}$. - A coopliRATTV se dissolverí de pleno direito:

a) Quando assim deliherat a Asscniblẻia Gieral, desde que os cooperados, totalizando o númeso mínimo exig̨ido por lei, nâo se dispuseren a assegurar a sua continuidade;

b) Pela consecuçío dos objetivos predeterminados;

c) Devido à alteraçito de sua forma juridica;

d) Pela reduçĭo do número mínimo dic conperados ou do capital soxial minimo, respectivamente, se até a Assembléia Geral subseqüente, realizada em ptazo näo inferiot a 06 (scis) meses, teles ilao forem estabclecidos;

e) Pelo cancelamento da autorizaşăo de funcionamento;

f) Pela paralisiçuo de suas atividades por mais de cento vinte (120) dias.

Paràgráío único - A dissoluçấo da COOPERATIVA importará no cancelamento da autorizaçăo para funcionamentu e do respectivo registron.

Art. $48^{\circ}$. Quando a dissoluçao da COOPERATIVA nän for promovida voluntariamente, nas

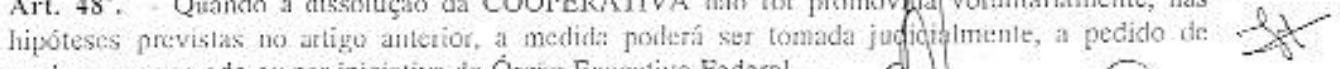
qualquer cooperado ou por iniciativa do Orgao Fixecutivo Federal. =
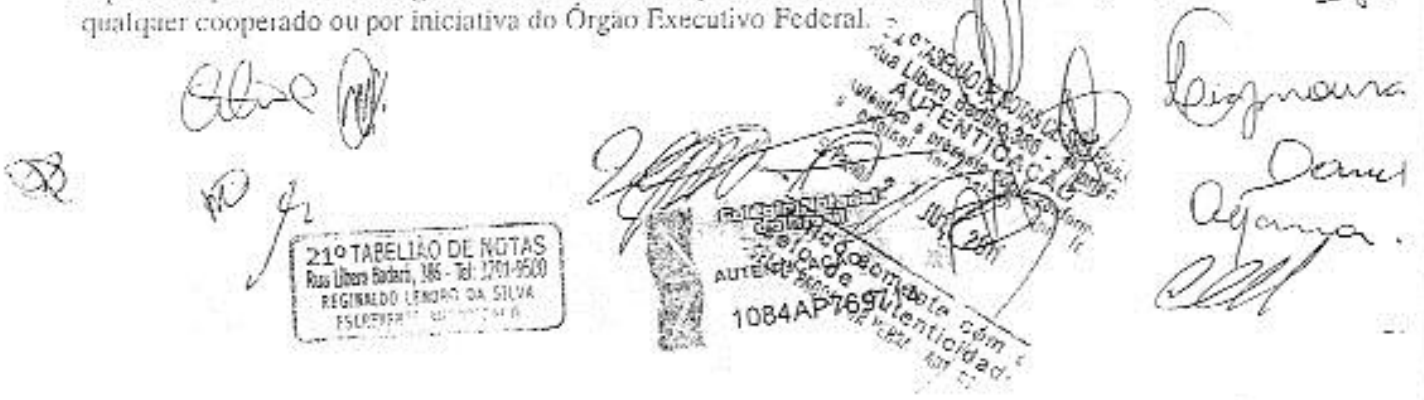
Parágrafo único - Ouando a dissoirç̧o for colibcradi pela Assembléia Geral

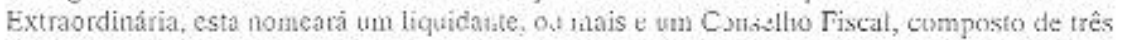
(03) membros, para pruceder a sua liquidaçao.

\section{CAPITULO XII}

\section{1).AS DISPOSICOKS GERAIS TETR ANSTTORLAS}

Art, 49". - O Regimenio Interm deverá set constituido encluido s aprovado atç 06 (scis) meses. coutades a partir da data de reg̣tstro deste lstaisto nu : tanta Comercial, e definira dentre ountos disprositivos:

a) As normas de funcionamento de cada bigär social (Conselhu Administrativa e Corsciho Fiscal),

b) As nomns uggulanentadoręs diss Reuniōes Gerais;

c) As infraçöes e sançồes disciplinares, hem como stua forma de apuraçato e aplicaçăo;

d) $A$ forma de divisaio e condenaçio dos setores;

c) o processo cleitoral;

Paragrafo único - O rep̧alamento disciplinador dos Fundos será anexado a Regimento literno e registrados juntamente com este no Cartorio de Titulos e Documentos.

Art. 50". - São inelegiveis, aicm das pessons impedidas por lei, os condenados i pentis que vede, ainda que temporariamente, o acesso a cargos públicos, ou por crime falimentar, de prevaricaçắs, peita uu subono, concussao, peculatr, nu contra a comomia popular, a fé publica ou a propricdade.

Art. 51". - A COOPIIRATIVA pnderi associar-se ou filiar-se i centrais ou federacoes de COOPHRATIVAS, anda a sociedades que tenham igual identidade ou busquem us mesmes: clijelivos, inclusive sindicato.

Art. 52". - Os casos omissos serāo resolvidos pelo Conselho, de acurdo com a Lei te us princípios doutrinários, suvidos os órgãos sociais da COOPERATIVA, submetidos ì homologaçáo da Asscmblęa Gicral que sc rcalizar.

- O presente estatuto foí aprovado pela Assembléia Geral de Constituigio em 09 de junho de 2011 no município de Săo Patulo.

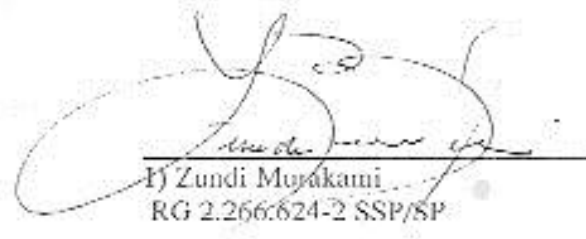

$\mathrm{RG} 2.2666624-2 \mathrm{SSP} / \mathrm{sP}$

12
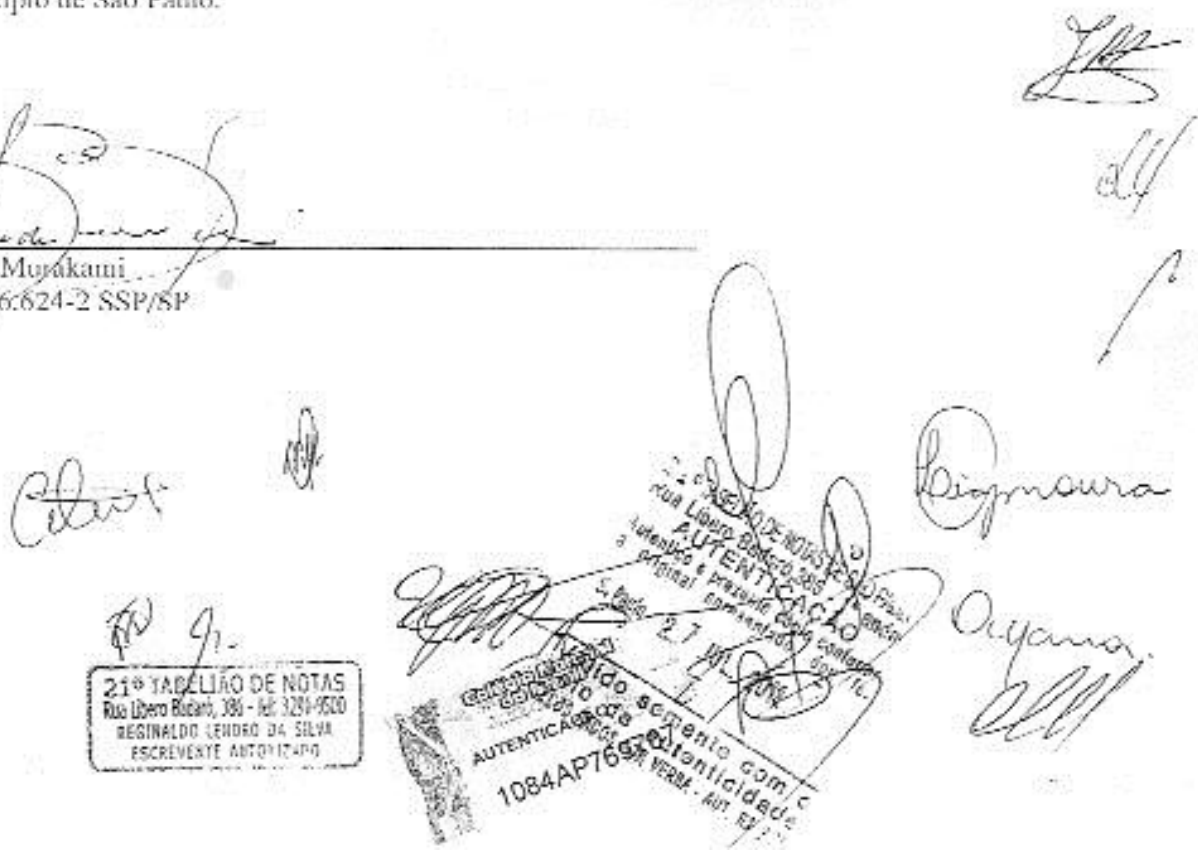
Gruksto akio OyAma

2) Emesto Akio Oyama

RG 29.299.846-6-SSP/SP

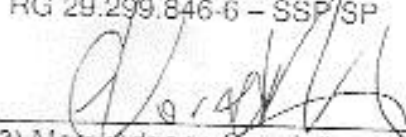

3) Mara-Adnana Corade!lo

RG $10,678.279-97$ - SSP/SP

Pow Qup de mous

4) Lia Coos delmoirr

RG 25.341.398 $\times$ - SSP/SF

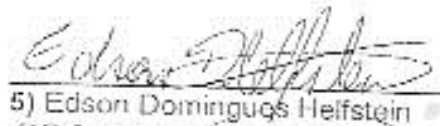

RG $34,679.179-0-\mathrm{SSP} / \mathrm{SP}$

6) Roberto Cactos dasitva

RG $15.378 .5 / 4-2 / S S P / S P$

7rosvaido wao Ochi

RG 4.939.944-5-SSP/SP

2 wewkento

8) Marsa Jose Kunikawa,

RG 7.F73.918-5-SSP/SP

Pcinal Pofinas doescumbir

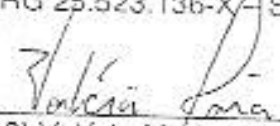

10) Valéria Mária Macoratti

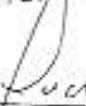

Lonatio

RG 18.124.512-7-SSP/SP

11) Massue Mizogttis Shirazawa shagow a

RG 5.843.824 S-SSP/SP

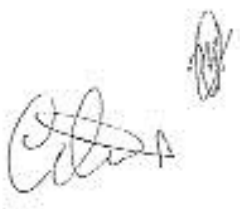

21
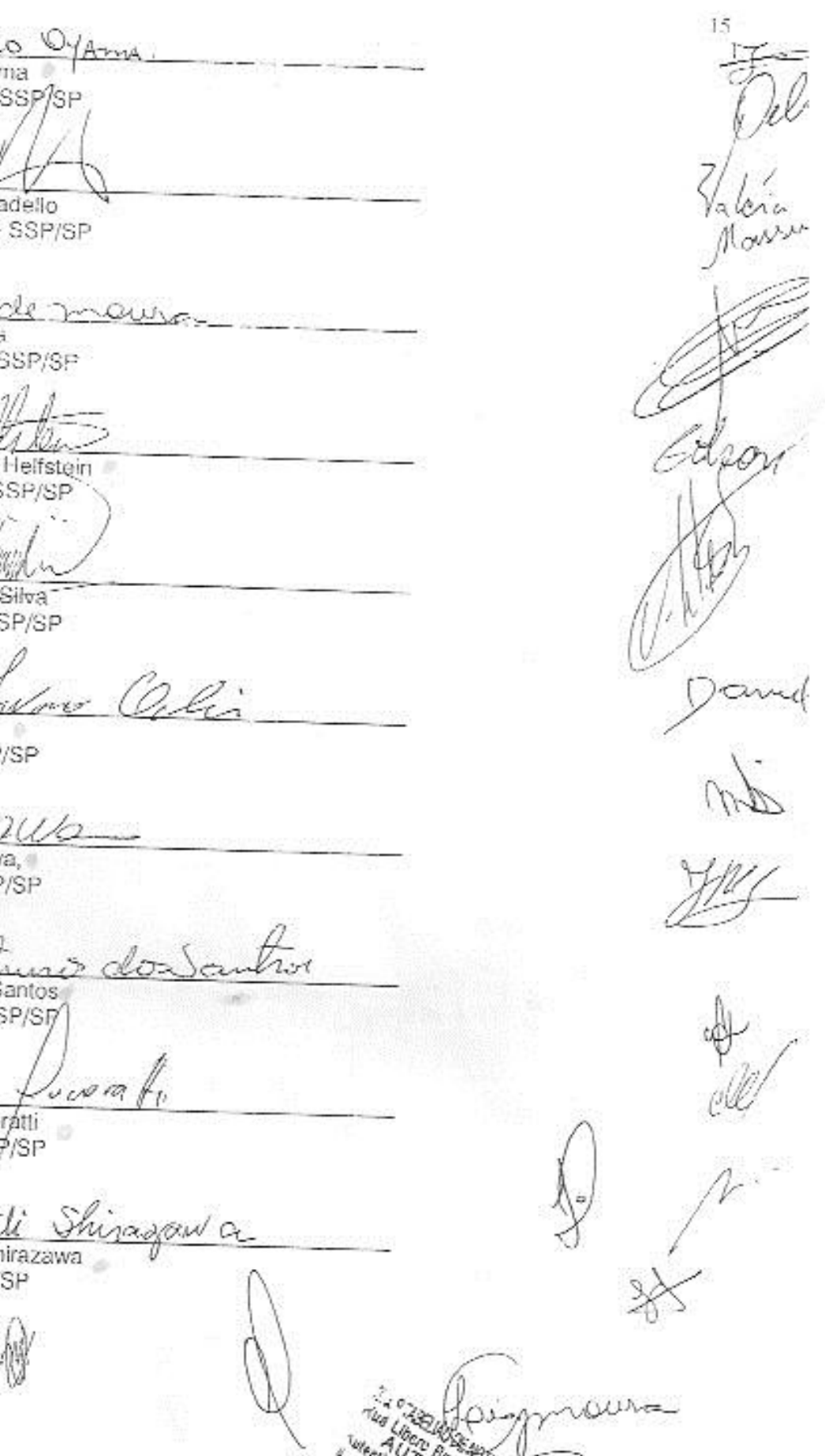

8
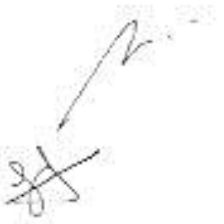
$\frac{\text { How in - Snma Som }}{\text { 12) Maria Irma Santiago Passos }}$ RG 17.017.303-3-SSP/MG

13) Celestino da Mata

$\mathrm{RG} 36.664 .504-3-5 \mathrm{SP} / \mathrm{SP}$

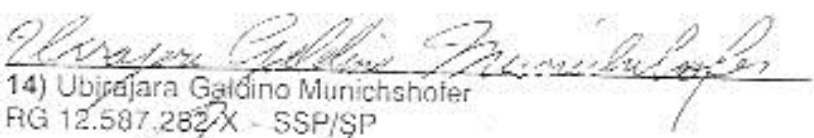

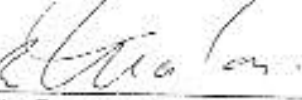

15) Leila Ramos Matajson fic $12.271 .886-59 \% / \mathrm{sP}$

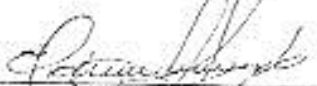

16) Edmundo dos Santos

RG $9.144-592.9-8$ SI /SP

17) Monica Ferreira Caetano RG 16.777.7415-SSP/SP

$\because(-)(x)-1)+1)$

18) Celina Marizdos Santos Fontan

RG 13.271.425 5 - SSP/SP

9) Vanje-tolaria Ferreira dos Santos

4G-S2.004.833-4 - SSP/SP

20) Mauri Joaquim da Silva

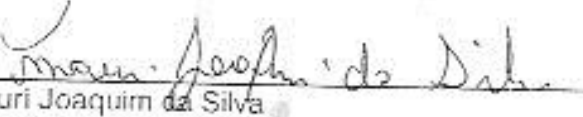

RG 32.325 .162 .6 - SSP/SP

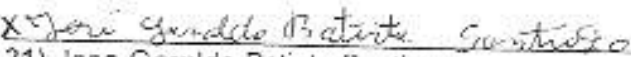

21) Joso Geraldo Batista Santiago

RG 16.709.518-03-. SSP/MG

(1)

aty

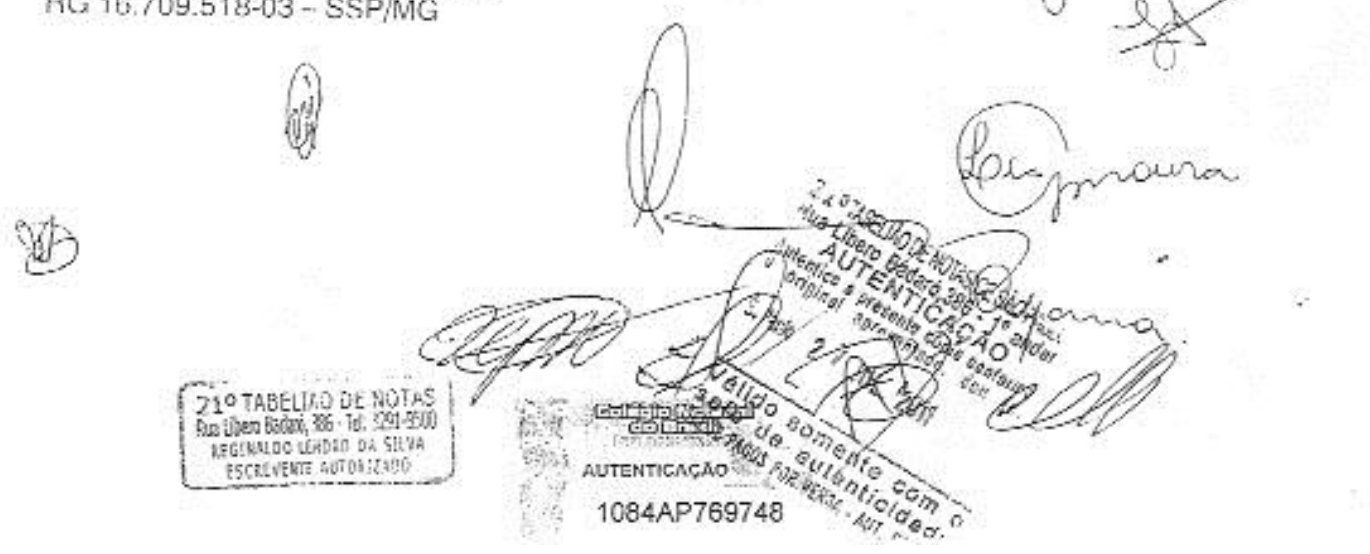

$-x+2=$

olow

Valeia

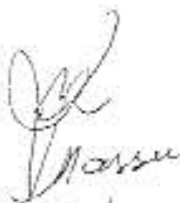

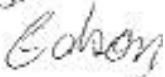
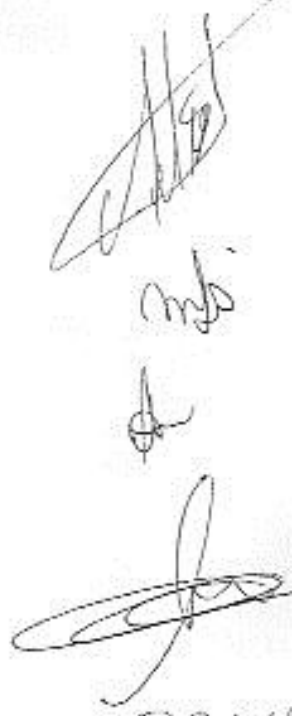

Conme

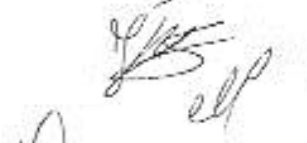

10

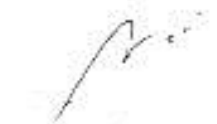


22) Jose Luiz da Silva FG $38,447.073-7-58 \mathrm{P} / \mathrm{SP}$

$\frac{x}{23)}$ vose Mauro Furtado Fidelis

PG 1.739.101-7-SSP/SP

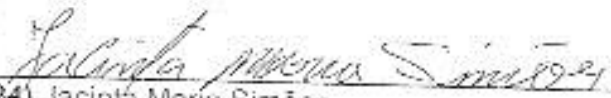

24) Jacinta Marí Simōos

RG 17.226.854.0-SSP/SP

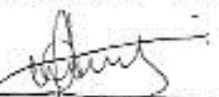

25) Vanderlei Amorim da Silva

$\mathrm{RG} 18.114 .410-\times \mathrm{SSP} / \mathrm{SP}$

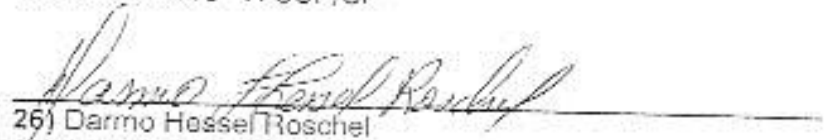

RC 3.363.823-8 SSP/SP

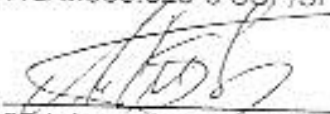

27-) Antonio Massami Nakagawa

RG $15.921 .737-4$ - SSP/SP

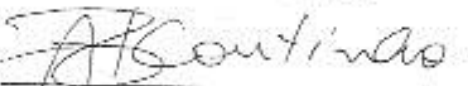

28) Ana Zilda Rodrigues Coutinho

HG 17.811.164-8 SSP/SP

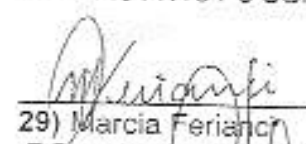

29) Marcia Ferianch/s
$\mathrm{RG} 11.824$. $803 \$ \mathrm{~s} / \mathrm{sP}$

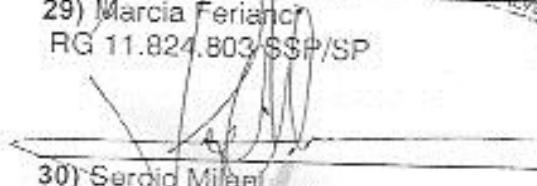

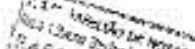

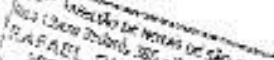

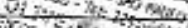

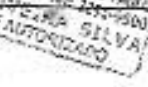

zolo somentioner

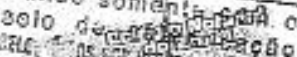

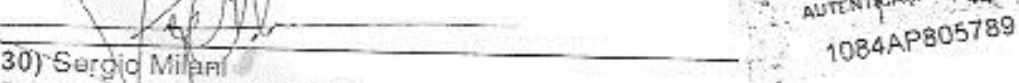

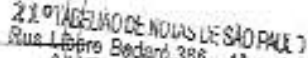

AUTENकIC $356-J^{2}$ and

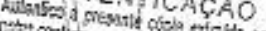

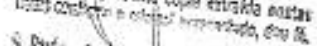

Perar $92 \times 6$ th 2019

RG $6.569,624-4$ - SSP/SP
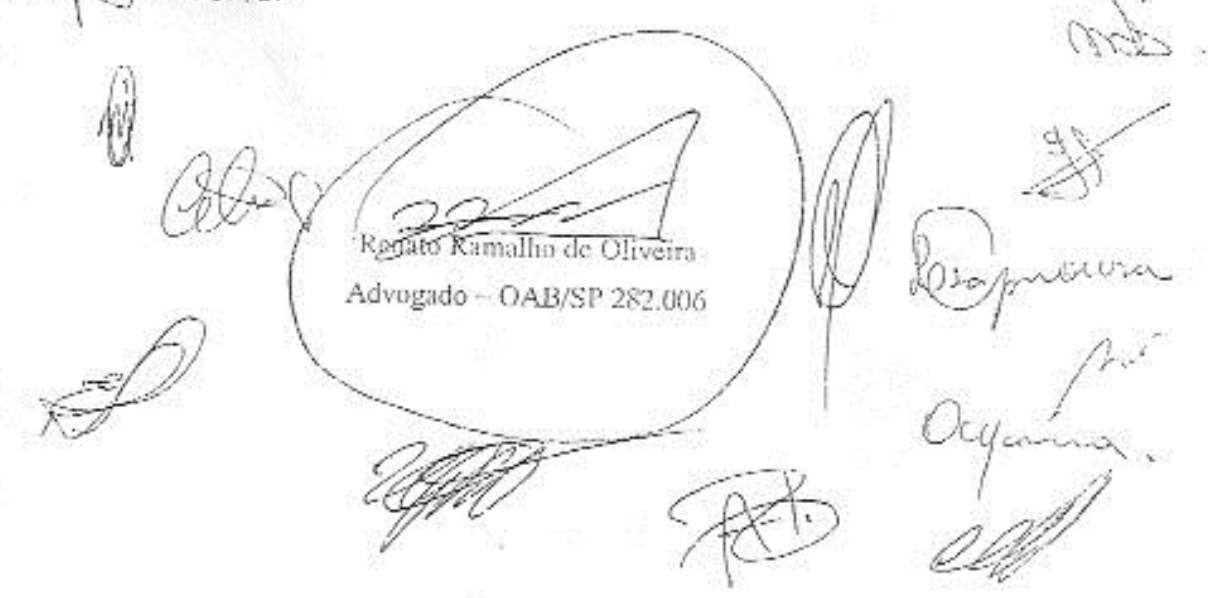
ANEXO E - Reportagem sobre a parceria da chef Paola Carosella, publicada na Revista São Paulo, da Folha de São Paulo, em 31 de julho de 2016. A versão a seguir foi retirada do digital. Disponível em: <http://www1.folha.uol.com.br/saopaulo/2016/07/1796981-paolacarosella-faz-parceria-com-agricultores-que-cultivam-organicos-em-sp.shtml>. Acesso em: 26 set. 2016.

FOLHA DE S.PAULO :

$\checkmark$ Assine a folha

\section{sãopaulo}

\section{Paola Carosella faz parceria com agricultores que cultivam orgânicos em SP}

CO URL CURTA TT MAIOR TT MENOR A ERAMOS?
TOMÁS CHIAVERINI
COLABORAÇĂO PARA A säopaulo
31/07/2016 002 hoo
Esse aqui é pra você, Paola", diz a agricultora Maria José Kuniwa, 61,
apontando um pé de salsinha que crescia num canteiro cercado por mata
nativa. "Tem meu nome escrito aí?", brinca a chef Paola Carosella, agachando-
se, puxando uma folhinha e colocando na boca. "Ah, essa tem!", responde ela,
feliz em mostrar a plantação à estrela do programa MasterChef, da Band.
O encontro, ocorrido numa quinta-feira de maio, não foi em algum sítio do
interior -como sugere o cenário rural- mas no município de São Paulo.
Carosella passou o dia visitando agricultores da região Parelheiros (zona sul),
como parte de uma recém-estabelecida parceria que está dando novo fôlego à
produção de orgânicos na cidade e, ao mesmo tempo, mudando a maneira
como a chef estrutura o cardápio de seu restaurante -o Arturito, em Pinheiros.

A cozinheira argentina andava em busca de fornecedores que não usassem agrotóxicos desde os idos de 2001, quando fincou raízes em São Paulo. "A gente sempre fez uma cozinha simples, que tenta levar pro prato o ingrediente brilhando no seu esplendor máximo. E o orgânico é ideal pra isso porque tem sabor melhor, além de outras vantagens."

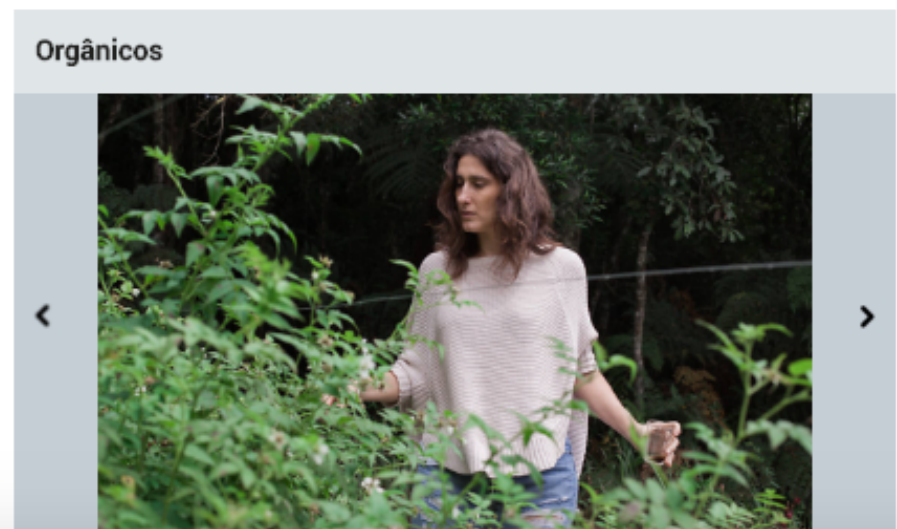

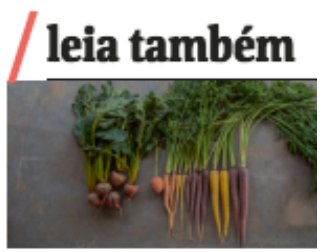

Preço alto atrapalha popularize orgânicos, diz professor

Confira 11 restaurantes e feira: comprar produtos sem agrotóx

Produção de orgânicos aument opçōes para os consumidores 
A escassez de produtores, contudo, sempre espalhou erva daninha nos planos, até que, no fim do ano passado, ela descobriu que os associados da Cooperapas plantavam a 50 quilômetros do centro, em Parelheiros.

Em fevereiro, após duas visitas à regiấo, Carosella propôs que eles se tornassem fornecedores oficiais: "eu me comprometi a comprar sempre, eles se comprometeram a ser a minha horta", diz a chef, que passou a adaptar o cardápio ainda mais ao que a terra oferece.

\section{TUDO A SEU TEMPO}

Diferentes produtos em diferentes estações do ano. Esse é o maior empecilho ao consumo de orgânicos, de acordo o engenheiro agrônomo e professor da Esalq (Escola Superior de Agricultura Luiz de Querioz), Carlos Armênio Khatounian, 56. Segundo ele, os orgânicos trazem beneficios à saúde e à natureza, mas os agrotóxicos permitem produzir continuamente alimentos destinados a crescer apenas em algumas épocas.

"Os venenos permitiram contornar um ambiente desfavorável a certas culturas. Mas é mais ou menos como criar um urso polar em Manaus. Você até consegue, mas é difícil e custoso", diz Khatounian, que também é $\mathrm{PhD}$ pela universidade de Iowa.

Carosella prefere os desafios da sazonalidade ao urso polar suando nos trópicos. $O$ vaivém no cardápio às vezes é simples (o acompanhamento das carnes, por exemplo, pode facilmente mudar de batata-doce para a mandioca), às vezes exige criatividade. "Eu não posso comprar 6.00o em um mês e mil no outro, porque quebro o agricultor. Então, se o seu Ismael está com muito almeirão, vamos fazer uma salada, uma empanada, alguma coisa para usar esse almeirão todo."

O "seu Ismael" a quem Carosella se refere é Ismael Helestein, 67, um homem de mãos grandes e cascudas, que há pouco mais de dez anos anos pensou em desistir de plantar porque nada mais crescia nas roças dele. "Colocamos tanto veneno que acabamos com a terra. Nem mandioca dava mais", conta.

A solução veio quando, dez anos atrás, uma ONG convenceu seu Ismael a migrar para o cultivo orgânico. Ele aprendeu técnicas para recuperar o solo, e, depois de dois anos de trabalho, voltou a produzir.

Na época, não existia agricultura orgânica estruturada na cidade. Agora, só na zona sul, são 12 agricultores certificados e cerca de 30 que ainda não têm o selo mas já produzem com boas práticas.

Os números são modestos diante dos cerca de 400 produtores convencionais da região. Mas, quem trabalha por lá garante que os resultados vão além da quantidade.

"O agricultor que se torna orgânico muda a forma de enxergar sua relação com a terra e com a produção", diz o geógrafo e gestor de projetos do Instituto Kairós, Arpad Spalding, 36. "Ele vai ter mais trabalho, mas ao produzir de forma ecologicamente correta, vai perceber que está fazendo algo pela sociedade e vai se sentir mais valorizado. Isso incentiva o homem a ficar no campo e pode diminuir o inchaço das cidades."

Spalding, um dos responsáveis pela "conversão" de seu Ismael e pela parceria, estava havia mais de uma década envolvido em projetos de capacitação na zona sul -em parceria com a secretaria Municipal do Verde e do Meio Ambienteaté que, três anos atrás, a casa onde morava, na Vila Madalena, acabou demolida para a construção de um prédio.

Foi o empurrão que faltava: arregimentou três sócios, comprou uma roça em Parelheiros e passou a plantar lado a lado com os agricultores que ajudou a converter. O sítio Quinta Estação, que já produz frutas vermelhas, gengibre e ervas, tem outros objetivos: "A ideia é criar uma unidade de desenvolvimento tecnológico, ambiental e social para a região", explica Spalding.

Ali, depois de passar o dia provando orgânicos, Carosella pensou em como sua maneira de cozinhar mudou ao longo do tempo. "Hoje eu me emociono muito mais servindo uma salada de folhas orgânicas do que ralando uma trufa importada." 